\title{
Климат \\ Юго-Западного Алтая
}



Восточно-Казахстанский Государственный Университет

им. С. Аманжолова

Усть-Каменогорский филиал Казахского Географического Общества

\section{Климат \\ Юго-Западного Алтая}

Издание 2-е. дополненное

Под ред. А.В. Егориной

Усть-Каменогорск, 2014 
УДК 551.58(571. 15)

ББК 26.234 .7

E 30

Рецензенты:

В.С.Ревякин, доктор географических наук, профессор -Алт.гос. технич. ун-т

им. И. Ползунова (Россия);

Р.В. Плохих, доктор географических наук,Институт Географии (Казахстан)

Е 30 Климат Юго-Западного Алтая /Под ред. докт.геогр. наук, проф. А.В.Егориной.Семей, 2015.- 315 с.: ил. 65, табл. 67

Фото: Зинченко Ю.К.

ISBN 9965-578-02-8

УДК $551.58(571.15)$

ББК 26.234.7

Монография отражает особенности климата природно-территориальных комплексов Юго-Западного Алтая. Анализируются взаимосвязи элементов климата с другими компонентами природной среды. Определены геофизические параметры радиационного, теплового и водного балансов исследуемой территории. Разработана система картосхем, составляющих климата. Все картосхемы оригинальны и имеют самостоятельное значение. Рассмотрены особенности вероятных региональных изменений климата в результате антропогенных нагрузок.

Монография дополнена главой - Туманы. Книга рассчитана на климатологов, научных и практических работников, природопользователей, преподавателей, магистрантов и студентов вузов и всех, кто интересуется вопросами климата.

ISBN 9965-578-02-8

$\underline{\mathrm{E} 1805040500}$

$00(05) 01$
(С)Авторский коллектив, 2015

СВКГУ им. С.Аманжолова, 2015

(C) Усть-Каменогорский филиал

(c) «Казахское Географическое общество»

При перепечатке ссылки обязательны 
«Для славы мертвых нет»

A. Ахматова

70-летию Великой Победы

Памяти наших отияов, мужей и братьев - солдат-победителей Саваченко Ивана Акимовича, Павла Ивановича, Дмитрия Ивановича, Попова Валентина Егоровича, Егорина Василия Петровича, Дюкарева Дмитрия Петровича, Кондратьева Павла Мартемьяновича п освяща в т я 


\section{П Р Е ДИ С Л О В И Е}

Среди научных публикаций до настоящего времени нет обобщающих исследований по климату и геоэкологии Юго-Западного Алтая. Представленная работа в определенной степени заполняет этот пробел и является, по сути, первым трудом по геоэкологии региона.

Изучение геофизических процессов позволяет раскрыть физические корни климата и показывает его роль как одного из механизмов, обеспечивающих постоянный обмен веществом и энергией в экосистемах. Через пространственновременную структуру геофизических полей может быть раскрыта ландшафтная самоорганизация биоты экосистем, где все природные компоненты в одинаковой степени необходимы, а организующая роль живого вещества в их развитии не противоречит важности и необходимости функций абиогенных и биокосных элементов. Предложенные авторами геоэкологические модели иллюстрируют основные связи системной организации природных комплексов Юго-Западного Алтая.

В работе на основе 65-летнего периода наблюдений дается заключение о региональных особенностях современного изменения климата в ходе геоэкологических процессов. Картосхемы геофизических полей позволяют охарактеризовать степень устойчивости геосистем к антропогенным нагрузкам.

В основу книги легли материалы кандидатских и докторских диссертаций авторов, а также труды по Алтаю известных ученых М.В. Тронова, В.В. Сапожникова, Л.Н. Ивановского, А.В. Куминовой, Б.Ф. Петрова, М.Х. Байдала, В.С. Ревякина, В.И. Русанова.

Авторы использовали результаты отечественного и зарубежного опыта изучения климата с позиций эколого-географического подхода.

Книга рассчитана на читателя, знакомого с географией и биологией: студента, аспиранта, преподавателя-эколога, учителя школы. Полезную для себя информацию найдут в ней агроном, лесовод и градостроитель, фермер и руководитель промышленного производства.

Авторы монографии: Введение - написано К.И. Поповой; главы 1, 23 - А.В. Егориной и К.И. Поповой; 4 - А.Д. Дюкаревым, В.П. Кондратьевым и К.И. Поповой; 5 - К.И. Поповой и А.В. Егориной; заключение - К.И. Поповой и В.П. Кондратьевым; Глава Туманы - А.С. Чурсиным.

Авторы надеются, что их труд поможет в разработке и осуществлении программы устойчивого развития горных геосистем Юго-Западного Алтая с позиций рационального освоения и охраны их природных ресурсов.

Приведенные в книге картосхемы геофизических полей - результат коллективной работы А.В. Егориной, К.И. Поповой, Ю.В. Стрельникова, А.С. Чурсина. Картосхема биопродуктивности ландшафтов разработана А.В. Егориной, высоты снежного покрова - А.Д. Дюкаревым, фотографии выполнены Ю.К. Зинченко.

Создатели монографии выражают искреннюю благодарность лицам, прочитавшим рукопись и сообщившим свои замечания. 


\title{
В В Е Д Е Н ИЕ
}

\author{
Человеческое общество всегда \\ зависело от климата, и в наше время в силу \\ ряда причин эта зависимость не \\ уменьшается, а скорее увеличивается.
}

Академик Г.С. Голицыьн

Экологический ман и фбест : «Воздух-наш отец, вода-мать, Земля - дом, роса - национальное сокровище».

Настало время осознать, что наша Земля - одинокий небесный цветок, расположенный на удачном расстоянии от Солнца.

Мы взрываем в одуванчике бомбы! Мы разрушаем его ранимую оболочку. Птицы и звери, цветы и деревья взывают к человеку: сбереги, сохрани, где стоишь, где живешь - на расстоянии взгляда и голоса, хотя бы на расстоянии вытянутой руки! И твое личное пространство, помноженное на миллионы, станет охраняемым пространством отечества, помноженное на миллиарды - охраняемым пространством мира.

Человечество переступило порог третьего тысячелетия. Мы должны, наконец, ясно понять, что спастись и спасти жизнь на Земле невозможно в одной отдельной стране, даже самой благополучной. Необходимо создать всемирный экологический совет с правом накладывать вето на любое ядовитое производство. Идея украшения, исцеления, озеленения, очищения Земли должна стать главной государственной идеей, смыслом существования и национальной гордостью каждого народа.

Настало время разработать новую категорию прав - права природы. Общими усилиями мы должны реанимировать города, попавшие в черный экологический список. Настанет час, когда страны будут гордиться не заводами, не задымленными горизонтами, а зелеными листьями, чистой росой и освежающей прохладой.

Мы верим, что школьники будут писать по слогам: воздух - наш отец, вода - мать, Земля - дом, роса - национальное сокровище.

В предлагаемой работе климат рассматривается как компонент природно-территориальных комплексов регионального 
ранга. Исследование выполнено с позиций эколого-географического подхода, учитывая, что биота любой экосистемы генетически связана с физико-географическими условиями местообитания и наиболее адаптирована к средним метеорологическим условиям или климатическим нормам $[1,2,3,4]$.

Изучение климатических ресурсов Юго-Западного Алтая имеет сугубо практическое значение. В структуре экологического потенциала ландшафта главное место принадлежит климату. Его элементы имеют лимитирующее экологическое значение.

В трудах крупных ученых-климатологов разных лет - А.И. Воейкова, И.В. Фигуровского, Е.Е. Федорова, В. Кеппена, Б.П. Алисова, Л.С. Берга, Е.С. Рубинштейна, П.И. Колоскова, О.А. Дроздова, А.А. Борисова и других даются разные определения климата. Столь многочисленные толкования этого понятия связаны с различными направлениями, существующими в климатологии. Представителем одного из них является Л.С. Берг, который рассматривал климат как часть ландшафта или географического процесса.

Влияние горных систем Юго-Западного Алтая на климат проявляется не только внутри региона, но и на соседних территориях. Климатический режим горных стран зависит от географической зоны, абсолютной высоты, протяженности и плановой структуры хребтов, экспозиции склонов и их морфологии.

Специфика горного климата заключается в высотном изменении значений метеоэлементов температуры, осадков, скорости и направления ветра, снежного покрова и др. Исключительную роль играют климатические аспекты экзогенных процессов: эрозии склонов, снежных лавин, селевых потоков и т.д.

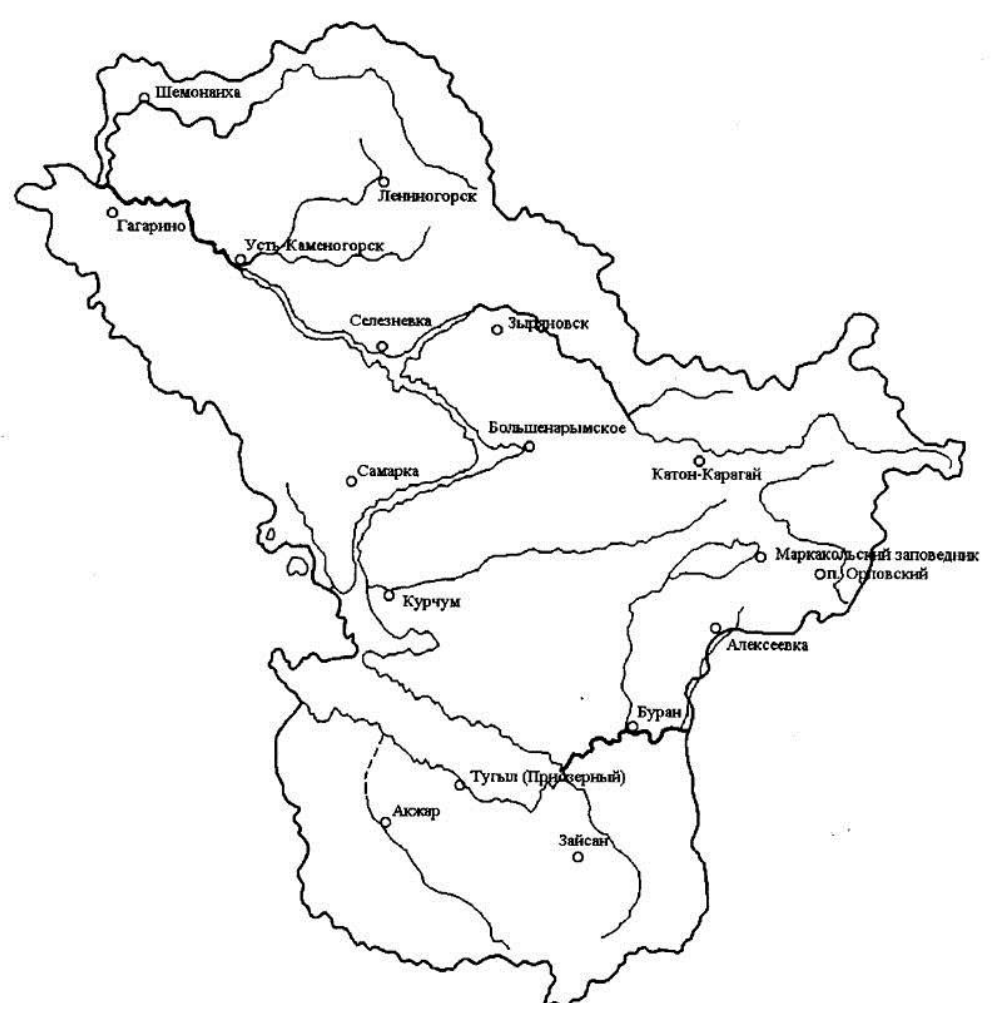

Рис. 1. Расположение метеостанций на территории Юго-Западного Алтая 
Локальные климаты Юго-Западного Алтая до сих пор изучены слабо из-за недостаточного количества опорных метеорологических станций и отсутствия аэрологических наблюдений. Основная цель данной работы - создание климатического очерка региона на основе эколого-географического подхода.

Исходными материалами для исследования послужили фондовые и архивные данные Восточно-Казахстанского центра гидрометеорологии Казгидромета, Западно-Сибирского управления, Новосибирской машиносчетной станции.

Система экологического мониторинга представлена 16 метеостанциями и 40 гидрологическими постами (рис.1). 


\section{ГЛАВА І. УСЛОВИЯ ФОРМИРОВАНИЯ КЛИМАТА ЮГО- ЗАПАДНОГО АЛТАЯ, ЕГО ОСНОВНЫЕ ЧЕРТЫ}

\section{1. Физико-географическая характеристика территории}

Территория Юго-Западного (Казахстанского) Алтая расположена в глубине материка на границе великих равнин и горных систем Евразии в южной части умеренного климатического пояса.

Являясь южной периферией Алтайской горной системы, к Казахстанскому Алтаю относятся горные сооружения Рудного и Южного Алтая, их западное продолжение - Калбинский хребет. С юга к ним примыкает Зайсанская впадина, которая представляет собой обширный межгорный прогиб. Согласно В.С. Ерофееву, сюда можно отнести и горную систему Саур-Тарбагатая в связи с особенностями развития тектонических процессов в палеогене и неогене.

Располагаясь в бассейне Верхнего Иртыша, между $47-51^{0}$ с. ш. и $81-87^{0}$ в.д., территория региона простирается почти на 450 км как в широтном, так и в меридиональном направлениях, площадь составляет более 97 тыс. км².

Климат Казахстанского Алтая умеренный, переходный: от европейского умеренно континентального к восточно-сибирскому, крайне континентальному, с четким выделением сезонов. По М.В. Тронову - регион лежит на стыке трех типов климата: монгольского, среднеазиатского и западносибирского [5].

Исследуемая территория является форпостом Высокой Азии, большая ее часть имеет облик горной страны. Высоты местности варьируют от 200 м на крайнем северо-западе в прииртышской части до 4500 м на востоке (г. Белуха, 4506 м). Рельеф местности имеет сложную плановую структуру с наличием орографических узлов, от которых хребты расходятся веером в западной половине горизонта (рис. 2).

Современный горный рельеф Казахстанского Алтая тесно связан с геологической историей его развития. Горные хребты здесь возникли во время герцинского орогенеза, глубинные разломы подновлялись несколько раз в палеозое и в период неотектоники. В результате 65\% площади Рудного Алтая составляют интрузии, более половины слагающих территорию палеозойских толщ состоит из 
вулканических пород. Интрузивные и вулканические породы несут оруденение цветных и редких металлов, определяя извечное большое «загрязнение» ландшафтов солями этих элементов.

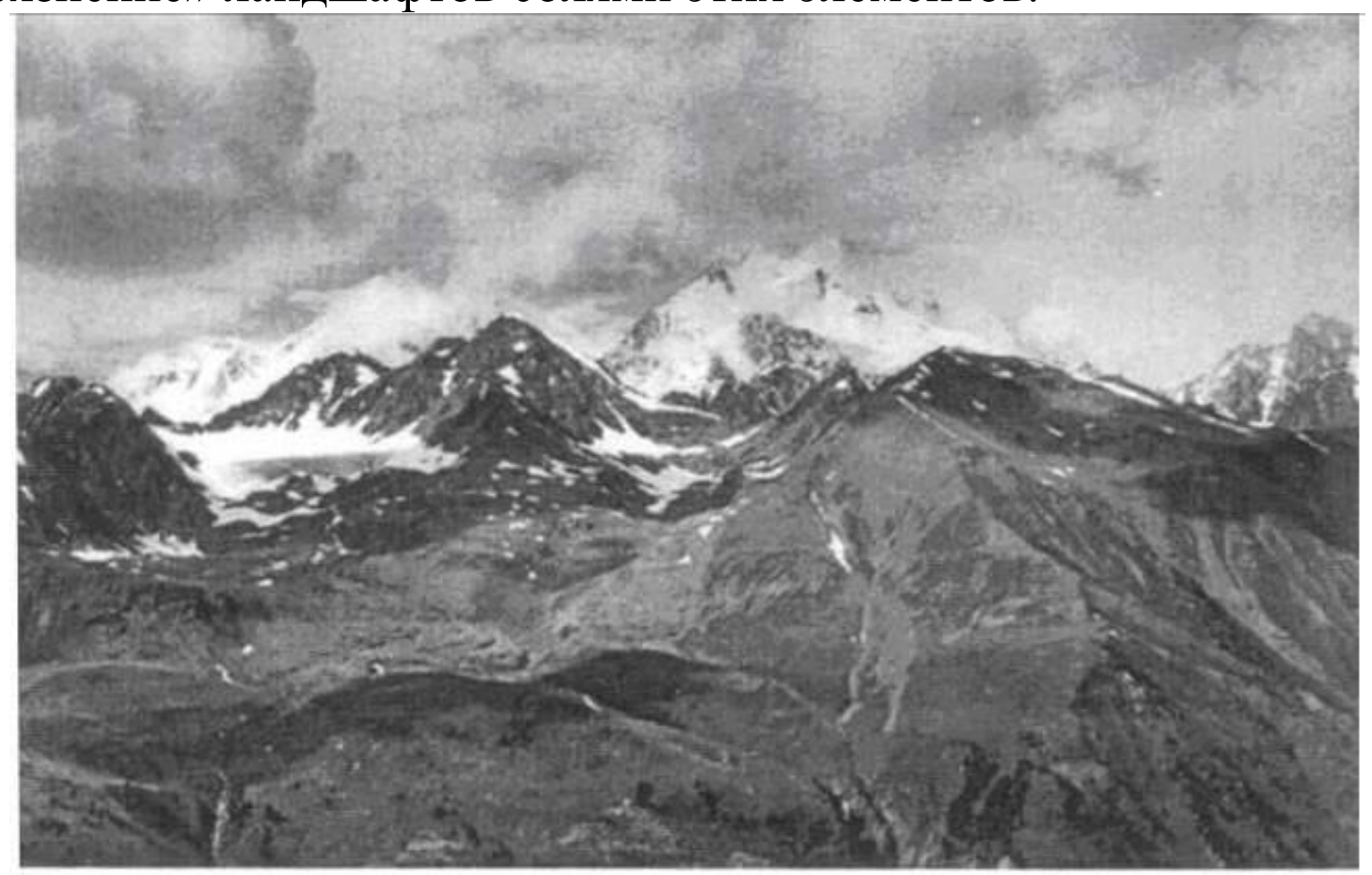

Рис. 2. Гора Белуха - высшая точка Алтая

С конца палеозоя и в течение всего мезозоя, вплоть до неогена, весь Алтай находился в периоде континентального покоя. На месте гор образовалась обширная денудационная равнина. В результате последующих перемещений по древним швам на фоне сводовых поднятий сформировался современный горный рельеф Алтая. Неотектонические движения не закончились до сих пор, о чем свидетельствуют землетрясения (особенно сильные произошли в Зайсанской котловине и областном центре: июнь 1990 года, сентябрь 2003). Складчатый фундамент герцинид, «пропитанный» интрузивными породами палеозоя, при напряженных поднятиях и прогибах растрескивался, чаще всего по древним швам, на отдельные полосы и глыбы. Одни из этих глыб испытали поднятия, другие остались на месте либо опустились. Поднятия в современном рельефе образуют горные цепи, измененные ветром, текучими водами, ледниками, физическим выветриванием, опущенные участки представляют - современные продольные долины и межгорные впадины. Рассмотренные процессы обусловили в рельефе ЮгоЗападного Алтая преобладание пологих склонов (крутизной от 3-5 до 
10-15 ${ }^{0}$ ) и выровненных участков пенеплена, поднятых на различные гипсометрические уровни. Крутые склоны и ущельеобразные долины приурочены к зонам разломов (растрескивания). В плейстоцене горы подвергались значительному оледенению $[6,7,8,9]$.

Рудный Алтай простирается вдоль правобережья Иртыша между устьями рек Убы и Нарыма. Пограничными хребтами между Рудным и Горным Алтаем являются Тигирецкий, Коксуйский, Холзун, Листвяга. Абсолютные отметки центральных частей этих хребтов лежат в пределах 1500-2500 м (рис. 3).

К району сходимости хребтов Коксуйский и Холзун с запада подходят Ульбинский, Ивановский и Убинский хребты, образуя орографический узел Рудного Алтая. Эти горы сравнительно невысокие: от 600-1000 до 2000-2800 м, наибольшие высоты находятся на Ивановском хребте. Для них характерны

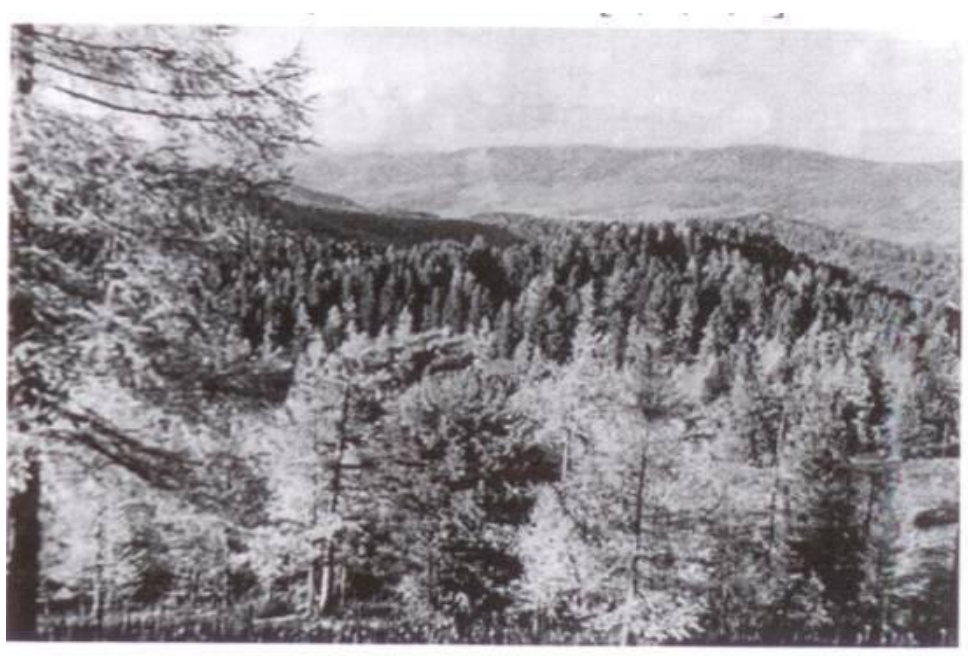

Рис. 3. Рудный Алтай как пологие (северные), так и крутые (южные) склоны (рис. 4).

Водораздельные участки хребтов на высотах 2000-2500 м сильно расчленены, широко развиты ледниковые формы рельефа. Участки гор наряду с сильным расчленением имеют мягкие округлые вершины и пологие склоны. Хребты перемежаются с внутригорными впадинами (Лениногорская, Зыряновская и др.). В северо-западном и западном направлениях Рудный Алтай, постепенно снижаясь, сливается с равнинами Прииртышья.

Особенности орографии Рудного Алтая обусловливают большое увлажнение его территории.

По вертикали четко выражены четыре пояса: предгорный степной (до 600 м), выше - лесной (до 1900 м), альпийско-луговой (до 2000 м), выше - нивальный (снежно-ледниковый). Лесные ландшафты характерны для северных, лесостепные и кустарниковые заросли - для южных склонов. 


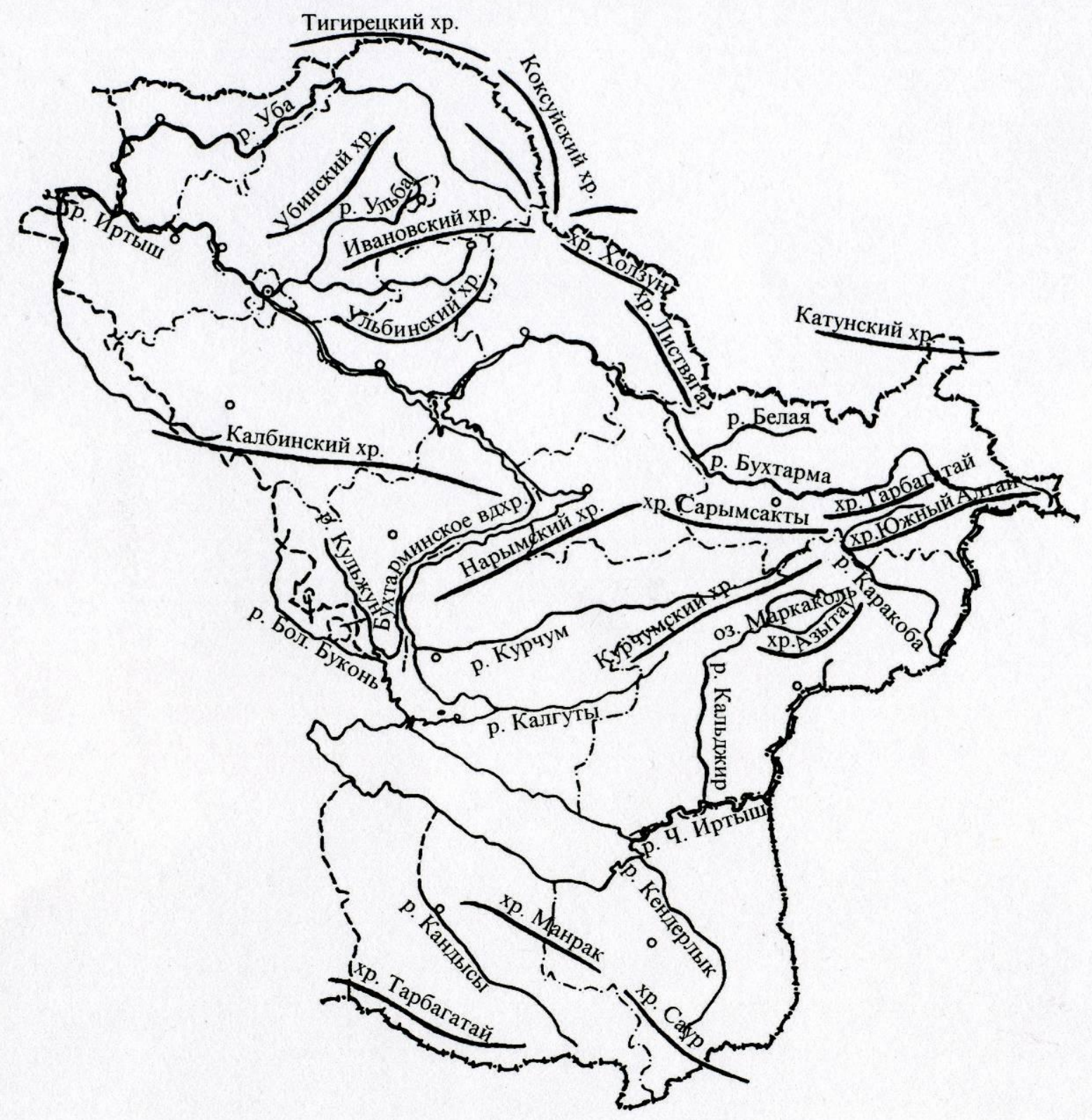

Рис. 4. Орогидрографическая схема Юго-Западного Алтая

Другой крупной орографической единицей является система гор Южного Алтая. От Рудного Алтая она четко отделяется межгорной Нарымо-Бухтарминской впадиной. Состоит Южный Алтай из субширотно простирающихся хребтов и разделяющих их межгорных понижений. Абсолютные высоты возрастают от 500-600 на западе и юго-западе до 2800-3600 м на востоке и юго-востоке. Северные склоны хребтов крутые и короткие, южные - сравнительно пологие и длинные. Хребты разделяются внутригорными впадинами, наиболее значительные из которых Маркакольская, Орловская, ВерхнеКаракабинская, Бобровская. В северной части Южного Алтая 
(с запада на восток) простираются хребты: Нарымский, СарымСакты, Тарбагатай Алтайский, южнее - хребты Курчумский и Южный Алтай (рис. 5).

Хребет Азутау с абсолютными высотами 1800-2300 м с юга окаймляет озеро Маркаколь. Вблизи плато Укок, в верховьях реки Бухтармы эти хребты образуют орографический узел, в пределах которого М.В. Тронов выделил Южно-Алтайский центр оледенения [5]. Снеговая линия Южного Алтая лежит на высотах 2600-2800 м. Вторичный центр оледенения расположен в истоках реки Курчум, где сходятся хребты Сарым-Сакты и Курчумский. Сравнительно густая сеть рек, относящихся к системе Кара-Кабы, Курчума, и наличие центра оледенения указывает на значительное увлажнение этого района (годовые суммы осадков до 1500 мм).

При движении с юго-запада на северовосток выделяются пояса: пустынный (до 400-500), степной (до 1200-1400), лесной (до 2100-2400 м). Выше альпийско-тундровый пояс, который граничит с нивальным на высотах 2800-3000 м.

\section{Рудный и Южный} Алтай разделены гра-

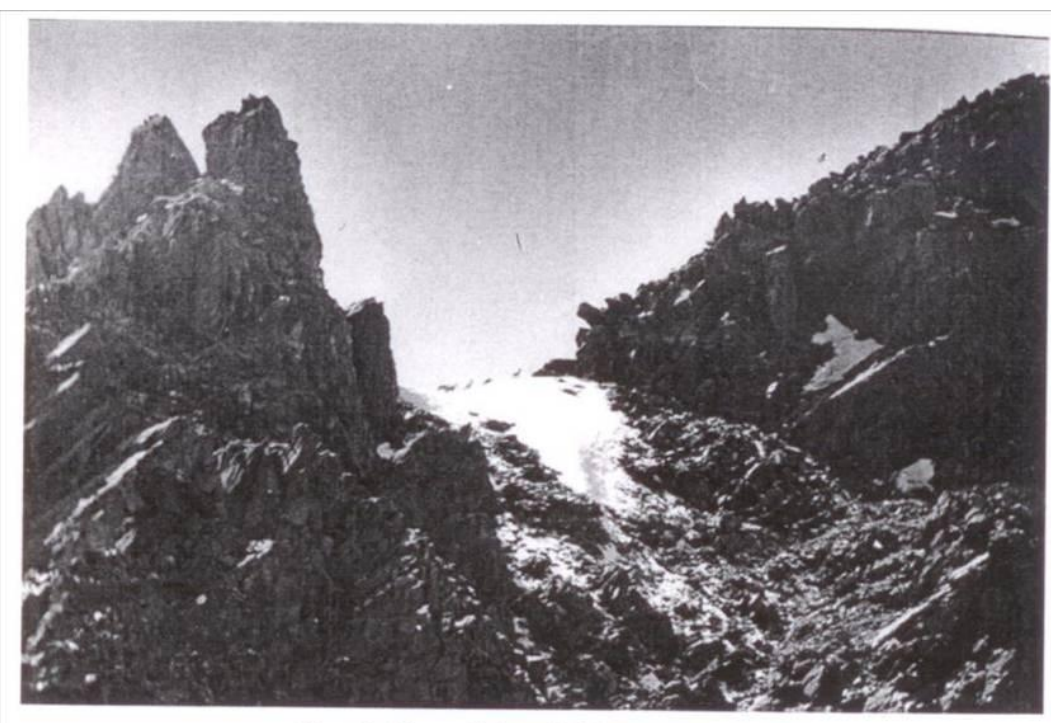

Рис. 5. Южный Алтай. Курчумский хребет

беном - это обширная территория Зыряновского низкогорья с высотами в отдельных массивах в 800-1200, изредка 1500-1700 м. Излучина нижнего течения реки Бухтармы ограничивает с востока и севера Зыряновское низкогорье. Абсолютные высоты долины - 400$500 \mathrm{M}$.

Узкая тектоническая впадина между Рудным и Южным Алтаем, занятая долинами рек Бухтармы и Нарыма, является четкой климатической границей: к северу от нее осадков выпадает в 1,5-2 раза больше, чем к югу, что отчетливо прослеживается в годовом выводе и особенно в холодный период. Данный факт объясняется не характером рельефа, а положением территории под центральной частью западного отрога азиатского антициклона (форма рельефа 
лишь усиливает антициклоническое влияние за счет выхолаживания и стоковых явлений).

Обособленное поднятие, располагающееся на левобережье Иртыша, представляет Калба - хребет массивен, протягивается в западно-северо-западном направлении на 200-230 км при максимальной ширине 50-70 км. Высоты хребта постепенно возрастают с запада на восток от 400 до 1606 м и вновь снижаются к долине прорыва Иртыша до 400 м. Рельеф Калбы низкогорный, преимущественно крутосклонный, местами низкогорно-долинный. Водораздельная часть хребта образована остатками поверхностей выравнивания (древних пенепленов). Своеобразный облик имеют массивы этих гор, сложенные гранитами, отличающиеся причудливыми формами многочисленных скал (Каиндинский, Аюдинский, Шибындинский и другие массивы). В таких горах или у их подножий встречаются небольшие озера. На юге хребта хорошо развиты предгорья. Водораздельные части имеют холмистоувалистый рельеф (рис. 6).

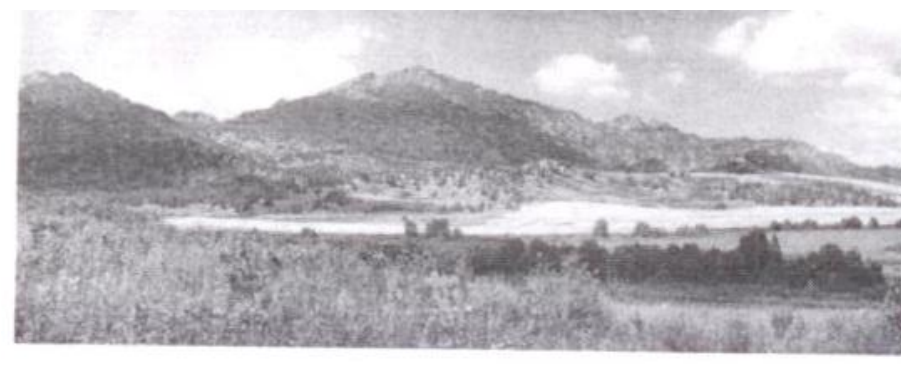

Рис. 6. Калибинский хребет

Предалтайский прогиб представлен Зайсанской впадиной. Это геологически молодое образование. Ступенчатый фундамент палеозоя в ее осевой части погружен на глубину 1600-1700 м. Вся вышележащая толща состоит из континентальных (аллювиальных, озерно-аллювиальных и аллювиально-проллювиальных) отложений верхнемелового, палеогенового, неогенового и четвертичного возраста. В их составе преобладают песчано-галечниковые, песчаноалевролитово-глинистые слои.

Являясь самым обширным межгорным прогибом между Южным Алтаем и системой хребтов Саур-Тарбагатая, Зайсанская впадина заметно суживается к востоку и прослеживается за пределами государственной границы. Только в пределах исследуемого региона она достигает 120 км в длину и примерно столько же в ширину. Абсолютные высоты впадины составляют 400600 м. Поверхность характеризуется равнинным и слабоувалистым рельефом, который в ряде мест нарушается поднятием отдельных сопок и возвышенностей [10]. 
Пониженную часть впадины занимает озеро и окружающая его плоская озерно-аллювиальная равнина. Восточнее и северо-западнее озера расположены террасированные аллювиальные равнины долин рек Иртыша и Черного Иртыша. Большая часть запада и юга котловины занята плоскими наклонными равнинами (рис. 7).

Крайний юго-восток территории представлен системой гор Саура и Тарбагатая. Горная система Саура сложена сильно дислоцированными осадочными породами - сланцами, известняками, песчаниками палеозоя. Северные предгорья сложены континентальными осадками палеогенового и частично (на востоке) неогенового возраста.

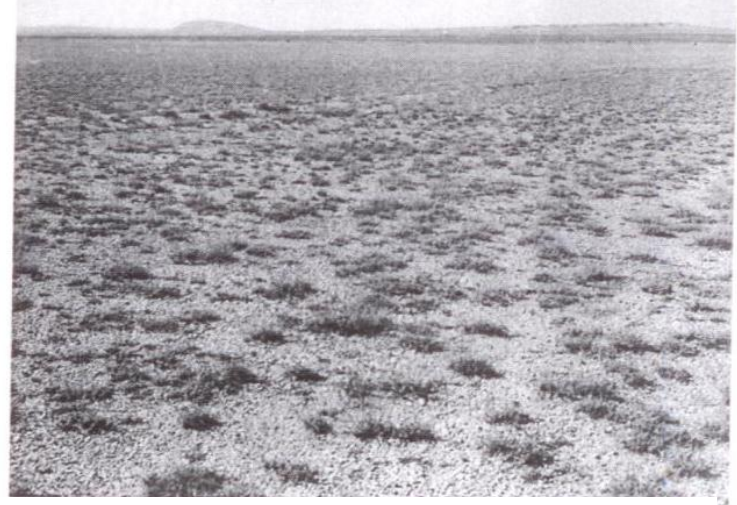

Рис. 7. Полупустынный ландшафт. Зайсанская впадина

Хребет Тарбагатай состоит из двух сближающихся к востоку субширотных антиклинориев. Восточный Тарбагатай представляет собой массивное блоковое поднятие, в строении которого приняли участие осадочные породы палеозоя сланцы, известняки, песчаники $[11,12,13]$.

Рельеф Саур-Тарбагатая представлен рядом горных хребтов и понижений. На западе с ним граничит хребет Манрак с высотами от 900-1000 до 2000 м. Восточная часть Саура достигает высот 3700-3800 м, склоны хребта асимметричны: крутые - южные и пологие - северные. К западу хрбет Саур разветвляется на два отрога; широтная его часть, постепенно снижаясь, сменяется Чиликтинской впадиной (рис. 8).

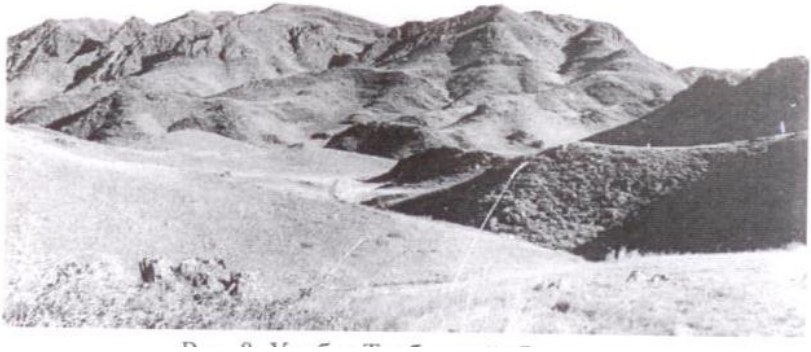

Рис. 8. Хребет Тарбагатай. Сухая горгая степь

Небольшой, параллельный Сауру хребет Сайкан отделен от него межгорной впадиной Ак-Кезень, абсолютные высоты превышают $2000 \mathrm{M}$.

Западнее Саура расположен хребет Восточный Тарбагатай с абсолютными высотами 2300-2500 м; хребет снижается в западном направлении. Склоны его крутые, сильно расчленены и часто осложнены разломами. 
В метеорологическом отношении этот район практически не освещен, но в пределах гор проложено несколько снегомерных маршрутов.

\section{2. Радиационные особенности климата}

Солнечная радиация, поступающая на верхнюю границу атмосферы, значительно ослабляется на пути к земной поверхности за счет рассеяния и поглощения аэрозолями.

Годовые суммы возможной суммарной радиации в пределах Юго-Западного Алтая возрастают с севера на юг с 6,9 до 7,2 тыс. МДж/м ${ }^{2}$ (табл. 1). Большое влияние на ослабление солнечной радиации дополнительно оказывает облачность. Исследования Н.А. Ефимовой и Т.Г. Берлянд [14] показали, что зависимость суммарной радиации Q при действительных средних условиях облачности может быть представлена в следующем виде:

$$
\mathrm{Q}=\mathrm{Q}_{0}[1-(\mathrm{a}+\mathrm{bn}) \cdot \mathrm{n}]
$$

где $\mathrm{Q}_{0}$ - суммарная радиация при безоблачном небе, $\mathrm{n}$ количество облаков по общей облачности в долях единицы, $\mathrm{a}$ и $\mathrm{b}-$ коэффициенты, зависящие от широты. При расчете эти коэффициенты для исследуемого региона, принимались: $\mathrm{a}=0,40, \mathrm{~b}=$ 0,38. О степени ослабления возможной суммарной радиации можно судить по отношению наблюдавшейся продолжительности солнечного сияния к возможной. Данные параметры имеют прикладное значение и приводятся в табл. 2 и приложениях I, II, III; их значения необходимо учитывать в годы жестоких засух (для исследуемого региона - 1974, 1991, 2008 гг.), когда возможная и действительная суммарная солнечная радиация в летние месяцы была практически одинакова.

При большой континентальности климата в регионе наблюдается меньшая облачность, чем на тех же широтах, в частности, на Украине. Поэтому обилие тепла и света на Алтае ускоряет вегетацию растений. Это имеет экологическое значение в связи с тем, что для исследуемой территории характерны поздние весенние и ранние осенние заморозки. В табл. 2 для сравнения приведены данные по Киеву и Кировограду (Украина), расположенных на тех же широтах, что Усть-Каменогорск и Буран. Зимой солнечное сияние составляет за месяц в Риддере 43-56, в УстьКаменогорске - 34-44, а в Киеве лишь 12-22\% от возможного. 
Суммарная солнечная радиация $\left(\mathrm{Q}_{0}\right)$ при условии безоблачного неба (МДж/м²)

\begin{tabular}{|c|c|c|c|c|c|c|c|c|c|c|c|c|c|}
\hline \multirow{2}{*}{$\begin{array}{l}\text { Широта } \\
\text { места }\end{array}$} & \multicolumn{13}{|c|}{ M е с } \\
\hline & $\mathrm{I}$ & II & III & IV & $\mathrm{V}$ & VI & VII & VIII & IX & $\mathrm{X}$ & XI & XII & Год \\
\hline $55^{0}$ с. ш. & 129.9 & 259.8 & 490.2 & 724.9 & 896.7 & 980.5 & 917.6 & 750.0 & 540.5 & 326.8 & 167.6 & 96.4 & 6280.8 \\
\hline $\begin{array}{l}50^{0} \text { с. ш. Усть- } \\
\text { Каменогорск }\end{array}$ & 201.1 & 343.6 & 557.3 & 775.2 & 930.2 & 976.3 & 946.9 & 800.3 & 603.4 & 406.4 & 243.0 & 163.4 & 6947.0 \\
\hline $\begin{array}{l}49^{0} 02^{\prime} \text { с. ш. } \\
\text { Самарка }\end{array}$ & 217.9 & 360.3 & 569.8 & 783.5 & 934.4 & 993.0 & 951.1 & 808.7 & 615.9 & 423.2 & 259.8 & 180.2 & 7097.9 \\
\hline $\begin{array}{l}48^{0} 42 \text { с. ш. } \\
\text { пос. Орловский }\end{array}$ & 222.1 & 366.2 & 573.6 & 786.0 & 934.4 & 993.0 & 953.2 & 811.2 & 618.4 & 425.7 & 264.8 & 185.2 & 7134.0 \\
\hline $48^{0} 00$ Буран & 233.0 & 378.8 & 582.4 & 791.9 & 936.9 & 997.2 & 955.3 & 817.0 & 628.5 & 435.8 & 276.5 & 196.9 & 7231.9 \\
\hline $\begin{array}{l}47^{0} 48^{\prime} \text { с. ш. } \\
\text { Приозерный }\end{array}$ & 235.9 & 380.4 & 584.9 & 791.9 & 937.3 & 997.2 & 957.8 & 817.0 & 628.9 & 440.0 & 276.5 & 201.1 & 7249.1 \\
\hline $\begin{array}{l}47^{0} 20 \text { с. ш. } \\
\text { Зайсан }\end{array}$ & 244.3 & 391.3 & 549.3 & 797.8 & 939.4 & 997.2 & 959.3 & 822.9 & 593.3 & 447.5 & 288.3 & 209.5 & 7240.3 \\
\hline $45^{0} 00$ с. ш. & 280.7 & 431.6 & 620.1 & 817.0 & 946.9 & 1001.4 & 972.1 & 842.2 & 662.0 & 481.8 & 326.8 & 247.2 & 7630.0 \\
\hline
\end{tabular}


Отношение наблюдавшейся продолжительности солнечного сияния к возможной, \%

\begin{tabular}{|c|c|c|c|c|c|c|c|c|c|c|c|c|c|}
\hline Станция & I & II & III & IV & $\mathrm{V}$ & VI & VII & VIII & IX & $\mathrm{X}$ & XI & XII & Год \\
\hline Киев & 16 & 22 & 28 & 39 & 54 & 54 & 56 & 56 & 48 & 37 & 20 & 12 & 34 \\
\hline Катон-Карагай & 55 & 60 & 60 & 61 & 61 & 61 & 63 & 65 & 65 & 52 & 46 & 46 & 60 \\
\hline Зыряновск & 35 & 51 & 51 & 56 & 57 & 61 & 65 & 68 & 57 & 46 & 33 & 29 & 51 \\
\hline Буран & 55 & 57 & 59 & 65 & 72 & 72 & 74 & 77 & 74 & 61 & 48 & 45 & 66 \\
\hline Семипалатинская аэрол. ст. & 45 & 53 & 57 & 61 & 67 & 67 & 68 & 71 & 72 & 48 & 40 & 38 & 60 \\
\hline Кокпекты & 53 & 55 & 58 & 65 & 71 & 71 & 71 & 74 & 73 & 57 & 46 & 45 & 64 \\
\hline Аягуз & 54 & 56 & 55 & 64 & 70 & 72 & 74 & 76 & 75 & 60 & 52 & 47 & 65 \\
\hline
\end{tabular}


Та же картина прослеживается в Зайсанской впадине. В Буране и Зайсане солнечное сияние с ноября по март составляет 45-57\% от возможного, в Кировограде - 13-21\%. Зимой продолжительность солнечного сияния в пределах Казахстанского Алтая в 2-3 раза больше, чем в центральных районах Украины, летом - на 20-25\%.

Следует отметить, что вероятность ясного неба увеличивается с высотой, так как зимой в горах большую повторяемость имеют слоистые облака, занимающие среднюю часть склонов (под слоем температурной инверсии). Данная закономерность хорошо прослеживается по метеостанциям, расположенным на различных гипсометрических уровнях (табл. 3).

Т а бли ц а 3

Повторяемость ясного (0-2 балла) состояния неба по общей и нижней облачности, \%

\begin{tabular}{|c|c|c|c|c|c|c|c|}
\hline \multirow{2}{*}{ Метеостанция } & \multirow{2}{*}{$\begin{array}{c}\text { Высота } \\
\text { над уровнем } \\
\text { моря, м }\end{array}$} & \multirow{2}{*}{$\begin{array}{c}\text { Вид } \\
\text { облачности }\end{array}$} & \multicolumn{5}{|c|}{ М е с яцы } \\
\hline & & & XI & XII & I & II & III \\
\hline $\begin{array}{l}\text { Прапорщиково } \\
\text { (Усть-Каменогорск) }\end{array}$ & 284 & $\begin{array}{l}\text { Общая } \\
\text { Нижняя }\end{array}$ & $\begin{array}{l}26 \\
53\end{array}$ & $\begin{array}{l}39 \\
59\end{array}$ & $\begin{array}{l}39 \\
68\end{array}$ & $\begin{array}{l}40 \\
69\end{array}$ & $\begin{array}{l}34 \\
66\end{array}$ \\
\hline Риддер & 808 & $\begin{array}{l}\text { Общая } \\
\text { Нижняя }\end{array}$ & $\begin{array}{l}28 \\
57\end{array}$ & $\begin{array}{l}30 \\
62\end{array}$ & $\begin{array}{l}41 \\
72\end{array}$ & $\begin{array}{l}42 \\
75\end{array}$ & $\begin{array}{l}36 \\
72\end{array}$ \\
\hline Катон-Карагай & 1080 & $\begin{array}{l}\text { Общая } \\
\text { Нижняя }\end{array}$ & $\begin{array}{l}34 \\
81\end{array}$ & $\begin{array}{l}37 \\
89\end{array}$ & $\begin{array}{l}47 \\
94\end{array}$ & $\begin{array}{l}48 \\
95\end{array}$ & $\begin{array}{l}41 \\
98 \\
\end{array}$ \\
\hline
\end{tabular}

Повышенная повторяемость ясного состояния неба и продолжительность солнечного сияния обусловлены положением гор в поясе антициклональной инверсии температуры воздуха и антициклональных фёнов. Пояс хорошо выражен в Рудном Алтае на высотах от 600 до 1300-1400, в Южном - от 800 до 1500 м, что открывает большие возможности для зимней рекреации.

Важной характеристикой радиационного режима, имеющей прикладное значение, является продолжительность солнечного сияния в часах. В пределах Казахстанского Алтая число часов солнечного сияния колеблется от 2287 в Усть-Каменогорске до 2566 в Большенарымском и 2778 часов в год в Буране (табл. 4).

Расчет суммарной солнечной радиации каждого месяца проводился по формуле:

$$
\Sigma \mathrm{Q}=49 \mathrm{~S}^{1,31} \cdot 10^{-4}+10,5\left(\sin \mathrm{h}_{0}\right)^{2,1},
$$

где $\Sigma \mathrm{Q}$ - суммарная радиация за месяц, $\mathrm{S}$ - продолжительность солнечного сияния в часах за месяц, $\mathrm{h}_{0}$ - полуденная высота Солнца на 15 число каждого месяца. Величины суммарной радиации приводятся в табл. 5. Точность расчета суммарной радиации лежит в пределах от 5 до $20 \%$. 
Продолжительность солнечного сияния, часы

\begin{tabular}{|c|c|c|c|c|c|c|c|c|c|c|c|c|c|}
\hline Станция & $\mathrm{I}$ & II & III & IV & $\mathrm{V}$ & VI & VII & VIII & IX & $\mathrm{X}$ & $\mathrm{XI}$ & XII & Год \\
\hline Зыряновск * & 91 & 142 & 187 & 229 & 268 & 297 & 317 & 300 & 221 & 152 & 89 & 72 & 2365 \\
\hline Буран & 139 & 150 & 205 & 261 & 327 & 331 & 343 & 329 & 269 & 194 & 124 & 106 & 2778 \\
\hline Зайсан & 136 & 150 & 191 & 228 & 280 & 290 & 311 & 296 & 249 & 183 & 126 & 105 & 2545 \\
\hline Семипалатинская аэрол. ст. & 113 & 137 & 197 & 238 & 302 & 314 & 321 & 305 & 251 & 153 & 103 & 89 & 2523 \\
\hline Усть-Каменогорск ${ }^{* *}$ & 74 & 106 & 161 & 212 & 292 & 314 & 323 & 292 & 228 & 136 & 96 & 53 & 2287 \\
\hline
\end{tabular}

* Продолжительность солнечного сияния подсчитана за 1980-1989 гг. ;

** За период 1970-1979 гг. 
Т а бли ц а 5

Суммарная солнечная радиация (Q) при действительных (средних) условиях облачности в пределах Юго-Западного Алтая, МДж/м²

\begin{tabular}{|c|c|c|c|c|c|c|c|c|c|c|c|c|c|}
\hline Станция & $\mathrm{I}$ & II & III & IV & $\mathrm{V}$ & VI & VII & VIII & IX & $\mathrm{X}$ & $\mathrm{XI}$ & XII & Год \\
\hline \multicolumn{14}{|c|}{ Измеренная суммарная солнечная радиация } \\
\hline Приозерный & 198 & 305 & 499 & 612 & 761 & 786 & 769 & 702 & 511 & 332 & 194 & 164 & 5833 \\
\hline * (Боран) & 184 & 285 & 457 & 587 & 742 & 775 & 763 & 670 & 499 & 323 & 193 & 138 & 5615 \\
\hline & 180 & 243 & 394 & 566 & 737 & 771 & 779 & 704 & 528 & 331 & 176 & 134 & $\overline{5543}$ \\
\hline Селезневка & 151 & 246 & 472 & 557 & 702 & 720 & 723 & 649 & 457 & 266 & 143 & 103 & 5191 \\
\hline \multicolumn{14}{|c|}{ Подсчитанная по методике С.И. Сивкова } \\
\hline $\begin{array}{l}\text { Большенарым } \\
\text { (Улкен Нарын) }\end{array}$ & 163 & 231 & 374 & 416 & 680 & 728 & 736 & 651 & 496 & 290 & 158 & 109 & 5033 \\
\hline $\begin{array}{l}\text { Усть- } \\
\text { Каменогорск }\end{array}$ & 101 & 176 & 318 & 478 & 666 & 729 & 733 & 633 & 453 & 243 & 134 & 71 & 4735 \\
\hline Катон-Карагай & 155 & 247 & 381 & 524 & 645 & 683 & 700 & 608 & 469 & 285 & 155 & 105 & 4957 \\
\hline Зайсан & 172 & 268 & 377 & 524 & 666 & 708 & 733 & 662 & 503 & 327 & 184 & 138 & 5271 \\
\hline \multicolumn{14}{|c|}{ Подсчитанная по методике Т.Г. Берлянд } \\
\hline Зыряновск ${ }^{*}$ & 119 & 218 & 353 & 504 & 633 & 704 & 727 & 646 & 445 & 273 & 231 & 90 & 4943 \\
\hline & 109 & $\overline{197}$ & $\overline{331}$ & $\overline{503}$ & $\overline{616}$ & $\overline{637}$ & $\overline{616}$ & $\overline{570}$ & $\overline{436}$ & $\overline{222}$ & $\overline{143}$ & $\overline{92}$ & $\overline{4458}$ \\
\hline Шемонаиха & 126 & 218 & 344 & 486 & 616 & 683 & 666 & 578 & 419 & 235 & 126 & 71 & 4567 \\
\hline Курчум & 163 & 189 & 394 & 553 & 658 & 725 & 712 & 654 & 486 & 302 & 172 & 122 & 5129 \\
\hline Самарско & 155 & 260 & 398 & 406 & 654 & 721 & 696 & 616 & 482 & 298 & 168 & 113 & 4965 \\
\hline Буран & 168 & 251 & 393 & 536 & 649 & 700 & 687 & 612 & 486 & 310 & 184 & 126 & 5103 \\
\hline \multicolumn{14}{|c|}{ Измеренная на станциях Семипалатинского Прииртышья } \\
\hline $\begin{array}{l}\text { Аэрологическая } \\
\text { станция, Семей }\end{array}$ & 163 & 251 & 448 & 566 & 717 & 729 & 708 & 629 & 453 & 260 & 151 & 117 & 5191 \\
\hline Кокпекты & 176 & 230 & 390 & 545 & 721 & 763 & 754 & 687 & 520 & 310 & 172 & 130 & 5397 \\
\hline Пос. Орловский & 158 & 260 & 287 & 527 & 626 & 665 & 639 & 560 & 458 & 294 & 172 & 120 & 4764 \\
\hline
\end{tabular}

- В числителе фактически наблюдаемая величина, в знаменателе рассчитанная по методике С.И. Сивкова.

Годовой ход суммарной солнечной радиации и согласованность расчетных данных с фактическими иллюстрируется графиком (рис. 9).

Анализ карт географического распределения годовых сумм солнечной радиации [14], показывает, что самые высокие значения ее параметров отмечаются в южной половине умеренного пояса Евразии над Срединным регионом (60-90 Западного Алтая. В северных его районах суммарная радиация составляет 4,6-4,7, в центральных - 4,8-5,0 и в Зайсанской впадине 5,3-5,8 тыс. МДж/ $\mathrm{M}^{2}$ в год. 
Рассчитанные суммарной радиации выровненным расположенным на различных гипсометрических уровнях, и к пологим склонам хребтов (рис.10).

На территории Юго-Западного Алтая преобладают склоны крутизной от 10 до $30^{0}$, первые из них чаще всего используются под пашни, вторые - под пастбища. Летом на широте $50^{\circ}$ при действительных условиях облачности южные склоны крутизной $30^{0}$ получают суммарной радиации на 5-6\% меньше, а зимой, наоборот, на 22-38\% больше, чем горизонтальная поверхность.

Северные склоны такой же крутизны летом получают суммарной радиации на 16-20\% меньше, чем горизонтальная поверхность, зимой
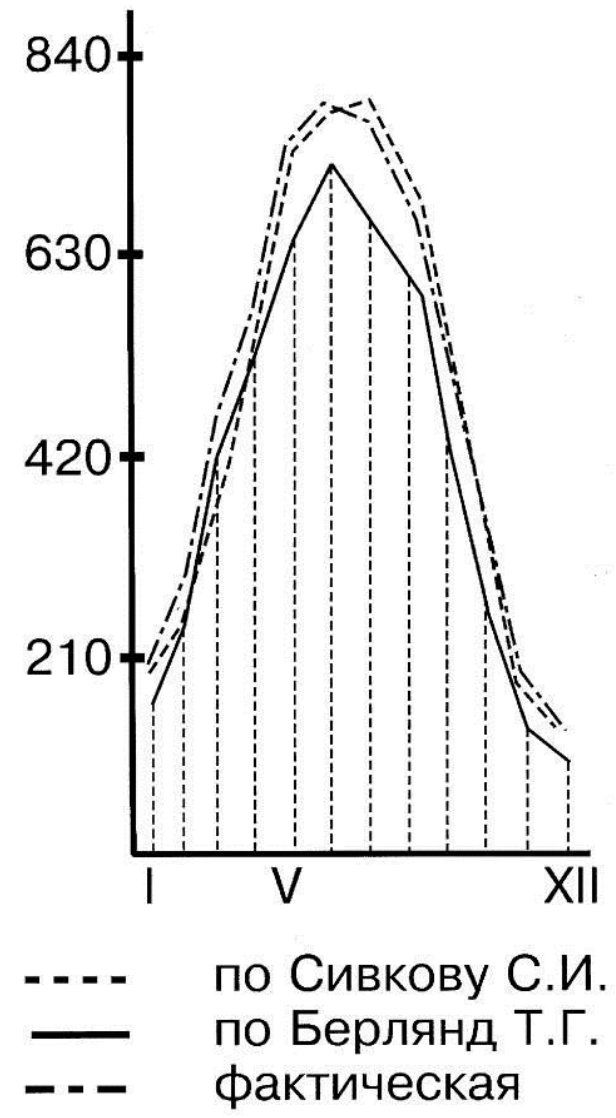

Рис. 9. Годовой ход суммарной солнечной радиации

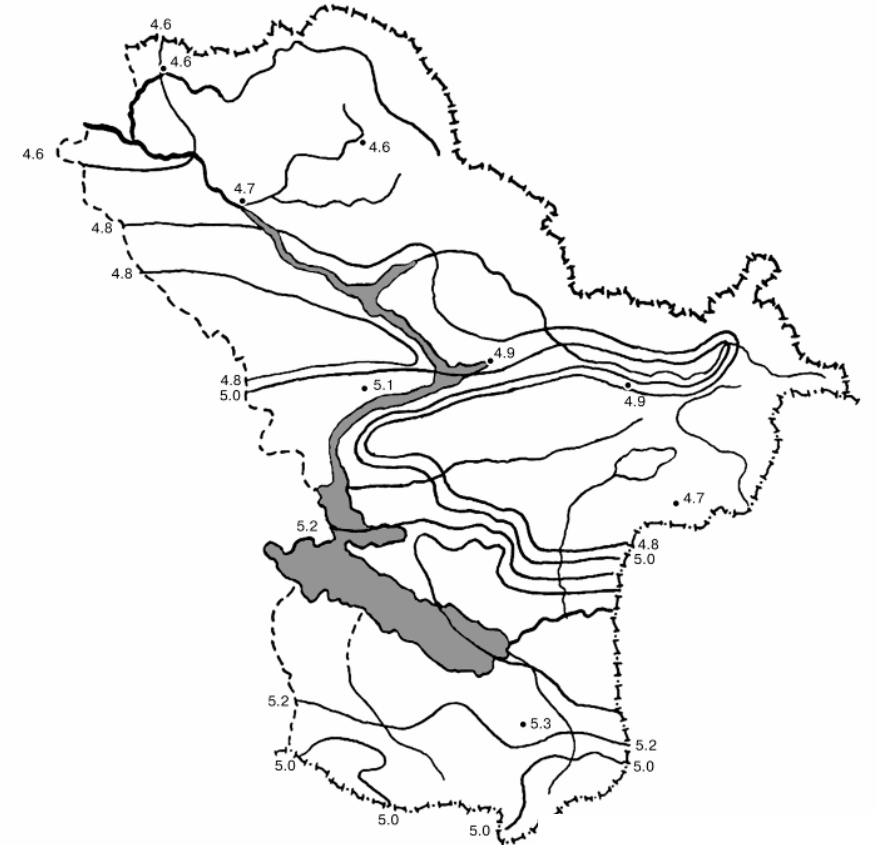

- 4.8 - изолинии суммарной солнечной радиации / в тыс. МДж/м². год

- 4.6 станции

Рис. 10. Картосхема суммарной солнечной радиации. Год приток радиации к северным склонам близок к нулю. Южные склоны крутизной $10^{0}$ летом получают на горизонтальную поверхность $101 \%$ от суммарной радиации, a зимой $115 \%$. Северные склоны летом получают 96, а зимой $84 \%$.

На приток радиации оказывают влияние не только географическая широта и высота местности, но и такие факторы как прозрачность воздуха, режим облачности и ряд других. В годовом выводе с высотой местности идет медленное нарастание значений суммарной солнечной радиации. Так, в Усть-Каменогорске (высота 284 м) Q равна 4735, в 
Риддере (809 м) - 4814, в Катон-Карагае (1080 м) - 4957 МДж/м² в год. В летние месяцы, особенно в июле, августе, а также в октябре в Рудном Алтае в среднегорье и высокогорье мощная облачность меняет характер распределения суммарной радиации по высоте. Выше 1600 м даже отмечается ее снижение. Часто на одной и той же высоте, но в различных формах рельефа (на склоне хребта и котловине) суммарная радиация количественно различна.

По наблюдениям, в Южном и Центральном Алтае в июне отмечен вертикальный градиент сумм солнечной радиации в 36 МДж/м $\mathrm{M}^{2}$, что составляет 5\% на каждые 1000 м поднятия [8,15]. По мнению других авторов, он может доходить до 10\% на каждые 1000 м поднятия. Поэтому для характеристики радиационного режима климата Юго-Западного Алтая только анализа распределения радиации по высоте места и географическому положению недостаточно. Для этого необходимо рассматривать особенности прихода и расхода радиационного тепла в пределах отдельных крупных геосистем региона.

Составляющие радиационного баланса подстилающей поверхности. В годовом выводе прямая солнечная радиация на горизонтальную поверхность ( $\left.\mathrm{S}^{\prime}\right)$ составляет в Буране 65, в Тугыле (Приозерное) 63, в Селезневке 58\% от суммарной. С увеличением облачности возрастает удельный вес рассеянной радиации (Д). В суточном ходе она преобладает утром и вечером, в годовом ходе зимой (табл. 6,7 ).

Т а бли ц а 6

Годовой ход сумм измеренной прямой солнечной радиации на горизонтальную поверхность (S'), МДж/м²

\begin{tabular}{|c|c|c|c|c|c|c|c|c|c|c|c|c|c|}
\hline Станции & I & II & III & IV & V & VI & VII & VIII & IX & X & XI & XII & Год \\
\hline $\begin{array}{l}\text { Буран } \\
48^{0} 00^{\prime} \text { с. ш. }\end{array}$ & $\frac{92}{50}$ & $\frac{147}{52}$ & $\frac{262}{57}$ & $\frac{385}{66}$ & $\frac{503}{68}$ & $\frac{545}{70}$ & $\frac{528}{69}$ & $\frac{474}{71}$ & $\frac{360}{72}$ & $\frac{210}{65}$ & $\frac{92}{48}$ & $\frac{54}{39}$ & $\frac{3654}{65}$ \\
\hline $\begin{array}{c}\text { Тугыл } \\
47^{0} 48^{\prime} \text { с. ш. }\end{array}$ & $\frac{87}{44}$ & $\frac{147}{48}$ & $\frac{241}{48}$ & $\frac{376}{61}$ & $\frac{510}{67}$ & $\frac{547}{70}$ & $\frac{538}{70}$ & $\frac{503}{72}$ & $\frac{352}{69}$ & $\frac{200}{60}$ & $\frac{96}{49}$ & $\frac{71}{43}$ & $\frac{3668}{63}$ \\
\hline $\begin{array}{c}\text { Селезневка } \\
49^{0} 40^{\prime} \text { с. ш. }\end{array}$ & $\frac{55}{36}$ & $\frac{93}{38}$ & $\frac{226}{48}$ & $\frac{310}{56}$ & $\frac{440}{63}$ & $\frac{461}{64}$ & $\frac{473}{65}$ & $\frac{437}{67}$ & $\frac{301}{66}$ & $\frac{144}{54}$ & $\frac{61}{43}$ & $\frac{28}{27}$ & $\frac{3033}{58}$ \\
\hline
\end{tabular}

Пр и ме ч а н и : Знаменатель - отношение прямой солнечной радиации к суммарной, \%. 
Оценочные данные по радиационному балансу подстилающей поверхности получены на основе величин суммарной солнечной радиации и по соотношению $\mathrm{B}$ : Q, измеренных в различных природных ландшафтах Казахстанского и Горного Алтая, а также других районов $[13,15,16,17]$. Величины радиационного баланса приведены на рис. 11 и в табл. 8.

Так, в полупустыне (пос. Тугыл) $\mathrm{B}: \mathrm{Q}=0,34$, в степи (Семей) 0,36, лесостепи (Селезневка) - 0,38, во влажных ландшафтах Горного Алтая - 0,38, в украинской лесостепи (Киев) - 0,40.

Т а б ли ц а 7

Альбедо естественных поверхностей (по М.И. Будыко, 1971)

\begin{tabular}{|c|c|}
\hline Вид поверхности & Альбедо \\
\hline \multicolumn{2}{|l|}{ Снег } \\
\hline Свежий сухой снег & $0.85-0.95$ \\
\hline Чистый влажный снег & $0.60-0.70$ \\
\hline Загрязненный снег & $0.40-0.50$ \\
\hline \multicolumn{2}{|l|}{ Обнаженная почва } \\
\hline Темные почвы & $0.05-0.15$ \\
\hline Влажные серые почвы & $0.10-0.20$ \\
\hline Сухие глинистые или серые почвы & $0.20-0.35$ \\
\hline Сухие светлые песчаные почвы & $0.35-0.40$ \\
\hline \multicolumn{2}{|l|}{ Поля, луга, тундра } \\
\hline Поля ржи и пшеницы & $0.10-0.25$ \\
\hline Картофельные поля & $0.15-0.25$ \\
\hline Луга & $0.15-0.25$ \\
\hline Лесостепь & $0.15-0.20$ \\
\hline Сухая степь & $0.20-0.30$ \\
\hline Полупустыня и пустыня & $0.28-0.35$ \\
\hline Тундра & $0.15-0.20$ \\
\hline \multicolumn{2}{|l|}{ Древесная растительность } \\
\hline Хвойные леса & $0.10-0.15$ \\
\hline Лиственные леса & $0.15-0.20$ \\
\hline Лес при снежном покрове (неустойчивом) & $0.25-0.30$ \\
\hline Лес при снежном покрове (устойчивом) & $0.40-0.45$ \\
\hline
\end{tabular}

Годовые величины радиационного баланса изменяются в предгорных равнинах от 1690 МДж/м² (Шемонаиха), в низкогорье от 1838-1862 МДж/м² (Зыряновск, Большенарымское) до 1996 МДж/м² (пос. Тугыл). В сухих горных котловинах он составляет 1763 МДж/м² 
(пос. Орловский), в высокогорных пустынях (Кош-Агач) из-за большого эффективного излучения радиационный баланс уменьшен и составляет только 1446 МДж/м². В горах с увеличением высоты он не уменьшается, а, наоборот, возрастает, так как при переходе от равнин к склонам растет облачность. В частности, в Усть-Каменогорске годовой радиационный баланс составляет 1752, в Риддере - 1829, в Селезневке-1953МДж/ ${ }^{2}$.

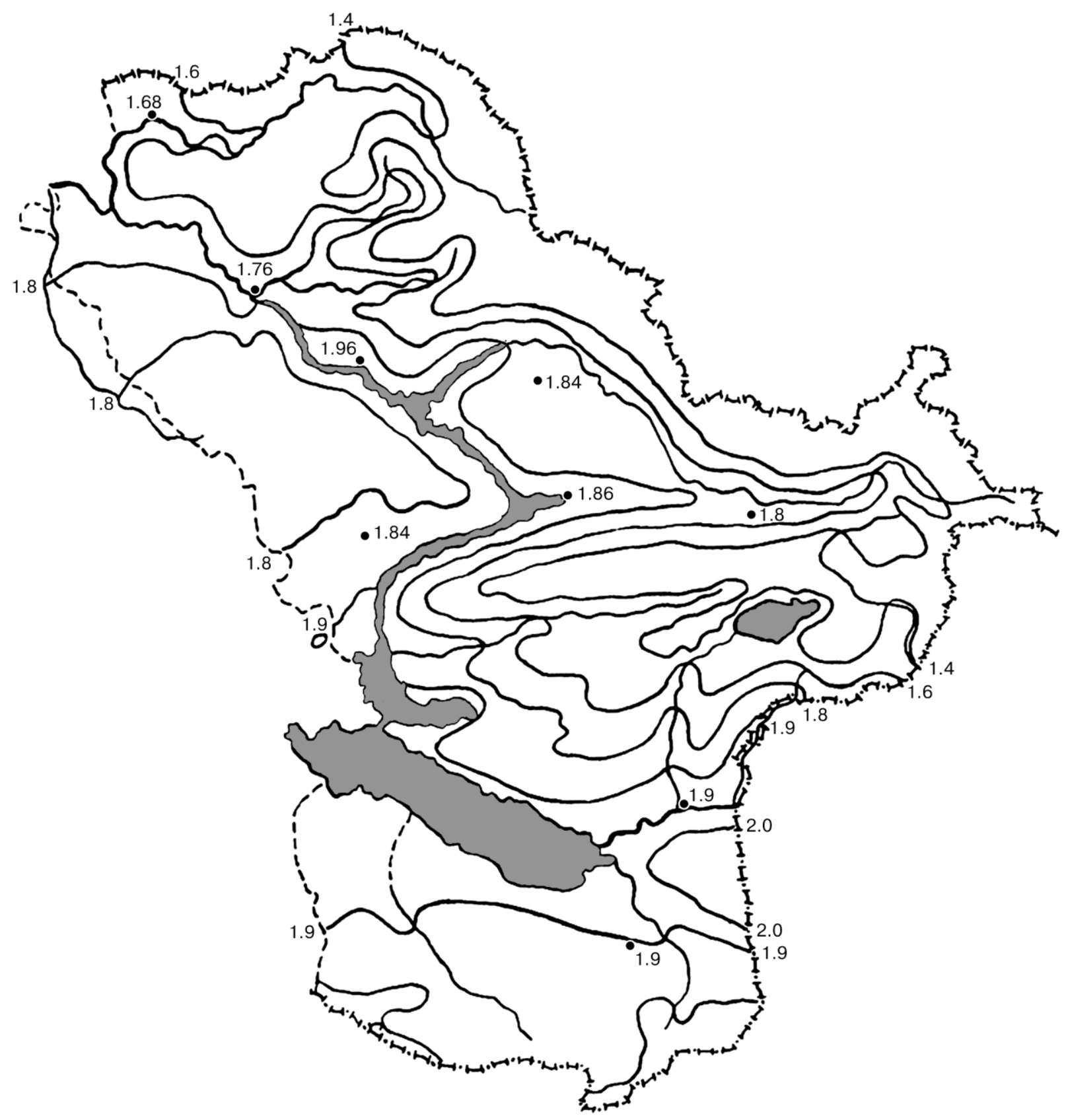

Радиационный баланс

/ в тысячах мДж/м²• год /

Рис. 11. Картосхема радиационного баланса. Год 
Радиационный баланс подстилающей поверхности, МДж/м² год (ккал/см² год)

\begin{tabular}{|c|c|c|c|}
\hline Станция, координаты местности & $\begin{array}{l}\text { Высота, } \\
\text { м }\end{array}$ & $\mathrm{B}: \mathrm{Q}$ & $\begin{array}{l}\text { Радиационнь } \\
\text { й баланс }\end{array}$ \\
\hline 1. Зайсан, $47^{0} 28^{\prime}$ с. ш., $84^{0} 55^{\prime}$ в.д. & 603 & 0.36 & $1898(45.3)$ \\
\hline 2. Тугыл (Приозерный), 470048' & & 0.34 & $1996(47.6)$ \\
\hline 3. Буран, $48^{0} 00^{\prime}$ с. ш., $85^{0} 12^{\prime}$ в.д. & 410 & 0.34 & $1909(45.6)$ \\
\hline 4. Курчум, $48^{0} 35^{\prime}$ с. ш., $83^{0} 39^{\prime}$ в.д. & 432 & 0.36 & $1846(44.0)$ \\
\hline 5. Кокпекты, $48^{0} 45^{\prime}$ с. ш., $82^{0} 22^{\prime}$ в.д. & 511 & 0.36 & $1943(46.4)$ \\
\hline 6. Самарка, $49^{0} 02^{\prime}$ с. ш., $83^{0} 24^{\prime}$ в.д. & 500 & 0.37 & $1837(43.8)$ \\
\hline 7. Большенарымское, $49^{0} 10^{\prime}$ с. ш., $84^{0} 30^{\prime}$ в.д. & 350 & 0.37 & $1862(44.4)$ \\
\hline 8. Катон-Карагай, $49^{0} 10^{\prime}$ с. ш., $85^{0} 39^{\prime}$ в.д. & 1080 & 0.37 & $1834(43.8)$ \\
\hline 9. Селезневка, $49^{0} 40^{\prime}$ с. ш., $83^{0} 31^{\prime}$ в.д. & 396 & 0.38 & $1959(46.8)$ \\
\hline 10. Зыряновск, $49^{0} 44^{\prime}$ с. ш., $84^{0} 18^{\prime}$ в.д. & 457 & 0.38 & $1838(43.9)$ \\
\hline $\begin{array}{l}\text { 11. Усть-Каменогорск, } 49^{0} 57^{\prime} \text { с. ш., } \\
82^{0} 43^{\prime} \text { в.д. }\end{array}$ & 284 & 0.37 & $1752(41.8)$ \\
\hline $\begin{array}{l}\text { 12. Риддер (Лениногорск), } 50^{0} 20^{\prime} \text { с. ш., } \\
83^{0} 33^{\prime} \text { в.д. }\end{array}$ & 809 & 0.38 & $1829(43.6)$ \\
\hline $\begin{array}{l}\text { 13. Семей (Семипалатинск), 50²4' с. ш., } \\
80^{\circ} 13^{\prime} \text { в.д. }\end{array}$ & 202 & 0.36 & $1864(44.6)$ \\
\hline 14. Шемонаиха, $50^{0} 38^{\prime}$ с. ш., $81^{0} 55^{\prime}$ в.д. & 309 & 0.37 & $1690(40.3)$ \\
\hline 15. Пос. Орловский, $48^{0} 42^{\prime}$ с. ш., $86^{0} 29^{\prime}$ в.д. & 1100 & 0.37 & $1763(42.1)$ \\
\hline 16. Кош-Агач, $50^{0} 01^{\prime}$ с. ш., $88^{0} 41^{\prime}$ в.д. & 1922 & $\begin{array}{c}\text { Измеренные } \\
(88,89)\end{array}$ & $1446(34.5)$ \\
\hline 17. Ак-Кем, $49^{0} 55^{\prime}$ с. ш., $86^{0} 33^{\prime}$ в.д. & 2060 & - & $1831(43.7)$ \\
\hline 18. Кара-Тюрек, $49^{0} 59^{\prime}$ с. ш., $86^{0} 25^{\prime}$ в.д. & 2750 & - & $1563(37.3)$ \\
\hline 19. Усть-Кокса, $50^{0} 17^{\prime}$ с. ш., $85^{0} 37^{\prime}$ в.д. & 931 & - & $1923(45.9)$ \\
\hline
\end{tabular}

Приме чание : 1. Bсе параметры радиационного баланса (В) относятся к горизонтальной поверхности либо к пологим склонам хребтов. 1 ккал/см ${ }^{2}=41,9$ МДж/м ${ }^{2}$.

2. Здесь и далее прочерки в таблице обозначают отсутствие данных.

Но в поясе снежности из-за большого альбедо и излучения снежной поверхности его величины могут резко уменьшиться.

Таким образом, из-за большой пространственной изменчивости величин радиационного баланса можно говорить лишь о тенденции изменения сумм радиационного тепла, полученных расчетным методом (см. табл. 7). Изменения радиационного баланса за год приведены в табл. 9.

Как видно из таблицы, период отрицательных значений радиационного баланса на всех высотах длится 3-4 месяца. Переход его через ноль происходит в первой декаде марта и в конце первой декады ноября, быстрый рост от марта к апрелю обусловлен 
увеличением высоты Солнца над горизонтом и сходом снежного покрова. Максимальные средние значения баланса приходятся на май-июль. Летом радиационный баланс составляет 18-21\% годовой суммы. В суточном ходе переход радиационного баланса через ноль наблюдается спустя час после восхода Солнца и за 1 час 10 мин. до его захода.

Т а бли ц а 9

Изменения радиационного баланса подстилающей поверхности, МДж/м² · месяц

\begin{tabular}{|c|c|c|c|c|c|c|c|c|c|c|c|c|c|}
\hline \multirow[b]{2}{*}{ Станция } & \multicolumn{13}{|c|}{ Месяцы } \\
\hline & I & II & III & IV & V & VI & VII & VIII & IX & $X$ & XI & XII & $\begin{array}{c}\text { Сум- } \\
\text { ма }\end{array}$ \\
\hline Селезневка & -23 & -13 & 32 & 265 & 377 & 390 & 381 & 318 & 188 & 76 & -5 & -27 & 1959 \\
\hline Прио & -23 & -9 & 69 & 294 & 366 & 365 & 382 & 296 & 184 & 95 & 4 & -27 & 1996 \\
\hline $\mathrm{y}_{\mathrm{cTt}}$ & -29 & 13 & 117 & 314 & 352 & 360 & 327 & 264 & 176 & 59 & -4 & -25 & 1923 \\
\hline Ак-Кем & -4 & 13 & 130 & 256 & 390 & 339 & 302 & 260 & 168 & 25 & -25 & -21 & 1831 \\
\hline
\end{tabular}

Данные, полученные в результате исследования изменения величины радиационного баланса и его составляющих в различных природных комплексах Юго-Западного Алтая, были использованы для составления картосхемы радиационного баланса.

Анализ картосхемы показывает, что в условиях равнинного рельефа изолинии суммарной радиации и радиационного баланса должны проходить примерно вдоль параллелей. В восточной части региона изолинии отклоняются к югу, что указывает на уменьшение их величин: суммарной радиации - за счет увеличения облачности над горами, а радиационного баланса - за счет роста с высотой эффективного излучения и альбедо поверхности, то есть, за счет более длительного залегания снежного покрова [18].

Тип ландшафта, их биоклиматический и экологический потенциалы определяются соотношением тепла и влаги.

Структуру теплового баланса подстилающей поверхности в общем виде можно представить формулой:

$$
\mathrm{B}=\mathrm{LE}+\mathrm{P}+\mathrm{V} \text {, }
$$

где B - радиационный баланс, LE - затраты тепла на испарение осадков, P - турбулентный теплообмен между подстилающей поверхностью и атмосферой, V - теплообмен в почве. В годовом выводе $\mathrm{B}=\mathrm{LE}+\mathrm{P}$, так как теплообмен в почве равен нулю. Величина испарения (Е)на предгорных равнинах Рудного Алтая в годовом 
выводе достигает 400-450 мм. В Зайсанской впадине испарение составляет 180-250 мм в год (рис. 12).

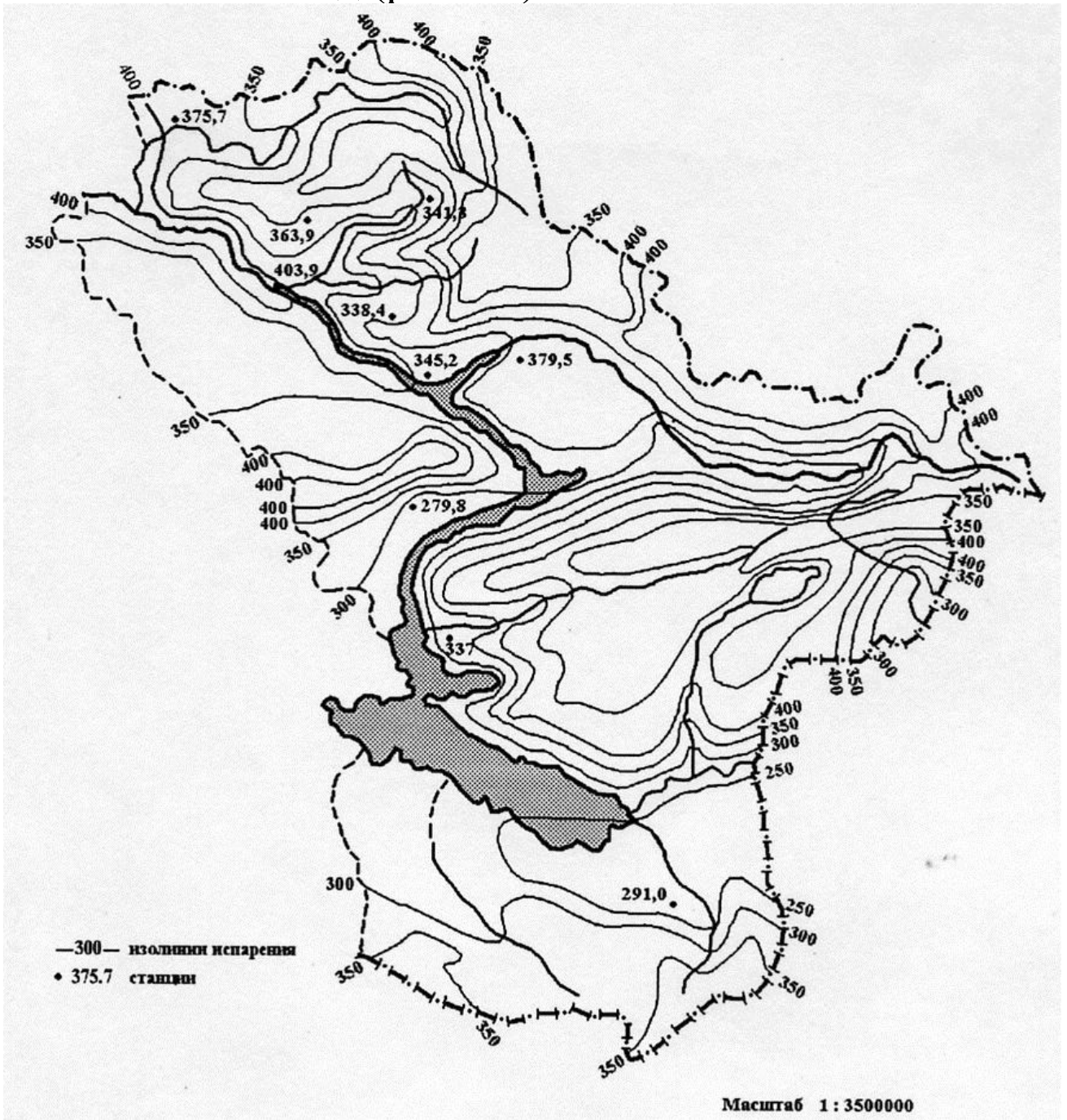

Рис. 12. Картосхема испарения с почвы снега. Год

Т а бли ц а 10

Структура теплового баланса подстилающей поверхности по ландшафтным провинциям, МДж/м² год

\begin{tabular}{|c|c|c|c|}
\hline Метеостанция & $\mathrm{B}$ & LE & $\mathrm{P}$ \\
\hline \multicolumn{4}{|c|}{ Р удн ны й Ал та й } \\
\hline Усть-Каменогорск & 1752 & 914 & 838 \\
\hline Шемонаиха & 1690 & 913 & 777 \\
\hline Зыряновск & 1838 & 951 & 887 \\
\hline \multicolumn{4}{|c|}{ Ю ж н ы й А л т а й } \\
\hline Катон-Карагай & 1835 & 712 & $1123 *$ \\
\hline Пос. Орловский & 1763 & 582 & 1181 \\
\hline Самарка & 1837 & 704 & 1133 \\
\hline \multicolumn{4}{|c|}{ Зайсанскаявпадина } \\
\hline Буран & 1909 & 733 & 1176 \\
\hline Зайсан & 1898 & 557 & 1341 \\
\hline
\end{tabular}


Испарение влаги с поверхности почвы и снега (в мм) по станциям Юго-Западного Алтая

\begin{tabular}{|c|c|c|c|c|c|c|c|c|c|c|c|c|c|}
\hline Метеостанция & $\mathrm{I}$ & II & III & IV & $\mathrm{V}$ & VI & VII & VIII & IX & $X$ & $\mathrm{XI}$ & XII & Год \\
\hline \multicolumn{14}{|c|}{ Рудный Алтай } \\
\hline Усть-Каменогорск & -5 & -3 & 12 & 45 & 65 & 69 & 74 & 68 & 27 & 12 & 1 & -6 & 363 \\
\hline Зыряновск & -5 & -4 & 6 & 44 & 71 & 85 & 94 & 66 & 25 & 12 & -7 & -6 & 379 \\
\hline Риддер & 0 & 2 & 17 & 30 & 55 & 68 & 76 & 55 & 17 & 5 & 1 & -5 & 321 \\
\hline \multicolumn{14}{|c|}{ Южный Алтай } \\
\hline Курчум & -5 & 1 & 13 & 42 & 57 & 67 & 78 & 57 & 24 & 10 & 0 & -7 & 337 \\
\hline \multicolumn{14}{|c|}{ Калба } \\
\hline Самарка & -2 & 1 & 16 & 37 & 56 & 58 & 54 & 40 & 18 & 9 & 0 & -6 & 281 \\
\hline Семей & -2 & 3 & 16 & 44 & 54 & 55 & 61 & 50 & 20 & 11 & -1 & -6 & 303 \\
\hline \multicolumn{14}{|c|}{ Зайсанская впадина } \\
\hline
\end{tabular}


Для метеостанций Юго-Западного Алтая расчет испарения выполнен по методике А.Р. Константинова [19]. Полученные величины относятся не только к данному метеорологическому пункту, но и характеризуют определенную территорию, так как температура и влажность воздуха отражают гидротермические свойства ландшафта, в пределах которого расположена метеостанция. В связи с тем, что в регионе ряд метеостанций располагается вблизи русел рек, то возможно завышение величины испарения, поскольку близость к водоему может привести к некоторому завышению упругости водяного пара в приземном слое.

Структура теплового баланса по метеостанциям Юго-Западного Алтая отражена в табл. 10, месячные и годовые величины испарения приведены в табл. 11.

Оценочные данные по радиационному балансу (В), испарению (Е), $\mathrm{F}$ - стоку и коэффициенту стока $\left(\mathrm{K}=\frac{F}{r}\right.$, где $\mathrm{r}$ - атмосферные осадки) представлены в табл. 12.

Т а бли ц а 12

Физические параметры для расчета составляющих водного баланса

\begin{tabular}{|l|c|c|c|c|c|c|}
\hline \multicolumn{1}{|c|}{ Метеостанция } & $\begin{array}{c}\text { В, } \\
\text { ккал/см год }\end{array}$ & Е, см & r, см & F, см & $\frac{B}{L r}$ & К $=\frac{F}{r}$ \\
\hline Шемонаиха & 40.3 & 36.0 & 40.0 & 4.0 & 1.6 & 0.10 \\
\hline Усть-Каменогорск & 41.8 & 36.3 & 50.0 & 13.7 & 1.4 & 0.27 \\
\hline Зыряновск & 43.9 & 37.9 & 56.5 & 18.5 & 1.3 & 0.33 \\
\hline Самарка & 43.8 & 28.1 & 36.5 & 8.4 & 2.0 & 0.23 \\
\hline Пос. Орловский & 42.1 & 23.2 & 32.8 & 9.6 & 2.0 & 0.29 \\
\hline Буран & 45.6 & 29.2 & 18.9 & - & 4.0 & - \\
\hline Зайсан & 45.3 & 22.1 & 29.1 & 7.0 & 2.6 & 0.24 \\
\hline
\end{tabular}

Приведенные данные показывают, что приток солнечной радиации определяет структуру теплового и водного балансов. Эти данные будут необходимы при проведении мероприятий по оптимизации окружающей среды.

Испаряемость. Наряду с действительным испарением, испаряемость характеризует термический потенциал природных ландшафтов. Действительное же испарение зависит от наличия влаги в почве и обусловлено: притоком солнечной радиации, дефицитом влажности, скоростью ветра и давлением атмосферы. В годовом выводе испаряемость определяется величиной радиационного 
баланса и характеризует запас тепловой энергии в ландшафте или иссушающую способность воздуха. Интенсивность испаряемости находится в зависимости от дефицита влажности воздуха и величины турбулентного влагообмена.

Результаты расчетов испаряемости по Н.Н. Иванову [20] представлены в табл. 13.

Т а блиц а 13

Испаряемость $\left(\mathrm{E}_{0}\right)$ в мм и коэффициент увлажнения

по Иванову-Высоцкому $\left(\frac{r}{E_{0}}\right)$

\begin{tabular}{|c|c|c|c|c|c|c|c|c|c|c|c|c|c|c|}
\hline Станции & I & II & III & IV & V & VI & VII & VIII & IX & $\mathrm{X}$ & XI & XII & Год & $\mathrm{K}=\frac{r}{E_{0}}$ \\
\hline \multicolumn{15}{|c|}{ Рудный Алтай } \\
\hline $\begin{array}{l}\text { Усть- } \\
\text { Каменогорск }\end{array}$ & 3 & 4 & 13 & 40 & 109 & 128 & 133 & 118 & 87 & 52 & 16 & 6 & 719 & 0.63 \\
\hline Шемонаиха & 2 & 2 & 9 & 40 & 102 & 124 & 128 & 118 & 82 & 43 & 12 & 4 & 666 & 0.60 \\
\hline $\begin{array}{l}\text { Пос. } \\
\text { Северный }\end{array}$ & 7 & 7 & 15 & 49 & 103 & 107 & 111 & 110 & 93 & 51 & 14 & 7 & 674 & 0.85 \\
\hline Зыряновск & 0 & 0 & 4 & 24 & 94 & 102 & 102 & 93 & 62 & 28 & 5 & 1 & 515 & 1.10 \\
\hline Риддер & 8 & 9 & 18 & 49 & 91 & 104 & 100 & 93 & 71 & 45 & 16 & 9 & 613 & 1.03 \\
\hline \multicolumn{15}{|c|}{ Калба } \\
\hline Самарка & 2 & 4 & 13 & 69 & 133 & 164 & 179 & 173 & 129 & 68 & 15 & 3 & 952 & 0.38 \\
\hline $\begin{array}{l}\text { Семипалати } \\
\text { нск аэролог. } \\
\text { станция }\end{array}$ & 3 & 3 & 10 & 54 & 122 & 160 & 156 & 140 & 98 & 51 & 14 & 5 & 816 & 0.35 \\
\hline \multicolumn{15}{|c|}{ Южный Алтай } \\
\hline Курчум & 1 & 1 & 9 & 64 & 129 & 150 & 152 & 147 & 116 & 61 & 14 & 2 & 845 & 0.30 \\
\hline $\begin{array}{l}\text { Катон- } \\
\text { Карагай }\end{array}$ & 7 & 10 & 23 & 57 & 96 & 104 & 109 & 102 & 87 & 53 & 16 & 8 & 672 & 0.64 \\
\hline $\begin{array}{l}\text { Пос. } \\
\text { Орловский }\end{array}$ & 0 & 0 & 5 & 29 & 89 & 101 & 95 & 83 & 65 & 32 & 4 & 0 & 503 & 0.65 \\
\hline \multicolumn{15}{|c|}{ Зайсанская впадина } \\
\hline Зайсан & 2 & 3 & 16 & 78 & 149 & 208 & 229 & 221 & 160 & 75 & 17 & 4 & 1162 & 0.25 \\
\hline Буран & 2 & 3 & 8 & 75 & 140 & 172 & 176 & 164 & 118 & 65 & 18 & 5 & 946 & 0.20 \\
\hline
\end{tabular}

В пределах предгорных равнин Рудного Алтая испаряемость за год достигает: в Зыряновске - 522, в пос. Северный - 663, в Шемонаихе - 665, в окрестностях Усть-Каменогорска - 742, в Зайсанской котловине - 1200 мм (рис. 13).

В марте и апреле величины испарения и испаряемости на севере территории близки между собой. На юге - уже в апреле испаряемость значительно превышает испарение. Так, в Зайсане испаряемость составляет 78, а испарение - 35 мм. 


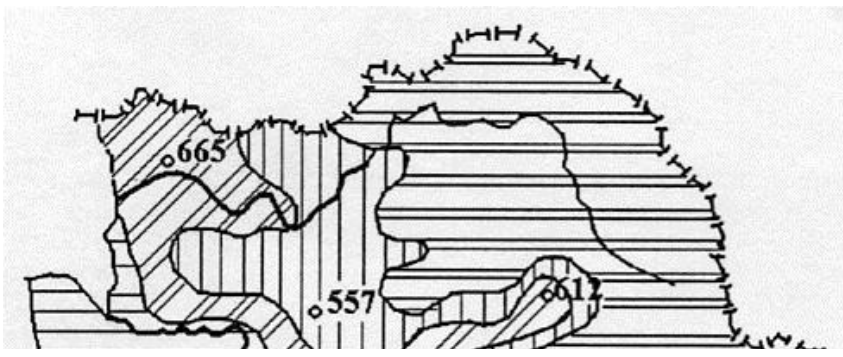

Рис. 13. Картосхема испаряемости. Год

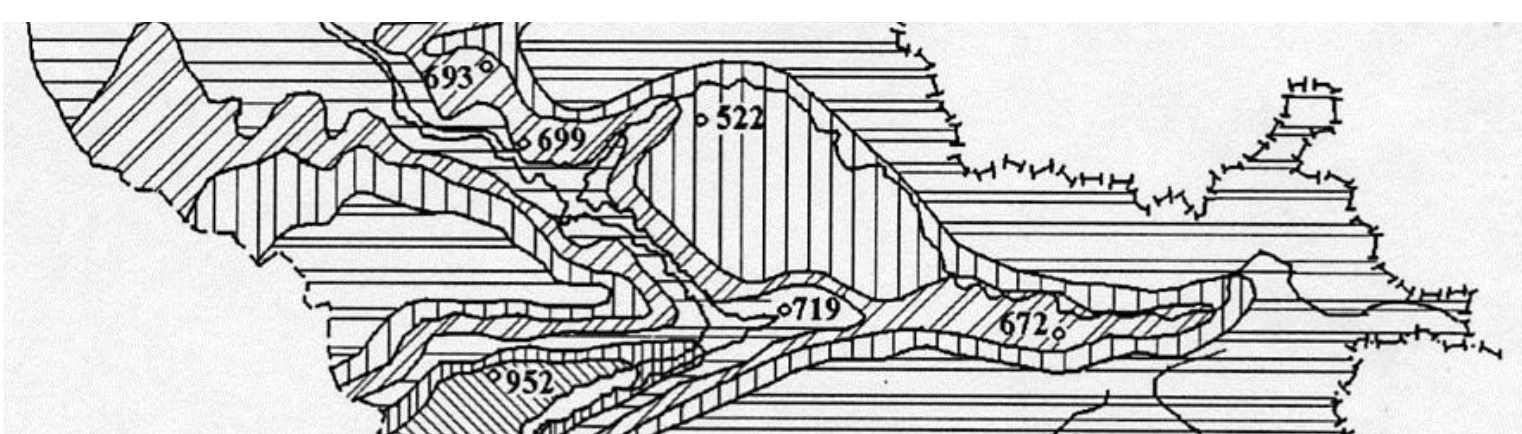




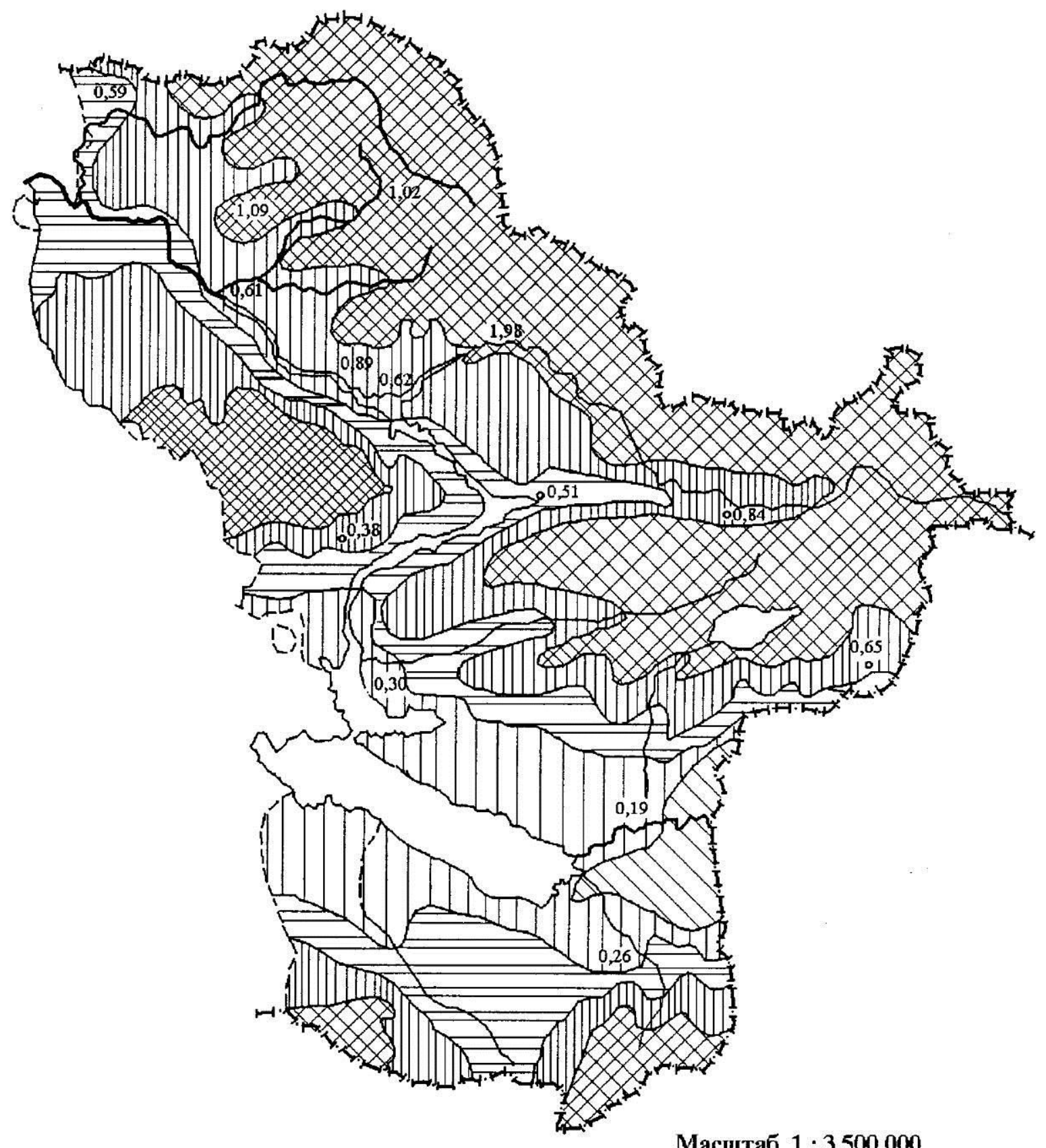

Коэффициент увлажнения. Год

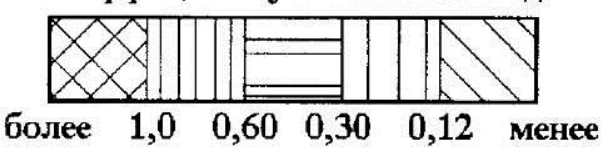

Рис. 14. Картосхема годового коэффициента увлажнения Юго-Западного Алтая. Год 

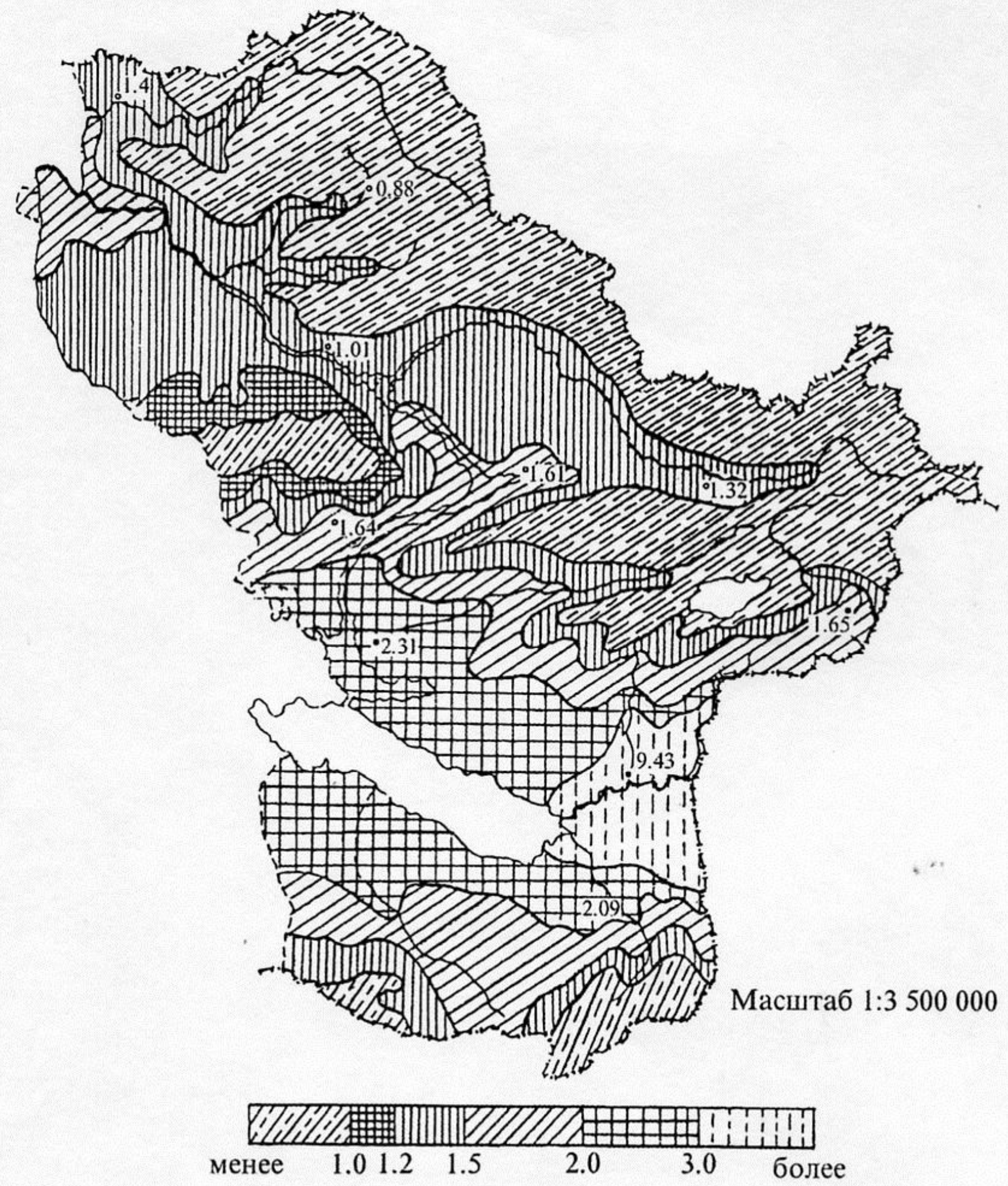

0.88 - значение индекса сухости

Рис. 15. Картосхема радиационного индекса сухости. Год 
Максимальное испарение и испаряемость на предгорных равнинах Рудного Алтая наблюдаются в июне и июле, при этом испаряемость почти в 2 раза превышает испарение. В горно-степных районах Калбинского нагорья, при максимуме испаряемости в июле и августе, максимум испарения приходится на май и июнь. В июле отмечается незначительное уменьшение испарения. В августе оно составляет примерно 65-70\% от июньского. Испаряемость превышает испарение в июне в 2,5-2,7, а в июле более чем в три раза. В Зайсанской котловине максимальное испарение приходится на майиюнь. В последующие месяцы, в связи со снижением содержания влаги в почве, испарение резко уменьшается и в августе составляет около 55\% от июньского. Максимум же испаряемости приходится на июль и август, то есть на месяцы наибольшего прогрева воздушных масс над котловиной: 220-230 мм в месяц, превышая в 6-7 раз испарение.

Таким образом, структура гидротермического компонента наиболее четко выражается через соотношение тепла и влаги и представлена различными коэффициентами увлажнения, которые и являются индикаторами ландшафтов (рис. 14, 15).

Отношение осадков к испаряемости показывает степень увлажненности ландшафтов. Оптимальные условия для развития растительности создаются тогда, когда осадки равны испаряемости или коэффициент (К) Иванова-Высоцкого равен 1.

$$
\mathrm{K}=\frac{r}{E_{0}},
$$

где $\mathrm{r}$ - осадки в мм, $\mathrm{E}_{0}$ - испаряемость в мм.

В зависимости от величины годового коэффициента принято выделять следующие зоны:

1. Избыточного увлажнения; K > 1,5. Формируются ландшафты влажных лесов (черневая тайга);

2. Достаточного увлажнения; $\mathrm{K}$ от 1,0 до 1,5. В умеренных широтах она представлена хвойными и лиственными лесами;

3. Умеренного увлажнения; $\mathrm{K}$ от 0,60 до 1,0. Ландшафты лесостепей, разнотравно-злаковых степей;

4. Слабого увлажнения; $\mathrm{K}$ от 0,30 до 0,60. Преобладают ландшафты степей. Устойчивые урожаи можно получать при орошении сельскохозяйственных угодий; 
5. Скудного увлажнения; К от 0,13 до 0,30. Формируются ландшафты полупустынь;

6. Сухая зона; К от 0,00 до 0,13. Ландшафты пустынь.

Согласно данным табл. 13, Усть-Каменогорск расположен в зоне злаковых типичных степей, Зыряновск - в зоне разнотравно-злаковых степей и лесостепей, Зайсан - в зоне скудного увлажнения и полупустынных ландшафтов (см. рис. 8).

\section{3. Циркуляция атмосферы}

Циркуляция атмосферы является важнейшим климатообразующим фактором. Она определяет перенос воздушных масс, их трансформацию в результате взаимодействия с подстилающей поверхностью, а также процессы фронто-, цикло- и антициклогенеза. Каждый регион при этом имеет свое место в системе общей циркуляции атмосферы.

Установлено, что в развитии циркуляции атмосферы проявляются периоды относительно устойчивой (однородной) циркуляции, в течение которых барические образования сохраняют направление своего движения, а барические поля - свое географическое положение. Эти периоды получили название естественно-синоптических периодов (ЕСП), а циркуляционные процессы - названий элементарного циркуляционного механизма (ЭЦМ). Типизация периодов, степень их обобщения определяются размерами исследуемого региона и целевой установкой.

В наиболее обобщенном виде циркуляция атмосферы представлена в известных работах Г.Я. Вангенгейма и А.А. Гирса [21, 22]. В зависимости от характера зонального потока и образующихся в нем меридиональных волн учеными выделено три типа циркуляции: зональный $(\mathrm{W})$ и два меридиональных (Е - восточный и $\mathrm{C}$ меридиональной циркуляции).

Вопросы региональной атмосферной циркуляции разрабатывались также М.X. Байдалом для Казахстана, В.А. Бугаевым для Средней Азии, В.В. Орловой для Западной Сибири, А.П. Слядневым, К.И. Поповой для Алтая [23, 24, 25, 26, 27].

В работах этих авторов показано, что система общей циркуляции атмосферы состоит из подсистем регионального ранга, включающих в себя типы (системы) локального характера. Региональные типы циркуляции конкретизируют проявление 
глобальных, являясь их подсистемами в условиях конкретных физико-географических особенностей территории.

Исходя из данных закономерностей, циркуляция атмосферы в исследуемом регионе не может быть рассмотрена вне связи с циркуляционным режимом Алтая и циркуляцией атмосферы в Срединном секторе Евразии (60-120 обусловлено размерами барических образований (циклонов и антициклонов) и направленностью развития циркуляции атмосферы умеренного географического пояса как в пространстве (западновосточный перенос), так и во времени (сезонная динамика процессов).

Над территориями, небольшими по сравнению со Срединным сектором, главная роль в формировании пространственно-временных циркуляционных и климатических различий принадлежит отдельным процессам синоптического масштаба. При обобщении этих процессов учитывается преобладание над территорией циклонического или антициклонического режима в период действия конкретного ЭЦМ. При таком подходе взаимосвязанные синоптические и макромасштабные процессы не исключают друг друга, а наоборот, позволяют полнее характеризовать циркуляционные механизмы, уточняя их характер над исследуемой территорией [28].

\section{Общая характеристика барико-циркуляционного режима.}

На исследуемый регион обычно смещаются циклоны арктического и полярного фронтов, а также антициклоны, сформированные в умеренном, арктическом и реже - тропическом воздухе.

З и о й вся территория Юго-Западного Алтая попадает под непосредственное воздействие западного отрога мощного азиатского антициклона (средняя мощность 1040 гПа). В многолетнем режиме он определяет погодно-климатические условия зимнего сезона в регионе: слабые и умеренные ветры, большую повторяемость штилей, инверсии температуры воздуха. Атмосфера в этих условиях характеризуется большой устойчивостью: из-за отсутствия турбулентного перемешивания и слабого рассеивания не происходит ее самоочищение, и все промышленные выбросы остаются в приземном слое. Подобные неблагоприятные метеорологические условия способствуют накоплению примесей и формируют высокие и очень высокие уровни загрязнения атмосферы в регионе [29]. 
Летом за счет большого притока суммарной радиации формируется термическая депрессия с центром над юго-западной Азией. Ее воздействия нередко распространяются через Среднюю Азию далеко на север, в пределы Алтая, в южные районы ЗападноСибирской низменности. Над югом Западной Сибири происходит обострение «иранской» ветви полярного фронта и смещение ее к северу, где активно взаимодействуют континентальные - умеренные и тропические воздушные массы. В сложившихся циркуляционных условиях активно развиваются процессы циклогенеза, с которыми связано увеличение повторяемости юго-западных (аральских, каспийских, реже - черноморских) циклонов над Северным Казахстаном и югом Западной Сибири. Летние антициклоны, в отличие от зимних, имеют незначительную мощность (1014-1018 гПа) и реже стационируют. Над Алтаем и сопредельными районами формируются области размытого барического рельефа.

При формировании малоподвижного циклона над средним и нижним течением Енисея, когда ложбина циклона направлена на юго-запад, в предгорьях Алтая на холодных фронтах довольно часто возникает волновая деятельность, вплоть до образования частных циклонов. Часто при волновой деятельности на предгорных равнинах и в горах за счет поступления новых порций холодного воздуха устанавливается сравнительно длительный период облачной и пасмурной погоды с перемежающимися интенсивными дождями и понижением температуры ото дня ко дню.

С интенсивным развитием волновой деятельности связаны мощные летние снегопады в ледниковой зоне Алтая, обусловленные смещением северо-западных циклонов и формированием высотного циклона над горной страной [30, 31].

До $52^{0}$ с. ш. преобладают полярно-фронтовые циклоны, которые обеспечивают в исследуемом регионе от 40 до $60 \%$ осадков по отдельным месяцам. В их теплые сектора выносится сухой туранский тропический воздух. К северу от $52^{0}$ резко увеличивается роль западных циклонов. Этим объясняется более контрастный, по сравнению с Восточной Европой, переход от степей к лесам в Западной Сибири, и меньший уровень увлажнения, в степях Западной Сибири и Казахстана.

В в е с ен н и м е я цы (апрель-май) над Западной Сибирью и Казахстаном можно выделить три циркуляционные зоны (которые с небольшими изменениями границ сохраняются и в другие сезоны): 
северную, лежащую севернее $64^{0}$ с. ш.; среднюю, между 56-64 ${ }^{0}$ с. ш., зону наибольшей циклонической деятельности Сибири с повторяемостью преимущественно западных циклонов; южную, к югу от $56^{0}$ с. ш., в которой повторяемость юго-западных и южных циклонов нарастает от 42 в северной половине и до $70 \%-$ в южной $[27,32]$.

Процессы антициклогенеза в данный период получают наибольшее развитие в зоне степей и лесостепей. Максимальная их повторяемость отмечается в полосе $48-52^{0}$ с. ш. (приложение IV). Кроме того, пополнение этой области высокого давления происходит за счет арктических вторжений, которые часто происходят в тылу северо-западных, реже западных циклонов, смещающихся через центральные районы Западно-Сибирской низменности. В этот период на высоко поднятых плато Алтая и Монголии в условиях отсутствия снежного покрова идет интенсивный прогрев воздушных масс, что является основной причиной разрушения восточной части азиатского антициклона.

Так же весной, в связи с усилением антициклонической деятельности над Алтаем и Казахстаном, наблюдается большая повторяемость антициклональных фёнов в горах, повышение температуры воздуха и резкое снижение его относительной влажности (особенно в мае), что и является причиной развития майско-июньских засух, в частности, над северными и восточными районами Казахстана.

При развитии волновой деятельности в Предалтае мощность холодного воздуха первоначально не превышает 1,5-2,0 км, так как уже на уровне поверхности 700 гПа над горами возникают югозападные или западные потоки теплого воздуха. Такое расслоение атмосферы - необходимое условие волновой деятельности. Ее окончание связано со сменой юго-западных и западных течений, на северо-западные или северные [27,32].

О с енью увеличиваются контрасты между субтропическими, умеренными и полярными широтами. За счет большего эффективного излучения происходит выхолаживание поверхности. Увеличиваются горизонтальные градиенты давления воздуха, что ведет к усилению общего западно-восточного переноса, активизации циклонической деятельности на арктическом и полярном фронтах. С первым, связано увеличение повторяемости циклонов над северной половиной 
Западно-Сибирской низменности, со вторым - над Казахстаном и Алтаем (см. приложение IV).

К октябрю зона наибольших контрастов в средней тропосфере смещается к югу и располагается между $48-52^{\circ}$ с. ш., что приводит к росту скорости переноса воздушных масс и увеличению поступления влаги с Атлантики. Высоко поднятые склоны хребтов Юго-Западного Алтая омываются этими потоками, получая обильные атмосферные осадки [33, с. 172]. Максимум осадков отмечается в орографическом узле Рудного Алтая.

В осенний период наибольшую повторяемость имеют югозападные барические образования. Роль западных циклонов в создании барического поля сезона значительно меньше, чем западных антициклонов. Циклоны полярного и старого арктического фронта имеют наибольшие глубины (1008-1017 гПа). Они смещаются со средней скоростью 960-1200 км в сутки.

Над южной половиной Западной Сибири, Казахстаном, Монголией общий уровень давления воздуха увеличивается за счет динамического и термического факторов, формируются подвижные антициклоны. Смещаясь на восток, они часто стационируют над плато Алтая и Монголией, а также над равнинами, прилегающими к оз. Балхаш. Южнее $52^{0}$ с. ш. в сентябре повторяемость антициклонов значительно (в 3-5 раз) превышает повторяемость циклонов. Формируется западный отрог азиатского антициклона.

Характеристика региональных типов циркуляции. Все разнообразие ЭЦМ над Алтаем и смежными с ним территориями объединяет восемь основных типов циркуляции [27]. При их классификации учитывался основной поток воздушных масс в средней тропосфере за ЕСП по картам АТ-500 и характер приземного барического поля за те же ЕСП по сборно-кинематическим картам. Для контроля привлекались данные по температуре и осадкам. Типы циркуляции с выделенными подтипами, их повторяемость по сезонам года приводятся в табл. 14. Наименование типа циркуляции определяется названием господствующего переноса воздушных масс и барическим полем над Алтаем.

1. Западный антициклонический тип с тремя подтипами $(A, \overline{\text {, }}$ $B$ ) характеризуется западно-восточным переносом воздушных масс в средней тропосфере и антициклоническими полями над Алтаем и предгорнымиравни-нами. $\mathrm{B}$ подтипе $A$ по Западно-Сибирской низменности смещаются циклоны, в подтипе Б - антициклогенез 
охватывает Западную Сибирь, в подтипе $B$ - над Западной Сибирью развивается циклоническая деятельность в двух фронтальных зонах, усилен западный перенос воздушных масс и вынос влаги с Атлантики. При подтипе $B$ осадки выпадают не только над ЗападноСибирской низменностью, но и в предгорьях Алтая; на западных склонах гор и в орографических узлах они могут быть значительными. В зимний период при подтипах $A$ и $E$ на предгорных равнинах формируются умеренно (минус $2,5 \div$ минус $12,4^{0} \mathrm{C}$ ) и

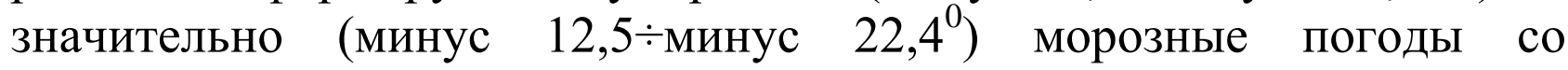
снегопадами, а в котловинных формах - значительно и сильно (минус $22,5 \div$ минус $32,4^{0}$ ) морозные погоды (рис. 16).

2. Западньй циклонический тип с подтипами (А, Б) характеризуется развитием западного переноса в средней тропосфере и смещением у земли западных циклонов по югу Западной Сибири и северу Казахстана. Алтай при этом типе циркуляции всегда находится под воздействием циклонических полей.

В подтипе 2A циклоническая деятельность охватывает Алтай, Казахстан, большую часть ЗападноСибирской низменности. Повсеместно выпадают дожди, особенно обильные в горах, летом часты грозы. В подтипе 2Б к северу от Алтая смещаются антициклоны. В чистом виде западный тип циркуляции атмосферы бывает сравнительно редко. Обычно западный поток претерпевает возмущения, так что в толще тропосферы постепенно начинают развиваться стационарные волны большой амплитуды.

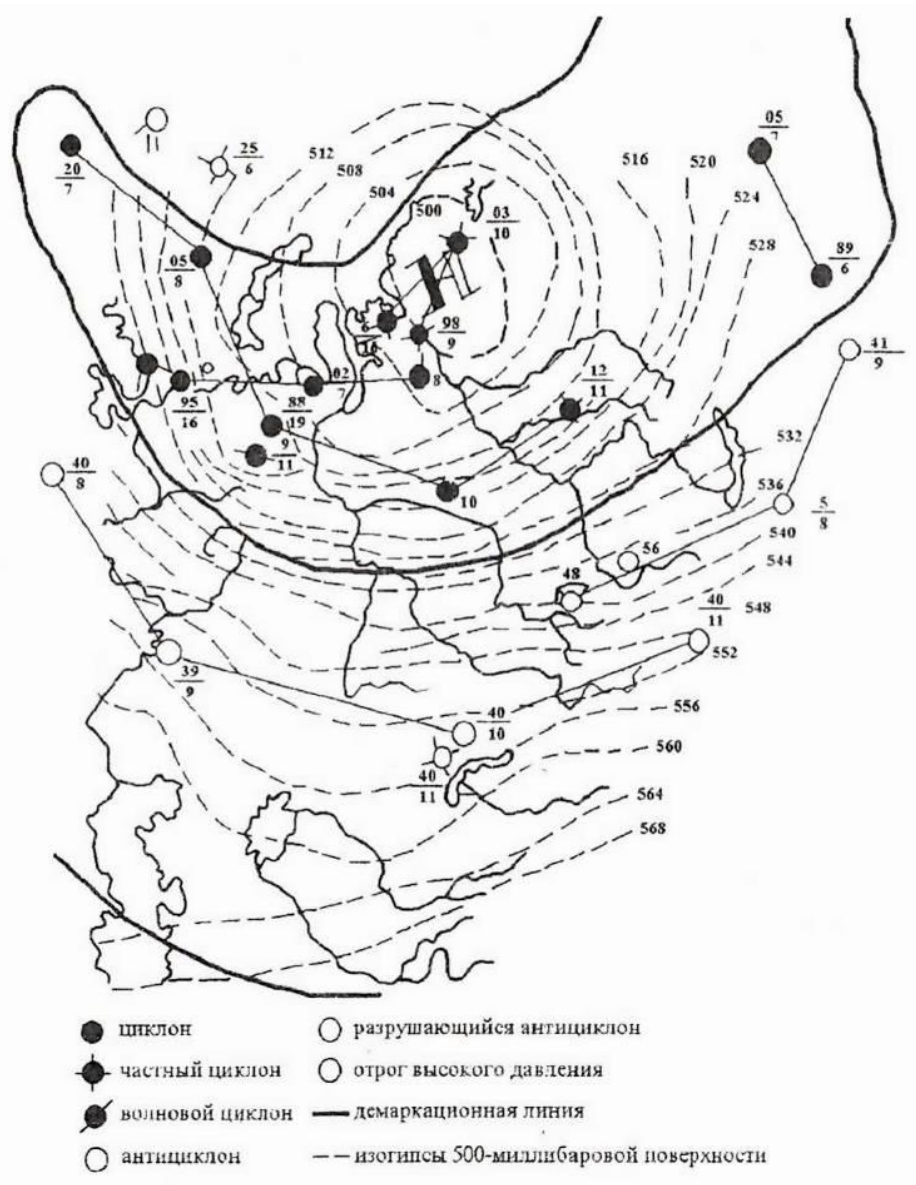

Рис. 16. Западный антициклонический процесс над Алтаем. 1-А (ЕСП 6-11 ноября 1968 г.) 
Повторяемость типов и подтипов циркуляции атмосферы (в числе случаев ЕСП и в \%) по сезонам года в пределах Алтая и прилегающих территорий (1954-1978 гг.)

\begin{tabular}{|c|c|c|c|c|c|c|c|c|c|c|c|c|c|}
\hline \multirow{2}{*}{$\begin{array}{c}\text { Типы } \\
\text { циркуляции } \\
\text { атмосферы }\end{array}$} & \multirow{2}{*}{$\begin{array}{c}\text { Подтипы } \\
\text { циркуляции } \\
\text { атмосферы }\end{array}$} & \multicolumn{2}{|c|}{$\begin{array}{l}\text { Весна } \\
(\mathrm{IV}-\mathrm{V})\end{array}$} & \multicolumn{2}{|c|}{$\begin{array}{c}\text { Лето } \\
\text { (VI-VIII) }\end{array}$} & \multicolumn{2}{|c|}{$\begin{array}{l}\text { Осень } \\
(\mathrm{IX}-\mathrm{X}) \\
\end{array}$} & \multicolumn{2}{|c|}{$\begin{array}{l}\text { Теплый период } \\
\text { (IV-X) }\end{array}$} & \multicolumn{2}{|c|}{$\begin{array}{c}\text { Холодный период } \\
\text { (XI-III) }\end{array}$} & \multicolumn{2}{|c|}{ Год } \\
\hline & & ЕСП & $\%$ & ЕСП & $\%$ & ЕСП & $\%$ & ЕСП & $\%$ & ЕСП & $\%$ & ЕСП & $\%$ \\
\hline \multirow{3}{*}{ I } & $\mathrm{A}$ & 66 & 22 & 92 & 21 & 79 & 27 & 237 & 23 & 205 & 29 & 442 & 26 \\
\hline & Б & 4 & 2 & 15 & 3 & 14 & 5 & 33 & 3 & 20 & 3 & 53 & 3 \\
\hline & B & 21 & 7 & 8 & 2 & 18 & 6 & 47 & 5 & 25 & 3 & 72 & 4 \\
\hline \multirow{2}{*}{ II } & A & 10 & 3 & 21 & 5 & 8 & 3 & 39 & 4 & 17 & 2 & 56 & 3 \\
\hline & Б & 10 & 3 & 21 & 5 & 2 & 1 & 33 & 3 & 7 & 1 & 40 & 2 \\
\hline \multirow{2}{*}{ III } & A & 30 & 10 & 23 & 5 & 17 & 6 & 70 & 7 & 43 & 6 & 103 & 6 \\
\hline & Б & 46 & 15 & 34 & 8 & 25 & 9 & 105 & 10 & 78 & 11 & 183 & 10 \\
\hline IV & & 16 & 5 & 33 & 7 & 10 & 3 & 59 & 6 & 8 & 1 & 67 & 4 \\
\hline \multirow{2}{*}{ V } & A & 55 & 18 & 81 & 18 & 75 & 25 & 211 & 20 & 194 & 27 & 405 & 24 \\
\hline & Б & 3 & 1 & 7 & 2 & 4 & 2 & 14 & 1 & 18 & 2 & 32 & 2 \\
\hline VI & & 34 & 11 & 79 & 18 & 31 & 10 & 144 & 14 & 47 & 7 & 191 & 11 \\
\hline VII & & 5 & 2 & 2 & 0 & 5 & 2 & 12 & 1 & 49 & 7 & 61 & 3 \\
\hline VIII & & 2 & 1 & 27 & 6 & 4 & 1 & 33 & 3 & 10 & 1 & 43 & 2 \\
\hline ИТОГО: & & 302 & 100 & 443 & 100 & 292 & 100 & 1037 & 100 & 721 & 100 & 1758 & 100 \\
\hline
\end{tabular}


Ослабление интенсивности зональной циркуляции и усиление межширотного обмена приводит к возникновению процессов типа Е и С - по классификации Г.Я. Вангенгейма [21]. Эти процессы сопровождаются повышенной активностью арктического фронта. При типе Е в средней тропосфере над большей частью Западной Сибири расположена высотная ложбина, а над Европой - гребень, которые обусловливают северо-западные потоки над Западной Сибирью и Казахстаном.

3. Северо-западный антициклонический тип и его подтипы (A, Б) включают все процессы, когда над Западной Сибирью и востоком Казахстана в средней тропосфере (по АТ-500) осуществляется северозападный поток, а над Алтаем и прилегающими предгорьями на приземных картах - антициклоны. В подтипе 3А антициклогенез охватывает территории к северу и западу от Алтая, в подтипе $3 Б-к$ востоку или северо-востоку от Алтая расположены области пониженного давления. В первом случае на всей территории сухо и сравнительно холодно, во втором - над Алтаем, в его восточных районах бывает облачно, небольшие осадки, усиление ветра (рис. 17).

4. Северо-западный цииклонический тип - это летневесенний тип циркуляции. По Западной Сибири с северо-запада смещаются циклоны. В их тыл поступают порции арктического или прежнего арктического воздуха. Летом прохладная дождливая погода. В горах при прохождении холодного фронта выше границы леса обычно выпадает снег. Если траектория циклона проходит через горную страну, а циклон над нею углубляется, то в ледниковой зоне

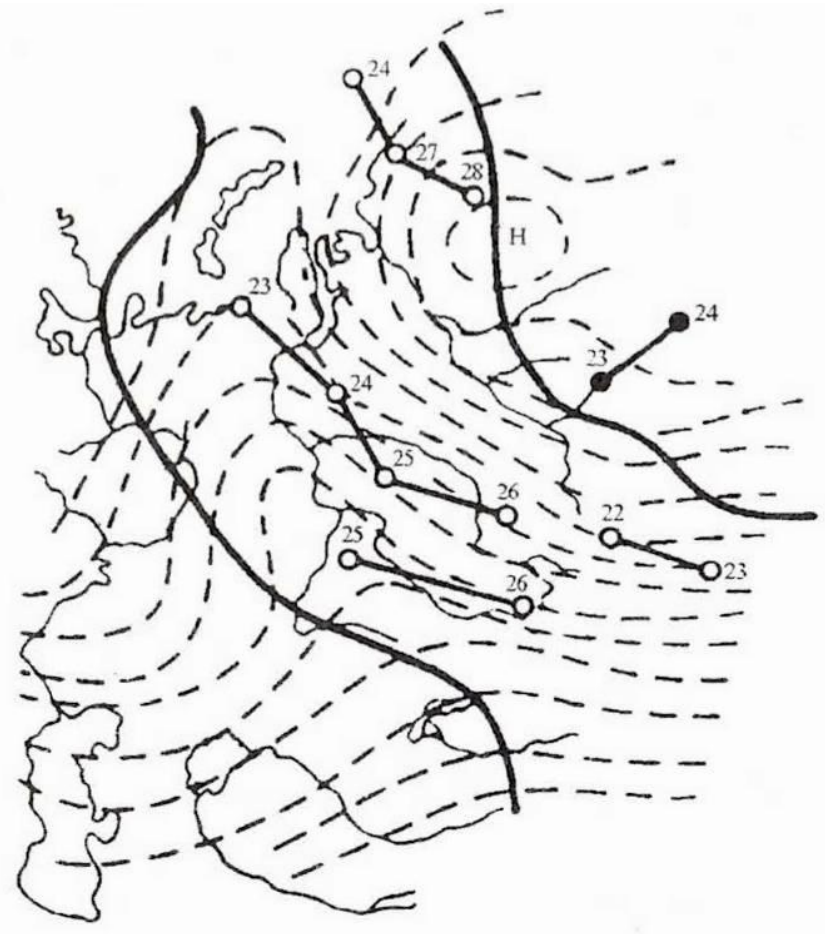
наблюдаются мощные снегопады Рис. 17. Северо-западный антициклонический которые в летнее время Нє процесс. Подтип III-A (23-28 февраля 1955 г.) несколько дней прекращают абляцию ледников. Если снегопад такой мощности отмечается в конце августа или первых числах сентября, то он фиксирует конец абляционного периода (август 1957, 1967 гг.) [30]. 
Юго-западные процессы над Алтаем связаны с развитием меридиональной формы циркуляции типа С. В это время Алтай и юго-восток Западной Сибири находятся под западной частью высотного гребня, обусловливающего вынос тепла на эти территории.

5. Юго-западный антициклонический тип с подтипами (А, Б) объединяет процессы, при которых в средней тропосфере отмечается юго-западный перенос, а над Алтаем и прилегающими предгорными равнинами смещаются или стационируют антициклоны (рис. 18). Этот тип циркуляции занимает второе место по повторяемости ЭЦМ в годовом выводе. Подтип VA характеризуется наличием

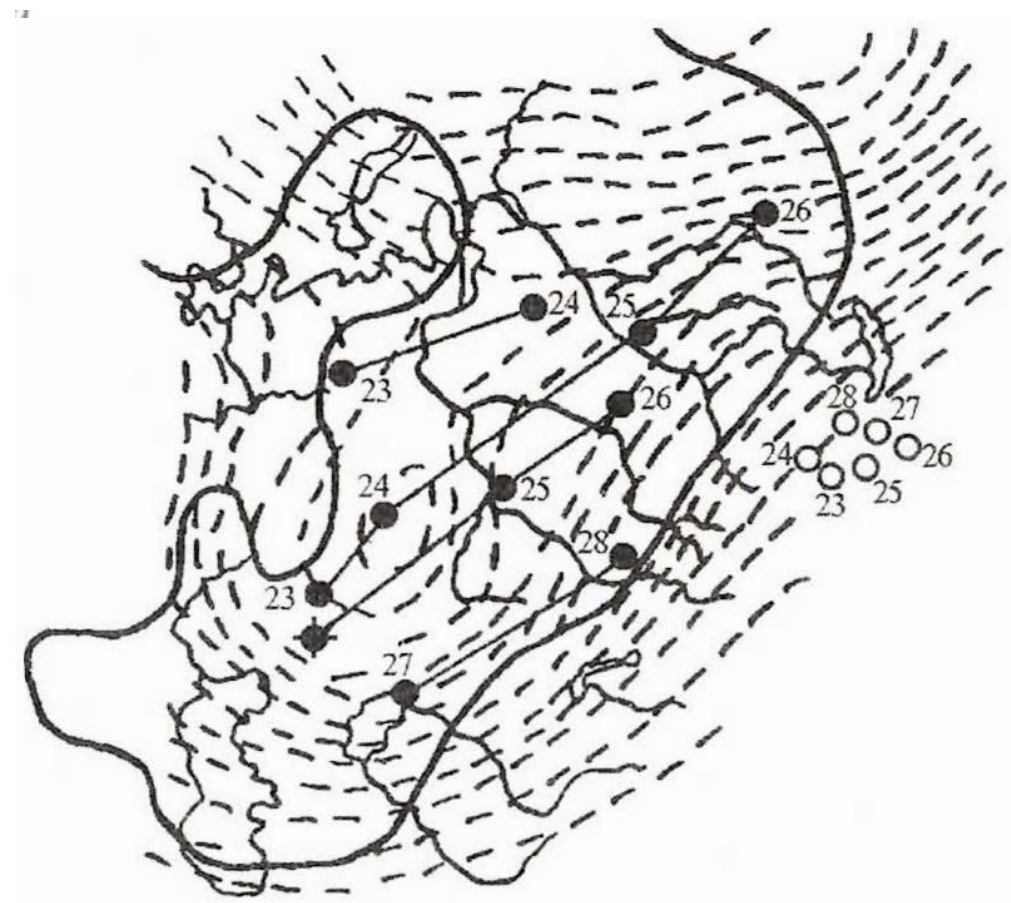

Рис. 18. Юго-западный антициклонический процесс. Подтип V-A (23-28 февраля 1955 г.) циклонических полей над центром Казахстана и юго-востоком ЗападноСибирской низменности. В этом случае высотное поле имеет вид глубокой ложбины, ось которой проходит через Урал или Ямал на Каспий или Аральское море. Алтай находится под восточной частью ложбины.

В подтипе VБ Алтай, Казахстан и юг Западной Сибири охвачены антициклоническими полями. На картах АТ-500 над Европой часто располагается пологая ложбина, а над Западной Сибирью - пологий гребень, ось которого направлена из районов Алтая на море Лаптевых. Этот тип обусловливает адвекцию тепла с юга и югозапада. Летом наблюдается жаркая, умеренно засушливая, облачная погода (при VA); реже суховейно-засушливая, с относительной влажностью менее 40\% (при VБ).

6. Юго-западный изиклонический тип охватывает все ЭЦМ, при которых осуществляется выход юго-западных циклонов из районов Каспия, Арала, Черного моря на юго-восток Западной Сибири и Алтая. В средней тропосфере располагается ложбина, ось ее проходит 
обычно с низовьев Оби на юго-западные районы Западной Сибири. Весной, летом, осенью с этим типом циркуляции часто формируется пасмурная с дождем, иногда с грозою погода. Летом 1955,1974, 1981, 1991 годов наблюдался именно этот тип циркуляции, но с ним практически не было осадков, так как на полярном фронте взаимодействовали очень сухие континентальные воздушные массы умеренного и тропического воздуха. Сравнительно часто формируется погода среднеазиатской термической депрессии жаркая, тихая, ясная, при низком давлении атмосферы. Такой тип погоды очень тяжело переносится людьми с сердечно-сосудистыми заболеваниями.

7. Ультраполярные вторжения - это проявление меридиональной циркуляции типа Е. Арктический воздух с Карского моря и районов Таймыра в виде антициклонов и антициклонических ядер в тылу северо-западных циклонов проникает до Казахстана и Алтая. Высотная карта в этих случаях характеризуется резко выраженной меридиональностью изогипс. Над северными морями располагается гребень, над Якутией обычно формируется высотный циклон, ложбина которого направлена на районы среднего течения p. Иртыш. Над югом Западной Сибири и Казахстаном иногда располагается

«лежащая» ложбина, ось ее идет с востока на запад [34]. Над Западной Сибирью, севером Средней Сибири господствуют северные и северо-восточные потоки. При этом на АТ-500 над Алтаем могут быть и северо-западные и даже западные потоки. Долины горной страны постоянно «заливает» арктический воздух, вытесняя умеренный вверх. Поэтому перед резким

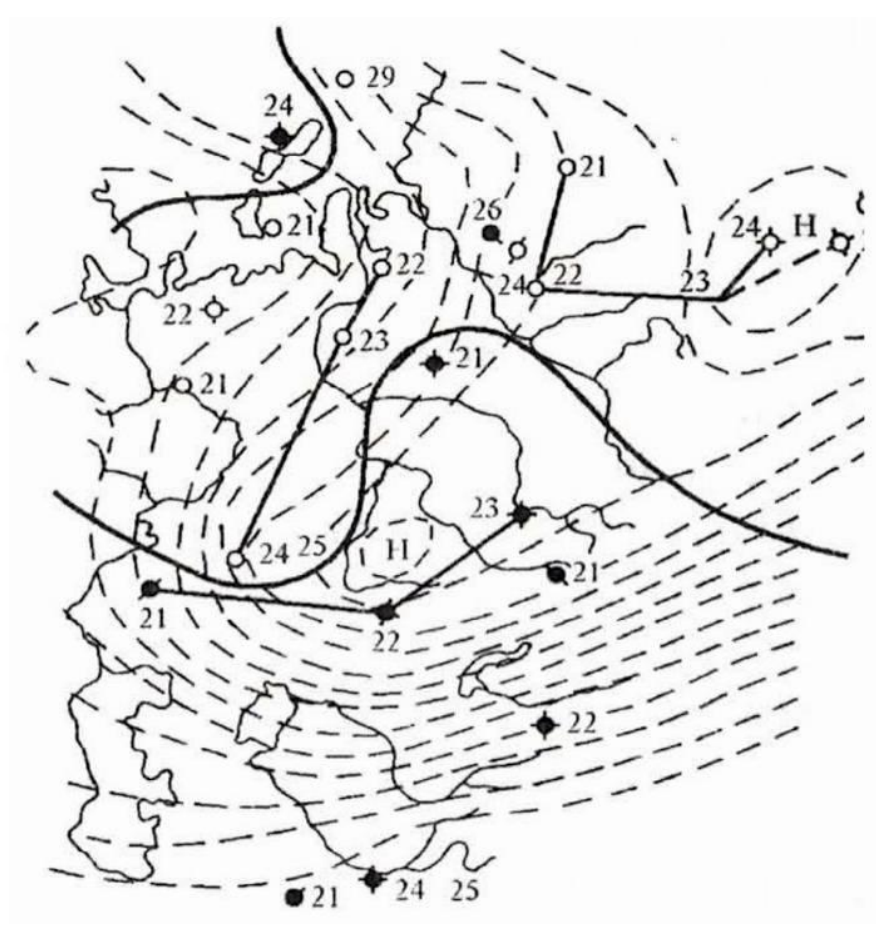
похолоданием в горах, особенно в ледниковой зоне, могут выпадать дожди, переходящие в снегопады (рис. 19). 
8. Стационирование цүиклонов - образование малоподвижного циклона тесно связано с развитием высотного термобарического поля, известного под названием «омега». Циклон является высоким барическим образованием, время его существования определяется продолжительностью ЕСП. Малоподвижный циклон чаще всего образуется в правой ложбине «омеги», для его возникновения необходима изоляция холодного воздуха над Алтаем или юговосточными районами Западно-Сибирской низменности. Стационирование циклона при таких процессах обеспечивается тем, что к моменту его образования ПВФЗ, с которой связан арктический фронт, располагается вне циклона. С этим типом процесса отмечаются интенсивные летние снегопады в ледниковой зоне, в предгорных районах могут быть погоды с грозой. Грозы объясняются прохождением вторичных холодных фронтов. Стационирование циклона над востоком Казахстана, юго-востоком Западной Сибири может длиться до двух недель. Обычно наблюдаются облачные или пасмурные погоды с грозами и ливневыми осадками, которые выпадают в основном за счет развития конвекции в местной умеренной воздушной массе. Стационирование циклона приводит к формированию отрицательных аномалий температуры в летний период (рис. 20).

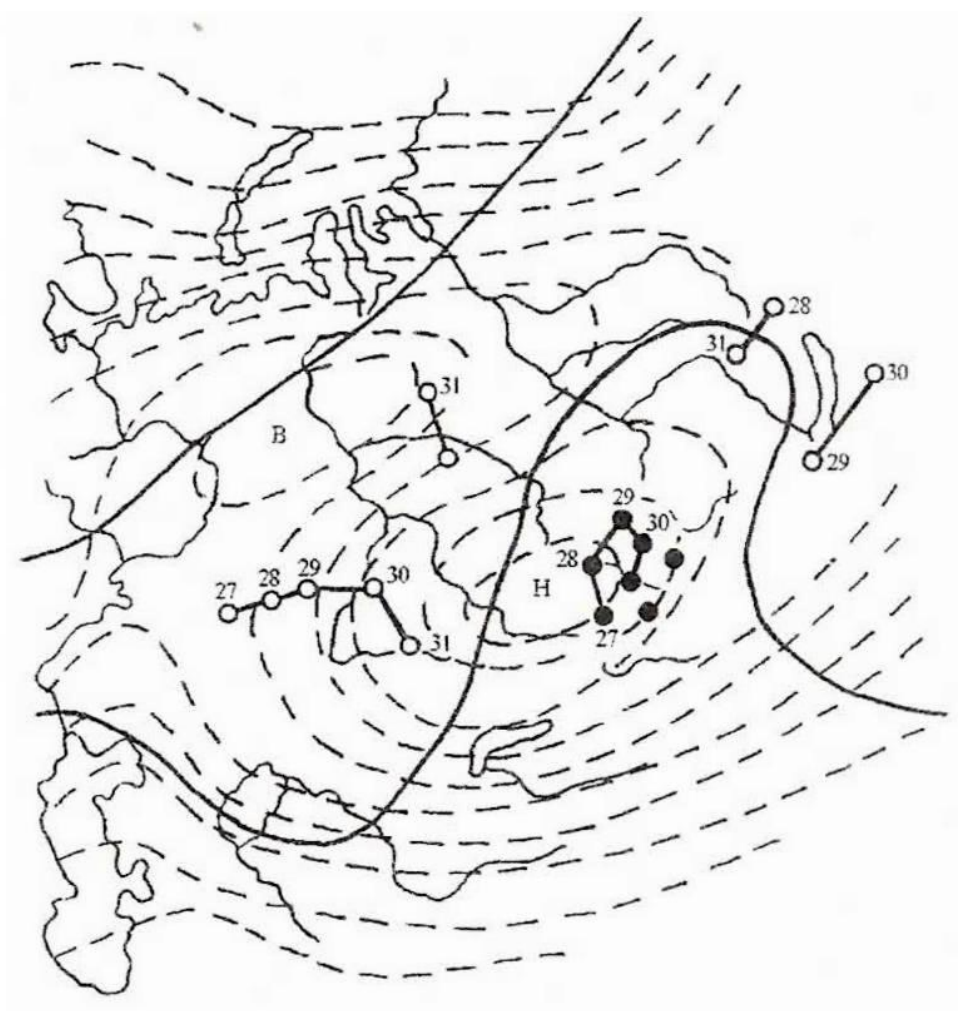

Рис. 20. Стационирование циклона. Тип VII (27 декабря 1955 г. - 1 января 1956 г.)

Выделенные восемь типов циркуляции не могут полностью отразить всего многообразия синоптических процессов над Алтаем, а календари типов - объяснить всех проявлений погоды. Последняя определяется гидротермическим комплексом геосистемы и развитием его в конкретных условиях типа циркуляции и рельефа. При классификации ЭЦМ прослеживалось развитие синоптических процессов, учитывались структура высотного барического поля над 
всей Западной Сибирью и Казахстаном. Для контроля привлекались данные по температуре и осадкам.

Анализ 1758 ЭЦМ, рассмотренных за 25-летний период, показал следующее: на весенние месяцы приходится 302 ЭЦМ, что составляет $17,2 \%$ от их общей повторяемости. Соответственно, на летние месяцы 443 или 25,2; на осенние - 292 или 16,6; на холодный период - 721 ЭЦМ или 41,0\% (см. табл. 14).

\section{Сезонная ритмика барико-циркуляционного режима.}

В природных условиях влагооборот и циркуляция атмосферы, являясь функциями геосистем, выступают и действуют неразрывно. Влагооборот, с позиций системного подхода, является истинно географическим процессом, который состоит из многих разнокачественных звеньев: в нем сочетаются и переходят друг в друга чисто механические движения (выпадение осадков, их стекание, просачивание в грунт) и молекулярно-физические процессы (капиллярные поднятия влаги, испарение с поверхности и конденсация водяного пара), химические процессы (гидратация и дегидратация) и биологические составляющие (транспирация, участие воды в фотосинтезе) $[1,2]$.

Между влагооборотом и энергетикой природного комплекса существует тесная зависимость. По данным М.И. Будыко и О.А. Дроздова, приток тепла в результате влагооборота, в частности, в предгорьях Алтая в среднем составляет 838 МДж/м ${ }^{2}$ год, что сравнимо с турбулентным потоком тепла от подстилающей поверхности к атмосфере [14]. Сток в любом природном комплексе является фактором денудации и аккумуляции, почвообразования и водного питания растений. Он является и основным водным ресурсом, который можно перераспределить и тем самым обеспечить преобразование ландшафтов с целью оптимизации природной среды. Итак, циркуляция атмосферы и влагооборот обусловливают конкретный ход погодно-климатических условий как в сезонном цикле, так и от года к году.

Циркуляциионные процессы холодного периода развиваются при отрицательном радиационном балансе подстилающей поверхности. Воздушные массы, охлаждаясь от поверхности, имеют преимущественно устойчивую стратификацию. Осадки выпадают в твердом виде, различие ландшафтов нивелируется, так как деятельной поверхностью становится устойчивый снежный покров с альбедо 60-80\%. 
Процессы антициклогенеза, как правило, усиливаются на приподнятых плато и в котловинных формах рельефа. Средняя мощность зимних антициклонов составляет 1040, а максимальная 1070-1075 гПа. Зимой одновременно развивается циклоническая деятельность на арктических фронтах, реже на полярном. Средние глубины циклонов составляют 1005-1010, а максимальные - 970 гПа.

За холодный период (ноябрь-март) с 1954 по 1978 гг. отмечено 721 ЕСП. Из них на циклонические процессы приходится 12, на антициклонические - 88\%. Западный антициклонический составляет 35 , юго-западный - 29 и северо-западный - $10 \%$ от общей повторяемости ЕСП (см. табл. 14). На западные циклонические и антициклонические процессы приходится 38 , на юго-западные - 36\%, то есть общий западный и юго-западный потоки над Алтаем имеют одинаковые значения.

Центры циклонов через систему Алтая проходят очень редко: мала повторяемость циклонических типов циркуляции, при этом югозападные циклоны выходят в два раза чаще, чем западные, стационирование циклона также редкое явление. С выходом циклонических образований связываются обильные осадки над регионом. Умеренные и слабые осадки обычно выпадают при развитии подтипов IA, VA, когда восточная часть исследуемой территории находится под воздействием антициклонических полей, а через центральные районы Западной Сибири с запада или центральные районы Казахстана с юго-запада смещаются циклоны. Их фронтальные разделы обостряются перед горной системой Алтая.

Третье место по повторяемости занимают северо-западные процессы $-18 \%$. Ультраполярные вторжения имеют наибольшую повторяемость в центральные месяцы зимы - 9\%, в марте их еще 5 , а в ноябре только $3 \%$ - это значит, что азиатский антициклон формируется за счет западных и северо-западных антициклонов. Ультраполярные вторжения для территории Алтая в холодный период не характерны. Они составляют 7\% и наиболее часто наблюдаются в декабре и феврале: 12 раз за 25-летний период. Этот тип циркуляции определяет жестоко морозные типы погоды не только в декабре-феврале, но и в ноябре. Например, в ноябре 1987 г. температура воздуха опускалась до минус $51^{\circ} \mathrm{C}$, а в самую холодную зиму ХХ века:1967-1968 гг.- такие типы погоды преобладали.

Антициклоны с юго-запада в пределы Монголии выходят сравнительно редко. Подтип VA формируется чаще всего в 
результате смещения западных антициклонов через центральные районы Казахстана и последующим их стационированием над плато Центральной Азии. По их западной и северо-западной периферии в пределы Юго-Западного Алтая и юго-востока Западной Сибири выходят аральские и каспийские циклоны. Высотное поле над территорией Центрального и Восточного Казахстана в этом случае характеризуется меридиональностью. На холодных фронтах перед Алтаем возникают волны, которые при неустойчивой стратификации атмосферы могут перейти в частные циклоны. С волновыми процессами на холодных фронтах обычно связываются значительные осадки в предгорьях и на наветренных склонах [35, 36, 37, 38].

Решающую роль в формировании погодно-климатических условий играют циркуляционные процессы в холодный период. Зима на исследуемой территории обычно, умеренно-холодная, продолжительная, безветренная, значительно снежная в Рудном и умеренно снежная в Южном Алтае, малоснежная в Зайсанской котловине. На высотах 600-1600 м инверсии температуры за счет нисходящих токов в антициклонах и фёновые явления, обусловили прослойку более теплого воздуха (в январе минус 12 - минус $14^{0}$ ). В предгорьях температура воздуха в январе составляет минус 17 минус $20^{\circ}$. Зимой в регионе преобладают облака верхнего и среднего яруса (при подтипах циркуляции IA, VA), а число часов солнечного сияния значительно больше, чем на тех же широтах европейской части России.

Циркулячия атмосферы теплого периода (апрель-октябрь) имеет свои характерные особенности. Радиационный баланс подстилающей поверхности положителен, континент прогрет, формируется общий пониженный фон атмосферного давления. Циркуляция атмосферы над Алтаем и прилегающими к нему территориями характеризуется усилением процессов турбулентности, что вызвано различным прогревом неоднородных ландшафтов в условиях западного переноса воздушных масс, открытостью исследуемого района к западу, северу и юго-западу и расположением его на границе великих равнин Сибири и Казахстана с Высокой Азией. Турбулентность проявляется в возникновении кратковременных и небольших по площади циклонических вихрей, обусловливающих пятнистость распределения по территории интенсивных ливней. Свободный воздухообмен с севером, югом и западом объясняет большую повторяемость циклонических 
образований во внутриконтинентальных условиях и увеличение доли осадков при движении с запада на восток, значительное увлажнение горной страны, в особенности ее западной, северо-западной и северной периферии.

Анализ из 1037 ЕСП теплого периода выявил, что на циклонические типы циркуляции приходится 30 , на антициклонические -70\%. Увеличение повторяемости циклонических типов циркуляции практически в одинаковой степени шло за счет западных, юго-западных процессов, стационирование циклонов (повторяемость в процентах увеличилась в 2-2,5 раза). Особо надо отметить увеличение в шесть раз повторяемости северо-западных циклонических типов - это объясняется изменением муссонного (термического) фактора в пределах материк - Ледовитый океан. Для смещения северо-западных циклонов на исследуемую территорию необходим заток более холодного воздуха в тыл циклона, чем тот, который находится перед циклоном (см. табл. 14).

Летние циклоны менее глубокие, чем зимние, но они могут давать большее количество осадков за счет увеличения содержания влаги в воздухе и уменьшения скорости движения. Кроме того, вторичные холодные фронты практически упорядочивают термическую конвекцию, способствуют выпадению ливневых осадков $[27,39,40]$.

В в есенний пери од повторяемость западных процессов $37 \%$, северо-западных - 30, юго-западных - 30, на ультраполярные приходится 2 и стационирование циклона 1\%. При этом повторяемость циклонических типов западных и северо-западных равна повторяемости юго-западных. Следует отметить увеличение повторяемости северо-западных процессов как циклонических, так и антициклонических, что указывает на усиление меридиональной составляющей циркуляции в этот период по сравнению с другими сезонами, хотя основная циклоничность весной в Западной Сибири и северной части Казахстана создается западными циклонами. Следовательно, западно-восточный перенос воздушных масс в указанных районах устойчив даже при усилении меридиональной циркуляции атмосферы. Увеличение абсолютной влажности воздушных масс и повторяемости циклонов привело к значительному увеличению осадков в весенние месяцы, по сравнению с зимними. На большей части исследуемой территории осадки от марта к апрелю и от апреля к маю возрастают примерно на $30 \%$. 
Антициклонические типы циркуляции над Алтаем весной составляют 77\% от общей повторяемости ЕСП, чем обусловливается большая континентальность климата и весенне-летние засухи. Из них $31 \%$ приходится на западные, 25\% - на северо-западные, обычно с ними связаны поздние весенние заморозки. Юго-западные составляют 19\% повторяемости, вынос в них континентального тропического воздуха обусловливает весенние максимумы температуры до $30^{\circ} \mathrm{C}$. Циклонические типы циркуляции составляют $23 \%$, при этом значительно возросла роль юго-западных и северозападных циклонических процессов (см. табл. 14).

Весна обычно солнечная, со слабыми ветрами, теплая и умеренно влажная во второй половине, но почти каждая третья засушливая. Заморозки по всей территории кончаются к середине мая.

О сень ю резко обостряются температурные контрасты между воздушными массами арктического бассейна и умеренных широт. На предгорных равнинах Рудного и Южного Алтая температура сентября составляет $10-13^{0}$, в октябре $1,5-5,0^{0} \mathrm{C}$. Снижение температуры сопровождается повышением относительной влажности воздуха: в сентябре она составляет 63-72\% на предгорных равнинах, $45-56 \%$ в Зайсанской котловине, 66\% в высокогорных котловинах. В октябре соответственно - 70-78, 56-62 и в Орловской котловине 70\%. Лишь на склонах гор, где отмечаются благоприятные условия для развития антициклонального фёна, относительная влажность ниже летней (ст. Катон-Карагай). Повышение относительной влажности ведет к снижению нижней границы облаков. Осенью влагосодержание над исследуемым районом колеблется в основном в

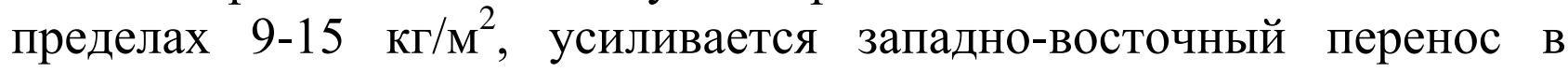
умеренных широтах и циклоническая деятельность, особенно в октябре.

Антициклоны смещаются в основном в широтной зоне $48-56^{0}$ с. ш., их мощность достигает 1025-1035 гПа, циклоны же наиболее часто смещаются в широтной полосе $56-64^{0}$ с. ш. (см. приложение IV). Их глубины увеличиваются от сентября к октябрю, соответственно от 1002-1007 до 1002-995 гПа. Антициклонические типы составляют 82\% ЕСП, при этом на западные процессы приходится 38, на юго-западные - 27 и на северо-западные антициклонические - 15, ультраполярные вторжения - 2\% ЕСП (см. табл. 14). 
Структура барического поля осенью существенно отличается от весенней: весной преобладают западные (31\%) и северо-западные $(25 \%)$ антициклонические типы циркуляции, осенью - западные (38\%) и юго-западные (27\%). Повторяемость антициклонических типов осенью на 5\% больше, чем весной, в основном за счет югозападных и западных процессов. Повторяемость северо-западных процессов на 10\% меньше, чем в весенний период. На циклонические типы циркуляции осенью приходится $18 \%$, из них 10 - на югозападные, 4 - на западные, 3 - на северо-западные, и лишь 1\% повторяемости приходится на стационирование циклона.

Несмотря на уменьшенную повторяемость циклонических процессов по сравнению с весной, осадки осени и предзимья, особенно в Рудном Алтае, значительно больше. Весною под $50^{0}$ с. ш. ослаблен перенос воздушных масс в средней тропосфере, так как здесь располагаются центры стационирующих антициклонов, изогипсы над этой территорией на картах АТ-500 проходят редко. А осенью зона наибольших контрастов располагается как раз под 50-й параллелью, к западной окраине Алтая выносятся большие массы влаги с Атлантики не только в октябре, но и в ноябре. Ее конденсация осуществляется на наветренных западных, северо- и юго-западных склонах, а также в предгорьях за счет предвосхождения.

В летние месяцы радиационный баланс подстилающей поверхности достигает максимальных значений, идет интенсивный прогрев воздушных масс, абсолютная влажность воздуха достигает 912 г/м ${ }^{3}$, влагосодержание в атмосфере в июле составляет $18027 \mathrm{\kappa г} / \mathrm{m}^{2}$. Нарастает неустойчивость воздушных масс. Циклоническая деятельность развертывается как на арктическом, так и полярном фронтах на более низком общем фоне давления. В июле глубины циклонов составляют 998-1000 гПа, скорости смещения уменьшаются до 850-950 км/сутки. Это способствует продолжительности циклонической погоды и увеличению атмосферных осадков. Циклоны, связанные с типами VA и VI, являются, как правило, полярно-фронтовыми, на них приходится $36 \%$ осадков.

Юго-западные процессы обусловливают адвекцию тепла, но они не ведут к адвекции влаги, так как абсолютная влажность воздуха к югу и юго-западу от исследуемого района уменьшается $[25,41]$. При выходе юго-западного циклона на исследуемую территорию редко наблюдаются обильные осадки (более 20 мм в сутки). Но так как югозападные процессы являются преобладающими, то на них приходится 
от 30 до $60 \%$ выпадающих осадков по отдельным станциям. Обильные осадки в горах выпадают в том случае, когда юго-западные циклоны стационируют в пределах юго-востока Западной Сибири и в его систему вовлекается смещающийся с севера фронт. В широтном поясе исследуемого региона $\left(48-52^{0}\right.$ с. ш.) юго-западные циклоны составляют две трети от общей повторяемости. В их теплых секторах выносится очень сухой туранский тропический воздух. Для выпадения значительных осадков необходимы очень большие контрасты температур в планетарно-высотной фронтальной зоне (ПВФЗ).

Западный и северо-западный циклонические типы имеют одинаковую повторяемость от общей ЕСП, составляя 16\%. Для этих условий характерным является стационирование циклона (6\% повторяемости ЕСП). Его значение велико в формировании повышенного увлажнения, с этим типом связывают длительные периоды осадков и грозовой деятельности, часто с ливнями и градом [18, 37, 39].

Процессы антициклогенеза над прогретым материком ослаблены. Антициклоны смещаются реже, и их мощности уменьшаются. Так, средняя мощность юго-западных антициклонов в широтном поясе исследуемой территории (48-52 ${ }^{0}$ с. ш.) колеблется от 1010-1018 гПа, западных - 1015-1019 гПа.

Итак, структура барического поля летом над Алтаем характеризуется преобладанием юго-западных типов циркуляции, они составляют 38 , западные - 34 , северо-западные $-21 \%$ от общего количества ЭЦМ. На антициклонические типы циркуляции приходится 60, на циклонические - $40 \%$.

Лето, как правило, теплое, на юге жаркое, ясное, число часов солнечного сияния составляет от 2000 до 3000, преобладают облака верхнего и среднего ярусов, ландшафты продуваются слабо, господствуют слабые ветры. Количество осадков возрастает с юга на север и с запада на восток.

Разнообразие региональных циркуляционных процессов обусловлено положением Алтая на границе двух естественносиноптических секторов: первого - атлантико-европейского (до $120^{\circ}$ в.д.) и второго - азиатского. Разнообразие циркуляционных механизмов, каждый из которых формирует в конкретных физикогеографических условиях определенные типы погоды, обусловили разнообразие погодно-климатических режимов исследуемого 
региона, что нашло наглядное отражение в сложной структуре его ландшафтов.

Нормальная ритмичность циркуляционных механизмов нарушается в периоды солнечной активности. Циркуляция региона является подсистемой общей циркуляции, которая и «диктует» направленность развития своих подсистем, сама испытывая планетарно-космические воздействия.

Динамика структуры общей циркуляции атмосферы определяется влиянием ритмов солнечной активности, динамикой мгновенного полюса вращения Земли и связанного с ними положения полюса атмосферной циркуляции [23, 28, 42, 43, 44].

В данном исследовании границы эпох взяты по М.Х. Байдалу с некоторыми изменениями по Е.Н. Пановой [45]. Изменчивость атмосферных осадков и температуры воздуха в пределах ЮгоЗападного Алтая рассмотрена по эпохам: Е (1930-1939 гг.), С (19401949 гг.), комбинированной циркуляции Е+С (1950-1965 гг.), Е (19661979 гг.) и Е+C (1980-1990 гг.). С 1992 года началась эпоха циркуляции, спрогнозированная М.Х. Байдалом как эпоха Е. 


\section{ГЛАВА ІІ. ОСНОВНЫЕ ЭЛЕМЕНТЫ КЛИМАТА. АТМОСФЕРНЫЕ ЯВЛЕНИЯ}

\section{1. Ветер}

Движение воздуха относительно земной поверхности называется ветром. Причиной его возникновения является неравномерное распределение давления атмосферы в горизонтальной плоскости. На направление и скорость ветра оказывает большое влияние отклоняющая сила вращения Земли - сила Кориолиса, а также силы трения.

С поднятием вверх сила трения частиц воздуха о подстилающую поверхность ослабевает, поэтому скорость ветра с высотой увеличивается. На высотах 1,0-1,5 км ветер дует обычно вдоль изобар. Если изобары прямолинейные, то такой ветер называется геострофическим. Скорость его $\left(\mathrm{V}_{\mathrm{r}}\right)$ определяется по формуле:

$$
\mathrm{V}_{\mathrm{r}}=\frac{\Gamma}{2 w \sin \varphi \rho}(1)
$$

При нормальных условиях $\rho=0,001293 \Gamma / \mathrm{cm}^{3}$ и $2 \mathrm{w}=1,458 \cdot 10^{-4}$ сек $^{-1}$, тогда формула примет вид:

$$
\mathrm{V}_{\mathrm{r}}=\frac{4,8}{\sin \varphi} \cdot \Gamma, \mathrm{M} / \mathrm{c}(2)
$$

где $\mathrm{w}$ - угловая скорость земли, $\varphi$ - широта места, $\rho$ - плотность воздуха, Г - градиент давления, гПа на 111,2 км. Если градиент $\Gamma=1$ гПа/111 км, то скорость геострофического ветра на $30^{\circ}$ с.ш. составит 9,6 м/с, на $45^{0}-6,8$, на $50^{0}-6,3$, на $60^{0}-5,5$ м/с. Так как скорость находится в обратной зависимости от $\sin$ широты $(\varphi)$ и плотности воздуха, то ее величина летом на $10 \%$ больше, чем зимой, а на высоте 7 км примерно в 2 раза больше, чем на уровне 1 км. При одной и той же величине градиента давления атмосферы (Г) скорость реального ветра (на высоте флюгера) в среднем составляет 60\% от скорости геострофического ветра.

Направление и скорость ветра у поверхности земли зависят от распределения атмосферного давления, рельефа местности и других физико-географических особенностей. Направление ветра указывает на ту часть горизонта, откуда дует ветер.

Сезонная смена полей давления определяет ветровой режим. График повторяемости направлений ветра (в \%) в январе за 
многолетний период показывает преобладание ветров восточных румбов на станциях, расположенных в горных районах Рудного и Южного Алтая. Ветры южных румбов преобладают в предгорьях Алтая и на Калбе; ветры западных румбов - в открытых котловинах Южного Алтая (рис. 21).

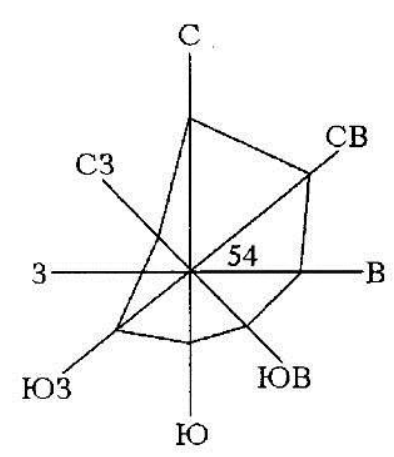

Самарка (Калба)

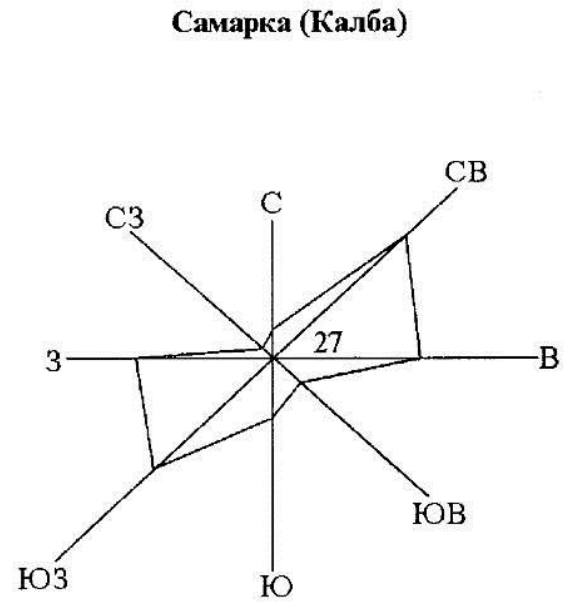

Лениногорск
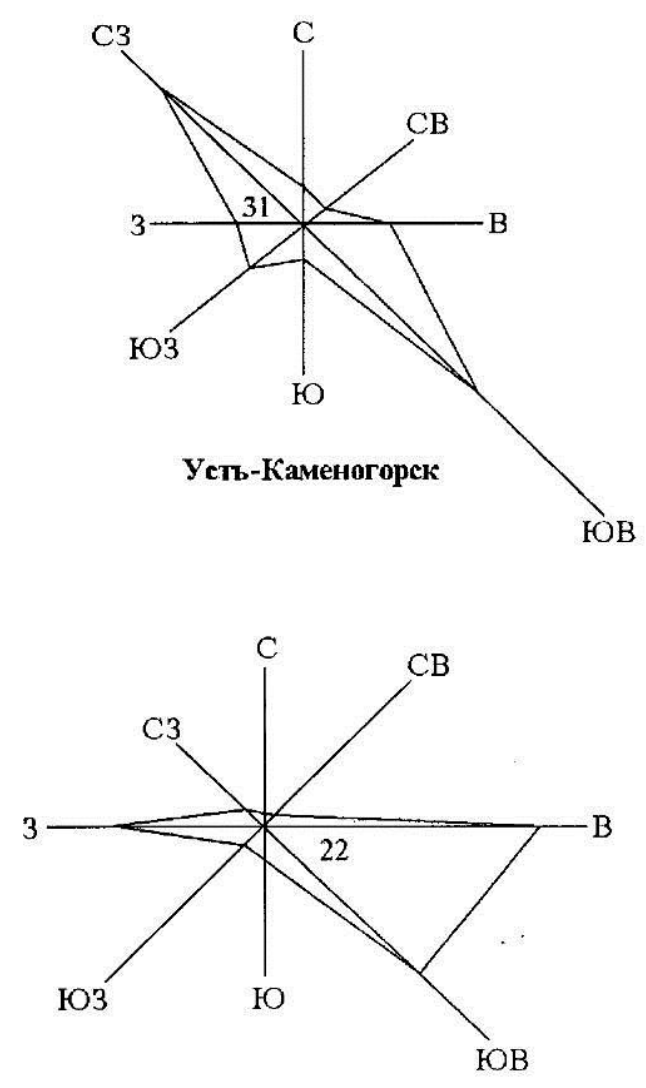

Катон-Карагай

31 - повторяемость штилей в \% от общего числа наблюдений

Рис. 21. Повторяемость направлений ветра и штилей (розы ветров)

Восточные, юго-восточные, северо-восточные и юго-западные ветры по станциям исследуемого региона отражают общую закономерность распределения давления: на востоке оно высокое, к западу падает. Полоса повышенного давления (ось западного отрога азиатского антициклона) рассекает регион на две части: его юг и север. Юг характеризуется северо-восточными ветрами, а север юго-западными и юго-восточными.

Особо выделяются геосистемы Зайсана, долины реки Курчум, Зыряновской впадины, где господствующие ветры не согласуются с общими закономерностями распределения давления. Градиент давления направлен с востока на запад, а господствующие ветры - 
западные. Эти станции расположены в отрицательных формах рельефа, где при усилении азиатского антициклона происходит застой воздуха и преобладают штили. При развитии же циклонической деятельности все вышеназванные станции фиксируют западные ветры.

Для исследуемого региона характерна большая повторяемость штилей. Они составляют по отдельным месяцам холодного периода (в процентах от общего числа наблюдений) в Зыряновске от 85 до 92, пос. Орловский от 60 до 67, в Зайсане от 20 до 28, Катон-Карагае от 22 до 27, Самарке от 55 до 74, Буране от 32 до 51, Усть-Каменогорске от 25 до 43. Обусловленный градиентом давления ветер изменяет свое направление под действием рельефа: в горах и предгорьях он обычно дует вдоль долин крупных рек. Так, в Усть-Каменогорске в течение всего года преобладают ветры вдоль долины р. Иртыш: юговосточные или северо-западные (см. рис. 21).

В холодный сезон исследуемая территория располагается под отрогом высокого давления оси Воейкова. В этот период над УстьКаменогорском наблюдается максимум повторяемости штилей 43\%, повторяемость юго-восточных ветров составляет 35-47, а северо-западных - 16-28\%. В Риддере - штили - до 34\%, северовосточные и восточные направления ветров - 44-51, юго-западные и западные - 25-44\%. В Зыряновске юго-западные и западные - 51-53, в Буране северо-восточные и восточные - 71-82\%.

Летом на территории Юго-Западного Алтая распространена среднеазиатская термическая депрессия, что связано с увеличением повторяемости ветров северных румбов: в Усть-Каменогорске до 3846 , в Риддере до 34 , в Зыряновске до 38 , Буране до $15 \%$. В то же время, уменьшается повторяемость штилей до 21-35\%

В горных районах в слое, близком к земной поверхности, циркуляция воздуха находится в исключительной зависимости от рельефа. Известно, что горные хребты являются препятствием для свободного переноса воздушных масс. Механическое воздействие хребтов приводит к перетеканию воздуха через горные препятствия либо к обтеканию их с боковых сторон, в результате чего меняется направление и скорость ветра. Над хребтами при перетекании происходит сгущение линий тока и, как следствие, усиление скоростей ветра, на подветренной стороне скорости резко уменьшаются либо характерны штили. В узких и глубоких долинах 
при прорывах воздушного течения скорости ветра резко увеличиваются, а в отдельных ущельях достигают штормовых.

В горах, в результате неравномерного нагревания поверхности, возникает целая система местных ветров: прежде всего, это склоновые и горно-долинные ветры (днем поток воздуха идет по долине вверх, а ночью холодный воздух стекает вниз по долине), а также фёны (сухие теплые ветры с гор). Они возникают в результате перетекания воздуха через хребет с подветренной стороны, а на наветренной стороне выпадают осадки. Фёны часты в Катон-Карагае, на Катунском хребте на станции Ак-Кем. Антициклональные фёны наблюдаются одновременно по обоим склонам хребта, скорости таких ветров обычно невелики. Для подробного описания систем потоков воздуха в горной стране нет достаточной информации. О характере течений и скоростях движений воздуха приходится часто судить по общим климатическим картам. Так, над исследуемым регионом на высоте 1 км над уровнем моря зимой преобладают юговосточные ветры, их средние скорости в предгорных равнинах составляют около $8 \mathrm{~m} / \mathrm{c}$, скорости течений к востоку (над горами) уменьшаются. На высоте 3 км уже преобладают западные ветры со средней скоростью 10-11 м/с, на высоте 5 км - западные со скоростью 13-14 м/с и, наконец, на высоте 7 км - ветры западных румбов со средней скоростью 16-18 м/с.

Летом над Алтаем на высоте 1 км преобладают северо-западные и западные ветры со средней скоростью 6-7 м/с. На высоте 3 км ветры тех же румбов, но их скорость 10-11 м/с, на 7 км - западные, 12-13 м/с. В обработку вошли только утренние наблюдения, период наблюдений составил от 11 до 20 лет [46].

Особенности структуры барического поля над исследуемым регионом обусловили малые скорости ветра у земной поверхности в течение всего года. При определении средних скоростей ветра учтена повторяемость штилей (табл. 15). Барические градиенты, определяющие скорость ветра на метеорологических станциях Казахстанского Алтая, практически одни и те же. Большие различия в скоростях ветра определяются особенностями физикогеографических условий расположения станций: влияние абсолютной высоты местности и характера рельефа, степени защищенности флюгера высокими постройками города и древесными насаждениями, склонами гор и рек. Над котловинами зимой сильные ветры просто проскальзывают, не возмущая приземной слой воздуха. 
Средняя месячная и годовая скорость ветра (м/с)

\begin{tabular}{|c|c|c|c|c|c|c|c|c|c|c|c|c|c|c|}
\hline $\begin{array}{c}\text { Метеорологическая } \\
\text { станция, их абсолютная } \\
\text { высота, м } \\
\end{array}$ & $\begin{array}{c}\text { Высота } \\
\text { флюгера, } \\
\text { м }\end{array}$ & I & II & III & IV & V & VI & VII & VIII & IX & $X$ & XI & XII & Год \\
\hline Шемонаиха, 327 & 13 & 2.7 & 2.6 & 3.0 & 3.3 & 3.7 & 3.4 & 3.1 & 3.0 & 2.7 & 3.3 & 3.2 & 3.5 & 3.1 \\
\hline Риддер, 809 & 10 & 2.6 & 2.4 & 2.9 & 2.8 & 2.7 & 2.4 & 2.0 & 2.0 & 2.5 & 3.5 & 3.0 & 3.1 & 2.6 \\
\hline Секисовка, 449 & 10 & 2.7 & 2.2 & 2.3 & 2.5 & 2.7 & 2.3 & 1.9 & 1.6 & 1.8 & 3.5 & 3.6 & 3.3 & 2.5 \\
\hline $\begin{array}{l}\text { Усть-Каменогорск, } \\
285\end{array}$ & 11 & 2.5 & 2.4 & 2.4 & 2.9 & 3.5 & 2.8 & 2.3 & 2.1 & 2.3 & 3.0 & 3.3 & 3.2 & 2.7 \\
\hline $\begin{array}{l}\text { Усть-Каменогорск, } \\
284\end{array}$ & 12 & 2.5 & 2.4 & 2.8 & 2.5 & 2.3 & 2.0 & 1.7 & 1.5 & 1.6 & 2.6 & 3.3 & 3.3 & 2.4 \\
\hline Пос. Северный, 793 & 10 & 5.6 & 4.8 & 4.8 & 4.6 & 4.5 & 3.7 & 3.5 & 3.6 & 3.8 & 4.7 & 5.4 & 5.7 & 4.6 \\
\hline Зыряновск, 457 & 9 & 0.3 & 0.3 & 0.5 & 1.0 & 1.7 & 1.2 & 0.9 & 0.9 & 0.8 & 0.8 & 0.6 & 0.4 & 0.8 \\
\hline $\begin{array}{l}\text { Бухтарма } \\
\text { (Серебрянск), } 376\end{array}$ & 9 & 4.0 & 3.2 & 3.0 & 3.0 & 2.6 & 2.3 & 2.3 & 2.2 & 2.2 & 2.5 & 2.7 & 3.4 & 2.8 \\
\hline $\begin{array}{l}\text { Большенарымское, } \\
402\end{array}$ & 12 & 1.1 & 1.3 & 1.4 & 2.1 & 2.4 & 2.2 & 2.1 & 2.1 & 1.8 & 1.7 & 1.4 & 1.2 & 1.7 \\
\hline Катон-Карагай, 1080 & 12 & 4.6 & 4.0 & 3.8 & 4.1 & 3.9 & 3.4 & 3.1 & 3.3 & 3.3 & 3.8 & 3.7 & 4.3 & 3.8 \\
\hline Самарка, 497 & 10 & 0.8 & 1.0 & 1.4 & 2.3 & 2.4 & 2.1 & 2.0 & 1.9 & 1.6 & 1.5 & 1.3 & 0.9 & 1.6 \\
\hline $\begin{array}{l}\text { Пос. Орловский, } \\
1080\end{array}$ & 10 & 0.4 & 0.7 & 0.7 & 1.4 & 2.2 & 1.7 & 1.4 & 1.3 & 1.4 & 1.2 & 0.7 & 0.6 & 1.1 \\
\hline Курчум, 427 & 11 & 1.1 & 1.5 & 1.7 & 2.9 & 2.8 & 2.3 & 1.9 & 1.9 & 2.1 & 2.5 & 1.9 & 1.5 & 2.0 \\
\hline Буран, 412 & 11 & 3.8 & 3.1 & 3.7 & 3.7 & 3.7 & 3.1 & 2.5 & 2.2 & 2.6 & 3.6 & 4.1 & 4.1 & 3.4 \\
\hline Тополев мыс, 292 & 11 & 2.0 & 2.4 & 2.8 & 3.3 & 4.6 & 4.4 & 4.2 & 4.2 & 3.9 & 4.1 & 3.5 & 2.4 & 3.5 \\
\hline Зайсан, 603 & 8 & 1.7 & 2.0 & 2.3 & 3.8 & 4.6 & 4.3 & 4.1 & 3.6 & 3.4 & 3.0 & 2.3 & 1.9 & 3.1 \\
\hline
\end{tabular}


Фактический материал таблицы 15 характеризует важнейшее свойство климата исследуемого региона, имеющее исключительно большое экологическое значение: преобладание ветров с малыми скоростями обусловливает слабое продувание природных ландшафтов. Такой режим ветра и зимой и летом создает оптимальные условия рекреации, но в то же время он определяет и наибольший потенциал загрязнения атмосферы (ПЗА) промышленными выбросами, в частности, ПЗА может достигать IV и $\mathrm{V}$ степеней.

Действительная экологическая напряженность в ландшафтах подчеркивается вероятностью повторяемости конкретных градаций скоростей ветра (табл. 16, 17).

Т а бли ц а 16

Вероятность скоростей ветра по градациям (в \% от общего числа случаев)

\begin{tabular}{|c|c|c|c|c|c|c|c|c|c|c|c|}
\hline $\begin{array}{c}\text { Месяц } \\
\text { ы }\end{array}$ & $0-1$ & $2-3$ & $4-5$ & $6-7$ & $8-9$ & $10-11$ & $12-13$ & $14-15$ & $16-17$ & $18-19$ & $21-24$ \\
\hline \multicolumn{10}{|c|}{ Риддер } \\
\hline I & 57.7 & 22.1 & 5.4 & 5.0 & 2.5 & 2.4 & 0.9 & 0.9 & 1.6 & 1.2 & 0.3 \\
\hline V & 51.0 & 19.0 & 12.1 & 9.1 & 4.0 & 2.5 & 1.0 & 0.4 & 0.7 & 0.2 & - \\
\hline VII & 60.7 & 18.9 & 10.8 & 5.8 & 1.7 & 1.0 & 0.5 & 0.3 & 0.2 & 0.1 & - \\
\hline IX & 57.2 & 19.2 & 8.6 & 7.0 & 3.0 & 2.5 & 1.0 & 0.5 & 0.6 & 0.4 & - \\
\hline \multicolumn{10}{|c|}{ Усть-Каменогорск } \\
\hline I & 62.3 & 12.2 & 8.3 & 5.8 & 3.7 & 3.0 & 2.2 & 1.1 & 1.3 & 0.1 & - \\
\hline V & 41.2 & 21.9 & 14.8 & 8.8 & 5.1 & 4.0 & 2.2 & 1.1 & 0.9 & - & - \\
\hline VII & 52.1 & 22.9 & 13.4 & 6.4 & 2.5 & 1.3 & 0.8 & 0.2 & 0.3 & 0.1 & - \\
\hline IX & 54.4 & 20.1 & 12.7 & 7.1 & 3.2 & 1.2 & 0.7 & 0.2 & 0.3 & 0.1 & \\
\hline \multicolumn{10}{|c|}{ Катон-Карагай } \\
\hline I & 29.9 & 18.8 & 16.5 & 12.8 & 9.2 & 5.1 & 4.3 & 1.3 & 1.8 & 0.3 & - \\
\hline V & 28.5 & 23.3 & 22.0 & 14.0 & 8.2 & 1.3 & 1.6 & 0.2 & 0.6 & 0.3 & - \\
\hline VII & 33.1 & 29.8 & 21.4 & 10.3 & 3.9 & 0.5 & 0.6 & 0.1 & 0.3 & - & - \\
\hline IX & 34.1 & 27.8 & 19.5 & 9.7 & 6.2 & 1.2 & 1.0 & 0.1 & 0.4 & - & - \\
\hline \multicolumn{10}{|c|}{ Зайсан } \\
\hline I & 58.9 & 31.6 & 6.3 & 1.4 & 0.6 & 0.2 & 0.1 & 0.0 & 0.7 & 0.1 & - \\
\hline V & 22.9 & 30.0 & 20.7 & 10.5 & 5.5 & 2.6 & 1.9 & 1.4 & 3.1 & 1.3 & 0.1 \\
\hline VII & 24.0 & 31.6 & 23.2 & 10.5 & 4.1 & 1.8 & 1.1 & 0.5 & 2.3 & 0.8 & 0.1 \\
\hline IX & 33.4 & 34.5 & 17.3 & 6.4 & 2.6 & 1.6 & 0.9 & 0.5 & 2.3 & 0.5 & - \\
\hline
\end{tabular}

На слабые ветры в зимний период приходится в Риддере 85, в Усть-Каменогорске 83, в Катон-Карагае 65 и Зайсане 97\% от общего числа случаев. Рассеяние вредных примесей зависит от вертикального профиля температуры и ветра в нижнем слое воздуха. Они определяют перемешивание (турбулентность) воздуха. 
Только редкие сильные ветры, сильные снегопады или ливни сравнительно хорошо очищают атмосферу городов от промышленного загрязнения. Ветры со скоростью 4-5 м/с часто приводят к выносу загрязнения из-под факелов промышленных труб в приземные слои. Загрязненный воздух промышленных районов захватывается облачными системами и переносится на значительные расстояния.

Т а б ли ц а 17

Вероятность ветра различной скорости по направлениям, \% *

\begin{tabular}{|c|c|c|c|c|c|c|c|c|}
\hline Скорость, м/с & $\mathrm{C}$ & $\mathrm{CB}$ & $\mathrm{B}$ & ЮB & $Ю$ & Ю3 & 3 & $\mathrm{C} 3$ \\
\hline \multicolumn{9}{|c|}{ Катон-Карагай - Январь } \\
\hline $0-1$ & 0.7 & 0.4 & 10.6 & 9.5 & 1.6 & 1.1 & 4.0 & 2.0 \\
\hline $2-5$ & 0.1 & 0.3 & 16.4 & 13.3 & 1.0 & 0.5 & 3.1 & 0.7 \\
\hline $6-9$ & 0 & 0.1 & 12.3 & 8.7 & 0.1 & 0.03 & 0.6 & 0.1 \\
\hline $10-13$ & 0.03 & 0.03 & 6.0 & 3.3 & 0.1 & 0 & 0 & 0 \\
\hline $14-17$ & 0.03 & 0.03 & 2.2 & 0.7 & 0.1 & 0 & 0.03 & 0 \\
\hline $18-20$ & 0 & 0 & 0.2 & 0.03 & 0.03 & 0 & 0 & 0 \\
\hline \multicolumn{9}{|c|}{ Катон-Карагай - Июль } \\
\hline $0-1$ & 0.6 & 0.5 & 9.4 & 4.8 & 2.0 & 1.8 & 11.4 & 2.6 \\
\hline $2-5$ & 0.7 & 0.6 & 15.5 & 10.9 & 1.6 & 2.4 & 15.5 & 3.9 \\
\hline $6-9$ & & 0.1 & 6.5 & 4.4 & 0.2 & 0.2 & 2.3 & 0.6 \\
\hline $10-13$ & & & 0.5 & 0.3 & 0.1 & 0 & 0.2 & \\
\hline $14-17$ & & & 0.2 & & 0.1 & 0.03 & 0.03 & \\
\hline \multicolumn{9}{|c|}{ Зайсан - Январь } \\
\hline $0-1$ & 0.4 & 1.7 & 6.0 & 9.3 & 14.0 & 13.9 & 12.2 & 1.9 \\
\hline $2-5$ & 0.5 & 1.1 & 4.8 & 5.2 & 4.6 & 8.7 & 10.4 & 1.7 \\
\hline $6-9$ & & 0.04 & 0.1 & 0.2 & 0.1 & 0.5 & 1.1 & 0.3 \\
\hline $10-13$ & & & 0 & 0 & 0.04 & 0.1 & 0.2 & \\
\hline $14-17$ & & & 0.04 & 0.04 & 0.2 & 0.3 & 0.2 & \\
\hline $18-20$ & & & & & & 0.9 & & \\
\hline \multicolumn{9}{|c|}{ Зайсан - Июль } \\
\hline $0-1$ & 2.7 & 1.7 & 1.8 & 1.6 & 5.6 & 5.2 & 4.2 & 2.9 \\
\hline $2-5$ & 5.2 & 4.2 & 3.0 & 2.0 & 10.4 & 12.4 & 9.0 & 7.6 \\
\hline $6-9$ & 0.8 & 0.2 & 0.2 & 0.2 & 2.8 & 4.1 & 2.7 & 2.5 \\
\hline $10-13$ & 0.1 & & 0 & 0.04 & 0.6 & 1.2 & 0.6 & 0.3 \\
\hline $14-17$ & 0.1 & & 0.04 & & 0.6 & 1.4 & 0.4 & 0.5 \\
\hline $18-20$ & & & & & 0.1 & 0.6 & 0.2 & 0.1 \\
\hline $21-24$ & & & & & & 0.08 & & \\
\hline
\end{tabular}

*- составлено по [13].

Бризовая циркуляция в предгорьях и горно-долинные ветры часто выносят загрязнения на склоны гор и в верхнюю часть речных 
долин. Отмечено, что в течение всех сезонов года на предгорных равнинах, во впадинах и особенно в котловинных формах рельефа насчитывается до 24-27 дней в месяц со слабыми, 3-4 дня с умеренными и лишь 1-3 дня с сильными и штормовыми ( $\geq 15 \mathrm{~m} / \mathrm{c}$ ) ветрами.

Представляют практический интерес знания средней и максимальной скорости ветра различного направления. В табл.18 и 19 приводятся многолетние данные за 1951-1965 гг. Средняя скорость ветра дается без учета повторяемости штилей.

На предгорных равнинах Рудного Алтая (по наблюдениям в Усть-Каменогорске) наибольшие средние скорости в годовом выводе отмечаются при ветрах южной половины горизонта (4,6-5,4 м/с). Ветры со скоростью $\geq 15 \mathrm{~m} /$ с наибольшую повторяемость имеют с октября по февраль [47]; за 15-летний период наблюдений их насчитывается до 18-23 случаев в месяц. Преобладающими направлениями являются ветры юго-восточные и юго-западные. Летом только северные и северо-западные ветры достигают штормовой скорости ( $\geq 15 \mathrm{M} / \mathrm{c})$ (табл. 18, 19, 20).

Т а бли ц а 18

Средняя скорость ветра (м /с) по направлениям - Усть-Каменогорск

\begin{tabular}{|c|c|c|c|c|c|c|c|c|c|}
\hline $\begin{array}{c}\text { Месяц } \\
\text { ы }\end{array}$ & С & СВ & В & ЮВ & Ю & Ю3 & 3 & С3 & $\begin{array}{c}\text { Средняя } \\
\text { скорость }\end{array}$ \\
\hline $\mathrm{I}$ & 1.7 & 2.7 & 4.6 & 5.7 & 5.5 & 5.8 & 3.5 & 2.4 & 4.0 \\
\hline $\mathrm{V}$ & 6.1 & 4.0 & 3.8 & 4.1 & 4.1 & 4.7 & 4.5 & 5.7 & 4.6 \\
\hline $\mathrm{VII}$ & 5.1 & 3.0 & 3.1 & 3.2 & 2.5 & 3.4 & 3.1 & 4.3 & 3.5 \\
\hline $\mathrm{IX}$ & 3.6 & 2.6 & 2.8 & 3.5 & 4.5 & 4.8 & 3.6 & 4.0 & 3.7 \\
\hline $\mathrm{X}$ & 4.2 & 2.5 & 3.3 & 4.8 & 5.2 & 6.3 & 4.0 & 4.1 & 4.3 \\
\hline Год & 3.9 & 2.7 & 3.7 & 4.6 & 4.5 & 5.2 & 3.8 & 3.9 & 4.0 \\
\hline
\end{tabular}

Т а б ли ц а 19

Максимальные скорости ветра по направлениям за 15-летний период (1951-1965 гг.) - Усть-Каменогорск

\begin{tabular}{|c|c|c|c|c|c|c|c|c|c|}
\hline Месяцы & С & СВ & В & ЮВ & Ю & Ю3 & 3 & C3 & Мax. \\
\hline I & 0.4 & 10 & 10 & 17 & 16 & 16 & 17 & 10 & 17 \\
\hline V & 17 & 12 & 12 & 17 & 17 & 17 & 14 & 17 & 17 \\
\hline VII & 17 & 10 & 0.8 & 12 & 12 & 12 & 12 & 18 & 18 \\
\hline IX & 17 & 0.9 & 0.9 & 14 & 12 & 20 & 12 & 17 & 20 \\
\hline XII & 0.6 & 0.3 & 20 & 28 & 18 & 20 & 20 & 12 & 28 \\
\hline
\end{tabular}


Среднее число дней с сильными ветрами $(\geq 15 \mathrm{~m} / \mathrm{c})$ по метеостанциям Юго-Западного Алтая

\begin{tabular}{|l|c|c|c|c|c|c|c|c|c|c|c|c|c|}
\hline \multicolumn{1}{|c|}{ Станция } & I & II & III & IV & V & VI & VII & VIII & IX & X & XI & ХII & Год \\
\hline Шемонаиха & 1.6 & 1.7 & 2.3 & 1.3 & 1.8 & 1.1 & 0.9 & 1.3 & 1.3 & 1.6 & 1.1 & 2.1 & 18 \\
\hline Риддер & 3.5 & 2.9 & 3.4 & 3.5 & 2.2 & 1.4 & 1.2 & 1.7 & 2.3 & 3.9 & 3.3 & 4.0 & 33 \\
\hline Усть-Каменогорск & 2.7 & 3.2 & 2.3 & 3.1 & 4.4 & 3.5 & 2.3 & 2.6 & 2.3 & 3.2 & 2.7 & 3.6 & 36 \\
\hline г. Усть-Каменогорск & 1.6 & 1.5 & 1.3 & 1.1 & 1.8 & 1.6 & 1.0 & 1.1 & 1.1 & 1.4 & 3.0 & 2.9 & 19 \\
\hline Пос. Северный & 2.2 & 2.3 & 2.2 & 2.4 & 2.0 & 1.1 & 0.9 & 1.0 & 1.4 & 1.4 & 2.4 & 3.1 & 22 \\
\hline Зыряновск & 0.5 & 0.5 & 0.8 & 1.2 & 1.4 & 1.3 & 1.0 & 1.0 & 0.8 & 1.1 & 1.1 & 0.8 & 12 \\
\hline Большенарымское & 0.2 & 0.3 & 0.3 & 0.9 & 0.9 & 0.5 & 0.8 & 0.9 & 0.6 & 0.6 & 0.2 & 0.4 & 7 \\
\hline Катон-Карагай & 3.1 & 2.9 & 2.8 & 2.6 & 2.1 & 1.2 & 1.1 & 1.0 & 1.3 & 2.9 & 2.3 & 3.7 & 27 \\
\hline Самарка & 0.2 & 0.6 & 0.3 & 0.8 & 1.5 & 1.3 & 1.0 & 1.4 & 1.0 & 0.5 & 0.4 & 0.4 & 9 \\
\hline Пос. Орловский & 0.2 & 0.1 & 0.2 & 0.5 & 1.4 & 1.0 & 0.9 & 1.2 & 1.0 & 0.4 & 0.2 & 0.1 & 7 \\
\hline Курчум & 0.8 & 1.4 & 1.5 & 2.8 & 2.5 & 1.7 & 1.5 & 1.4 & 1.9 & 3.3 & 2.3 & 1.7 & 23 \\
\hline Буран & 4.6 & 3.4 & 4.5 & 3.1 & 4.0 & 2.1 & 1.0 & 1.7 & 1.4 & 4.2 & 3.4 & 3.7 & 37 \\
\hline Зайсан & 1.4 & 2.9 & 3.6 & 7.2 & 8.8 & 8.3 & 8.1 & 6.1 & 5.8 & 5.9 & 3.5 & 3.0 & 65 \\
\hline
\end{tabular}

Как видно из табл. 20, количество дней с сильными ветрами изменяется по метеостанциям Казахстанского Алтая от 7 до 65 дней в году. В горах на выровненных открытых площадках скорость ветра усиливается, примером может служить режим ветра в пос. Северный и на станции Проходной Белок. Большие скорости ветра объясняются и стоковыми явлениями на станциях, расположенных в долинах рек с большим уклоном русла (Катон-Карагай, Лениногорск, Буран).

Зимой в замкнутых котловинах, где нет стока холодных масс воздуха, сильные ветры очень редки (например, пос. Орловский, высота 1100 м).

Большие скорости ветра определяются в первую очередь большими горизонтальными градиентами давления атмосферы. Они создаются при сближении периферий мощных подвижных антициклонов и очень глубоких циклонов, а также при прохождении через восток Казахстана планетарно-высотной фронтальной зоны, систем холодных фронтов глубоких циклонов. Расчетные скорости ветра в горах Алтая могут достигать в зимние месяцы 25, а на высоких водоразделах до 40-50 м/с [48]. Расчеты подтверждены наблюдениями. Так, зимой 1972 года на хребте Холзун отмечено 40 дней с сильной метелью. Проведение геолого-разведывательных и других работ было практически невозможно из-за сильных ветров (до 25 м/с) и обильных снегопадов. Установлено, что на водораздельных гребнях и перевалах с широким распространением карнизов снега, 
заструг и фирнизированных корок, ветры со скоростью 16-25 м/с и более - обычное явление $[15,49]$. Сильные ветры наиболее вероятны при часто повторяющихся их направлениях, такие случаи отмечались в регионе преимущественно зимой (январь-февраль 1966 года, ноябрь-декабрь и март 1968/1969 гг.). Данные о сильном ветре представляют практический интерес, так как с ними обычно связаны экстремальные условия погоды, наносящие материальный ущерб народному хозяйству и здоровью людей, работающих зимой на открытом воздухе (возможно обморожение). Вероятность больших скоростей ветра представлена в табл. 21.

Т а бли и а 21

Наибольшие скорости ветра различной вероятности по [13]

\begin{tabular}{|l|c|c|c|c|}
\hline \multirow{2}{*}{ Станция } & \multicolumn{4}{|c|}{ Скорость ветра в м/с, возможная 1 раз в } \\
\cline { 2 - 5 } & год & 5 лет & 10 лет & 20 лет \\
\hline Риддер & 29 & 36 & 40 & 43 \\
\hline Усть-Каменогорск & 22 & 25 & 27 & 29 \\
\hline Катон-Карагай & 23 & 26 & 28 & 30 \\
\hline Зайсан & 28 & 35 & 39 & 42 \\
\hline
\end{tabular}

О суточном ходе скорости ветра можно судить по табл. 22.

Т а бли ц а 22 Средняя месячная скорость ветра (м/с) в различные часы суток по станциям Юго-Западного Алтая [13]

\begin{tabular}{|c|c|c|c|c|c|c|c|c|c|c|c|c|}
\hline Часы & I & II & III & IV & V & VI & VII & VIII & IX & X & XI & XII \\
\hline \multicolumn{10}{|c|}{ Усть-Каменогорск $(284$ м $)$} \\
\hline 1 & 2.4 & 2.1 & 2.0 & 2.0 & 2.0 & 1.4 & 1.2 & 1.0 & 1.4 & 2.5 & 3.4 & 3.1 \\
\hline 7 & 2.3 & 2.3 & 2.1 & 2.3 & 2.7 & 2.1 & 1.4 & 1.2 & 1.6 & 2.3 & 3.0 & 3.2 \\
\hline 13 & 2.7 & 2.9 & 3.2 & 4.8 & 5.3 & 4.0 & 3.6 & 3.5 & 3.6 & 4.4 & 3.7 & 3.5 \\
\hline 19 & 2.5 & 2.2 & 2.3 & 3.1 & 4.1 & 3.8 & 3.2 & 2.8 & 2.4 & 2.6 & 3.2 & 2.9 \\
\hline \multicolumn{10}{|c|}{ Катон-Карагай (1080 м) } \\
\hline 1 & 5.2 & 4.6 & 4.3 & 4.3 & 3.5 & 3.2 & 3.1 & 3.3 & 3.6 & 4.4 & 4.2 & 4.7 \\
\hline 7 & 5.2 & 5.1 & 5.2 & 5.2 & 4.8 & 4.2 & 3.9 & 4.2 & 4.1 & 4.7 & 4.4 & 5.1 \\
\hline 13 & 3.6 & 3.0 & 3.0 & 4.1 & 4.3 & 3.6 & 3.3 & 3.5 & 3.3 & 3.5 & 3.0 & 3.7 \\
\hline 19 & 4.4 & 3.4 & 2.7 & 2.8 & 3.0 & 2.7 & 2.2 & 2.3 & 2.0 & 2.9 & 3.3 & 4.3 \\
\hline
\end{tabular}

Суточный ход скорости ветра на предгорных равнинах во все месяцы характеризуется дневным максимумом, который связан с усилением вертикального турбулентного обмена и переносом количества движения по вертикали. Вихри, проникающие из верхних 
слоев в нижние, способствуют увеличению скорости в нижних слоях, а на высоте 220-300 м скорость ветра уменьшается.

В вечерние часы уменьшаются конвекция и соответственно вертикальная турбулентность, поэтому скорости ветра на высоте вновь возрастают. Такой их ход наиболее резко выражен в ясные солнечные дни. В жаркие летние дни граница нижнего, приземного слоя воздуха (высота обращения ветра) доходит до 300 м и падает до 20 м в дни зимних инверсий температуры.

На метеостанциях, расположенных на склонах гор (Риддер), вторичный максимум скоростей ветра приходится на ночные часы, а над более высокими склонами (нишами на склонах) основной максимум создается за счет стока охлажденных масс воздуха в ночное время (Катон-Карагай). Стоковые явления определяют более высокие температуры воздуха зимой на склонах в сравнении с долинами, котловинами без стока холодных масс. Например, пос. Орловский (1100 м), Катон-Карагай (1080-1100 м). Зимой в Катон-Карагае средняя температура января составляет минус $13.6^{0}$, в пос. Орловский минус $27.1^{0} \mathrm{C}$, средняя скорость ветра соответственно, 4,6 и $0,4 \mathrm{~m} / \mathrm{c}$.

Из 15-летнего ряда наблюдений (1955-1970 гг.) были выявлены синоптические ситуации сильных ( $\geq 12 \mathrm{~m} / \mathrm{c})$ и штормовых $(\geq 18 \mathrm{~m} / \mathrm{c})$ ветров в пределах Юго-Западного Алтая. Наиболее часто в холодный период сильные ветры наблюдаются при юго-западном антициклоническом типе циркуляции, подтипе VA (31-35\% от общего числа дней с сильными и штормовыми ветрами), на втором месте по повторяемости (27-32\%) стоят процессы подтипа IA, реже усиление ветра до 15-18 м/с наблюдается при подтипе ІІІБ. Летом сильные ветры редки и связаны в основном с циклоническими типами циркуляции. Чаще это бывает при прохождении через регион систем холодных фронтов и точек окклюзий фронтов: с ними обычны грозы с сильными, порывистыми ветрами.

Во всех случаях штормовых и сильных ветров в пределах ЮгоЗападного Алтая в подтипе I-A над Алтаем и Западной Сибирью отмечается слияние двух фронтальных зон - арктической и полярной. В 50\% случаев зона наибольших контрастов проходила над Алтаем (28-32 дкм на 1000 км). При этом циклоны, смещающиеся по центральной части Западно-Сибирской низменности, углубляются до 995-985 гПа. Одновременно с ними сопряженно над Монголией располагаются антициклоны с давлением 1060-1070 гПа. Часто 
планетарная высотная фронтальная зона с контрастами 28-32 дкм располагалась под $55^{0}$ с. ш. В этот же период сильные ветры наблюдались на ряде станций Юго-Западного Алтая.

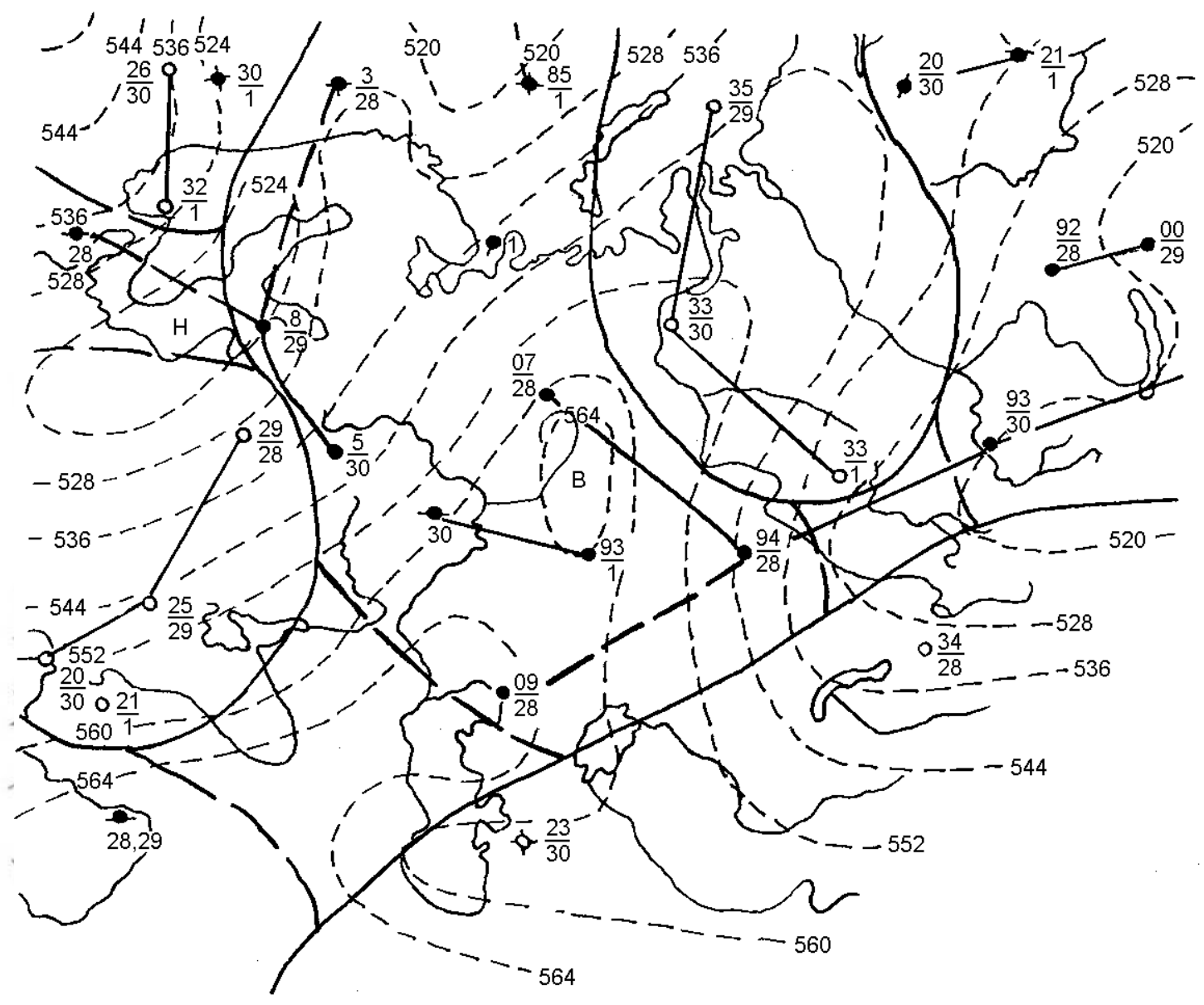

Рис. 22. Совмещенная карта АТ-500 и сборной кинематики за 28.XI - 1. XII 1968 г.

Примером подтипа I-A может служить процесс в естественносиноптическом периоде 28-31 января 1966 г. Центральная часть фронтальной зоны тогда располагалась под $55^{\circ}$ с. ш. Контрасты в ней составляли 40 дкм/1000 км. У земли наблюдалась интенсивная циклоническая деятельность как на арктическом, так и на полярном фронтах. Над Монголией и юго-востоком Западной Сибири стационировали антициклоны. Большие скорости ветра отмечались 31 января 1966 г. Они были связаны с тем, что над Западной Сибирью произошла регенерация полярно-фронтового циклона на арктическом фронте. Глубина циклона, расположенного над Омском, составляла 995 гПа. Циклон, смещаясь на восток, углублялся, и в 15 часов 31 января 1966 года его центр был расположен над Новосибирском и очерчен изобарой 985 гПа. Давление над Аралом составляло 1030 мб. Над исследуемым регионом увеличились градиенты давления. Так, скорость ветра в Большенарыме и Курчуме составила 20, в Акжаре - 
32, в Буране - 14, в Зайсане -8 м/с. Циклон 1 февраля 1966 г. смещался на восток, а через Юго-Западный Алтай проходила система холодных фронтов, на горных станциях скорость ветра достигала $15-20 \mathrm{~m} / \mathrm{c}$.

При ультраполярных вторжениях обычно создаются большие градиенты давления над южными районами наблюдаемого региона, что часто приводит к возникновению сильных ветров в Буране, Зайсане, Катон-Карагае. Штормы на открытых склонах, перевалах нередко сопровождаются выпадением обильных осадков (рис. 22).

\section{2. Термический режим}

Термический режим территории Казахстанского Алтая формируется под влиянием взаимодействующих радиационных, циркуляционных факторов с подстилающей поверхностью.

Тепло от подстилающей поверхности передается в результате турбулентной теплопроводности, влагооборота, развития конвекции, эффективного излучения и молекулярной теплопроводности. Надо отметить, что турбулентная теплопроводность воздуха примерно в 500 тыс. раз больше молекулярной. Свойства воздушной массы определяются характером природных ландшафтов, над которыми она находится длительное время, сами же воздушные массы являются носителями тепла и влаги.

Средние температуры воздуха соответствуют температуре местной воздушной массы - континентально-умеренного воздуха (КУВ). Для Казахстанского Алтая характерны температурные контрасты, вызываемые затоками континентального арктического воздуха (КАВ) с севера и континентального тропического (КТВ) с юга. Периодичность поступления солнечной радиации обусловила суточный и годовой ритмы температуры. В горной стране температура воздуха подвержена изменению в результате термодинамических процессов: восходящие и нисходящие токи воздуха сопровождаются соответственно понижением температуры (сухоадиабатический градиент $\gamma=1^{0} / 100$ м) либо ее повышением; агрегатные изменения влаги в атмосфере идут с затратой тепловой энергии на испарение и таяние или ее выделением при конденсации и сублимации. Эта энергия также затрачивается на нагревание воздуха.

Температурный режим воздуха горной страны в меньшей степени зависит от абсолютной высоты местности и в большей от форм рельефа - котловина, склон, вершина (закон Воейкова). 
Параметры температуры воздуха. Юго-Западный Алтай

\begin{tabular}{|c|c|c|c|c|c|c|c|c|c|c|c|c|c|c|}
\hline \multirow{2}{*}{ Метеостанция } & \multirow{2}{*}{$\begin{array}{l}\text { Bысота } \\
\text { (H), } \mathrm{M} \\
\end{array}$} & \multicolumn{13}{|c|}{ Месяцы } \\
\hline & & $\underline{I}$ & $\underline{\text { II }}$ & III & IV & $\mathrm{V}$ & VI & VII & VIII & $\underline{\mathrm{IX}}$ & $\underline{X}$ & $\underline{\mathrm{XI}}$ & XII & Год \\
\hline \multicolumn{15}{|c|}{ РУДНЫЙ АЛТАЙ } \\
\hline \multicolumn{15}{|c|}{ Средняя месячная температура } \\
\hline Шемонаиха & 329 & -18.2 & -17.2 & -10.2 & 2.2 & 11.7 & 17.6 & 19.6 & 17.6 & 11.5 & 3.2 & -7.8 & -15.2 & 1.2 \\
\hline $\begin{array}{l}\text { Усть- } \\
\text { Каменогорск }\end{array}$ & $\underline{285}$ & $\underline{-17.0}$ & -16.0 & -7.7 & $\underline{4.7}$ & 13.4 & $\underline{18.8}$ & $\underline{20.8}$ & $\underline{18.3}$ & $\underline{12.5}$ & $\underline{5.0}$ & $\underline{-6.2}$ & -14.1 & 2.7 \\
\hline Риддер & $\underline{809}$ & -12.9 & -12.7 & -7.3 & 2.1 & 9.7 & $\underline{15.1}$ & 16.7 & 15.1 & 9.6 & 2.0 & -7.8 & -12.2 & 1.5 \\
\hline Зыряновск & $\underline{457}$ & $\underline{-23.8}$ & $\underline{-22.0}$ & $\underline{-13.9}$ & $\underline{-0.7}$ & 11.2 & $\underline{16.5}$ & $\underline{18.5}$ & 16.5 & 10.2 & 1.5 & -11.6 & $\underline{-20.3}$ & -1.5 \\
\hline \multicolumn{15}{|c|}{$\overline{\text { Средний минимум температуры }}$} \\
\hline Шемонаиха & $\underline{329}$ & -24.3 & -24.0 & -16.7 & -3.6 & 4.7 & 9.9 & $\underline{12.2}$ & 10.0 & 4.2 & -2.1 & 12.3 & -20.5 & -5.2 \\
\hline $\begin{array}{l}\text { Усть- } \\
\text { Каменогорск }\end{array}$ & $\underline{285}$ & -22.4 & -22.4 & -13.8 & $\underline{-1.2}$ & $\underline{6.1}$ & $\underline{11.4}$ & 13.6 & $\underline{10.9}$ & $\underline{5.3}$ & $\underline{-0.3}$ & $\underline{-10.8}$ & $\underline{-19.2}$ & $\underline{-3.6}$ \\
\hline Риддер & $\underline{809}$ & -18.8 & -18.8 & -13.8 & $\underline{-4.5}$ & 2.4 & 7.1 & $\underline{9.0}$ & 7.8 & 2.8 & -3.4 & -12.2 & $\underline{-17.4}$ & $\underline{-5.0}$ \\
\hline Зыряновск & 457 & -30.2 & -28.7 & -21.2 & $\underline{-6.9}$ & $\underline{3.1}$ & 7.9 & $\underline{10.0}$ & 7.6 & 1.9 & -4.5 & -16.4 & -26.0 & $\underline{-8.6}$ \\
\hline \multicolumn{15}{|c|}{ Средний максимум температуры } \\
\hline Шемонаиха & $\underline{329}$ & -12.6 & -11.2 & -3.8 & $\underline{8.6}$ & $\underline{19.3}$ & $\underline{25.0}$ & 27.0 & 25.5 & 19.9 & 10.1 & $\underline{-2.9}$ & -10.4 & 7.9 \\
\hline $\begin{array}{l}\text { Усть- } \\
\text { Каменогорск }\end{array}$ & 285 & -11.1 & -9.1 & -1.6 & $\underline{11.3}$ & 21.0 & 26.4 & 28.2 & 26.1 & 20.6 & $\underline{11.5}$ & -1.3 & $\underline{-8.6}$ & 9.4 \\
\hline Риддер & $\underline{809}$ & -7.1 & $\underline{-5.7}$ & $\underline{-0.1}$ & $\underline{8.6}$ & $\underline{16.4}$ & 21.9 & 23.5 & 22.3 & $\underline{17.0}$ & $\underline{8.8}$ & $\underline{-2.1}$ & $\begin{array}{l}-7.0 \\
\end{array}$ & $\underline{8.0}$ \\
\hline Зыряновск & 457 & $\underline{-17.6}$ & -14.2 & $\underline{-5.6}$ & 5.8 & $\underline{19.2}$ & 24.6 & 26.5 & 25.4 & 19.6 & $\underline{9.5}$ & -5.4 & -14.7 & 6.1 \\
\hline \multicolumn{15}{|c|}{ 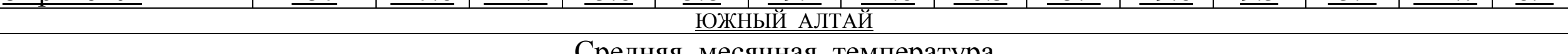 } \\
\hline & & 140 & & СредН & s Mec & чLная & емпер & тура & & & & & & \\
\hline Курчум & $\frac{1001}{425}$ & $\frac{-14.0}{-20.4}$ & $\frac{-12.5}{-18.9}$ & $\frac{-6.1}{-9.9}$ & $\underline{3.2}$ & $\frac{10.2}{137}$ & $\frac{15.1}{19.0}$ & $\frac{17.2}{210}$ & $\underline{15.2}$ & $\frac{10.6}{13.3}$ & $\frac{2.8}{4.8}$ & $\frac{-8.5}{-7.3}$ & $\frac{-13.6}{-17.4}$ & $\underline{1.6}$ \\
\hline Маркаколь & 1410 & -25.9 & $-\underline{-22.8}$ & -15.4 & $-\overline{-5.1}$ & 4.0 & 11.9 & 14.1 & 13.1 & $\underline{8.1}$ & $\underline{0.0}$ & -9.6 & -21.5 & -4.1 \\
\hline Пос. Орловский & 1100 & -27.1 & -23.4 & -14.7 & -1.3 & 8.9 & 14.0 & 15.6 & 13.6 & $\underline{7.6}$ & $\underline{-0.8}$ & -14.2 & -24.2 & -3.8 \\
\hline Самарка & $\underline{500}$ & -17.9 & -15.4 & -8.1 & 4.9 & 13.4 & 19.0 & 21.4 & 19.8 & 13.7 & 4.9 & -7.2 & -15.6 & 2.7 \\
\hline
\end{tabular}


Продолжение таблицы 23

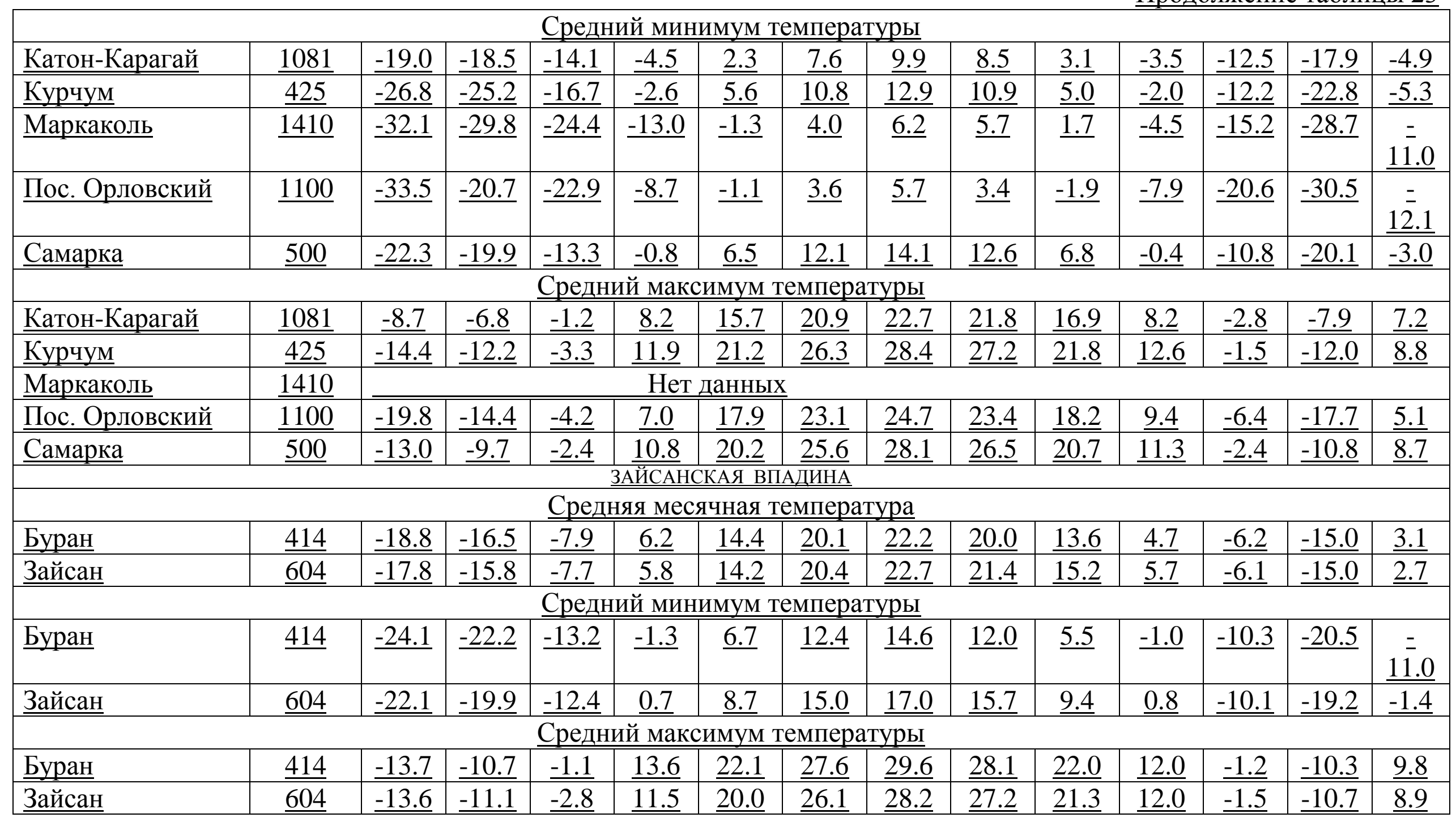


Ниже приводятся параметры температуры для характерных форм рельефа в пределах провинций Юго-Западного Алтая.

Зимой температура местного КУВ на предгорных равнинах изменяется от минус 17 до минус $22^{0}$, на склонах гор от минус 13 до минус $15^{0}$, в горных котловинах от минус 24 до минус $27^{0} \mathrm{C}$. Абсолютная влажность этого воздуха мала и колеблется от 0,5 до 2,0 $\Gamma / \mathrm{m}^{3}$. Летом КУВ имеет большие запасы и тепла и влаги. Средние температуры на предгорных равнинах составляют 18-23, на склонах гор $16-18^{0} \mathrm{C}$, в горных котловинах от 14 до $16^{\circ} \mathrm{C}$. Абсолютная влажность местного КУВ достигает $12-15 \Gamma^{2} \mathrm{~m}^{3}$. Летом процессы трансформации (прогрев и обогащение влагой) проходят гораздо интенсивнее, чем зимой. Так, среднее суточное нарастание температуры на высоте 1,5 км может достигать до 2,8-4,0 $0^{0} \mathrm{C}$ : в 13 ч. температура воздуха составляет $24-26^{\circ} \mathrm{C}$, а максимальная $30-36^{\circ} \mathrm{C}$ [50]. Табл. 23 характеризует среднюю суточную амплитуду хода температуры по месяцам.

В котловинах, долинах суточная амплитуда температуры в ясные дни будет более значительной, чем на соседних холмах и склонах хребтов. Эти различия будут тем больше, «чем менее облаков, чем менее абсолютная и относительная сырость и чем слабее ветер, особенно ночью» [51].

Зимой на предгорных равнинах и склонах Рудного Алтая средняя суточная амплитуда температуры составляет минус $10-12^{0} \mathrm{C}$, в Зыряновском низкогорье в котловинах минус $12,6^{0}$; на Южном Алтае минус $10-12^{0}$, в Орловской котловине минус $14^{0} \mathrm{C}$. Летом она увеличивается и составляет в Рудном Алтае $14-16^{0}$, в Южном Алтае $15-19^{0} \mathrm{C}$. Столь большие амплитуды колебания температуры в течение суток характерны для континентального типа климата.

Зимой происходит радиационное выхолаживание воздуха, средние минимумы на предгорных равнинах составляют минус $21^{0}$, минус $25^{0}$, на склонах среднегорий минус $17^{0}$, минус $19^{0}$, в котловинах минус $26^{0}$, минус $33^{\circ} \mathrm{C}$. Абсолютные минимумы по отдельным станциям составляют минус $40 \div 54^{0} \mathrm{C}$ (табл. 24).

Абсолютный максимум и абсолютный минимум - это предельные уровни температуры воздуха, зафиксированные на станциях один раз за весь период наблюдений. Они обусловлены интенсивным выносом на территорию Казахстанского Алтая континентального тропического и континентального арктического воздуха. Средний из абсолютных минимумов температуры воздуха 
дает представление о величине абсолютного минимума, который можно ожидать ежегодно. Так, в Рудном Алтае он составляет минус $33 \div$ минус $44^{0} \mathrm{C}$, в Южном минус $31 \div$ минус $47^{0} \mathrm{C}$ (Орловская котловина), в Зайсанской впадине минус $34 \div$ минус $40^{\circ} \mathrm{C}$. В летние месяцы, кроме июля, в котловинах возможны заморозки до минус $4^{0} \mathrm{C}$.

Т а бли ц а 24

Предельные уровни температуры воздуха по провинциям Юго-Западного Алтая в характерных типах рельефа [13]

\begin{tabular}{|c|c|c|c|c|c|c|c|c|c|c|c|c|c|}
\hline Станция & I & II & III & IV & $\mathrm{V}$ & VI & VII & VIII & IX & $\mathrm{X}$ & XI & XII & Год \\
\hline \multicolumn{14}{|c|}{ Абсолютные минимумы температуры } \\
\hline \multicolumn{14}{|c|}{ Рудный Алтай } \\
\hline $\begin{array}{l}\text { Усть-Камено- } \\
\text { горск (долина, } \\
\text { предгорье) }\end{array}$ & -49 & -47 & -40 & -30 & -9 & -1 & 4 & -1 & -7 & -19 & -44 & -48 & -49 \\
\hline $\begin{array}{l}\text { Риддер } \\
\text { (склон) }\end{array}$ & -41 & -47 & -39 & -30 & -13 & -3 & 2 & -2 & -9 & -26 & -44 & -44 & -47 \\
\hline $\begin{array}{l}\text { Зыряновск } \\
\text { (котловина) }\end{array}$ & -51 & -50 & -47 & -27 & -11 & -4 & -4 & -4 & -12 & -29 & -49 & -50 & -51 \\
\hline \multicolumn{14}{|c|}{ Южный Алтай } \\
\hline $\begin{array}{l}\text { Катон-Карагай } \\
\text { (сев. склон) }\end{array}$ & -39 & -44 & -34 & -22 & -14 & -4 & 0 & -3 & -10 & -26 & -43 & -41 & -44 \\
\hline $\begin{array}{l}\text { Самарка } \\
\text { (долина) }\end{array}$ & -41 & -42 & -33 & -26 & -11 & -1 & 5 & -1 & -4 & -19 & -41 & -40 & -42 \\
\hline $\begin{array}{l}\text { Пос. } \\
\text { Орловский } \\
\text { (котло- вина) }\end{array}$ & -54 & -52 & -46 & -33 & -15 & -7 & -4 & -9 & -14 & -29 & -54 & -52 & -54 \\
\hline \multicolumn{14}{|c|}{ Зайсанская впадина } \\
\hline Буран & -49 & -48 & -43 & -26 & -9 & -2 & 3 & -1 & -10 & -23 & -42 & -51 & -51 \\
\hline Зайсан & -46 & -43 & -36 & -19 & -12 & 0 & 6 & 3 & -4 & -20 & -40 & -43 & -46 \\
\hline \multicolumn{14}{|c|}{ Абсолютный максимум температуры воздуха } \\
\hline \multicolumn{14}{|c|}{ Рудный Алтай } \\
\hline $\begin{array}{l}\text { Усть- } \\
\text { Каменогорск }\end{array}$ & 8 & 8 & 20 & 33 & 38 & 38 & 43 & 40 & 37 & 29 & 19 & 14 & 43 \\
\hline Риддер & 13 & 15 & 16 & 24 & 32 & 33 & 35 & 35 & 31 & 25 & 17 & 14 & 35 \\
\hline \multicolumn{14}{|c|}{ Южный Алтай } \\
\hline Катон-Карагай & 7 & 15 & 21 & 26 & 31 & 33 & 34 & 34 & 32 & 26 & 16 & 14 & 34 \\
\hline Самарка & 2 & 6 & 21 & 31 & 35 & 37 & 39 & 39 & 35 & 28 & 20 & 6 & 39 \\
\hline $\begin{array}{l}\text { Пос. } \\
\text { Орловский }\end{array}$ & 0 & 4 & 9 & 26 & 31 & 34 & 35 & 36 & 31 & 26 & 13 & 4 & 36 \\
\hline \multicolumn{14}{|c|}{ Зайсанская впадина } \\
\hline Буран & 7 & 9 & 22 & 33 & 36 & 38 & 40 & 39 & 37 & 27 & 17 & 6 & 40 \\
\hline Зайсан & 10 & 11 & 22 & 32 & 35 & 38 & 40 & 39 & 37 & 28 & 17 & 12 & 40 \\
\hline
\end{tabular}


Амплитуда годового хода температуры в котловинах составляет $40-43^{0} \mathrm{C}$ (в Маркакольской $-40^{0}$, Зыряновской $42^{0}$, ВОрловской $-43^{0}$ ), на предгорных равнинах до $35-37^{\circ} \mathrm{C}$, а на склонах хребтов (Риддер, Катон-Карагай) $\quad-$ порядка $30^{\circ} \mathrm{C}$. Вертикальные градиенты температуры воздуха в летний сезон на большей части Казахстанского Алтая колеблются от 0,5 до $0,7^{0} \mathrm{C}$ на 100 м поднятия. Так в пределах Рудного и Южного Алтая они чаще всего достигают $0,2-0,4^{0} \mathrm{C}$.

В зимний период на склонах гор отмечается сток холодного воздуха вниз по склону, в условиях антициклона эти процессы усиливаются нисходящими токами. Поэтому вертикальные градиенты температуры отрицательные (температура воздуха возрастает с высотой на склонах) и составляют даже по многолетним средним $0,8-1,1^{0} \mathrm{C}$ на 100 м поднятия $\left(-\Delta \mathrm{T}=-0,8 \div-1,1^{0} \mathrm{C}\right)$. Но вертикальный градиент температуры между котловинами, расположенными на различных высотах, зимой положительный и составляет $0,5-0,6^{0}$ C на 100 м поднятия. Это объясняется увеличением с высотой эффективного излучения подстилающей поверхности. Зимой эффективное излучение оказывается значительно выше радиационного баланса, что обусловливает интенсивное радиационное выхолаживание приземного слоя воздуха. Кроме того, на дно долин стекают струи холодного воздуха со склонов. Поэтому над котловинами происходит усиление процессов антициклогенеза: рост давления воздуха, нисходящие токи за счет уплотнения охлажденных приземных слоев при отсутствии стока из котловин.

В связи с этим представляют интерес данные о ходе градиентов температуры. Так, вертикальный градиент температуры воздуха между Зыряновской и Чуйской, Зыряновской и Орловской котловинами составляют $\Delta \mathrm{T}=0,5 \div 0,6^{0} \mathrm{C}$ на 100 м. С высотой котловины становятся более холодными, а склоны - более теплыми. В январе температура воздуха в Усть-Каменогорске составляет минус $17,0^{0} \mathrm{C}$, на этой же широте в Риддере $\left(809\right.$ м) минус $12,9^{\circ} \mathrm{C}$, в КатонКарагае $\left(1080\right.$ м) минус $14,8^{0}$, в Катон-Карагае (метеостанция Северная) минус $13,6^{0}$, в Кара-Тюреке (2600 м) минус $16,9^{0} \mathrm{C}$ (табл. 25).

Интенсивное вертикальное перемешивание воздуха, развитие конвективных токов происходит при градиенте температуры большем, чем сухоадиабатический $\left(\gamma=1{ }^{0} \mathrm{C}\right.$ на 100 м поднятия). В июне и июле вертикальные градиенты между Зыряновском и 
вышележащими станциями - Риддер, Катон-Карагаем составляют в среднем 0,2-0,4 $4^{0}$ на 100 м. Такие градиенты обычны для устойчивой стратификации атмосферы. Даже в неглубоких котловинах и долинах зимой наблюдаются застойные явления, характерны инверсии температуры, образуется так называемый инверсионный пояс температуры за счет антициклональных фёнов сжатия и классических фёнов переваливания. Наиболее четко этот пояс выражен в Рудном Алтае на высотах от 600-700 до 1300-1400 м, в Южном Алтае от 800900 до 1600 м, а также, вероятно, и выше. Располагаясь в лесных ландшафтах, этот пояс характеризуется ясной, слабо и умеренно морозной погодой.

Средние температуры воздуха в котловинах Алтая , ${ }^{0} \mathrm{C}$

Т а бли ц а 25

\begin{tabular}{|lr|c|c|c|c|}
\hline \multicolumn{2}{|c|}{ Станция } & Высота, & \multicolumn{3}{c|}{ Месяцы } \\
\cline { 4 - 6 } & м & XII & I & II \\
\hline Зыряновск & 457 & -20.3 & -23.8 & -22.0 \\
\hline Пос. Орловский & 1100 & -24.2 & -27.1 & -23.4 \\
\hline $\begin{array}{l}\text { Кош-Агач (Чуйская котловина } \\
\text { Горном Алтае) }\end{array}$ & в & 1758 & -27.4 & -32.1 & -28.8 \\
\hline
\end{tabular}

Повышенная повторяемость таких погод составляет от 71 до $90 \%$ и без ограничения может быть использована для отдыха и туризма.

Но для промышленных центров Казахстанского Алтая подобные застойные явления, связанные с ослабленным турбулентным перемешиванием воздуха на высоте 3 км и образованием температурных инверсий опасны, так как создают экологически неблагоприятную обстановку с высоким и очень высоким потенциалом загрязнения атмосферы [29].

Краткая характеристика ресурсов тепла в теплом периоде. Теплый период для Казахстанского Алтая характеризуется интенсивным нарастанием температуры, уже заметным от марта к маю за счет увеличения продолжительности дня, высоты солнца и схода снежного покрова к апрелю. Температура мая и сентября примерно одинакова и составляет в пределах предгорных равнин 11$12^{0} \mathrm{C}$, в Зайсанской котловине $13-15^{\circ} \mathrm{C}$.

Весной и осенью большое практическое значение имеют даты перехода среднесуточных температур через $0^{0}, 5^{0}, 10^{0} \mathrm{C}$ (табл. 26). Дата устойчивого перехода температуры через $0^{0} \mathrm{C}$ весной указывает на конец зимы и начало дружного снеготаяния. Количество дней 
между такими температурными пределами является общей продолжительностью теплового периода. Устойчивый переход температуры через $5^{0} \mathrm{C}$ весной и осенью совпадает с возобновлением или прекращением вегетации озимых культур и большинства древесной растительности - это период вегетации. Он длится от 160 до 170 дней на севере исследуемой территории и до 180-190 дней в Зайсанской котловине. $\mathrm{C}$ высотой его продолжительность уменьшается: в Усть-Каменогорске 176 дней, в Риддере до 159, в Орловском поселке до 150, в Зайсане 189 дней. Сумма положительных температур воздуха за вегетационный период составляет на предгорных равнинах Рудного Алтая $2600^{\circ}$, на склонах гор высотой до 1000 м - 2000-2100 ${ }^{\circ}$, в Зыряновской котловине $2700^{\circ}$, в Зайсанской котловине до $3200-3300^{0}$ [52].

Т а бли ц а 26

Даты перехода средней суточной температуры воздуха через $0,+5,+10,+15^{0} \mathrm{C}$ и продолжительность (дни) с температурой выше указанных пределов

\begin{tabular}{|c|c|c|c|c|}
\hline Станция & $0^{0}$ & $5^{0}$ & $10^{\circ}$ & $15^{0}$ \\
\hline \multirow{3}{*}{ Шемонаиха } & 10.IV & 23.IV & $9 . \mathrm{V}$ & $30 . \mathrm{V}$ \\
\hline & $26 . X$ & $10 . \mathrm{X}$ & 21.IX & 1.IX \\
\hline & 198 & 169 & 134 & 93 \\
\hline \multirow{3}{*}{ Риддер } & 7.IV & 26.IV & $16 . \mathrm{V}$ & 12.VI \\
\hline & $23 . X$ & $4 . X$ & 13.IX & 18.VIII \\
\hline & 198 & 160 & 119 & 66 \\
\hline \multirow{3}{*}{ Усть-Каменогорск АМСГ } & 6.IV & 20.IV & 7.V & $28 . \mathrm{V}$ \\
\hline & $28 . \mathrm{X}$ & 12.X & 21.IX & 1.IX \\
\hline & 204 & 174 & 136 & 95 \\
\hline \multirow{3}{*}{ Зыряновск } & 16.IV & 26.IV & $9 . \mathrm{V}$ & $5 . \mathrm{VI}$ \\
\hline & $20 . \mathrm{X}$ & $6 . X$ & 16.IX & 25.VIII \\
\hline & 186 & 162 & 129 & 80 \\
\hline \multirow{3}{*}{ Большенарымское } & 8.IV & 20.IV & $4 . \mathrm{V}$ & $26 . \mathrm{V}$ \\
\hline & $24 . \mathrm{X}$ & $11 . \mathrm{X}$ & 25.IX & 5.IX \\
\hline & 198 & 173 & 143 & 101 \\
\hline \multirow{3}{*}{ Катон-Карагай } & 4.IV & 22.IV & 14.V & 14.VI \\
\hline & $23 . \mathrm{X}$ & $10 . \mathrm{X}$ & 19.IX & 18.VIII \\
\hline & 201 & 170 & 127 & 64 \\
\hline \multirow{3}{*}{ Самарка } & 2.IV & 15.IV & $1 . \mathrm{V}$ & $22 . \mathrm{V}$ \\
\hline & $30 . \mathrm{X}$ & $15 . \mathrm{X}$ & 29.IX & 10.IX \\
\hline & 210 & 182 & 150 & 110 \\
\hline \multirow{3}{*}{ Маркаколь } & $2 . \mathrm{V}$ & $19 . \mathrm{V}$ & $5 . \mathrm{VI}$ & - \\
\hline & $16 . X$ & 29.IX & 6.IX & - \\
\hline & 166 & 132 & 92 & - \\
\hline \multirow{3}{*}{ Буран } & 1.IV & 10.IV & 27.IV & $17 . \mathrm{V}$ \\
\hline & $29 . X$ & $15 . X$ & 28.IX & 16.IX \\
\hline & 210 & 187 & 153 & 121 \\
\hline \multirow{3}{*}{ Зайсан } & 31.III & 12.IV & 28.IV & $19 . \mathrm{V}$ \\
\hline & $30 . X$ & $18 . \mathrm{X}$ & $4 . X$ & 16.IX \\
\hline & 212 & 188 & 158 & 119 \\
\hline
\end{tabular}


Для вегетационного периода исследуемого региона характерны заморозки - понижение минимальной температуры ниже $0^{0} \mathrm{C}$ на фоне положительных температур. Первые заморозки (средняя дата) на равнинах северной части региона могут быть на 20-25 дней раньше, чем на юге (Шемонаиха -12 сентября, Зайсан - 9 октября); на горных склонах - позже, чем в котловинах, (Катон-Карагай -7 сентября, Риддер - 6 сентября, Зыряновск - 2 октября). Заморозки радиационного характера возникают за счет сильного эффективного излучения в безоблачные ночи. В таких случаях они наблюдаются у подножия склонов и в ложбинах, а на холмах и склонах их может и не быть. Радиационно-адвективные заморозки бывают достаточно сильными как в сентябре, так и в середине мая, когда температура воздуха снижается до минус $3^{0} \mathrm{C}$ и более. Заморозки такого типа объясняются смещением на территорию Юго-Западного Алтая прежнего арктического воздуха и его дальнейшего охлаждения за счет радиационного выхолаживания (табл. 27-31).

Активный рост большинства сельскохозяйственных культур начинается при средней суточной температуре $10^{\circ} \mathrm{C}$ и выше - это период активной вегетации, а сумма температур выше $10^{0} \mathrm{C}$ называется суммой эффективных температур (см. табл. 27).

Важное практическое значение имеет информация о средней (самой ранней и самой поздней) дате последнего заморозка весной и первого заморозка осенью, а также продолжительности безморозного периода (см. табл. 28-30). Продолжительность безморозного периода уменьшается с юго-запада на северо-восток исследуемой территории от 160 до 100 дней. По продолжительности безморозного периода выделены зоны, которые достаточно хорошо совпадают с границами природных зон и характеризуются определенной величиной суммы эффективных температур. Так, в зоне полупустынь и пустынь продолжительность безморозного периода составляет 135-160 дней, суммы эффективных температур $2800-3000^{\circ} \mathrm{C}$. В горном лесном поясе безморозный период менее 100 дней, а суммы эффективных температур не превышают $1800^{\circ} \mathrm{C}$. На предгорных равнинах безморозный период 125-135 дней с суммой температур 2200-2400 ${ }^{\circ} \mathrm{C}$. При таких условиях могут нормально развиваться все культуры умеренных широт.

Термическая характеристика холодного периода. Холодный период на исследуемой территории продолжается с ноября по март и характеризуется 
подстилающей поверхности, морозными погодами, наличием устойчивого снежного покрова. Деятельной поверхностью становится поверхность снега с альбедо от 60 до 80\%. Малое содержание влаги в холодном воздухе обусловливает большую прозрачность атмосферы для длинноволнового излучения земли. Эффективное излучение становится ведущим климатообразующим фактором. Снежный покров защищает почву от сильного промерзания, но в то же время усиливает выхолаживание прилегающих слоев воздуха. Устойчивый снежный покров на территории формируется в основном в первой декаде ноября, при переходе средней суточной температуры через минус $5^{0} \mathrm{C}$, а в горах в третьей декаде октября. Сход снежного покрова происходит на большей части региона во второй или третьей декаде апреля. Самым холодным месяцем является январь со средней температурой от минус 13 до минус $27^{0} \mathrm{C}$ (см. табл. 23). Быстрое снижение температуры идет от ноября к декабрю (от минус $6 \div 10^{0} \mathrm{C}$ до минус $15 \div 24^{0} \mathrm{C}$ ), а быстрое нарастание от февраля к марту (от минус $15 \div 23^{0} \mathrm{C}$ до минус $6 \div 15^{0} \mathrm{C}$ ). Переход средней суточной температуры через $0^{0} \mathrm{C}$ в период спада осуществляется в третьей декаде октября; через минус $5^{0} \mathrm{C}-$ в первой декаде ноября; через минус $10^{\circ} \mathrm{C}$ - в третьей декаде ноября; через минус $15^{\circ} \mathrm{C}-$ в первой и второй декаде декабря, а в Зыряновской и Орловской котловинах в третьей декаде ноября. Период с температурой ниже минус $15^{\circ} \mathrm{C}$ является центральной частью холодного периода и длится в Орловском поселке 121 день (16 ноября-16 марта), 109 дней в Зыряновске (25 ноября-13 марта), 80 - в Шемонаихе (13 декабря-2 марта), 77 - в Прапорщиково (Усть-Каменогорск) - (16 декабря-2 марта), 72 - в Самарке (10 декабря-19 февраля), 69 - в Зайсане (14 декабря-20 февраля) и только 7 дней в Катон-Карагае (8 января-14 января). В Риддере и Северном поселке переходов среднесуточных температур через минус $15^{\circ} \mathrm{C}$ не отмечается. Переход средних температур через минус $20^{\circ} \mathrm{C}$ наблюдается в Зыряновской котловине и через минус $25^{\circ} \mathrm{C}$ - в Орловской. Период устойчивых морозов длится 4-5 месяцев. За день с морозом принят день с максимальной температурой от $0^{0} \mathrm{C}$ и ниже. Продолжительность устойчивых морозов приводится в табл. 32. При нарастании температуры переход через минус $10^{0} \mathrm{C}$ происходит в течение марта: в Катон-Карагае - 1 марта, Риддере -8 марта, Зайсане - 11 марта, пос. Северный - 11 марта, Самарке - 12 марта, Курчуме - 17 марта, Зыряновске - 27 марта, пос. Орловский - 28 марта. 
Сумма положительных температур воздуха за период со среднесуточной температурой выше $10^{0} \mathrm{C}$, нарастающим итогом на последний день декады

\begin{tabular}{|c|c|c|c|c|c|c|c|c|c|c|c|c|c|c|c|c|c|c|c|c|c|}
\hline \multirow[t]{2}{*}{ Станции } & \multicolumn{3}{|c|}{ Апрель } & \multicolumn{3}{|c|}{ Май } & \multicolumn{3}{|c|}{ Июнь } & \multicolumn{3}{|c|}{ Июль } & \multicolumn{3}{|c|}{ Август } & \multicolumn{3}{|c|}{ Сентябрь } & \multicolumn{3}{|c|}{ Октябрь } \\
\hline & I & II & III & $\mathrm{I}$ & II & III & $\mathrm{I}$ & II & III & I & II & III & I & II & III & $\mathrm{I}$ & II & III & I & II & III \\
\hline Шемонаиха & & & 28 & 88 & 191 & 348 & 522 & 705 & 899 & 1103 & 1304 & 1525 & 1715 & 1897 & 2069 & 2208 & 2324 & 2383 & 2392 & & \\
\hline Риддер & & & 5 & 31 & 86 & 203 & 342 & 495 & 658 & 890 & 1000 & 1187 & 1349 & 1505 & 1644 & 1749 & 1816 & 1839 & 1841 & & \\
\hline $\begin{array}{l}\text { Большена- } \\
\text { рымское }\end{array}$ & & 3 & 27 & 102 & 218 & 390 & 566 & 752 & 950 & 1156 & 1361 & 1590 & 1791 & 1983 & 2166 & 2315 & 2445 & 2510 & 2525 & & \\
\hline Катон-Карагай & & & 7 & 34 & 88 & 200 & 332 & 477 & 632 & 795 & 957 & 1137 & 1297 & 1450 & 1588 & 1688 & 1746 & 1766 & & & \\
\hline Самарка & & 10 & 52 & 146 & 274 & 454 & 637 & 831 & 1035 & 1248 & 1460 & 1696 & 1905 & 2109 & 2304 & 2466 & 2610 & 2694 & 2716 & 2718 & \\
\hline Курчум & & 17 & 69 & 178 & 315 & 500 & 687 & 884 & 1092 & 1305 & 1519 & 1756 & 1964 & 2166 & 2360 & 2521 & 2661 & 2746 & 2770 & 2774 & \\
\hline Зайсан & 2 & 27 & 93 & 214 & 360 & 553 & 751 & 959 & 1180 & 1407 & 1637 & 1892 & 2118 & 2338 & 2553 & 2729 & 2890 & 3006 & 3048 & 3058 & 3059 \\
\hline
\end{tabular}

* Примечание: Научно-прикладной справочник по агроклиматическим ресурсам СССР. Сер.2. Средние данные за 19511985 годы. Часть I, вып.18. Республика Казахстан. - Алма-Ата, 1992. - Табл. 9. - С. 88. 
Дата первого и последнего заморозков и продолжительность безморозного периода

\begin{tabular}{|c|c|c|c|c|c|c|c|c|c|}
\hline \multirow[b]{3}{*}{ Станция } & \multicolumn{6}{|c|}{ Дата заморозка } & \multirow{2}{*}{\multicolumn{3}{|c|}{$\begin{array}{c}\text { Продолжительность безморозного } \\
\text { периода (в днях) }\end{array}$}} \\
\hline & \multicolumn{3}{|c|}{ последнего } & \multicolumn{3}{|c|}{ первого } & & & \\
\hline & средняя & $\begin{array}{l}\text { самая } \\
\text { ранняя }\end{array}$ & $\begin{array}{c}\text { самая } \\
\text { поздняя }\end{array}$ & средняя & $\begin{array}{l}\text { самая } \\
\text { ранняя }\end{array}$ & $\begin{array}{c}\text { самая } \\
\text { поздняя }\end{array}$ & средняя & меньшая & большая \\
\hline Шемонаиха & $21 . \mathrm{V}$ & $25 . \mathrm{IV}$ & 16.VI & 12.IX & 19.VIII & 25.IX & 113 & 85 & 142 \\
\hline Риддер & $3 . \mathrm{VI}$ & $28 . I V$ & 19.VI & $6 . I X$ & 24.VIII & 23.IX & 94 & 69 & 138 \\
\hline г. Усть-Каменогорск & $11 . \mathrm{V}$ & 21.IV & - & 21.IX & 27.VIII & $2 . X$ & 132 & 87 & 163 \\
\hline пос. Северный & $18 . \mathrm{V}$ & $25 . \mathrm{IV}$ & 19.VI & 21.IX & 28.VIII & $12 . \mathrm{X}$ & 125 & 88 & 156 \\
\hline Зыряновск & $29 . \mathrm{V}$ & $3 . \mathrm{V}$ & 28.VII & 2.IX & 11.VIII & 30.IX & 95 & 76 & 128 \\
\hline Катон-Карагай & $28 . \mathrm{V}$ & $5 . \mathrm{V}$ & 20.VII & 7.IX & 3.VIII & 30.IX & 101 & - & 147 \\
\hline Усть-Каменогорск & 14.V & 17.IV & 13.VI & 17.IX & 25.VIII & $10 . \mathrm{X}$ & 125 & 86 & 163 \\
\hline Самарка & $16 . \mathrm{V}$ & 20.IV & 18.VI & 25.IX & 27.VIII & $26 . X$ & 131 & 87 & 164 \\
\hline Курчум & 17.V & 26.IV & $2 . \mathrm{VI}$ & 16.IX & 27.VIII & 29.IX & 121 & 92 & 155 \\
\hline Буран & $6 . \mathrm{V}$ & 23.IV & - & 19.IX & 27.VIII & $5 . X$ & 135 & - & - \\
\hline Зайсан & $2 . \mathrm{V}$ & $4 . I V$ & $28 . \mathrm{V}$ & $9 . X$ & 19.IX & $28 . X$ & 159 & 117 & 194 \\
\hline
\end{tabular}

\section{Даты последнего заморозка различной вероятности}

\begin{tabular}{|c|c|c|c|c|c|c|c|c|}
\hline \multirow{2}{*}{$\begin{array}{c}\text { Средняя } \\
\text { дата }\end{array}$} & \multicolumn{7}{|c|}{ Вероятность заморозков в указанные даты } & \multirow{2}{*}{$\begin{array}{c}\text { Самая поздняя } \\
\text { дата }\end{array}$} \\
\hline & 95 & 90 & 75 & 50 & 25 & 10 & 5 & \\
\hline $11 . \mathrm{V}$ & 22.IV & 27.IV & $3 . \mathrm{V}$ & 11.V & $18 . \mathrm{V}$ & $25 . \mathrm{V}$ & $29 . \mathrm{V}$ & $6 . \mathrm{VI}$ \\
\hline $21 . \mathrm{V}$ & $2 . \mathrm{V}$ & $7 . \mathrm{V}$ & $13 . \mathrm{V}$ & $21 . \mathrm{V}$ & $28 . \mathrm{V}$ & 4.VI & $8 . \mathrm{VI}$ & 16.VI \\
\hline $1 . \mathrm{VI}$ & $12 . \mathrm{V}$ & $17 . \mathrm{V}$ & $23 . \mathrm{V}$ & 1.VI & 7.VI & 14.VI & 18.VI & 26.VI \\
\hline
\end{tabular}


Дата первого заморозка различной вероятности

\begin{tabular}{|c|c|c|c|c|c|c|c|c|}
\hline \multicolumn{2}{|c|}{ Даты } & \multicolumn{5}{|c|}{ Вероятность заморозка в указанные и более ранние даты, \% } \\
\hline $\begin{array}{c}\text { Средн } \\
\text { яя }\end{array}$ & $\begin{array}{c}\text { Самая } \\
\text { ранняя }\end{array}$ & 5 & 10 & 25 & 50 & 75 & 90 & 95 \\
\hline $1 . \mathrm{IX}$ & $1 . \mathrm{VIII}$ & $16 . \mathrm{VIII}$ & $20 . \mathrm{VIII}$ & $26 . \mathrm{VIII}$ & $1 . \mathrm{IX}$ & $8 . \mathrm{IX}$ & $13 . \mathrm{IX}$ & $16 . \mathrm{IX}$ \\
\hline $11 . \mathrm{IX}$ & $11 . \mathrm{VIII}$ & $26 . \mathrm{VIII}$ & $30 . \mathrm{VIII}$ & $5 . \mathrm{IX}$ & $11 . \mathrm{IX}$ & $18 . \mathrm{IX}$ & $23 . \mathrm{IX}$ & $26 . \mathrm{IX}$ \\
\hline $21 . \mathrm{IX}$ & $21 . \mathrm{VIII}$ & $5 . \mathrm{IX}$ & 9.IX & $15 . \mathrm{IX}$ & $21 . \mathrm{IX}$ & $28 . \mathrm{IX}$ & $3 . \mathrm{X}$ & $6 . \mathrm{X}$ \\
\hline $1 . \mathrm{X}$ & $1 . \mathrm{IX}$ & $15 . \mathrm{IX}$ & $19 . \mathrm{IX}$ & 25.IX & $1 . \mathrm{X}$ & $3 . \mathrm{X}$ & $13 . \mathrm{X}$ & $16 . \mathrm{X}$ \\
\hline
\end{tabular}

Т а бли и ц 31

Зависимость заморозков от средней минимальной температуры воздуха за декаду, \%

\begin{tabular}{|l|c|c|c|c|c|c|c|c|c|c|c|c|c|c|c|c|c|c|c|}
\hline \multirow{2}{*}{ Сезон } & \multicolumn{10}{|c|}{ Средняя минимальная $\mathrm{t}^{0}$ за декаду } \\
\cline { 2 - 2 } & -5 & -4 & -3 & -2 & -1 & 0 & 1 & 2 & 3 & 4 & 5 & 6 & 7 & 8 & 9 & 10 & 11 & 12 & 13 \\
\hline \multicolumn{10}{|c|}{ Сильные заморозки в воздухе $\left(-3^{0}\right.$ и ниже) } \\
\hline Весна & & $\circ$ & $\circ$ & 86 & 79 & 73 & 65 & 57 & 48 & 40 & 33 & 26 & 21 & 17 & 13 & 10 & $\square$ & & \\
\hline Осень & & $\circ$ & $\circ$ & $\circ$ & 88 & 80 & 70 & 58 & 46 & 34 & 26 & 18 & 13 & 9 & 5 & $\square$ & & & \\
\hline \multicolumn{10}{|c|}{ Пустынные и полупустынные районы } \\
\hline Весна & $\circ$ & $\circ$ & 89 & 82 & 75 & 67 & 57 & 46 & 36 & 27 & 20 & 14 & 9 & $\square$ & & & & & \\
\hline Осень & $\circ$ & $\circ$ & 89 & 80 & 71 & 61 & 51 & 42 & 33 & 25 & 17 & 10 & $\square$ & & & & & & \\
\hline
\end{tabular}

П р и м е ч а н и е : О - вероятность лет более $90 \%$, $\square$ - вероятность лет менее $5 \%$

Переход средней температуры через минус $5^{0} \mathrm{C}$ осуществляется в течение второй-третьей декад марта и первой декады апреля: в Шемонаихе - 17 марта, Риддере - 22 марта, Самарке - 23 марта, Зайсане - 22 марта, пос. Орловский - 7 апреля, Маркаколе - 16 апреля.

Т а бли ца 32

Средние даты наступления, прекращения и продолжительность устойчивых морозов [13]

\begin{tabular}{|l|c|c|c|}
\hline \multirow{2}{*}{\multicolumn{1}{|c|}{ Метеостанция }} & \multicolumn{3}{|c|}{ Устойчивый мороз } \\
\cline { 2 - 4 } & Наступление & Прекращение & Продолж-ность (дни) \\
\hline Шемонаиха & $11 . \mathrm{XI}$ & $30 . \mathrm{III}$ & 140 \\
\hline Риддер & $12 . \mathrm{XI}$ & $12 . \mathrm{III}$ & 121 \\
\hline Усть-Каменогорск, город & $24 . \mathrm{XI}$ & $17 . \mathrm{III}$ & 114 \\
\hline Зыряновск & $4 . \mathrm{XI}$ & $5 . \mathrm{IV}$ & 153 \\
\hline Катон-Карагай, северная & $12 . \mathrm{XI}$ & $13 . \mathrm{III}$ & 122 \\
\hline Самарка & $12 . \mathrm{XI}$ & $19 . \mathrm{III}$ & 128 \\
\hline Пос. Орловский & $2 . \mathrm{XI}$ & $29 . \mathrm{III}$ & 148 \\
\hline Маркаколь & $8 . \mathrm{XI}$ & $16 . \mathrm{IV}$ & 160 \\
\hline Курчум & $12 . \mathrm{XI}$ & $26 . \mathrm{III}$ & 135 \\
\hline Зайсан & $11 . \mathrm{XI}$ & $20 . \mathrm{III}$ & 130 \\
\hline
\end{tabular}


Суммы средних суточных отрицательных температур позволяют оценить условия перезимовки озимых культур, а также температурную напряженность для биоты геосистем (табл. 33).

Т а б ли ц а 33

Суммы средних суточных отрицательных температур воздуха ниже $0^{0},-5^{0},-10^{0},-15^{0},-20^{0},-25^{0} \mathrm{C}$

\begin{tabular}{|l|c|c|c|c|c|c|}
\hline \multicolumn{1}{|c|}{ Метеостанция } & $0^{\circ} \mathrm{C}$ & $-5^{\circ} \mathrm{C}$ & $-10^{\circ} \mathrm{C}$ & $-15^{\circ} \mathrm{C}$ & $-20^{\circ} \mathrm{C}$ & $-25^{\circ} \mathrm{C}$ \\
\hline Шемонаиха & -2102 & -2038 & -1842 & -1368 & & \\
\hline Риддер & -1609 & -1534 & -1417 & & & \\
\hline Секисовка & -2160 & -2091 & -1891 & -1432 & & \\
\hline Усть-Каменогорск & -2087 & -2028 & -1819 & -1345 & & \\
\hline Пос. Северный & -1700 & -1626 & -1407 & & & \\
\hline Зыряновск & -2858 & -2805 & -2641 & -2273 & -1668 & \\
\hline Большенарымское & -2579 & -2529 & -2374 & -2040 & -1359 & \\
\hline Катон-Карагай & -1608 & -1550 & -1358 & -149 & & \\
\hline Самарка & -1938 & -1882 & -1707 & -1147 & & \\
\hline Пос. Орловский & -3266 & -3202 & -3055 & -2772 & -2274 & -1359 \\
\hline Маркаколь & -3081 & -2994 & -2766 & -2453 & -1938 & -876 \\
\hline Курчум & -2230 & -2171 & -2009 & -1711 & -636 & \\
\hline Буран & -1925 & -1857 & -1644 & -1232 & & \\
\hline Зайсан & -1880 & -1822 & -1640 & -1147 & & \\
\hline
\end{tabular}

Для исследуемого региона характерны зимние оттепели, то есть повышение температуры воздуха до $0^{0} \mathrm{C}$ и выше на фоне устойчивых морозов. Период с оттепелями ограничивается десятью днями с начала наступления устойчивого мороза и десятью днями до его прекращения (табл. 34).

Т а бли ц а 34

Повторяемость оттепелей (дни) в среднем за месяц по метеостанциям Юго-Западного Алтая [13]

\begin{tabular}{|l|c|c|c|}
\hline \multicolumn{1}{|c|}{ Метеостанция } & XII & I & II \\
\hline Риддер & 5.2 & 2.1 & 4.6 \\
\hline Катон-Карагай & 4.9 & 2.3 & 4.9 \\
\hline Пос. Орловский & 0.1 & 0.04 & 0.2 \\
\hline Зайсан & 12.6 & 0.6 & 2.2 \\
\hline
\end{tabular}

Различают два рода оттепелей: адвективные под «влиянием теплых ветров» и радиационные под действием солнечных лучей [51]. В середине зимнего сезона дни, когда в суточном ходе максимальная температура воздуха была $0^{0} \mathrm{C}$ и выше, отнесены к оттепели. Кроме того, зимой в теплой воздушной массе могут отмечаться кратковременные прояснения, которые при большой 
интенсивности солнечных лучей усиливают адвективную оттепель. Такой вид оттепели носит смешанный характер - адвективнорадиационный.

Так, в Усть-Каменогорске в январе за 10-летний период (19651974 гг.) оттепель наблюдалась 24 дня, при этом 10 дней приходилось на оттепели продолжительностью в 1 день, 8 дней - на оттепель продолжительностью в 2 дня. Кроме того, выделен один период непрерывной оттепели в 6 дней (январь 1966 года с первого по шестое). В частности, максимальная температура 5 января достигала $3^{0}$. В этот же период оттепели отмечались по большинству станций Юго-Западного Алтая, что объясняется особенностями циркуляции над регионом. Так, в январе за десятилетний период насчитывается 15 ЕСП с оттепелями: в четырех из них наблюдались западные процессы циркуляции, в шести - юго-западные антициклонические (VA, VБ), в трех - юго-западные циклонические и в двух - северозападные циклонические типы циркуляции.

Необходимо отметить, что в ноябре и марте часты случаи, когда при отрицательной среднесуточной температуре максимумы выше нуля. В ноябре такие оттепели связаны с адвекцией тепла, а в марте они носят радиационный характер. Так, в марте отмечается большая повторяемость антициклонических погод и растет полуденная высота Солнца, 21 марта она составила уже $40^{\circ}$.

Последующие исследования зим десятилетия 1981-1990 гг. показали, что оттепели в этот период были частым явлением, но эти характеристики пока не нашли отражения в справочной и периодической литературе. Оттепели такого типа сближают континентальный климат Казахстанского Алтая с климатом Восточной Европы, а сильные морозы (до минус 40, минус $50^{\circ} \mathrm{C}$ ), которые могут наблюдаться даже в начале холодного периода (ноябрь 1987 г.), сближают с климатом Восточной Сибири (см. табл.34).

\section{3. Режим увлажнения}

Соотношение тепла и влаги определяет тип ландшафта. Количество выпадающих осадков в значительной мере определяет водный режим территории, а соотношение между осадками, испарением и стоком составляет ее водный баланс.

Атмосферные осадки. Теория вопросов влагосодержания, влагооборота и формирования осадков достаточно подробно 
рассмотрена в работах О.А. Дроздова, М.И. Будыко, А.С. Григорьевой, С.И. Жакова, Л.П. Кузнецовой и др. [53-57].

Для образования осадков необходимы одновременно влага в атмосфере, восходящие в ней движения и благоприятные условия для достижения влажным воздухом уровня конденсации.

Упорядоченные восходящие токи наблюдаются в циклонах, наиболее четко они выражены вблизи фронтальных поверхностей теплого и холодного фронтов, при развитии конвекции в теплый период года и при вынужденном подъеме воздушного потока перед горными хребтами, а также по склонам гор и в продольных долин рек, суживающихся к орографическому узлу. Облака образуются в результате конденсации или сублимации водяного пара в атмосфере при понижении температуры воздуха ниже точки росы и наличии ядер конденсации. Осадки могут выпадать, если вертикальная мощность облака превышает 1,2 км. Умеренные и сильные осадки в основном связываются со слоисто-дождевыми (Ns) и кучеводождевыми (Св) облаками, а незначительные осадки могут быть при высокослоистых (As) облаках.

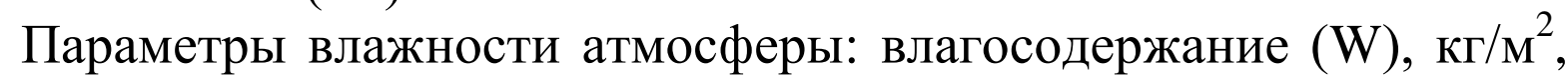
коэффициент влагоиспользования (j), величина отношения влагосодержания к абсолютной влажности $\left(\mathrm{K}=\frac{W}{a}\right)$ рассчитаны по методике О.А. Дроздова и приведены в табл. 35. Летом влагосодержание изменяется по исследуемой территории от 15,5 до

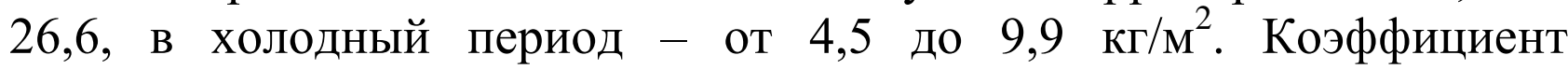
влагоиспользования колеблется в больших пределах - от 4 до 29\%; его малые величины приурочены к районам интенсивной антициклоничности и развития фёнов, наибольшие - к районам усиленного переноса воздушных масс и развития восходящих токов. В холодный период осадки в горных районах в основном выпадают за счет горизонтальных потоков влаги, поэтому перед «стеною гор» и в орографическом узле Рудного Алтая величина коэффициента влагоиспользования в отдельные месяцы достигает 28-38\% за счет «предвосхождения» и подъема по склонам гор в суживающихся долинах. Летом роль «барьерного» эффекта уменьшается в связи со снижением скоростей горизонтального переноса воздушных масс и усилением вертикальных потоков влаги с подстилающей поверхности. Кроме того, 38\% повторяемости ЭЦМ приходится на юго-западные процессы, с которыми связана адвекция тепла. Приток 
тепла способствует испарению влаги с подстилающей поверхности, а ее выносу до уровня конденсации препятствует устойчивая стратификация атмосферы. Ярким примером может служить величина влагоиспользования в Зыряновске (Рудный Алтай), расположенном в неглубокой котловине перед горной системой. В летние месяцы величина влагоиспользования там в 3-4 раза меньше, чем в зимние [58].

Проведем анализ связей осадков с типами циркуляции по сезонам года, так как осадки являются доминирующим потоком вещества, идущим от воздушных масс к другим компонентам природного комплекса $[53,59]$.

Т а блица 35

Параметры влажности воздуха

\begin{tabular}{|c|c|c|c|c|c|c|c|}
\hline \multirow{2}{*}{$\begin{array}{l}\text { Мес } \\
\text { яцы }\end{array}$} & \multirow{2}{*}{$\begin{array}{l}\text { Параметры } \\
\text { влажности }\end{array}$} & \multicolumn{3}{|c|}{ Рудный Алтай } & \multirow{2}{*}{$\begin{array}{c}\text { Южный } \\
\text { Алтай } \\
\text { Катон- } \\
\text { Карагай }\end{array}$} & \multirow{2}{*}{$\begin{array}{c}\text { Калба } \\
\begin{array}{c}\text { Самар } \\
\text { ка }\end{array}\end{array}$} & \multirow{2}{*}{$\begin{array}{c}\text { Зайсанская } \\
\text { впадина } \\
\text { Зайсан }\end{array}$} \\
\hline & & $\begin{array}{c}\text { Усть- } \\
\text { Камено } \\
\text { горск }\end{array}$ & Риддер & $\begin{array}{c}\text { Зырянов } \\
\text { ск }\end{array}$ & & & \\
\hline 1 & 2 & 3 & 4 & 5 & 6 & 7 & 8 \\
\hline $\mathrm{I}$ & $\begin{array}{c}\mathrm{K}=\frac{W}{a_{0}} \\
\mathrm{a}_{0}\left(\Gamma / \mathrm{M}^{3}\right) \\
\mathrm{W}\left(\kappa \Gamma / \mathrm{M}^{2}\right) \\
\mathrm{j}(\%)\end{array}$ & $\begin{array}{l}1.4 \\
8.0 \\
8.1\end{array}$ & $\begin{array}{l}1.4 \\
7.7 \\
5.5 \\
\end{array}$ & $\begin{array}{c}0.9 \\
4.5 \\
28.2\end{array}$ & $\begin{array}{l}1.2 \\
6.0 \\
8.6\end{array}$ & $\begin{array}{c}1.2 \\
5.4 \\
12.5\end{array}$ & $\begin{array}{l}1.2 \\
4.8 \\
6.0\end{array}$ \\
\hline II & $\begin{array}{c}\mathrm{K}=\frac{W}{a_{0}} \\
\mathrm{a}_{0}\left(\Gamma / \mathrm{M}^{3}\right) \\
\mathrm{W}\left(\kappa \Gamma / \mathrm{M}^{2}\right) \\
\mathrm{j}(\%)\end{array}$ & $\begin{array}{c}1.4 \\
7.7 \\
10.2\end{array}$ & $\begin{array}{l}1.6 \\
8.0 \\
4.5\end{array}$ & $\begin{array}{c}1.1 \\
5.5 \\
17.5\end{array}$ & $\begin{array}{l}1.4 \\
6.3 \\
8.8\end{array}$ & $\begin{array}{l}1.4 \\
6.3 \\
9.6\end{array}$ & $\begin{array}{l}1.4 \\
4.9 \\
6.6\end{array}$ \\
\hline III & $\begin{array}{c}\mathrm{K}=\frac{W}{a_{0}} \\
\mathrm{a}_{0}\left(\Gamma / \mathrm{M}^{3}\right) \\
\mathrm{W}\left(\kappa \Gamma / \mathrm{M}^{2}\right) \\
\mathrm{j}(\%)\end{array}$ & $\begin{array}{c}2.5 \\
7.5 \\
12.5\end{array}$ & $\begin{array}{l}2.2 \\
6.6 \\
8.8 \\
\end{array}$ & $\begin{array}{c}2.0 \\
4.8 \\
18.8 \\
\end{array}$ & $\begin{array}{l}2.0 \\
4.8 \\
9.4 \\
\end{array}$ & $\begin{array}{c}2.3 \\
5.5 \\
12.3 \\
\end{array}$ & $\begin{array}{l}2.6 \\
6.2 \\
8.3 \\
\end{array}$ \\
\hline IV & $\begin{array}{c}\mathrm{K}=\frac{W}{a_{0}} \\
\mathrm{a}_{0}\left(\Gamma / \mathrm{M}^{3}\right) \\
\mathrm{W}\left(\kappa / \mathrm{M}^{2}\right) \\
\mathrm{j}(\%)\end{array}$ & $\begin{array}{c}4.4 \\
13.2 \\
7.8\end{array}$ & $\begin{array}{c}3.6 \\
10.8 \\
13.0\end{array}$ & $\begin{array}{c}4.0 \\
9.6 \\
12.2\end{array}$ & $\begin{array}{c}3.4 \\
8.2 \\
10.0\end{array}$ & $\begin{array}{l}4.1 \\
9.8 \\
8.5\end{array}$ & $\begin{array}{l}4.1 \\
9.8 \\
9.5\end{array}$ \\
\hline
\end{tabular}


Продолжение таблицы 35

\begin{tabular}{|c|c|c|c|c|c|c|c|}
\hline V & $\begin{array}{c}\mathrm{K}=\frac{W}{a_{0}} \\
\mathrm{a}_{0}\left(\Gamma / \mathrm{M}^{3}\right) \\
\mathrm{W}\left(\kappa \Gamma / \mathrm{M}^{2}\right) \\
\mathrm{j}(\%)\end{array}$ & $\begin{array}{c}6.6 \\
15.8 \\
10.3\end{array}$ & $\begin{array}{c} \\
5.4 \\
13.0 \\
22.1 \\
\end{array}$ & $\begin{array}{c}6.4 \\
15.4 \\
11.7\end{array}$ & $\begin{array}{c}5.0 \\
12.0 \\
15.0\end{array}$ & $\begin{array}{c}5.9 \\
14.2 \\
7.3 \\
\end{array}$ & $\begin{array}{c}5.7 \\
13.7 \\
9.4 \\
\end{array}$ \\
\hline VI & $\begin{array}{c}\mathrm{K}=\frac{W}{a_{0}} \\
\mathrm{a}_{0}\left(\Gamma / \mathrm{M}^{3}\right) \\
\mathrm{W}\left(\kappa \Gamma / \mathrm{M}^{2}\right) \\
\mathrm{j}(\%)\end{array}$ & $\begin{array}{c}9.4 \\
22.6 \\
8.3\end{array}$ & $\begin{array}{c}8.1 \\
19.4 \\
15.3\end{array}$ & $\begin{array}{c}9.4 \\
22.6 \\
8.3\end{array}$ & $\begin{array}{c}7.7 \\
18.5 \\
11.4 \\
\end{array}$ & $\begin{array}{c}2.4 \\
\\
8.4 \\
20.2 \\
6.3 \\
\end{array}$ & $\begin{array}{c}2.04 \\
\\
7.6 \\
15.5 \\
8.8 \\
\end{array}$ \\
\hline 1 & 2 & 3 & 4 & 5 & 6 & 7 & 8 \\
\hline VII & $\begin{array}{c}\mathrm{K}=\frac{W}{a_{0}} \\
\mathrm{a}_{0}\left(\Gamma / \mathrm{M}^{3}\right) \\
\mathrm{W}\left(\kappa \Gamma / \mathrm{M}^{2}\right) \\
\mathrm{j}(\%)\end{array}$ & $\begin{array}{c}11.1 \\
26.6 \\
7.3\end{array}$ & $\begin{array}{c}9.6 \\
23.0 \\
14.3\end{array}$ & $\begin{array}{c}11.1 \\
26.5 \\
8.5\end{array}$ & $\begin{array}{c}9.1 \\
21.8 \\
9.9\end{array}$ & $\begin{array}{c}2.4 \\
\\
9.5 \\
22.8 \\
5.9\end{array}$ & $\begin{array}{c}2.04 \\
\\
8.7 \\
17.8 \\
6.7\end{array}$ \\
\hline VIII & $\begin{array}{c}\mathrm{K}=\frac{W}{a_{0}} \\
\mathrm{a}_{0}\left(\Gamma / \mathrm{M}^{3}\right) \\
\mathrm{W}\left(\kappa \Gamma / \mathrm{M}^{2}\right) \\
\mathrm{j}(\%)\end{array}$ & $\begin{array}{c}9.8 \\
23.5 \\
5.9\end{array}$ & $\begin{array}{c}8.6 \\
20.6 \\
11.3\end{array}$ & $\begin{array}{c}9.5 \\
23.0 \\
7.3\end{array}$ & $\begin{array}{c}7.9 \\
19.0 \\
9.9\end{array}$ & $\begin{array}{c}8.4 \\
20.2 \\
5.3\end{array}$ & $\begin{array}{c}2.04 \\
\\
7.8 \\
15.9 \\
5.5\end{array}$ \\
\hline IX & $\begin{array}{c}\mathrm{K}=\frac{W}{a_{0}} \\
\mathrm{a}_{0}\left(\Gamma / \mathrm{M}^{3}\right) \\
\mathrm{W}\left(\kappa \Gamma / \mathrm{M}^{2}\right) \\
\mathrm{j}(\%)\end{array}$ & $\begin{array}{c}2.4 \\
\\
6.8 \\
16.3 \\
5.9\end{array}$ & $\begin{array}{c}2.4 \\
\\
5.8 \\
13.9 \\
16.0\end{array}$ & $\begin{array}{c}2.4 \\
\\
6.5 \\
15.6 \\
8.3\end{array}$ & $\begin{array}{c}2.4 \\
\\
5.3 \\
12.7 \\
9.4\end{array}$ & $\begin{array}{c}2.4 \\
\\
5.9 \\
14.2 \\
6.8\end{array}$ & $\begin{array}{c}2.4 \\
\\
5.6 \\
13.4 \\
5.7\end{array}$ \\
\hline$X$ & $\begin{array}{c}\mathrm{K}=\frac{W}{a_{0}} \\
\mathrm{a}_{0}\left(\Gamma / \mathrm{M}^{3}\right) \\
\mathrm{W}\left(\kappa \Gamma / \mathrm{M}^{2}\right) \\
\mathrm{j}(\%)\end{array}$ & $\begin{array}{c}3.0 \\
\\
4.4 \\
13.2 \\
10.5\end{array}$ & $\begin{array}{c}3.0 \\
\\
3.6 \\
10.3 \\
18.5\end{array}$ & $\begin{array}{c}4.3 \\
10.3 \\
16.9\end{array}$ & $\begin{array}{c}3.4 \\
8.2 \\
13.8\end{array}$ & $\begin{array}{c}2.4 \\
\\
3.9 \\
9.4 \\
11.4\end{array}$ & $\begin{array}{l}2.4 \\
\\
4.1 \\
9.8 \\
7.9\end{array}$ \\
\hline XI & $\begin{array}{c}\mathrm{K}=\frac{W}{a_{0}} \\
\mathrm{a}_{0}\left(\Gamma / \mathrm{M}^{3}\right) \\
\mathrm{W}\left(\kappa \Gamma / \mathrm{M}^{2}\right) \\
\mathrm{j}(\%)\end{array}$ & $\begin{array}{c}2.6 \\
10.4 \\
14.1\end{array}$ & $\begin{array}{c}2.2 \\
8.8 \\
15.5\end{array}$ & $\begin{array}{c}2.2 \\
8.8 \\
20.8\end{array}$ & $\begin{array}{c}2.0 \\
8.0 \\
11.3\end{array}$ & $\begin{array}{c}3.0 \\
\\
2.5 \\
7.5 \\
19.6\end{array}$ & $\begin{array}{c}3.4 \\
\\
2.6 \\
6.2 \\
11.3\end{array}$ \\
\hline XII & $\begin{array}{c}\mathrm{K}=\frac{W}{a_{0}} \\
\mathrm{a}_{0}\left(\Gamma / \mathrm{M}^{3}\right) \\
\mathrm{W}\left(\kappa \Gamma / \mathrm{M}^{2}\right) \\
\mathrm{j}(\%)\end{array}$ & $\begin{array}{c}1.8 \\
9.9 \\
11.4\end{array}$ & $\begin{array}{l}1.7 \\
8.5 \\
9.5\end{array}$ & $\begin{array}{c}1.2 \\
6.0 \\
29.0\end{array}$ & $\begin{array}{c}1.5 \\
6.8 \\
10.4\end{array}$ & $\begin{array}{c}1.5 \\
6.8 \\
14.2\end{array}$ & $\begin{array}{l}1.6 \\
5.6 \\
9.2\end{array}$ \\
\hline
\end{tabular}


По картам АТ-500 за 10-летний период (1961-1970 гг.) по восьми репрезентативным метеостанциям Юго-Западного Алтая проведен совместный анализ календарей суточных сумм осадков и типов ЭЦМ. Последние содержат информацию о потоках влаги, механизм же выпадения осадков проявляется через структуру ЭЦМ.

Их совместный анализ позволил сделать следующее заключение: осадки холодного периода преимущественно (73-80\%) или почти исключительно (> 80\%) формируются из влаги западного и юго-западного воздушных потоков. На первый в пределах Рудного

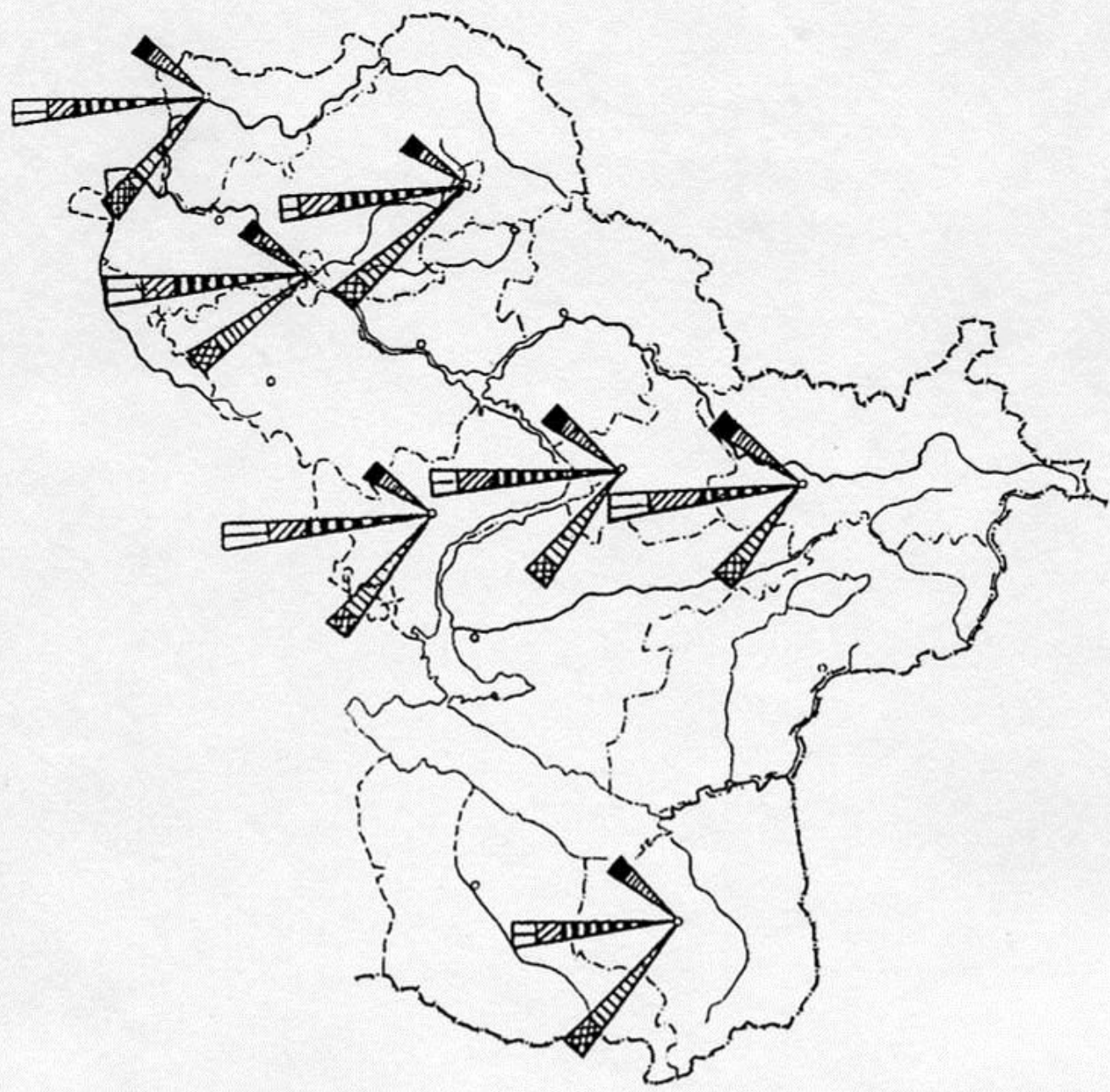

Структура потоков влаги в процентах: северо-запанного

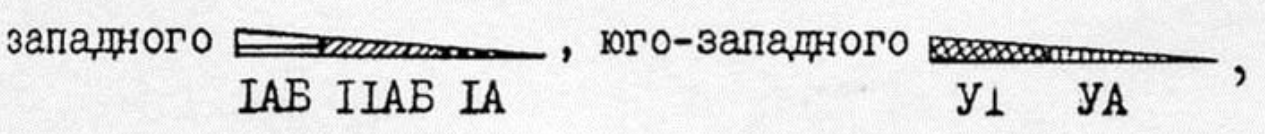

IA - УI - механизмы выпдения атмосқеерных осаднов.

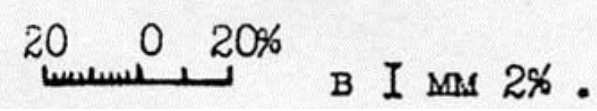

Рис. 23. Пространственная структура потоков влаги и механизмов выпадения атмосферныхосадков холодного периода за 1961-1970 гг. 
Алтая приходится 43-48\% нормы осадков, на северных склонах Южного Алтая 47-49, в Зайсанской впадине 38\% нормы осадков. На второй, соответственно, 32-40, 24-31 и 35\% (рис. 23).

В формировании осадков Рудного Алтая роль западной влаги увеличивается с высотой. Этот регион в осенне-зимний период попадает в зону наибольших скоростей западно-восточного переноса воздушных масс. Основными механизмами выпадения осадков при западном потоке являются подтипы I-A(52-62\% осадков), тип II (21$27 \%$ ), при юго-западном потоке - подтип VA (до 77-86\% осадков данного потока). Повторяемость западного и юго-западного циклонических типов мала, всего лишь $12 \%$, но они обеспечивают выпадение значительных осадков - до 10 и более миллиметров в сутки по ряду станций Юго-Западного Алтая. Обычно при югозападном типе осадки в два раза интенсивнее, чем при западном. Особенно они значительны на склонах хребтов, перпендикулярно расположенных к направлению основного воздушного потока, или если этот поток попадает в суживающиеся продольные долины, сходящиеся к орографическому узлу. При северо-западном переносе влаги выпадает 12-27\% осадков холодного периода, от 60 до 100\% осадков этого потока связывается с типом VIII (приложение V). Осадки, отнесенные к ультраполярным процессам, выпадают из влаги любого из рассмотренных потоков. На станциях, расположенных у подножия или на склонах гор, их удельный вес увеличивается до 4\%, так как арктический воздух вытесняет вверх воздушную массу, ранее находившуюся над этими районами.

Характер циркуляционных процессов за исследуемое десятилетие близок к многолетним средним (1954-1978 гг.).

Влагосодержание воздушных масс от марта к маю быстро растет, достигая в мае $12-16 \mathrm{\kappa г} / \mathrm{m}^{2}$, а относительная влажность уменьшается и составляет на предгорных равнинах и на склонах хребтов 54-58, в Зайсанской впадине -46-52\%. При относительной влажности менее 50\% интенсивность осадков быстро снижается, а менее $30 \%$ - из облачных систем осадки практически не выпадают.

В есенний период исследуемого десятилетия по количеству осадков оказался ниже нормы: в апреле на 17-20, в мае на 13-24\%. Циркуляция характеризуется уменьшением повторяемости типа II почти в два раза и подтипа I-B в 1,5 раза, при одновременном увеличении повторяемости подтипов I-A и VA в сравнении с нормой. От апреля к маю отмечается увеличение осадков в 1,3-2,2 раза, так 
как увеличивается влагосодержание воздушных масс и возрастает повторяемость циклонических типов циркуляции: западных в 2,5, северо-западных в 2, юго-западных в 1,6 раза. Начинает развиваться конвекция. Западные потоки обеспечивают в Рудном Алтае 44-49, на северных склонах Южного Алтая - 42-44, в Зайсанской впадине 47\% весенних сумм осадков. Юго-западные потоки соответственно 33-35, 25-32 и 26\%, северо-западные - 16-20, 25-29 и 27\% (рис. 24). Осадки преимущественно выпадают с подтипами IA,VA, IIIA и IIIБ (см. приложение IV).

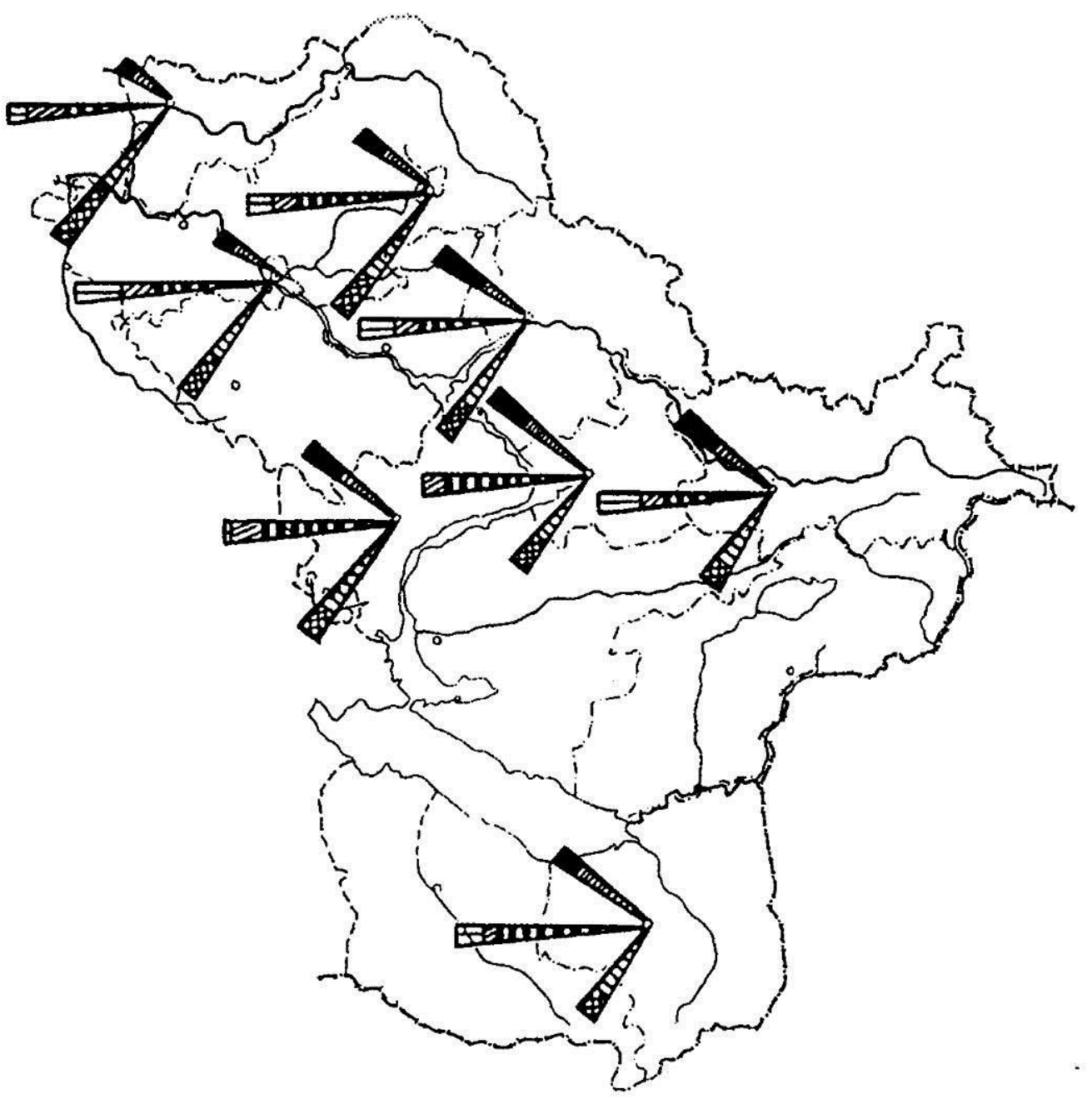

Структура потоков влаги в процентах: северо-заладного

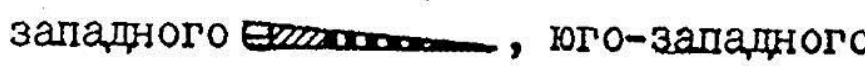
II IA

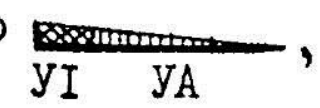

IY IIIAE

IA - УI - механизмы выпатения атмосфернах осаднов.

\section{$20 \quad 20 \%$ B I. $20 \%$}

Рис. 24. Пространственная структура потоков влаги и механизмов выпадения атмосферныхосадков весной за 1961-1970 гг. 
Л етом циклоническая деятельность развивается в двух фронтальных зонах: на арктическом и полярном фронтах. Внутри континента перед горной системой на волновых возмущениях фронтов часто возникают небольшие по площади циклонические вихри, обусловливающие пятнистость распределения интенсивных ливней по территории $[37,39,40,58]$. Юго-западные процессы обеспечивают в основном 40-43, западные - 26-34, северо-западные 22-29\% летних сумм осадков по отдельным станциям (рис. 25). Роль северо-западных потоков влаги в формировании осадков возрастает в

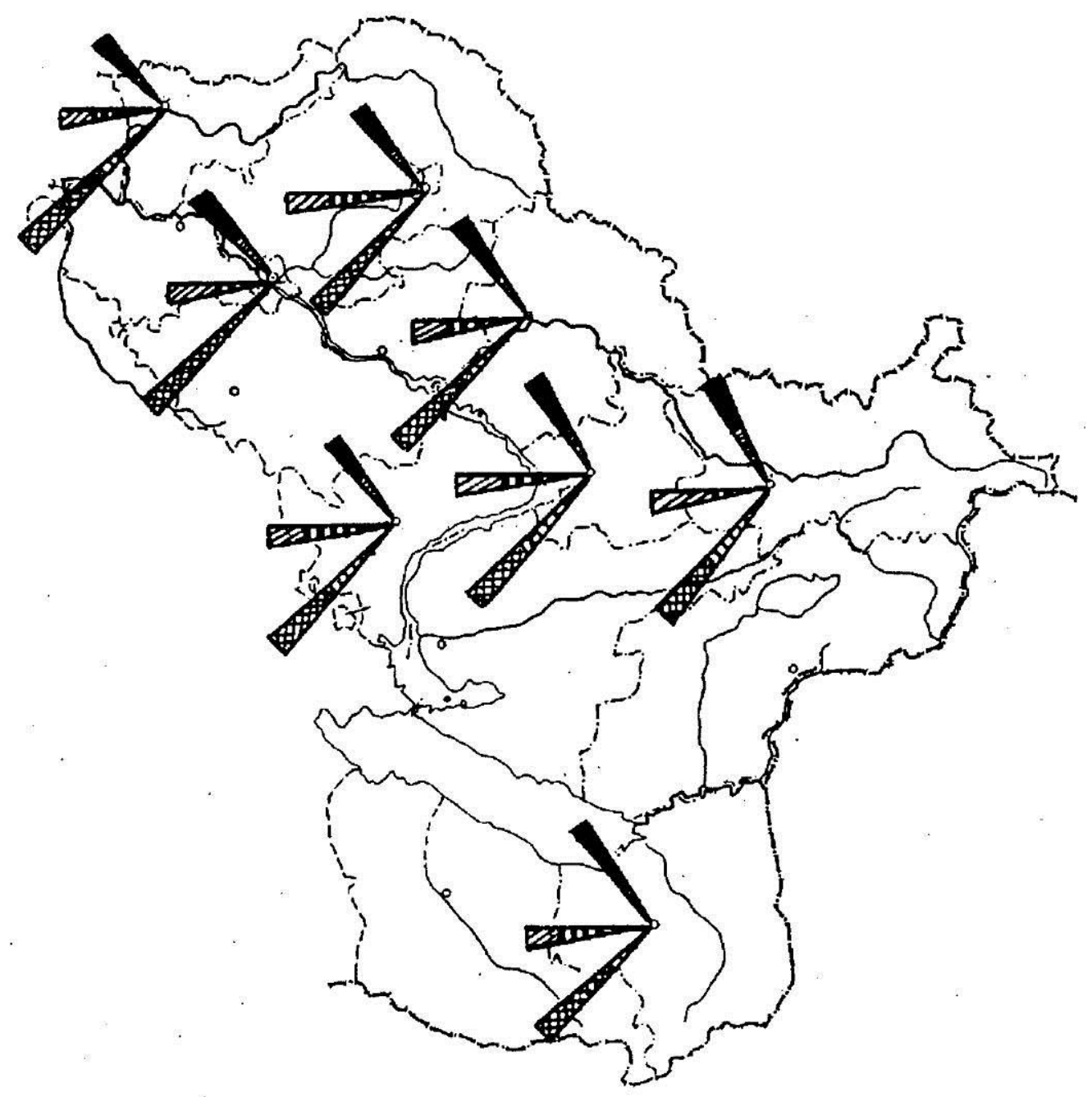

Структура потоков влаги в. процентах:северо-запапного шшшшімим.

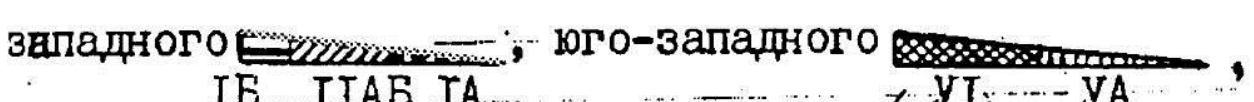

IA - УI - механизмы выпадения атмосфіерных осадков.

, $20 \quad 0 \quad 20 \%$

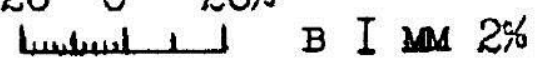

Рис. 25. Пространственная структура потоков влаги и механизмов выпадения атмосферныхосадков летом за 1961-1970 гг. 
сравнении с другими сезонами. Особо следует подчеркнуть: только в июле при всех направлениях потоков влаги осадки преимущественно (от 60 до 80\%) выпали в II, IV, V, VI циклонических типах циркуляции. Исследуемое десятилетие по количеству осадков было близко к норме (82-104\%).

Структура циркуляционных процессов осени близка к летней в связи с инерцией последней. О сенью влагосодержание еще колеблется в пределах 9-15 кг/м². От августа к сентябрю количество осадков уменьшается, кроме станций, расположенных в

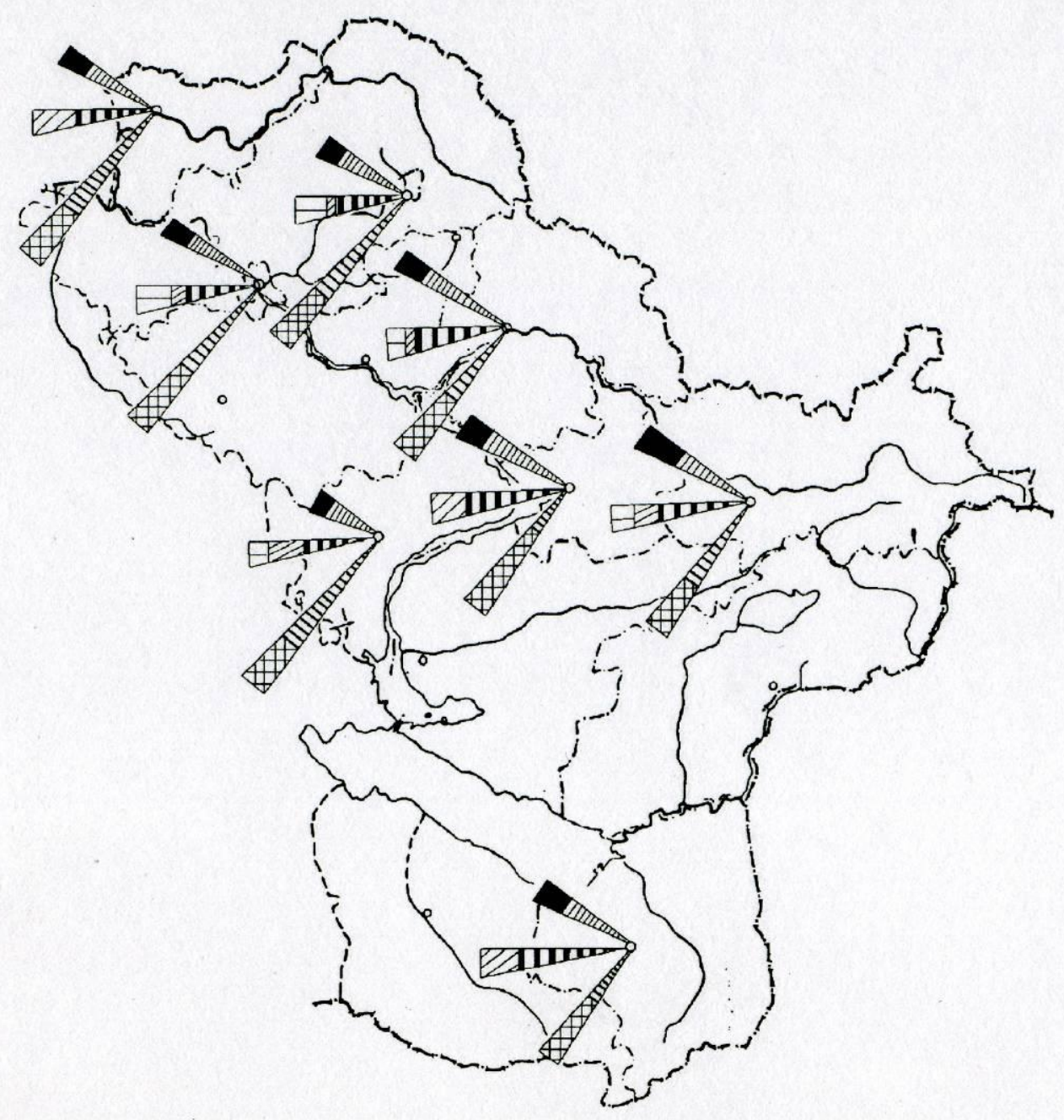

Структура потоков влаги в процентах: северо-западного

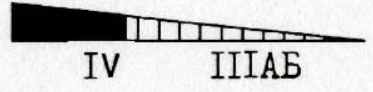
западного

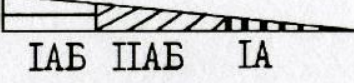
юго-западного
IA - VI - Механизмы выпадения атмосферных осадков
20 $20 \%$
в 1 мм. $2 \%$

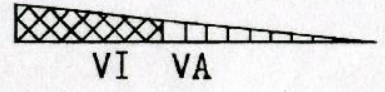


орографических узлах. От сентября к октябрю, наоборот, наблюдается увеличение осадков в предгорных районах и в долинах Рудного Алтая, открытых для западного и юго-западного потоков. В исследуемом десятилетии атмосферное увлажнение осени составило 100-120\% нормы. В формировании осадков преобладают югозападные потоки влаги (от 37 до 49\%), роль западных и северозападных потоков практически одинакова (рис. 26). Основными механизмами выступают циклонические типы II, IV, VI, а также подтипы IA, IIIA (см. приложение V).

Сложность процессов формирования осадков над исследуемой территорией в значительной степени объясняется особенностями ее географического положения на стыке трех типов климата [33].

\section{Пространственно-временная структура атмосферных} осадков. Формирование и география атмосферных осадков тесным образом связаны с циркуляцией атмосферы и особенностями ее взаимодействия с формами рельефа. Для составления картосхем распределения осадков проведен анализ системных связей между количеством выпавших осадков, особенностями развития циркуляционных процессов над территорией Юго-Западного Алтая и в конкретных геосистемах, а также между поверхностным стоком вод и типами ландшафтов [3, 25, 28, 38, 53, 59, 60, 61, 62, 63].

География годовых сумм осадков. Картина распределения годовых сумм осадков по территории Юго-Западного Алтая представлена картосхемой изогиет. Ее анализ позволяет выделить следующие пространственные закономерности распределения осадков: их количество в одинаковых формах рельефа уменьшается с севера на юг; большие вертикальные градиенты осадков, порой достигающие 200 мм на 100 м поднятия, связаны с проявлением «барьерного эффекта» (рис. 27).

Годовые суммы осадков по территории Юго-Западного Алтая изменяются от 119-220 мм в центральных частях Зайсанской котловины (станции Рождественское, Благодарненское) до 2000-2500 мм в пределах орографического узла Рудного Алтая и до 1200-1500 мм в орографическом узле Южного Алтая. На предгорных равнинах Рудного Алтая осадки колеблются от 300 до 500 мм в год. На склонах хребтов, независимо от их географического положения, количество осадков увеличивается с высотой. Основная доля выпадающих осадков над исследуемой территорией обусловлена развитием циклонической деятельности на арктическом и полярных фронтах. 
Повторяемость циклонических образований уменьшается от центральных районов Западной Сибири к центральным районам Казахстана (см. приложение IV). Необходимо отметить, что циклоны очень редко проходят своей центральной частью через горную страну. Но перед горными системами происходит обострение фронтальных разделов вплоть до образования частных циклонов, с ними-то и связаны обильные осадки. Ход годовых изогиет строго подчинен рельефу Г27. 58, 641.
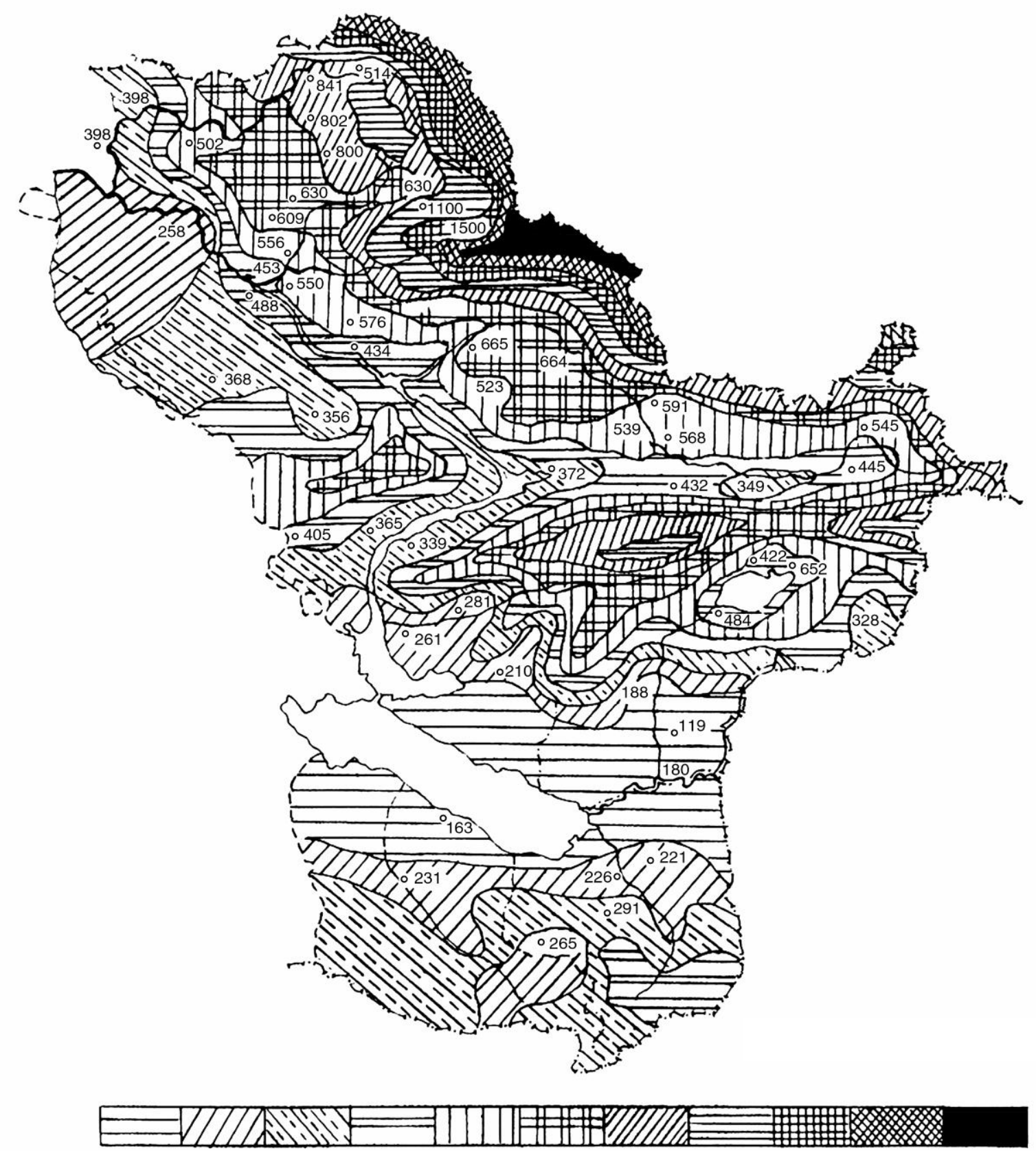

менее 2003004005006008001000150018002000 более

- 1500 количество осадков / мм/год /

Рис. 27. Картосхема годового количества осадков 
Наиболее увлажненным районом в пределах Юго-Западного Алтая является орографический узел Рудного Алтая.

Долины рек Уба, Ульба являются ведущим ложем западных атмосферных потоков к орографическому узлу Рудного Алтая. На картосхеме его очерчивают изогиеты 1800-2000 мм (см. рис. 27).

Количество осадков резко убывает в направлении от гор к долине Иртыша. Вертикальные градиенты в этом районе колеблются от 60 (ст. Орловка, Малая Ульба) до 120 мм на 100 м поднятия (станция Северный поселок, Малая Ульба). При этом ход изогиет хорошо согласуется с формами рельефа: широкие долины рек и котловины очерчиваются «ложбинами» малого количества осадков, а хребты выступают как гребни повышенного увлажнения. Орографической «воронкой» является пространство между хребтами Ульбинский и Холзун. С приближением к ним количество осадков быстро нарастает и может достигать 2000 мм и более.

Узкую Нарымо-Бухтарминскую тектоническую впадину очерчивает изогиета 400 мм.

На предгорных равнинах Рудного Алтая с высотами 300-500 м осадков выпадает порядка 450-600 мм (ст. Усть-Каменогорск, Зыряновск, Шемонаиха). Изогиета 600 мм хорошо согласуется с верхней границей лесостепи и проходит в северной части региона на высотах порядка 500, в Зыряновском низкогорье на высотах около $600 \mathrm{M}$.

Количество осадков резко увеличивается в районе схождения хребтов Сарым-Сакты, Курчумский, Южный Алтай и Тарбагатай Алтайский. Этот орографический узел Южного Алтая несет значительное оледенение и дает начало рекам Алаха, Канасу и другим. Изогиета 500 мм охватывает западную часть хребтов СарымСакты и Нарымского на высотах от 700 до 1000 м. Метеорологические станции в пределах Южного Алтая фиксируют следующее количество горных осадков: в бассейне реки Курчум 261-281 мм; в котловинах Маркакольской - 484 мм, Орловской - 328 мм. Осадки быстро нарастают на склонах гор: начиная с высот 16002000 м располагается зона высокого увлажнения, в ледниковой зоне (2600-2800 м) их выпадает от 800 до 1500 мм. Выделение зоны высокого увлажнения подтверждается стоком (модуль стока до 50 л/сек с кв. км). В Рудном Алтае на высотах 1500-1600 м осадки возрастают до 1500 мм (Малая Ульба) и достигают 2500 мм на уровне снеговой границы - 2100-2300 м [8, 18, 65]. Выше указанные 
величины для гляциально-нивального пояса подтверждены расчетами, проведенными по методике А.Н. Кренке.

На левобережье Иртыша наибольшее количество осадков (вероятно, до 700-800 мм в год) приурочено к восточной, более высокой части Калбинского хребта (1400-1600 м). На периферии Калбы осадки уменьшаются до 350-400 мм (рис. 28).

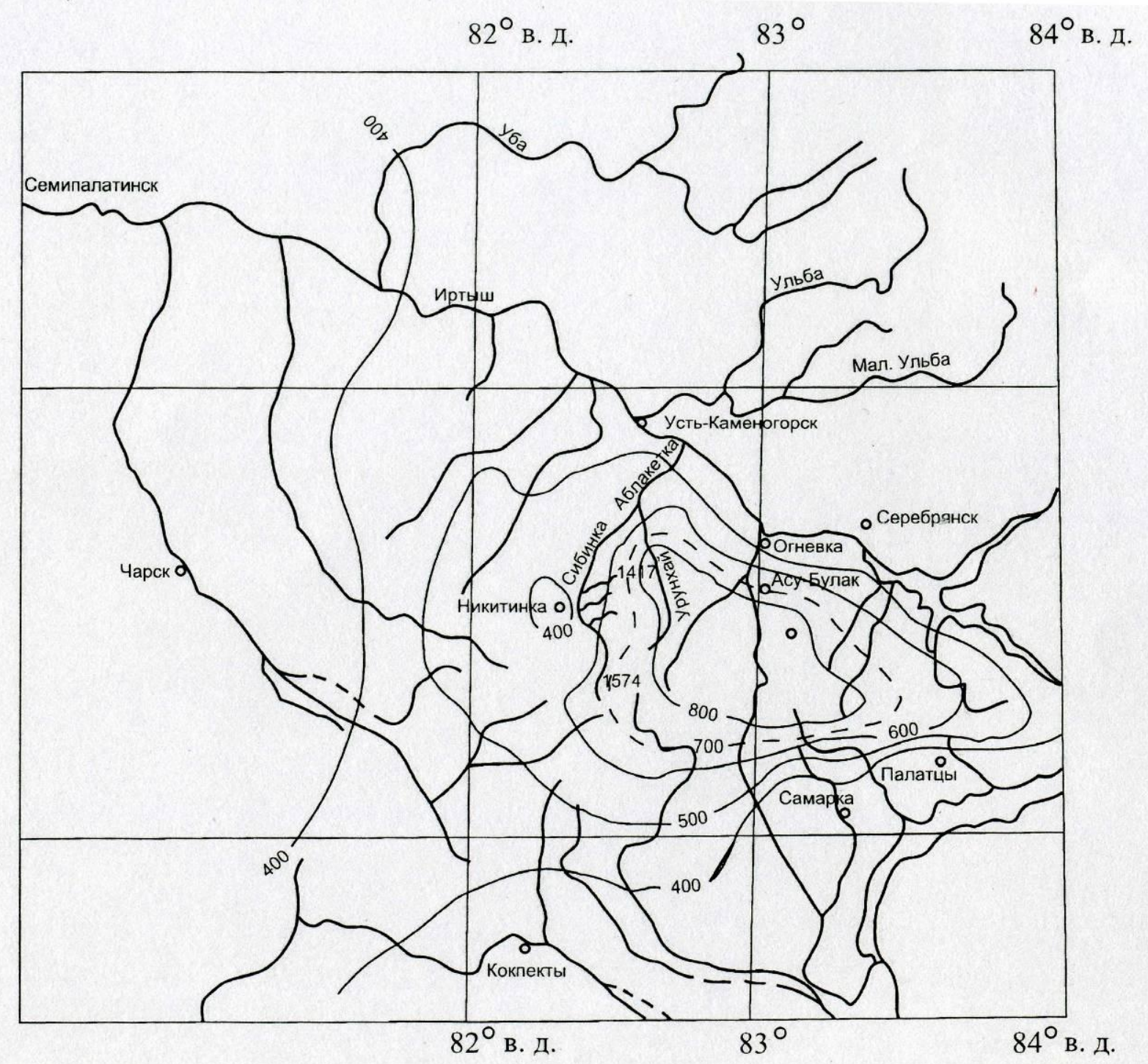

Рис. 28. Картосхема годовых осадков Калибинского нагарья, мм

Горные районы юга Саура и Тарбагатая совершенно не освещены в метеорологическом отношении. По обобщенным оценочным данным И.С. Соседова, Р.И. Гальперина и других авторов, на северных склонах Саура и Тарбагатая осадки составляют порядка 300-500, на северных склонах высокогорья в зоне леса - 800 мм [63].

Структура годового цикла увлажнения. Внутриконтинентальное положение Казахстанского Алтая усиливает роль подстилающей поверхности как климатообразующего фактора и вклинившейся в эти зоны горной системы Алтая. ослабляет роль 
циркуляционного. Граничащие с Алтаем степи и полупустыни Монголии, сухие степи юга Казахстана, полупустыни и пустыни Средней Азии имеют резко континентальный климат и оказывают влияние на формирование климатических условий вклинившейся в эти зоны горной системы Алтая.

Следует различать понятия «годовой ход осадков» и «структура годового цикла увлажнения». Когда речь идет о годовом ходе осадков, то имеется в виду характер распределения их по месяцам, структура же увлажнения характеризуется соотношением тепла и влаги. Зная годовой ход осадков, можно выявить структуру годового цикла увлажнения как соотношение осадков и радиационного баланса. Структура годового цикла увлажнения в работе характеризуется коэффициентами радиационного индекса сухости по А.А. Григорьеву и М.И. Будыко, а также коэффициентом увлажнения Иванова-Высоцкого. Структуру годового цикла увлажнения в значительной степени будет определять годовой ход осадков, выраженный в пределах Казахстанского Алтая в несравненно большей степени, чем величина радиационного баланса (см. рис. 14,15).

Годовой ход осадков рассмотрен по данным 130 метеорологических станций Казахстанского и Горного Алтая, расположенных в разнообразных формах рельефа. Проведенный анализ данных позволил обоснованно выделить три вида типичных структур годового цикла увлажнения. За основу такой классификации принят генетический принцип, связанный с особенностями расположения исследуемого региона на стыке трех типов климата: монгольского, западно-сибирского и среднеазиатского [33].

Монгольский, или центральноазиатский, характеризуется преобладанием в зимний период антициклональных типов погоды. Летом на исследуемой территории наблюдаются облачные системы и выпадают незначительные осадки из влаги континентальных воздушных масс - как на фронтальных разделах циклонов, так и за счет конвекции.

Для западносибирского климата свойственно развитие интенсивной циклонической деятельности как в летний, так и в зимний периоды. Этот тип климата М.В. Тронов назвал континентально-циклоническим [5,15].

Для среднеазиатского типа характерна его сухость летом, что объясняется развитием термической депрессии. Основная масса 
осадков в этом типе приходится на весну и осень, когда развивается циклоническая деятельность на полярном фронте (иранская ветвь).

Взаимное проникновение и различное сочетание этих трех типов климата с характером подстилающей поверхности обусловили особенности структуры годового цикла увлажнения исследуемой территории. Анализ внутригодового хода осадков по метеорологическим станциям позволил выделить здесь три основных типа распределения осадков.

Первый тип характеризуется четко выраженным летним максимумом и глубоким минимумом осадков зимой. Летний максимум связан с развитием циклонической деятельности на арктическом и полярном фронтах над Западной Сибирью и Казахстаном. Минимум обусловлен распространением Монгольского (азиатского) антициклона на Горный Алтай. При этом процессы антициклогенеза усиливаются над котловинными формами рельефа. Этот тип является результатом взаимного проникновения и влияния западносибирского и монгольского типов климата. Он наблюдается на территории Алтайской горной страны и характерен для станций, расположенных на плато и часто в неглубоких котловинах на склонах гор (Усть-Кокса, Катанда, Ак-Кем, Кара-Тюрек, Катон-Карагай, Риддер и др.). Осадки холодного периода составляют 17-20, осадки весны - 16-21, осенние - 13-21, летние - 42-49\% годовой суммы. По величине годовой суммы осадков в данном типе выделяется два подтипа: I-A и І-Б. Станции с годовыми осадками 350 мм и менее относятся к монгольскому подтипу I-A и располагаются в основном в степных ландшафтах. Подтип ІБ характеризуется преобладанием западно-сибирского влияния, годовые суммы осадков составляют 350-600 мм - это предгорные станции Чарышское, Чемал, КызылОзек, а в Центральном Алтае - Кара-Тюрек и Ак-Кем; в пределах Юго-Западного Алтая этот подтип отмечен в Катон-Карагае и Риддере [33].

Второй тип годового хода осадков характеризуется наличием нескольких максимумов и минимумов. Он соответствует показаниям станций Усть-Каменогорск, Зыряновск, Шемонаиха, Уба, Большие Пороги, Змеиногорск, Кондома, Талон и др. Структура годового цикла осадков II типа формируется в результате взаимодействия среднеазиатского и западно-сибирского влияний. Летний максимум обусловлен развитием циклонической деятельности над Западной Сибирью и Казахстаном, осенний и весенний максимумы формируют 
циклоны арктического, полярного и староарктического фронтов. В пределах Юго-Западного Алтая данный тип характеризуется небольшими значениями годовых сумм осадков и более равномерным распределением их в течение года. Увеличение осадков с приближением к Алтайской горной стране уже заметно к востоку от Центрального Казахстана. В пределах Восточно-Казахстанского региона под $49-51^{0}$ с. ш. горизонтальный градиент осадков равен 60 мм на 100 км. Наибольшая интенсивность осадкообразующих процессов фиксируется в суженных трогообразных долинах, упирающихся в орографический узел Рудного Алтая. Так, станции Большие пороги и Уба Большие пороги за год фиксируют 850-900 мм осадков, а станции Проходной Белок и Малая Ульба, расположенные близ орографического узла уже от 1100 до 1500 мм.

Осенний максимум второго типа определяется структурой высотного поля: от лета к осени усиливается западно-восточный перенос, и ПВФЗ чаще располагается между $48-52^{0}$ с. ш. В этих же широтах находятся мощные орографические узлы Алтая, с веерообразно расходящимися на запад горными хребтами. В этом типе выделяется три подтипа: IIA, ІІБ, IIB. Подтип IIA характеризуется годовой суммой осадков 400-600 мм. Главный максимум приходится на июль, вторичный - на ноябрь.

В подтипе ІІБ - основной максимум осадков осенне-зимний, вторичный максимум приходится на лето (июль). Годовая их сумма составляет 800 мм и более (станции Александровка, Орловка, Большие Пороги, Кондома, Междуреченск, Змеиногорск).

К подтипу IIB относятся станции, расположенные близ орографических узлов: ход осадков характеризуется многовершинной кривой. Максимумы наблюдаются весной и осенью. Исключительное значение имеет положение станций по отношению к основным потокам влаги, а также ориентация долин, подводящих воздушный поток к горному узлу. Годовые суммы осадков в этом подтипе колеблются от 600 до 1500 мм (станции Секисовка, Проходной Белок, Катунь, Талон, Малая Ульба).

Осадки холодного сезона во втором типе составляют 27 40\%, весенние - 10-13...19, осенние $13-16 \ldots 23 \%$, на самую влажную четверть года приходится от 28 до $34 \%$ годовой суммы. Такой равномерный годовой ход атмосферной влаги характерен для Западной Европы на широте $50-55^{0}$ с. ш. Подобное распределение осадков наблюдается при переходе от морского климата к 
континентальному, где обильные осадки сочетаются с большой относительной влажностью воздуха.

Третий тип годового хода осадков формируется в результате взаимодействия и проникновения монгольских и среднеазиатских влияний на местный климат. Для третьего типа характерен основной максимум осадков майско-июньский, вторичный - в октябре-ноябре, минимум приходится на зимние месяцы. Такая структура годового цикла увлажнения присуща ландшафтам Зайсанской котловины (станции Зайсан, Буран и др.). Сочетание монгольских и среднеазиатских влияний формирует климат сухих степей, полупустынь с годовыми осадками 200-300 мм и их равномерным распределением в течение года.

Таким образом, наличие в пределах Юго-Западного Алтая трех типов годового хода осадков с их подтипами, прежде всего, указывает на климатическую неоднородность территории. Годовой ход осадков всех типов невозможно объяснить одним каким-либо общим процессом, так как он чаще всего проявляется через конкретные мезопроцессы, при этом ведущими из них надо считать влагосодержание и циркуляцию атмосферы во взаимодействии их с рельефом. Разнообразие типов и подтипов годового хода осадков в пределах горной страны подчеркивает большое влияние рельефа на распределение осадко и на особенности годового хода. Яркой чертой климата региона является неравномерность распределения атмосферной влаги в пространстве и во времени (по сезонам), а также преобладание на большинстве станций осадков теплого периода: до 60-80\% годовой суммы.

Атмосферные осадки теплого периода. Наибольший вклад осадков теплого периода (80-84\% годовой суммы) отмечается в узкой тектонической впадине верхнего и среднего течения реки Бухтармы и в межгорных котловинах (станции Риддер, Громотуха и др.).

На предгорных равнинах Рудного Алтая до высот 400-500 м и в Зайсанской котловине за теплый сезон выпадает примерно две трети их годовых сумм. С приближением к орографическим узлам распределение осадков в течение всего года становится более равномерным: доля теплого периода года составляет 60\%. По ряду станций летние максимумы их годового хода смещены на осеннезимние. Так, на станции Большие Пороги (Рудный Алтай) за три летних месяца выпадает 252, а за октябрь, ноябрь, декабрь - 312 мм. 
Аналогичную картину представляют станции Уба Большие Пороги и другие.

Картосхема изогиет теплого периода (рис.29) близка к картосхеме годовых изогиет (см. рис. 27).

Ее анализ показывает, что южные и юго-западные склоны хребтов Тигирецкий, Коксуйский, Холзун на высотах 1600-1800 м получают за теплый сезон до 1000 мм. В Лениногорской впадине осадки составляют 630 мм, на склонах окружающих хребтов они нарастают: вертикальный градиент здесь составляет 100-200 мм на 100 м поднятия.

Изогиета 600 мм, очерчивая подножья хребтов, хорошо согласуется с западной границей распространения пихтовых лесов на хребте Листвяга, а изогиета 500 мм в Южном Алтае соответствует нижней границе распространения лиственничных лесов. Изогиета 400 мм проходит на границе лесостепных и степных ландшафтов. В орографическом узле Южного Алтая выпадает от 700 до 1000 мм (оценочные данные по стоку).

В Зайсанской котловине, в ландшафтах сухих степей и полупустынь - менее 200, в пустынных ландшафтах - менее 100 мм.

Атмосферные осадки холодного периода. Осадки холодного периода в пределах исследуемого региона составляют 17-40\% годовой суммы. Основная их доля выпадает в ноябре-декабре, составляя 52-56\% сумм сезона. Данный факт объясняется еще сравнительно большими запасами влаги, оставшимися от теплого сезона (коэффициент влагоиспользования составляет от 6 до 10 $\kappa г / \mathrm{M}^{2}$ ), а также особенностями развития циркуляции атмосферы холодного периода, когда исследуемая территория попадает в зону повышенных скоростей западно-восточного переноса воздушных масс [11, 36, 65].

Закономерности распределения осадков холодного сезона представлены на рис.30. Отрицательные формы рельефа (котловины) выделяются как районы уменьшенного количества осадков. В пределах исследуемого региона выделяется три формы котловин: а) замкнутые межгорные; б) котловины типа цирка; в) узкие долины крупных рек. 


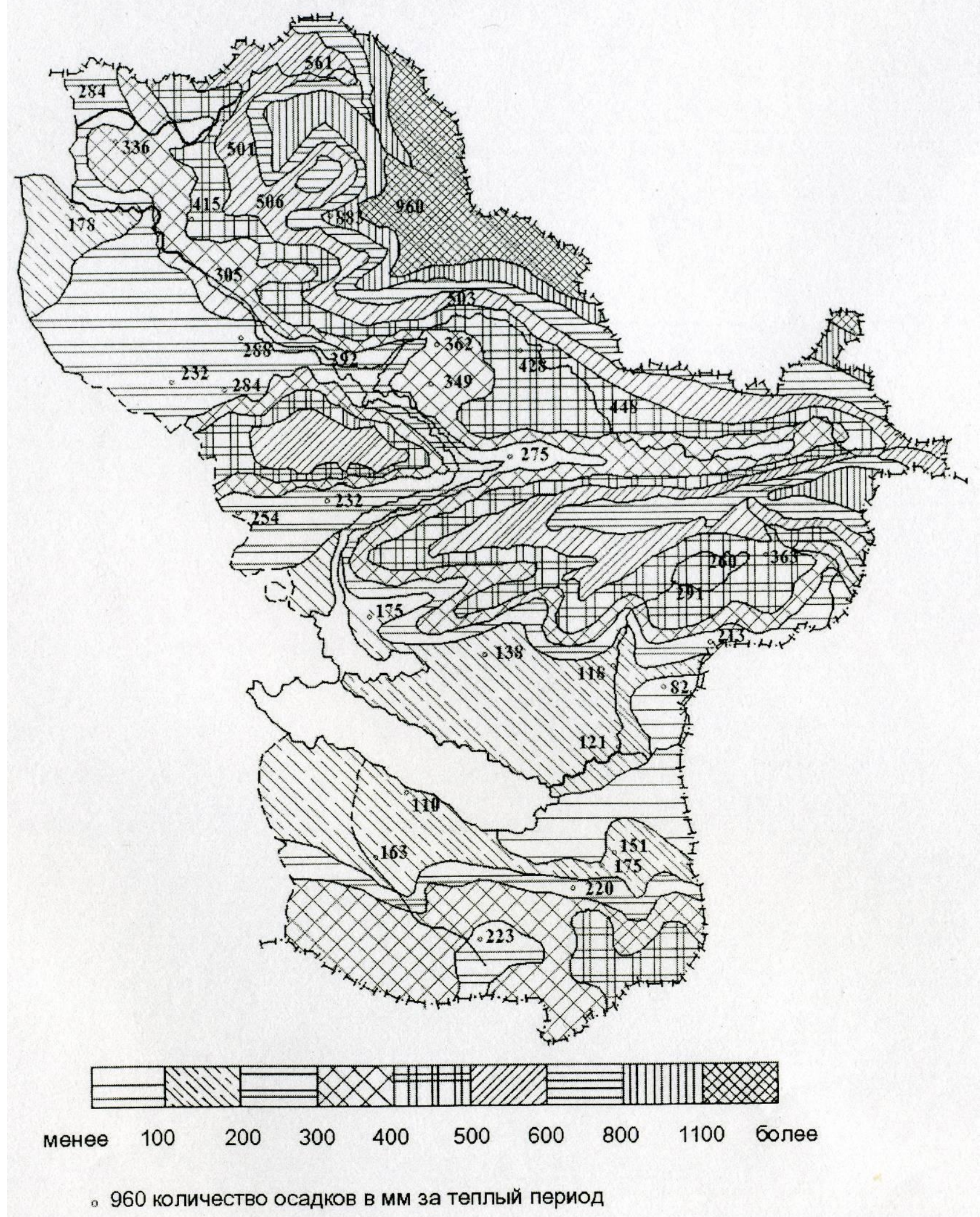

Рис. 29. Картосхема осадков теплого периода 

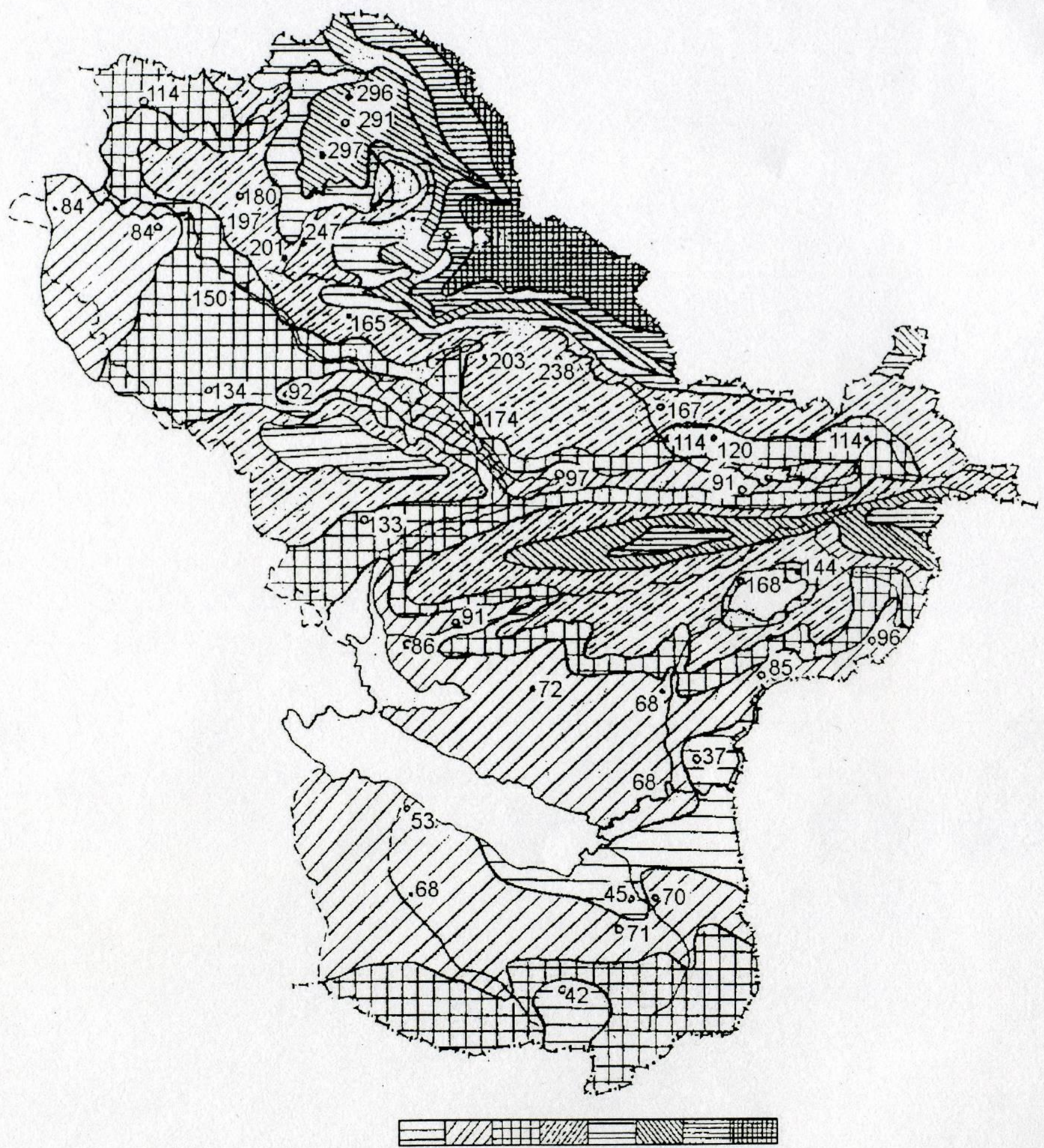

менее 50100200250300500700 более

- 556 количество осадков в мм за холодный период

Рис. 30. Картосхема осадков холодного периода 
Межгорные котловины - Зайсанская, Чингистайская, Маркакольская, Орловская, Бобровская и др. - очерчены изогиетами 100 и 50 мм. Самая крупная из них Зайсанская, в ее пределах количество осадков закономерно уменьшается с запада на восток. На внутренних склонах хребтов, окаймляющих котловину оз. Маркаколь, их выпадает до 150-200 мм.

Котловины типа цирка - Лениногорская, Катон-Карагайская расположены на склонах хребтов и имеют сток холодного воздуха вниз по долинам. Осадки там составляют 100 мм или немногим более. Такое их количество объясняется нисходящими стоковыми движениями воздуха по долине, что приводит к размыву облачности и, следовательно, к уменьшению осадков. Для обеих метеостанций характерны фёны.

Третий тип котловин - узкие долины крупных рек: Иртыш, Бухтарма, Нарым. На картосхеме они вырисовываются как полосы пониженных осадков (от 200 до 100 мм).

Наветренные западные и юго-западные склоны гор и орографические узлы выступают как районы наибольшего увлажнения. На хребтах Рудного Алтая в пределах высот 1600-1800 м проходит изогиета 700 мм, в Южном Алтае на высоте 1300 м изогиета 200 мм, на высотах 2800-3000 м (высота снеговой линии) изогиета 500 мм.

Распределение осадков данного сезона на Рудном и Южном Алтае существенно различается. Анализ наблюдений по снегомерным маршрутам в высокогорье более чем за 20-летний период позволил выяснить, что увлажнение холодного периода Южного Алтая значительно меньше, чем Рудного. Осадки на высотах 1800-2000 м на Рудном Алтае в 2-2,5 раза больше, чем на тех же высотах в Южном Алтае. Так, на высоте 2000 м в Рудном Алтае они составляют 600-800 мм, а на Южном Алтае на тех же широтах порядка 300-400 мм, на высотах 1100-1200 м на Рудном Алтае выпадает 400-430 мм влаги, а на Южном - только 100-180 мм. Зона наибольшей снежности в Южном Алтае лежит гораздо выше, чем в Рудном. В высокогорной части Рудного Алтая осадки холодного периода оцениваются в 36-40\% от годовых сумм, в Южном - 30-37\%.

Количество осадков резко убывает при движении от орографических узлов к предгорным равнинам. На высотах 1300-1500 м в Рудном Алтае проходит изогиета 400 мм. В районе Зыряновского 
низкогорья на высотах 500-600 м и в предгорьях Рудного Алтая изогиета 250 мм.

Калбинский хребет по увлажнению выступает обособленно. Максимальное количество осадков холодного сезона составляет там 250-300 мм, то есть 35-36\% годовой суммы, на высотах 600 м всего лишь 150-200 мм. Левобережье Иртыша (ниже Усть-Каменогорска) очерчено изогиетой 100 мм.

Обеспеченность годового количества осадков. Динамичность циркуляционных факторов климата обусловливает значительные колебания не только месячных, но и годовых сумм осадков.

Очень большое количество осадков (обеспеченность 10\%) в пределах исследуемого региона наблюдалось в 1930, 1935, 1946, 1960 годы. Так, в Усть-Каменогорске, при годовой норме 455 мм, осадки $10 \%$-ной обеспеченности составляли 600 мм, соответственно в Зыряновске 565 и 740 мм, в Катон-Карагае 432 и 600 мм, в Орловском поселке при норме 328 максимальные 440 мм, в Зайсане 291 и 390 мм. То есть осадки 10\%-ной обеспеченности превышали нормальные годовые суммы в Рудном Алтае на 30, в Южном Алтае и Зайсанской котловине на 35-40\%. Столь же часто в другие годы осадков может быть меньше нормы в Рудном Алтае на 25, в Южном Алтае на 25, в Зыряновской котловине на 30 , Орловской котловине и Зайсанской впадине - на 35-37\%.

Кроме того, годовые суммы атмосферных осадков характеризуются большой амплитудой колебания. Так, по наблюдениям, в самом засушливом 1955 г. атмосферные осадки в Усть-Каменогорске составляли 60\% нормы, то есть 263 мм, а во влажном 1960 г. - в 1,7 раза превысили ее (788 мм). Наблюдаемые максимумы составляли в Усть-Каменогорске 788 (1960 г.), в Зыряновске 906 (1960 г.), в Катон-Карагае 778 (1946 г.), в Орловском поселке 570 (1915 г.), в Зайсане 546 мм (1935 г.). Наблюдаемый минимум составлял в Усть-Каменогорске 263 (1955 г.), в Зыряновске 326 (1904 г.), в Катон-Карагае 274 (1962 г.), в Орловском поселке 130 (1918 г.) и 135 мм (1915 г.) в Зайсане [13].

Горные районы метеорологически освещены недостаточно. Наблюдавшиеся годовые максимумы осадков приведены по метеостанциям предгорных равнин и межгорных котловин. Метеостанция Катон-Карагай (1081 м н. у. м.) является самой высокогорной станцией в пределах Юго-Западного Алтая. Эти пробелы Восточно-Казахстанский центр по гидрометеорологии в 
какой-то мере восполняет наблюдениями на снегомерных маршрутах. Наблюдениями охвачены 10 речных бассейнов Юго-Западного Алтая, где установлены 45 суммарных осадкомеров в интервале высот от 800 до 2600 м. Период наблюдений на отдельных маршрутах составляет от 30 до 3 лет. Максимальная сумма месячных осадков (964 мм) зарегистрирована в мае 1971 г. в верховьях Малой Ульбы. Осадкомер был установлен на высоте 1200 м над уровнем моря. По метеопосту Малая Ульба (1600 м) в июне 1980 г. осадки составили 901 мм, в бассейне реки Сарым-Сакты на высоте 2420 м в июле 1967 г. выпало 647 мм, а месячный максимум осадков в бассейне реки Белая Берель на высоте 2000 м в июне 1961 года составил 530 мм. Кроме того, месячные суммы порядка 400-500 мм зафиксированы в бассейне реки Шаровка (приток Ульбы), а также в бассейнах рек Хамир и Курчум (наблюдения А.Д. Дюкарева).

В табл. 36 приводятся нормы месячных осадков в высокогорье, подсчитанные по ряду лет, указанному в скобках, и наблюдавшиеся месячные максимумы осадков. Приведенные данные подтверждают большое увлажнение среднегорья и высокогорья Юго-Западного Алтая, а расчетные годовые суммы составили до 2000-2500мм в Рудном Алтае и до 1500 мм - в Южном. Такие суммы осадков достаточно близки к достоверным данным: удовлетворительно подтверждаются стоком, наличием ледниковых центров (в частности, по М.В. Тронову - Южно-алтайский), а также сближением границ леса и снеговой линии. Оценка осадков на линии снеговой границы, проведена по методике А.Н. Кренке [61].

В каждой ландшафтной зоне годовой цикл увлажнения имеет свои пределы неустойчивости. Вероятность повторяемости «нормы» атмосферных осадков составляет порядка 50\%, а амплитуда колебания годовых сумм определяется зонально провинциальной структурой ландшафтов. Средняя изменчивость годовых осадков колеблется в пределах 16-18\%. Считается, что осадки, составляющие $80-120 \%$ от нормы, обеспечивают нормальное увлажнение ландшафта. В Рудном Алтае годовые их суммы изменяются в пределах: от более 60 и меньше 170\% нормы, в Южном Алтае соответственно - более 50 и менее 166\% нормы. Амплитуды колебаний практически одинаковые, но в Южном Алтае она наблюдается на фоне общего понижения увлажнения. 
Месячное и годовое количество осадков в высокогорной зоне Юго-Западного Алтая (по А.Д. Дюкареву)

\begin{tabular}{|c|c|c|c|c|c|c|c|c|c|c|c|c|c|c|c|}
\hline$\underline{\text { Бассейн реки }}$ & $\frac{\text { Абсолют. }}{\frac{\text { высота, }}{\underline{M}}}$ & & $\underline{I}$ & $\underline{\text { II }}$ & $\underline{\text { III }}$ & $\underline{\text { IV }}$ & $\underline{\mathrm{V}}$ & $\underline{\mathrm{VI}}$ & $\underline{\text { VII }}$ & $\underline{\text { VIII }}$ & $\underline{\mathrm{IX}}$ & $\underline{X}$ & $\underline{\underline{\mathrm{XI}+}}$ & $\begin{array}{l}\text { Годов. } \\
\text { сумма }\end{array}$ & $\begin{array}{c}\frac{\text { Год. }}{\underline{\text { в }}} \\
\text { котор. } \\
\text { набл. }\end{array}$ \\
\hline Белая Берель & 1080 & макс.* & $\underline{155}$ & $\underline{113}$ & 255 & $\underline{298}$ & $\underline{260}$ & $\underline{530}$ & 264 & $=$ & $\underline{431}$ & $\underline{265}$ & $\underline{226}$ & 2801 & 1961 \\
\hline$\overline{(1959-1987 \text { гг.) }}$ & $\underline{1980}$ & норм. ${ }^{*}$ & 62 & 48 & $\overline{55}$ & $\overline{78}$ & $\overline{131}$ & 222 & 119 & - & 232 & 142 & 147 & $\overline{1186}$ & $\overline{1986}$ \\
\hline Белая Берель & & макс. & $\underline{90}$ & $\underline{120}$ & $\underline{33}$ & 119 & 276 & $\underline{344}$ & 188 & $=$ & $\underline{240}$ & 226 & $\underline{163}$ & 1017 & 1984 \\
\hline$\overline{(1968-1987 \text { гг.) }}$ & $\underline{1300}$ & $\overline{\text { норм. }}$ & $\overline{22}$ & 22 & $\overline{15}$ & $\overline{40}$ & $\overline{88}$ & $\overline{91}$ & $\overline{99}$ & - & $\overline{153}$ & 117 & $\overline{70}$ & $\overline{670}$ & 1969 \\
\hline Сарым-Сакты & & макс. & $\underline{85}$ & $\underline{36}$ & $\underline{50}$ & $\underline{186}$ & $\underline{299}$ & $\underline{439}$ & 647 & $=$ & $\underline{730}$ & $\underline{202}$ & $\underline{162}$ & 2038 & $\underline{1987}$ \\
\hline$(1963-1987$ гг.) & 2420 & $\overline{\text { норм. }}$ & $\overline{24}$ & $\overline{14}$ & $\overline{19}$ & $\overline{43}$ & $\overline{110}$ & $\overline{146}$ & $\overline{230}$ & - & $\overline{307}$ & 97 & $\overline{69}$ & $\overline{1017}$ & $\overline{1973}$ \\
\hline Сарым-Сакты & & макс. & 45 & 28 & 26 & $\underline{68}$ & 131 & 126 & 180 & $=$ & 224 & 116 & 76 & $\underline{748}$ & 1987 \\
\hline$(\overline{(1971-1987 \text { гг.) }}$ & $\underline{1840}$ & $\overline{\text { норм. }}$ & $\overline{13}$ & $\overline{9}$ & $\overline{9}$ & $\overline{25}$ & $\overline{60}$ & $\overline{80}$ & $\overline{98}$ & - & $\overline{142}$ & $\overline{65}$ & $\overline{40}$ & $\overline{542}$ & $\overline{1972}$ \\
\hline Кара-Каба & 1800 & макс. & 143 & $\underline{150}$ & $\underline{54}$ & $\underline{108}$ & 213 & $\underline{108}$ & 124 & 133 & $\underline{111}$ & 200 & 244 & 1012 & 1987 \\
\hline (1975-1987 гг.) & & $\overline{\text { норм. }}$ & $\overline{44}$ & $\overline{35}$ & $\overline{18}$ & $\overline{55}$ & $\overline{57}$ & $\overline{55}$ & $\overline{68}$ & $\overline{70}$ & $\overline{59}$ & $\overline{87}$ & $\overline{115}$ & $\overline{666}$ & $\overline{1985}$ \\
\hline Кара-Каба & & макс. & $\underline{12}$ & $\underline{9}$ & 7 & 28 & 126 & 114 & 150 & 167 & 124 & $\underline{56}$ & 39 & $\underline{606}$ & 1987 \\
\hline (1975-1987 гг.) & $\underline{16 / 0}$ & $\overline{\text { норм. }}$ & $\overline{5}$ & $\overline{5}$ & $\overline{3}$ & $\overline{15}$ & $\overline{54}$ & 63 & 0 & 5 & 62 & 34 & 20 & 406 & 1980 \\
\hline Ульба & & макс. & 214 & $\underline{186}$ & 90 & 399 & $\underline{664}$ & $\underline{346}$ & $\underline{515}$ & 201 & $\underline{265}$ & $\underline{557}$ & $\underline{490}$ & 2199 & $\underline{1979}$ \\
\hline$\overline{(1960-1987 ~ г г .) ~}$ & 1600 & $\overline{\text { норм. }}$ & $\overline{95}$ & $\overline{73}$ & $\overline{52}$ & $\overline{126}$ & $\overline{206}$ & $\overline{145}$ & $\overline{179}$ & $\overline{106}$ & $\overline{120}$ & $\overline{223}$ & $\overline{232}$ & $\overline{1554}$ & $\overline{1976}$ \\
\hline Ульба & & макс. & $\underline{183}$ & $\underline{164}$ & $\underline{220}$ & $\underline{206}$ & $\underline{964}$ & $\underline{268}$ & $\underline{533}$ & $\underline{150}$ & $\underline{193}$ & $\underline{529}$ & $\underline{369}$ & 2706 & $\underline{1971}$ \\
\hline$\overline{(1970-1987 ~ г г .) ~}$ & $\underline{1200}$ & $\overline{\text { норм. }}$ & $\overline{83}$ & $\overline{67}$ & $\overline{54}$ & $\overline{106}$ & $\overline{215}$ & $\overline{111}$ & $\overline{153}$ & $\overline{84}$ & $\overline{98}$ & $\overline{196}$ & $\overline{208}$ & $\overline{1370}$ & $\overline{1976}$ \\
\hline
\end{tabular}

* Норма подсчитана из ряда наблюдений, указанного в скобках. Максимумы месячных сумм выбраны из указанного в скобках ряда наблюдений. 
Средняя изменчивость осадков теплого периода составляет 16$22 \%$. Амплитуда колебаний осадков теплого периода в Рудном Алтае находится в пределах от 56 до 167\% нормы, в Южном - от 55 до 186\%.В холодный период может выпадать от 40 до 230\% нормы осадков, а средняя их изменчивость составляет 19-25\%.

В Рудном Алтае в среднем за исследуемый период (47-50летний ряд наблюдений) во влажную зиму сумма осадков могла превышать норму на одну треть (30-34\%), а недобор нормы (сухие зимы) составлял не более $20 \%$. Но повторяемость зим с недобором осадков и превышением норм примерно одинакова.

Несколько иная картина в Южном Алтае: там положительные аномалии в среднем составляют 32-36\% нормы, а отрицательные 16-20\%. Но повторяемость зим с недобором осадков в1,5-3 раза больше, чем с положительными аномалиями. Большая континентальность климата Южного Алтая, в сравнении с Рудным, проявляется и через бо́льшую пестроту распределения осадков в пространстве и бо́льшую их изменчивость, о чем свидетельствуют данные годовых сумм осадков различной обеспеченности в пределах исследуемого региона (табл. 37).

Т а блица 37

Годовые количества осадков различной обеспеченности, мм [13]

\begin{tabular}{|c|c|c|c|c|c|c|c|c|c|c|c|}
\hline \multirow{2}{*}{$\begin{array}{c}\text { Среднее } \\
\text { кол-во } \\
\text { осадков }\end{array}$} & 5 & 10 & 20 & 30 & 40 & 50 & 60 & 70 & 80 & 90 & 95 \\
\hline 150 & 219 & 199 & 178 & 164 & 152 & 139 & 130 & 121 & 106 & 90 & 72 \\
\hline 200 & 292 & 266 & 240 & 223 & 207 & 190 & 177 & 166 & 145 & 124 & 103 \\
\hline 250 & 364 & 333 & 301 & 280 & 261 & 240 & 225 & 210 & 184 & 158 & 133 \\
\hline 300 & 436 & 400 & 363 & 337 & 314 & 290 & 272 & 254 & 223 & 193 & 164 \\
\hline 350 & 508 & 466 & 423 & 394 & 367 & 340 & 319 & 298 & 263 & 227 & 195 \\
\hline 400 & 582 & 535 & 485 & 451 & 421 & 390 & 366 & 343 & 301 & 261 & 225 \\
\hline 450 & 654 & 602 & 546 & 508 & 474 & 440 & 413 & 387 & 340 & 296 & 256 \\
\hline 500 & 726 & 669 & 607 & 565 & 527 & 490 & 560 & 431 & 379 & 330 & 286 \\
\hline 550 & 798 & 735 & 669 & 622 & 580 & 540 & 506 & 476 & 418 & 365 & 317 \\
\hline 650 & 942 & 869 & 790 & 736 & 680 & 641 & 599 & 563 & 496 & 434 & 377 \\
\hline 700 & 1014 & 934 & 850 & 793 & 739 & 691 & 646 & 608 & 534 & 469 & 407 \\
\hline 800 & 1158 & 1067 & 972 & 907 & 845 & 790 & 738 & 696 & 612 & 538 & 468 \\
\hline 900 & 1302 & 1200 & 1094 & 1020 & 951 & 890 & 831 & 784 & 691 & 607 & 530 \\
\hline 1000 & 1456 & 1338 & 1217 & 1137 & 1059 & 992 & 926 & 875 & 768 & 678 & 591 \\
\hline 1200 & 1757 & 1614 & 1467 & 1369 & 1274 & 1198 & 1120 & 1056 & 926 & 821 & 716 \\
\hline 1300 & 1906 & 1750 & 1591 & 1483 & 1381 & 1300 & 1216 & 1149 & 1005 & 892 & 779 \\
\hline 1500 & 2205 & 2020 & 1836 & 1711 & 1593 & 1504 & 1408 & 1333 & 1162 & 1036 & 905 \\
\hline
\end{tabular}


Число дней с осадками и их продолжительность. Число дней с осадками распределяется по территории Юго-Западного Алтая в той же закономерности, как и их количество, то есть уменьшаясь с севера на юг и увеличиваясь с запада на восток. В Усть-Каменогорске 135 дней с осадками ( $\geq 0,1$ мм), на склонах Ульбинского хребта до 150 дней (Малая Ульба), в Орловском поселке 113 дней. Главный максимум числа дней с осадками в Рудном Алтае приходится на начало зимы: в ноябре 14, в декабре 13 дней, вторичный максимум летний - в июле 12 дней. Минимум дней с осадками приходится на сентябрь $(8,5)$ и на апрель $(8,9)$. В Южном Алтае максимум летний: июнь и июль - 11-13 дней в месяц, минимум в апреле - порядка 7 дней. В Зайсанской котловине максимум числа дней с осадками летний: в июне и июле по 9 дней.

Осадки за теплый период, промачивающие почву до узла кущения ( $\geq 5$ мм) в сутки, наблюдаются в Усть-Каменогорске 21,5 , в Орловском поселке - 16,8, в Зайсане - 14,7 дня. В холодный период их продолжительность составляет 8,6 дней в Усть-Каменогорске и 5,1 дня в Орловском поселке.

Осадки $\geq 10,0$ мм наблюдаются 10 дней в году в УстьКаменогорске и 6 дней в Орловском поселке [13]. Необходимо отметить, что на склонах гор резко возрастают как суточные суммы, так и количество дней с осадками.

Т а бли ц а 38

Вероятность (Р) выпадения обильных осадков ( $\geq 30$ мм в сутки), наблюденный суточный и средний многолетний максимумы осадков (по А.Д. Дюкареву)

\begin{tabular}{|l|c|c|c|}
\hline \multicolumn{1}{|c|}{ Пункт наблюдения } & Р & $\begin{array}{c}\text { Наблюденный суточный } \\
\text { мах. осадков, мм }\end{array}$ & $\begin{array}{c}\text { Средний многолетний } \\
\text { суточный мах. осадков, мм }\end{array}$ \\
\hline Шемонаиха & 0.22 & $61.5(1$. VII.1960) & 43.8 \\
\hline Риддер & 1.00 & $58.8(8$. VII.1968) & 36.3 \\
\hline $\begin{array}{l}\text { Усть- } \\
\text { Каменогорск }\end{array}$ & 0.35 & $88.8(16 . V I .1940)$ & 40.0 \\
\hline Зыряновск & 0.35 & 52.6 (II.V.1973) & 35.3 \\
\hline Большенарым & 0.16 & $41.6(16$. VII.1967) & 34.8 \\
\hline Катон-Карагай & 0.25 & $53.3(7 . V I I 1964)$ & 36.0 \\
\hline Самарка & 0.31 & $45.7(10 . V I I I .1958)$ & 33.2 \\
\hline Пос. Орловский & 0.10 & $37.5(31 . V I I .1910)$ & 31.6 \\
\hline Кумашкино & 0.08 & $33.4(30 . V I .1957)$ & 93.9 \\
\hline Малая Ульба & 16.00 & $174.1(29 . V .1979)$ & \\
\hline
\end{tabular}


В табл. 38 представлены вероятность выпадения обильных осадков ( $\geq 30$ мм в сутки), а также наблюденный максимум осадков за весь период существования станции. Вероятность выпадения обильных осадков рассчитана как отношение числа дней с обильными осадками к периоду наблюдений.

По метеопосту Малая Ульба за период 1978-1987 гг. отмечено 160 случаев выпадения осадков свыше 30 мм, из которых 93 случая с осадками от 30 до 50 мм. В 56 случаях осадки были от 50 до 100 мм, в 11 случаях - более 1 мм. В среднегодовом выводе больше всего дней с обильными осадками (более 30 мм) приходится на ноябрь - 3 дня, меньше всего на февраль - 0,4 дня. В 1980 году в июне зарегистрировано 11 дней с осадками свыше 30 мм, в ноябре - 10 дней. В отдельные годы (1979 г.) наблюдалось до 42 дней в году с осадками свыше 30 мм - метеопост Малая Ульба. Осадки более 2000 мм в год фиксировались в верховьях рек Малая Ульба, Белая Берель, Хамир, Курчум. Так, в 1961 г. в бассейне Белой Берели они достигали 3000 мм, в 1979 г. на метеопосту Малая Ульба - до 4000 мм в год (наблюдения А.Д. Дюкарева). Район Малой Ульбы наиболее влажный в пределах Алтае-Саянской горной страны. Осадки такого же порядка, возможно, несколько больше, отмечаются в нивальногляциальном поясе Кузнецкого Алатау $[8,66]$. Данные наблюдения имеют большое прикладное значение. Осадки в высокогорной и верхней частях среднегорья в 1,5-3 раза больше, чем на предгорных равнинах и низкогорьях. С ними связываются опасные паводки рек, эрозия почв, в теплый период оползни, в зимний - массовый сход лавин свежевыпавшего снега.

В связи с глобальным потеплением нижних слоев атмосферы (прогноз по М.И. Будыко, Ю.А. Израэлю и др., в умеренных широтах будет учащаться повторяемость как засух, так и обильных (катастрофических) осадков, особенно в горах [43, 59, 67].

\section{4. Атмосферные явления. Характеристика гроз}

Гроза представляет собой атмосферное явление, когда в мощных кучево-дождевых (Св) облаках, а также между облаками и земной поверхностью возникают сильные электрические разряды молнии, сопровождающиеся громом.

Чтобы развивалось грозовое облако, необходимы условия: восходящие потоки теплого воздуха со скоростью 10-15 м/сек и 
более. Такие вертикальные движения возникают в результате неравномерного нагрева земной поверхности либо вынужденного подъема воздуха вдоль фронтального раздела или горного склона. Грозовые процессы наблюдаются при большой влагонеустойчивости воздушной массы, когда мощность кучево-дождевых облаков превосходит 4-5, иногда 7-8 км, в таких случаях теплота конденсации поддерживает интенсивность восходящих токов. С последними связано разделение по высоте в облаке как частиц различного агрегатного состояния, так и объемных зарядов: малые элементы (снежинки, кристаллы, мелкие капли) несут избыточный положительный заряд, а более крупные - отрицательный, поэтому в верхней части облака скапливается, соответственно, положительный объемный заряд, а в нижней-отрицательный.

Исследования показали, что для возникновения гроз мощность облака над нулевой изотермой должна быть не менее 1,5-2 км. Следовательно, процессы электризации при фазовых переходах и при взаимодействии твердых и жидких частиц играют решающую роль в регенерации электричества и создании объемных зарядов в облаках.

Центр верхнего объемного положительного заряда в облаке расположен на высотах между изотермами минус $10^{0}-$ минус $30^{\circ} \mathrm{C}$. Центр тяжести объемного отрицательного заряда находится в среднем на высоте 3 км от основания облака. Так как здесь объемная плотность заряда больше, его носителями являются переохлажденные водяные частицы. В области положительных температур вблизи нижней границы облака возникают небольшие положительные крупнокапельные объемные заряды.

На предгорных равнинах Рудного Алтая нижняя граница грозового облака обычно расположена на высоте 1000-1500 м, а при температурах воздуха выше $25^{0} \mathrm{C}$ она может достигать 2000-2500 м.

В пределах Юго-Западного Алтая повторяемость гроз в годовом выводе увеличивается с запада на восток от 25 до 40 дней. Северная полоса: Шемонаиха - 28, Усть-Каменогорск - 34, Риддер - 42 дня; южная полоса: Зайсан - 27, Катон-Карагай - 29, Зыряновск - 33, Северный поселок - 34 дня. В среднем в летние месяцы наблюдается 7-11 дней с грозой общей продолжительностью 15-21 час. Для УстьКаменогорска характерна средняя, а для Риддера большая активность гро3. Повторяемость гроз в годовом ходе в целом для региона сравнительно медленно растет от мая к июлю и быстро падает от июля к сентябрю. В суточном ходе идет медленный рост 
повторяемости гроз от утренних часов к 12 часам дня и быстрый рост от 12 часов к 16, а от 18 к 21 часу наблюдается резкое снижение грозовой активности [68]. Средняя продолжительность грозы в день с грозой составляет в Усть-Каменогорске 1,8, в Риддере - 1,6 часа (рис. 31, 32).

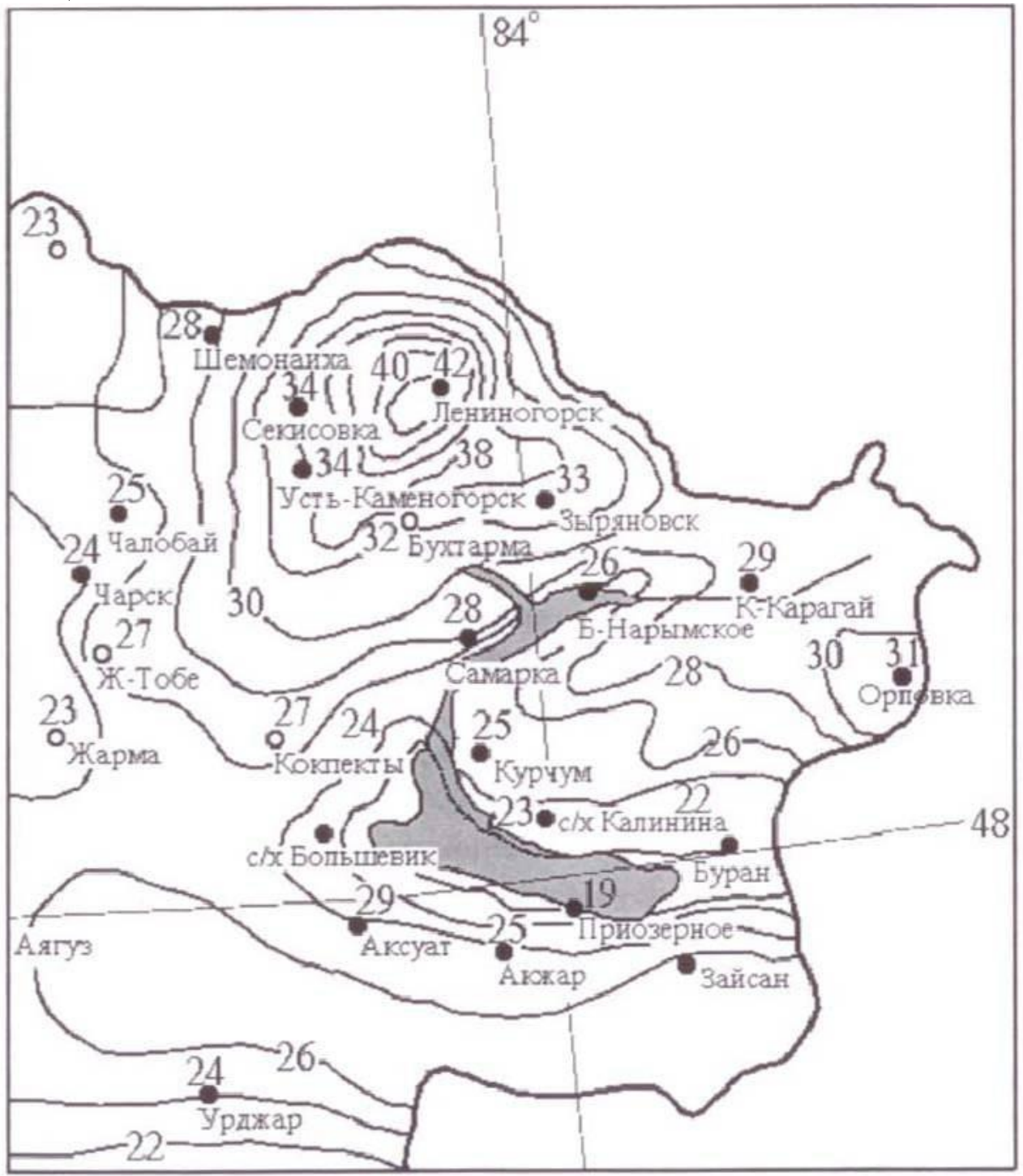

Рис. 31. Распределение числа дней с грозами по территории Юго-Западного Алтая

Установлено, что в районах юго-востока Западной Сибири и северо-востока Казахстана 80-81\% гроз - фронтальные, из них две трети приходится на холодные фронты [69].

За период 1966-1975 гг. для Усть-Каменогорска выяснена связь гроз с типами циркуляции [70].

Так, грозовая деятельность получает наибольшее развитие при циклонических типах циркуляции: II, IV, VI, VIII. Этот вывод хорошо согласуется с результатами Г.И. Парфеновой, указанные типы 
соответствуют выделенным ею типам I, III и II, IV. Значительное число дней с грозой над Рудным Алтаем связано с антициклоническими типами и их подтипами (IA, IIIБ, VA). При подтипах I-A и VA грозы, как правило, бывают на холодных фронтах западных и юго-западных циклонов. Эти холодные фронты попадают в параллельные высотные потоки и на них перед горными системами возникают волновые и частные циклоны $[32,39]$. Наибольшее число дней с грозой (26) отмечено в июле при стационировании циклона, в этом случае грозовая деятельность может наблюдаться несколько дней подряд. Осадки по существу выпадают из местной воздушной массы, а вторичные холодные фронты упорядочивают конвекцию [40, 58]. Основную роль в формировании гроз июля играют юго-западные и западные типы, при этом удельный вес юго-западных процессов в два раза больше западных: 43 против 22 (табл. 39).

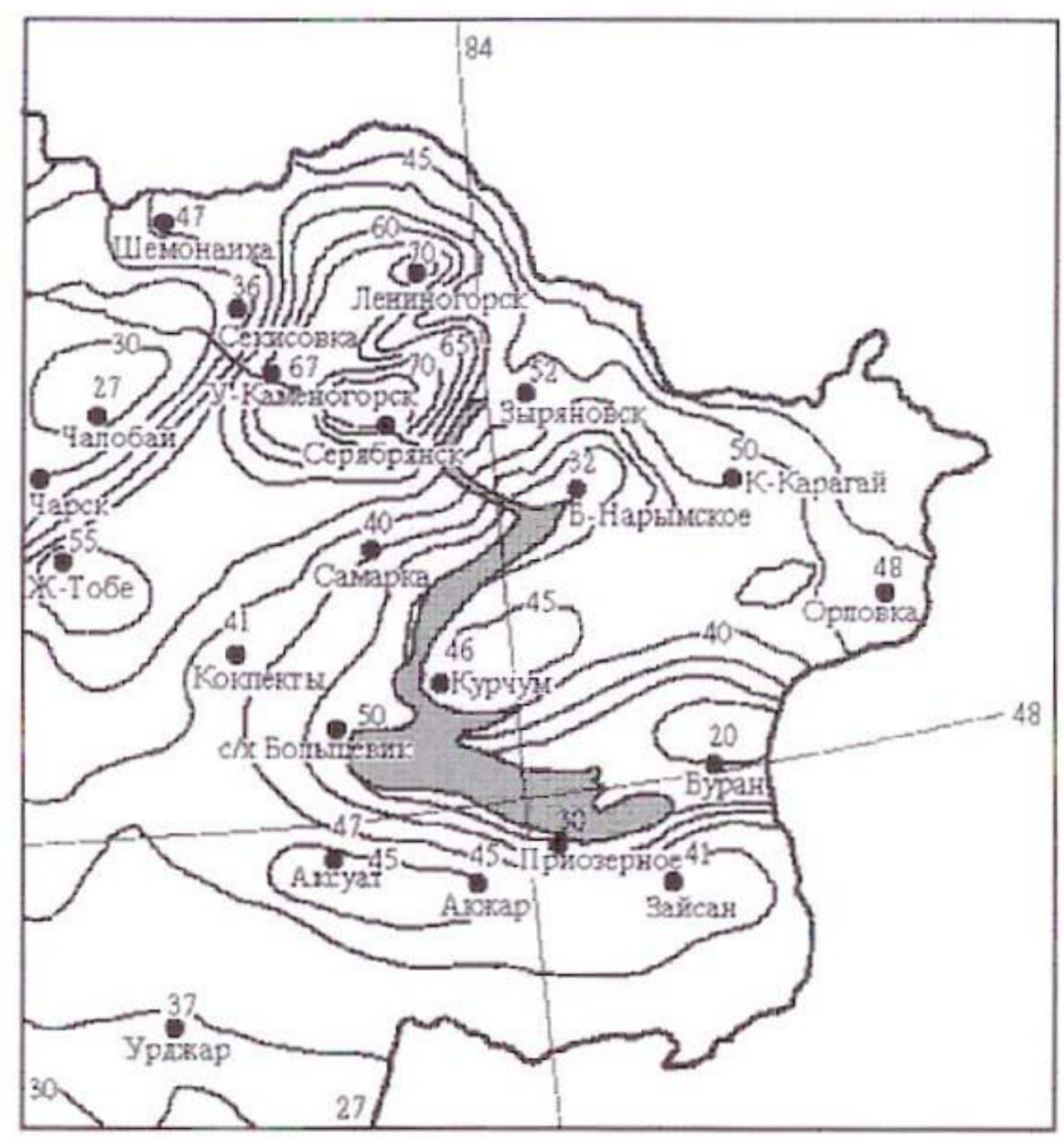

Рис. 32. Распределение грозовой деятельности по территории ЮгоЗападного Алтая 
Повторяемость гроз (число случаев) в связи с типами циркуляции за 10-летний период (1966-1975 гг.), г. Усть-Каменогорск [70]

\begin{tabular}{|l|c|c|c|c|c|c|c|}
\hline \multicolumn{1}{|c|}{$\begin{array}{c}\text { Типы и подтипы } \\
\text { циркуляции }\end{array}$} & \multicolumn{9}{c|}{ Месяцы } \\
\cline { 2 - 9 } & IV & V & VI & VII & VIII & X & Год \\
\hline 1. Западно-антициклонический & 2 & 11 & 14 & 4 & 11 & 0 & 42 \\
\hline 2. Западно-циклонический & 3 & 6 & 8 & 17 & 15 & 1 & 50 \\
\hline 3. Северо-западный антициклонический & 1 & 0 & 2 & 2 & 9 & 3 & 17 \\
\hline 4. Северо-западный циклонический & 0 & 2 & 0 & 15 & 0 & 0 & 17 \\
\hline 5. Юго-западный антициклонический & 0 & 5 & 19 & 8 & 6 & 2 & 40 \\
\hline 6. Юго-западный циклонический & 0 & 8 & 24 & 22 & 6 & 0 & 60 \\
\hline 7. Ультраполярные вторжения & 0 & 0 & 0 & 0 & 0 & 0 & 0 \\
\hline 8. Стационирование циклона & 0 & 0 & 6 & 26 & 3 & 1 & 36 \\
\hline ИТОГО: & 6 & 32 & 73 & 94 & 50 & 7 & 262 \\
\hline
\end{tabular}

В августе над исследуемым регионом усиливается западный перенос воздушных масс, он связан с типами циркуляции II и I. Тогда перед орографическим узлом Рудного Алтая создаются благоприятные условия для интенсивной конденсации влаги, что и обусловливает активную грозовую деятельность в окрестностях Риддера, Зыряновска, Усть-Каменогорска. Необходимо подчеркнуть, что северо-западные циклонические типы циркуляции могут дать грозу только в июле.

Зимой основным циркуляционным процессом является охлаждение воздушных масс, что приводит к резкому уменьшению их влагосодержания (до 3-4 кг/м² против 19-25 летом) и увеличению устойчивости стратификации атмосферы, именно поэтому в зимние месяцы гроз практически не бывает. Однако в последние двадцать лет (1980-2000 гг.), которые характеризовались сравнительно мягкими зимами, наблюдалось несколько случаев зимних гроз (в феврале и марте). Это объясняется тем, что происходил интенсивный вынос тропического воздуха в окклюдированных юго-западных циклонах и их регенерация на арктическом фронте в пределах юго-востока Западной Сибири и северо-востока Казахстана.

В связи со сложностью рельефа грозообразовательные процессы в регионе протекают разнообразно. Частота и интенсивность гроз зависит от местных условий и барико-циркуляционных особенностей развития процесса влажнонеустойчивого состояния. За исследуемый период повторяемость гроз от года к году резко колеблется: наибольшее число гроз в году достигло в Шемонаихе- 48, Риддере - 
61, Усть-Каменогорске - 62, Северном поселке - 57, Зыряновске - 54, Большенарыме - 42, Катон-Карагае - 45, Самарке - 45, в Буране - 33, в Зайсане -51[71]. Наблюдается также тесная связь между средним числом дней с грозой и количеством осадков за теплый период. Краткий анализ основных метеорологических характеристик (температуры, влажности, ветра, осадков), обусловливающих или сопутствующих грозообразованию, приводится ниже, в основном на примере Усть-Каменогорска.

Температура воздуха в момент грозы и за сутки до нее во все месяцы с грозами выше, чем средняя многолетняя температура суток. Так, в областном центре 70\% гроз наблюдается при температурах 16$25^{\circ} \mathrm{C}, 17 \%$ - при температурах выше $26^{\circ} \mathrm{C}$ и только $13 \%$ - при температурах ниже $16^{0} \mathrm{C}$. Экстремально высокая температура при грозе зафиксирована 11 июля 1974 г. Она составляла $36,6^{\circ} \mathrm{C}$, а экстремально низкая 20 мая 1971 г. $-9,1^{0} \mathrm{C}$.

Упругость водяного пара за сутки к моменту грозы во все месяцы повышается в среднем на 1,5 гПа, а удельная влажность на 0,8 г/кг.

В Усть-Каменогорске и его окрестностях только 83\% гроз сопровождаются выпадением осадков, а 17\% приходится на так называемые «сухие грозы».

Для Рудного Алтая характерной чертой грозовой деятельности является развитие грозы при штиле (повторяемость 11-18\%), а также при слабых и умеренных ветрах. Однако при грозах скорости ветра на 3-5 м/с больше средних многолетних. В июле наблюдаются грозы при ветрах со скоростью более $11 \mathrm{~m} / \mathrm{c}$, в другие месяцы подобные метеоявления бывают чрезвычайно редко. За 15-летний ряд наблюдений только один раз в мае была гроза при скорости ветра до $16 \mathrm{~m} / \mathrm{c}(11$ мая 1972 г.).

На розе скоростей ветра в июне и июле прослеживаются закономерности многолетнего хода повторяемости направления ветра в городе Усть-Каменогорске, где преобладают ветры юго-восточной и северо-западной четвертей. В июле роза скоростей ветра различных градаций по направлениям отражает особенности структуры грозообразующих процессов в разгар лета. В отличие от других месяцев, наибольшая повторяемость дней с грозой связывается со стационированием циклонов (тип VIII). Стационирующие циклоны обусловливают повторяемость дней с грозой в 4-9 раз большую, чем в июне и августе (табл. 39). В окклюдированных высоких циклонах 
основным механизмом выпадения осадков является термическая конвекция, которая упорядочивается вторичными холодными фронтами [15, 27, 37, 70].

Туман и дымка возникают в результате конденсации водяного пара в приземном слое атмосферы. При тумане видимость до 1 км, при дымке от 1 до 10 км. Ухудшение видимости приводит к ограничению, а иногда и к прекращению работы транспорта. В зависимости от дальности видимости, выделяют следующие по интенсивности виды тумана: очень сильный, видимость до 50 м; сильный - от 50 до 200 м; умеренный - от 200 до 500 м; слабый - от 500 до 1000 м.

Наблюдения показали, что при температуре минус $18^{0} \mathrm{C}$, минус $20^{\circ} \mathrm{C}$ туманы преимущественно состоят из капель воды, при температуре минус $30^{\circ} \mathrm{C}$ и ниже - из кристаллов льда. Водность туманов зависит от температуры. Для туманов средней

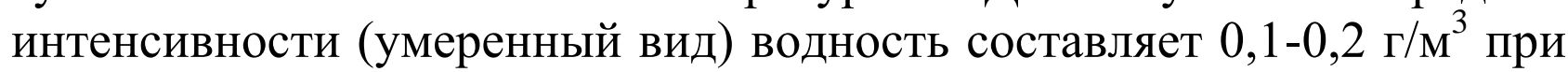
температуре минус $15 \div$ минус $20^{\circ} \mathrm{C}$, при температуре $5-10^{0} \mathrm{C}$ водность повышается до $0,5-1,0$ г/ $\mathrm{M}^{3}$.

Зимой при туманах относительная влажность воздуха бывает менее $100 \%$, что соответствует состоянию насыщения по отношению ко льду. В промышленных городах в этот сезон туманы наблюдаются при влажности 70-80, а летом при влажности 95-100\%. В теплое время года туманы не образуются, если влажность воздуха менее $80 \%$. В практике для рассеивания тумана часто применяются тепловой, физико-химический, механический и другие способы воздействия.

Суточный ход тумана определяется суточным ходом температуры. Так как основной причиной образования туманов является понижение температуры, то их максимум повторяемости приходится на ранние утренние часы и минимум - после полудня. Летом туманы быстро рассеиваются после восхода солнца, потому что упругость паров при положительных температурах больше, чем при отрицательных и нарастает летом значительно быстрее, чем зимой.

В годовом ходе максимум повторяемости туманов приходится на зимние месяцы. Следует отметить четкий годовой ход продолжительности тумана. Их средняя непрерывная продолжительность зимой в 2-4 раза больше, чем летом (табл. 40). 
Характеристика повторяемости и продолжительности туманов по метеостанциям Юго-Западного Алтая

\begin{tabular}{|c|c|c|c|c|c|c|c|c|c|c|c|c|c|}
\hline \multirow{2}{*}{ Станция } & \multicolumn{3}{|c|}{ Январь } & \multicolumn{3}{|c|}{ Май } & \multicolumn{3}{|c|}{ Июль } & \multicolumn{3}{|c|}{ Сентябрь } & Год \\
\hline & $1^{*}$ & 2 & 3 & 1 & 2 & 3 & 1 & 2 & 3 & 1 & 2 & 3 & 1 \\
\hline $\begin{array}{l}\text { 1. Усть-Каме- } \\
\text { ногорск }\end{array}$ & 8 & 15 & 6.4 & 0.2 & 1 & 2 & 2 & 8 & 1.5 & 5 & 8 & 2.8 & 53 \\
\hline 2. Риддер & 2.3 & & & 0.6 & 2 & & 0.2 & 2 & & 0.9 & 4 & & 9 \\
\hline 3. Шемонаиха & 2 & 8 & & 0.5 & 3 & & 0.8 & 7 & & 2 & 10 & & 16 \\
\hline 4. Зыряновск & 12 & 23 & & 1 & 5 & & 5 & 13 & & 4 & 10 & & 77 \\
\hline $\begin{array}{l}\text { 5. Большена- } \\
\text { рымское }\end{array}$ & 6 & 19 & 3.8 & 0.2 & 2.1 & 1.5 & 0.1 & 1 & 0.01 & 0.1 & 1 & 2 & 24 \\
\hline 6. Катон-Карагай & 0.8 & 4 & & 1 & 5 & & 0.5 & 3 & & 1 & 3 & & 13 \\
\hline 7. Самарка & 1 & 6 & & 0.1 & 1 & & 0 & 1 & & 0.1 & 1 & & 9 \\
\hline 8. Курчум & 2 & 6 & & 0.1 & 1 & & 0 & 1 & & 0.3 & 2 & & 13 \\
\hline 9. Буран & 2 & 7 & & 0.1 & 1 & & 0 & 1 & & 0.4 & 2 & & 14 \\
\hline 10. Зайсан & 3 & 12 & 4.3 & 0.3 & 2 & 1.3 & 0 & 0 & 0 & 0.1 & 1 & 1 & 20 \\
\hline 11. Бухтарма & 2 & & & 0.1 & & & 0.1 & & & 0.4 & & & 7 \\
\hline 12. Секисовка & 3 & & & 1 & & & 6 & & & 8 & & & 46 \\
\hline $\begin{array}{l}\text { 13. Пос. Орлов- } \\
\text { ский }\end{array}$ & 2 & 7 & & 0.5 & 3 & & 2 & 5 & & 1 & 3 & & 19 \\
\hline $\begin{array}{l}\text { 14. Пос. Север- } \\
\text { ный }\end{array}$ & 0.7 & 4 & & 4 & 9 & & 2 & 6 & & 4 & 11 & 41 & \\
\hline
\end{tabular}

*1 - среднее число дней с туманом; 2 - наибольшее число дней с туманом; 3 - средняя продолжительность тумана в день с туманом, ч.

Повторяемость туманов зависит от ряда особенностей: рельефа, характера подстилающей поверхности, близости водоемов, а также от синоптических процессов и обогащения атмосферы ядрами конденсации (повышенная запыленность, промышленные выбросы в атмосферу, дым). При одной и той же температуре и влажности воздуха, ночью в котловинных формах рельефа возникает радиационный туман (действует закон Воейкова), а на склонах хребтов, в связи со стоком охлажденного воздуха вниз, температура не снижается до точки росы. Этот пример очень хорошо иллюстрируют станции предгорных котловин Секисовка, Зыряновск, где дней с туманом в 5-7 раз больше, чем в Риддере или КатонКарагае, которые расположены на склонах хребтов.

Известно также, что в горах приподнятый туман воспринимается как облака горные стратусы (стратус - слоистый). Поэтому метеостанции, расположенные на склонах, имеют противоположный режим повторяемости туманов в долинах. Кроме 
того, летом в среднегорье и высокогорье кучевые облака часто рождаются в так называемом ночном «озере тумана», то есть от поднятия ночного тумана с восходом солнца из котловины вверх по склону (см. табл. 40). Так, в Усть-Каменогорске максимум повторяемости туманов приходится на зимние месяцы, а в Северном поселке на весну и осень, при этом в среднем за год там насчитывается 41 день с туманом, в Риддере всего лишь 9 дней, в Катон-Карагае - 13, здесь туманы чаще всего бывают весной и осенью.

Большая повторяемость туманов в Усть-Каменогорске объясняется не его положением в горах Алтая, а наличием зимней полыньи ниже Усть-Каменогорской ГЭС, которая распространяется вниз по Иртышу на 13-15 км. Туман образуется под влиянием испарения с поверхности теплой воды в относительно холодный воздух и называется туманом испарений. Однако основную роль в образовании таких туманов играет радиационное охлаждение воздуха, испарение лишь усиливает эффект охлаждения. Когда сильный туман возникает над поверхностью Иртыша и Ульбы и на набережных, то он наблюдается и в других районах города, но с меньшей интенсивностью. Дни с туманами испарений обычно характеризуются наличием низкой (до 50-100 м) инверсией температуры. Если инверсионный слой располагается на высотах более 200 м, то туман не образуется, так как водяной пар переносится в более высокие слои.

Периоды длительных радиационных туманов наблюдаются и в условиях малоподвижных антициклонов, сформированных в прежнем арктическом воздухе. В таких случаях приземные радиационные инверсии смыкаются в них с инверсионным слоем оседания (сжатия), а температура воздуха в приземной атмосфере снижается до минус $30^{\circ} \mathrm{C}$ и ниже. Наиболее часто туманам сопутствует слабый ветер или штиль, низкие температуры воздуха зимою (от минус $20^{\circ} \mathrm{C}$ до минус $30^{\circ} \mathrm{C}$ ).

Если в условиях антициклона температуры воздуха достигают минус $10^{0}$, минус $15^{\circ} \mathrm{C}$, то условия для образования капельно-жидкого тумана над снежной поверхностью неблагоприятны, так как упругость паров насыщения над водой больше, чем надо льдом. Воздух по отношению к водной поверхности не насыщен, а по отношению ко льду - пересыщен, при этом начинается сублимация водяного пара на снежной поверхности, что препятствует 
конденсации влаги в воздухе в виде капель тумана. По этой же причине с удалением от рек туман испарений становится менее интенсивным, капельки воды вблизи снежной поверхности испаряются, а водяной пар оседает на снежинках (процесс сублимации). Так как в Рудном и Южном Алтае на склонах гор в холодный период преобладают температуры воздуха от минус $10^{0} \mathrm{C}$ до минус $15^{0} \mathrm{C}$, то туманы там не возникают.

Еще один вид туманов - адвективные. Это фронтальные туманы, которые образуются вблизи теплого и холодного фронтов. Так, на обширной территории юго-востока Западной Сибири за 2-3 дня до периода туманов отмечается значительное потепление, оно связано обычно с выходом на территорию Западной Сибири и востока Казахстана юго-западных, западных и северо-западных циклонов. В тылу этих циклонов отмечается адвекция холода и формирование мощного антициклона, который усиливается над этими регионами. Происходит уменьшение скоростей ветра в приземном слое, где формируется (и продолжается выше) интенсивная инверсия температуры. В соответствии с изменением барического поля в период формирования устойчивых туманов на обширных площадях предгорий Алтая происходит и смена ветров с юго-западных и западных, на северо-западные, северные и северовосточные, температура за 2-3 дня понижается на $10^{0}-20^{\circ} \mathrm{C}$.

Благоприятными метеорологическими условиями для образования тумана являются слабые ветры у поверхности земли, высокая относительная влажность, понижение температуры (особенно ночью) и наличие мощной инверсии, которая препятствует выносу влаги из приземных слоев.

Ниже приводятся вероятностные характеристики повторяемости туманов. Среднее значение дней с туманом за год в УстьКаменогорске за счет большой повторяемости лет с числом дней с туманом 11-30, а также 51-70 дней, в Риддере 6-10 (59\%), в Зыряновске за счет повторяемости зим с числом дней с туманом 8190 (32\%), 50-60 (13\%), 21-30 (27\%), в пос. Орловский - 16-20 и 11-15, в Зайсане максимальную повторяемость имеют зимы с числом дней с туманом 16-20 (31\%) и 21-25 (28\%).

Метель - явление, с которым связывается перенос снега над поверхностью земли. Выделяют низовую и общую метель. При низовой, снег не выпадает, а происходит перенос сильным ветром ранее выпавшего снега до высоты нескольких метров. Общая метель 
(вьюга, буран, пурга) - перенос почти в горизонтальном направлении как ранее выпавшего, так и выпадающего снега. В Западной Сибири и на северо-востоке Казахстана снег выпадает при более низкой температуре, чем на тех же широтах европейской территории России, поэтому он более сухой, измельчается при трении частиц и легко поднимается ветром. Даже при ветре со скоростью 4-5 м/с наблюдаются поземки, то есть перенос снега лишь в очень тонком слое, непосредственно прилегающим к земной поверхности. Плотность свежевыпавшего снега достигает 0,1 г/ $\mathrm{cm}^{3}$. При метелях скорость ветра обычно составляет 6 м/с. В таких случаях вздымается

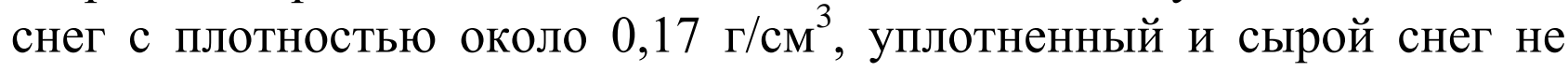
переносится. Метелевые явления объясняются развитием циклонической деятельности над восточными районами Казахстана и юго-востоком Западной Сибири.

Над Рудным Алтаем, в районе его предгорий, среднее число дней с метелью за год убывает с северо-запада на юго-восток от 35-40 до 20 дней. Так, в Шемонаихе - 32 дня в году с метелью, Риддере 24, Усть-Каменогорске - 22, пос. Северном - 20, Катон-Карагае - 19, Зайсане - 8. Наибольшее же число дней с метелью за год составляет: в Шемонаихе - 56, Усть-Каменогорске - 44, Катон-Карагае - 34, Буране - 21, Зайсане - 18. Чаще всего метели наблюдаются в сезон с декабря по февраль. Средняя непрерывная их продолжительность составляет 6-7 часов, но в Усть-Каменогорске она 5,7, Риддере - 8,5, Катон-Карагае - 5,1, Зайсане - 3,3 часа. Годовая продолжительность метелей составляет в Усть-Каменогорске - 123, Риддере - 222, КатонКарагае - 96, Зайсане - 28 часов. Кроме того, на территории Рудного Алтая в одном случае из десяти можно ожидать продолжительность метели от 12 до 18 часов, а в трех случаях из ста метель длится 24 часа. Метелевые явления горных районов не получили освещения [13].

Анализ материалов показывает, что в Усть-Каменогорске метели наблюдаются при слабо и умеренно морозных погодах до 8891\% повторяемости, а от 6 до 9\% повторяемости бывают при температурах ниже минус $15^{0} \mathrm{C}$, возможны и при положительных температурах: от 2,2 до 2,6\% повторяемости в декабре-феврале и, до 7,5\% в ноябре. Высокие температуры при метелях связаны не только с адвекцией тепла, но и с проявлением фёнового эффекта.

Треть метелей отмечается при умеренном ветре со скоростью 69 м/с, до 40\% метелей при сильном ветре - 10-13 м/с и 25\% метелей - 
при штормовых ветрах. Направление ветра при метелях обусловлено особенностями физико-географического положения станции (табл. 41).

Повторяемость различных направлений ветра при метелях, \%

\begin{tabular}{|l|c|c|c|c|c|c|c|c|}
\hline \multicolumn{1}{|c|}{ Станция } & С & СВ & В & ЮВ & Ю & Ю3 & 3 & С3 \\
\hline Риддер & & & 1 & 11 & 23 & 37 & 28 & \\
\hline Усть-Каменогорск & & & 12 & 62 & 5 & 8 & 6 & 7 \\
\hline Катон-Карагай & 2 & 1 & 38 & 25 & 4 & 2 & 26 & 2 \\
\hline Пос. Орловский & 4 & & 2 & 23 & 23 & 21 & 15 & 12 \\
\hline Зайсан & & & 2 & 3 & 8 & 29 & 45 & 13 \\
\hline
\end{tabular}

В Риддере метели часто бывают при юго-западных и западных ветрах, Усть-Каменогорске - при юго-восточных, Катон-Карагае при восточных, юго-восточных и западных, Зайсане - при западных и юго-западных ветрах.

Резкое усиление скоростей ветра наблюдается, когда вблизи Алтая происходит слияние ПВФЗ, а приземные циклоны в предгорьях Алтая углубляются. Режим ветра при метелях зависит от типа и интенсивности синоптических процессов. При сильных ветрах переносится значительное количество снега, в результате одни участки поверхности оголяются, а на других происходит его аккумуляция.

Установлено, что более 95\% массы снега переносится в слое 0-2 м над поверхностью снежного покрова. Средняя интенсивность переноса снега пропорциональна третьей степени скорости ветра.

Снегоперенос, как правило, измеряется метелемерами, а скорость ветра - анемометрами. Обычно расчет объема снегопереноса ведется в кубических метрах на погонный метр. Над Юго-Западным Алтаем объем снегопереноса 5\%-ной обеспеченности при сильных метелях менее $200 \mathrm{~m}^{3} /$ пог. м [12, 49].

Расчет объема снегопереноса за отдельные зимы проводится по эмпирическим формулам.

\section{5. Температура почвы}

Почва является основой деятельного слоя, приемника и трансформатора лучистой солнечной радиации в земные виды энергии. Состояние деятельного слоя зависит от атмосферных воздействий. Атмосфера и деятельный слой подстилающей 
поверхности образуют единую изменчивую глобальную систему, которую можно назвать климатической [72].

Основным источником нагревания почвы является солнечная радиация, а также теплообмен с воздушными массами и процессами агрегатных переходов воды, находящийся во взаимодействии с почвой. Интенсивность нагревания почвы определяется величиной ее альбедо и физическими свойствами, такими как удельная теплоемкость (С), плотность ( $\rho)$, коэффициенты теплопроводности $(\lambda)$ и температуропроводности $\mathrm{K}=\frac{\lambda}{C \rho}$. Поток тепла $(\mathrm{Q})$ вглубь почвы возможен лишь при наличии градиента температуры. Тепловой поток равен произведению градиента температуры на коэффициент теплопроводности

$$
\mathrm{Q}=\lambda \cdot \mathrm{a}, \text { где } \mathrm{a}-\text { градиент температуры. }
$$

Основными законами распространения температуры вглубь почвы являются: а) суточный и годовой периоды колебаний, при этом температуры остаются неизменными на всех глубинах; б) амплитуда колебаний температуры с глубиной уменьшается; в) наступление минимумов и максимумов температуры с глубиной запаздывает (суточные максимумы и минимумы запаздывают на каждые 10 см глубины на 2,5-3,5 часа); г) глубины постоянной суточной и годовой температуры соотносятся как корни квадратные из периодов соответствующих колебаний.

Тепловые характеристики почвы в значительной степени зависят от состояния ее увлажнения. Почва трансформирует солнечную энергию в тепловую, и расходует ее на испарение влаги, нагревание воздуха и более нижних слоев почвы. В теплый период года почва аккумулирует приходящее извне тепло, в холодный отдает его. В зимнее время на температуру почвы большое влияние оказывает снежный покров, обладающий большой теплоизоляционной способностью. Так, промерзание почвы при плотности снега, равной 0,25, уменьшается примерно на удвоенную высоту залегания снега по сравнению с оголенной почвой $[11,73]$.

Отмеченные закономерности распространения тепла в глубь почвы иллюстрируются графиком термоизоплет для метеостанции Усть-Каменогорск. Максимальная температура поверхности почвы приходится на июль и составляет $25^{\circ} \mathrm{C}$, а минимальная на январь минус $18^{0} \mathrm{C}$. Годовая амплитуда температуры почвы составляет $43^{\circ} \mathrm{C}$, она на 4,6 $6^{0}$ больше годовой амплитуды температуры воздуха. 


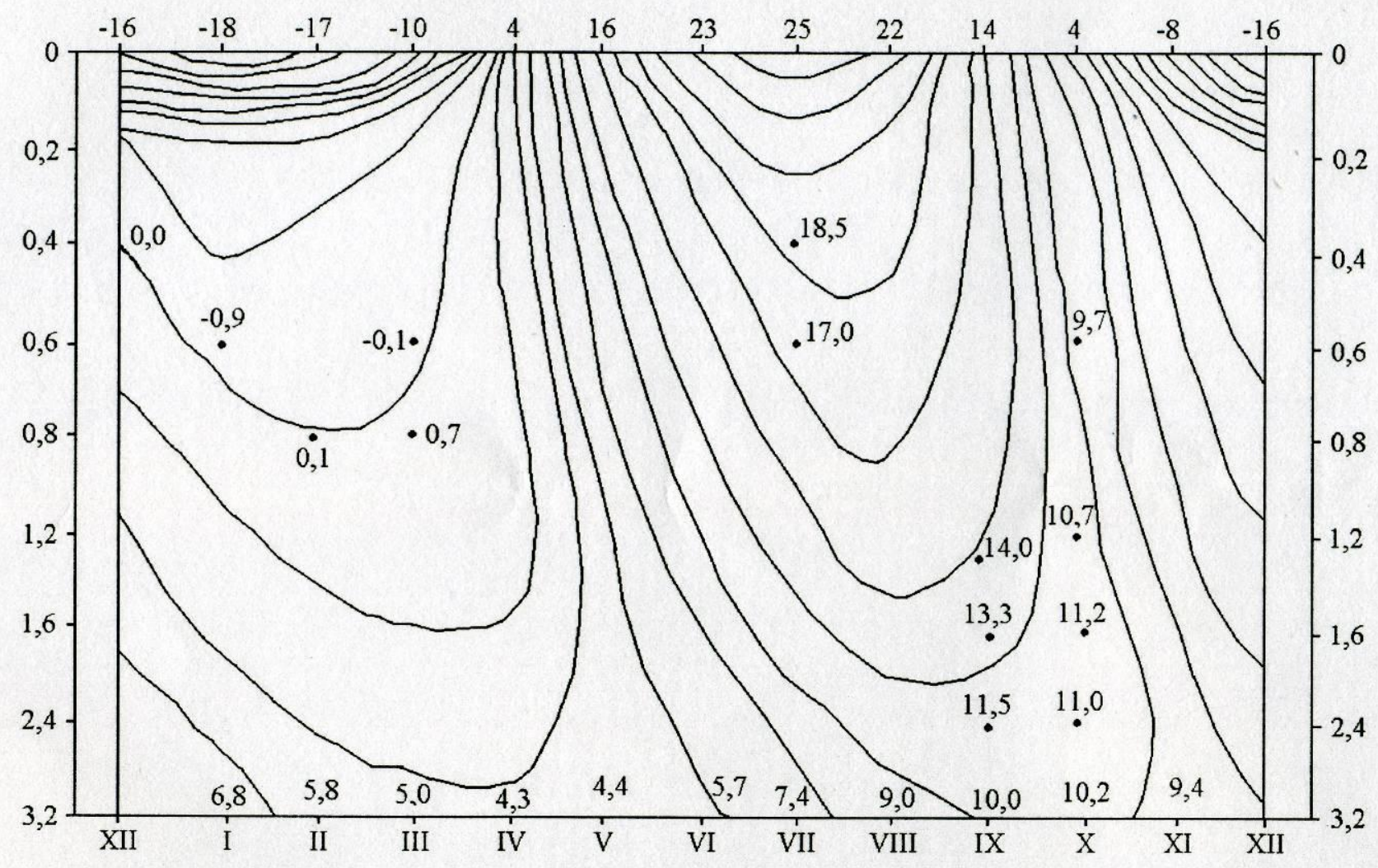

Рис. 33. Термоизоплеты почвы (в многолетнем выводе) на метеостанции Усть-Каменогорск
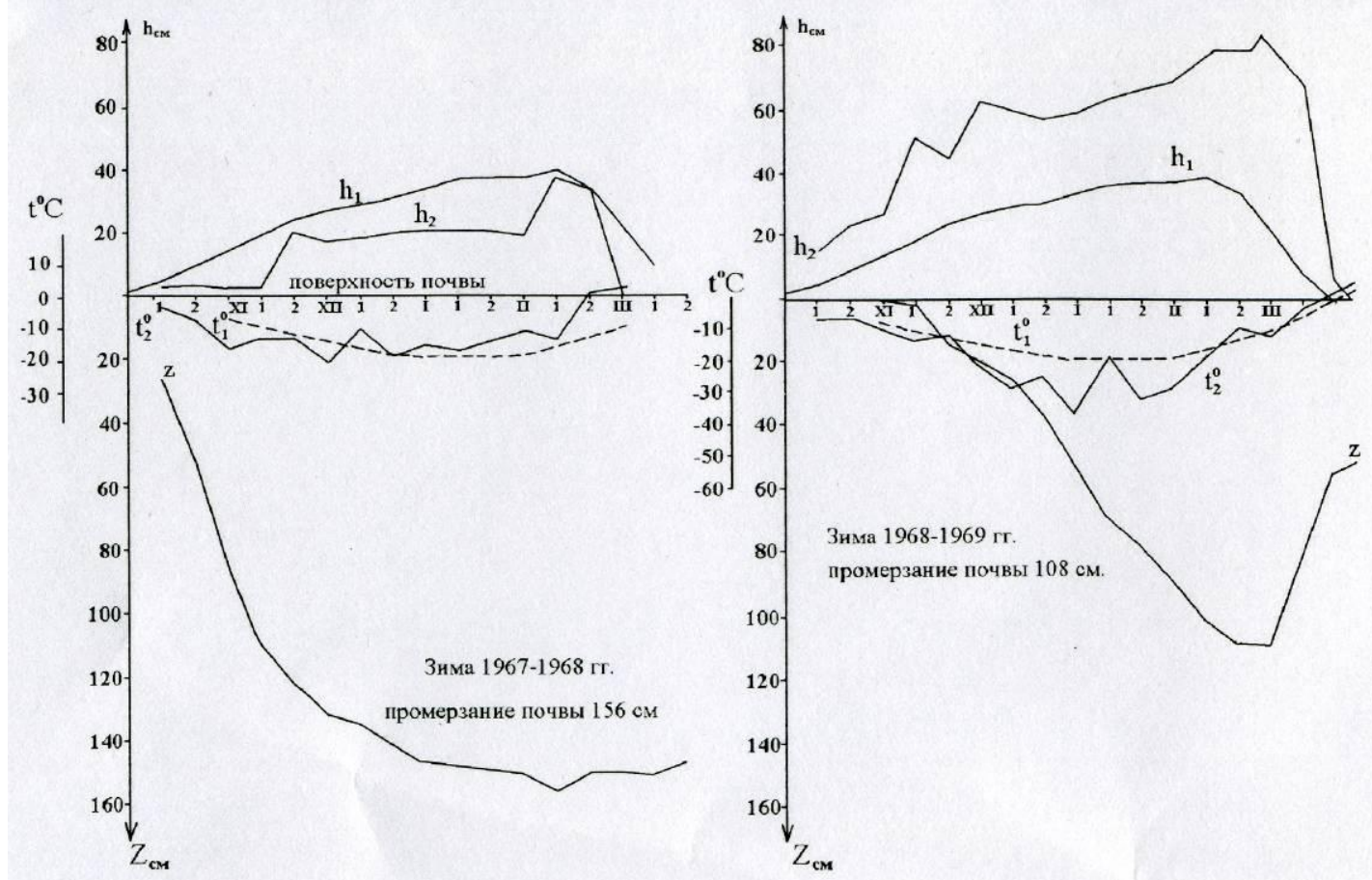

Рис. 34. Динамика накопления снега и промерзания аочвы на метеостанции Усть-каменогорск в зимах 1967-68 гг. и 1968-69 гг. 
Важной характеристикой является средняя глубина промерзания почвы ход изотермы $0^{0}$. В Усть-Каменогорске она составляет 75 см при средней высоте снежного покрова 40 см. Глубина промерзания почвы находится в тесной связи с высотой снежного покрова и, особенно - со временем его образования. Раннее его установление

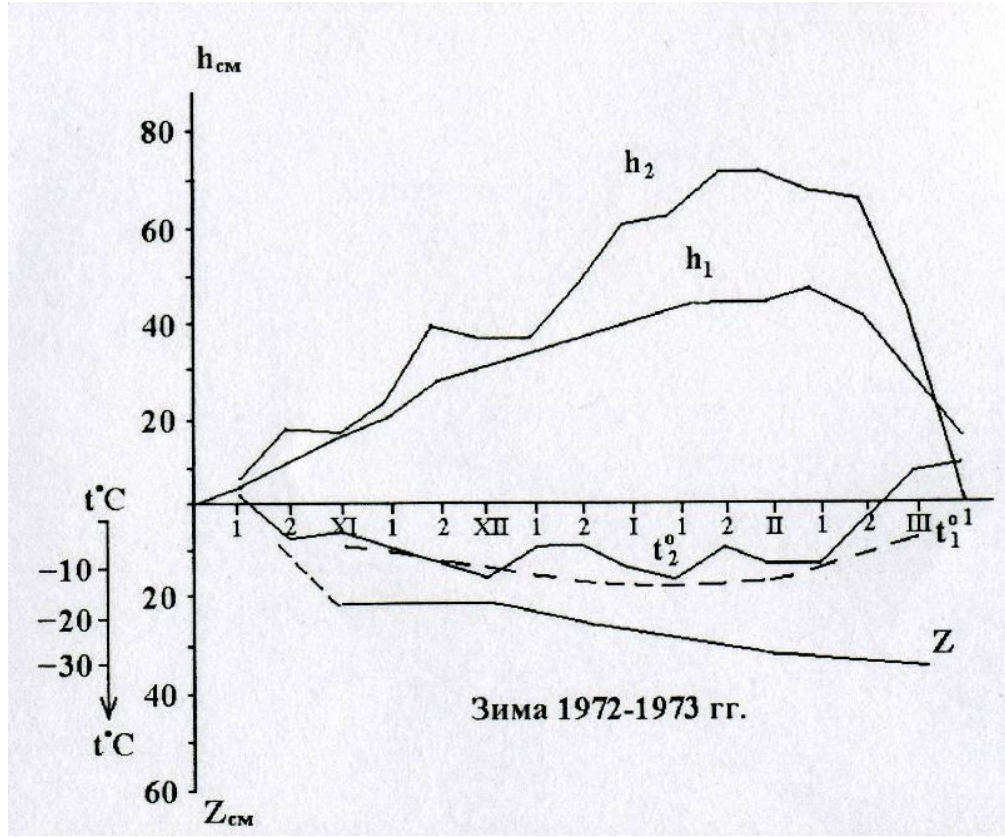

Рис. 35. Динамика накопления снега и промерзания почвы на метеостанции Усть-Каменогорск

определяет малое промерзание почвы даже при очень низких температурах воздуха. Позднее выпадение снега ведет к глубокому промерзанию почвы (зима 1967-1968, 2013-2014 гг.). Наибольшее проникновение нулевой изотермы в глубь почвы составляет 178 см в феврале, в марте - 172 см [13]. Так, промерзание почвы в зиму $1967 / 1968$ гг. составило 156 см, снежный покров в ту зиму установился только после 17 декабря, хотя к марту его высота была близка к норме и составляло 38 см - рис. 34, а в зиму 2013-2014 гг. в Усть-Каменогорске снежный покров установился только после 25 января.

Переход температуры поверхности почвы через $0^{0} \mathrm{C}$ и выпадение снега в этот же период способствуют продолжительному сохранению тепла в почве и, следовательно, малому ее промерзанию. Подобная ситуация наблюдалась в зиму 1972-1973 гг. (рис. 35). Эта зима была теплой и влажной, проникновение нулевой температуры было лишь до глубины 35 см. В самую холодную зиму ХХ в., 1968/1969 гг., раннее выпадение обильного снегопада сохранило почву от сильного промерзания. Уже в первую декаду декабря высота снежного покрова составила 52 см, а максимальное промерзание почвы лишь 108 см (см. рис. 32). Параметры температуры поверхности почвы приводятся в табл. 42. 
Т а бли ц а 42

Средняя месячная максимальная и минимальная температура почвы

\begin{tabular}{|c|c|c|c|c|c|c|c|c|c|c|c|c|c|}
\hline $\begin{array}{l}\mathrm{t}^{0} \\
\text { почвы }\end{array}$ & I & II & III & IV & $\mathrm{V}$ & VI & VII & VIII & IX & $\mathrm{X}$ & $\mathrm{XI}$ & XII & Год \\
\hline 1 & 2 & 3 & 4 & 5 & 6 & 7 & 8 & 9 & 10 & 11 & 12 & 13 & 14 \\
\hline \multicolumn{14}{|c|}{ Шемонаиха (почва - чернозем суглинистый) } \\
\hline Средняя & -19 & -18 & -10 & 4 & 16 & 23 & 25 & 23 & 14 & 4 & -8 & -16 & 3 \\
\hline $\begin{array}{l}\text { Средний } \\
\text { максимум }\end{array}$ & -10 & -7 & 1 & 18 & 35 & 44 & 46 & 44 & 33 & 15 & -1 & -9 & 17 \\
\hline $\begin{array}{l}\text { Абсолютн } \\
\text { ый } \\
\text { максимум }\end{array}$ & 5 & 10 & 22 & 46 & 58 & 64 & 64 & 62 & 57 & 40 & 20 & 8 & 64 \\
\hline $\begin{array}{l}\text { Средний } \\
\text { минимум }\end{array}$ & -26 & -26 & -18 & -5 & 3 & 9 & 11 & 9 & 3 & -3 & -14 & -22 & -7 \\
\hline $\begin{array}{l}\text { Абсолютн } \\
\text { ый } \\
\text { минимум }\end{array}$ & -48 & -50 & -46 & -30 & -13 & -1 & 2 & -4 & -9 & -27 & -48 & -48 & -50 \\
\hline \multicolumn{14}{|c|}{ Риддер (почва - чернозем суглинистый) } \\
\hline Средняя & -16 & -15 & -9 & 2 & 13 & 20 & 22 & 19 & 11 & 2 & -9 & -14 & 2 \\
\hline $\begin{array}{l}\text { Средний } \\
\text { максимум }\end{array}$ & -8 & -4 & 3 & 16 & 32 & 40 & 42 & 38 & 28 & 12 & -2 & -7 & 16 \\
\hline $\begin{array}{l}\text { Абсолютн } \\
\text { ый } \\
\text { максимум }\end{array}$ & 10 & 14 & 16 & 42 & 56 & 58 & 59 & 57 & 48 & 38 & 16 & 11 & 59 \\
\hline $\begin{array}{l}\text { Средний } \\
\text { минимум }\end{array}$ & -23 & -24 & -18 & -6 & 4 & 7 & 9 & 7 & 2 & -5 & -15 & -21 & -7 \\
\hline $\begin{array}{l}\text { Абсолютн } \\
\text { ый } \\
\text { минимум }\end{array}$ & -45 & -53 & -44 & -33 & -15 & -6 & 0 & -3 & -14 & -29 & -48 & -48 & -53 \\
\hline 1 & 2 & 3 & 4 & 5 & 6 & 7 & 8 & 9 & 10 & 11 & 12 & 13 & 14 \\
\hline \multicolumn{14}{|c|}{ Усть-Каменогорск (Прапорщиково) почва суглинистая } \\
\hline Средняя & -18 & -17 & -9 & 5 & 17 & 24 & 26 & 22 & 14 & 4 & -7 & -15 & 4 \\
\hline $\begin{array}{l}\text { Средний } \\
\text { максимум }\end{array}$ & -10 & -6 & 2 & 19 & 36 & 44 & 46 & 43 & 34 & 15 & -1 & -9 & 18 \\
\hline $\begin{array}{l}\text { Абсолютн } \\
\text { ый } \\
\text { максимум }\end{array}$ & 3 & 9 & 20 & 53 & 61 & 68 & 69 & 62 & 52 & 38 & 22 & 8 & 69 \\
\hline $\begin{array}{l}\text { Средний } \\
\text { минимум }\end{array}$ & -28 & -28 & -18 & -4 & 3 & 9 & 12 & 10 & 3 & -3 & -14 & -24 & -7 \\
\hline $\begin{array}{l}\text { Абсолютн } \\
\text { ый } \\
\text { минимум }\end{array}$ & -48 & -50 & -44 & -31 & -10 & -3 & 4 & -2 & -11 & -26 & -40 & -47 & -50 \\
\hline \multicolumn{14}{|c|}{ Пос. Северный (почва - горный чернозем) } \\
\hline Средняя & -15 & -14 & -9 & 2 & 12 & 20 & 22 & 19 & 12 & 3 & -8 & -14 & 2 \\
\hline $\begin{array}{l}\text { Средний } \\
\text { максимум }\end{array}$ & -9 & -7 & -1 & 14 & 29 & 39 & 40 & 38 & 30 & 12 & -2 & -9 & 14 \\
\hline $\begin{array}{l}\text { Абсолютн } \\
\text { ый } \\
\text { максимум }\end{array}$ & 6 & 11 & 16 & 41 & 56 & 62 & 61 & 59 & 52 & 39 & 19 & 8 & 62 \\
\hline
\end{tabular}


Продолжение таблицы 42

\begin{tabular}{|c|c|c|c|c|c|c|c|c|c|c|c|c|c|}
\hline \\
\hline $\begin{array}{l}\text { Средний } \\
\text { максимум }\end{array}$ & -16 & -8 & 2 & 14 & 39 & 45 & 43 & 43 & 35 & 20 & -2 & -15 & 17 \\
\hline $\begin{array}{l}\text { Абсолютн } \\
\text { ый } \\
\text { максимум }\end{array}$ & 3 & 8 & 15 & 45 & 59 & 64 & 65 & 64 & 54 & 42 & 21 & 5 & 65 \\
\hline $\begin{array}{l}\text { Средний } \\
\text { минимум }\end{array}$ & -37 & -34 & -27 & -11 & -2 & 3 & 6 & 4 & -2 & -8 & -23 & -34 & -14 \\
\hline $\begin{array}{l}\text { Абсолют- } \\
\text { ный } \\
\text { минимум }\end{array}$ & -58 & -56 & -51 & -37 & -16 & -7 & -4 & -9 & -14 & -36 & -57 & -56 & -58 \\
\hline \multicolumn{14}{|c|}{ Зайсан (почва - супесчаная ) } \\
\hline Средняя & -20 & -18 & -9 & 6 & 17 & 25 & 27 & 24 & 16 & 5 & -8 & -17 & 4 \\
\hline $\begin{array}{l}\text { Средний } \\
\text { максимум }\end{array}$ & -10 & -5 & 3 & 23 & 38 & 48 & 50 & 48 & 38 & 22 & 2 & -9 & 20 \\
\hline $\begin{array}{l}\text { Абсолют- } \\
\text { ный } \\
\text { максимум }\end{array}$ & 10 & 11 & 28 & 52 & 60 & 66 & 68 & 68 & 59 & 45 & 28 & 10 & 68 \\
\hline $\begin{array}{l}\text { Средний } \\
\text { минимум }\end{array}$ & -28 & -26 & -18 & -4 & 5 & 12 & 13 & 11 & 4 & -4 & -14 & -25 & -6 \\
\hline $\begin{array}{l}\text { Абсолют- } \\
\text { ный } \\
\text { минимум }\end{array}$ & -53 & -50 & -44 & -23 & -16 & -5 & 2 & -2 & -9 & -24 & -46 & -49 & 53 \\
\hline
\end{tabular}

Прогревание и охлаждение почвы происходит постепенно в направлении от поверхности вглубь. Нагрев и охлаждение верхних слоев почвы идет более интенсивно, чем нижних, поэтому наступление максимумов и минимумов с глубиной запаздывает. Так, минимум температуры поверхности почвы приходится на январь, на глубине 320 см и отмечается еще в апреле, соответственно летний максимум перемещается с июля на октябрь. Летом температура почвы с глубиной понижается от $+25^{0} \mathrm{C}$ на поверхности до $7,4^{0} \mathrm{C}$ на глубине $320 \mathrm{~cm}$, а зимой повышается от минус $18^{0} \mathrm{C}$ на поверхности до $6,8^{0} \mathrm{C}$ на глубине. Температура почвы в весенний период понижается от поверхностного слоя до глубин 1,2-2,4 м, а затем повышается. Так, температура почвы в апреле изменяется от $4^{0} \mathrm{C}$ на поверхности до $1,5^{0} \mathrm{C}$ на глубине 1,2 м и до $4,3^{0} \mathrm{C}$ на глубине 3,2 м. Осенью наблюдается противоположный весне ход температуры почвы. Так, в октябре температура поверхности почвы достигает почти $4^{0} \mathrm{C}$, на глубине 1,6 м она понижается до минус $11,2^{0} \mathrm{C}$, а на глубине 3,2 м составляет минус $10,2^{0} \mathrm{C}$.

Исходя из анализа графика термоизоплет, можно выделить четыре типа распределения тепла в почве. Летом - носит тип инсоляции, зимой - излучения, весной и осенью - сложный тип: весной холодный слой лежит между двумя теплыми, осенью - теплый 
слой между двумя холодными. График термоизоплет позволяет получить необходимую информацию по температурному режиму поверхности почвы (см. рис. 26 и 27).

Рассматривая ход термоизоплет, можно отметить, что наиболее густо они идут в верхнем двадцатисантиметровом деятельном слое почвы. В нем же, отмечаются и максимальные вертикальные градиенты температуры: (в июле 0,23 , в январе - 0,74 град/см. По графику можно определить и среднюю температуру почвы на любой глубине и в любое время. Так, изотерма $10^{\circ} \mathrm{C}$ на глубине $10 \mathrm{~cm}$ проходит 3 мая, а на глубине $20 \mathrm{~cm}-7$ мая. Слой почвы в $20 \mathrm{~cm}$ нагревается до $4^{0} \mathrm{C}$ к 17 апреля.

Промерзание пахотного слоя в 20 см происходит в среднем 25 октября - 21 ноября, а оттаивание идет очень быстро, в течение всего лишь 7 дней, с 31 марта по 7 апреля. Промерзание почвы идет от поверхности вглубь, а оттаивание - с глубин к поверхности.

На предгорных равнинах Рудного Алтая средняя глубина промерзания составляет в марте от 75-90 до 100-125 см; на склонах гор со снежным покровом от 40 до 146 см (Катон-Карагай). В лесах, где высота снежного покрова более 70 см, почва промерзает не более чем на 30-40 см, а к сходу снежного покрова она, как правило, оттаивает. В степных ландшафтах Южного Алтая и Калбы почва промерзает до 126-150, в Зайсанской котловине - до 250 см. В целом в пределах Юго-Западного Алтая оголенная почва может промерзать до глубин 201-205 см [11, 13].

Кроме того, необходимо отметить, что термический режим почвы больше зависит от местных условий, чем режим воздуха. На температуру почвы большое влияние оказывают экспозиция и крутизна склона, механический состав почвы, ее влажность и другие физико-географические условия.

Зимой средняя месячная температура поверхности почвы на 1$2^{0} \mathrm{C}$ ниже температуры воздуха, летом - наоборот, выше на $3-5^{0} \mathrm{C}$. Средние максимумы температуры почвы на $15-20^{\circ} \mathrm{C}$ выше, чем такие же параметры воздуха, а абсолютные - на $20-25^{\circ} \mathrm{C}$. Зимой в ясные тихие ночи разность между температурами почвы и воздуха составляет от 6-7 до $10-12^{0} \mathrm{C}$. Абсолютные максимумы температуры почвы по исследуемому региону составляют $59-68^{0} \mathrm{C}$, в то время как для атмосферного воздуха они не превышают $40-43^{\circ} \mathrm{C}$. Важным показателем состояния почвы являются средние температуры пахотного слоя. В степной и лесостепной зонах, переход средней 
суточной температуры через $0^{0}$ в пахотном слое осуществляется в апреле и октябре (табл. 43).

Т а б ли ц а 43

Средняя месячная температура почвы по коленчатым термометрам [13]

\begin{tabular}{|c|c|c|c|c|c|}
\hline Глубина, м & V & VI & VII & VIII & IX \\
\hline \multicolumn{7}{|c|}{ Шемонаиха } \\
\hline 0.05 & 13.9 & 21.4 & 24.1 & 21.7 & 14.0 \\
\hline 0.10 & 12.8 & 20.5 & 23.2 & 21.4 & 14.5 \\
\hline 0.15 & 11.7 & 19.6 & 22.6 & 21.1 & 14.7 \\
\hline 0.20 & 10.8 & 18.9 & 22.0 & 21.0 & 14.8 \\
\hline \multicolumn{7}{|c|}{ Риддер } \\
\hline 0.05 & 11.5 & 18.6 & 20.5 & 18.6 & 11.7 \\
\hline 0.10 & 10.8 & 17.8 & 19.7 & 18.2 & 11.9 \\
\hline 0.15 & 10.0 & 17.0 & 19.0 & 18.0 & 11.9 \\
\hline 0.20 & 9.3 & 16.3 & 18.3 & 17.8 & 11.9 \\
\hline \multicolumn{7}{|c|}{ Зыряновск } \\
\hline 0.05 & 14.1 & 21.5 & 23.9 & 21.3 & 13.6 \\
\hline 0.10 & 12.9 & 20.5 & 23.2 & 21.1 & 14.2 \\
\hline 0.15 & 11.7 & 19.7 & 22.5 & 20.7 & 14.4 \\
\hline 0.20 & 10.5 & 18.7 & 21.8 & 20.4 & 14.4 \\
\hline \multicolumn{7}{|c|}{ Катон-Карагай } \\
\hline 0.05 & 10.6 & 17.3 & 19.5 & 18.1 & 11.7 \\
\hline 0.10 & 10.0 & 16.6 & 18.8 & 17.7 & 12.0 \\
\hline 0.15 & 9.1 & 15.8 & 18.1 & 17.4 & 12.0 \\
\hline 0.20 & 8.2 & 15.0 & 17.4 & 16.9 & 11.9 \\
\hline \multicolumn{7}{|c|}{ Зайсан } \\
\hline 0.05 & 15.3 & 21.7 & 24.0 & 23.0 & 16.0 \\
\hline 0.10 & 14.0 & 20.5 & 22.8 & 22.2 & 16.2 \\
\hline 0.15 & 12.9 & 19.5 & 21.8 & 21.4 & 16.3 \\
\hline 0.20 & 12.2 & 18.7 & 21.1 & 20.7 & 16.4 \\
\hline \multicolumn{7}{|l|}{} \\
\hline
\end{tabular}

Среднее число дней с температурой почвы $\leq 0^{0} \mathrm{C}$ на глубине 20 см составляет от 100 до 140. За исследуемый период в $11 \%$ от числа зим на такой глубине не наблюдалось отрицательных температур, а на глубине 40 см - в 20\% зим. После схода снежного покрова от апреля к маю и от мая к июню идет быстрое нарастание температуры в пахотном слое, так же быстро происходит спад температуры от августа к сентябрю и октябрю.

Полное оттаивание пахотного слоя в предгорных степных ландшафтах и лесостепном низкогорье наступает в третьей декаде апреля. Температура почвы в мае на глубине 20 см составляет в Катон-Карагае 8 , в Зайсане $12^{0} \mathrm{C}$, в июне и июле соответственно 
19-20, в сентябре $12-16^{0} \mathrm{C}$, в октябре на этой же глубине температура почвы переходит через $0^{0}$.

В среднегорном поясе (выше 1000 м н. у. м.) в июне-июле температура почвы на глубине 20 см достигает минус $20^{0} \mathrm{C}$ и ниже.

В начале мая на глубине заделки семян (5 cм) температура почвы и воздуха почти одинакова, на черноземах может быть несколько выше. Весной переход температуры почвы через $0^{0}$ в воздухе и на глубине 40 см также происходит почти одновременно.

Зимой температура почвы на глубине 20-40 см значительно выше, чем температура воздуха.

Средняя длительность периода с положительными температурами почвы на глубине 20-40 см превышает таковой в воздухе примерно на 20-30 дней за счет более позднего перехода средней температуры почвы осенью через $0^{0}$. В то же время продолжительность безморозного периода на поверхности почвы меньше, чем в воздухе. Так, по метеостанции Секисовка, первый длится 78, второй - 93 дня, соответственно по метеостанции Тополев Мыс - 140-156, в пос. Северный - 120, в Зайсане - 159 дней. Безморозный период в почве (20-40 см) на высотах от 300 до 1100 м (от Усть-Каменогорска до Катон-Карагая) длится 220-245 дней на глубине 20 см и 230-260 дней на глубине 40 см. На исследуемой территории тепла в воздухе и почве достаточно для получения хороших урожаев на плодородных черноземных почвах, но решающим фактором в начале лета является запас продуктивной влаги в почве. В урожайные годы запасы влаги в пахотном горизонте в зоне степей составляют 40 и 140 мм в метровом горизонте. В типичных степях повторяемость подобных запасов бывает примерно 2 раза в десять лет. В зоне наиболее плодородных черноземных и каштановых почв хорошее увлажнение обеспечено далеко не ежегодно, поэтому важным агромелиоративным мероприятием является сбережение талых вешних вод в почве. 


\section{ГЛАВА ІІІ. ОПИСАНИЕ КЛИМАТА ЮГО-ЗАПАДНОГО АЛТАЯ ПО СЕЗОНАМ ГОДА}

Неповторимые свойства геосистем регионального ранга, прежде всего их гидроклиматогенная и биогенная основы, динамика происходящих в них процессов определяются конкретным географическим положением геосистемы в комплексе высшего ранга. При этом целостность региональной геосистемы рассматривается как результат специфического взаимодействия ее компонентов с зональными, поясными, секторными особенностями надсистемы. Все эти многочисленные взаимодействия приводят к порождению «местных» региональных геоструктур и определяют их положение в геоструктуре высшего ранга $[1,2,3,4]$.

В ландшафтных провинциях Юго-Западного Алтая на общем фоне континентального умеренного климата выделяются его подтипы. В них наиболее четко проявляются различия в степени и структуре годового цикла увлажнения.

\section{1. О выделении сезонов}

В годовом ходе всех климатических элементов исследуемого региона выделяются четыре сезона. Переход от сезона к сезону выражается изменением всего комплекса климатических характеристик, что обусловлено сезонным притоком солнечного тепла (табл. 44).

Тем не менее, резких границ между сезонами не наблюдается. Сроки наступления сезонов изменяются от года к году, продолжительность их испытывает значительные колебания. Наиболее четко выражены два сезона - зима и лето. В течение каждого из них высота Солнца и продолжительность дня изменяются незначительно (см. приложение II).

Пример: на $50^{0}$ с. ш. с 25 мая по 20 июля полуденная высота Солнца превышает $61^{0}$, изменяясь в пределах от $61^{0}$ до $63,4^{0}$, а зимой, с 26 ноября по 17 января - от $16,5^{\circ}$ до $19^{0}$.

Количество солнечного тепла поступает на горизонтальную поверхность пропорционально не высоте Солнца $\left(\mathrm{h}_{0}\right)$, a синусу высоты $\left(\sin \mathrm{h}_{0}\right)$, поэтому приняты контрасты температуры воздуха (и 
Характеристики для определения климатического сезона *

\begin{tabular}{|c|c|c|c|c|c|c|c|c|c|c|c|c|}
\hline \multirow[t]{2}{*}{ Характеристика } & \multicolumn{3}{|c|}{ Зима } & \multicolumn{2}{|c|}{ Весна } & \multicolumn{3}{|c|}{ Лето } & \multicolumn{2}{|c|}{ Осень } & \multicolumn{2}{|c|}{ Зима } \\
\hline & I & II & III & IV & $\mathrm{V}$ & VI & VII & VIII & IX & $X$ & XI & XII \\
\hline 1 & 2 & 3 & 4 & 5 & 6 & 7 & 8 & 9 & 10 & 11 & 12 & 13 \\
\hline \multirow{2}{*}{\multicolumn{13}{|c|}{$\begin{array}{c}\text { РУДНЫЙ АЛТАЙ } \\
\text { Усть-Каменогорск } \quad(285 \text { м) }\end{array}$}} \\
\hline & & & & & & & & & & & & \\
\hline 1. Средняя $\mathrm{t}^{0} \mathrm{C}$ & -17.0 & -16.0 & -7.7 & 4.7 & 13.4 & 18.8 & 20.8 & 18.3 & 12.4 & 5.0 & -6.2 & -14.1 \\
\hline $\begin{array}{l}\text { 2. Число дней с t около } 0^{0} \\
(\max \geq 0, \min \leq 0)\end{array}$ & 2.1 & 4.6 & 14.1 & 13.3 & 2.3 & 0.0 & 0.0 & 0.2 & 3.1 & 12.7 & 11.3 & 5.2 \\
\hline 3. Число дней с морозом $(\max <0)$ & 28.8 & 23.3 & 15.0 & 2.0 & 0.1 & 0.0 & 0.0 & 0.0 & 0.0 & 0.9 & 15.4 & 25.7 \\
\hline 4. Число дней с $\mathrm{t}^{0} \geq 10^{0} \mathrm{C}$ & 0.0 & 0.0 & 0.1 & 7.0 & 23.9 & 29.7 & 31.0 & 30.4 & 21.2 & 6.8 & 0.1 & 0.0 \\
\hline 5. Число дней $\mathrm{c} \mathrm{t}^{0} \geq 15^{0} \mathrm{C}$ & 0.0 & 0.0 & 0.0 & 1.3 & 13.6 & 26.2 & 30.4 & 25.2 & 8.2 & 1.6 & 0.0 & 0.0 \\
\hline 6. Число дней с f \% $\leq 30 \%$ & 0.1 & 0.0 & 0.3 & 6.7 & 11.8 & 6.6 & 4.6 & 6.6 & 8.4 & 7.4 & 0.9 & 0.1 \\
\hline 7. Число дней с f \% $\geq 80 \%$ & 6.8 & 5.1 & 4.8 & 3.6 & 1.6 & 1.6 & 1.3 & 1.4 & 1.7 & 4.2 & 6.9 & 7.7 \\
\hline 8. Число дней с грозой & 0.0 & 0.0 & 0.0 & 0.9 & 4.0 & 9.0 & 11.0 & 6.0 & 2.0 & 0.2 & 0.0 & 0.0 \\
\hline 9. Число дней с метелью & 5.0 & 4.0 & 2.0 & 0.6 & 0.0 & 0.0 & 0.0 & 0.0 & 0.0 & 0.2 & 3.0 & 7.0 \\
\hline \multicolumn{13}{|c|}{ Риддер (809 м) } \\
\hline 1. Средняя $t^{0} \mathrm{C}$ & -12.9 & -12.7 & -7.3 & 2.1 & 9.7 & 15.1 & 16.7 & 15.1 & 9.6 & 2.0 & -7.9 & -12.2 \\
\hline $\begin{array}{l}\text { 2. Число дней с t около } 0^{0} \\
(\max \geq 0, \min \leq 0)\end{array}$ & 4.0 & 6.5 & 16.8 & 19.2 & 8.0 & 0.8 & 0.0 & 1.0 & 6.0 & 18.7 & 11.2 & 6.2 \\
\hline 3. Число дней с морозом $(\max <0)$ & 26.9 & 21.6 & 13.4 & 2.9 & 0.1 & 0.0 & 0.0 & 0.0 & 0.0 & 3.1 & 17.9 & 24.6 \\
\hline 4. Число дней с $\mathrm{t}^{0} \geq 10^{0} \mathrm{C}$ & 0.0 & 0.0 & 0.0 & 2.5 & 17.2 & 27.0 & 30.8 & 27.8 & 13.8 & 0.4 & 0.0 & 0.0 \\
\hline 5. Число дней $\mathrm{ct}^{0} \geq 15^{0} \mathrm{C}$ & 0.0 & 0.0 & 0.0 & 0.2 & 6.0 & 16.8 & 22.0 & 16.8 & 0.2 & 0.0 & 0.0 & 0.0 \\
\hline 6. Число дней с f \% $\leq 30 \%$ & 1.8 & 1.4 & 3.3 & 9.2 & 11.7 & 5.8 & 3.9 & 5.4 & 8.6 & 9.1 & 2.1 & 1.4 \\
\hline 7. Число дней с f \% $\geq 80 \%$ & 6.1 & 3.6 & 4.0 & 4.8 & 2.8 & 3.1 & 2.8 & 3.0 & 3.6 & 5.3 & 6.5 & 8.0 \\
\hline 8. Число дней с грозой & 0.0 & 0.0 & 0.0 & 0.6 & 5.0 & 10.0 & 14.0 & 10.0 & 2.0 & 0.2 & 0.0 & 0.0 \\
\hline 9. Число дней с метелью & 5.0 & 4.0 & 4.0 & 0.9 & 0.1 & 0.0 & 0.0 & 0.0 & 0.0 & 0.5 & 4.0 & 6.0 \\
\hline
\end{tabular}


Продолжение табл. 44

\begin{tabular}{|l|c|c|c|c|c|c|c|c|c|c|c|c|c|c|}
\hline \multicolumn{1}{|c|}{1} & 2 & 3 & 4 & 5 & 6 & 7 & 8 & 9 & 10 & 11 & 12 & 13 \\
\hline
\end{tabular}

* Примечание: f \%-относительная влажность воздуха (\%)

Устойчивые морозы в Зыряновске 4.XI-5.IV- 153 дня, Усть-каменогорске 24.XI-17.III - 114,

Риддере 12.XI-12.III - 121, Шемонаихе 11.XI-30.III - 140, Зайсане 11.XI-20.III - 130 дней. 
Т а б ли ц 45

Агрометеорологическая (экологическая) характеристика времен года Юго-Западного Алтая

\begin{tabular}{|c|c|c|c|c|c|c|c|c|c|c|c|c|c|}
\hline \multirow{3}{*}{$\begin{array}{c}\text { Метеорологичес } \\
\text { кая станция, абс. } \\
\text { высота } \\
\text { н. у. м., м }\end{array}$} & \multicolumn{5}{|c|}{ Весна, IV-V * } & \multicolumn{3}{|c|}{ Лето, VI-VIII } & \multicolumn{5}{|c|}{ Осень, IX-X } \\
\hline & \multirow[b]{2}{*}{$\begin{array}{c}\text { Продолжитель- } \\
\text { ность, } \\
\text { дни }\end{array}$} & \multicolumn{3}{|c|}{ Сумма температур } & \multirow{2}{*}{$\begin{array}{c}\text { К-во } \\
\text { осад-в } \\
\text { r, мм } \\
\text { IV-V }\end{array}$} & \multirow{2}{*}{$\begin{array}{c}\text { Продолжите } \\
\text { ль-ность, } \\
\text { дни }\end{array}$} & \multirow[b]{2}{*}{$\begin{array}{l}\sum \mathrm{t} \geq \\
15^{0} \mathrm{C}\end{array}$} & \multirow{2}{*}{$\begin{array}{c}\text { К-во } \\
\text { осад-в } \\
\text { r, мм } \\
\text { VI-VIII }\end{array}$} & \multirow[b]{2}{*}{$\begin{array}{c}\text { Продолжитель- } \\
\text { ность, } \\
\text { дни }\end{array}$} & \multicolumn{3}{|c|}{ Сумма $\mathrm{t}^{0} \mathrm{C}$} & \multirow{2}{*}{$\begin{array}{c}\text { Кол-во } \\
\text { осадков } \\
\text { r, мм } \\
\text { IX-X }\end{array}$} \\
\hline & & $\underset{0^{0} \mathrm{C}}{\geq}$ & $\underset{5^{0} \mathrm{C}}{\geq}$ & $\underset{10^{0} \mathrm{C}}{\geq}$ & & & & & & $\begin{array}{c}\geq \\
10^{0} \mathrm{C}\end{array}$ & $\underset{5^{0} \mathrm{C}}{\geq}$ & $\stackrel{\geq}{0^{0} \mathrm{C}}$ & \\
\hline 1 & 2 & 3 & 4 & 5 & 6 & 7 & 8 & 9 & 10 & 11 & 12 & 13 & 14 \\
\hline \multicolumn{14}{|c|}{ Рудный Алтай } \\
\hline $\begin{array}{l}\text { УстьКаменогорск, } \\
285\end{array}$ & $\begin{array}{c}48 \\
(3 . I V-21 . V)\end{array}$ & 522 & 492 & 369 & 74 & $\begin{array}{c}107 \\
(21 . V-6 . I X)\end{array}$ & 1927 & 159 & $\begin{array}{c}54 \\
(6 . \mathrm{IX}-30 . \mathrm{X})\end{array}$ & 2506 & 2761 & 2844 & 72 \\
\hline Большенарым, 400 & $\begin{array}{c}48 \\
(8 . I V-26 . V)\end{array}$ & 486 & 459 & 361 & 78 & $\begin{array}{c}101 \\
(26 . \mathrm{V}-5 . \mathrm{IX})\end{array}$ & 1861 & 132 & $\begin{array}{c}50 \\
\text { (5.IX-24.X) }\end{array}$ & 2436 & 2664 & 2732 & 65 \\
\hline Зыряновск, 457 & $\begin{array}{c}59 \\
(16 . \mathrm{IV}-5 . \mathrm{VI})\end{array}$ & 439 & 415 & 298 & 91 & $\begin{array}{c}80 \\
\text { (5.VI-25.VIII) }\end{array}$ & 1625 & 178 & $\begin{array}{c}54 \\
(25 . \text { VIII-20.X) }\end{array}$ & 2168 & 2447 & 2508 & 93 \\
\hline Риддер, 809 & $\begin{array}{c}67 \\
(7 . I V-12 . V I)\end{array}$ & 372 & 334 & 205 & 131 & $\begin{array}{c}66 \\
\text { (12.VI-18.VIII) }\end{array}$ & 1224 & 263 & $\begin{array}{c}66 \\
\text { (18.VIII-23.X) }\end{array}$ & 1850 & 2144 & 2241 & 129 \\
\hline \multicolumn{14}{|c|}{ Южный Алтай } \\
\hline Курчум, 425 & $\begin{array}{c}49 \\
(3 . I V-22 . V)\end{array}$ & 595 & 569 & 468 & 54 & $\begin{array}{c}109 \\
\text { (22.V-9.IX) }\end{array}$ & 2138 & 77 & $\begin{array}{c}50 \\
(9 . I X-29 . X)\end{array}$ & 2871 & 3107 & 3178 & 44 \\
\hline Самарка, 500 & $\begin{array}{c}50 \\
(9 . I V-22 . V)\end{array}$ & 595 & 569 & 468 & 57 & $\begin{array}{c}110 \\
(22 . V-10 . I X)\end{array}$ & 1809 & 113 & $\begin{array}{c}50 \\
(10 . I X-30 . X)\end{array}$ & 2774 & 3005 & 3067 & 62 \\
\hline $\begin{array}{l}\text { Катон-Карагай, } \\
1080\end{array}$ & $\begin{array}{c}72 \\
(4 . I V-14 . V I)\end{array}$ & 396 & 359 & 182 & 82 & $\begin{array}{c}64 \\
\text { (14.VI-18.VIII) }\end{array}$ & 1085 & 188 & $\begin{array}{c}66 \\
(18 . V I I I-23 . X)\end{array}$ & 1829 & 2182 & 2254 & 71 \\
\hline $\begin{array}{l}\text { Пос. Орловский, } \\
1100\end{array}$ & $\begin{array}{c}68 \\
(18 . I V-24 . V I)\end{array}$ & 307 & 280 & 135 & 45 & $\begin{array}{c}36 \\
\text { (24.VI-31.VIII) }\end{array}$ & 687 & 138 & $\begin{array}{c}73 \\
\text { (31.VII-13.X) }\end{array}$ & 1548 & 1861 & 1928 & 49 \\
\hline \multicolumn{14}{|c|}{ Зайсанская впадина } \\
\hline $\begin{array}{l}\text { Приозерный } \\
\text { (Тополев мыс), } 392\end{array}$ & $\begin{array}{c}42 \\
(8 . I V-20 . V)\end{array}$ & 545 & 507 & 413 & 31 & $\begin{array}{c}114 \\
(20 . \mathrm{V}-12 . \mathrm{IX})\end{array}$ & 2172 & 55 & $\begin{array}{c}50 \\
(12 . I X-I . X I)\end{array}$ & 2788 & 3028 & 3096 & 24 \\
\hline Буран, 409 & $\begin{array}{c}48 \\
\text { (I.IV-18.V) }\end{array}$ & 619 & 587 & 473 & 36 & $\begin{array}{c}114 \\
(18 . V-10 . I X)\end{array}$ & 2132 & 52 & $\begin{array}{c}50 \\
(10 . I X-29 . X)\end{array}$ & 2806 & 3041 & 3117 & 33 \\
\hline Зайсан, 604 & $\begin{array}{c}49 \\
(31 . I I I-19 . V)\end{array}$ & 664 & 630 & 524 & 68 & $\begin{array}{c}119 \\
(19 . \mathrm{V}-16 . \mathrm{IX})\end{array}$ & 2258 & 105 & $\begin{array}{c}44 \\
(16 . I X-30 . X)\end{array}$ & 2992 & 3216 & 3292 & 47 \\
\hline
\end{tabular}


Продолжение табл. 45

\begin{tabular}{|c|c|c|c|c|c|c|c|c|c|c|c|c|c|c|c|c|c|}
\hline \multirow{3}{*}{$\begin{array}{c}\text { Метеорологи- } \\
\text { ческая } \\
\text { станция, } \\
\text { абс. высота } \\
\text { н. у. м., м }\end{array}$} & \multicolumn{6}{|c|}{ Зима, XI - III } & \multirow{3}{*}{$\begin{array}{l}\text { Безмо- } \\
\text { розный } \\
\text { период, } \\
\text { дни }\end{array}$} & \multirow{2}{*}{\multicolumn{5}{|c|}{$\begin{array}{l}\text { Параметры } \\
\text { (за год) }\end{array}$}} & \multirow{2}{*}{\multicolumn{2}{|c|}{$\begin{array}{l}\text { Продол-ть } \\
\text { (дни) } \\
\text { вегетац. } \\
\text { периода с } \\
\text { темпера- } \\
\text { турой } \\
\end{array}$}} & \multirow{2}{*}{\multicolumn{3}{|c|}{$\begin{array}{c}\text { Биопродуктив- } \\
\text { ность }(\text { РП), } \\
\text { ц/га, при } \\
\text { осадках }\end{array}$}} \\
\hline & \multirow{2}{*}{$\begin{array}{l}\text { Продолжи- } \\
\text { тельность, } \\
\text { дни }\end{array}$} & \multicolumn{4}{|c|}{ Сумма температур } & \multirow{2}{*}{$\begin{array}{c}\text { К-во } \\
\text { осад- } \\
\text { ков, } \\
\text { мм }\end{array}$} & & & & & & & & & & & \\
\hline & & $\begin{array}{l}< \\
0^{\circ} \mathrm{C}\end{array}$ & $\begin{array}{c}\leq \\
-5^{0} \mathrm{C}\end{array}$ & $\begin{aligned} \leq- \\
10^{\circ} \mathrm{C}\end{aligned}$ & $\begin{array}{c}\leq- \\
15^{0} \mathrm{C}\end{array}$ & & & $\begin{array}{c}\mathrm{r}, \\
\mathrm{MM}\end{array}$ & \multirow{2}{*}{$\begin{array}{c}\mathrm{E}_{0}, \\
\text { мM } \\
10 \\
\end{array}$} & \multirow{2}{*}{\begin{tabular}{c|} 
E, \\
MM \\
11 \\
\end{tabular}} & \multirow{2}{*}{$\begin{array}{c}\mathrm{B}, \\
\mathrm{MДж} \\
/ \mathrm{M}^{2} \\
12 \\
\end{array}$} & $\begin{array}{l}\mathrm{B} / \mathrm{L}_{\mathrm{r}} \\
\mathrm{r}^{2} / \mathrm{cm}^{2}\end{array}$ & $\stackrel{\geq}{5^{0} \mathrm{C}}$ & $\underset{10^{0} \mathrm{C}}{\geq}$ & \multirow{2}{*}{$\begin{array}{c}\text { Hop- } \\
\text { мa, } \\
\text { r }\end{array}$} & \multirow{2}{*}{$\begin{array}{l}80 \% \\
\text { обес- } \\
\text { печ. } \\
17\end{array}$} & $\begin{array}{l}\mathrm{r}=\mathrm{E}_{0} \\
\mathrm{~K}=1\end{array}$ \\
\hline 1 & 2 & 3 & 4 & 5 & 6 & 7 & 8 & 9 & & & & 13 & 14 & 15 & & & 18 \\
\hline \multicolumn{18}{|c|}{ Рудный Алтай } \\
\hline $\begin{array}{l}\text { Усть-Камено- } \\
\text { горск, } 285\end{array}$ & $\begin{array}{c}156 \\
(30 . X-3 . I V)\end{array}$ & -2087 & -2028 & -1819 & -1345 & 150 & $\begin{array}{c}125 \\
(83-163)\end{array}$ & 455 & 719 & 363 & $\begin{array}{l}1752 \\
(42)\end{array}$ & 1.4 & 174 & 136 & 80 & 55 & 100 \\
\hline $\begin{array}{l}\text { Большенарым, } \\
400\end{array}$ & $\begin{array}{c}166 \\
\text { (24.X-8.IV) }\end{array}$ & -2579 & -2529 & -2374 & -2040 & 97 & $\begin{array}{c}150 \\
(89-150) \\
\end{array}$ & 372 & - & - & $\begin{array}{l}1862 \\
(44)\end{array}$ & 2.0 & 173 & 143 & 50 & - & 100 \\
\hline Зыряновск, 457 & $\begin{array}{c}179 \\
\text { (20.X-16.IV) }\end{array}$ & -2858 & -2805 & -2641 & -2273 & 203 & $\begin{array}{c}95 \\
(76-128)\end{array}$ & 565 & 515 & 379 & $\begin{array}{l}1838 \\
(44)\end{array}$ & 1.3 & 162 & 129 & 90 & 75 & 105 \\
\hline Риддер, 809 & $\begin{array}{c}166 \\
(23 . X-7 . I V)\end{array}$ & -1609 & -1534 & -1417 & - & 107 & $\begin{array}{c}94 \\
(69-138) \\
\end{array}$ & 630 & 613 & 321 & $\begin{array}{l}1829 \\
(44)\end{array}$ & 1.2 & 160 & 119 & 95 & 80 & 100 \\
\hline \multicolumn{18}{|c|}{ Южный Алтай } \\
\hline Курчум, 425 & $\begin{array}{c}157 \\
\text { (29.X-3.IV) }\end{array}$ & -2230 & -2171 & -2009 & -1711 & 86 & $\begin{array}{c}121 \\
(92-155)\end{array}$ & 261 & 845 & 337 & $\begin{array}{l}1846 \\
(44)\end{array}$ & 28 & 184 & 151 & 35 & 10 & 105 \\
\hline Самарка, 500 & $\begin{array}{c}155 \\
\text { (30.X-2.IV) }\end{array}$ & -1938 & -1882 & -1707 & -1147 & 133 & $\begin{array}{c}131 \\
(87-164)\end{array}$ & 365 & 252 & 281 & $\begin{array}{l}1837 \\
(44)\end{array}$ & 2.0 & 182 & 150 & 50 & 30 & 100 \\
\hline $\begin{array}{l}\text { Катон-Карагай, } \\
1080\end{array}$ & $\begin{array}{c}163 \\
\text { (23.X-4.IV) }\end{array}$ & -1608 & -1550 & -1358 & -149 & 91 & $\begin{array}{c}101 \\
(-147) \\
\end{array}$ & 432 & 672 & 283 & $\begin{array}{l}1834 \\
(44)\end{array}$ & 1.7 & 170 & 127 & 65 & 35 & 100 \\
\hline $\begin{array}{l}\text { Пос. Орловский, } \\
1100\end{array}$ & $\begin{array}{c}188 \\
\text { (13.X-18.IV) }\end{array}$ & -3266 & -3202 & -3055 & -2772 & 96 & -52 & 328 & 503 & 232 & $\begin{array}{l}1763 \\
(42)\end{array}$ & 2.1 & 148 & 108 & 40 & 25 & 100 \\
\hline \multicolumn{18}{|c|}{ Зайсанская впадина } \\
\hline $\begin{array}{l}\text { Приозерный (То- } \\
\text { полев мыс, 392) }\end{array}$ & $\begin{array}{c}159 \\
\text { (1.XI-8.IV) }\end{array}$ & -2153 & -2095 & -1905 & -1601 & 53 & -156 & 163 & - & - & $\begin{array}{l}1996 \\
(48)\end{array}$ & 4.9 & 178 & 149 & 10 & & 120 \\
\hline Буран, 409 & $\begin{array}{c}155 \\
\text { (29.X-1.IV) }\end{array}$ & -1925 & -1857 & -1644 & -1232 & 68 & -135 & 189 & 946 & 292 & $\begin{array}{l}1909 \\
(46)\end{array}$ & 4.0 & 187 & 153 & 10 & - & 110 \\
\hline Зайсан, 604 & $\begin{array}{c}153 \\
\text { (30.X-31.III) } \\
\end{array}$ & -1880 & -1822 & -1640 & -1147 & 71 & $\begin{array}{c}159 \\
(117-194) \\
\end{array}$ & 291 & 1162 & 221 & $\begin{array}{l}1898 \\
(45)\end{array}$ & 2.5 & 188 & 158 & 35 & 15 & 110 \\
\hline
\end{tabular}


* Примечание: За теплый период данные приводятся по ( I ), ПР - растительный покров, биомасса в ц/га наземной и подземной частей растений в сухом весе, r, мм - годовая сумма осадков, $\mathrm{E}_{0}$, мм - испаряемость, В, мДж/м² - радиационный баланс, В - индекс радиационной сухости.

$\mathrm{L}_{\mathrm{r}}$

Метеорологи к весне относят период со средними суточными температурами $>0^{0} \mathrm{C}$ (устойчивый переход через $0^{0}$ при нарастании температуры); к летнему сезону $->15^{0} \mathrm{C}, \quad$ к осени - период от $15^{0}$ до $0^{0}$, к зиме - период с устойчивыми среднесуточными температурами $<0^{0}$.

В Зыряновске $\sum \mathrm{t} \leq-20$ составляет $-1668^{0}$, Большенарыме $\sum \mathrm{t} \leq-20--1359^{0}$, Курчуме $\sum \mathrm{t} \leq-20--636^{0}$, Тополев мыс $\sum \mathrm{t} \leq-20--507^{0}$, пос. Орловский $\sum \mathrm{t} \leq-20$ составляет $-2274^{0}, \sum \mathrm{t} \leq-25$ составляет $-1359^{0}$. 
почвы) летнего и зимнего сезонов. Каждый из сезонов характеризуется однотипностью, общей направленностью климатообразующих процессов, своеобразным гидротермическим режимом и особым аспектом ландшафта [74, 75, 76, 94]. Резкие же изменения высоты Солнца и продолжительности дня в переходные сезоны ведут к относительно быстрой перестройке структуры радиационного, теплового и водного балансов подстилающей поверхности (см. табл. 9, 10, 12, 13).

В климатологии к весне относят апрель и май; к лету июнь август, к осени сентябрь - октябрь; к зиме ноябрь - март (табл. 44). В метеорологии границы сезонов связывают с переходом средней суточной температуры через определенные пределы. Обычно, в зоне степей весна начинается с устойчивого перехода среднесуточной температуры через $0^{0}$, начало лета - с переходом через $15^{0} \mathrm{C}$ при нарастании температуры. На спаде температуры, после июля, с переходом среднесуточной через $15^{0} \mathrm{C}$ начинается осень, её конец и начало зимы - с переходом температуры через $0^{0} \mathrm{C}$ (табл. 45). В лесостепной и лесной зонах граница лета часто определяется переходом суточной температуры через $10^{\circ} \mathrm{C}$. Соотношение тепла и влаги определяет тип ландшафта.

Исследуемая территория относится к классу горных ландшафтов. В пределах класса выделены подклассы: предгорный, низкогорный, среднегорный, высокогорный внутригорных и межгорных впадин [45, 77]. Порядковые номера видов ландшафтов исследуемого региона соответствуют обозначению на ландшафтной карте Республики Казахстан [78].

Согласно карте (приложение VIII), на Юго-Западном Алтае преобладают степные и лесные типы ландшафтов с наибольшей биопродуктивностью в сравнении с другими типами.

\section{2. Климат степей. Сезонная динамика явлений природы}

Экология степных ландшафтов впервые была описана в конце прошлого века В.В. Докучаевым в работе «Наши степи прежде и теперь» (1892 г.). С этой работой перекликается содержательный труд А.А. Чибилева о степях Казахстана. Авторами отмечено, что растительность целинной степи для ее обводнения имела не меньшее значение, чем лес. Современная сбитая скотом степь не в состоянии впитывать выпадающие осадки. Человек, уничтожив войлок степи, 
лишил ее возможности задерживать на своей поверхности снег, который сносится в низины, а оголенная почва глубоко промерзает. Весной, не успев оттаять, почва не может впитывать талые воды $[79,80]$.

Запасы почвенной влаги зависят от степени пастбищного угнетения растительности и сохранности дерновидных злаков. Для степи опасен как перевыпас, так и недовыпас. В последнем случае разрастаются дернины ковылей и вытесняют другие злаки, а скот втаптывает в почву семена. В степи растительность и фауна взаимно определяют существование друг друга [81]. В умеренных широтах степные ландшафты формируются при индексе сухости 1-2 (от 1,0 до 1,5 - лесостепи и разнотравно-злаковые степи, 1,5-2,0 - типичные и сухие степи) или коэффициенте Иванова-Высоцкого соответственно 1,0-0,6 и 0,6-0,3 (типичная степь) [20].

Естественные степи в предгорьях Юго-Западного Алтая почти полностью распаханы и сохранились только в западных районах и там, где затруднено их хозяйственное использование. В высотном поясе Рудного Алтая степи располагаются ниже горной лесостепной очень влажной и умеренно влажной зон Южного Алтая [73, 82].

Выделяют три основных зональных типа степей: 1) разнотравнозлаковые на типичных черноземах; 2) настоящие (типичные) на обыкновенных черноземах; 3 ) сухие (южные) на южных черноземах и каштановых почвах.

Разнотравно-злаковая степь характеризуется умеренно влажным и умеренно теплым климатом (см. табл. 45). Формируется этот тип степей при радиационном балансе 1,75-1,86 тыс. МДж/м² год, радиационном индексе сухости 1,25-1,5, коэффициенте увлажнения Иванова-Высоцкого от 1,0 до 0,8 (зона умеренного увлажнения, ландшафты лесостепей и разнотравных степей). Их важной экологической характеристикой является сумма эффективных температур - $1800^{0}-2200^{\circ}$, атмосферные осадки 450-600 мм в год, средняя месячная относительная влажность летом 60\%, испаряемость близка к величине атмосферных осадков (приведенные показатели соответствуют метеостанциям: Зыряновск, Северный поселок, Камешки, Секисовка) (рис. 36, 37, приложение VIII).

В степях наблюдается обильное разнотравье и часто - сплошной растительный покров; подзона является одним из основных земледельческих районов с естественными высокопродуктивными сенокосами, пастбищами и пчеловодством. К этому подтипу степей 
отнесены виды ландшафтов 394, 395, 408, 413. Безморозный период в разнотравных степях зависит от рельефа: в котловинах он составляет 85-90, на склонах холмов до 105 суток. Биопродуктивность и биоклиматический потенциал растительного покрова (РП) оцениваются в 80-105 ц/га годичного прироста биомассы наземных и подземных частей растений в сухом весе (см. табл. 45) [84].

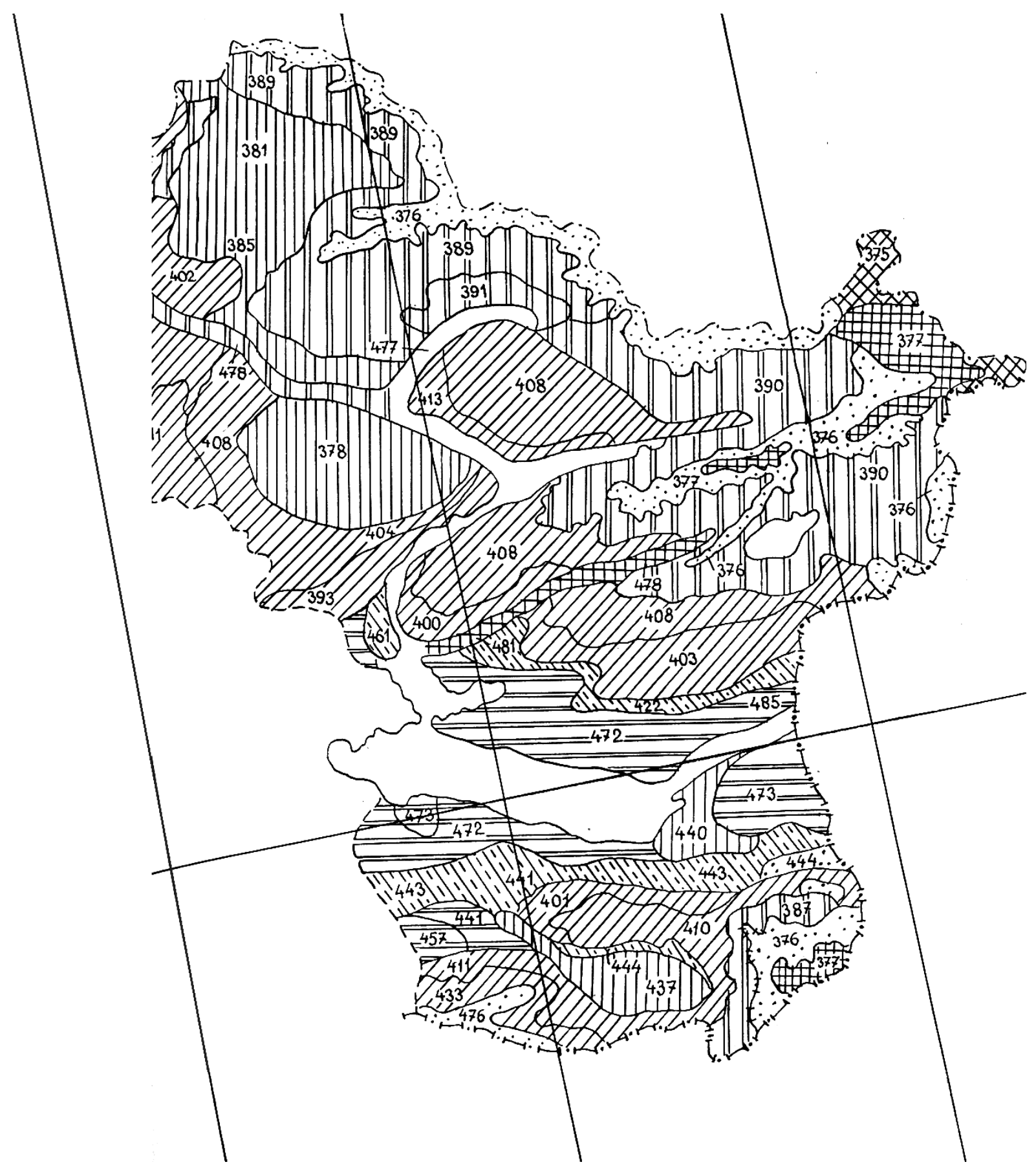

Рис. 36. Ландшафтная карта Юго-Западного Алтая 


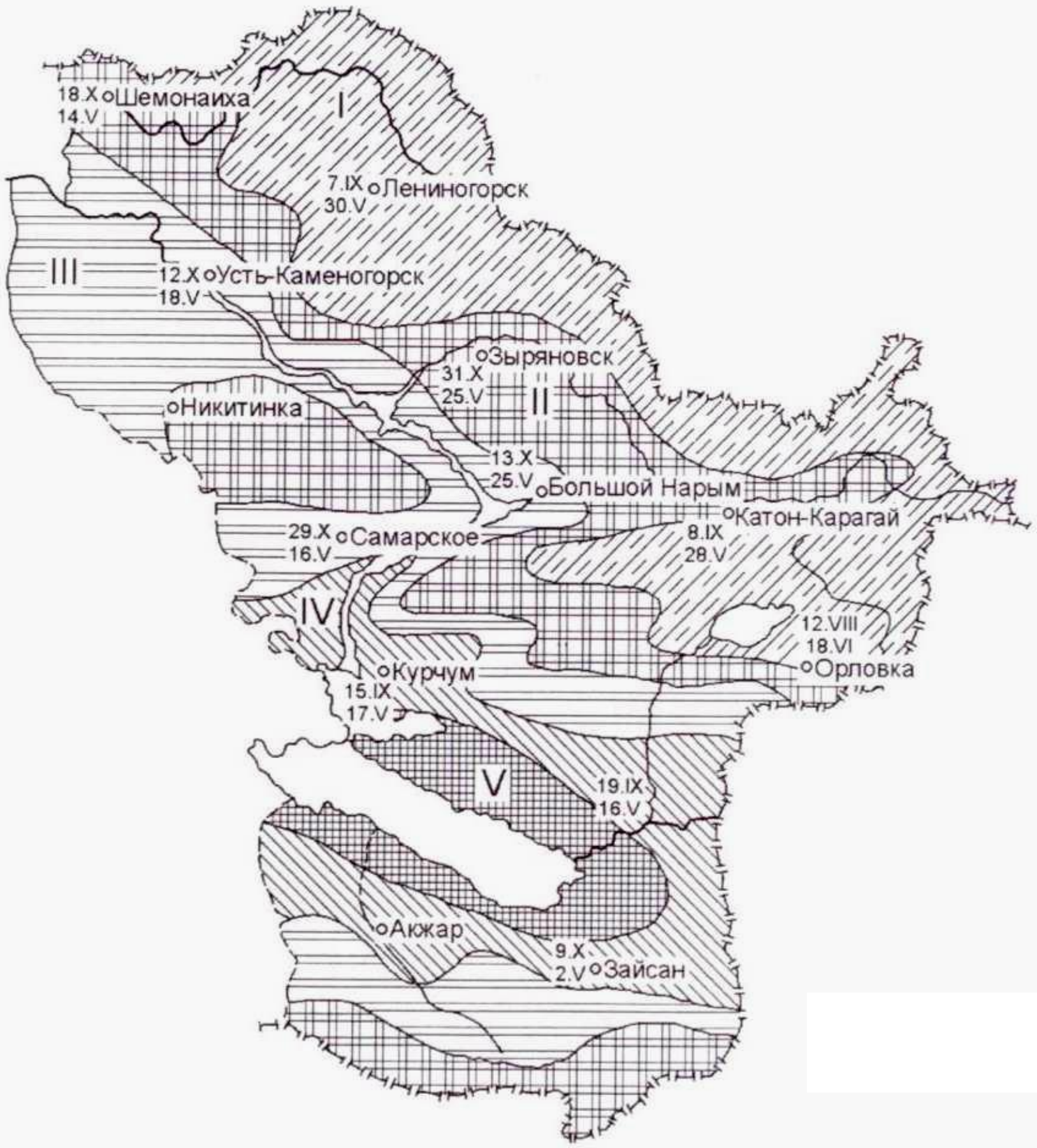

Средняя продолжительность безморозного периода (в днях)

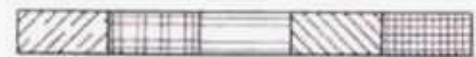

менее 100125135150 более

Рис. 37. Картосхема агроклиматических районов 
Зимы в разнотравно-злаковых степях умеренно холодные, со средней температурой сезона от минус $17^{0} \mathrm{C}$ до минус $10^{0} \mathrm{C}$, и холодные со средней температурой ниже минус $17^{0} \mathrm{C}$, значительно снежные и многоснежные. Почвы - типичные и выщелоченные черноземы, гумусовый горизонт составляет 80-100 см, структура орехово-зернистая или зернистая, содержание гумуса в верхнем горизонте 7-10\%, реакция почвенных растворов слабокислая. Вскипание от соляной кислоты ниже гумусово-аккумулятивного горизонта отмечается на глубинах до 150 см [71].

В частности, А.А. Соколов относит типичные ландшафты разнотравно-злаковых степей Зыряновского низкогорья к «горной лугово-степной, влажной» подзоне [82, 83]. Приведем более подробную характеристику климатических ресурсов этого района, что очень важно для выявления предела устойчивости экосистемы, которая в настоящее время относится к зоне антропогенного экологического поражения, с действующим здесь длительное время комплексом горнодобывающей и перерабатывающей отраслей и местной хозяйственной инфраструктурой.

На рис. 38 представлена модель разнотравно-злаковых степей Зыряновского низкогорья. Как уже указывалось выше, район Зыряновска с прилегающими территориями относится к зоне экологического поражения. Степные районы Зыряновской котловины испытывают хроническое техногенное загрязнение практически всех природных сред, и прежде всего атмосферы, в результате выпадения кислотных дождей, приносимых сюда облачными системами, загрязненными еще в предгорной части. Зимой, при отрицательных градиентах температуры, атмосфера характеризуется большой устойчивостью, ослабленным вертикальным воздухообменом и образованием температурных инверсий. Поэтому практически все загрязнения от промышленных выбросов остаются в приземном атмосферном слое. Подобные техногенные загрязнения серьезно угрожают здоровью и жизни людей, изменяют состояние естественных экологических систем и наносят заметный экологический ущерб. Сохранение экологической чистоты атмосферы для Зыряновской котловины, а значит, и ландшафтов, является важнейшей социально-экономической потребностью. 

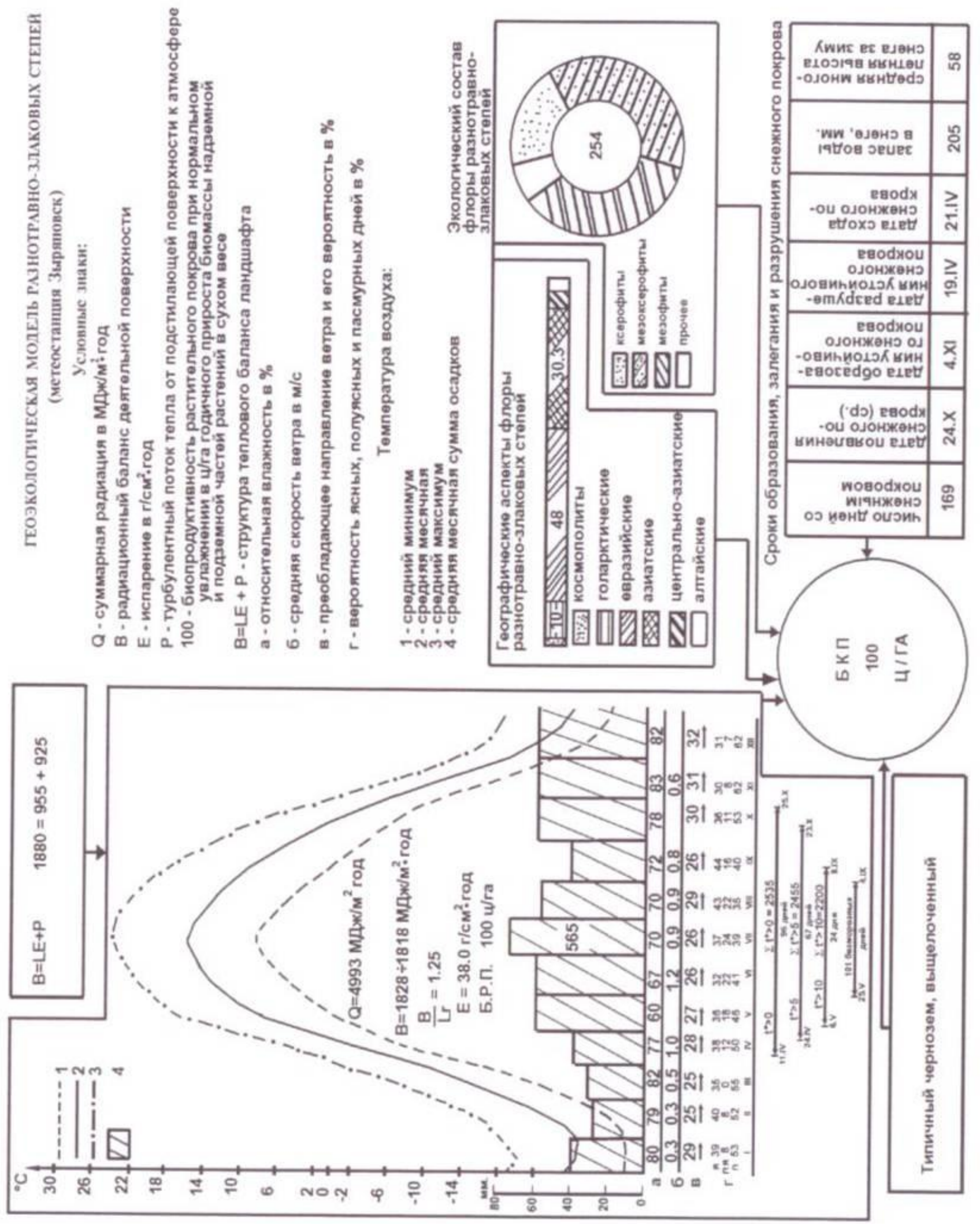

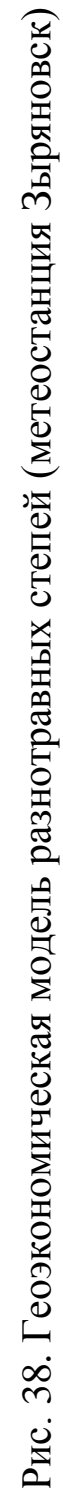


По наблюдениям на метеостанции Зыряновск, средняя годовая температура воздуха составляет минус $0,8^{0} \mathrm{C}$, максимальная среднемесячная в июле $-18,9^{\circ} \mathrm{C}$, минимальная в январе - минус $23,3^{0} \mathrm{C}$, годовая амплитуда среднемесячных температур $-42,2^{0} \mathrm{C}$. Абсолютный минимум температуры наблюдался до минус $51{ }^{\circ} \mathrm{C}$ (1940 г.), минус $50^{\circ} \mathrm{C}\left(1943\right.$ г.), возможны заморозки до $2-3^{0} \mathrm{C}$ во все месяцы лета. Абсолютный максимум температуры составил $40^{\circ} \mathrm{C}$ (июль 1900 г.) и $39^{\circ} \mathrm{C}$ (август 1968 г.). Период вегетации длится в среднем 167 дней, и сумма активных температур выше $5^{0} \mathrm{C}$ составляет $2455^{0}$, период активной вегетации $\left(\mathrm{t}^{0}>10^{0} \mathrm{C}\right)$ длится 124 дня, с 6 мая по 8 сентября, безморозный период 101 день, с 25 мая по 4 сентября. Сумма активных температур выше $10^{\circ} \mathrm{C}$ составляет $2200^{\circ}$. Годовая сумма осадков порядка 600 мм. Наличие в растительном покрове Зыряновского низкогорья до $75 \%$ (см. рис. 30) мезофитов и мезоксерофитов, при широком географическом спектре флоры (большой диапазон генной информации) указывает на устойчивость природных ландшафтов. Этот вывод подтверждается высоким биоклиматическим потенциалом ландшафтов низкогорья.

Благоприятное сочетание энергетических, тепловых и водных ресурсов обеспечивает получение в среднем до 30-48 ц/га зерна яровой пшеницы. Особенностями климата в Зыряновской котловине являются высокая годовая амплитуда температуры воздуха, малые скорости ветра, преобладание штилей в течение всего года и высокая относительная влажность воздуха (табл. 46).

Казахстанские типчаково-ковыльные степи протянулись сплошной полосой от Урала до Алтая. На территории исследуемого региона настоящие (типичные) степи располагаются западнее и южнее разнотравнозлаковых степей в районах с меньшим увлажнением и более высокими температурами воздуха (см. табл. 24, 45). Эти ландшафты занимают предгорные равнины и западные, наветренные склоны низкогорий и среднегорий до высоты 350-450 м (рис. 39).

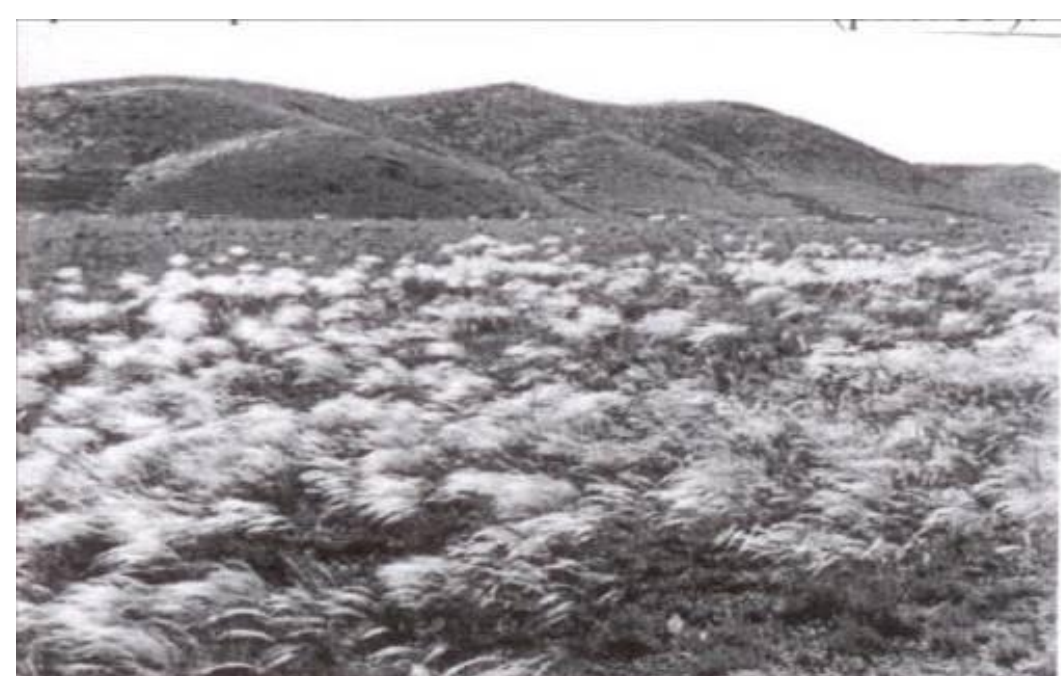

Рис. 39. Ковыльная степь 
Климат подзоны умеренно засушливый и теплый, в южной части умеренно жаркий $[71,82]$. Радиационный индекс сухости 1,51,8, коэффициент увлажнения близок к 0,8. За год выпадает 350-450 мм осадков, причем максимум приходится на лето (июль). Сумма эффективных температур (выше $+10^{\circ} \mathrm{C}$ ) составляет 2200-2500. Безморозный период длится от 125 до 135 суток (см. рис. 37). Зима умеренно-холодная, умеренно и значительно-снежная $[85,86]$.

По многолетним наблюдениям, средняя температура января составляет минус $17^{0} \mathrm{C}$ - минус $18^{0} \mathrm{C}$. Весна и осень теплые: средняя температура мая в пределах $12,13^{0} \mathrm{C}$, сентября $11,5-15,5^{0} \mathrm{C}$, лето теплое и даже жаркое, средняя температура июля $19,5^{0}-21,5^{0} \mathrm{C}$ (см. табл. 24, 45).

На черноземах обыкновенных (содержание гумуса 6-8\%, реакция почвенного раствора - нейтральная), доля злаков в травостое достигает 70-80\%, доминируют типчак и южные виды ковылей, разнотравье бедное, засухоустойчивое. Биоклиматический потенциал ландшафтов составляет 50-80 ц/га (табл. 45).

Настоящие степи (см. приложение VIII) представлены 395, 397 , 402, 411 видами ландшафтов, которые характеризуются следующими годовыми величинами осадков: метеостанции Шемонаиха - 400, Усть-Каменогорск - 455, Самарка - 365, Таинты - 356, Огневка 420 мм.

Типичные степи используются в качестве пастбищных и сенокосных угодий. Значительную площадь занимают посевы зерновых культур. Специализация сельского хозяйства зерномолочно-мясная. Для поддержания ландшафтно-экологического равновесия необходимо проведение комплекса мероприятий: травопольных севооборотов, полезащитного лесоразведения, регулирования стока (накопление и сбережение влаги).

Сухая или опустыненная степь находится между типичной степью и пустынями (см. рис. 36 и 37). Ее южную границу, вероятно, надо связывать с радиационными индексами сухости 2,0-2,5 и коэффициентом увлажнения 0,3. Сумма эффективных температур этих ландшафтов составляет 2500-2800, продолжительность безморозного периода 130-150 суток. Испаряемость в 2-3 раза превышает осадки (см. табл. 44, 45). Низкая обеспеченность сухих степей влагой приводит к засухам. На всей исследуемой территории памятны засухи 1955, 1974, 1991, 2008 годов. Но бывает, что 
засушливый год сменяется влажным. Так, после засушливого 1991 года лето 1992 было очень влажным, особенно его вторая половина.

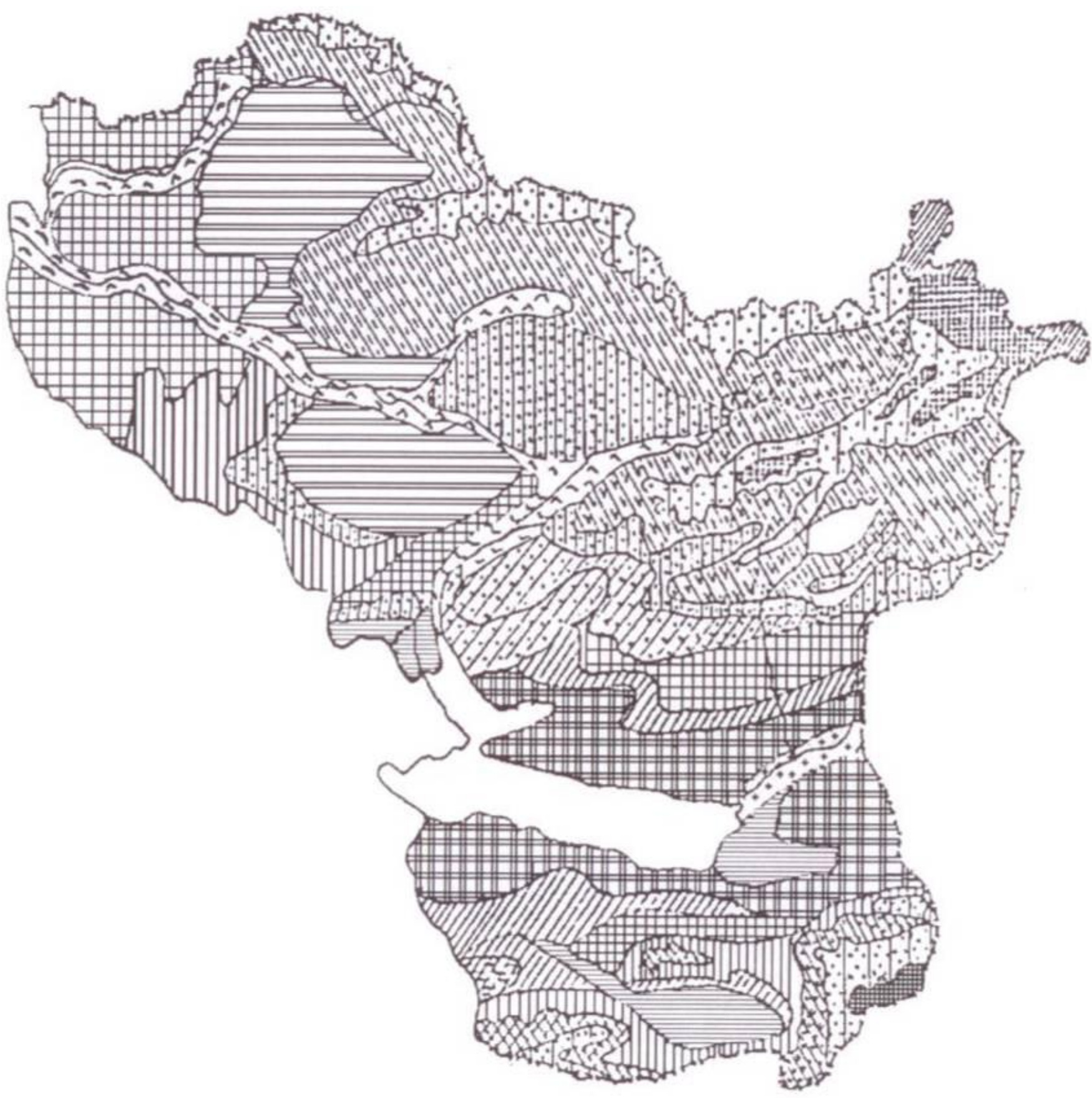

Рис. 40. Картосхема биопродуктивности природных комплексов Юго-Западного Алтая 
Условные обозначения к карте биопродуктивности

\begin{tabular}{|c|c|c|c|c|c|}
\hline & Тип ландшафта & $\Sigma \mathrm{T} 10^{\circ}$ & $\frac{\mathrm{B}}{\mathrm{Lr}}$ & 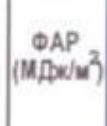 & \begin{tabular}{|l} 
Продук. \\
тивность \\
$(\psi /$ га)
\end{tabular} \\
\hline & Среднегорный луговой & менее 1000 & менее 0,5 & 2478 & 30 \\
\hline & Среднегорный лесной (таежный) & $1000-1400$ & $0,5-0,8$ & 2407 & $95-105$ \\
\hline & Низкогорный лесной & $1800-2000$ & $1,0-1,2$ & 2229 & $90-100$ \\
\hline & Низкогорный лесостепной & 2200 & $1,3-1,4$ & 2367 & $60-85$ \\
\hline & Низкогорный и предгорный степной & 2300 & $1,6-1,8$ & 2284 & $40-60$ \\
\hline$\hat{n} \hat{n}$ & Долинные & 2400 & 1,3 & 2284 & $45-50$ \\
\hline & Высокогорный & менее 1000 & & & \\
\hline & Высокогорный тундровый & 1000 & 0,5 & 2562 & $\approx 15$ \\
\hline & Высокогорный и среднегорный луговой & 1200 & $0,5-0,7$ & 2474 & $30-45$ \\
\hline & Среднегорный лесной (таежный) & $1400-1800$ & 1,0 & 2470 & $90-100$ \\
\hline & Низкогорный лесостепной & $1800-2000$ & $1,2-1,3$ & 2357 & 70-90 \\
\hline & Низкогорный степной & 2200 & $1,4-1,5$ & 2591 & $50-65$ \\
\hline & Равнинно-подгорный сухо-степной & $2400-2600$ & $1,6-1,7$ & 2587 & $40-45$ \\
\hline & Полупустынный межгорных впадин & $2600-2800$ & 3,0 & 2698 & 20-35 \\
\hline & Долинные & 2600 & 2,3 & 2564 & $30-33$ \\
\hline & Ср. и низкогорный лесо-луговой & 2000 & $1,0-1,1$ & 2487 & $\approx 80-90$ \\
\hline & Низкогорный лесостепной & 2400 & $1,2-1,5$ & 2635 & $60-80$ \\
\hline & Низкогорный лугово-степной & $2500-2600$ & $1,5-1,8$ & 2471 & $40-50$ \\
\hline & Низкогорный степной кустарниковый & $2500-2600$ & $1,5-1,8$ & 2471 & $40-50$ \\
\hline & Равнинно-подгорный сухо-степной & 2600 & 2,5 & 2580 & $\approx 30$ \\
\hline & Полупустынный межгорных впадин & 2800 & 2,7 & 2698 & $15-25$ \\
\hline & Равнинно-подгорный сухо-степной & 2600 & 2,3 & 2580 & $25-35$ \\
\hline & Предгорный полупустынный & 2700 & 3,0 & 2636 & $25-28$ \\
\hline \#\# & Пустынный межгорных впадин & 3000 & 3,4 & 2471 & 15 \\
\hline & Полупустынный межгорных впадин & 2900 & 3,0 & 2579 & $20-23$ \\
\hline $\mathrm{H}_{+}^{+}+$ & Сухо-степной межгорных впадин & 2900 & 2,7 & 2698 & $=25-35$ \\
\hline
\end{tabular}



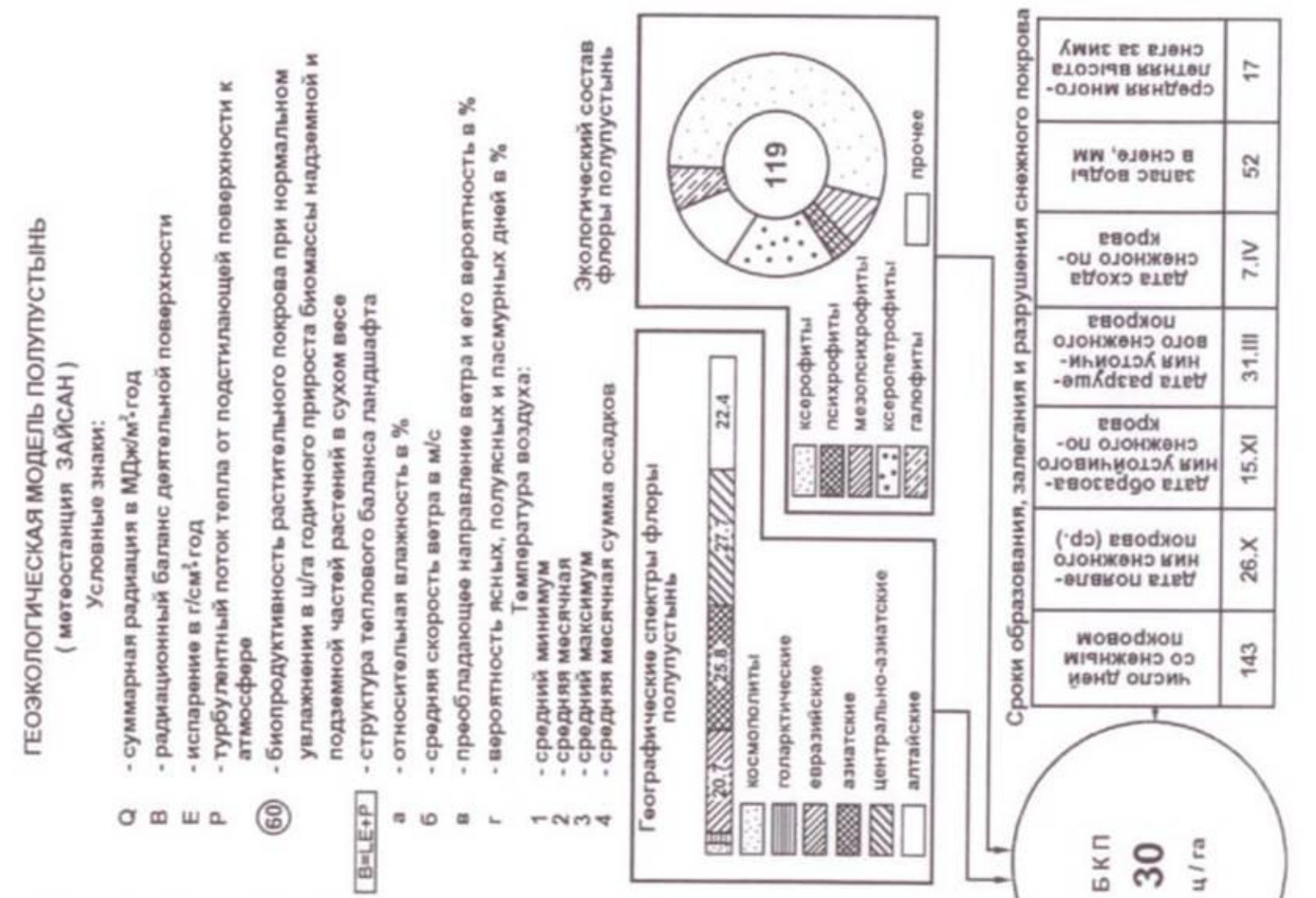
В сухой степи преобладают дерновинные злаки и большое количество ксерофитных полукустарников (в основном полынь) на южных черноземах, где мощность гумусового горизонта составляет 50-60 см, а содержание гумуса доходит до 4-7\% в каштановых почвах. Биологическая продуктивность сухих степей оценивается от 30 до 50 ц/га (см. табл. 45). На ландшафтной карте к сухостепным ландшафтам отнесены виды 401, 403, 404, 410, 493 (см. приложение VIII).

Обратимся к геоэкологической модели сухих степей, метеостанции Зайсан и Рождественское (рис.41). Радиационный баланс там достигает 1900 МДж/м² год, годовое количество осадков до 300 мм, радиационный индекс сухости составляет 2,5, относительная влажность воздуха с мая по сентябрь бывает в пределах 43-46\%. Средняя температура летних месяцев поднимается до $20-23^{0} \mathrm{C}$, средняя скорость ветра в теплый период до 4,4-5,4 м/сек. Устойчивый снежный покров образуется в середине ноября, а его сход происходит в первой декаде апреля, средняя высота снежного покрова 17 см, запас воды в нем 52 мм.

Экологический состав флоры характеризуется господством ксерофитов, географический спектр флоры указывает на их азиатское и центрально-азиатское происхождение. Биологическая продуктивность растительности составляет 35-40 ц/га, однако ресурсы ФАР могут обеспечить биопродуктивность до 110 ц/га. Территория сухих степей используется в качестве пастбищных угодий и для развития орошаемого земледелия.

Сезонная динамика отдельных явлений природы. На исследуемой территории переходный месяц от зимы к весне - март. За счет прогрева высокоподнятой поверхности Центральной Азии разрушается Азиатский антициклон. Центр его смещается на Алтай, а в апреле - на Южный Урал.

В первой половине марта обычно сохраняется зимний характер ландшафта. Средняя температура воздуха на всей территории ЮгоЗападного Алтая отрицательная (минус $7^{0}-9^{0} \mathrm{C}$ ). Осадков в марте обычно мало: в Зайсане 11, в Таинты 12, в Катон-Карагае 14, в Шемонаихе 18 мм, но могут быть и аномалии. Так, аномально многоснежными были зимы 1965-1966, 2000-2001 гг. Почти во всех горных районах в марте прошли такие обильные снегопады, что на железной дороге по направлениям Усть-Каменогорск - Риддер и Усть-Каменогорск - Зыряновск из-за снежных лавин на двое суток 
было приостановлено движение поездов, а высота снега в среднегорье (метеопост Малая Ульба) превышала 3 м.

После снегопадов в котловинах обычно стоят сильные морозы (Риддер, Зыряновск). Но уже к середине месяца, как правило, появляются проталины и «соты» с южной стороны снежных валов, особенно в городе. Кончаются устойчивые морозы.

Начало астрономической весны 21 марта (день весеннего равноденствия). В местный полдень Солнце в зените на экваторе, а на широте $50^{0}$ с. ш. (широта г. Усть-Каменогорска, Серебрянска, Зыряновска) в полдень оно находится на $40^{\circ}$ над горизонтом (см. приложение II).

M.M. Пришвин назвал март «весною света». Признаки весны появляются и в лесу, кроны деревьев сбрасывают снег. Он подтаивает у стволов, альбедо ландшафта сразу уменьшается. В конце месяца практически на всей исследуемой территории наблюдается разрушение снежного покрова, хотя средняя температура все еще отрицательная. По многолетним наблюдениям, обычно в марте прилетают грачи.

Апрель - первый месяц весны. Суточная температура переходит через $0^{0} \mathrm{C}$. Даты схода снежного покрова на предгорных равнинах почти повсюду совпадают с датой перехода температуры через $0^{0} \mathrm{C}$, в горах эти явления несколько запаздывают, то есть переходят на конец месяца (см. табл. 44, 45).

На склонах хребтов с высотами от 500 до 1500 м средняя суточная температура воздуха переходит через 0 в течение первой декады апреля, на высотах 2000 м - в третьей декаде, а на высоте 2500 м - в первой декаде мая [15].

Полуденная высота Солнца на $50^{0}$ с. ш. 15 апреля составляет $49^{0}$ (Усть-Каменогорск, Зыряновск, Серебрянск, Риддер, $\varphi=50^{0}$ с. ш.), а день длится 13,5 часов. Средняя температура месяца $1 \div 6^{0}$ : в Шемонаихе $2,2^{\circ} \mathrm{C}$, в Риддере $2,1^{\circ} \mathrm{C}$, в Усть-Каменогорске $4,7^{0} \mathrm{C}$, в Самарке $4,9^{0} \mathrm{C}$, Катон-Карагае $3,2^{0} \mathrm{C}$, в Буране $6,2^{0} \mathrm{C}$, в Зайсане $5,8^{0} \mathrm{C}$. В атмосфере - изотермия, с высотой температура не уменьшается, а порой остается даже выше, чем на нижележащей метеостанции. Устойчивая стратификация атмосферы мало способствует рассеиванию атмосферных загрязнений.

Со сходом снежного покрова резко уменьшается альбедо поверхности, влажная почва быстро прогревается, и от нее прогревается воздух. Развиваются восходящие токи, содержание в 
атмосфере паров увеличивается в 1,5-2 раза, появляются кучевые облака (см. табл. 46). В дневные часы столбик термометра может подниматься до $16-18^{0} \mathrm{C}$ тепла (16-17 апреля 1985 г.), хотя абсолютный максимум в апреле в Рудном Алтае составил $24-29^{0} \mathrm{C}$, а на юге региона $34-35^{\circ} \mathrm{C}$.

Реки Юго-Западного Алтая вскрываются от Зайсана к северу с 11 до 21 апреля, а на южных склонах Калбы - с 1 по 11 апреля.

Как только сходит снег, сразу зеленеет трава, прилетают скворцы, жаворонки, коноплянки.

Май теплее апреля на 7,6-0,6 ${ }^{\circ} \mathrm{C}$. Дневные температуры достигают $16-21^{\circ} \mathrm{C}$, возможны жаркие дни, температурные максимумы могут быть $25-30^{0} \mathrm{C}$. Переход средней суточной температуры через $10^{\circ} \mathrm{C}$ в степях осуществляется в первую декаду мая, в лесостепных ландшафтах - во вторую. Прогрев воздуха идет настолько быстро, что испарение не успевает насыщать воздух влагой. Относительная влажность в этом месяце самая низкая в году (см. табл. 46). В мае уже часты суховеи. Средняя месячная температура в целом по исследуемому региону составляет $10-15^{0} \mathrm{C}$ (см. табл. 23). В полдень 15 мая на $50^{0}$ с. ш. высота Солнца над горизонтом равна $38,6^{0}$, день длится 15 ч. 15 мин., а 31 мая - высота Солнца у нас равна $58,6^{0}$ и день длится 15 ч. 50 мин. (см. приложение II). Воздух струится над прогретой землей, формируются кучевые облака. При прохождении фронтальных разделов циклонов возможны ливни, довольно часто с грозой, реже с сильным градом (в конце мая 1988 г. после грозы с градом в Усть-Каменогорске слой града составил несколько сантиметров).

После весенней грозы и дождя легче дышится, «душой весны природа оживает». Ветер, дождь очищают задымленный, отравленный промышленными выбросам воздух городов.

После гроз возможны возвраты холодов, когда средняя температура суток снижается до 2-6 ${ }^{0}$, отмечаются и заморозки, особенно в котловинах, долинах, сырых низинах. Последние заморозки на севере региона кончаются в третьей декаде мая, по некоторым пунктам - во вторую: Усть-Каменогорск 14 мая, пос. Северный 18 мая, на Калбе - во второй декаде (Самарское 16 мая), в Зайсанской котловине - в начале первой декады. На Южном Алтае, в зависимости от высоты и форм рельефа, период с заморозками длится третью декаду мая и почти весь июнь: в Катон-Карагае последний 
заморозок отмечается (в среднем)28 мая, в Курчуме - 17 мая, пос. Орловский - 24 июня, на Маркаколе - 24 июня.

В мае обостряются контрасты между Арктикой и умеренными широтами, усиливается циклоническая деятельность, что приводит к увеличению осадков от апреля к маю. Так, майские осадки составляют в Шемонаихе 45, в Секисовке 57, в Усть-Каменогорске 43 мм, но в Карагужихе (станция Уба Большие пороги) 92, а в Малой Ульбе уже 162, в Самарке 32, Курчуме 30,в Зайсане 40 мм. По метеостанциям Рудного Алтая осадки апреля-мая составляют 17-21, Южного Алтая 14-20, Зайсанской котловины 20-23\% их годовых сумм. Одновременно весной над всей территорией Юго-Западного Алтая увеличиваются скорости ветра. Весна обычно засушливая. Необходимо отметить, что даже в мае на всей территории Казахстанского Алтая испаряемость больше осадков: в Рудном Алтае - в 1,7-2,5, на Калбе - в 4,1, на юге региона - в 3,7- 4,3 раза.

В степях к этому времени пахотный слой уже прогрет до 20 см. Средняя месячная температура почвы на глубине 5 см составляет в Шемонаихе 13,9, в Зыряновске 14,1, в Усть-Каменогорске 16,3, в Большенарыме 14,8, в Зайсане 15,4, а на глубине 20 см - до $10-13^{0} \mathrm{C}$. Май - весенняя посевная страда земледельца. Основная задача сберечь в почве влагу от таяния снега.

В степи и на лугах все выше поднимаются травы, на склонах цветут гусиный лук, подснежники, сон-трава, тюльпаны, огоньки, зацветают бобовые, ирисы, пионы. По лощинам в сиреневом наряде кустарники дикого миндаля, покрывается душистыми кистями черемуха, жасмин, по долинам рек в цвету дикая яблоня.

В мае птичьи голоса наполняют леса и парки. Поют одновременно и соловьи и кукушки. Вокруг «буйство бытия».

Итак, весна для Юго-Западного Алтая - ясный и наиболее ветреный сезон. Он характеризуется быстрым нарастанием радиационного баланса поверхности и температур воздуха. Структура температурного поля изменяется с высотой: на смену инверсионному состоянию - температура с высотой понижается, хотя вертикальные градиенты меньше $0,6^{0} \mathrm{C}$ на 100 м поднятия.

Для сезона характерна большая изменчивость погоды. Вынос континентального тропического воздуха из Средней Азии обусловливает максимумы температуры (до $30^{0}$ C) и низкую относительную влажность. Затоки континентального арктического воздуха с Арктики вызывают даже после схода снежного покрова 
снегопады и кратковременные снежные покровы. Такие явления могут повторяться на предгорных равнинах 2-3 раза в 10 лет. В мае обычно прекращаются заморозки: на юге - в первой, в центральной части - во второй, в северной части и межгорных котловинах - в третьей декадах мая.В мае перед системой гор часто углубляются циклоны, что ведет к усилению процессов осадкообразования $[27,32]$. С антициклонами этого месяца, как с северными, так и сместившимися с запада и юго-запада, связаны суховеи. В степях могут возникнуть палы, особенно после малоснежных зим [87].

Лето в степях Юго-Западного Алтая длится в среднем от 80 до 120 дней (см. табл. 45). Началом лета считают 21 июня - день летнего солнцестояния, когда наблюдаются самая короткая ночь и самый длинный день в году (см. приложение II).

Средняя дата последнего заморозка в Шемонаихе 21 мая, а первого - 12 сентября. Средняя продолжительность безморозного периода длится 113 суток, наименьшая составляет всего 85, а наибольшая - 142 дня; в Усть-Каменогорске, соответственно, 132, 87 и 163 дня (1927 г.); в Зыряновске - 95, 76 (1939, 1948 гг.), 128 (1952 г.); в Самарке - 131, 87 (1929 г.) и 164 (1941 г.); в Зайсане - 159, 117 (1933г.), наибольшая длительность безморозного периода наблюдалась 194 дня (1935 г.) - см. рис. 37. Первым летним месяцем считают июнь. Температура июня 16,5 в Зыряновске, 17,6 в Шемонаихе, 18,8 в Усть-Каменогорске, 19,0 в Самарке и 20,4 $4^{0}$ в Зайсане.

$B$ июне стоит преимущественно жаркая и значительно теплая погода. Июнь - месяц цветов. На лесных полянах и лугах цветут одуванчик, герань луговая, мышиный горошек, в конце месяца зацветает зверобой. У пернатых появляются птенцы, и меньше становится песен. Над цветущим полем много разноцветных бабочек, пчел, мушек, жучков. А сельский труженик и дачник в открытом грунте сеют огурцы, кабачки, фасоль, высаживают рассаду томатов, перца, баклажанов.

Дней с осадками бывает 10-11. Испаряемость превышает осадки (табл. 13, 47). Необходимо учитывать, что снижение продуктивной влаги в пахотном слое до 20 мм и меньше затрудняет минеральное питание растений. Для широкого использования удобрений необходимо, чтобы запасы продуктивной (доступной растению) влаги в пахотном слое были около 30 мм. 
Среднее количество осадков, приведенное к показаниям осадкомера, мм

\begin{tabular}{|c|c|c|c|c|c|c|c|c|c|c|c|c|c|c|c|}
\hline \multirow{2}{*}{ Станция } & \multicolumn{15}{|c|}{ Месяцы } \\
\hline & $\mathrm{I}$ & II & III & IV & $\mathrm{V}$ & $\mathrm{VI}$ & VII & VIII & IX & $\mathrm{X}$ & $\mathrm{XI}$ & XII & XI-III & IV-X & Год \\
\hline 1. Шемонаиха & 17 & 16 & 18 & 29 & 45 & 48 & 57 & 36 & 29 & 40 & 34 & 29 & 114 & 284 & 398 \\
\hline 2. Камешки & 24 & 25 & 37 & 28 & 47 & 60 & 74 & 45 & 34 & 50 & 47 & 31 & 164 & 338 & 502 \\
\hline 3. Секисовка & 25 & 26 & 41 & 50 & 57 & 53 & 82 & 48 & 32 & 93 & 54 & 48 & 194 & 415 & 609 \\
\hline $\begin{array}{l}\text { 4. Зерносовхоз им. Кали- } \\
\text { нина }\end{array}$ & 11 & 10 & 16 & 20 & 28 & 27 & 38 & 27 & 18 & 20 & 25 & 18 & 80 & 178 & 258 \\
\hline $\begin{array}{l}\text { 5. Семипалатинское опыт- } \\
\text { ное поле }\end{array}$ & 15 & 12 & 15 & 13 & 24 & 32 & 35 & 23 & 18 & 24 & 24 & 18 & 84 & 169 & 253 \\
\hline 6. Пос. Васильевский & 8 & 9 & 19 & 23 & 38 & 39 & 69 & 36 & 36 & 46 & 21 & 14 & 71 & 287 & 358 \\
\hline 7. Зыряновск & 39 & 27 & 28 & 35 & 56 & 56 & 70 & 52 & 39 & 54 & 55 & 54 & 203 & 362 & 565 \\
\hline 8. Никитинка & 21 & 18 & 21 & 25 & 32 & 38 & 42 & 33 & 29 & 33 & 44 & 30 & 13 & 232 & 366 \\
\hline 9. Самарка & 21 & 17 & 21 & 25 & 32 & 38 & 42 & 33 & 29 & 33 & 44 & 30 & 133 & 232 & 365 \\
\hline 10. Зайсан & 9 & 9 & 16 & 28 & 40 & 41 & 37 & 27 & 23 & 24 & 21 & 16 & 71 & 220 & 291 \\
\hline
\end{tabular}


Июль - вершина лета и самый теплый месяц года. На большей части Юго-Западного Алтая это самый влажный и самый грозовой месяц. Осадков выпадает от 40 до 70 мм, 10-12 дней бывает с грозой. Все цветет, благоухает, цветет клевер красный, на насыпях дорог кипрей, видны куртины цветов синюхи. На перелесках голубые колокольчики, василек, в цвету кусты шиповника. Над полями жужжат, стрекочут насекомые.

Июль - хлопотный и трудный месяц, пора ухода за зерновыми, овощными, садовыми культурами. Июльский зной, когда на небе ни облачка и полыхают сиреневые зори, иссушает все живое на корню (засухи 1974, 1991, 2008 гг.). В период 1980-1990 и 1996-2008 гг. июль был самым сухим месяцем лета, осадки его составляли 10-20\% нормы. Максимальные температуры сезона также приходятся на июль $-18,5-22,7^{\circ} \mathrm{C}$. В отдельные дни жара может достигать $36-40^{\circ} \mathrm{C}$. К ночи температура значительно понижается, о чем можно судить по величине средних минимумов (см. табл. 23). В июле на севере региона средние минимумы равны $10-12$, на юге $-14-17^{0} \mathrm{C}$. На летние месяцы приходится максимум солнечной энергии. Суммарная радиация за июнь-август в разнотравно-злаковой степи составляет от 42 до 44\% годовой величины; в типичной $-41-42$, в сухих степях и полупустынях $-40 \%$ (см. табл. 5).

На радиационный баланс летних месяцев приходится $50-56 \%$ от годовой суммы. Значительная часть его расходуется на испарение, которое составляет в Шемонаихе 59, в Усть-Каменогорске 58, в Зыряновске 62, в Самарке 54, Семипалатинске 55, в Зайсане $47 \%$ его годовой суммы (см. табл. $8,10,45)$.

Испаряемость за летние месяцы составляет 54-57\% годовой величины (см. табл. 13). Все приведенные данные указывают на большой энергетический потенциал сезона. Сумма температур выше $15^{\circ} \mathrm{C}$ достигает $1600-1900^{\circ} \mathrm{C}$ на севере региона, до $1800-2200^{\circ} \mathrm{C}$ в его южной половине (см. табл. 45). Сумма эффективных $\left(\mathrm{t}^{0}>10^{0} \mathrm{C}\right)$ температур, накопленных к концу лета, составляет: в Шемонаихе 2069, Большенарыме 2166, в Самарке 2304, Зайсане 2553 [52]. Несмотря на такую большую обеспеченность теплом, в июле температура может понижаться до $2-5^{0} \mathrm{C}$.

Летние осадки по региону составляют $31-36 \%$ их годовой суммы: в Самарке 31, в Зыряновске 32, в Усть-Каменогорске, Большенарыме 35 , в Зайсане $36 \%$ (табл. 45). Основная их масса 
Число дней с осадками различной величины

\begin{tabular}{|c|c|c|c|c|c|c|c|}
\hline \multirow{2}{*}{ Месяцы } & \multicolumn{6}{|c|}{ Осадки, мм } & \multirow[b]{2}{*}{$\geq 30.0$} \\
\hline & $\geq 0.1$ & $\geq 0.5$ & $\geq 1.0$ & $\geq 5.0$ & $\geq 10.0$ & $\geq 20.0$ & \\
\hline \multicolumn{8}{|c|}{ Усть-Каменогорск } \\
\hline 1 & 11.1 & 7.7 & 5.5 & 1.0 & 0.2 & 0.02 & 0.0 \\
\hline II & 10.7 & 6.7 & 5.0 & 1.1 & 0.2 & 0.02 & 0.0 \\
\hline III & 12.1 & 7.6 & 6.0 & 1.6 & 0.4 & 0.02 & 0.0 \\
\hline IV & 8.9 & 7.0 & 5.8 & 2.2 & 0.7 & 0.1 & 0.0 \\
\hline $\mathrm{V}$ & 10.9 & 9.2 & 7.9 & 3.4 & 1.0 & 0.1 & 0.0 \\
\hline VI & 10.7 & 9.1 & 7.7 & 3.7 & 1.6 & 0.4 & 0.1 \\
\hline VII & 11.9 & 10.0 & 8.7 & 4.2 & 2.0 & 0.4 & 0.04 \\
\hline VIII & 10.1 & 8.2 & 7.0 & 2.9 & 1.1 & 0.3 & 0.04 \\
\hline IX & 8.5 & 6.8 & 5.6 & 2.2 & 0.8 & 0.1 & 0.0 \\
\hline $\mathrm{X}$ & 12.3 & 9.3 & 7.7 & 2.9 & 1.0 & 0.1 & 0.04 \\
\hline XI & 14.1 & 10.8 & 8.4 & 2.9 & 0.7 & 0.1 & 0.02 \\
\hline XII & 13.8 & 10.0 & 7.1 & 2.0 & 0.6 & 0.1 & 0.0 \\
\hline Год & 135 & 102 & 82 & 30 & 10 & 2 & 0.2 \\
\hline \multicolumn{8}{|c|}{ пос. Орловский } \\
\hline I & 9.2 & 6.7 & 4.9 & 0.9 & 0.2 & & \\
\hline II & 7.7 & 5.9 & 4.3 & 0.7 & 0.1 & & \\
\hline III & 7.8 & 5.6 & 3.7 & 0.8 & 0.3 & 0.02 & \\
\hline IV & 6.6 & 5.4 & 4.2 & 1.1 & 0.4 & 0.1 & \\
\hline $\mathrm{V}$ & 9.0 & 7.3 & 6.1 & 2.1 & 0.6 & 0.04 & \\
\hline VI & 10.7 & 8.7 & 7.6 & 3.1 & 0.8 & 0.04 & \\
\hline VII & 13.2 & 11.0 & 9.4 & 4.0 & 1.5 & 0.2 & 0.1 \\
\hline VIII & 11.6 & 9.5 & 7.8 & 3.2 & 1.2 & 0.2 & 0.02 \\
\hline IX & 7.9 & 6.3 & 5.2 & 1.7 & 0.4 & 0.04 & 0.0 \\
\hline $\mathrm{X}$ & 8.4 & 6.7 & 5.4 & 1.6 & 0.4 & 0.1 & 0.02 \\
\hline XI & 10.0 & 7.8 & 6.1 & 1.3 & 0.2 & 0.04 & 0.0 \\
\hline XII & 11.3 & 9.0 & 6.8 & 1.4 & 0.1 & & \\
\hline Год & 113 & 90 & 72 & 22 & 6 & 0.8 & 0.1 \\
\hline \multicolumn{8}{|c|}{ Зайсан } \\
\hline I-III & \multicolumn{7}{|c|}{ Нет данных } \\
\hline IV & 7.2 & 5.8 & 5.0 & 1.8 & 0.7 & 0.2 & 0.02 \\
\hline $\mathrm{V}$ & 9.4 & 7.9 & 6.8 & 2.9 & 1.1 & 0.1 & 0.03 \\
\hline VI & 8.9 & 7.6 & 6.3 & 2.8 & 1.2 & 0.2 & 0.1 \\
\hline VII & 9.3 & 7.7 & 6.5 & 2.5 & 1.2 & 0.2 & 0.1 \\
\hline VIII & 7.5 & 6.2 & 5.2 & 1.6 & 0.6 & 0.1 & 0.03 \\
\hline IX & 6.3 & 5.2 & 4.5 & 1.5 & 0.6 & 0.2 & 0.03 \\
\hline$X$ & 7.1 & 5.5 & 4.7 & 1.6 & 0.6 & 0.1 & 0.01 \\
\hline XI-XII & & & Нет & ных & & & \\
\hline
\end{tabular}

выпадает на фронтальных разделах циклонов, возникших как на арктическом, так и полярном фронтах. Их количество определяется значительной упругостью водяных паров: 12-15 гПа в Рудном Алтае, 
11-13 - на Калбе и 10-12 - в Зайсанской впадине (см. табл. 46), а также большим влагосодержанием воздушных масс - 20-25 кг/м², в Зайсанской котловине - 16-18 кг (см. табл. 35).

В степях и лесостепях лето является наиболее обеспеченным осадками в сравнении с другими сезонами года (см. табл. 47).

По мере приближения к горным системам увеличивается сумма осадков и становится более четко выраженным их вторичный осенний максимум (табл. 48).

В степях количество осадков в июне колеблется от 40 до 60, в июле - от 40 до 80 мм. При этом на юге региона насчитывается 8-9, на севере 11-12 дней с осадками, в высокогорной степи Орловского поселка до 13 дней. Осадки интенсивностью 5 мм и более в сутки (промачивающие почву до узла кущения) наблюдаются 3-4 дня в месяц, а 10 мм и более - всего 6-10 раз в году. Летом они могут быть менее продолжительными, чем зимой и чаще носят ливневой характер. Средний дефицит влажности в летние месяцы колеблется от 8 до 10 гПа.

Летом над регионом характерна грозовая деятельность. Картосхемы распределения числа дней с грозой и продолжительности гроз приведены на рис. 31, 32. На картосхеме видно очаговое распределение гроз. Очаги совпадают с районами интенсивных осадкообразовательных процессов: близ фронтальных разделов у горных систем и близ орографических узлов.

Данные о грозовой деятельности необходимы в различных отраслях хозяйства региона: энергетикам для рационального внедрения средств грозозащиты линий электропередачи, метеорологам-прогнозистам - для обеспечения более полными прогнозами авиации, сельского и лесного хозяйства. Обеспеченность (продолжительность) числа дней с грозой для расчетного периода в 5 лет составляет 80, в 10 лет - 90, в 15 лет - 93,3\%. Средние значения полученных величин существенно меньше тех, что встречаются раз в 5 лет, и особенно для 10 и 15 лет (табл. 49, 50). Например, в Риддере при средней повторяемости гроз 42 дня один раз в 10 лет может быть 52 грозовых дня.

На исследуемой территории выделяются три района грозовой деятельности: 1) приозерный (Зайсанский) характеризуется повторяемостью гроз 20-25 дней, продолжительностью 20-30 ч., числом разрядов до 200 на 100 км$^{2}$; 2) степной - повторяемость гроз 20-25 дней, продолжительность 35-40 часов, число разрядов около 
400 на 100 км²; 3) предгорный и горный - повторяемость 30-40 дней,

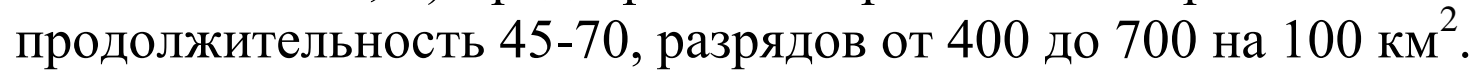

Т а б ли ц а 49

Число дней с различной повторяемостью гроз (по А.Г. Ивановой и др.)

\begin{tabular}{|l|c|c|c|c|c|}
\hline \multirow{2}{*}{\multicolumn{1}{c|}{ Пункт }} & \multirow{2}{*}{$\begin{array}{c}\text { Среднее } \\
\text { число дней }\end{array}$} & $\begin{array}{c}\text { Среднее } \\
\text { квадратическ }\end{array}$ & \multicolumn{2}{|c|}{ Повторяемость гроз: один раз } \\
\cline { 5 - 6 } & с грозой & в & в лет & в 10 лет & в 15 лет \\
& 42 & 9.9 & 49 & 52 & 54 \\
\hline 1. Риддер & 33 & 8.4 & 40 & 43 & 45 \\
\hline 2. Зыряновск & 28 & 8.4 & 35 & 38 & 40 \\
\hline 3. Шемонаиха & 34 & 8.2 & 41 & 44 & 46 \\
\hline 4. Секисовка & 34 & 9.2 & 41 & 44 & 46 \\
\hline 5. Усть-Каменогорск & 28 & 9.7 & 35 & 38 & 40 \\
\hline 6. Самарка & 26 & 6.7 & 33 & 36 & 38 \\
\hline 7. Большенарым & 29 & 6.6 & 36 & 39 & 41 \\
\hline 8. Катон-Карагай & 25 & 8.7 & 32 & 35 & 37 \\
\hline 9. Курчум & 19 & 6.2 & 26 & 29 & 31 \\
\hline 10. Приозерный & 19 & 7.0 & 26 & 29 & 31 \\
\hline 11. Буран & 27 & 8.4 & 34 & 37 & 39 \\
\hline 12. Зайсан & 25 & 8.0 & 32 & 35 & 37 \\
\hline 13. Семей & 31 & 7.7 & 38 & 41 & 43 \\
\hline 14. Пос. Орловский & & & & & \\
\hline
\end{tabular}

Август - конец лета. Но первая его декада мало отличается от июля. Созревают поля зерновых культур. Спеют рябина, шиповник, черемуха.

Начинается уборка основных сельскохозяйственных культур. Считается, что для зерновых решающее значение имеют осадки первой половины лета (июня и половины июля), для пропашных культур - осадки июля и августа. Если в каждый летний месяц выпадает до 40-50 мм осадков, то лето считается среднеувлажненным, и урожайность бывает близкая к средней. Если выпадает ежемесячно 60-70 мм - лето дождливое, если по 30 мм сухое $[11,41,73,83]$. В августе обычно уменьшается количество осадков, средний месячный недостаток насыщения составляет в Шемонаихе 9,0, в Зыряновске 7,4, в Самарке 12,0 гПа (см. табл. 47). Хорошие условия для работы комбайна наблюдаются при дефиците влажности 8 гПа и выше. В этом же месяце начинается сев озимых. Чтобы рассчитать срок посева, надо знать, когда осенью средняя суточная температура переходит через $5^{0} \mathrm{C}$, то есть это дата прекращения вегетации озимых. Отсчитав от нее назад 50 дней, 
получаем срок посева озимых. Такой срок нужен для нормального развития озимых культур и подготовки их к перезимовке (см. табл. 26). Если в конце осени днем стоит ясная теплая погода, а ночью бывают слабые морозы (до минус $2 \div 5^{0}$ ), то закаливание растений идет нормально. Дожди и высокая относительная влажность воздуха мешают закаливанию озимых, узел кущения которых находится на глубине 3-4 см. Критической температурой на вымерзание является температура минус $20 \div$ минус $24^{0} \mathrm{C}$. При ровном снежном покрове толщиной 15-20 см озимым не грозит вымерзание [73, 79, 88].

Т а блиц а 50

Продолжительность гроз с различной повторяемостью, ч

\begin{tabular}{|c|c|c|c|c|c|}
\hline \multirow{2}{*}{ Пункт } & \multirow{2}{*}{$\begin{array}{c}\text { Средняя } \\
\text { многолетняя } \\
\text { продолжительн } \\
\text { ость } \\
\end{array}$} & \multirow{2}{*}{$\begin{array}{c}\text { Среднее } \\
\text { квадратическое } \\
\text { отклонение }\end{array}$} & \multicolumn{3}{|c|}{$\begin{array}{c}\text { Продолжительность гроз } \\
\text { за период } \\
\end{array}$} \\
\hline & & & 5 лет & 10 лет & 15 лет \\
\hline 1. Риддер & 70 & 32.5 & 101 & 126 & 146 \\
\hline 2. Зыряновск & 52 & 21.1 & 79 & 106 & 128 \\
\hline 3. Шемонаиха & 47 & 21.8 & 70 & 100 & 115 \\
\hline 4. Секисовка & 36 & 12.9 & 40 & 64 & 76 \\
\hline 5. Усть-Каменогорск & 67 & 29.3 & 100 & 131 & 160 \\
\hline 6. Самарка & 40 & 21.0 & 63 & 88 & 100 \\
\hline 7. Большенарымское & 32 & 18.1 & 46 & 70 & 85 \\
\hline 8. Катон-Карагай & 50 & 24.1 & 70 & 96 & 122 \\
\hline 9. Курчум & 46 & 24.0 & 75 & 112 & 142 \\
\hline 10. Приозерный & 30 & 15.3 & 50 & 77 & 100 \\
\hline 11. Буран & 20 & 13.2 & 36 & 59 & 80 \\
\hline 12. Зайсан & 41 & 24.2 & 60 & 73 & 85 \\
\hline 13. Семей & 40 & 22.3 & 60 & 86 & 105 \\
\hline 14. Пос. Орловский & 48 & 20.4 & 72 & 100 & 125 \\
\hline
\end{tabular}

Осень. Сентябрь - первый месяц осени, происходит переход суточной температуры через $15^{0} \mathrm{C}$, наблюдаются первые заморозки. Началом осени считают 23 сентября - день осеннего равноденствия.

$\mathrm{B}$ типичных степях переход температуры через $15^{\circ} \mathrm{C}$ происходит: в Шемонаихе и Усть-Каменогорске I сентября, в Самарке 10 сентября, в Большенарыме 5 сентября; в сухой степи во второй декаде месяца в Зайсане 16 сентября. В этот месяц заканчивается период активной вегетации и происходит переход суточной температуры через $10^{0} \mathrm{C}$ : в Шемонаихе и УстьКаменогорске 21 сентября, в Самарке 29 сентября, а в Зайсане - уже 4 октября. В разнотравно-злаковой степи на высотах 450-500 м переход 
через $15^{\circ} \mathrm{C}$ наблюдается раньше: в Секисовке 24 августа, в Зыряновске 25 августа, через $10^{0} \mathrm{C}$ соответственно 15 и 16 сентября. Средняя дата первого заморозка наблюдается также в этом месяце в Шемонаихе, Большенарыме - 12, в Секисовке - 3, Усть-Каменогорске $($ АМСГ) - 16, в Зыряновске - 2, в Самарке - 25 сентября, а в Зайсане только 9 октября. Бывают годы, когда в сентябре заморозков нет (так было в 1936, 1957, 1959 гг.). Заморозки были отмечены только в октябре: в Усть-Каменогорске и Северном поселке 12 октября 1957 г., в Большенарыме 1 октября 1959 г., в Самарке 26 октября 1936 г.

В сентябре часты периоды продолжительностью в 6-10 дней, когда стоит «золотая осень» - тихая, ясная, теплая погода, чарует расцвеченный лес и парки. В пору длинного «бабьего лета» может начаться вторичное цветение. Распускаются метелки цикория, лиловая герань, незабудки. Цветут не только лютик, одуванчик, но и кустарники: черемуха, сирень, а также яблони.

Случается, что в сентябре на территорию Юго-Западного Алтая вторгаются массы арктического воздуха, тогда стоит холодная, сырая, дождливая и ветреная погода. На Калбе даже появляется снег (сентябрь 1964, 1992 гг.). Резкое понижение температуры на 20-250 наблюдалось в течение суток в сентябре 1964. Скорость ветра над Алтайским краем достигала 130-150 км/час. Для Юго-Западного Алтая эта осень была холодной и очень холодной, гидротермические условия в Зыряновске и Риддере обозначались числовыми индексами 5,1 - очень холодный и сухой сезон, в Усть-Каменогорске и Зайсане 3,2 - холодный сезон с нормальным увлажнением. Сентябрь 1992 г. был холодным, дождливым, ветреным. На Калбе выпал снег. Но, как правило, сентябрь бывает сухим, солнечным, теплым (табл. 44, 45, 47, 48). Это месяц уборки урожая огородных и садовых культур и позднеспелых зерновых. На полях еще созревает кукуруза.

Переход к осени характеризуется значительным понижением температуры, что определяется уменьшением притока тепла. Август холоднее июля только на $2,0-2,5^{0} \mathrm{C}$, сентябрь холоднее августа на 5,7$6,4^{0} \mathrm{C}$ (табл. 23). Уменьшается абсолютная влажность воздуха (табл. 46). Сентябрь в степях - самый сухой месяц в теплом периоде, с наименьшим количеством дней с осадками (в среднем от 18 до 39 мм), а дней с осадками бывает 6-8 (табл. 47, 48).

Октябрь - настоящий осенний месяц. Средняя температура воздуха в степях в октябре от 1,5 до $5,7^{0} \mathrm{C}$. Октябрь холоднее сентября на $7,5-9,5^{0} \mathrm{C}$ (табл. 23). В воздухе сыро, прохладно, 
относительная влажность на большей части степей до 70\% (в Зыряновске 78, в Зайсане 56\%) (табл. 46). Испарение в сравнении с сентябрем уменьшилось вдвое и составляет от 9 до 12 мм (табл. 10). Число пасмурных дней по нижней облачности увеличилось: в Шемонаихе от 1,6 в сентябре до 3,6 в октябре, в Усть-Каменогорске соответственно от 2,4 до 6,1 , в Зыряновске от 3,2 до 4,0, в Большенарыме от 1,6 до 3,0, в Самарке от 1,3 до 2,4 и в Зайсане от 1,1 до 2,0 в октябре.

В октябре над Арктикой уже стоит полярная ночь, и над умеренными широтами возрастают контрасты температур, увеличиваются скорости переноса воздушных масс. Обостряются контрасты и во фронтальных зонах (ПВФЗ), усиливается циклоническая деятельность. С ней обычно связаны облачность и значительные осадки, в частности, в 1,4-2 раза больше, чем в сентябре, а в целом по исследуемому региону они могут составлять от 24 до 93 мм. В этот период также увеличиваются скорости ветра.

Уменьшение полуденной высоты Солнца и продолжительности дня, увеличение облачности ведут к уменьшению суммарной солнечной радиации. В сентябре она была на уровне 450-500, а в

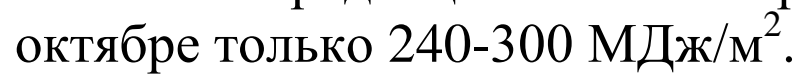

Кончается вегетационный период. С 6 по 19 октября происходит переход средней суточной температуры через $5^{0} \mathrm{C}$. Средний минимум температуры (ночные температуры) на всех метеостанциях отрицательный: от минус 0,3 до минус $4,0^{0} \mathrm{C}$, кроме Зайсана, где он равен $0,8^{0} \mathrm{C}$. Средний максимум температуры (температура в 13 ч.) составляет $9-12^{0} \mathrm{C}$. После утренников в ясную погоду начинается сильный листопад. Ветер снимает листву раньше всего с черемухи, затем у клена, рябины и березы. К этому времени уже умолкает хор пернатых в лесах и парках. В октябре улетают зяблики, грачи, скворцы. В третьей декаде месяца появляется первый снежный покров. Средняя суточная температура переходит через $0^{0}$, а через минус $5^{0} \mathrm{C}$ ее переход осуществляется уже в ноябре (см. табл. 45 ).

Устойчивый снежный покров формируется при средних температурах минус $5^{0} \mathrm{C}$. Между датами появления снежного покрова и установления его на зиму в среднем приходится 19-22 дня на предгорных равнинах, в котловинных формах рельефа 11-15 дней.

С наступлением устойчивых морозов в первой декаде ноября и установлением снежного покрова наступает зимний режим погоды, который в Юго-Западном Алтае длится с ноября по март. 
В степных районах устойчивые морозы (дневной максимум температуры ниже $0^{0}$ ) наблюдаются от 128 до 148 дней: в Шемонаихе 140, Зыряновске 153, в Самарке 128, в Орловском поселке 148, Зайсане 130 дней.

Холодный период со средними суточными температурами минус $15^{0} \mathrm{C}$ длится: 121 день в Орловском поселке, 109 в Зыряновске, 77 в Усть-Каменогорске, 72 в Самарке, 69 в Зайсане. Сумма отрицательных температур позволяет оценить условия перезимовки озимых культур, а также температурную напряженность биоты.

Краткая характеристика климатических сезонов. В степной зоне Евразии в течение года наблюдается четыре типа климатического режима: зимой - арктический, в начале весны режим тундры. Он сменяется режимом лесной зоны и, наконец, летом свой степной режим. Можно добавить пятый режим, присущий степям - пустынный, он наблюдается в период засух при суховеях $[80,89]$.

Краткую характеристику климатических сезонов степных ландшафтов приведем на примере разнотравно-злаковых степей Зыряновского низкогорья. Здесь календарные границы сезонов хорошо согласуются с их синоптическими границами.

Для зимы характерны морозные погоды, устойчивый снежный покров в течение 169 дней, а также отрицательный радиационный баланс подстилающей поверхности. Кроме того, антициклонические типы циркуляции, малые горизонтальные градиенты давления и слабые ветры, близко к предельной повторяемости штилей, интенсивные инверсии температуры. Радиационное выхолаживание воздуха в условиях котловинной формы рельефа привело к снижению средних месячных температур в сравнении с температурой на метеостанциях, расположенных на предгорных равнинах и склонах гор. Средняя температура зимы в Зыряновске минус 17,5, а января минус $23,3^{0} \mathrm{C}$. Средний минимум минус 28,9 , абсолютный минимум минус $51{ }^{0} \mathrm{C}$. Могут создаваться чрезвычайно суровые условия, если сильный мороз наблюдается при ветре, особенно при увеличении его скорости до 5 м /с (рис. 42).

На рисунке выделены зоны: первая является комфортной при нормальной защищенности организма и небольших скоростях ветра. Условия второй зоны воспринимаются (ощущаются) как холод, третьей - как сильный холод. В четвертой начинается обморожение 
тела, пятая зона - летальная (смертельная), для выживания требуются специальные мероприятия (сравните с табл. 23, 24) [90, 91].

Сильные морозы в Зыряновске наблюдаются, как правило, при штилях или очень слабых ветрах, что позволяет человеку сравнительно легко переносить столь низкие температуры. Устойчивые морозы продолжаются обычно 153 дня, с 4 ноября по 5 апреля. Период с отрицательными температурами длится 179 дней - с 20 октября по 16 апреля, их сумма составляет $-2858^{\circ} \mathrm{C}$. Период с температурами ниже минус $15^{\circ} \mathrm{C}$ наблюдается с 25 ноября по 13 марта, то есть 109 дней. Сумма отрицательных температур ниже минус $15^{0}$ составляет $-2273^{0} \mathrm{C}$, а ниже минус $20^{\circ} \mathrm{C}-1668^{0} \mathrm{C}$ (с 13 декабря по 23 февраля).

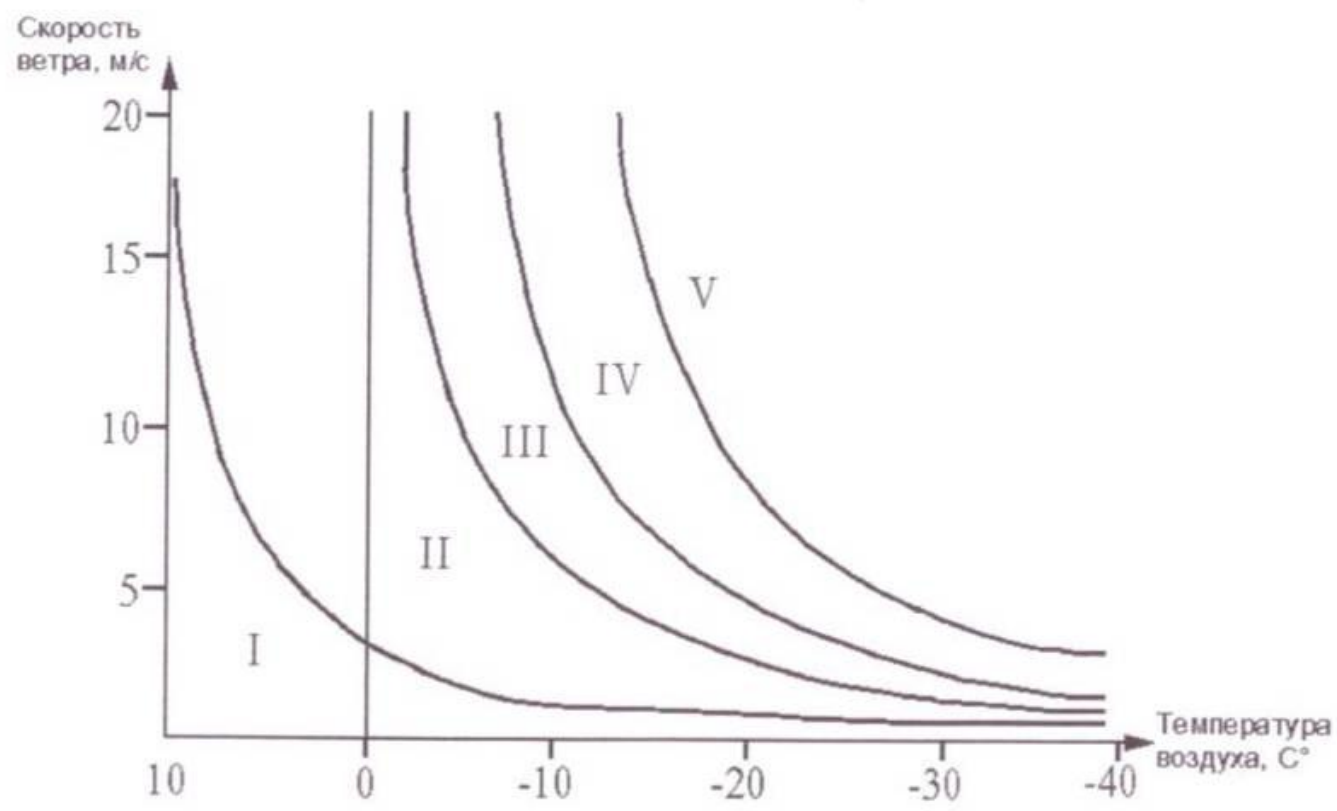

Рис. 42. Пять зон (I-V) совместного воздействия ветра и температуры на организм человека

Отопительный сезон в городе длится 221 день, средняя температура отопительного сезона минус $12,1^{0} \mathrm{C}$, расчетная зимняя вентиляционная температура составляет $26^{\circ} \mathrm{C}$. Это средняя температура наиболее холодной части отопительного периода, составляющей $15 \%$ его длительности [65]. Расчетная температура самой холодной пятидневки минус $41^{0} \mathrm{C}$. Для сравнения: в УстьКаменогорске она равна минус $33^{\circ} \mathrm{C}$, Катон-Карагае минус $31^{\circ} \mathrm{C}$, в Риддере минус $29^{\circ} \mathrm{C}$. Если учесть, что синоптическая ситуация в самую холодную пятидневку Зыряновска, Катон-Карагая и Риддера одна и та же, но в Катон-Карагае (1080 м) температура оказывается на 
$10^{0} \mathrm{C}$, а в Риддере (809 м) на $12^{0} \mathrm{C}$ выше, чем в Зыряновске (457 м), это объясняется наличием в Зыряновске мощной температурной инверсией. Расчетный вертикальный градиент температуры между Зыряновском и Катон-Карагаем составляет минус $1,6^{\circ} \mathrm{C}$, а между Зыряновском и Риддером минус $2,6^{\circ} \mathrm{C}$ на 100 м поднятия. Интенсивное охлаждение (промерзание) массивных ограждающих конструкций (стен) происходит, если низкая температура наружного воздуха держится в течение пяти дней подряд (эта информация нужна как для строителей, так и для экологов).

Сильные температурные инверсии отмечаются во все зимние месяцы (см. табл. 23). Инверсии при сильно морозной погоде с радиационным туманом обусловливают накопление промышленных выбросов в нижних слоях атмосферы в самом городе и его окрестностях. Низкие зимние температуры являются причиной высокой относительной влажности воздуха, средняя месячная ее величина колеблется от 79 в феврале до $83 \%$ в ноябре. Увеличение в атмосфере ядер конденсации за счет загрязнения часто приводит к возникновению туманов, которые в таких условиях является смогом. В среднем за год в Зыряновске насчитывается 77 дней с туманом, причем 55 из них приходится на зиму. Наибольшее число дней с туманом составило 115, из них 77 - в холодный период. С декабря по февраль преобладает значительно морозная и сильно морозная погода, в теплые зимы - умеренно, значительно и слабо морозная, в холодные - сильно и жестоко морозная погода - зима (1968-1969 гг.) (см. табл. 49).

На холодный период приходится 203 мм или 36\% годовой суммы осадков. Снегопады обычно бывают при штилях либо при слабых ветрах. Метели для Зыряновской котловины не характерны. За зиму в среднем насчитывается 7 дней с метелью. Устойчивый снежный покров лежит с 4 ноября по 21 апреля. Средняя декадная высота снежного покрова по постоянной рейке (местоположение открытое) во второй декаде марта достигает максимума и составляет 80 см. Из наибольших значений за зиму: средняя высота 86 см, максимальная - 132 см, минимальная - 47 см (период наблюдений: 1936-1981 гг.) [92] Высота снежного покрова за этот же период наблюдается по снегосъемкам на последний день декады (Зыряновск, поле) - средняя из наибольших - 92, максимальная -139, минимальная - 50 см, плотность снежного покрова - средняя при наибольшей декадной высоте составляет 208 кг/м³ (табл. 51). 
Даты появления исхода снежного покрова, образования и разрушения устойчивого снежного покрова Юго-Западного Алтая

\begin{tabular}{|c|c|c|c|c|c|c|c|c|c|c|c|c|c|}
\hline \multirow{2}{*}{ Станция } & \multirow{2}{*}{$\begin{array}{c}\text { Число } \\
\text { дней со } \\
\text { снежны } \\
\text { м покр. }\end{array}$} & \multicolumn{3}{|c|}{$\begin{array}{c}\text { Дата появления } \\
\text { снежного покрова }\end{array}$} & \multicolumn{3}{|c|}{$\begin{array}{c}\text { Дата образования } \\
\text { устойчивого снежного } \\
\text { покрова }\end{array}$} & \multicolumn{3}{|c|}{$\begin{array}{c}\text { Дата разрушения } \\
\text { устойчивого снежного } \\
\text { покрова }\end{array}$} & \multicolumn{3}{|c|}{$\begin{array}{c}\text { Дата схода снежного } \\
\text { покрова }\end{array}$} \\
\hline & & $\begin{array}{c}\text { Сред- } \\
\text { няя }\end{array}$ & Ранняя & $\begin{array}{c}\text { Позд- } \\
\text { няя }\end{array}$ & $\begin{array}{c}\text { Сред- } \\
\text { няя }\end{array}$ & Ранняя & $\begin{array}{c}\text { Позд- } \\
\text { няя }\end{array}$ & $\begin{array}{c}\text { Сред- } \\
\text { няя }\end{array}$ & Ранняя & $\begin{array}{c}\text { Позд- } \\
\text { няя }\end{array}$ & $\begin{array}{c}\text { Сред- } \\
\text { няя }\end{array}$ & Ранняя & $\begin{array}{c}\text { Позд- } \\
\text { няя }\end{array}$ \\
\hline Шемонаиха & 162 & 20. $X$ & $5 . \mathrm{X}$ & 7.XI & 8.XI & $13 . X$ & 13.XII & 11.IV & 18.III & $11 . \mathrm{V}$ & 19.IV & 29.III & $20 . \mathrm{V}$ \\
\hline Риддер & 179 & 7.X & 21.IX & 3.XI & 29.X & $8 . X$ & 10.XI & 13.IV & 28.III & $3 . \mathrm{V}$ & $4 . \mathrm{V}$ & $6 . I V$ & 9.VI \\
\hline Усть-Каменогорск & 153 & 21.X & 10.IX & 8.XI & 12.XI & $24 . X$ & XII & 31.III & 14.III & 25.IV & 11.IV & 21.III & $18 . \mathrm{V}$ \\
\hline Пос. Северный. & 176 & $10 . X$ & 14.IX & $26 . X$ & 1.XI & $13 . \mathrm{X}$ & $28 . \mathrm{XI}$ & 14.IV & 28.III & 25.IV & 28.IV & 9.IV & $20 . \mathrm{V}$ \\
\hline Зыряновское & 169 & $24 . X$ & 30.IX & $6 . \mathrm{XI}$ & 4.XI & $25 . X$ & $20 . \mathrm{XI}$ & 19.IV & $5 . I V$ & $10 . \mathrm{V}$ & 21.IV & $5 . I V$ & $20 . \mathrm{V}$ \\
\hline Большенарымское & 159 & $23 . X$ & $1 . X$ & 12.XI & 9.XI & $24 . X$ & 10.XII & 10.IV & 27.III & 24.IV & 17.IV & 31.III & $15 . \mathrm{V}$ \\
\hline Катон-Карагай & 168 & $14 . X$ & 6.IX & $3 . \mathrm{XI}$ & 3.XI & $8 . X$ & $1 . \mathrm{I}$ & $6 . I V$ & 1.III & 3.IV & 26.IV & 24.III & 13.VI \\
\hline Самарка & 154 & 29.X & $13 . \mathrm{X}$ & 17.XI & 9.XI & $18 . \mathrm{X}$ & 11.XII & 8.IV & 25.III & 26.IV & 10.IV & 25.III & 30.IV \\
\hline Пос. Орловский. & 169 & $26 . X$ & 30.IX & 22.XI & 5.XI & $15 . \mathrm{X}$ & $30 . \mathrm{XI}$ & 20.IV & 31.III & $8 . \mathrm{V}$ & 23.IV & 31.III & $15 . \mathrm{V}$ \\
\hline $\begin{array}{l}\text { Курчум } \\
\text { (Кумашино) }\end{array}$ & 144 & 31.X & 2.X & 20.XI & 14.XI & 31.X & 13.XII & 1.IV & 17.III & 20.IV & 8.IV & 17.III & $10 . \mathrm{V}$ \\
\hline Буран & 127 & 3.XI & 11.X & 26.XI & 21.XI & $30 . X$ & 17.XII & 20.III & 29.I & 21.IV & 30.III & 27.II & 26.IV \\
\hline Тополев Мыс & 133 & 7.XI & $23 . X$ & 3.XII & $24 . \mathrm{XI}$ & $3 . \mathrm{XI}$ & 25.XII & 28.III & 28.II & 19.IV & 1.IV & 17.III & 21.IV \\
\hline Зайсан & 143 & $26 . X$ & 25.IX & $26 . X I$ & $15 . \mathrm{XI}$ & $29>X$ & 17.XII & 31.III & 12.III & 20.IV & 7.IV & 19.III & $15 . \mathrm{V}$ \\
\hline
\end{tabular}


Зима в Зыряновске и его окрестностях умеренно суровая, снежная, с преобладанием ясной погоды в особенности по нижней облачности, с исключительно сильно выраженной инверсией температуры. Характерна слабая продуваемость ландшафтов.

В календарных сроках весна продолжается с 1 апреля по 31 мая. В метеорологии начало весны связано с переходом среднесуточной температуры через $0^{0}$. Для Зыряновска и его окрестностей он осуществляется в среднем 11-16 апреля. Окончание весны относят к переходу температуры через $15^{0} \mathrm{C}-$ в среднем от 28 мая до 5 июня. Весной с увеличением высоты Солнца над горизонтом растет продолжительность дня, суммарная радиация, радиационный баланс и, как следствие, температура и влагосодержание воздуха. Если 22 марта полуденная высота Солнца $\left(\mathrm{h}_{\mathrm{o}}\right)$ на $50^{\circ}$ с. ш. равна $40^{\circ}$ и день длится 12 ч., то 15 апреля $\mathrm{h}_{0}$ составляет 49,3 ${ }^{0}$, продолжительность дня 13 ч. 34 мин., 15 мая $\mathrm{h}_{0}-58,6^{0}$, день длится 15 ч. 15 мин., 31 мая полуденная высота Солнца $-61,7^{0}$, продолжительность дня 15 ч. 50 мин.

Суммарная радиация в апреле в Зыряновске и окрестностях составляет 504-416, в мае - 633-680 МДж/м² (см. табл. 5). Средняя месячная температура воздуха $+1,5^{\circ} \mathrm{C}$, в мае $+12,1^{0} \mathrm{C}$. Для сравнения - в Большенарыме соответственно 4,3 и $13,3^{0} \mathrm{C}$. Влагосодержание в

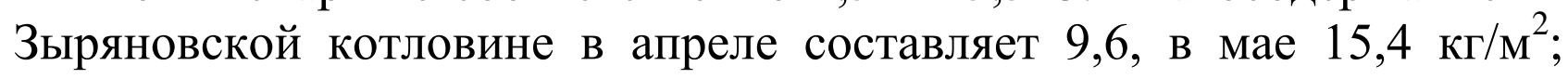
атмосферные осадки в течение весны увеличиваются от 35 мм в апреле и до 56 мм в мае. Средняя дата последнего заморозка в Зыряновске отмечена 25 мая, а самая ранняя 21-22 апреля (наблюдалась в 1967 г.).

Быстрое нарастание температуры воздуха приводит к понижению его относительной влажности, так как почва не прогрета, испарение влаги незначительно.

В течение года в мае самая низкая относительная влажность $60 \%$, а дефицит насыщения составляет в апреле 2,6, в мае 7,8 гПа (табл. 46). Весенне-летние засухи чаще бывают в мае, чем в июне. Продолжительность солнечного сияния в апреле составляет 229, в мае - 268 ч., в Большенарыме соответственно 241 и 299 ч. Наблюдаемая продолжительность солнечного сияния в Зыряновской котловине весной составляет 57-67\% от возможной, в то время как в Киеве под этой же широтой она составляет только 39-54\% (см. табл. 4). Весной, в связи с увеличением повторяемости циклонов в сравнении с зимним сезоном, возрастает средняя скорость ветра до 
1,0 м/с в апреле и до 1,7 м/с в мае. В течение всего сезона возможны заморозки и резкие понижения температуры. Средний из абсолютных минимумов температуры воздуха наблюдался в апреле до минус 17, в мае до минус $4^{0} \mathrm{C}$. Возможны и значительные повышения температуры: так, средний из абсолютных максимумов температуры воздуха в апреле может достигать 20 , а в мае $-30^{\circ} \mathrm{C}$. Резкие снижения температуры воздуха связаны с адвекцией холода (притоком с большими скоростями арктического воздуха), и, наоборот, адвекция тропического воздуха с юго-запада и фёновые процессы обусловливают аномально высокие температуры воздуха весной.

Итак, весна вЗыряновском низкогорье, солнечная, со штилем и слабыми ветрами, с заморозками, прохладная с туманами в первой половине и теплая, более ветреная, с грозами и фёнами во второй.

Летом приток солнечной радиации, особенно в июне и июле, соизмерим с притоком тепла на экваторе. Высота Солнца в полдень в окрестностях Зыряновска составляет $63,6^{0}$, продолжительность дня 16 ч., на экваторе соответственно 66,5 и 12 ч. Суммарная радиация за три месяца (июнь-август) равна 2077 МДж/м², это - 42\% от годовой, радиационный баланс 1083 МДж/м², или 58\% от его годовой величины. Суммарная радиация определяет уровень дневных и средних месячных температур. С радиационным балансом в тесной связи находится сумма эффективных температур $\left(\Sigma \mathrm{t}>10^{0} \mathrm{C}\right)$. Средняя месячная температура летом колеблется от 16,4 до $18,9^{0} \mathrm{C}$ (см. табл. 23). Средняя температура воздуха в 13 ч. может быть 26$28^{0} \mathrm{C}$, суточная амплитуда температуры воздуха $16-17^{0} \mathrm{C}$ (табл. 24). Максимальные температуры - от 33 до $40^{\circ} \mathrm{C}$ за счет прогрева в условиях антициклонов, а также за счет адвекции из Средней Азии континентального тропического воздуха. Сумма эффективных температур за лето составляет $1652^{\circ} \mathrm{C}$ за теплый период. Абсолютная влажность воздуха летом наибольшая в году и составляет в июне -

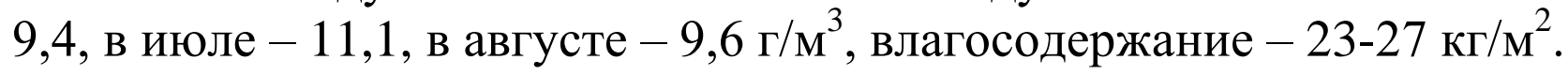

Зыряновская котловина находится под воздействием размытого барического поля. Малы горизонтальные градиенты давления и скорости ветра, средние не превышают 1 м/сек. Лето солнечное, повторяемость пасмурного состояния неба (8-10 баллов) по общей облачности 35-41\%, по нижней облачности - всего лишь 16-19\%. Преобладают теплая $\left(12,5-17,4^{0} \mathrm{C}\right)$, значительно теплая $\left(17,5-22,4^{0} \mathrm{C}\right)$, жаркая $\left(22,5-27,4^{0} \mathrm{C}\right)$ погода. При этом на значительно теплую погоду 
в июне приходится примерно 40, в июле - 60, в августе - 30\% от общего числа дней.

Летние осадки составляют лишь 30\% годовой суммы; суммы осадков с поправками на смачивание: за год - 605 мм, в июне - 60, в июле - 72, в августе - 54 мм [92]. Средние максимальные суточные осадки составляют: в июне - 17, в июле - 20, в августе - 15 мм, средние за год - 30 мм в сутки. Дожди, в основном, выпадают при прохождении фронтальных разделов циклонов, из слоисто-дождевых $\left(\mathrm{N}_{\mathrm{s}}\right)$, кучево-дождевых - грозовых $\left(\mathrm{C}_{\mathrm{B}}\right)$ облаков. С кучево-дождевыми облаками отмечаются ливни с грозами. В июне и августе в среднем насчитывается 7-8 дней с грозой, а в июле - 11. При активизации грозовой деятельности в отдельные месяцы бывает с грозой 13-18 дней [71]. В среднем, в северо-восточной половине Зыряновского низкогорья, за лето на площадь 100 км$^{2}$ приходится до 400-700 грозовых разрядов. Атмосферная засушливость не характерна для Зыряновска и его окрестностей (табл. 46).

Осень - сентябрь и октябрь. Переход средней суточной температуры воздуха через $15^{\circ} \mathrm{C}$ в среднем происходит 28 августа, через $10^{\circ} \mathrm{C}-8$ сентября. Спадает жара. Высота Солнца 23 сентября составляет $40^{\circ}$, день длится 12 ч. В сентябре стоит золотая осень, еще часты периоды длительной (от 7 до 10 дней) ясной, тихой теплой погоды - «бабьего лета». При средней месячной температуре $10,5^{0} \mathrm{C}$, средняя максимальная температура составляет $20,0^{\circ} \mathrm{C}$, а средняя минимальная - $2,5^{0}$. Но можно ежегодно ожидать снижение температуры воздуха до минус $5^{0} \mathrm{C}$ и повышения до $28^{0} \mathrm{C}$ (см. табл. 23). В сентябре, в течение первых двух декад, продолжает нарастать сумма средних суточных температур выше $10^{\circ} \mathrm{C}$. На последний день третьей декады августа $\Sigma \mathrm{t}^{0}>10^{0} \mathrm{C}$ составляет $1986^{0}$, а на последний день второй декады сентября она уже достигает $2200^{\circ}$. В сентябре атмосфера еще богата влагой: абсолютная влажность равна 6,5 г/ $\mathrm{m}^{3}$,

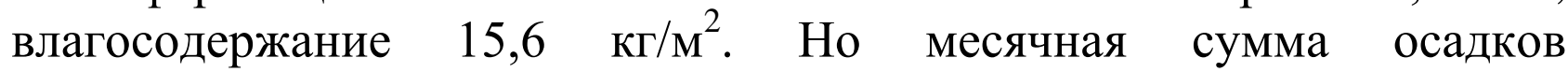
сравнительно мала: 39 мм или 7\% годовой суммы, хотя соседние месяцы получают 9\% (см. рис. 38). Повторяемость пасмурного неба (8-10 баллов) по общей облачности 40, по нижней - всего $21 \%$.

В октябре Солнце опускается ниже над горизонтом, короче становится день: 15 октября в полдень высота Солнца составляет $31^{0} 52^{\prime}$, а продолжительность дня - 10 ч. 40 мин. (см. приложение II). Резко, на $8,3^{0} \mathrm{C}$ снизилась средняя температура воздуха, она составляет только $2,2^{0} \mathrm{C}$. В связи с этим уменьшилось 
влагосодержание: $\mathrm{a}\left(\right.$ г $\left./ \mathrm{m}^{3}\right)=4,3$ и w $\left(\kappa г / \mathrm{m}^{2}\right)=10,3$. Но за счет усиления западно-восточного переноса воздушных масс и орографического эффекта возрастает коэффициент влагоиспользования и количество осадков до 54 мм (табл. 47). Для осени характерны жидкие, твердые, смешанные атмосферные осадки. Средние скорости ветра в сентябре и октябре составляют 0,8 м/сек. Средняя дата первого заморозка в Зыряновске и его окрестностях ожидается 2 сентября, самая ранняя 11 августа (1937 г.), самая поздняя - 30 сентября (1911 г.). Средняя продолжительность безморозного периода 95 дней (с 29 мая по 2 сентября). Средняя дата появления снежного покрова 24 октября, самая ранняя - 30 сентября, самая поздняя - 6 ноября (см. табл. 48).

Осень в Зыряновской котловине ясная, теплая, безветренная, засушливая, с осадками ливневого типа и редкими грозами в своей первой половине. Облачность, количество осадков, скорость ветра увеличиваются от сентября к октябрю, при этом происходит резкое понижение температуры воздуха. В октябре средний минимум составляет $12^{\circ} \mathrm{C}$ (см. табл. 23). Происходит перестройка структуры радиационного и теплового баланса подстилающей поверхности на зимний тип, радиационного и циркуляционного режима природных комплексов Зыряновской котловины и всей системы Рудного Алтая.

\title{
3.3. Климат лесов. Сезонная динамика явлений природы
}

\author{
Образуя живой растительный покров \\ земной поверхности, наиболее мощный \\ и наиболее активный, лес является \\ важным биофизическим фактором жизни \\ не только как производитель полезного \\ органического вещества, преимущественно \\ древесины, но и как агент так называемой \\ лесной пертиненции, т.е. распространи- \\ тельного влияния на климат, режим грунто- \\ вых вод и речной сток.
}

Акад. Г.Н. Высоикий,

Лес является элементом географического ландшафта и основным компонентом ресурсов биосферы, выполняя функцию легких для всего живого на Земле.

Экологическая роль леса в промышленных городах и их окрестностях исключительно велика: один гектар лесного массива поглощает в год от пяти до семи тонн углекислого газа. Санитарно- 
гигиеническое значение фитоценозов проявляется через выделение фитонцидов, которые подавляют деятельность болезнетворных бактерий. По фитонцидным свойствам первое место занимают кедровые и пихтовые леса, затем еловые и сосновые фитоценозы. Вполне оправдан опыт лечения больных туберкулезом в сосновом лесу. Экологи и геоботаники утверждают, что в городах ощутимый экологический эффект можно получить, если 20-25\% селитебной площади городов будет занята зелеными насаждениями, при этом две трети насаждений должны быть представлены крупными массивами паркового типа.

Леса являются не только источником чистого воздуха, они играют и противоэрозионную роль, приводя поверхностный сток в грунтовые воды, сохраняя тем самым горные склоны от размыва, а реки от обмеления.

Лес - важный климатообразующий фактор: под его кронами наблюдается меньшая интенсивность солнечных лучей, увеличивается влажность воздуха, затихают ветры, расходуя энергию на раскачивание стволов.

Наука давно отмечала целебные свойства лесного климата: отсутствие ветра, прохладу, высокую относительную влажность и чистоту атмосферы. Область эффективных температур 17,2-21,7 $\mathrm{C}$ при относительной влажности $30-70 \%$ и скорости ветра 0,5 м/сек считается зоной комфорта.

Наибольшее количество дней с комфортными эффективными температурами в темнохвойных лесах Алтая соответствует лучшим горным климатическим курортам [90, 91].

Лес (светлые леса, лесостепи) оказывает эстетическое воздействие на человека, действует успокаивающе на его нервную систему, «красота леса лечит душу» [93].

Формирование лесной флоры сопровождается увеличением разнообразия кустарников, преобладанием в лесу многолетних трав (до $85 \%$ ) за счет сокращения однолетних растений.

Экологический анализ показывает, что в основном лесная флора состоит из мезофитов, но при-сутствуют и другие экологические типы: ксерофиты, мезогиг-рофиты и др. (см. рис. 37). Многочисленные экологические формы в лесной формации гор отличают их от рав-нинных лесов. С этим связано большое видо-вое богатство горных об-ластей. Так, в черневой тайге Рудного Алтая насчитывается 220, в сосновых лесах - 260, в лиственничных - 340 
видов. Леса Юго-Западного Алтая отно-сятся к трем классам формаций: темно-хвойным, светлохвой-ным и лиственным. В лесном поясе Рудного Алтая на хвойные породы приходится до 75\% основных лесообразующих пород, на березо-осиновые с примесью других лиственных пород - 25\%. На большей части территории нижняя граница лесных ландшафтов должна проходить на 100-200 м ниже современной. Так, разнотравно-злаковые степи под пос. Секисовка формируются на месте вырубки березовых и сосновых лесов, а большетравные луга между пос. Черемшанка и пос. Зимовье в бассейне Ульбы, сформированные на подзолистых почвах, возникли на месте вырубок пихтовых лесов [94]. Предгорнонизкогорный район на высотах 350-450 м занят узким поясом осиново-березовых лесов и кустарников, выше он граничит с пихтово-осиновыми лесами и луговыми степями.

Верхняя граница леса претерпела меньшее антропогенное воздействие. Она представлена светолюбивыми породами: кедром, лиственницей, при этом на более сухих почвах произрастают лиственные леса, а на более влажных - кедровые (рис. 43).

Снижение верхней границы леса связано с интенсивным выпасом и вырубкой, прилегающих к пастбищам участков леса [95, с. 57, 89]. Верхняя граница леса в Рудном Алтае проходит на высоте 1900-2000 м. Наблюдения показали, что идет сближение верхней границы леса и снеговой линии, которая в Рудном Алтае

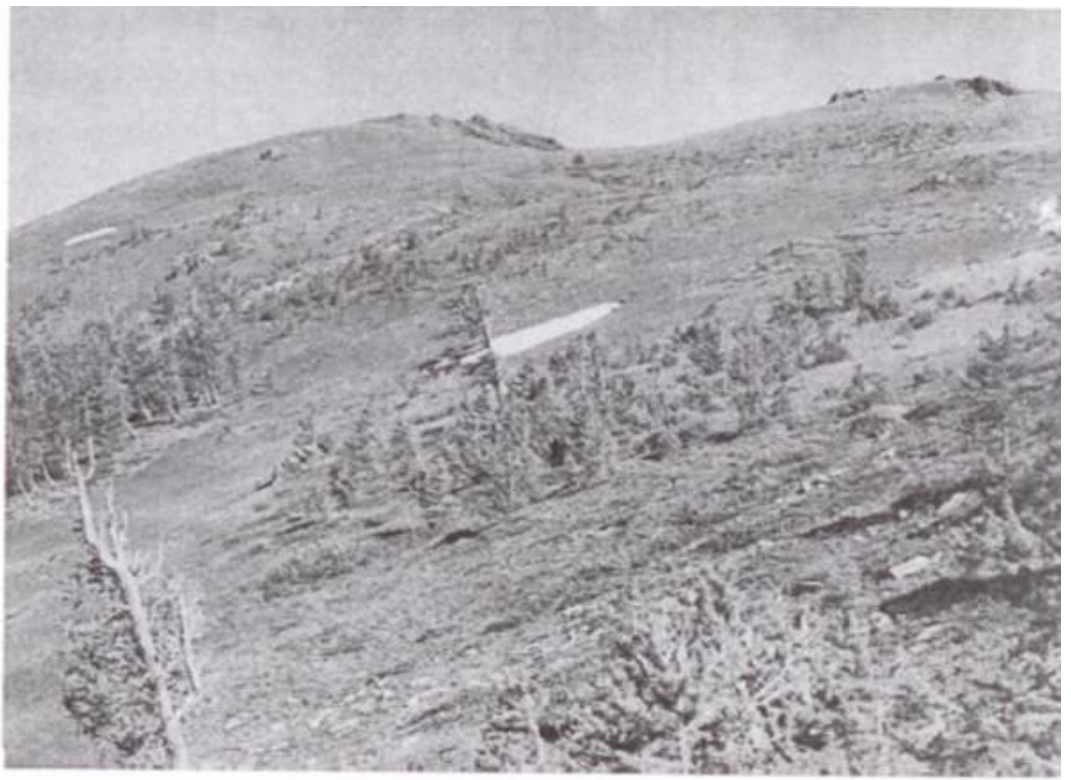

Рис. 43. Верхняя граница леса. Южный Алтай. Хребет Азутау располагается на высоте 2300 м. По мнению М.В. Тронова, сближение этих двух границ указывает на обильное увлажнение региона. На таких участках и вблизи орографических узлов годовая величина осадков состав-ляет 2300-2400 мм, а величина модулей стока - 50-60 л/сек с кв. км [15].

Особенностью видов ландшафтов 381, 389 (см. приложение VIII) является наличие в составе древостоя всех пяти глав-нейших 
хвойных пород, произрастающих в сибир-ской тайге пихты, кедра, лиственницы, ели, сосны (рис. 44). Кедр и лиственница доходят до верхней границы леса, ель и пихта до 1600 м, береза и осина до 1300-1400 м. На Рудном Алтае ель, пихта, кедр появляются на высоте 8001000 м. На высотах 1750-1900 м пихта смешивается с лиственницей и кедром, еще выше растительность приобретает характер криволесья, а затем постепенно переходит в субальпийские, альпийские луга и горные тундры.

\section{Для черневой}

тайги необходимы специфические ус-
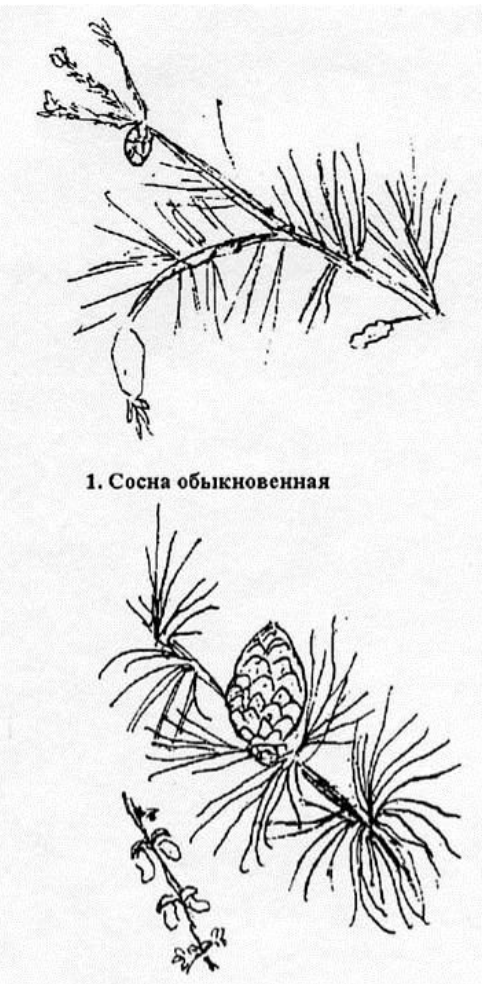

3. Лиственница

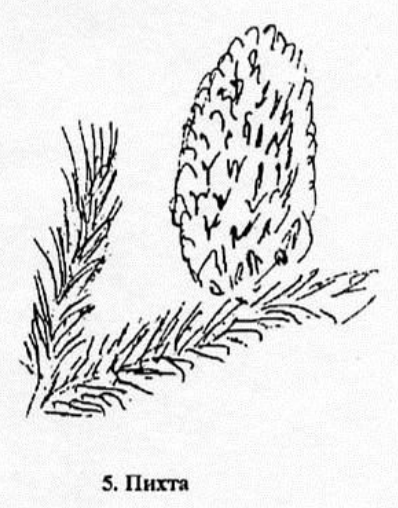

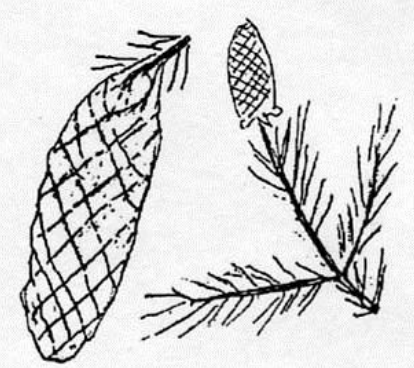

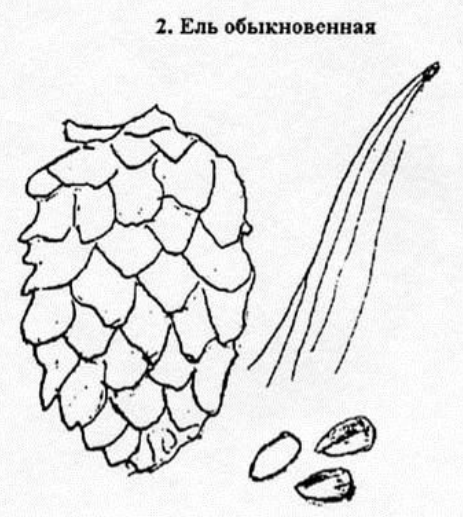

4. Сосна сибирская (кедр)

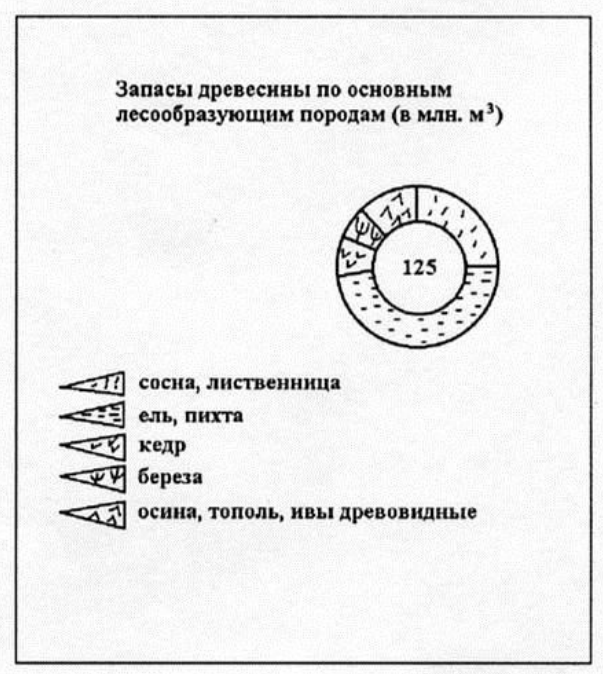

Рис. 44. Основные виды хвойных пород ловия обитания, хорошее увлаж-нение и значитель-ные запасы влаги. B.B. Протопопов считает, что оптимальными являются климатические условия с суммой активных температур выше $10^{\circ} \mathrm{C}$ более $1200^{\circ} \mathrm{C}$, продолжительностью вегетационного периода до 120 дней, средней температурой вегетационного периода $12^{0} \mathrm{C}$; суммой температур воздуха $600^{\circ} \mathrm{C}$ за период с температурой выше $5^{0} \mathrm{C}$, средней температурой июля $16^{0} \mathrm{C}$. Годовое количество осадков в темно-хвойных лесах должно соответствовать 1000-1800 мм, с гидротермическим коэффициентом около 3 , средней месячной 
относительной влажностью не ниже 60-70\% и положительным балансом влаги (см. табл. 44, 45). Только коренные растительные формации имеют подобный тип климата [93].

В Рудном Алтае климатические условия близки к оптимальным для черневой тайги. Там она занимает в основном северные и западные склоны хребтов Тигирецкий, Холзун, Ивановский, Убинский, Ульбинский и Листвяга. По А.В. Куминовой, для черневой тайги характерны:

- $\quad$ преобладание в древостое пихты, осины, подлесок состоит из крупных кустарников - черемухи, рябины, калины;

- в травостое - высокотравье, наличие в нем реликтов, свойственных типовому лесу;

\begin{tabular}{lr}
\multicolumn{1}{r}{ слабое } & раз- \\
витие $\quad$ или & полное \\
отсутствие & напоч- \\
венного & мохового \\
покрова. &
\end{tabular}

В состав растительности входят почти исключительно бореальные виды (северные, таежные). Географический анализ видового состава показывает, что почти половина из 220 видов приходится на долю евразийского ареала формирования и примерно в равной степени на долю голарктического и североазиатского ареалов (рис. 45). В черневой тайге, наряду с преобладанием мезофитов (66\%), большое

Лиственничный лес
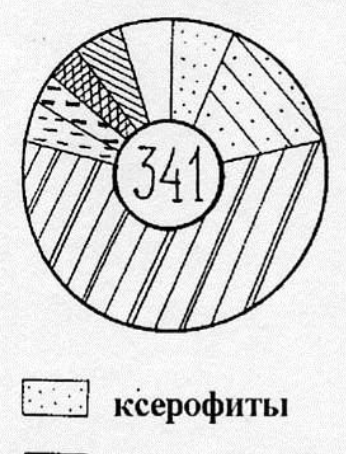

$\therefore$ мезоксерофиты

पाD мезофиты

меㅜㅝ мегигрофиты

Географические спектры флоры ВосточноКазахстанской области

3巨17.6 आIII 42.2 IIIIIIII 31 Лиственничный лес
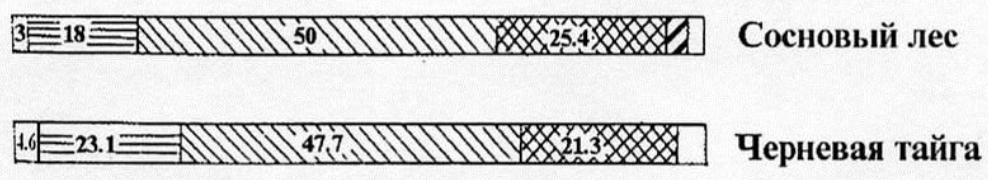

$\therefore$ космополиты голарктические

aili евразийские азиатские DD центрально-азиатские Рис. 45. Экологический состав флоры Юго-Западного Алтая количество 
мезогигрофитов (16\%). Энергично идущие процессы химического выветривания формируют мощный слой слабооподзоленных и неоподзоленных почв с отсутствием лесной подстилки (рис. 46).

Преобладающим типом растительности в ландшафтах 381, 389 являются пихтовые леса, произрастающие на высотах 450-1750 м [99]. Высокая производительность пихтачей наблюдается на хорошо дренированных увалах с тучными суглинистыми почвами в средних ярусах гор на северных склонах. Так, леса Малой Ульбы состоят из ровных стволов высотой до 28-30 м при толщине в 30-40 см с мелкослоистой древесиной, дающей выход отличного комлевого бревна.

На высотах 1000-1200 м радиационный баланс составляет 1,751,80 тыс. МДж/ $\mathrm{M}^{2} \cdot$ год, сумма эффективных температур $1500-1700^{\circ} \mathrm{C}$, годовая величина осадков 800-1500 мм. На более сырых местах, в логах и ущельях, пихта не уступает в росте, но дает рыхлую крупнослоистую древесину. На северных склонах или на вершинах низкогорий произ-растают пихтачи с подлеском из рябины и других лиственных пород. В них хорошо представлен пихтовый подрост, а моховой покров развит слабо. Ближе к поясу гольцов встречаются пихтачи-черничники. Они фор-мируются на мало-мощных и каменистых почвах. Кроме черни-ки, в травянистом покро-ве встречаются па-поротники, герань, незабудки, водо-сбор. Эти пихтачи обычно использу-ются в кА-честве дровяного ма-териала. По долинам рек к пихте при-мешивается ель.

Запасы древесины еловопихтовых лесов в пределах Юго-Западного Алтая оцениваются в 84-91 млн. м³ благоприятных условиях составляет от 5,6 до $10,3 \mathrm{~m}^{3} /$ га. На вырубках пихтовых лесов возобновление идет обычно со сменой пород через березу и осину (пихтачи возобновляются примерно через 80-100 лет).

В Рудном Алтае представлены ландшафты всех вертикальных поясов от степей до нивального пояса. Его территория характеризуется наибольшим увлажнением (до 2000 мм в междуречье Убы и Ульбы на высотах от 1000 до 1500 метров над уровнем моря). На Ивановском Белке, близ Риддера, имеется несколько небольших ледничков, снеговая граница лежит на высоте 2100-2300 м [8], а верхняя граница леса - на 1900-2000 м. 


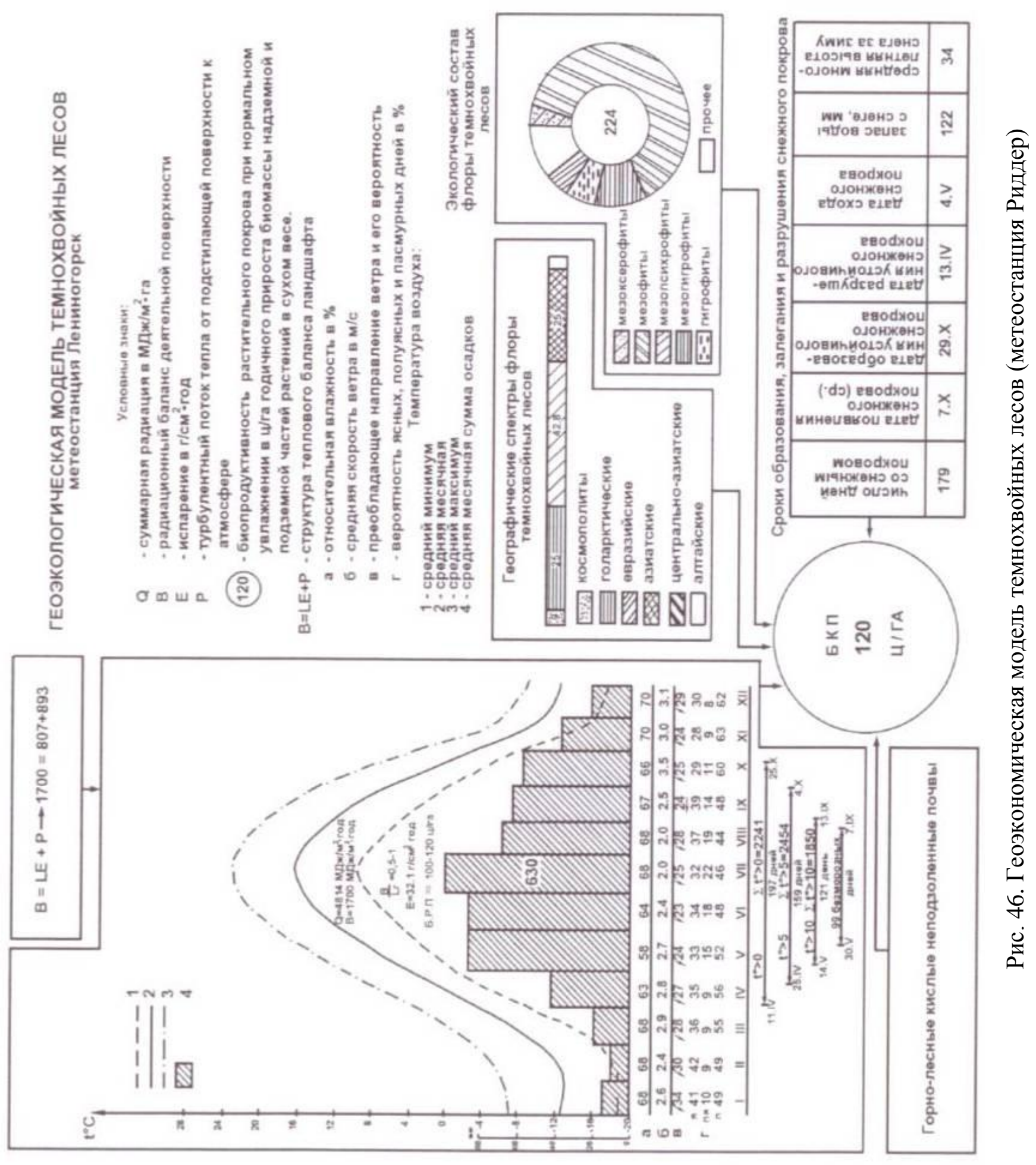


В среднегорье, в пределах Рудного Алтая, нет ни одной метеостанции, кроме метеопоста, расположенного на высоте 1600 метров. Там фиксируются осадки, превышающие 1500 мм в год. Для оценки годовых сумм осадков использованы косвенные наблюдения. О большом увлажнении территории Рудного Алтая свидетельствует разнообразие ландшафтов.

Наиболее разнообразны и богаты ландшафты Глубоковского района - хвойные леса с бонитетом 1-2, реже 3-5. До высот 500 м господствует умеренно-континентальный климат с теплым летом и умеренно холодной зимой. Оптимально зона хвойных лесов характеризуется как область с меньшей континентальностью климата: с умеренно холодной зимой и прохладным летом. Температура июля $15-17^{0} \mathrm{C}$. Сумма эффективных температур на высоте 800 м составляет $2200^{\circ} \mathrm{C}$ (пос. Александровка), а на верхней границе леса только $900^{\circ} \mathrm{C}$. Вегетационный период длится 140-160 дней, безморозный - до 100 дней (см. рис. 46). Максимум осадков выпадает в летне-осенний период. Средняя температура на склонах гор в январе составляет минус $15-12^{0} \mathrm{C}$. Все лесные ландшафты Глубоковского района могут быть отнесены к рекреационной зоне зимнего отдыха, туризма, охоты. Выше 2000 метров располагается холодный пояс, где эффективные температуры меньше $800^{\circ} \mathrm{C}$, средняя температура июня ниже $10^{\circ} \mathrm{C}$. Это район альпийских и снежно-ледниковых ландшафтов, для которых характерны холодные ветреные погоды, вегетационный период менее трех месяцев.

Зимой для всего района типичны инверсии температуры, большая повторяемость штилей (до 70\% по отдельным понижениям в рельефе), малые скорости ветра, но солнца сравнительно много. Ландшафты характеризуются богатством видов растительного и животного мира. Наиболее четко представлены растительные ассоциации леса, кустарников, луго-степей.

Интенсивное развитие промышленности и сельского хозяйства в низкогорье и среднегорье района без учета природных особенностей привело к загрязнению всех компонентов ландшафта: ухудшилось качество воздуха, питьевой воды, продуктов питания, что сказалось на здоровье самого человека. Демографические процессы этого региона характеризуются отрицательными аномалиями.

Нынешнее состояние экологической обстановки на территории Рудного Алтая характеризуется крайней неустойчивостью - от 
экологически благоприятной на востоке в районах девственной тайги до чрезвычайно опасной для проживания в районах, прилегающих к г. Риддеру и в полосе шириной около 30 км вдоль правого берега реки Иртыш. Именно на этих территориях расположен ряд поселков с предприятиями горнодобывающей, горноперерабатывающей и металлургической промышленности: Иртышский химикометаллургический завод, Иртышский медеплавильный завод, УстьКаменогорский и Риддерский промышленные комплексы и др. Это еще одна зона экологического поражения с негативными изменениями в природной среде.

В окрестностях Глубокого, Усть-Каменогорска, Риддера накоплены большие объемы промышленных отходов. Использование вторичного сырья, то есть рекуперация, становится важнейшей проблемой региона и, в частности, Глубоковского района. Комплексное использование природных ресурсов и сырья несколько ослабит напряжение антропогенных воздействий на геоэкологические процессы и будет соответствовать развитию тенденции перехода к рациональному природопользованию [96-99].

Переход к стратегии устойчивого развития, включающей экологическую регламентацию хозяйственной деятельности, ограничение вредных воздействий, утилизацию отходов производства и т.д., должен найти конкретное воплощение не только на государственном уровне, но и на уровне муниципальных и частных природопользователей.

Экологические проблемы региона могут обостриться в результате начавшегося глобального потепления нижних слоев атмосферы. Изменение климата носит региональный характер. В частности, в Западной Европе на широтах Рудного Алтая идет потепление летнего сезона при резком уменьшении осадков, а в Рудном Алтае потепление идет за счет зимнего и весеннего сезонов и усиления засушливости летнего. Из 19 лет наблюдений (1981-2000 гг.) в шестнадцати случаях лето было сухим в Усть-Каменогорске и в пятнадцати случаях - в Риддере. Общее потепление климата в глубине континента сопровождается учащением засух.

Светлохвойные формации на Юго-Западном Алтае представлены сосновыми и лиственничными лесами. Сосновые леса занимают небольшие площади. Они встречаются на террасах Иртыша ниже г. Усть-Каменогорска, на каменистых склонах некоторых водоразделов, сосново-березовые леса - в долине Ульбы; 
реликтовый бор - в Лениногорской депрессии. Сосновые леса распространены также по Калбинскому хребту. Район остепненных калбинских кустарниковых сосновых лесов представлен ландшафтами 378 (приложение VIII) - низкогорье холмисто увалистое, сложенное гранитами, с сосновыми лесами на горных каштановых почвах. Березовые леса, тополевники и ивняки распространены в межгорных долинах, по горным речкам [78, 93].

На Калбинском хребте (северный склон горы Медведка) сохранился уникальный памятник природы - Синегорская пихтовая роща. «Остров» пихты занимает площадь около 50 га. Сопутствующие нагорным соснякам фитоценозы образованы растительностью, присущей сосновым лесам большей части Евразии (см. рис. 45). В сосновом лесу преобладают мезофиты и мезоксерофиты, ареалы формирования евразийского и азиатского видов. В подлеске присутствуют жимолость татарская, шиповник, карагана, в местах с большим увлажнением прибавляется смородина. В травостое доминируют ковыль, мятлик, полыни, луки, реже осоки, чина, ирис и др. Запас древесины в наиболее продуктивных лесах достигает $200 \mathrm{~m}^{3} /$ га.

В связи с освоением ландшафтов Калбинского нагорья в рекреационных целях остановимся на климатических условиях. Рассматриваемые ландшафты расположены под $49,5^{0}$ с. ш. Суммарная солнечная радиация при действительных условиях облачности, по расчетным данным, составляет 4,96-5,03 тыс. МДж/м² в год, в летние месяцы она колеблется в среднем от 620 до 720 МДж/м² в месяц, в апреле-мае 400-650, в сентябре-октябре - 300-480 (табл. 5). Радиационный баланс подстилающей поверхности на высотах 500 м над у. м. порядка 1,84 тыс. МДж/м², на 1000 м - 1,75 тыс., на 1500 м - 1,65 МДж/м² в год (табл. 45). Атмосферные осадки нарастают с высотой. На высотах 500 м они составляют 360-400 мм (Самарка), на высоте 1000 м - 500-600 мм, на высоте 1500 м достигают 700-800 мм в год (см. табл. 47).

В течение года над Калбинским нагорьем на юго-западные потоки воздуха приходится 39, на западные 38 , северо-западные и северные $23 \%$ их общей повторяемости (табл. 14). В ближайшей от областного центра зоне отдыха для горожан природные ландшафты Калбы являются наиболее экологически чистыми, так как только с северо-западными и северными потоками может осуществляться 
вынос атмосферных загрязнений из промышленной зоны Рудного Алтая в район Калбы.

Радиационные индексы сухости $\left(\frac{B}{L r}\right)$ соответствуют: 2,0 типичные степи, 1,2 - лесостепные ландшафты, 0,9-1,0 - лесные ландшафты [20] .

О структуре теплового баланса подстилающей поверхности ландшафтов в окрестностях метеостанции Самарка можно судить по данным табл. 11.

Испаряемость на северо-востоке Калбы в лесах превышает осадки на 100-150, в лесостепных и степных ландшафтах - на 200-300 мм, что указывает на общую засушливость климата. Лето на Калбе теплое, его средняя температура колеблется от 19 до $21,5^{0} \mathrm{C}$ (Самарка), на высотах более 1000 м над у.м. от 15 до $18^{0} \mathrm{C}$. В апреле по метеостанциям Георгиевка (418 м над у.м.) и Самарка (500 м над у.м.) средняя температура воздуха составляет 3,4 и $4,9^{0} \mathrm{C}$, в мае соответственно 11,8 и $13-14^{0} \mathrm{C}$. Температуры осени по этим же метеостанциям: сентябрь 11,5 и $13,7^{0} \mathrm{C}$; октябрь 3,7 и $4,9^{0} \mathrm{C}$.

Вегетационный период длится 180-170 дней (15 апреля - 15 октября - Самарка); сумма температур выше $5^{0} \mathrm{C}$ составляет от 3000 на уровне 500 м до 2200 на высотах 1000-1100 м. Сумма эффективных температур $\left(\Sigma \mathrm{t}^{0}>10\right)$ на уровне $2800-1800^{0} \mathrm{C}$. Безморозный период в среднем длится 130 дней, в отдельные годы от 87 до 164 дней.

Зимний период со средними суточными температурами ниже нуля на высотах до 800 м над у.м. может продолжаться от 150 до 160 дней - с третьей декады октября до первой декады апреля, до 190-200 дней в наиболее высокой части хребта (см. табл. 45). Устойчивый снежный покров в северных предгорьях формируется при средней суточной температуре минус $5^{0} \mathrm{C}$, средняя дата разрушения устойчивого снежного покрова совпадает с переходом средней суточной температуры через $0^{0}$. Динамика снежного покрова представлена в табл. 47. Период с устойчивым снежным покровом в северных предгорьях длится 153 дня (с 12 ноября по 2 апреля), продолжительность этого периода на каждые 100 м высоты увеличивается в среднем на 4-5 суток. По снегосъемкам в лесных и лесостепных ландшафтах средняя из наибольших высот снежного покрова за зиму, по данным В.С. Ревякина, составляет 70-100, в степях - 30-70, в сухих степях - 20-30 см. Обеспеченность 
наибольшей декадной высоты снежного покрова в районе Самарки 60 см, что составляет 15,3\%, в Усть-Каменогорске - 50 см или 25,3\% $[8,49,85]$.

По продолжительности залегания и высоте снежного покрова зимы в предгорьях Калбы относятся к умеренно-снежным. На наветренных склонах выше 750 м над у. м. зимы следует относить к значительно снежным. Коэффициент снежности, по И.М. Осокину, от 20 до 40. Он характеризует умеренно снежные, от 40 до 70 - значительно снежные зимы [86].

Калбинские горы зимой находятся под центральной частью западного отрога Азиатского антициклона. В связи с этим на высотах 600-1400 м наблюдается пояс антициклонических фёнов, с температурами минус 13 - минус $14^{0} \mathrm{C}$. Нисходящие токи обеспечивают ясную тихую погоду, пояс является наиболее комфортным для рекреации.

Вертикальные градиенты температуры составляют минус $0,6^{0}$ минус $0,8^{0}$ на 100 м поднятия, атмосфера характеризуется устойчивой стратификацией. Проветривание ландшафтов слабое. Средние скорости ветра зимой не превышают 2 м/сек, в теплый период от 1,6 до 2,4 м/сек. Число дней с сильными ветрами (более15 м/сек) составляет на севере и востоке нагорья до 20, на высотах более 1000 м до 30 дней в году.

Летом ясная, теплая погода со слабыми ветрами, с редкими ливневыми осадками, с грозами обусловливается распространением на исследуемую территорию, и особенно на районы Калбы и Южного Алтая, Иранской термической депрессии. На Рудном Алтае и Калбе в течение всего года 80-90\% погод для рекреационных целей являются комфортными [90].

Калба имеет большие ресурсы тепла и света. Число часов солнечного сияния за год превышает 2400, число ясных дней за этот же период - 180. При общей облачности 5-6 баллов, вероятность повторяемости нижней облачности 0-2 балла по месяцам колеблется от 60 до $70 \%$.

Необходимо учитывать, что в широких долинах, межгорных понижениях часты штили, преобладают слабые ветры, четко выражены инверсии температуры (особенно зимой). Подобные условия могут обусловливать высокий потенциал загрязнения атмосферы в промышленных зонах. 
Лиственничные леса встречаются в горах Южного Алтая и Саура, преимущественно на склонах северных экспозиций. На Нарымском хребте леса начинаются с абсолютной высоты 1000-1050 и поднимаются до 2150-2250 м. На хребтах Курчумском и Азутау с 1300-1400 до 2300-2500 м, в горах Саура на высотах 1700-2600 м [93].

Основной лесообразующей породой является лиственница сибирская. На Сауре она образует чистые древостои, на Южном Алтае как чистые, так и смешанные насаждения с примесью кедра, пихты, ели, березы и осины.

Растительный покров Южного Алтая и Саура характеризуется сочетанием двух основных типов: леса и степи.

Кедр сибирский наиболее распространен в верхней части бассейна p. Бухтармы. Пихта и ель одиночными деревьями встречаются по тенистым логам бассейна р. Бухтарма и оз. Маркаколь. Верхнюю границу леса образуют кедр с лиственницей. На ландшафтной карте им соответствуют виды 390 и 387.

Ниже приводится описание (по В.В. Сапожникову) лиственничных лесов, структура которых напоминает парк (см. рис. 44, 45) [100].

Парковые лиственничные леса располагаются по долинам рек, шлейфам гор и пологим склонам гор. Древесный ярус парковых лиственничных лесов представлен крупными, взрослыми деревьями, принадлежащими к высокопродуктивным лесам в возрасте 60-80 лет, произрастающими на значительном расстоянии друг от друга. В результате чего развитие кроны не стесняется, и ветви широко раскинуты в разные стороны. Под пологом деревьев кустарниковый подлесок, как правило, отсутствует или встречается единично. Характерным ярусом выступает хорошо развитый травянистый покров.

На северных склонах хребта Южного Алтая лиственница господствует и предпочитает умеренно влажные, не слишком крутые склоны на горно-лесных оподзоленных почвах, нередко лиственница выходит на границу леса одна или вместе с кедром. Возраст лиственничных лесов составляет - 150-200 лет. Стволы в поперечнике обычно 50-60 см, в наиболее богатых теплом экологических нишах стволы достигают в поперечнике до 1,5 метров. Лиственничники - редкие леса (ландшафтный вид 390), между стволов густые заросли образуют разные виды таволги, к ним 
присоединяются малина, калина, бузина, смородина, боярышник, карагана и др.

Система гор Южного Алтая вклинивается в зону сухих степей, полупустынь и пустынь (см. табл. 45). Зимой располагается под отрогом Азиатского антициклона, летом часто оказывается на северозападной периферии Иранской депрессии. В обоих случаях формируются малоградиентные поля, в связи с чем, природные ландшафты горных степей и широких долин слабо продуваемы. Средние скорости ветра по месяцам практически не превышают 2 м/сек: в Большенарыме 1,1-2,4, Орловском поселке 0,4-2,2 (средняя за год 1,1), Самарке 0,8-2,4 (средняя за год - 1,6), Курчуме 1,1-2,9 м/сек (средняя за год - 2,0). При этом велика повторяемость штилей, особенно зимой: в Орловском поселке 60-67, в Самарке 62-74, в Курчуме до 45\% от общего числа наблюдений. Даже в КатонКарагае, для которого характерны стоковые ветры, штили зимой составляют 20-25\%. Летом повторяемость штилей составляет от 20 до $50 \%$. Зимой для региона наиболее характерны восточные и северовосточные ветры, летом - северные и северо-западные.

Южный Алтай богат теплом и светом. При общей облачности в течение года до 5-6 баллов, нижняя в холодный период составляет в среднем по месяцам 0,5-1,7, а летом - 3 балла. Продолжительность солнечного сияния на севере горной системы 2400-2500, на юге 2600-2700 часов в год. Суммарная радиация при безоблачном небе в Самарке 7098, в Орловском поселке 7134, в Буране 7232 МДж/м² год; суммарная солнечная радиация при действительных условиях облачности 5033 в Большенарыме, 4957 - в Катон-Карагае, 5129 - в Курчуме, 5103 МДж/м² год - в Буране (см. табл. 5).

Испаряемость на предгорных станциях колеблется от 946 мм в год в Буране, 952 в Самарке, 845 в Курчуме до 672 в Катон-Караге и 503 мм в Орловском поселке (см. табл. 13). Испаряемость с высотой уменьшается. В зоне лесов баланс влаги положителен, осадки превышают испаряемость. Радиационный баланс на высотах от 400 до 1100 м изменяется от 1,85 до 1,76 МДж/м² год, а радиационный индекс сухости от 2,8 до 1,7 , что соответствует степени увлажнения сухих степей (полупустынь) и степей. Распределение осадков в пространстве показано на картосхемах (см. рис. 27-30). Количество осадков нарастает интенсивно с высот 800-1000 м с приближением к орографическим узлам. Вертикальные градиенты годовых сумм осадков на периферии горной системы составляют 40-60 мм на 100 м 
поднятия, близ горных узлов, начиная с высот более 1500-1600 м они составляют 100-120 мм. Годовые суммы осадков в бассейне p. Курчум достигают 1200-1500 мм в год. В области орографического узла Южного Алтая, Южно-Алтайского центра оледенения осадки, вероятно, превышают 1500 мм в год. В поясе лесов в течение года они выпадают более равномерно, чем в поясе степей. На холодный период приходится $35-40 \%$ годовой суммы. Интенсивный вынужденный подъем воздушного потока по долине к вершине орографического узла приводит к резкому увеличению снегозапасов вверх по долине. По данным А.Д. Дюкарева, снегозапасы истоков в 810 раз выше, чем в приустьевых участках: в истоках Курчума высота снежного покрова 150, близ устья 20 см, на Малой Ульбе в Рудном Алтае соответственно 300 и 30 см [85].

В настоящее время считается установленным факт, что количество осадков в высокогорье в 8-10 раз больше, чем на окружающих равнинах $[8,95]$.

На верхней границе леса 2300-2600 м сумма эффективных температур составляет $900-1000^{\circ}$, средняя температура июля достигает $13^{0} \mathrm{C}$, вегетационный период длится до 3 месяцев. Снеговая линия над южно-алтайским центром оледенения лежит на высоте 2800-3000 м.

С верхней границей леса связана и граница земледелия. Так, вегетационный период в Большенарыме составляет 173 дня (высота 400 м), в Катон-Карагае 170 дней (высота 1100 м). Длительность вегетационного периода увеличена за счет развития фёнов, в Орловском поселке высота такая же, как и в Катон-Карагае, а вегетационный период на Маркаколе 132 дня (высота 1400 м). Если принять, что на каждые 100 м высоты вегетационный период сокращается на 5 дней (градиент оценен по станциям пос. Орловский и Маркаколь), то на уровне верхней границы леса он составит около 80 дней. Такой градиент наблюдается и в других районах Алтая.

По классификации Б.П. Алисова, Южный Алтай относится к области умеренного материкового климата с большими сезонными колебаниями температуры воздуха [74]. Осадки убывают с севера на юг, снежный покров невысокий. По классификации М.И. Будыко и А.А. Григорьева, Южный Алтай - это область теплого климата (суммы эффективных температур 2200) с умеренно суровой и малоснежной зимой [54]. Подобные характеристики больше относятся к ландшафтам степей и лесостепей. По сравнению с 
Рудным Алтаем, районы среднегорья и высокогорья Южного Алтая получают осадков в 1,5-3 раза меньше. Выше верхней границы леса в Южном Алтае их выпадает от 1200 до 1500 мм, а в орографическом узле, вероятно, и более. Это район значительного горного оледенения. Так, на хребте Южный Алтай насчитывается 183 ледника общей площадью 88,4 км², на хребте Сарым-Сакты - 94 ледника,

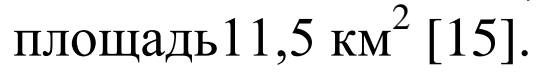

Южный Алтай имеет большие рекреационные возможности. Очень низкие зимние температуры (до минус $27^{\circ} \mathrm{C}$ в Орловском поселке, минус $26^{\circ} \mathrm{C}$ на Маркаколе) наблюдаются лишь в замкнутых котловинах, на склонах гор с высот 1000 и до 3000 м температура января составляет минус 13 , минус $15^{\circ} \mathrm{C}$ при частых штилях. Это район охоты, туризма, альпинизма.

В высокогорье (выше 2000 м, выше верхней границы леса) повсеместно распространены ледниковые формы рельефа - кары, цирки, троги.

Снеговая граница в Рудном Алтае на высотах 2200-2300 м, в Южном от 2600-2800 до 3000 м. Сумма положительных среднесуточных температур в высокогорье не превышает $1000^{\circ} \mathrm{C}$, на уровне снеговой границы $-600-800^{\circ} \mathrm{C}$. На Катунском хребте $(2000 \mathrm{M}$ над уровнем моря) продолжительность периода с положительными температурами составляет до 145 дней, а сумма положительных температур $900^{0}$, на уровне 2600-3000 м соответственно 105-80 дней и сумма температур - 350-200 ${ }^{\circ}$. Верхняя граница леса является индикатором тренда современного климата, в настоящее время с каждым годом она «молодеет», что соответствует отступанию, деградации ледников и снежников $[6,7,8,15]$. Количество осадков в высокогорье колеблется от 1500 до 2500 мм в год.

Большая интенсивность солнечной радиации летом и обильные осадки обусловили формирование богатых субальпийских лугов на склонах гор и заболоченных территорий на выровненных участках поверхности.

Субальпийские луга имеют густой и высокий травостой с ведущим ярусом 100-150 см. Слабо развит напочвенный моховой покров. Основным компонентом растительного покрова являются сложноцветные - маралий корень, бодяк разнолистный, горькуша широколиственная, а также герань белоцветная, огонек алтайский, водосбор, из бобовых - чина, из злаковых - мятлик сибирский, лисохвост и др. 
В высокогорье, выше границы леса, холодный период составляет 220-260 дней. Столь длительный период радиационного выхолаживания и наличие нисходящих токов атмосферы в антициклонах привели к формированию мощной (до 1,5-2,0 км) инверсии температуры воздуха и застоя переохлажденного воздуха в межгорных котловинах. Высокогорный пояс характеризуется нарастанием осадков, увеличением скоростей ветра и характерным перевеванием снега.

Согласно В.С. Ревякину, нарастание снегозапасов идет медленно до высот 1550-1600 м и в поле и в лесу, а затем отмечается скачкообразное увеличение снегозапасов [49]. Вероятно, такое распределение снежного покрова связывается с особенностями региональной циркуляцией атмосферы: скачок приурочен к верхней границе антициклональной инверсии; кроме того, на этом уровне на склонах часто находится нижняя граница слоистых облаков.

Взаимодействия циркуляции атмосферы с формами рельефа обусловили большую пестроту распределения осадков, накопления снега в этой высотной зоне. Наличие ледников, узла оледенения в Южном Алтае в глубине континента указывает на существенные различия структуры гидротермического потенциала ландшафтов на различных гипсометрических уровнях [5,9]. При глобальном потеплении нижних слоев тропосферы следует ожидать увеличение атмосферных осадков в высокогорье, именно начиная с уровня 1500$1600 \mathrm{M}$.

Надо отметить, что чем больше площадь оледенения в бассейне рек, тем более растянуто половодье. Ледниковые воды - это бесценный ресурс чистых вод, а ландшафты высокогорья несут большой потенциал рекреации. 


\section{ГЛАВА IV. СНЕЖНЫЙ ПОКРОВ. ЛАВИНЫ. РЕЖИМ РЕК И ОЗЕР}

\section{1. Снежный покров}

Необходимость изучения снегозапасов на территории ЮгоЗападного Алтая определяется прежде всего тем, что здесь формируется основной сток р. Иртыш, к его водным ресурсам тяготеют районы Центрального Казахстана [12].

Резкий контраст в распределении зимних осадков по территории исследуемого региона объясняется особенностями взаимодействия трех типов климата (монгольского, среднеазиатского и западносибирского) и основными чертами ландшафтной структуры региона.

Основные закономерности формирования снежного покрова. По режиму формирования снежного покрова выделены следующие районы:

1) предгорные равнины северо-запада Рудного Алтая;

2) горные хребты Казахстанского Алтая;

3) межгорные котловины Казахстанского Алтая;

4) Калбинское нагорье;

5) Зайсанская котловина;

6) система хребтов Саур-Тарбагатая.

По наблюдениям на снегомерных маршрутах ВосточноКазахстанской гидрометобсерватории за 1964-1994 гг. установлено, что запас воды в снеге на севере региона (высоты 1500-2000 м) достигает 1000 мм и более, а на юге (бассейн р. Кендерлык) - только около 100 мм. Содержание влаги в атмосфере в зимние месяцы над регионом отражено в табл. 35 (глава II), влагосодержание атмосферы

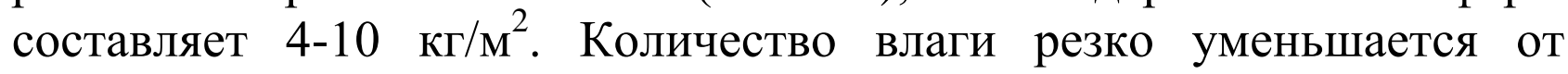
декабря к январю и медленно нарастает от января к февралю.

Развитие циркуляционной деятельности на востоке Казахстана характеризуется некоторыми особенностями: сгущением траекторий циклонов в связи с отклонением их под воздействием гор; обострением фронтальных разделов и возникновением частных циклонов за счет свободного затока арктического воздуха с севера и умеренного или прежнего тропического воздуха с юго-запада; развитием волновой деятельности на холодных фронтах; 
увеличением роли барьерного эффекта в связи с преобладанием зимой горизонтального потока влаги.

Траектории циклонов зимой через территорию Казахстанского Алтая проходят очень редко (12\%), но с ними связываются интенсивные зимние осадки.

Общее положение региона на периферии азиатского антициклона обусловило наличие в холодный период 40-45\% наблюдаемых за год дней с осадками (см. табл.14).

Особую роль в увлажнении играют западные процессы. Увлажнение нарастает с высотой. В высокогорье снегонакопление идет более интенсивно. На предгорных равнинах эти процессы обеспечивают 46-47\% (Усть-Каменогорск, Шемонаиха, Большенарым), на склонах гор (Катон-Карагай) 51\%, а в межгорных котловинах (Риддер, Зыряновск) 38-42\% зимней суммы осадков. Данная закономерность наиболее четко выступает в экстремальные по увлажнению зимы (1965-1966 гг.).

Распределение снежного покрова показано на рис. 47. Картосхема построена на основе анализа данных по снежному покрову, маршрутных и аэровизуальных снегосъемок, выполненных Восточно-Казахстанским центром гидрометеорологии Казгидромета и литературных источников [5, 9, 13, 49, 85].

Предгорные равнины северо-запада Рудного Алтая (240-600 м). Снежный покров здесь подвержен ветровой эрозии, его средняя высота к концу зимы достигает 20-70 см, а запас воды в снеге 120-130 мм. В 50\% случаев высота снежного покрова составляет 30-50 см. Основная масса осадков выпадает при западных и юго-западных процессах, их увеличение в восточном направлении связано с барьерным эффектом.

Горные хребты Казахстанского Алтая образуют несколько орографических узлов, являющихся «ловушками» для влагонесущих масс. Наиболее крупные из них: район сближения хребтов Ивановского, Ульбинского и Холзунского, Убинского и Тигирецкого, Нарымского, Сарым-Сакты и Курчумского, хребта Южный Алтай и Кадинских гор, орографический узел Белухи. Здесь берут начало наиболее полноводные реки Казахстанского Алтая: Малая Ульба, Тургусун, Белая Берель, Курчум, Арасан-Каба. В их истоках, имеющих наиболее крутой продольный профиль, происходит усиление осадкообразования и к ним приурочены пояса наибольшей снежности. Интенсивный вынужденный подъем воздушных масс 
обусловлен как нарастанием высоты местности, так и сужением продольных долин к вершинам орографических узлов. Снегозапасы у истоков в 8-10 раз выше, чем в приустьевых участках.

В бассейне р. Ульба авторами выделено четыре высотных пояса снежности:

1. Абсолютная высота от 600 до 1100 м - средняя многолетняя мощность снежного покрова от 50 до 100 см; запас воды в снеге до 300 мм.

2. Высота от 1100 до 1500 м - средняя многолетняя мощность снежного покрова от нижней до верхней границы изменяется от 100 до 230 см. Градиент может достигать 60 см на 100 м поднятия, водность от 300 до 800 мм.

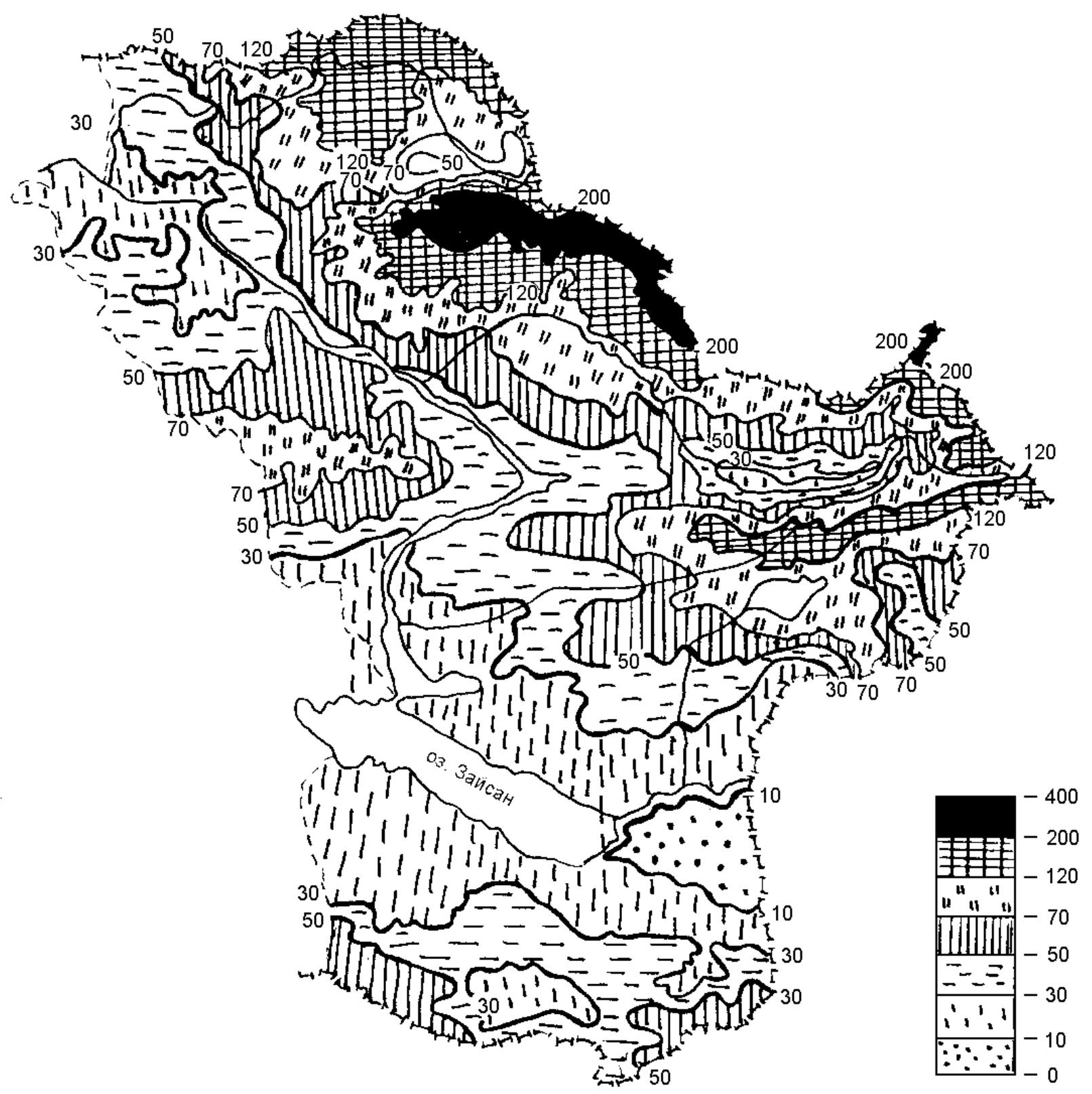

Рис. 47. Средняя высота снежного покрова Юго-Западного Алтая (за декаду, максимум), см 
3. Высота от 1500 до верхней границы леса - 1900 м. Средняя многолетняя высота снежного покрова 230-300 см. Интервал высот 1500-1900 м является своеобразным «поясом снежности» Рудного Алтая. Запас воды здесь 800-1000 мм.

4. Пояс выше границы леса характеризуется большими скоростями ветра. Здесь самая пестрая картина в распределении снегозапасов. Средняя многолетняя мощность снежного покрова колеблется от 10 до 250 см и выше. Водность в связи с продолжительным периодом снегонакопления достигает до 1000 мм и более.

Орографический узел Рудного Алтая характеризуется максимальной снежностью среди гор Южной Сибири. В октябредекабре здесь формируется до 70\% снегозапаса. Следует подчеркнуть, что расположение системы хребтов благоприятно для восходящего скольжения и конденсации влаги западных и югозападных потоков воздуха.

C продвижением на юго-восток усиливаются процессы антициклогенеза и уменьшается влагосодержание воздушных масс. В результате на одинаковых высотах в бассейне р. Белая Берель мощность снежного покрова в 1,5-2 раза меньше, чем на Рудном Алтае. Зона значительного нарастания снежности в хребтах Западного и Южного Алтая обычно начинается выше 800-1000 м, т.е. на границе облаков нижнего яруса. В ледниковых районах (2500-3500 м над у. м.), в районе г. Белуха мощность снежного покрова может достигать 3-5 м [15]. Увеличение снегозапасов с высотой происходит за счет роста абсолютной влажности и скорости переноса, а неравномерность в его распределении обусловлена влиянием экспозиции, микро- и мезорельефа на скорость и направление переноса.

К концу апреля в бассейне Ульбы граница снеговой линии проходит на высоте 900 м, в конце мая на высоте 1500 м. На юговостоке района (бассейн р. Белая Берель) в эти месяцы граница снеговой линии проходит примерно на 400 м выше, что связывается с быстрым разрушением снега из-за его меньшей мощности. К середине июня снежный покров сходит практически полностью, за исключением снежников, наибольшее количество которых приурочено к северным пригребневым частям хребтов в районах орографических узлов. 
В хребтах Южного Алтая сохраняются рассмотренные закономерности, однако, в связи с усилением к югу процессов антициклогенеза, максимальная мощность снежного покрова составляет 1,5-2 м (см. рис. 46).

Межгорные котловины Казахстанского Алтая. Гидротермический режим здесь определяется не только формой самой котловины и ее местоположением, но и характером окружающего рельефа.

Лениногорская котловина: абсолютные высоты от 600 до 900 м, рельеф увалисто-холмистый, преобладают лесостепные ландшафты. Дно долины окружено горными поднятиями с относительной высотой до 2000 м. За холодный период выпадает 107 мм осадков (17\% годовой суммы). В это же время по другую сторону Ивановского хребта, окаймляющего котловину с юга, на высоте 1600 метров, осадки холодного периода составляют 556 мм (станция Малая Ульба), или $37 \%$ годовой суммы. Это яркий пример взаимодействия форм рельефа и циркуляции атмосферы. Следует подчеркнуть, что в рассмотренном случае за холодный период осадки наветренных склонов гор в 2,5 раза больше, чем в котловине, в то время как для теплого периода это соотношение не превышает 1,8. Влияние рельефа на интенсивность осадкообразования зимой резко возрастает в связи с преобладанием горизонтальных потоков влаги. Высота снежного покрова в котловине достигает 30-50 см, а запас воды 120 мм, снежная толща имеет сложную структуру за счет оттепелей.

Чингистай-Катонская котловина. Сюда входят Чингистайская сухая степь, расположенная на высотах 850-950 м, и КатонКарагайская луговая степь в долине р. Сарым-Сакты на высотах 10001100 м. Превышение хребтов, окружающих котловину, достигает 2300 м. Средняя высота снежного покрова 20-30 см, около 70\% снегозапасов образуется до конца декабря. Запас воды в снеге 35-100 мм. Амплитуда колебания максимальных декадных высот составляет 30-280\% от нормы (метеостанция Катон-Карагай). Уменьшение количества осадков в данной котловине в сравнении с Лениногорской обусловлено нарастанием к югу-востоку антициклоничности и большей повторяемостью фёнов.

Бобровско-Орловская котловина крайний юго-восток Казахстанского

$(1000-1100$ м) занимает Алтая и характеризуется 
застойными явлениями. Средняя температура января минус $27,1^{0} \mathrm{C}$, высота снежного покрова 40-50 см, запас воды - 100-110 мм.

Зыряновская котловина представляет собой всхолмлённую денудационную равнину, расположенную перед двумя сопряженными орографическими «воронками», образованными хребтами Ульбинский и Холзун, Холзун и Нарымский с СарымСакты соответственно. Зимние осадки формируются на $30 \%$ за счет западных и на 42\% - юго-западных потоков влаги. Осадки холодного периода так же, как и в орографическом узле Рудного Алтая, составляют 35-36\% годовой суммы. Это указывает на то, что осадки над орографическим узлом и котловиной формируют одни и те же циркуляционные процессы, но интенсивность их на склонах гор выше. Котловинная форма рельефа обусловила низкие зимние температуры и высокую повторяемость штилей. Максимальная мощность снежного покрова, в сравнении с другими котловинами, здесь больше в 1,7-3,5 раза и составляет 83 см, а запас воды в снежном покрове в среднем 200-205 см.

Маркакольская внутригорная котловина лежит на высотах 1450-1500 м над у. м., но режим ее увлажнения подобен Зыряновской. Осадки холодного периода 160-200 мм или 38-40\% годовой суммы. Снежный покров 80-90 см, мощность снега с высотой быстро увеличивается и достигает в среднем 130 см на высотах около 1800 м (см. рис. 47).

Калбинский хребет (1000-1600 м над у. м.) относится к Алтайской горной стране. Горы сильно изрезаны. Влага вносится в основном западнымии юго-западными потоками, поэтому на наветренных склонах высота снега в 1,5-2 раза больше, чем на подветренных (Самарка - 60 см, Бозанбай - 25см). Мощность снежного покрова увеличивается с высотой, а его распределение тесно связано с экспозицией склонов и с характером растительности. Многолетний ряд наблюдений показал, что средняя мощность снежного покрова составляет в речной пойме 40-50, в горнокустарниковой степи 50-100, в открытой горной степи 5-10, на культурных полях 2-3 см, с надувами до 20-30, в осиново-березовых колках 60-80, в сосновом бору 45-60 см. Максимальная высота снега была отмечена в логах юго-западной экспозиции и достигала 2-3 м (февраль 1979 г.). Такое распределение снега связано с развитием метелевой деятельности. За зиму отмечается до 20-25 дней с метелями. В результате ветровой деятельности в отдельные годы 
сплошной снежный покров может существовать лишь на 30-40\% территории (зима 1975-1976 гг.) и даже в многоснежные зимы обычно не превышает 80-90\% (1978-1979 гг.).

Зайсанская котловина представляет собой обширный межгорный прогиб, простирающийся в широтном направлении через всю территорию области. Характерен слабоувалистый рельеф, преобладающие высоты 400-600 м. Котловина включает в себе акваторию озера Зайсан площадью около 1800 км² $^{2}$ В зимний период над районом расположена центральная часть западного отрога азиатского антициклона. На пути западных воздушных истоков нет орографических препятствий, поэтому они свободно проходят над котловиной. Максимум снежности находится восточнее, в Монгольском Алтае, где существует современное оледенение [49, 85]. Для района характерны самые минимальные снегозапасы на территории Юго-Западного Алтая, что объясняется малым количеством осадков и значительным испарением в течение холодного периода. Высота снежного покрова на подавляющей части территории не превышает 5-10 см и лишь в отдельные многоснежные и холодные годы достигает 30-40 см. К концу зимы снежный покров здесь обычно представляет редкие островки снега, покрытые слоем пыли.

Система хребтов Саур-Тарбагатая занимает крайний юг исследуемого региона. Включает в себя хребты Саур, Манрак, Тарбагатай. Для горной системы Саур характерна асимметрия склонов: короткие и крутые южные, длинные и пологие северные.

На открытых участках южной и западной экспозиции велико испарение снежного покрова. Здесь он отсутствует практически в течение всей зимы. В район входит обширная Шиликтинская долина (см. рис. 47).

Для хребта Саур наибольшая высота снега приурочена к низкогорному и высокогорному поясам. По наблюдениям в бассейне р. Кендерлык (1967-1984 гг.) средняя мощность снега составила на высотах 700 м - 35 см, 1500 м - 15 см, 2400 м - 7 см. На высоте около 2500 м в верховьях р. Кендерлык появляются обширные поверхности выравнивания, мощность снежного покрова на которых возрастает до 40-50 cм.

Данные о распределении снежного покрова в различных высотных зонах хорошо согласуются с количеством осадков, измеренным суммарными осадкомерами. На высоте 900 м за январь- 
март в 1970 - 1979 гг. они составляли в среднем 30,6 мм, на 1600 м 25,5 мм, на 2400 м - 16,5 мм. Такое распределение осадков связано с тем, что средневысотный пояс попадает в зону антициклональной инверсии.

На хребте Тарбагатай мощность снежного покрова постепенно увеличивается с востока на запад по мере возрастания абсолютных высот, достигая 140-150 см на высоте 2500 м (Карабугинский снегомерный маршрут 1967-1984 гг.). Максимум снегозапасов приходится на февраль.

Рассматривая особенности формирования снежного покрова по различным эпохам циркуляции за период 1959-1990 гг., отметим следующие характеристики снежной толщи: высоту, плотность, водность. Подсчет снегозапасов проводился на конец марта - период максимального снегонакопления для среднегорного пояса (табл. 52).

Т а блица 52

Характеристики снежного покрова на территории Юго-Западного Алтая по эпохам циркуляции атмосферы

\begin{tabular}{|c|c|c|c|}
\hline $\begin{array}{c}\text { Эпоха } \\
\text { циркуляции }\end{array}$ & Высота & Плотность & Водность \\
\hline $\mathrm{E}+\mathrm{C}$ & 2 & 1 & 1 \\
\hline $\mathrm{E}$ & 3 & 2 & 3 \\
\hline $\mathrm{C}+\mathrm{E}$ & 1 & 3 & 2 \\
\hline
\end{tabular}

1 - ниже средних многолетних значений, 2 - норма, 3 - выше средних многолетних значений.

Таким образом, для эпохи $\mathrm{E}+\mathrm{C}$ характерны нормальная высота снега, малая плотность и водность. Для эпохи Е - наибольшая высота снежного покрова, нормальная плотность и повышенный водозапас. Для эпохи $\mathrm{C}+\mathrm{E}-$ малая высота снежного покрова при наибольшей плотности и среднем водозапасе.

В зависимости от преобладающего направления движения воздушных масс в различные эпохи циркуляции склоны разных экспозиций получают неодинаковое количество осадков. Наибольший водозапас наблюдается на склонах всех экспозиций в эпоху Е (табл. 53). Это важно, так как в ближайшие годы получают развитие циркуляционные процессы типа Е. 
Средний запас воды и плотность снега $\left(г / \mathrm{cm}^{3}\right)$ на период максимального снегонакопления по эпохам циркуляции, в \% от нормы

\begin{tabular}{|l|c|c|c|}
\hline \multicolumn{1}{|c|}{ Районы } & $\mathrm{E}+\mathrm{C}$ & $\mathrm{E}$ & $\mathrm{C}+\mathrm{E}$ \\
\hline $\begin{array}{l}\text { Западный Алтай } \\
\text { (юго-западные склоны) }\end{array}$ & 84 & 108 & 96 \\
\hline $\begin{array}{l}\text { Южный Алтай } \\
\text { (юго-западные склоны) }\end{array}$ & 81 & 102 & 89 \\
\hline $\begin{array}{l}\text { Южный Алтай } \\
\text { (северные склоны) }\end{array}$ & 104 & 102 & 85 \\
\hline
\end{tabular}

В многолетнем снегонакоплении прослеживается следующая закономерность: резкое повышение плотности снежного покрова от

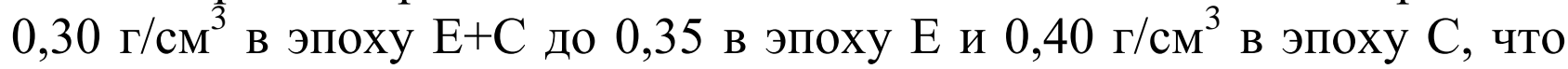
связанно со значительным потеплением зим.

За последние 30 лет (ст. Зыряновск) из десяти самых теплых зим одна пришлась на эпоху $\mathrm{E}+\mathrm{C}$, три - на эпоху Е и шесть на последнюю эпоху C+Е. Зима 1993-1994 гг. имела уже все черты эпохи Е (по М.X. Байдалу). Температура воздуха оказалась на 2-4 ниже нормы, водозапас порядка $107 \%$ от нормы, средняя плотность снежного

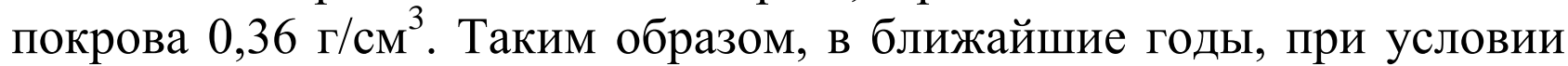
сохранения эпохи Е, можно ожидать примерно такую же ситуацию.

Сложное распределение характеристик снежного покрова по территории Юго-Западного Алтая обусловлено следующими особенностями климата и орографии:

- в условиях внутриконтинентального положения региона на стыке трех типов климата атмосферы взаимодействуют циркуляционные процессы с формами рельефа;

- влага, формирующая зимние осадки, поступает в основном (80-90\%) с западными и юго-западными потоками воздуха; до 70\% снегозапасов накапливается уже в октябре-декабре;

- высокая снежность орографических узлов Рудного Алтая среди гор Южной Сибири. Это связано с его расположением на западной периферии горного пояса, где под $50^{\circ}$ с. ш. проходит зона максимальной скорости западного переноса в средней тропосфере;

- проявление барьерного эффекта в формировании осадков зимой в 1,5-3 раза интенсивнее, чем летом. 


\section{2. Особенности образования и схода лавин в бассейнах рек Громотуха и Малая Ульба}

Наиболее лавиноопасной является их средняя часть, где высоты склонов достигают 600-1200 м над у. м., а средние многолетние запасы снега составляют 200-300 см [49, 101, 102]. Ландшафты данного района несут на себе как прямые (гляциальные), так и косвенные (геоморфологические и геоботанические) признаки высокой лавинной опасности. Лавинные снежники, ямы выбивания, лавинные бугры и прочесы до 600 м длиной и 50-60 м шириной встречаются здесь повсеместно, особенно на склонах северной экспозиции среднего течения р. Громотуха (см. рис. 47). Обычно область питания лавин находится на одном берегу, а область отложения - на противоположном. В составе отложений лавин имеются хорошо окатанные валуны и галька, выбитые лавинами из русла реки. Строение лавинных снежников нередко представлено в виде двух - или трехъярусного отложения материала, что говорит о неоднократном сходе лавин в одном лотке за зимний период. Характерным для схода лавин в бассейне р. Громотухи является и то, что их путь обычно заканчивается крутым уступом высотой 10-15 м у подножья склона.

Данный район является зоной формирования мощных и среднемощных лавин [101]. Сотрудниками снегомерногидрографической партии УГКС КазССР за период 1958-1985 гг. здесь отмечено свыше 500 случаев схода лавин, из них 136 достигают объема от 1000 до 100000 м $^{3}$ (табл. 54).

Следует отметить, что лавины в ноябре-декабре имеют сравнительно небольшой объем, в ноябре - до $1000 \mathrm{~m}^{3}$, в декабре 2500-3000 м². По генетической классификации В.А. Аккуратова, лавины в ноябре относятся к лавинам свежевыпавшего снега, а в декабре - подразделяются на два типа: свежевыпавшего снега и сублимационного деафтореза [102].

Количество сошедших лавин в январе увеличивается до $27 \%$, что связано с ростом количества дней с метелями в указанном месяце. Появляются лавины нового генетического типа - метелевого переноса. Для района Риддера характерны метели продолжительностью 2-3, максимум 5 суток, а скорости ветра часто достигают ураганной силы. Объем сошедших лавин в январе, 
несмотря на их большое число, в среднем не превышает 8000-10000 $\mathrm{m}^{3}$.

Количество учтенных лавин в отдельные месяцы в бассейнах рек Громотуха и Малая Ульба, за 1958-1985 гг.

\begin{tabular}{|l|c|c|c|c|c|c|c|c|}
\hline \multicolumn{1}{|c|}{ Бассейн } & \multicolumn{7}{|c|}{ М е я ц } \\
\cline { 2 - 9 } & ХI & XII & I & II & III & IV & V & Всего \\
\hline $\begin{array}{l}\text { p. Громотуха и } \\
\text { верховья р. Малая } \\
\text { Ульба до впадения в }\end{array}$ & 9 & 50 & 148 & 99 & 149 & 68 & 22 & 545 \\
$\begin{array}{l}\text { р. Марчиха (число } \\
\text { случаев) }\end{array}$ & 2 & 9 & 27 & 18.2 & 27.3 & 12.5 & 4 & 100 \\
\hline $\begin{array}{l}\text { \% от общего числа } \\
\text { случаев }\end{array}$ & 2 & & & & & \\
\hline
\end{tabular}

Февраль является одним из наиболее лавиноопасных периодов. К этому времени формируется основная масса снегозапасов, сглаживаются неровности рельефа, а для последней декады месяца характерны мощные снегопады. За сутки нередко выпадает от 50 до 100 мм осадков. Так, 26 февраля 1977 г. прирост снежного покрова за сутки составил свыше 100 см. Выпадение снега сопровождалось сильными порывами ветра. В ночь с 26 на 27 февраля в долинах рек Березовки и Громотухи сошли лавины объемом до $30000 \mathrm{~m}^{3}$. На реке Громотуха образовались снежные плотины. В отдельные годы именно в феврале отмечается максимум лавинной активности.

Лавины марта и апреля (40\%) оказывают наибольшее воздействие на ландшафты Западного Алтая. В этот период отмечается сход крупных (до $1000000 \mathrm{~m}^{3}$ ) и более мокрых лавин, образующих прочесы в лесу, выносящих каменистый материал со склонов и формирующих наиболее крупные завалы на реках.

Таким образом, мощные снегопады октября-декабря формируют до $70 \%$ снегозапасов зимнего сезона, и рассматриваемый район уже в ноябре включается в лавинную деятельность. Основной причиной, вызывающей сход лавин в первую половину зимы, являются снегопады в комплексе с другими факторами. За 25-26 декабря 1975 г прирост снега составил 1 м. На р. Марчиха к этому времени установился ледостав. На крутых береговых склонах выпавший снег ложился на лед, который был взломан рекой в результате потепления 28 декабря до $+1,5^{0} \mathrm{C}$. Снежный покров, лишившись опоры, начал «съезжать» в реку, вызвав на крутых склонах сход пластовых лавин. 
В бассейнах рек Малая Ульба и Тургусун на склонах южной и западной экспозиции широкое распространение имеют подвижки снега. Распространены они в основном на болотистых склонах и представляют собой глубокие, до грунта, трещины в снежном покрове. Расширяясь, такие трещины обычно вызывают сход снежных лавин. Причина их образования обусловлена интенсивной перекристаллизацией снега под действием тепла болотистых грунтов и инсоляции, а также малым сцеплением между снежным покровом и травянистой поверхностью таких склонов.

Потенциальная лавинная опасность на высотах около 2000 м существует в данном районе даже в летнее время, так как снегопады здесь отмечаются уже в июле и начале августа, хотя и очень редко.

Влияние лавинообразования на растительность. Большое количество осадков и значительный запас тепла способствуют развитию на территории Рудного Алтая своеобразной формации темнохвойных лесов, где основной лесообразующей породой является пихта сибирская. Доля пихты в горных лесах Казахстанского Алтая достигает 39,3, лиственницы сибирской - 13, осины - 10,2, березы - 9,1, кедра - 9,1, сосны обыкновенной - 3,2\%. Реже встречаются ель сибирская, тополь, ива древовидная и кустарниковые, произрастающие в поймах рек.

В распространении растительности ярко выражена вертикальная поясность. На высоте выше 1900-2000 м расположена растительность тундрового типа. Высоту 1500-1900 м занимает субальпийский пояс, для которого характерно широкое распространение субальпийских лугов, перемежающихся с небольшими перелесками из кедра, лиственницы и пихты. Ниже, расположен лесной пояс. Границу лесного и степного пояса определить очень трудно. Условно ее можно провести на высоте около 400 м. Вертикальные зоны растительности хорошо согласуются с распределением снежного покрова по высотным поясам.

Первый пояс высотой 600-1100 м над у. м. характеризуется мощностью снежного покрова 100-150 см. Запас воды в снеге 250-400 мм. Основные лесообразующие породы - пихта, осина, береза.

Во втором поясе (1100-1500 м над у. м.), высота снега колеблется от 150 до $230 \mathrm{~cm}$, водность $-400-800$ мм. В этом поясе широко представлены все основные лесообразующие породы Западного Алтая: пихта, лиственница, ель, кедр, осина, береза. Верхняя граница пояса является пределом распространения 
лиственных пород деревьев. Ниже 1100 м кедр и лиственница не спускаются.

Третий пояс - 1500-1900 м над у. м. Высота снежного покрова 230-300 см, водность - 800-1000 мм. Основными лесообразующими породами здесь являются лиственница, кедр и пихта. От 1600 м до 1750-1800 м расположено пихтовое редколесье. Верхнюю границу леса (1800-1900 м) в верховьях Громотухи и Малой Ульбы составляют лиственница и кедр с явным преобладанием лиственницы.

Четвертый пояс - от 1900 м над у. м. и выше - характеризуется отсутствием древесной растительности, большой скоростью ветра и неоднородностью высот снежного покрова. В зависимости от ориентации и крутизны склонов, мощность снега колеблется от 10 до 250 см и более. Запас воды в снежном покрове, в связи с продолжительным периодом снегонакопления, может превышать 1000 мм.

Следует отметить, что восточнее, в долине р. Белая Берель, верхняя граница леса проходит на 400 м выше, чем в бассейнах рек Малая Ульба и Громотуха. На таких же высотах в долине Белой Берели проходит и граница сезонной снеговой линии. Так, к концу мая нижняя граница снеговой линии в долине Малой Ульбы проходит на высоте 1500, а в Белой Берели - 1900 м.

Повреждения лесных массивов лавинной деятельностью в рассматриваемых бассейнах происходит ежегодно, особенно большой процент пораженного лавинами леса находится на северных склонах среднего течения р. Громотухи (табл. 55). Наиболее стойкой к лавинным ударам является лиственница, способная противостоять сильному механическому воздействию лавинного снега [74]. Лавины сухого свежевыпавшего снега могут проходить через лесной массив, не причиняя ему существенного вреда. Так, 26 февраля 1977 г. в результате мощного снегопада произошел массовый сход лавин, вызванный мощным снегопадом и приростом снега около одного метра. Однако лавины, проходя через чащу леса, выносили лишь сухие деревья и сучья. Основная масса леса гибнет от схода грунтовых лавин в весенний период (рис. 48).

На лавинную активность оказывают воздействие и лесные пожары.

На территории Западного Алтая воздействию пожара подвергается около 15\% всех лесных массивов. Вырубка леса после 
пожара приводит к тому, что уже в немногоснежном 1975 г. сход лавин отмечался там, где раньше его не было.

В среднегорной части бассейнов рек Громотуха и Малая Ульба травяной покров и кустарники из-за мощных снегозапасов не оказывают существенного влияния на снижение лавинной деятельности. В некоторых местах, где проводились наблюдения, кустарник с течением времени ложится вдоль склонов на землю и не препятствует скольжению снежной массы по прослойке разрыхления. В начальный период накопления снега кустарники увеличивают его критическую массу и лавины в данном районе имеют большой объем, несмотря на малую высоту склонов.

Роль лавин в формировании прорывных паводков. На территории Западного Алтая лавинами перекрываются русла практически всех крупных рек: Убы, Громотухи, Малой Ульбы, Тургусуна, Хамира. На-ибольшее количество све-дений имеется о запру-живании реки Громотуха в каньонообразном ущелье среднего течения (см. табл. 55).

туха (пло-щадь водосбора $\left.400 \mathrm{\kappa м}^{2}\right)$ отли-чается самой высокой на территории Западного Алтая водоносностью. Слой стока здесь достигает 1800-2200 мм, расход воды равен $200 \mathrm{~m}^{3} / \mathrm{c}$ в июне и $5-6 \mathrm{~m}^{3} / \mathrm{c}$ в зимние месяцы. В случае образования крупных лавинных плотин на реках, при расходах мень-

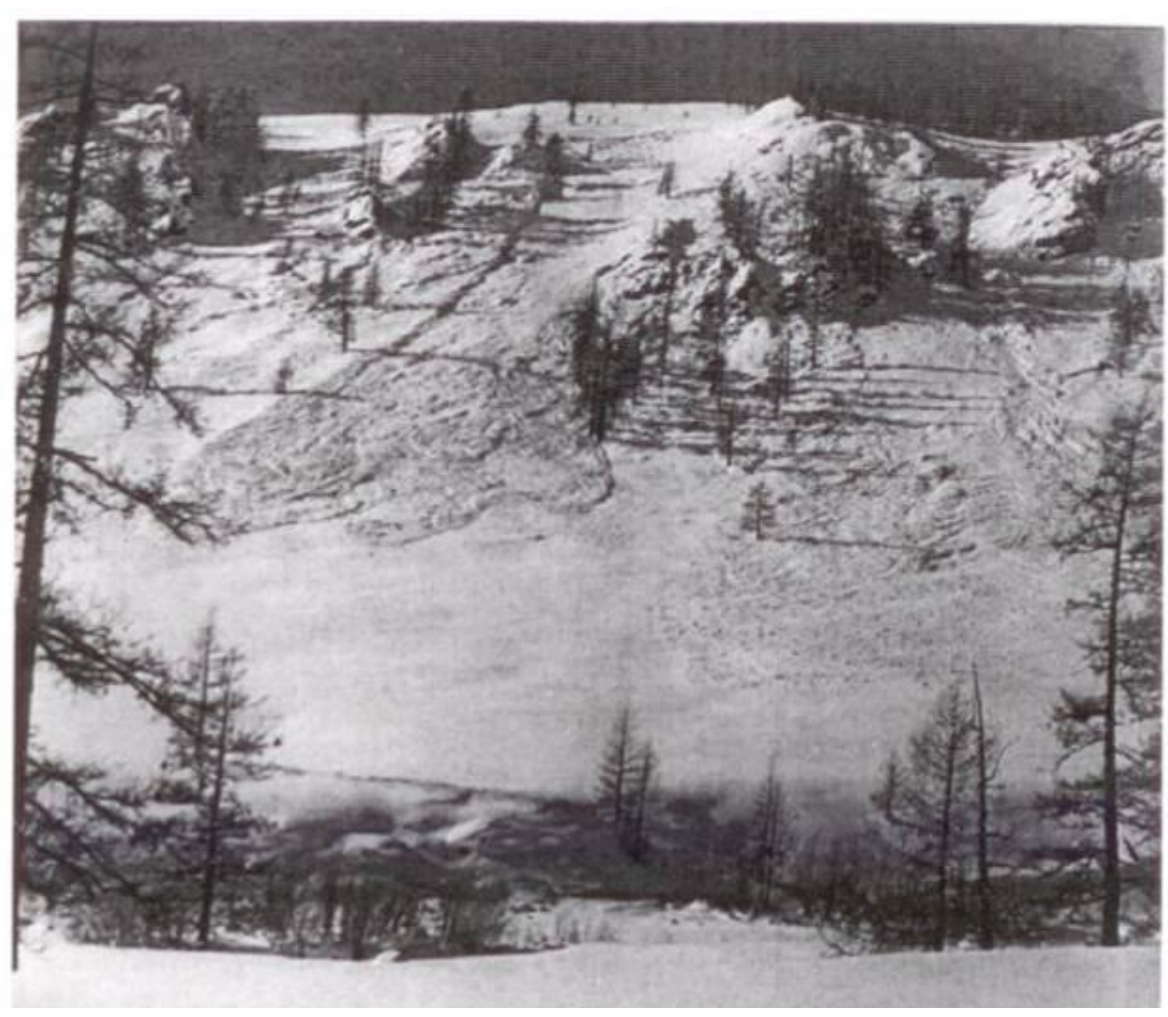

Рис. 48. Лавины в долине реки Тополевки.

Южный Алтай

ше $10 \mathrm{~m} / \mathrm{c}$ происходит плавное изменение уровня воды. При расходах больше $10 \mathrm{~m} / \mathrm{c}$ возможно возникновение прорывных паводков. На Громотухе неоднократно формировались паводки, связанные с перегораживанием русла реки лавинами. Так, например, 
максимальный подъем уровня после схода лавины 14 января 1971 г. достиг 82 см, а в марте 1966 и 1969 гг. - 100-104 см. Падение уровня происходит более плавно и не превышает обычно 30-40 см за сутки.

На р. Марчиха (21-24 марта) зарегистрирован подъем воды до 250 см. Причиной, вызвавшей массовый сход лавин, послужил снегопад с дождем.

С лавинами связаны и колебания расходов воды рек. Так, 22 марта 1969 г. после схода двадцати лавин, в среднем течении реки Громотуха образовалось восемь перемычек. Расход воды ниже перемычек упал с 9,5 до 4,6 м³. В результате прорыва лавинных мостов расход воды увеличился 27 марта до 17, а 29 и 30 марта - до $30,9 \mathrm{~m}^{3} / \mathrm{c}$.

Лавины могут перегораживать даже такие крупные реки как Уба. Десятого апреля 1978 г. в районе с. Гусляковка (среднее течение p. Уба) сошла крупная лавина, перекрывшая реку. Затор просуществовал около суток. На несколько часов была затоплена автодорога. Подобные явления наблюдались 26 февраля 1982 г. в среднем течении р. Кара-Каба [102].

Изложенные материалы позволяют заключить, что лавины на реках Западного и Южного Алтая способны перекрывать русла рек снежными плотинами и прекращать или значительно снижать сток ниже перемычек на время от 5-7 часов до 6 суток. Лавинные завалы сравнительно недолговечны. Как правило, после кратковременного запруживания вода свободно проходит под телом завала, после чего формируется своеобразный снежный мост. Иногда водная масса обходит тело лавины, размывая берега.

Территория Рудного Алтая характеризуется высокой лавинной опасностью. С этой точки зрения Рудный Алтай изучен далеко не достаточно, особенно бассейны рек Тургусун, Хамир и Черновая. Во время аэровизуального обследования на территории Казахстанского Алтая 5 апреля 1985 г. в бассейнах этих рек зарегистрирован массовый сход лавин (около 1000 случаев). В бассейнах других рек отмечены в это же время лишь единичные случаи. Особенностью перечисленных бассейнов является то, что они имеют наибольшие снегозапасы среди других районов Западного Алтая, отличающегося значительным увлажнением. В сочетании с крутосклонным рельефом большие снегозапасы делают рассматриваемый район одним из наиболее лавиноопасных не только в Казахстане, но и в СНГ. 
Характеристика лавинной деятельности в бассейнах рек Громотуха и Малая Ульба

\begin{tabular}{|c|c|c|c|}
\hline $\begin{array}{c}\text { Местоположение } \\
\text { и дата схода лавин }\end{array}$ & $\begin{array}{c}\text { К-во } \\
\text { лавин }\end{array}$ & $\begin{array}{l}\text { Объем, } \\
\text { тыс. м }\end{array}$ & $\begin{array}{c}\text { Явления, сопровождавшие } \\
\text { сход лавин }\end{array}$ \\
\hline 1 & 2 & 3 & 4 \\
\hline $\begin{array}{l}\text { Среднее течение р. Громотухи } \\
(20-26.1 .66 \text { г.) }\end{array}$ & 14 & $3-8$ & Поломаны деревья \\
\hline $\begin{array}{l}\text { р. Громотуха от р. Богданихи до } \\
\text { пос. Громотуха } \\
\text { (7-11.III. } 66 \text { г.) }\end{array}$ & 9 & До 5 & $\begin{array}{l}\text { Образована снежная } \\
\text { перемычка на р. Громотухе }\end{array}$ \\
\hline $\begin{array}{l}\text { Громотуха ниже устья р. Тишихи } \\
\text { (III.1966 г.) }\end{array}$ & 18 & До 100 & $\begin{array}{l}\text { Повален лес с большого } \\
\text { массива, камни, завалы на p. } \\
\text { Громотухе }\end{array}$ \\
\hline $\begin{array}{l}\text { Левый берег p. Громотухи в } \\
\text { среднем течении (III.1966 г.) }\end{array}$ & 3 & До 25 & $\begin{array}{l}\text { Камни, } \quad \text { повален лес, } \\
\text { перемычки на р. Громотухе }\end{array}$ \\
\hline $\begin{array}{l}\text { р. Марчиха у устья р. Погорелки } \\
\text { (12-18.III. } 68 \text { г.) }\end{array}$ & 1 & До 80 & $\begin{array}{l}\text { Засыпана дорога на } \\
\text { протяжении } 350 \text { м, сломаны } \\
\text { деревья }\end{array}$ \\
\hline $\begin{array}{l}\text { p. Громотуха, среднее течение } \\
(22 . \text { III.69 г.) }\end{array}$ & 20 & $\begin{array}{l}\mathrm{He} \\
\text { опр. }\end{array}$ & $\begin{array}{l}\text { В восьми местах образовало } \\
\text { запруды, нет воды в Риддере } \\
\text { до 28.III }\end{array}$ \\
\hline $\begin{array}{l}\text { р. Марчиха у устья р. Погорелки } \\
(21-24 . \text { III.69 г.) }\end{array}$ & 1 & До 30 & $\begin{array}{l}\text { Лавиной назван подъем воды } \\
\text { до } 250 \text { см, сломаны деревья }\end{array}$ \\
\hline $\begin{array}{l}\text { Среднее течение р. Громотухи } \\
(10-18.1 I .70 \text { г.) }\end{array}$ & 12 & $\begin{array}{l}\mathrm{He} \\
\text { опр. }\end{array}$ & $\begin{array}{l}\text { Завалило русло р. Громотухи, } \\
\text { образовало запруды на 5-7 час. }\end{array}$ \\
\hline $\begin{array}{l}\text { Среднее течение р. Громотухи } \\
(14-15.1 .71 \text { г.) }\end{array}$ & 20 & $\begin{array}{l}\mathrm{He} \\
\text { опр. }\end{array}$ & $\begin{array}{l}\text { Образовало запруды, нет воды } \\
\text { в г. Риддере до } 16.1 .\end{array}$ \\
\hline $\begin{array}{l}\text { p. Громотуха, среднее течение } \\
\text { (IV. } 1975 \text { г.) }\end{array}$ & 5 & $\begin{array}{l}\mathrm{He} \\
\text { опр. }\end{array}$ & Риддер без воды \\
\hline $\begin{array}{l}\text { p. Березовка в } 4 \text { км от устья } \\
(22.1 .77 \text { г.) }\end{array}$ & 1 & $6-7$ & Перекрыло р. Березовку \\
\hline $\begin{array}{l}\text { p. Тарасиха, левый приток } \\
\text { p. Громотухи (26.II.77 г.) }\end{array}$ & 1 & 3 & - \\
\hline $\begin{array}{l}\text { Бассейн р. Громотухи } \\
(24-28 . I I .77 г .)\end{array}$ & $\begin{array}{l}\text { Массо } \\
\text { вый } \\
\text { сход }\end{array}$ & $\begin{array}{l}\mathrm{He} \\
\text { опр. }\end{array}$ & $\begin{array}{l}\text { На p. Громотухе снежные } \\
\text { плотины; в г. Риддере нет } \\
\text { воды 25-28.ІІ. }\end{array}$ \\
\hline $\begin{array}{l}\text { Среднее течение р. Громотухи } \\
\text { (3-4.III.77 г.) }\end{array}$ & 22 & $30-40$ & $\begin{array}{l}\text { Снежные плотины на р. } \\
\text { Громотухе }\end{array}$ \\
\hline $\begin{array}{l}\text { p. Березовка, среднее течение } \\
\text { (15-16.IV.78 г.) }\end{array}$ & 1 & $0.6-0.9$ & $\begin{array}{l}\text { Подвержены } \\
\text { диаметром до 30-40 см }\end{array}$ \\
\hline $\begin{array}{l}\text { Верховье р. Марчихи } \\
\text { (15-16.IV.78 г.) }\end{array}$ & 1 & $0.6-0.9$ & $\begin{array}{l}\text { Поломано много деревьев; } \\
\text { снос их к реке }\end{array}$ \\
\hline $\begin{array}{l}\text { p. Громотуха, среднее течение } \\
\text { (I.1980 г.) }\end{array}$ & 2 & $6-7$ & $\begin{array}{lll}\text { Высота } & \text { лавинных } \\
\text { до } 8 \text { м } & & \\
\end{array}$ \\
\hline $\begin{array}{l}\text { p. Громотуха, среднее течение } \\
(15-16.1 .85 \text { г.) }\end{array}$ & 2 & $\begin{array}{l}\mathrm{He} \\
\text { опр. }\end{array}$ & $\begin{array}{l}\text { Перекрыло р. Громотуху; } \\
\text { г. Риддер без воды } 3 \text { дня }\end{array}$ \\
\hline
\end{tabular}




\section{3. Режим рек Юго-Западного Алтая}

Стержнем, объединяющим природные ландшафты, речные и озерные системы, является главная водная артерия региона р. Иртыш. От истоков до впадения в р. Обь длина Иртыша составляет 4248 км, площадь бассейна равна 1643 тыс. км². Река берет начало в Китае на западных склонах гор Монгольского Алтая и под названием Черный Иртыш течет до впадения в оз. Зайсан, вытекая из него под названием Иртыш (или Белый Иртыш). От границ КНР до г. Семея протяженность Иртыша составляет 900 км.

Годовой сток Иртыша с площади водосбора 146 тыс. км² за период наблюдений 1961-1980 гг., в створе Усть-Каменогорской ГЭС составил в среднем 15,2, наибольший 22,1, наименьший 10,4 км³. Средний годовой расход за этот период составил $483 \mathrm{\kappa m}^{3} / \mathrm{c}$, наибольший - 702, наименьший $-329 \mathrm{~m}^{3} / \mathrm{c}$. При этом не учтены водные ресурсы таких полноводных рек, как Ульба и Уба.

На участке от устья р. Бухтармы до г. Усть-Каменогорска Иртыш протекает по узкому скалистому ущелью. Прорвав Аблайкетскую гряду, река выходит за пределы предгорий. Во время строительства в этом «прорыве» Усть-Каменогорской ГЭС было установлено, что скальное основание русла Иртыша лежит на глубине 5-7 м, а при впадении р. Ульба - более 100 м.

Иртыш ниже впадения p. Ульба вступает в пределы Прииртышской аллювиальной равнины. Течение реки становится замедленным, средние скорости 1,2-1,4 м/с, русло расширяется от 230 м у Аблайкетки до 500 м ниже впадины р. Ульба. Близ Предгорного, ниже впадения р. Красноярки, долина Иртыша меняет простирание на западное.

По данным водно-энергетического кадастра Казахстана, в 1965 г. в регионе насчитывалось 817 рек длиной более 10 км, 48 рек длиной более 50 км и только 20 рек длиной более 100 км. Основные реки и гидропосты региона представлены на рис. 49.

На территории Юго-Западного Алтая насчитывается 1003 озера размером от одного гектара и выше с суммарной площадью водного

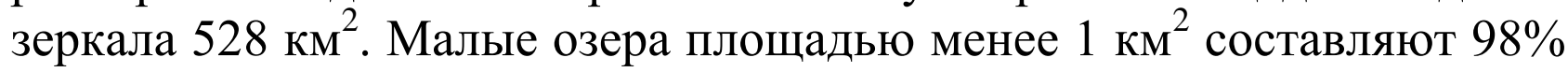
общей численности озер, а по площади - только 9\% [12]. Озера по территории региона размещены неравномерно. Крупные, тектонические - в межгорных впадинах (оз. Зайсан и Маркаколь). Более мелкие, ледникового происхождения - в высокогорной части. 
Озера реликтовые и связанные с выходом грунтовых вод, представлены на Калбе и предгорьях Южного Алтая (рис. 50).

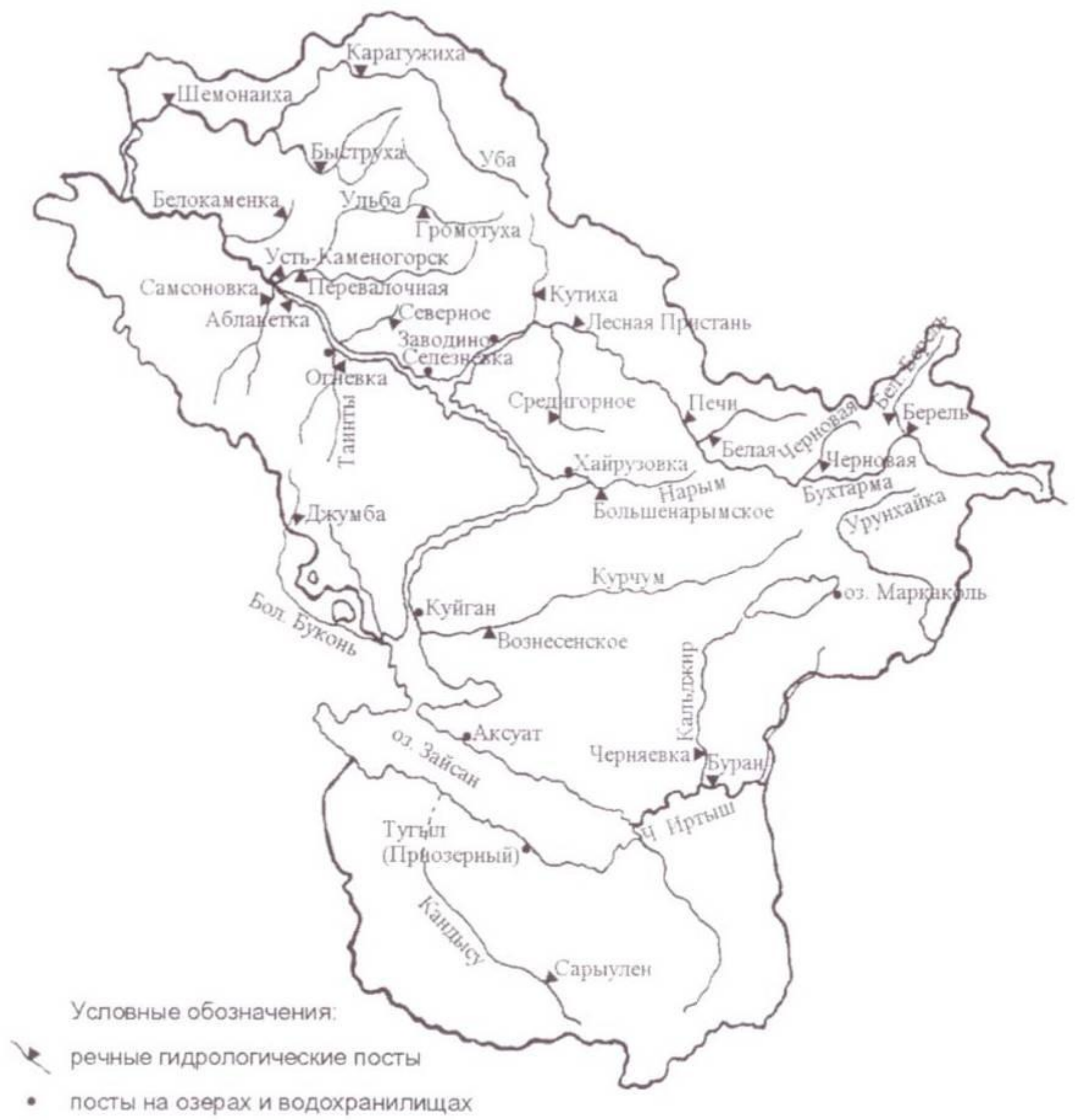

Рис. 49. Картосхема Юго-Западного Алтая с расположением гидропостов

Речная сеть Рудного Алтая возникла в доантропогеновое время. Долины Иртыша, Бухтармы, Убы выстланы нижнечетвертичными и плиоценовыми осадками. В долинах прослеживается от трех до пяти террас. На второй террасе археологами обнаружены следы деятельности древнего человека. По долине Иртыша в пределах г. Усть-Каменогорска и ниже, на второй террасе, таких следов не 
обнаружено. Это объясняется опусканием долины Иртыша ниже впадения в него Ульбы и древние террасы погребены под более молодыми [10].

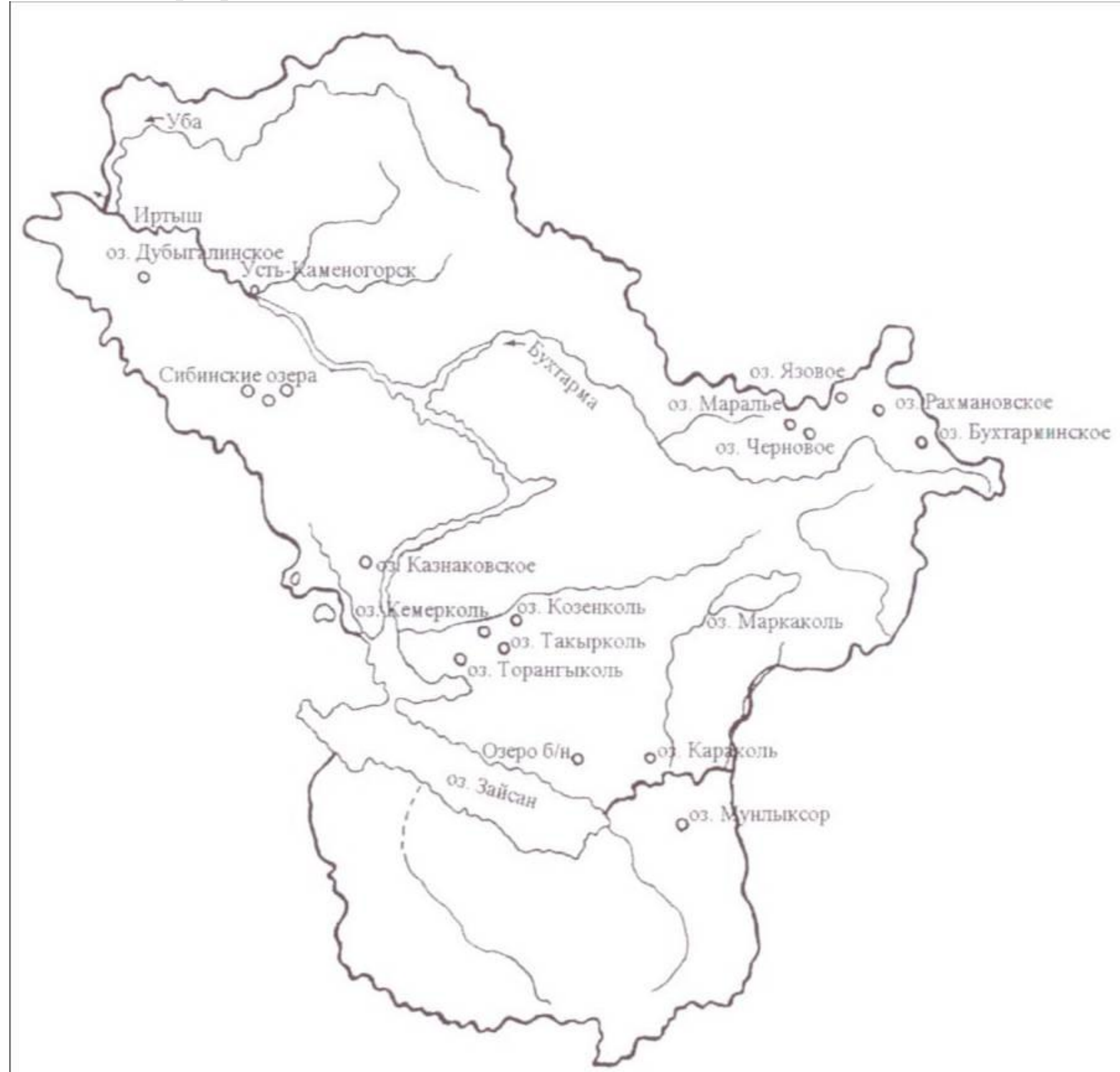

Рис. 50. Картосхема размещения озер плошадью более 1 кв. км на территории Юго-Западного Алтая

Ресурсы поверхностных вод в регионе для среднего по водности года равны 32,6 км³ ${ }^{3}$ из них на сток Иртыша, формирующегося за пределами Казахстана, приходится 7,7 км³ , на правобережье Иртыша в районе Южного Алтая (реки Кара-Каба, Кальджир, Курчум, Нарым) - 4,79, на Бухтарму - 7,50, на Ульбу (с. Ульба Перевалочная) - 3,21, на Убу (с. Нижне-Убинское) - 5,58, на небольшие речки 
правобережья - 0,81, на левобережье Иртыша, всего по региону - 2,96 $\mathrm{kм}^{3}$. Для многоводных лет (обеспеченность 10\%) ресурсы поверхностных вод могут достигать 46,2 км³, для маловодных (обеспеченность 75\%) - 25,2 и крайне маловодных (обеспеченность 95\%) $18,1 \mathrm{\kappa м}^{3}[12,62]$.

Долина Иртыша пересекает регион с юго-востока на северозапад. На правобережье реки горные ландшафты характеризуются преобладанием лесных, разнотравно-злаковых, высоко-нивальных видов, многоводностью и большой густотой речной сети: в Рудном Алтае 1,5-2,0, в Южном Алтае - 0,5-0,7 км/км². Реки характеризуются значительными уклонами (40-50 м на 1 км и более), большими скоростями течения $(2-5 \mathrm{M} / \mathrm{c})$.

Левобережье равнинное и холмисто-мелкосопочное, со степными, а на юго-западе полупустынными ландшафтами, густота речной сети 0,3-0,1 км / км² (см. приложение VIII).

Иртыш всегда полноводен. Пресная вода относится к гидрокарбонатному классу. Содержание растворенного кислорода в воде - 9,8-11,3 мг/л.

По запасам гидроэнергетических ресурсов территория региона относится к богатейшим районам Республики Казахстан. Энергетический потенциал р. Иртыш - 4 млн. кВт, р. Бухтармы более 1 млн. кВт. Значителен гидроэнергетический потенциал рек Ульба, Уба, Кальджир, Курчум.

Воды рек используются для водоснабжения городов и сел региона, для орошения, обводнения. Реки богаты рыбой, в водах Бухтармы, Курчума ловятся хариус, таймень, нельма, а на их берегах гнездится много водоплавающей птицы.

Орошение более всего развито в Зайсанском, Маркакольском, Тарбагатайском, Курчумском районах.

Для затопления пойменных лугов в долине Иртыша ежегодно производят попуски воды из Бухтарминского и Шульбинского водохранилищ.

Использование р. Иртыш как водного пути началось еще в конце XIX в., и судоходство по нему получило большое развитие как основное средство сообщения между Западной Сибирью и Рудным Алтаем. После строительства железнодорожных магистралей транспортное значение Иртыша несколько уменьшилось, но наряду с Бухтарминским водохранилищем, он по-прежнему остается 
основным средством связи с наиболее удаленными от железных дорог районами.

Навигационный период начинается в среднем в конце апреля и заканчивается в начале-середине ноября. Общая продолжительность навигации около 200 дней.

Водный режим рек области. Влагооборот - важнейшая функция геосистем, а реки - важное звено круговорота воды. Реки распределяют ресурсы пресной воды на суше и возвращают воду в Мировой океан. Речные воды обладают высокой активностью водообмена, смена воды в реке происходит в среднем каждые 11-15 суток. Колебания уровней воды в реках связаны с изменениями расходов воды. Уровни и расходы воды - главные характеристики водного режима рек.

Источниками питания рек являются жидкие атмосферные осадки, снежный покров, высокогорные снега и ледники, грунтовые воды. В зависимости от особенностей питания, выделяются фазы водного режима: половодье, паводки, межень. Речной сток является основным источником пресных вод. Он, кроме того, является распределимым водным ресурсом, что важно для рационального водопользования. Теоретически водные ресурсы неисчерпаемы, но в период НТР потребление воды растет такими темпами, что обеспечение потребностей человека в воде стало важной проблемой современности. Чрезвычайно много чистой воды расходуется на разбавление загрязненных сточных вод, что грозит качественным истощением ресурсов речного стока.

По характеру водного режима на территории Юго-Западного Алтая выделяют следующие типы рек:

1) с весенним половодьем; 2) с весенним половодьем и паводками в теплое время года; 3) с весенне-летним половодьем; 4) с летним половодьем; 5) выровненного (зарегулированного) режима [12, с. 102]. Первый тип характерен для рек левобережья со снеговым питанием (80-95\%). Ко второму относятся реки низкогорий Калбы, Алтая, Тарбагатая. Третий тип - реки среднегорья. Четвертый - реки с ледниковым питанием, для которых характерно летнее половодье. Пятый тип - небольшие водотоки грунтового питания, происходит выклинивание водоносного слоя.

По классификации Б.Д. Зайкова, река Иртыш и ее правые притоки Уба, Ульба, Бухтарма, Курчум снежно-дождевого питания относятся к алтайскому типу водного режима со снежно-дождевым 
питанием, с весенне-летним половодьем и дождевыми паводками в летнее время года, со сравнительно высокой летне-осенней и низкой зимней меженью. Питание их на 50\% и более снеговое, на 25-30\% дождевое, остальное приходится на грунтовый сток (рис. 51, 52).

Растянутый характер половодья в основном определяется разновременностью таяния снега в горах по отдельным высотным зонам и на склонах разной экспозиции.

Примеры гидрографов рек Бухтармы и Курчума за 1975 и 1978 гг. показаны на рис. 53-56. Весенне-летнее половодье на реках в 1975 г.

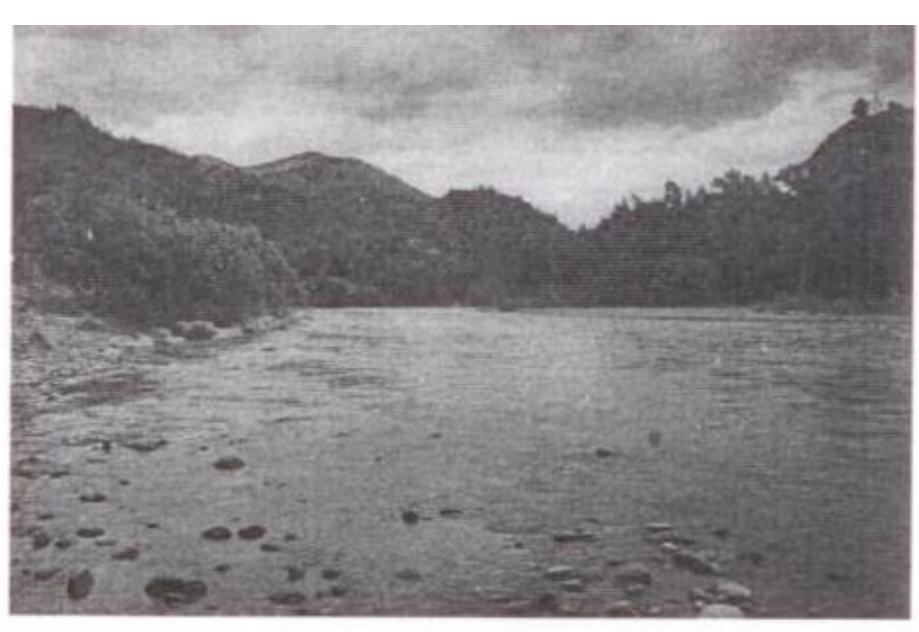

Рис. 51. Река Бухтарма было коротким, в 1978 г. - близкое к норме.

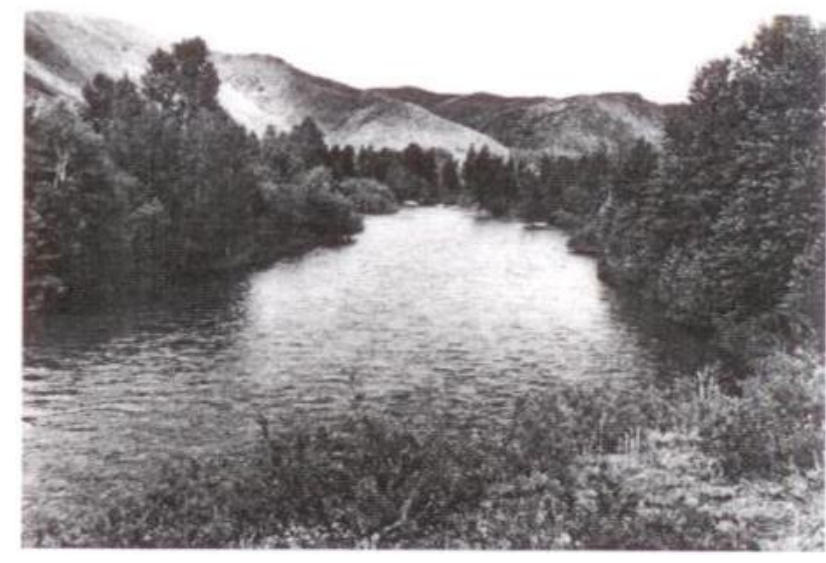

Рис. 52. Река Курчум

Структура годового цикла ГТК (зима 1974/75 гг.): Зыряновск - зима - 1,2, весна - 1,3, лето - 1,1, осень - 1,4. В Курчуме: зима $-1,1$ (нормальная по температуре и сухая, осадков меньше $80 \%$ нормы), весна - 5,2, лето - 1,1, осень - 1,2. Следовательно, высокий уровень воды летом в реках поддерживался в основном за счет летних осадков.

В 1978 г. в Зыряновске тип зимы 1977/78 гг. - 2,2 (теплая с нормальным увлажнением), весны $-2,2$, лета $-1,2$, осени $-2,1$. Зима и весна были теплыми, в горах в этих условиях накапливается снега больше нормы, а лето было по температуре и увлажнению нормальным. В Катон-Карагае все сезоны, кроме осени 1978 г., были нормальными и по температуре и по осадкам. Высокие уровни в апреле-мае 1978 г. связаны с интенсивным таянием снега в горах, зима и весна были теплыми (индекс 2,2).

Общий характер стока в регионе соответствует распределению осадков (см. рис. 27, 30, 47). В Рудном Алтае, на правобережье Бухтармы, в бассейнах Ульбы, Убы слой стока превышает 1000 мм, а 
близ орографических узлов достигает 1500-2000 мм [8, 103]. Высоким стоком также характеризуется Южный Алтай: вблизи ЮжноАлтайского центра оледенения, по северной, наиболее возвышенной цепи хребтов - до 1000 мм. На левобережье Иртыша в высокогорье Саура - около 500 мм и 300 мм на Калбинском хребте [8, 12, 62].

Градиенты стока достигают 80-100 мм и даже 140 мм на 100 м высоты на западных и юго-западных склонах периферийных хребтов Рудного Алтая (табл. 56).

Т а блиц а 56

Модули стока (л/с км²) на различных средневзвешенных высотах водосборов в Рудном Алтае

\begin{tabular}{|c|c|c|}
\hline $\begin{array}{c}\text { Средняя взвешенная высота } \\
\text { водосбора, м }\end{array}$ & $\begin{array}{c}\text { Модуль стока, } \\
\text { //с км }^{2}\end{array}$ & $\begin{array}{c}\text { Слой стока, } \\
\text { мм }\end{array}$ \\
\hline 400 & 4.62 & 146 \\
\hline 500 & 7.60 & 240 \\
\hline 600 & 10.5 & 331 \\
\hline 700 & 13.5 & 426 \\
\hline 800 & 16.5 & 520 \\
\hline 900 & 19.6 & 618 \\
\hline 1000 & 22.7 & 716 \\
\hline 1500 & 40.6 & 1280 \\
\hline 1600 & 44.5 & 1404 \\
\hline 1700 & 49.0 & 1545 \\
\hline 2000 & 51.0 & 1609 \\
\hline
\end{tabular}

В табл. 56 прослеживается рост значений модулей $\left(\mathrm{M}_{0}\right)$ стока с высотой. Между 400 и 500 м слой стока возрастает на 94, при поднятии с 600 до 700 м - на 95 мм, от 900 до 1000 м - на 98 мм. На высотах с 1600 до 1700 м вертикальный градиент стока составляет 141 мм.

Около орографического узла Рудного Алтая сток превышает 2000 мм (модуль стока достигает 65 л/с км²). В верховьях Ульбы

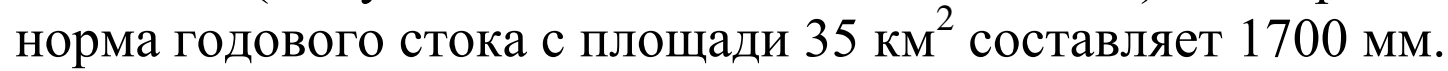

Отмечено изменение нормы годового стока р. Сарым-Сакты: модуль стока в устье равен 11 л/с км²; в 10 км от устья - 21, в 20 км от устья -31 , в 40 км от устья - 45 л/с км² [62, с. 96].

Лето 1978 г. было нормальным по температуре и осадкам. Поэтому гидрограф стока 1978 г. отражает 3-й тип водного режима.

Можно утверждать, что гидрографы 1983, 1986, 1989 гг. по Бухтарме и Курчуму будут аналогичными гидрографу 1975 г., а 1979, 1984, 1987 гг. - гидрографу 1978 г. [104]. 


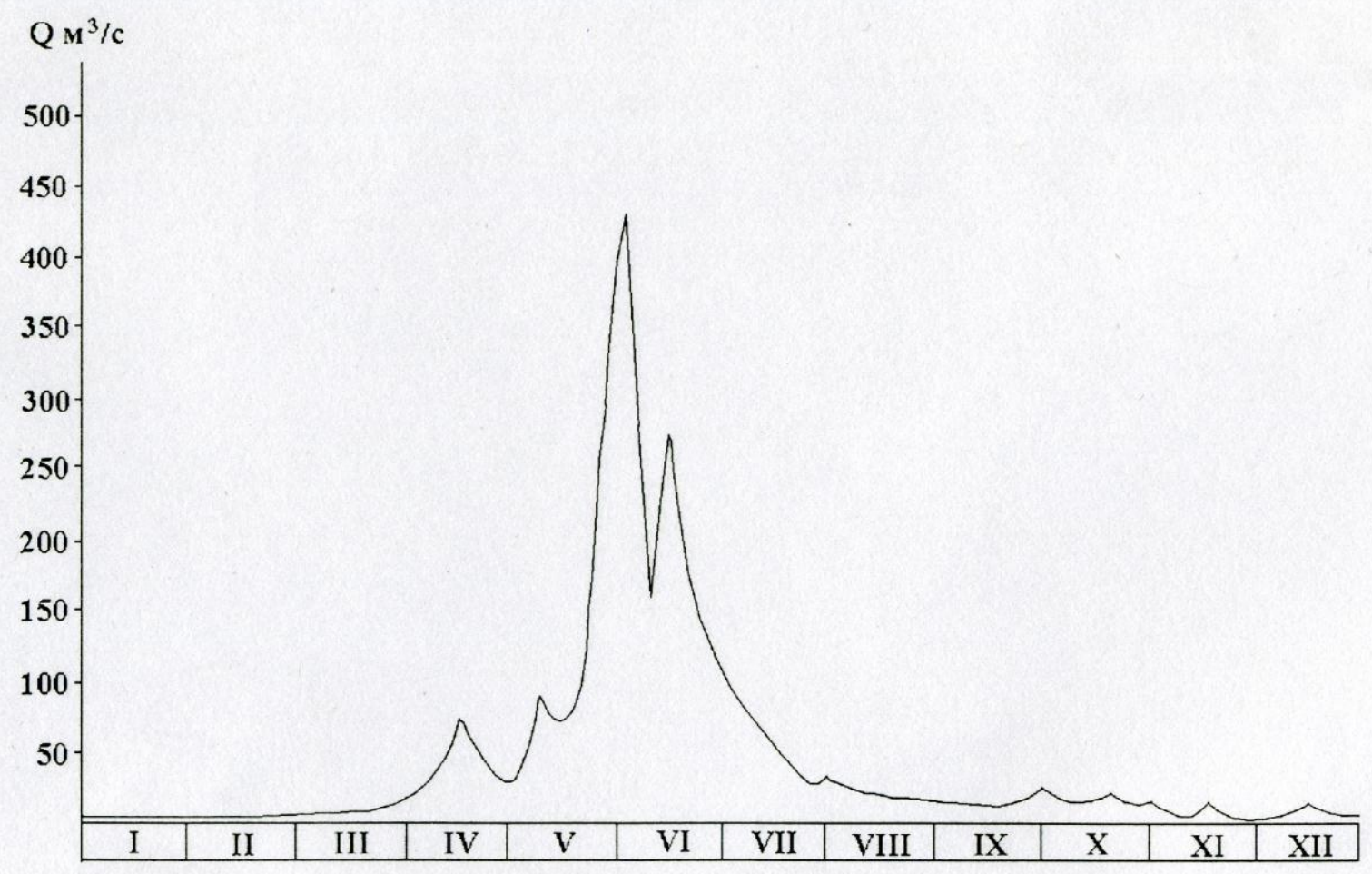

Рис. 53. Гидрограф стока реки Курчум. Село вознесенское. 1975 г.

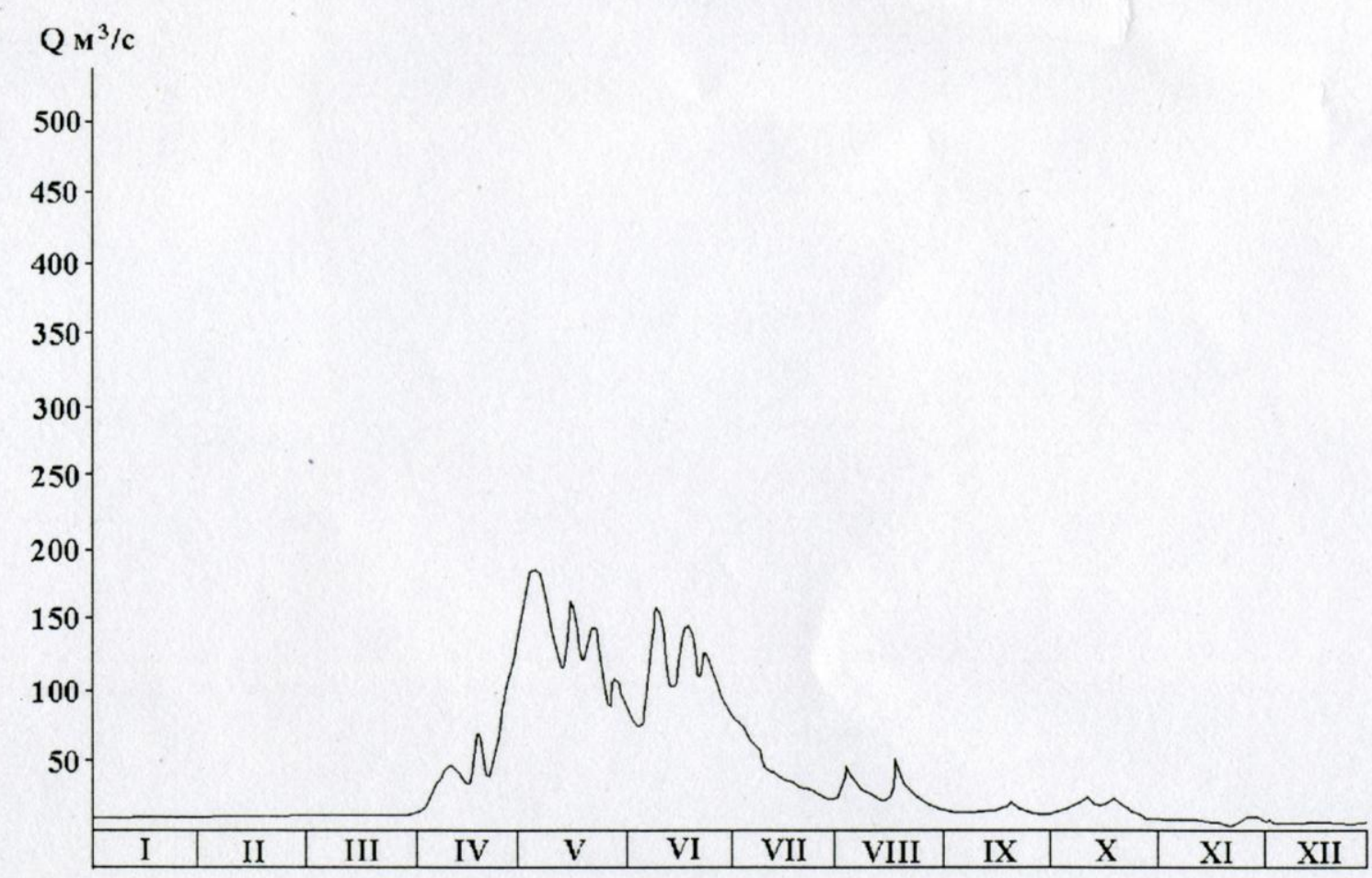

Рис. 54. Гидрограф стока реки Курчум. Село вознесенское. 1978 г. 


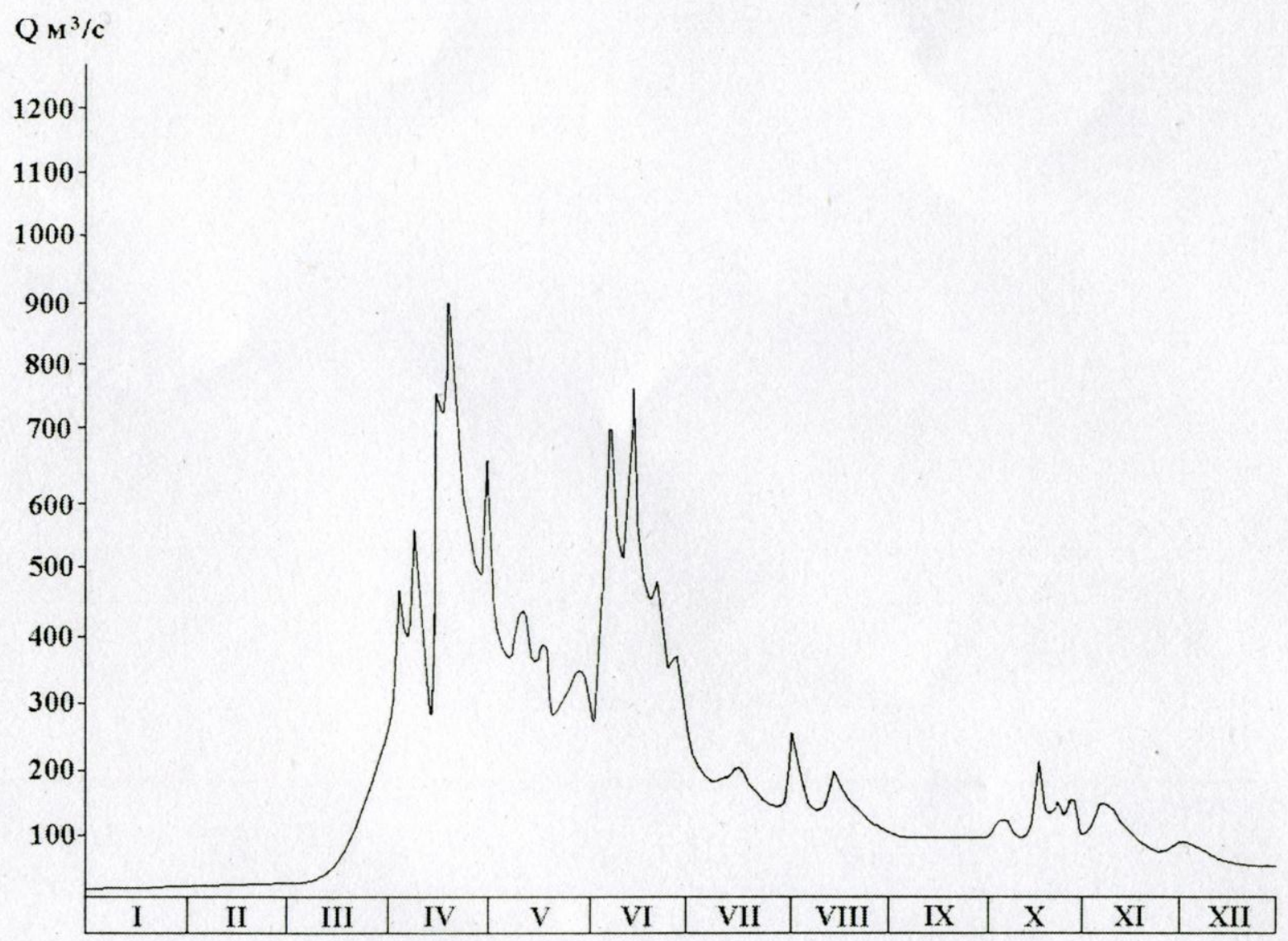

Рис. 55. Гидрограф стока реки Курчум. Село вознесенское. 1975 г.

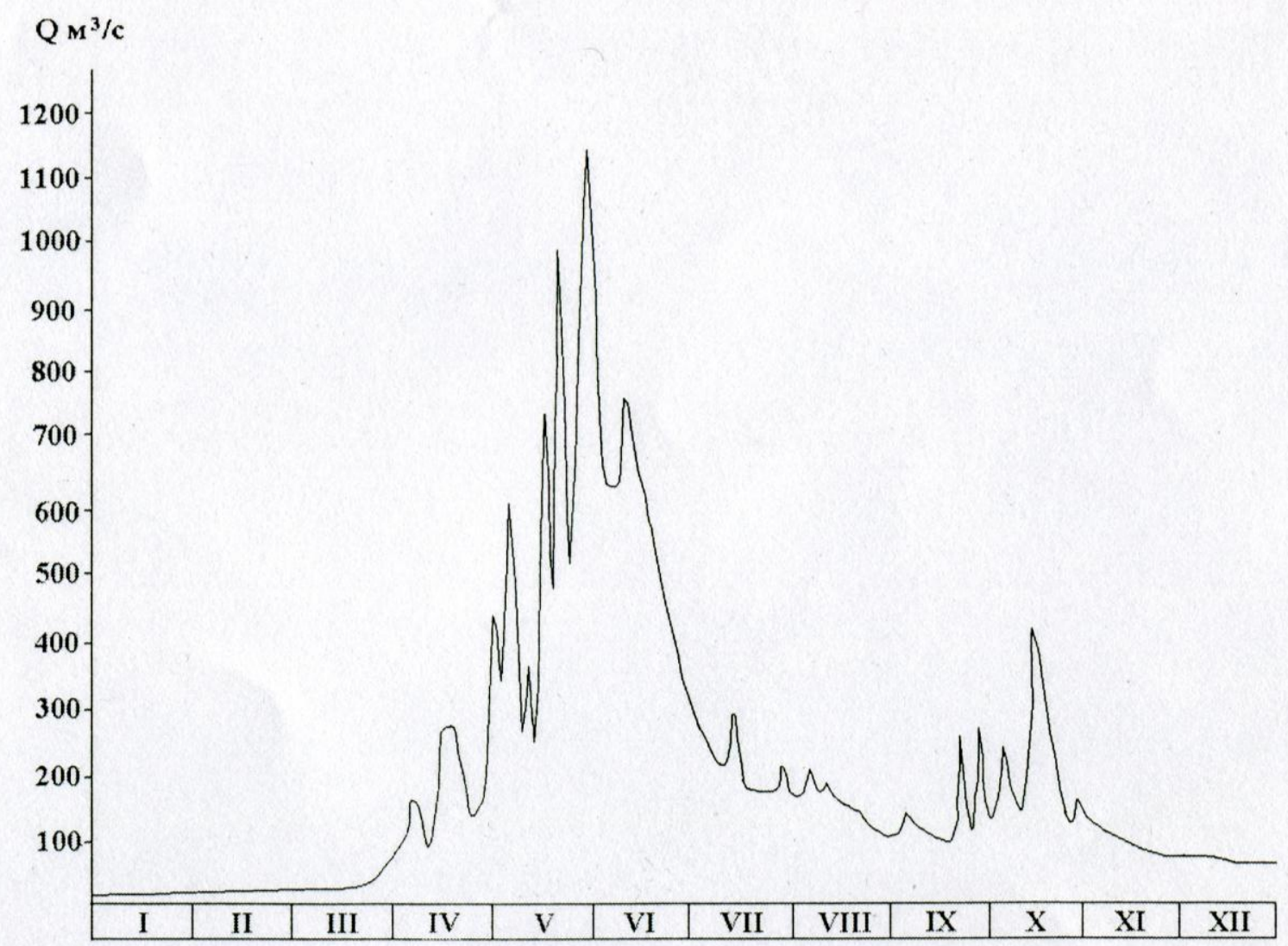

Рис. 56. Гидрограф стока реки Курчум. Село вознесенское. 1978 г. 
Река Бухтарма берет начало у ледников на высоте свыше 3000 м. Значительная часть площади ее бассейна покрыта лесом (с высот от 1000 до 2300 м). Долина шириною 4-5 км безлесна и имеет вид засушливой степи. В нижнем течении река изобилует порогами и отмелями.

В питании Бухтармы преимущественное значение имеют талые воды (более 50\%), которые весной образуются за счет таяния снега, а летом - от таяния снегов на белках и ледниках. Значительные атмосферные осадки при большой крутизне горных склонов и малая проницаемость грунтов обусловили до 30\% годового расхода воды. Грунтовое питание составляет 10-15\%.

Река вскрывается во второй половине апреля, продолжительность ледохода 5-10 дней. Ход весеннего половодья характеризуется постоянным нарастанием расходов за счет снеготаяния и многочисленными паводками от дождей (см. рис. 55). При ледоходе наблюдаются подъемы воды, обусловленные заторами люда. Спад половодья начинается с середины июля и идет весьма медленно, прерываясь дождевыми паводками. В засушливую осень устанавливаются на некоторое время устойчивые меженные уровни, но и осенью часты дождевые паводки. Осенний ледоход продолжается 15-20 дней. Ледостав во второй половине ноября (рис. 57).

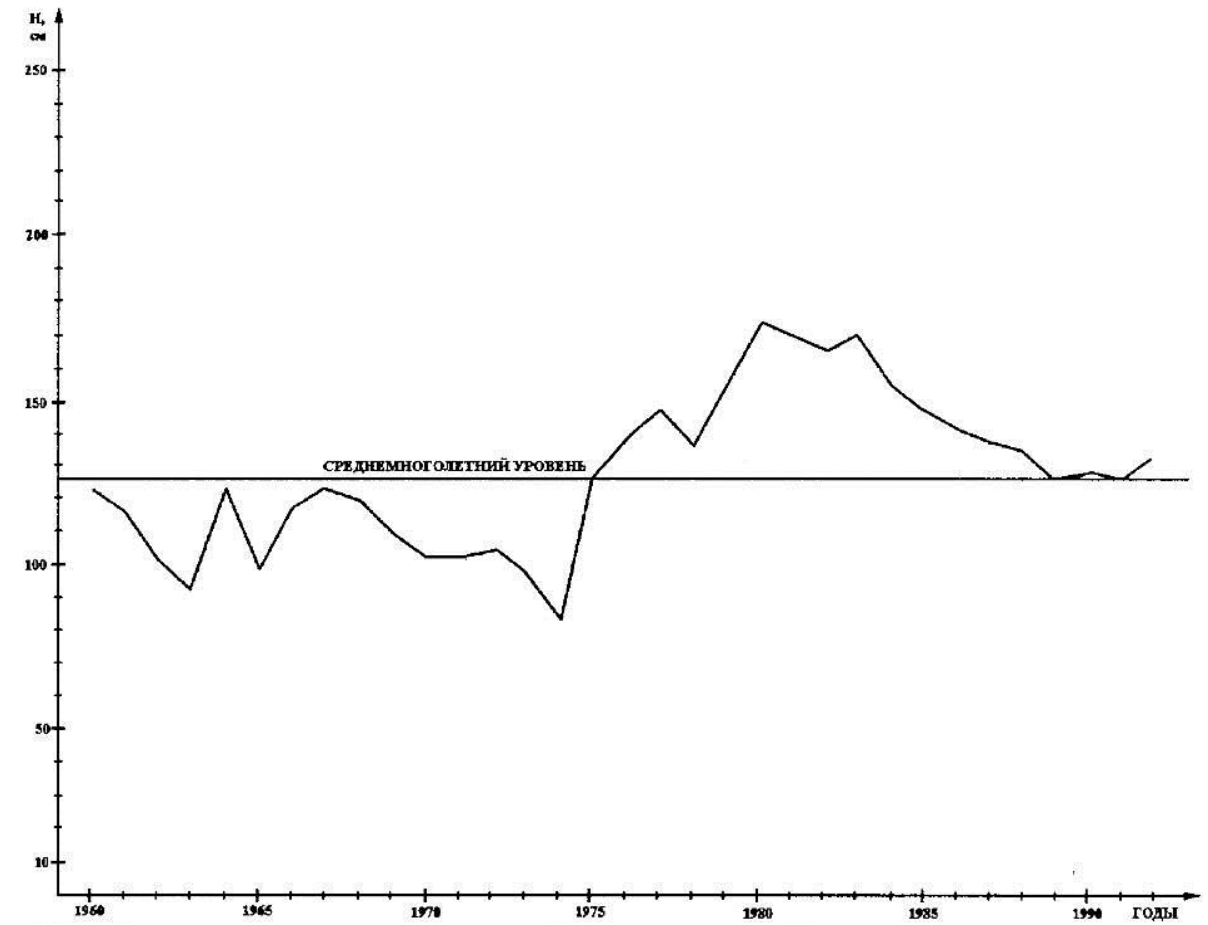

Рис. 57. Среднегодовые уровни р. Бухтарма - п. Берель 
Средние многолетние характеристики годового стока рек Бухтармы и Курчума приведены в табл. 57.

Т а блица 57

Средний многолетний сток рек Бухтарма и Курчум

\begin{tabular}{|c|c|c|c|c|c|c|c|}
\hline $\begin{array}{l}\text { Река, пункт } \\
\text { наблюдений }\end{array}$ & $\begin{array}{c}\text { Период на- } \\
\text { блюдений, } \\
\text { годы }\end{array}$ & $\begin{array}{c}\text { Площадь } \\
\text { бассейна, } \\
\text { км }^{2}\end{array}$ & $\begin{array}{l}\text { Средняя вы- } \\
\text { сота бассей- } \\
\text { на, м }\end{array}$ & $\begin{array}{c}\text { Расход } \\
\text { воды, } \\
\mathrm{m}^{3} / \mathrm{c} \\
\end{array}$ & $\begin{array}{l}\text { Модуль } \\
\text { стока, } \\
\text { л/с км }{ }^{2} \\
\end{array}$ & $\begin{array}{c}\text { Слой } \\
\text { стока, } \\
\text { мм }\end{array}$ & $\begin{array}{l}\text { Коэффи- } \\
\text { циент ва- } \\
\text { риации, } \mathrm{C}_{\mathrm{v}}\end{array}$ \\
\hline $\begin{array}{l}\text { Бухтарма, } \\
\text { с. Лесная } \\
\text { пристань }\end{array}$ & $1955-1980$ & 10700 & 1520 & 203 & 19.0 & 599 & 0.31 \\
\hline $\begin{array}{l}\text { Курчум, } \\
\text { с. Возне- } \\
\text { сенское }\end{array}$ & $1938-1982$ & 5840 & 1350 & 59.0 & 10.1 & 318 & 0.24 \\
\hline
\end{tabular}

Обе реки в верхнем и среднем течении имеют горный характер, средний уклон ложа реки Бухтармы составляет 5,6, Курчума - 9,9\%. Модули стока с высотой увеличиваются. Важно отметить, что режим уровней существенно различен в фазы высших (весеннего ледохода и половодья) и низших (в летнюю и зимнюю межень) уровней. Амплитуда колебаний уровней на Бухтарме (устье р. Березовка) в весенний ледоход достигает 207 см (высший 313, средний 199 и низший 106), в половодье 250 см (высший уровень 360, средний 283 и низший 211), в летнюю межень - 70, в зимнюю - 80 см.

Водный режим р. Иртыш. Первые водомерные посты были открыты в 1899 году. Средний многолетний слой стока р. Иртыш у г. Усть-Каменогорска (1902-1959 гг.) за весенне-летнее половодье (апрель-октябрь) составил 99,0 мм или 73,5\% годового стока, в лимитирующий период (ноябрь - март) соответственно 36,0 мм и 26,5\%. В маловодный, нелимитирующий период (октябрь - ноябрь) 17,3 мм, что составляет $12,7 \%$ годового стока; в зимнюю межень, в лимитирующий сезон (декабрь - март) - 19,0 мм и соответственно $13,8 \%$ годового стока, коэффициент вариации по сезонам изменяется от 0,23 до 0,27 [62].

За 63-летний период (1903-1965 гг.) на Иртыше в створе г. УстьКаменогорска, на расстоянии 1172 км от истока реки с площади водосбора в 147 тыс. км ${ }^{2}$ средний расход воды составил $623 \mathrm{~m}^{3} / \mathrm{c}$, модуль стока 4,24 л/с км², слой стока 134 мм, при коэффициенте вариации $\mathrm{C}_{\mathrm{V}}=0,21$, коэффициенте асимметрии 0,42. Расход воды $50 \%$-ной обеспеченности $-611,75 \%$-ной $-530,95 \%$-ной $-424 \mathrm{~m}^{3} / \mathrm{c}$. 
В среднем половодье длится 141 день: с 4 апреля по 23 августа. Самая ранняя дата половодья наблюдалась 1 марта 1948 г., наиболее поздняя - 1 мая 1912 г. В среднем максимальный расход воды приходится на 17 мая, самая ранняя дата расхода отмечалась 5 апреля 1948 года, самая поздняя - 19 июня 1946 года.

Средняя дата окончания половодья - 23 августа, наиболее ранняя - 21 июня 1955 г., а наиболее поздняя - 27 октября 1921 года. При этом среднее значение из наибольших среднесуточных расходов составляет $2260 \mathrm{~m}^{3} / \mathrm{c}$, наибольшей из максимальных - $3930 \mathrm{~m}^{3} / \mathrm{c}$ в 1937 г., его обеспеченность менее $1 \%$, наименьший из максимальных 1170 м с в 1933 году. Суммарный слой стока за половодье в среднем составляет 85 мм, или 63\% от годового (134 мм), наименьший - 77 мм, наибольший - 199 мм.

Летне-осенняя межень длится 90 дней, с 24 августа по 20 ноября, со средним расходом Иртыша $588 \mathrm{~m} / \mathrm{c}$, за наиболее маловодный период $512 \mathrm{~m}$ / c, средняя продолжительность 15 дней.

Продолжительность зимней межени 134 дня, в среднем с 21 ноября по 3 апреля, средний расход воды $264 \mathrm{~m} 3 / \mathrm{c}$, в наиболее маловодный период со средней длительностью 30 дней, средний расход воды $228 \mathrm{~m}^{3} / \mathrm{c}$ [62, с. 147-149].

За период наблюдений 1902-1951 гг. годовая амплитуда колебаний уровня Иртыша (г. Усть-Каменогорск, 1172 км от истока) составила в среднем 346 см, наибольшая 494 и наименьшая 212 см. С сооружением ГЭС внутрисуточный ход уровня зависит от энергопотребления. Самые низкие уровни наблюдаются в течение суток в ночное время, высшие - в дневное и вечернее.

Для обеспечения нормальной работы водного транспорта с мая по октябрь установлены гарантированные средние суточные расходы воды $550 \mathrm{~m}^{3} / \mathrm{c}$.

Ледоставу на Иртыше предшествует ледоход продолжительностью от 11 до 20 дней, в зависимости от характера зимы. С переходом температуры воды через $0,2^{0}$ осенью в начале ноября образуются забереги. Выпавший на воду снег - шуга, смерзаясь, образует ледоход. В узких участках русла и при его крутых резких поворотах могут образоваться заторы льда. В конце ноября река замерзает. Вскрывается в начале апреля.

Весной, с переходом температуры воздуха через $0^{0}$, начинается процесс таяния и разрушения льда. Средняя продолжительность ледохода - 0-8 дней, могут быть заторы. 
С заполнением водохранилища Усть-Каменогорской ГЭС на Иртыше ниже плотины в течение зимы сохраняется полынья от 1,5 до 13 км длиною. В очень теплые зимы (1980-1990 гг.) Иртыш ниже плотины ГЭС практически не замерзал от Усть-Каменогорска до Предгорного.

В табл. 58 приведены средние месячные расходы р. Иртыш в створе Усть-Каменогорской ГЭС за период наблюдений 1961-1980 гг. [105].

Средний годовой расход Иртыша за период наблюдений 19611980 гг. составил 546, наибольший - 730, наименьший $-369 \mathrm{~m}^{3} / \mathrm{c}$. Динамика водности Иртыша показана на средние годовые уровни p. Черный Иртыш (пос. Буран) за период 1960-1992 гг. Основным источником питания Черного Иртыша является таяние снега и ледников.

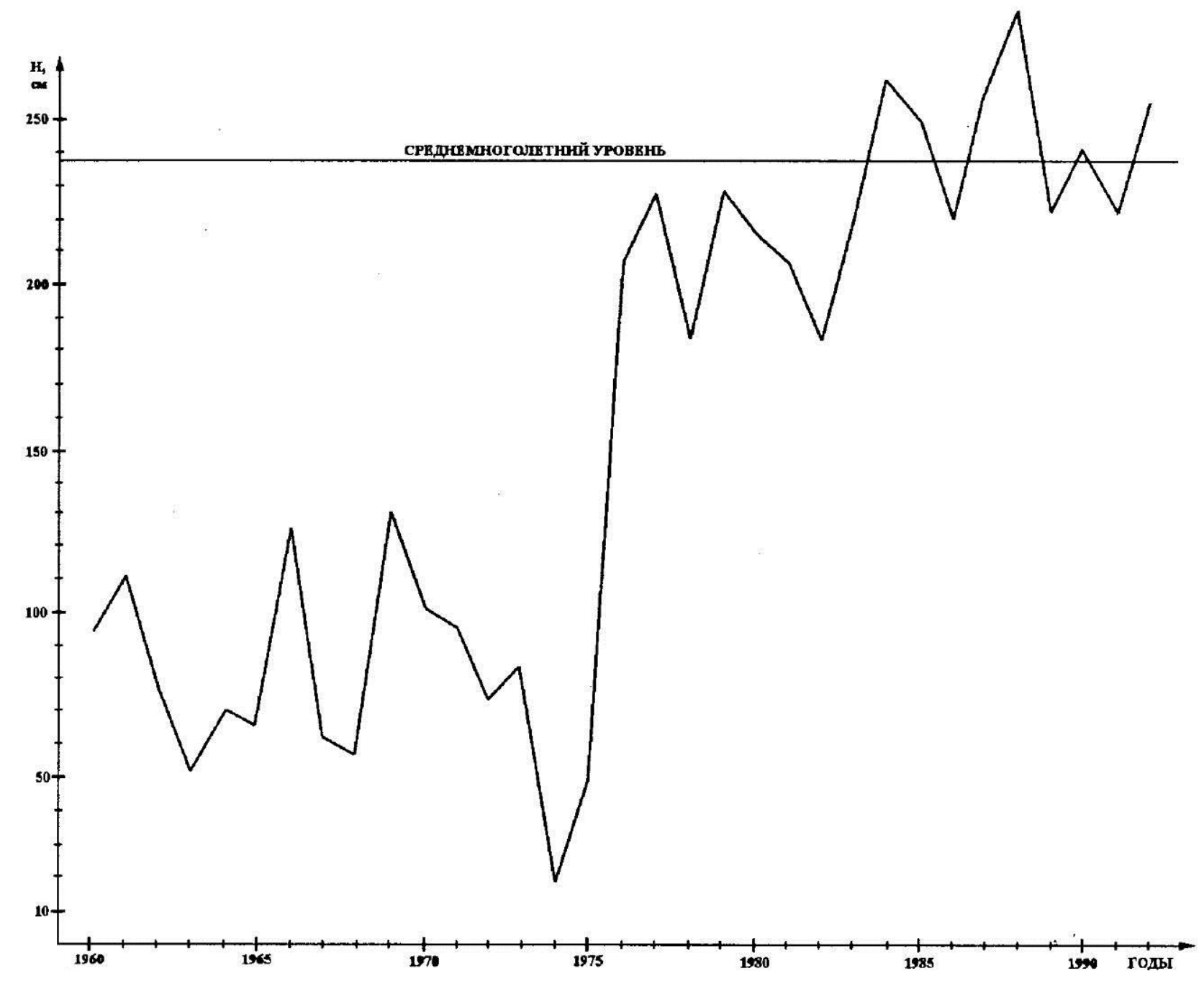

Рис. 58. Среднегодовые уровни р. Черный Иртыш - п. Буран 
Средние месячные расходы воды р. Иртыш - Усть-Каменогорская ГЭС (1961-1980 гг.) в разные по водности годы, м³/с

\begin{tabular}{|c|c|c|c|c|c|c|c|c|c|c|c|c|}
\hline $\begin{array}{l}\text { Год по } \\
\text { уровн } \\
\text { ю } \\
\text { воднос } \\
\text { ти }\end{array}$ & I & II & III & IV & V & VI & VII & VIII & IX & $\mathrm{X}$ & XI & XII \\
\hline $\begin{array}{l}\text { Средн } \\
\text { ий }\end{array}$ & 445 & 440 & 442 & 866 & 623 & 532 & 563 & 571 & 585 & 561 & 483 & 455 \\
\hline $\begin{array}{l}\text { Наибо } \\
\text { льший }\end{array}$ & 732 & 734 & 657 & 1410 & 968 & 741 & 747 & 738 & 802 & 768 & 702 & 741 \\
\hline $\begin{array}{l}\text { Наиме } \\
\text { ньший }\end{array}$ & 252 & 244 & 226 & 284 & 319 & 419 & 471 & 395 & 377 & 382 & 329 & 238 \\
\hline \multicolumn{13}{|c|}{$\begin{array}{c}\text { Характеристика расхода воды р. Черный Иртыш у с. Буран } \\
\text { в разные по водности годы }\end{array}$} \\
\hline \multirow{2}{*}{\multicolumn{3}{|c|}{\begin{tabular}{c|c}
$\begin{array}{c}\text { Год по уровню } \\
\text { водности }\end{array}$ \\
\end{tabular}}} & \multicolumn{5}{|c|}{ Наибольший } & \multicolumn{5}{|c|}{ Наименьший } \\
\hline & & & \multicolumn{3}{|c|}{\begin{tabular}{l|l}
$\mathrm{M}^{3} / \mathrm{c}$ & \\
\end{tabular}} & \multicolumn{2}{|c|}{ Дата } & \multicolumn{3}{|c|}{$\mathrm{m}^{3} / \mathrm{c}$} & \multicolumn{2}{|c|}{ Дата } \\
\hline \multicolumn{3}{|c|}{ Средний } & \multirow{2}{*}{\multicolumn{3}{|c|}{$\frac{1790}{2210}$}} & \multicolumn{2}{|c|}{ 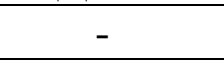 } & \multicolumn{3}{|c|}{250} & \multicolumn{2}{|c|}{-} \\
\hline \multicolumn{3}{|c|}{ Наибольший } & & & & \multirow{2}{*}{\multicolumn{2}{|c|}{$\frac{22.04 .73 \text {. }}{08.08 .63}$}} & \multicolumn{3}{|c|}{454} & \multicolumn{2}{|c|}{ 09.06.69. } \\
\hline \multicolumn{3}{|c|}{ Наименьший } & \multicolumn{3}{|c|}{563} & & & & 167 & & 12.03 & \\
\hline
\end{tabular}

Период с начала 70-х годов Байдал М.Х. относит к третьему геоклиматическому циклу, в течение которого отмечаются три одиннадцатилетних цикла солнечной активности: 20-й, особо интенсивный - 21-й и менее интенсивный - 22-й. Установлено, что в периоды максимумов солнечной активности сильных засух не бывает, зато они часты в периоды минимальных значений $(1974,1991$ гг.). С 1960 г. над исследуемым регионом преобладал тип циркуляции E (по Вангенгейму). При таких ситуациях циркуляционных процессов над Алтаем располагается циклогенетическая часть высотной ложбины, что определяет повышенную снежность в верхней части среднегорья и высокогорья. Уже с 1992 г. средний годовой уровень Черного Иртыша значительно превысил нормальный [43].

Термический режим. Изменения температуры воды производятся в период свободного русла. Зимой температура воды принимается равной $0^{0}$. Годовой ход температуры воды повторяет годовой ход температуры воздуха. Обычно рассматривают следующие уровни температуры воды: $0,2^{0}, 4^{0}, 10^{0} \mathrm{C}$. Температура 
$0,2^{0} \mathrm{C}$ характеризует появление ледовых явлений. Переход через $0,2^{0} \mathrm{C}$ осенью происходит с начала ноября до первой декады декабря, весной в среднем с конца марта до середины апреля. Температура $4^{0} \mathrm{C}$ характеризует начальную стадию нагревания или охлаждения воды и наибольшую ее плотность. Переход температуры через $4^{0} \mathrm{C}$ происходит весной в середине апреля - в начале мая, осенью - во второй половине сентября - середине октября. Температура $10^{0} \mathrm{C}$ держится в среднем с конца мая до второй половины сентября. Осенью между переходом температуры через $4^{0} \mathrm{C}$ и ледоставом проходит 20-55 дней. Максимальная температура на Иртыше в суточном ходе наблюдается в 18-22 часа, минимальная - перед восходом солнца. До постройки ГЭС в черте города температура воды Иртыша средняя за май-октябрь составляла $18,4^{0} \mathrm{C}$, в летние месяцы $-18-22^{0} \mathrm{C}$. На современном этапе ниже ГЭС поступает донная вода водохранилища, температура которой в теплый период составляет $8-12^{0} \mathrm{C}$.

Средняя месячная температура воды р. Иртыш с. Аблайкетка, ${ }^{0} \mathrm{C}$

$\begin{array}{cccccccccccc}\text { I } & \text { II } & \text { III } & \text { IV } & \text { V } & \text { VI } & \text { VII } & \text { VIII } & \text { IX } & \text { X } & \text { XI } & \text { XII } \\ 0.3 & 0.2 & 0.4 & 2.5 & 6.8 & 10.3 & 11.7 & 12.2 & 11.5 & 9.0 & 4.6 & 1.2\end{array}$

Санитарно-гигиеническое (экологическое) состояние поверхностных вод Иртыша, несмотря на его полноводность, характеризуется как «наиболее неблагоприятное» [97]. Основные загрязняющие вещества - медь, цинк, кадмий, свинец, мышьяк поступают в реку со сточными водами предприятий металлургической промышленности.

Сбросы сточных вод в поверхностные водоемы за последние пять лет практически не уменьшились. Так, в водоемы области поступило сточных вод в 1985 г. -378 млн. м ${ }^{3}$, в 1990 г. -359 , в 1991 г. -356, в 1992 г. -354 млн. м³.

Индекс загрязнения воды р. Иртыш

\begin{tabular}{|l|c|c|c|c|}
\hline \multirow{2}{*}{ Пункты определения ИЗВ } & \multicolumn{4}{|c|}{ Годы } \\
\cline { 2 - 5 } & 1990 & 1991 & 1992 & 1993 \\
\hline с. Буран & 3.48 & 2.48 & 2.35 & 2.84 \\
\hline г. Усть-Каменогорск & 3.94 & 2.95 & 3.02 & 2.38 \\
\hline пос. Глубокое & 4.01 & 3.21 & 3.09 & 3.04 \\
\hline с. Предгорное & 3.66 & 4.05 & 3.11 & 4.00 \\
\hline пос. Первомайка & 3.77 & 3.97 & 2.63 & 4.44 \\
\hline
\end{tabular}


В пределах региона сточные воды в реки бассейна Иртыша сбрасывают около ста предприятий. По индексу загрязнения воды (ИЗВ) качество воды чаще относится к 4 классу (загрязненные воды), реже - к 3 классу качества (умеренно загрязненные воды), либо к 5 классу качества - грязная вода. Динамика загрязнения воды вниз по течению Иртыша показана в табл. 59.

Из таблицы видно, что самоочищения реки не происходит, хотя расходы воды вниз по течению интенсивно нарастают (у Бурана 300, в Усть-Каменогорске - 600, Семипалатинске - $900 \mathrm{~m}^{3} / \mathrm{c}$ ). Концентрации загрязняющих веществ изменялись в УстьКаменогорске: меди - от 0 до 16 ПДК, нефтепродуктов - до 18 ПДК, фенолов - от 0 до 28 ПДК, цинка - до 6,8 ПДК. Наиболее загрязнены поверхностные воды створа «0,5 км ниже сброса ТМК», в котором зарегистрированы максимальные концентрации: фенолов 36 ПДК (13.09.91 г.), цинка 24,6 ПДК (03.03.92 г.), нефтепродуктов 218 ПДК (07.05.92 г.). В 1993 г. ИЗВ был равен 2,38, вода 3 класса качества умеренно загрязненная, а в 1990-1992 гг. - 4 класса качества загрязненная. После впадения в Иртыш р. Глубочанка концентрация загрязняющих веществ в р. Иртыш изменялась: меди - до 12 ПДК (максимум 23 ПДК 03.03.92 г.), цинка - до 5,8 ПДК, фенолов - до 21 ПДК (максимум - 37 ПДК 13.03.91 г.), азота нитратного - до 3,5 ПДК. После впадения р. Красноярки концентрация загрязняющих веществ составила: меди - до 24, цинка - до 9,6, фенолов до 34 ПДК. В районе с. Предгорное в 1991 г. воды Иртыша относились к 5 классу качества (грязные), в остальные годы - к 4-му (загрязненные).

Реки Ульба, Брекса, Тихая, Глубочанка, Красноярка на протяжении всего периода наблюдений относятся к рекам с самым низким классом качества воды - чрезвычайно грязные водоисточники [97, с. 37]. Среднегодовые концентрации основных загрязняющих веществ возрастали в р. Глубочанка до экстремальных уровней в 160 и максимальных значений в 800 ПДК (см. табл. 59).

Река Ульба образуется при слиянии рек Громотуха и Тихая, берущих начало в Ивановском и Убинском хребтах. Ее длина от истока реки Громотухи 156 км, площадь водосбора 4990 км². Река загрязнена с самого верховья. Лениногорский полиметаллический комбинат имеет 23 выпуска сточных вод в р. Филипповку, приток р. Тихой. Ульба только в среднем течении имеет нормальное содержание кислорода и удовлетворительные физические свойства. 
Близ устья ее вода по составу и свойствам приближается к разбавленной сточной воде. В Ульбу сбрасывают сточные воды ТМК и СЦК, которые содержат цинка до 20,0, мышьяка до 0,5, меди до 2,0 мг/л. Аварийный сброс технологического раствора на цинковом заводе СЦК 23 июля 1989 г. привел к гибели в устье реки около 3,5 млн. экземпляров рыбы, так как концентрация цинка даже через несколько часов после сброса достигала 571 мг/л. Заводу комитетом по охране природы предъявлен иск в 1,5 млн. рублей («Рудный Алтай», 12 августа 1989 г.).

Питание реки Ульбы смешанное: снеговое - 51, дождевое - 28, грунтовое - 21\%. Средний годовой расход воды 99,7, наибольший 160 , наименьший $-49,3$ м³. Коэффициент вариации $\mathrm{C}_{\mathrm{V}}=0,29$. Расход 1\%-ной обеспеченности составляет $184,10 \%$-ной $-155,50 \%$ ной - 98,9, 75\%-ной - 80,6, 95\%-ной $-59,2 \mathrm{~m}^{3} / \mathrm{c}$.

Годовой модуль стока: наибольший - 32,7, средний - 20,3, наименьший - 10,1 л/с км². Слой стока (за период 1930-39 гг., 1942-80 гг.) годовой: наибольший - 1031, средний - 641, наименьший -318 мм на средней высоте водосбора 960 м. Из наибольших расходов воды р. Ульбы средний равен 995, наибольший из максимальных 2220 (30.05.79), наименьший - $335 \mathrm{~m}^{3} / \mathrm{c}(18.04 .33)$.

Из наименьших: средний - 12,8, наибольший - 22,0 (28.0102.02.61), наименьший $-6,76 \mathrm{~m}^{3} / \mathrm{c}(07.11 .74)$.

Наименьший за период открытого русла: средний - 22,7, наибольший - 63,2 (03.08.46), наименьший - 10,0 м³ 1 (26-28.08.55 и 23-26.08.74).

Средний многолетний сток р. Ульбы определяется главным образом структурой водного баланса водосбора. Бассейн Ульбы получает обильные осадки, в устье - 500, на высоте 1,5 км - более 1500 , за холодный период - более 500 мм в год.

После перехода дневных и особенно среднесуточных температур воздуха через $0^{0}$ весной начинается интенсивное снеготаяние: в первый период от 4-6 до 15-16 мм в сутки, в заключительный период - 30-35 мм в сутки и более.

Весенне-летнее половодье, многоводный период приходится на апрель - июль, средний слой стока составляет 502 мм или 78,0\% годового, коэффициент вариации $\mathrm{C}_{\mathrm{V}}=0,32$. Начало половодья приходится на первую декаду апреля, продолжительность подъема достигает 50 дней, максимальные расходы половодья наблюдаются в первой-второй декадах мая и достигают 2000-2200 м³. Нарастание 
уровня воды происходит с постепенно увеличивающейся интенсивностью и перед пиком половодья достигает 100-150 см в сутки. На Ульбе во время весенне-летнего половодья амплитуда суточных колебаний уровня может достигать 50-100 см.

При больших запасах воды в снеге к началу формирования половодья, высоком увлажнении почвы осенью перед установлением снежного покрова, а также при нарушении нормальных условий хозяйственного использования водных ресурсов наблюдаются высокие и критические уровни воды.

Интенсивный поверхностный сток при высоких температурах воздуха весной способствует уменьшению против обычного потерь воды на инфильтрацию (1958, 1979, 1990, 1994, 2001 гг.). В 1958 г. за половодье слой стока составил 755 мм. Среднесуточный максимальный модуль достигал 408 л (с км²), продолжительность половодья составила 83 суток [62, с. 140]. На маловодный нелимитирующий сезон - летне-осеннюю межень (август - ноябрь) приходится 15,4\% годового стока или слой 103 мм, коэффициент вариации $\mathrm{C}_{\mathrm{V}}=0,46$. На зимнюю межень (лимитирующий сезон

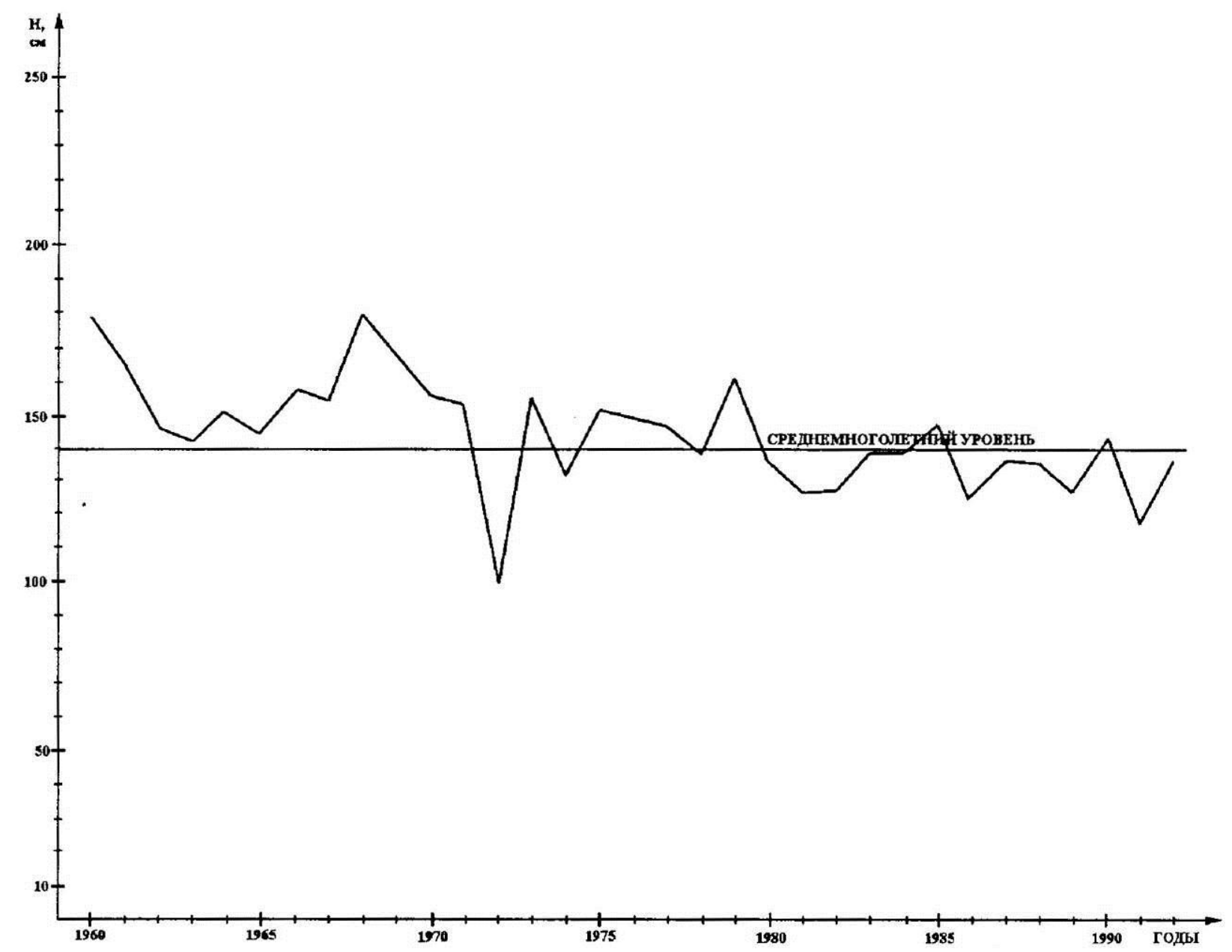

Рис. 59. Среднегодовые уровни р. Ульба - п. Ульба-Перевалочная 
декабрь - март) - 6,0\% или слой 42,6 мм при $\mathrm{C}_{\mathrm{V}}=0,33$. В пределах Рудного Алтая наибольшие зимние модули стока отмечаются в бассейне Ульбы и достигают 8,42 л/с км². За последние 12 лет (19801991 гг.) в связи с засушливым летом среднегодовой уровень ниже многолетнего. Основная причина, вероятно, связана с глобальным потеплением и уменьшением скоростей переноса воздушных масс в средней тропосфере (рис. 59).

Ульба замерзает в ноябре-декабре, вскрывается в апреле. Весенний ледоход на реке (с. Ульба-Перевалочная) в среднем начинается 7 апреля, заканчиваются ледовые явления обычно 14 апреля. В черте г. Усть-Каменогорска река полностью не покрывается льдом под влиянием промышленных стоков. В среднем течении мощность ледяного покрова от 12 до 79 см, максимальная мощность наблюдается в марте - 96 см. Годовая амплитуда колебания уровня реки в среднем составляет 217, максимальная - 388 см. В бассейне р. Ульбы расположен каскад малых ГЭС - Хариузовская, Тишинская, Ульбинская. На Ульбе стоят Лениногорск, Усть-Каменогорск. Воды реки используются в коммунальном хозяйстве, есть питьевые водозаборы. Летом в Ульбе купаются дети, температура воды в летние месяцы $-15-21^{0} \mathrm{C}$, максимальная $20-25^{\circ} \mathrm{C}$. В долине Ульбы сохранился хороший сосновый лес - зона отдыха горожан.

Р ека Уба образуется от слияния Белой и Черной Убы. Длина

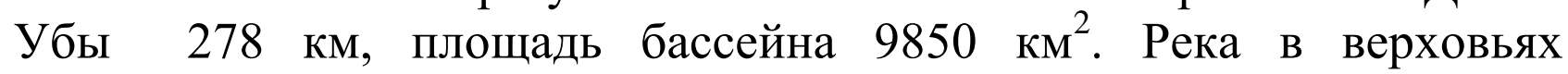
порожиста, в низовьях на предгорной равнине разбивается на рукава. Питание смешанное, преобладает снеговое. Половодье с апреля до середины июля. Замерзает в ноябре - начале декабря, вскрывается в апреле - начале мая. Средний расход воды в 8 км от устья $177 \mathrm{~m} / \mathrm{c}$.

Амплитуда колебаний уровня реки в период весеннего ледохода (с. Нижне-Убинское) составляет 160 см, при наивысших уровнях половодья - 157 см, при низших уровнях, в летнюю межень -110 , в зимнюю - 13 см. Бассейн Убы характеризуется высокой увлажненностью. Среднегодовые уровни p. Убы близки к многолетним (рис. 60).

Река сильно загрязнена с самых верховий. Высокие концентрации металлов в донных отложениях ведут к изменению структуры биоценозов: обедняется ихтиофауна, сокращается численность организмов - до полного исчезновения отдельных видов. Загрязнение вод идет также за счет сброса загрязнителей с сельскохозяйственных полей и животноводческих ферм $[97,108]$. 


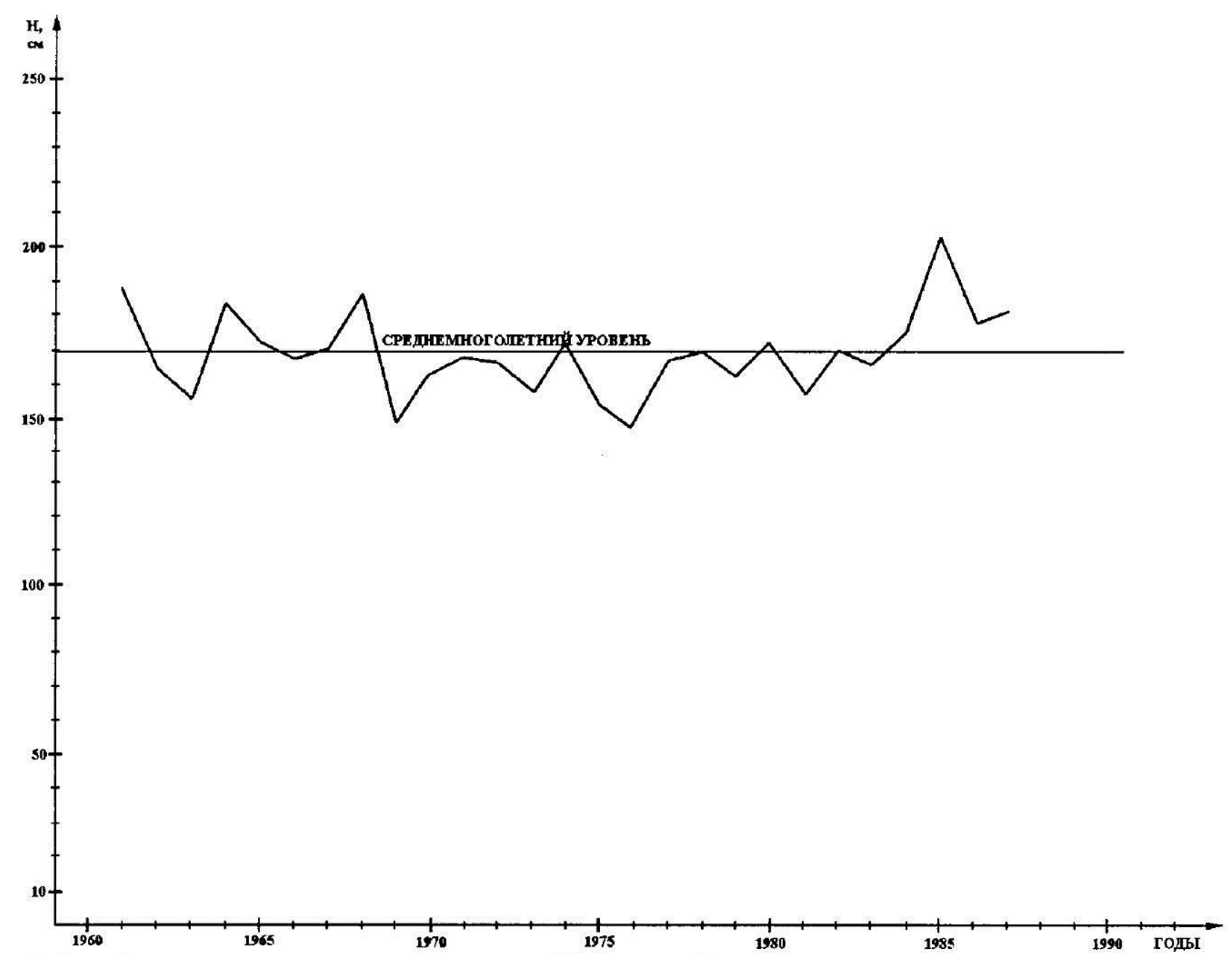

Рис. 60. Среднегодовые уровни р. Уба. Поселок Карагужиха

Реки левобережья Иртыша - Уланка, Дресвянка, Аблайкетка. Эти реки берут начало на Калбинском хребте. Весеннее половодье на них длится от 60 до 130 дней, максимальный сток в апреле-мае (40$45 \%$ годового стока), объем стока за половодье достигает 70-80\% годового.

Летне-осенняя межень длится 150-180 дней, доля меженного стока - до 3-5\%. Зимняя межень длится 140-150 дней, с ноября по март, минимальный сток в феврале-январе. Режим этих рек характеризует р. Аблайкетка (табл.60).

Средний годовой расход воды р. Аблайкетки - хутор Басова (1932, 1962-1980 гг.) составляет $5,15 \mathrm{~m}^{3} / \mathrm{c}$, средний годовой модуль стока 3,05 л (с км²), слой стока - 96 мм, наибольший - 213 мм. 
Половодье на р. Аблайкетка в среднем длится с 22 марта по 28 июня - 99 дней, наибольшая продолжительность была в 1963 г. - 132 дня, наименьшая в 1978 г. - 64 дня.

Т а бли ц а 60

Средний месячный расход воды

p. Аблайкетка - хутор Басов (1932, 1962-1980 гг.), м³/с

\begin{tabular}{|l|c|c|c|c|c|c|c|c|c|c|c|c|}
\hline $\begin{array}{c}\text { Год по } \\
\text { уровню } \\
\text { водности }\end{array}$ & I & II & III & IV & V & VI & VII & VIII & IX & X & XI & XII \\
\hline Средний & 1.37 & 1.29 & 4.45 & 16.0 & 16.1 & 6.39 & 3.08 & 2.55 & 2.0 & 2.52 & 2.44 & 1.71 \\
\hline $\begin{array}{l}\text { Наиболь- } \\
\text { ший }\end{array}$ & 2.93 & 2.44 & 2.03 & 43.0 & 50.5 & 15.0 & 7.09 & 13.0 & 5.47 & 6.61 & 5.73 & 4.28 \\
\hline $\begin{array}{l}\text { Наимень } \\
\text {-ший }\end{array}$ & 0.76 & 0.29 & 1.34 & 4.0 & 4.29 & 0.90 & 0.57 & 0.54 & 0.78 & 1.14 & 0.83 & 0.53 \\
\hline
\end{tabular}

Дата перехода температуры воды осенью через $0,2^{0}-13$ ноября (в 95\% случаев), весной - 6 апреля (в 89\%). Осенний ледоход начинается в среднем 3 ноября (83\%), начало ледостава приходится на 24 ноября, соответственно ранние даты - 18 октября (1972 г.) 6 ноября (1974 г.), поздние - 12 ноября (1964 г.) и 10 декабря (1963 г.).

Средняя дата весеннего ледохода - 30 марта, окончание ледовых явлений - 5 апреля, соответственно ранние - 29 марта $(1963,1968$ гг.) и 30 марта (1968 г.), поздние - 22 апреля (1979 г.) и 28 апреля (1969 г.), в летний период, июнь-август, температура воды в реке 17-20 ${ }^{0}$. Долины этих рек освоены как рекреационные зоны, а также для пригородного ведения сельского хозяйства и дачных участков.

Формирование стока. Анализируя осадки, формирующие сток данного года, Р.И. Гальперин выяснил, что наибольшая теснота связи достигается при сдвиге осадков на 3-5 месяцев. В Рудном Алтае оптимальный сдвиг составляет 3 , на Калбе - 4-5 месяцев. Преобладающие значения коэффициента корреляции находятся в пределах 0,7-0,9. Коэффициенты корреляции годовых расходов Иртыша и осадков по станции Усть-Каменогорск для различных эпох макроциркуляции атмосферы колеблются от 0,69 в период преобладания формы С циркуляции до 0,85 в эпоху циркуляции Е. Чем значительней водность реки, тем меньше сдвиг по времени между стоком и формирующими осадками: в 1931-1939 (эпоха Е) при $\mathrm{Q}=571 \mathrm{~m}^{3} / \mathrm{c}$ оптимальный сдвиг составил 7 месяцев, в 1940-1948 (эпоха С) при $\mathrm{Q}=681 \mathrm{~m}^{3} / \mathrm{c}-$ сдвиг 4 месяца. В эпоху С водность 
Иртыша особенно повышена весной, пик половодья приходит рано. В эпоху Е сток во многом зависит от осадков в январе-марте [63].

\section{4. Краткая характеристика режима водохранилищ и озер}

Самое крупное водохранилище на реке Иртыш -

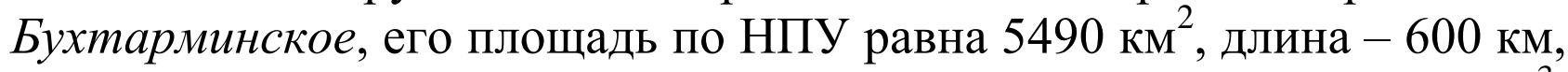
ширина - 40, глубины достигают 80 м, полный объем 49,621 км', введено в эксплуатацию в 1967 году. Плотина высотою 67 м перегораживает реку в узком месте, выше г. Серебрянска построена ГЭС мощностью 675 мВт.

Водохранилище включает оз. Зайсан, уровень воды в котором поднялся на 6 м. Это водохранилище называют Бухтарминским морем. На его берегах созданы базы отдыха для населения УстьКаменогорска, Зыряновска, Риддера.

Подъем уровня воды в водохранилище происходит с начала мая, достигая наивысшей отметки в августе. С сентября начинается осенне-зимняя сработка, продолжающаяся до конца апреля. Со второй декады апреля по вторую декаду мая происходит попуск воды для орошения поймы Иртыша. Амплитуда многолетних колебаний уровня водохранилища около 5 м.Наиболее продуктивный слой - 4 м, глубины богаты фито- и зоопланктоном. Ихтиофауна представлена 36 видами: щука, линь, карась, елец, судак, омуль, нельма, плотва, окунь и др. Вода пресная, мягкая, слабощелочная, относится к гидрокарбонатному классу.

Усть-Каменогорское водохранилище. Плотина Усть-Каменогорской ГЭС высотой более 40 м перегораживает русло Иртыша, где он прорывает Аблайкетскую гряду, выше впадения р. Аблайкетки. Параметры водохранилища: длина 77 км, ширина от 0,2 до 1,2 км, объем воды $0,65 \mathrm{~km}^{3}$, средняя глубина 17 , наибольшая $46 \mathrm{м}$. Водообмен в водохранилище происходит за 15 дней. Весной вскрытие водохранилища начинается с конца апреля, максимальный прогрев воды наблюдается в июле от 8,2 до $23,5^{\circ} \mathrm{C}$, придонный слой $8,0-13,5^{0} \mathrm{C}$. Ледоход - в конце октября. Прозрачность воды в приплотинной части 1,8-3,3 м. Содержание растворенного кислорода в воде в пределах нормы - 9,8-11,3 мг/л, вода ультрапресная, относится к гидрокарбонатному классу. Водная растительность камыш, осока, стрелолист, рогоз - расселилась узкой полосой вдоль 
побережья всей акватории водоема. В водохранилище обитает 22 вида рыб. Промысловыми являются плотва, ерш, елец, щука, окунь.

В состав основных сооружений ГЭС входят глухая и водосливная бетонные плотины, судоходный однокамерный шлюз и гидроэлектростанция мощностью 332 мВт.

Малоульбинское водохранилище расположено в межгорной котловине в районе истоков рек Малая Ульба и Громотуха. Водохранилище руслового типа, сезонного регулирования, проектной емкостью 84,5 млн.м³ . В состав водохранилища входят: подпорная каменно-набросная водохранилищьная плотина на р. Малая Ульба, высотой 34,5 м и две земляные плотины высотой 10 и 11 метров в межгорных впадинах; туннельный водосброс в р. Малая Ульба; туннельный водовыпуск для сброса воды в р. Левая Громотуха.

Нормальный подаорный уровень водохранилища 1572,5 м. Общая площадь водосбора 38,7 км², площадь водного зеркала 6,5 км², $^{2}$ наибольшая длинна 5 км, наибольшая ширина 3 км, наибольшая глубина 31,5 м.

Максимальный проектный расход воды через туннельный водосброс в р. Малая Ульба составляет 40,0 $\mathrm{m}^{3} / \mathrm{c}$. Минимальный проектный расход $-5,0 \mathrm{~m}^{3} / \mathrm{c}$.

Туннельный водовыпуск в $\mathrm{p}$. Левая Громотуха работает приемущественно в холодные периоды года, когда имеется необходимость проведения шугосбросных работ в русле р. Громотуха ниже по течению от водохранилища вплоть до водозабора Малоульбинского каскада ГЭС. Максимальный проектный расход водовыпуска $25,0 \mathrm{~m}^{3} / \mathrm{c}$, минимальный $-5,0 \mathrm{~m}^{3} / \mathrm{c}$.

В районе Малоульбинского водохранилища находятся водные обьекты: р. Малая Ульба, р Малая Ульбинка, ручей Рыбный Ключ, ручей Ключ Гремучий

Водный режим озер. Для режима озер региона характерен подъем их уровня в период весеннего снеготаяния. Наполнение талыми водами начинается во второй половине апреля - начале мая. Подъем уровня воды достигает 2 м. В июне-июле начинается медленный спад уровня. Минимальные уровни воды в озерах устанавливаются в октябре (см. рис. 50). Кроме сезонных, наблюдаются многолетние колебания уровней, связанные с колебаниями климатических условий.

Со сходом ледового покрова вода в озерах продолжает нагреваться, достигая в конце мая $7-15^{\circ} \mathrm{C}$, в июле-августе $-20^{\circ} \mathrm{C}$. 
Зимой, после установления ледового покрова, вода начинает нагреваться от дна, создается устойчивая стратификация: у дна температура около $+4^{0} \mathrm{C}$, а у нижней поверхности льда $0^{0}$.

На территории Южного Алтая самое большое озеро - Маркаколь. Расположено в тектонической котловине на высоте 1449 м над уровнем моря, площадь 455,0 км², длина 38, ширина 19 км, максимальная глубина достигает 27 м, объем воды - 6567 млн. м³,

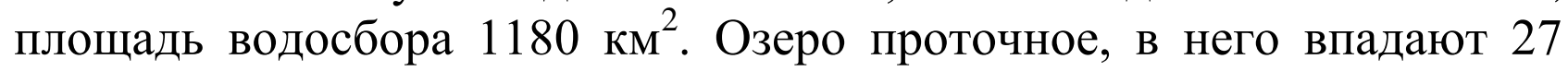
речек, вытекает только одна - Кальджир. Вся территория водосбора покрыта лесом, за исключением хребтов на высотах 2000-2300 м. Первые ледовые образования наблюдаются в конце октября - начале января, средняя дата установления ледостава 20 ноября, вскрытие происходит 9 мая, полное очищение ото льда 27 мая. Толщина льда от 53 до 116 см, средняя - 60-70 см. После очищения ото льда температура воды повышается, в июле-августе она равна $16-17^{0} \mathrm{C}$, в начале ноября $-0^{0} \mathrm{C}$.

Из рыб в озере обитают ленок (ускуч), хариус, голец, пескарь. На озере живут водоплавающие: утки, чайки, кулики. Район Маркаколя является заповедником.

Озеро Рахмановское, площадь 1,14 км², длина 2,6, ширина 0,6 км, высота над уровнем моря 1760 м. Высокие горные массивы (до 2600 м) окружают озеро, склоны их покрыты стройными лиственницами, кедрами, сосной, в низких местах - березой, ивой.

Озеро проточное, через него протекает р. Арасан. Озеро питается за счет талых вод, дождевого и грунтового стока. Средняя глубина - 19,5, максимальная - 30 м, объем воды - более 20 млн. км³ Среднегодовое колебание уровня воды составляет 1,5 м, высокий уровень в начале мая, низкий - в сентябре. На северо-западном берегу расположен бальнеологический санаторий Рахмановские Ключи.

Аблайкитские (Себинские, Сибинские) озера расположены на Калбинском хребте, на 750-830 м над уровнем моря, они лежат ступенеобразно, понижаясь с востока на запад: Кашкербай, Алка,

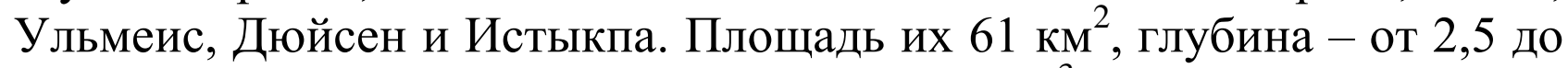
38 м. В них аккумулируется более 80 млн. м ${ }^{3}$ ультрапресной воды. Через все озера протекает безымянный ручей. Среднегодовые колебания уровня воды в озерах достигают 0,5 м. 


\section{ГЛАВА У. ИЗМЕНЕНИЯ КЛИМАТА ЮГО-ЗАПАДНОГО АЛТАЯ}

\section{1. Планетарно-космические факторы, колебания и изменения климата}

В Международной геосферно-биосферной программе «Глобальные изменения» ставилась задача тщательного изучения эволюции оболочек планеты в связи с тенденцией изменения климата. В настоящее время влияние человека на все оболочки Земли стало сравнимым по масштабу с процессами, происходящими в природе. С влиянием цивилизации связывается истощение биоресурсов, загрязнение атмосферы, вод, почвы, биоты, отходами производства, которые часто не включаются в естественные кругообороты. Системная организация природы позволяет заключить, что современное глобальное изменение климата в широком контексте является проблемой глобальных изменений окружающей среды $[98,115]$. Считается, что современное потепление климата может привести к усилению засушливости в степных и лесостепных зонах Евразии [67, 97]. Ученые климатологии предупреждают, что изменения климата столь сложны, что современный уровень наших знаний не позволяет уверенно судить ни о достоверности оценок изменений текущего климата, ни о его колебаниях. Необходимо физическое понимание глобальных атмосферных процессов и их конкретных структурных механизмов [23, 43].

До сих пор не существует единого взгляда на причины происходящих изменений климата. Так, Ван Лун, Ф. Кларк, А.И. Дуванин и другие ученые объясняют многолетние тренды гидрометеорологических элементов проявлением автоколебаний в системе Земля - Атмосфера. В. Старр, А. Оорт, К.Я. Кондратьев и другие относят изменения за счет астрономических факторов: колебаний спектрального состава солнечной радиации. С.А. Максимов, Н.П. Смирнов, М.Х. Байдал и другие отмечают существенное влияние на атмосферную циркуляцию и климат солнечной активности. Определенное влияние оказывают нутационные силы, обусловленные непостоянством местоположения мгновенного полюса вращения Земли (МПВ3). М.И. Будыко, К.Я. Винников, О.А. Дроздов и другие связывают изменения климата с 
прозрачностью атмосферы, с содержанием в ней углекислого газа $[53,59,67]$.

Существенные изменения климата в течение XX и начавшемся XXI веке, по мнению многих ученых, объясняются как естественными (планетарно-космическими), так и антропогенными факторами.

Известно, что процессы в биосфере в значительной степени контролируют состав атмосферы. Антропогенные воздействия на биосферу выступают факторами изменения климата, нарушая круговороты различных компонентов.

Возникновение и развитие жизни на Земле свидетельствует о том, что за 2-3 млрд. лет излучение Солнца и освещенность им Земли существенным образом не менялись.

Электромагнитные излучения Солнца охватывают более 40 октав: от области спектра гамма - лучей с длиной волны в тысячные доли нанометра, через видимую часть спектра с длиною волн 400-700 мм до метровых волн. Видимое излучение охватывает немного менее октавы спектра излучения. Октава - интервал спектра, на протяжении которого частота и, следовательно, длина волны меняются в два раза.

У нормальной солнечной фотосферы (нижней части атмосферы Солнца) температура близка к $6000^{\circ} \mathrm{K}$, в пятнах - к $4500^{\circ} \mathrm{K}$. Солнечные пятна характеризуются цикличностью в степени общей запятненности Солнца и сильным магнитным полем в каждом пятне. Интервал цикла - 11 лет, за его начало условно принято считать год минимума чисел Вольфа $(\mathrm{W})$, являющихся простейшим количественным индексом уровня солнечной активности в момент наблюдений.

В настоящее время выделяются 11-летние, 22-летние, вековые и многовековые циклы солнечной активности длительностью 18001900 лет [107]. В годы максимума солнечной активности чрезвычайно усиливается общая циркуляция атмосферы, чаще происходит смена теплых и холодных масс [23, 34, 108, 109].

По М.X. Байдалу, границы эпох циркуляции атмосферы находятся в тесной связи с циклами солнечной активности [43].

Международный геофизический год (МГГ) проводился в 19571958 гг. На эти годы приходился максимум вековой и 11-летней (девятнадцатый цикл) солнечной активности (W = 190); в максимум двадцатого цикла, в 1968 году, число Вольфа составило 106 единиц. В двадцать первом цикле (1980 г.) максимум достигал 155 единиц. 
Это был мощный цикл солнечной активности, его максимум был растянут на 3 года (1979-1981). Двадцать второй цикл начался в 1986 и достиг максимума в 1989 г. (158 единиц). Высокая активность Солнца сохранялась и в 1990-1991 гг.

Отмечено, что в вековом цикле солнечной активности имеются два высоких 11-летних максимума, разделенных более низким 11-летним циклом. В текущем вековом цикле максимумами были девятнадцатилетний и двадцать первый 11- летние циклы, двадцатый цикл был провалом между ними. Минимум векового цикла будет наблюдаться в двадцать четвертом 11-летнем цикле (2016 г.), двадцать второй и двадцать третий циклы будут сравнительно низкие (близки к минимуму). Следовательно, начало формирования циркуляции $\mathrm{W}$ возможно с двадцать второго или двадцать третьего циклов [108].

На процессах атмосферной циркуляции сказывается и положение планет по отношению к Солнцу и Земле.С расположением планет, в частности, связывается тридцатипятилетний брюкнеровский цикл изменения климата. Он хорошо прослеживался в климатических процессах XIX века.

Кроме солнечной активности, при определении границ эпох циркуляции берутся во внимание и циклы в динамике мгновенного полюса вращения Земли (МПВ3). С изменением положения МПВ3 происходит изменение траектории полюса атмосферной циркуляции. С динамикой МПВ3, по М.Х. Байдалу, связывается 35-летний геоклиматический цикл. Этот цикл или период колебаний климата является общим и характерен для всего комплекса гидрометеорологических явлений. Передающим звеном между климатическими колебаниями и динамикой МПВ3 служит атмосферная циркуляция [42, 43]. В периоды уменьшения радиусавектора происходит увеличение повторяемости зональных процессов атмосферной циркуляции. При этом увеличивается западновосточный перенос воздушных масс, вынос влаги с океана, годовое количество осадков, повышается средняя годовая температура воздуха, увеличивается сток рек и поднимаются уровни водоемов. Переход от большей повторяемости зональных процессов в конце геоклиматического цикла к минимальной в начале последующего происходит относительно быстро и охватывает обычно 5-6 лет. В этот период осуществляется скачкообразное изменение элементов климата от высоких значений к низким (наступление зональной 
циркуляции запаздывает от смещения MПВ3 за счет инерции процессов).

Начало первого геоклиматического цикла приходится на начало, конец - на середину тридцатых годов, переход от второго геоклиматического цикла к третьему приходится на конец 60-х и начало 70-х годов XX столетия. Ярким примером такого резкого скачка в ходе всех гидротермических характеристик климата в конце второго геоклиматического цикла является понижение температуры воздуха в самую холодную зиму века - 1968-69 года. В январе и феврале в предгорьях Рудного Алтая повторяемость жестоко морозной погоды составила 42-43\%. В этот период антициклон с центром в треугольнике Таймыр - Баренцево море - геофизический полюс был настолько развит, что оказал влияние не только на всю Арктику, но и на территорию до $60^{\circ}$ с. ш.

Таким образом, при изменении траектории МПВЗ происходит перемещение центра вращения воздуха в северном полушарии.

M.X. Байдал назвал этот центр полюсом атмосферной циркуляции, который может находиться не только в центре Арктики, но и на ее периферии: над Чукоткой, Таймыром, Баренцевым морем, Гренландией, Северной Канадой, Аляской. Для Казахстана особо опасными являются вторжения арктического воздуха, когда полюс циркуляции располагается над Таймыром, Баренцевым морем и над центром Арктики [42, 43]. Местоположения полюса циркуляции следуют друг за другом более или менее закономерно. От месяца к месяцу, от сезона к сезону полюс циркуляции перемещается чаще всего с востока на запад. Например, в апреле - мае 1987 года происходили интенсивные вторжения арктического воздуха через Западную Сибирь на Казахстан, и весна в этот год запоздала на месяц. В июле того же года арктические вторжения осуществлялись через Европу на Балканский полуостров и Малую Азию, что привело к вытеснению тропического воздуха из этих районов и из Средней Азии в пределы Казахстана, Западной Сибири и даже в Восточную Сибирь. Июль и первая половина августа на территории ЮгоЗападного Алтая были очень жаркими. Максимальные температуры достигали $38-42^{0} \mathrm{C}$.

Учет климатообразующих факторов - солнечной активности, мгновенного полюса вращения Земли, полюса и типа атмосферной циркуляции (W, E, C) позволяет в какой-то степени объяснить 
временные колебания гидротермического режима и дает возможность прогнозировать их на длительные отрезки времени.

\section{2. Антропогенный фактор в изменении климата}

Эффективная температура на верхней границе атмосферы Земли равна $\mathrm{T}_{э ф}=255^{\circ} \mathrm{K}$ или минус $18^{\circ} \mathrm{C}$, средняя температура воздуха у поверхности земли $\mathrm{T}$ равна $14^{0} \mathrm{C}$. Разность между этими температурами составляет $32^{0} \mathrm{C}$ и обусловлена так называемым парниковым эффектом атмосферы. Данное положение связано не с солнечной радиацией, а с характером круговорота вещества в природе, в особенности углеродного цикла. Суть парникового эффекта в том, что углекислота пропускает к поверхности Земли коротковолновое солнечное излучение и задерживает длинноволновое (тепловое) излучение планеты, что приводит к повышению ее средней температуры. Главную роль в создании парникового эффекта играют пары воды и углекислого газа. Удвоение концентрации углекислого газа обусловливает увеличение температуры нижнего (приземного) слоя воздуха на $2,3^{0} \mathrm{C}$. При этом происходит уменьшение атмосферных осадков в степной и лесостепной зонах Северной Америки и Евразии [67, с. 233].

Исследователи отмечают увеличение парникового эффекта, вызванного ростом таких малых газовых примесей, как озон, метан, окислы азота, хлорфторуглеводородные соединения (фреоны - ф).

В настоящее время парниковый эффект создается на 61\% воздействием углекислого газа, на $17 \%$ - метана $\left(\mathrm{CH}_{4}\right)$, на 12 фреонами и на 4\% воздействиями окислов азота $\left(\mathrm{NO}_{2}, \mathrm{~N}_{2} \mathrm{O}\right.$ и др.). Количество воды в атмосфере почти не изменяется. Фреоны разрушают озоновый слой, поднимаясь до стратосферы, и окисляются озоном. Окислы азота и озон поглощают, кроме длинноволнового излучения Земли, и ультрафиолетовые лучи Солнца. Малые примеси в значительной степени формируют термический режим стратосферы, а также оказывают влияние на температуру приземных слоев воздуха.

Изучение истории изменения газового состава атмосферы Земли показало, что практически все потепления в отдаленном прошлом происходили при повышенном уровне концентрации углекислого газа [110]. 
Последнему наиболее теплому этапу кайнозойского климата, так называемому климатическому оптимуму плиоцена, соответствовало наиболее высокое за последние 6-7 млн. лет содержание углекислого газа в атмосфере, равное $0,05-0,0645 \%$. В это время на юге Западной Сибири и севере Казахстана была зона лесов из пихты, тсуги и широколиственных. В плейстоцене - 0,75 млн. лет назад - отмечено несколько волн похолоданий. Есть указание на то, что глобальному оледенению предшествовало уменьшение концентрации $\mathrm{CO}_{2}$. Палеоботанические материалы показывают, что межледниковый климат был значительно теплее современного и может рассматриваться в качестве аналога климата будущего. Ранний и средний голоцен (10-5,5 тыс. лет назад) - время теплого и относительно стабильного климата с температурами в высоких широтах на 2-3 ${ }^{0} \mathrm{C}$ выше современных. Изменение концентрации $\mathrm{CO}_{2}$ регистрируется систематически с 1958 г. при помощи достаточно точных приборов. За 27 лет с 1958 по 1984 гг. концентрация $\mathrm{CO}_{2}$ повысилась с 315 до 343 млн.-1, в середине XIX в. она определяется в 280 млн. $^{-1}$. К концу столетия концентрация $\mathrm{CO}_{2}$ достигала 375-385 млн. ${ }^{-1}[67]$.

Первые предположения о том, что сжигание все возрастающего количества угля, нефти, газа и другого углеродного топлива приведут к заметному увеличению количества углекислого газа в атмосфере, было высказано в конце XIX и первой половине XX вв. Аррениусом и Коллендером. Эти работы были забыты, на них впервые указал М.И. Будыко.

Данные наблюдений последних десятилетий фиксируют возрастание количества $\mathrm{CO}_{2}$ на $0,3 \%$ ежегодно. За период с середины $\mathrm{XIX}$ в. до середины 80-х годов XX века количество $\mathrm{CO}_{2}$ возросло на 20-25\%. Такая концентрация $\mathrm{CO}_{2}$ оказывает влияние на глобальный климат и на биосферу в целом. Сейчас в атмосфере содержится примерно половина углерода, высвобожденного из горючих ископаемых во время промышленной революции. Предполагается, что остаток был поглощен океаном, где масса неорганического углерода, растворенного в морской воде, примерно в 60 раз больше, чем в атмосфере.

Климатологи утверждают, что с начала XX в. до 80-х годов средняя температура на планете возросла на $0,5^{0} \mathrm{C}$, за период 1980 1990 гг. - на $0,25^{\circ} \mathrm{C}$. Если не ограничить возрастающие объемы сжигания органического топлива и не остановить сведение лесов (в 
стволах которых накапливается углерод), не уменьшить выброс фреонов, разрушающих озоновый слой, климатическая катастрофа будет неизбежной: таяние ледников, подъем уровня океана, увеличение засушливости климата и учащения засух в главных зернопроизводящих районах мира; нарушение озонового слоя и возможная гибель всего живого под воздействием солнечной радиации.

Картина экологического бедствия осложняется тем, что под действием глобального потепления повышается температура поверхности океана, и растворенный в морской воде углерод будет испаряться в атмосферу, что может привести к катастрофическим изменениям на Земле [29, 34, 67, 111$]$.

Надо отметить, что исследования по изменению климата были начаты в СССР намного раньше, чем за рубежом. В 1961 г. коллегия Госкомгидромета признала возможность развития антропогенного потепления. Первый реалистический прогноз «Влияние человека на климат» был разработан М.И. Будыко в 1972 г. [54]. В 1975 г. в ГГИ был организован отдел по этой проблеме.

С 1972 г. начинается советско-американское сотрудничество по проблеме антропогенного изменения климата. В Женеве в 1979 г. состоялась Первая всемирная конференция по климату. В 1985 г. в Феллахе (Австрия) Всемирной метеорологической организацией было проведено совещание по антропогенному изменению климата. Наиболее широкие исследования по данной проблеме ведутся в США, Англии, Германии, Швеции. В книге «Антропогенные изменения климата» (1987 г.) излагаются результаты исследований, проведенных в основном в ГГО, ГГИ и других институтах Академии наук СССР [67, 98].

Вторая всемирная климатическая конференция (Женева, 1990 г.) отметила, что интенсивно начавшееся с 80-х годов потепление климата, вызываемое естественными планетарно-космическими воздействиями, превышает степень его колебания. Повышение температуры нижних слоев атмосферы объясняется антропогенным воздействием на ее химический состав. Изменилось и альбедо поверхности, что связано с распашкой и орошением земли, перевыпасом пастбищ, вырубкой лесов. Эти процессы повлияли на структуру радиационного и теплового балансов геосистем и нарушили режим общей циркуляции атмосферы, что в свою очередь 
вызвало направленное изменение климата - глобальное потепление нижних слоев атмосферы.

Академик Г.С. Голицын отмечал, что изменение климата атмосферы следует рассматривать как часть общей проблемы глобальных изменений природной среды. Данный вывод подтвержден в решениях Всемирной конференции по охране окружающей среды (Рио-де-Жанейро, 1992) [112].

М.И. Будыко предполагал, что к концу столетия, глобальная температура повысится, по сравнению с доиндустриальной эпохой, на $1,3^{0} \mathrm{C}$, к 2025 г. - на $2,5^{\circ} \mathrm{C}$, а к середине XXI в. - на $3,4^{0} \mathrm{C}$ [89].

Установлено, что под влиянием солнечной активности в разных регионах Земли возникает различный климатический эффект $[42,109$, 113]. Так, значительное потепление климата в Европе, особенно в зимний период, наблюдалось с начала XX века до 40 годов. На Алтае в этот период не было потепления. В настоящее время потепление климата в Западной и Южной Европе идет наиболее интенсивно за счет летнего сезона, а на Алтае за счет зимнего.

Выявление региональных особенностей современных изменений климата Юго-Западного Алтая важно не только с географической, но и с экологической точек зрения: соотношение тепла и влаги определяют формирование типа ландшафта, его биопродуктивность и направленность геоэкологических процессов. Само же соотношение тепла и влаги в первую очередь подвержено колебаниям в связи с нарушением режима циркуляции атмосферы.

Научно-технический прогресс привел к нарушению динамического равновесия между живой и косной природой. Загрязнение окружающей среды значительно выше ПДК привело к стремительному развитию экологического кризиса: уменьшению продуктивности экосистем, заболеванию населения, вымиранию представителей флоры и фауны. Потенциал устойчивости биосферы нарушен. Из-за антропогенной перегрузки не происходит самоочищения экосистем, их самовосстановления, а загрязнения ландшафтов в регионе значительно превышают ПДК. Человек стал ведущим фактором развития биосферы. Он обладает разумом, имеет ясную цель и понимание обстановки, имеет резервы реализации перехода биосферы в новую геологическую эпоху - ноосферу. Но в ноосферу может вступить лишь по-настоящему интеллигентное общество, понимающее цели, отдающее себе отчет в трудностях, стоящих на пути развития, способное соизмерить свои потребности с 
теми возможностями, которые дает ему Природа. Единение Человека с Природой, сотворчество «разумного гения человека с творящей силой естества» позволит Человеку выжить, соблюдая экологический императив - считаться не только с законами природы, но и с предъявляемыми его «техническими условиями». Важное место в геоэкологии занимает проблема предотвращения экологических кризисов [114].

\section{3. Региональные особенности изменения климата}

В настоящем исследовании границы эпох циркуляции приняты согласно принципам казахстанской школы геофизиков [43, 45]. Изменение структуры общей циркуляции атмосферы и ее динамики обусловлено изменением солнечной активности, положением мгновенного полюса вращения Земли (МПВ3) и связанного с ними полюса циркуляции атмосферы. Если полюс циркуляции атмосферы находится над Таймыром или Карским морем, то над территорией Юго-Западного Алтая происходят интенсивные «обвалы» арктического воздуха, как, например, в январе и феврале 1969, в декабре 1984, в ноябре 1987 гг. При максимумах солнечной активности на Юго-Западном Алтае засух не наблюдалось, но они часты на западе Казахстана.

Особенности изменения климата горной страны Юго-Западного Алтая и сопредельных территорий представлены на региональных климатических моделях местных типов циркуляции атмосферы, которые по генерализации процессов на порядок ниже типов общей циркуляции. За климатическую модель циркуляции атмосферы над территорией Юго-Западного Алтая взят барикоциркуляционный режим за период 1954-1978 гг. Все разнообразие элементарных циркуляционных механизмов естественно-синоптических периодов объединено в 8 типов циркуляции (см. табл. 14, 55).

В годовом выводе климатическая модель циркуляции атмосферы региона характеризуется преобладанием западных (38\%) и юго-западных (37\%) атмосферных процессов с господством антициклонических барических образований в течение всего года. На них приходится 78\%, на циклонические $22 \%$ от общей повторяемости естественно-синоптических периодов. Северо-западные процессы составляют 20\%, их циклонические типы свойственны весеннелетнему периоду. Стационирование циклонов и ультраполярные 
вторжения для региона не типичны. Первые наблюдаются в основном летом, вторые - зимой. Такая структура барико-циркуляционных процессов формирует гидротермический и ветровой режимы климата Казахстанского Алтая. Для выяснения климатической структуры и динамики гидротермического компонента проведена типизация сезонов года по температуре и осадкам в типичных ландшафтах горной страны за период от 52 до 57 лет. Об изменчивости температуры обычно судят по отклонению ( $\Delta$ T) наблюдаемой температуры от многолетней средней (табл. 61, 62). За критерий аномальности принято среднее квадратическое отклонение - $\sigma$ (сигма). Степень аномальности выражена в градациях величины б: отклонения меньше $\sigma$, от 1,0 до 1,5 $\sigma$, от 1,5 до 2,0 б и более $2 \sigma$. Соответственно выделены и условно оценены баллами термические условия сезонов: при $( \pm \Delta \mathrm{T})$ меньше величины $\sigma$ сезон относится к нормальным и оценивается баллом 1 , баллом 2 - теплый $(\Delta \mathrm{T}>\sigma)$, баллом 3 - холодный $(-\Delta \mathrm{T}>\sigma)$, баллом 4 - очень теплый, баллом $5-$ очень холодный, баллом 6 - экстремально теплый, когда $\Delta \mathrm{T} \geq 2 \sigma$ и баллом 7 - экстремально холодный $(-\Delta \mathrm{T} \leq-2 \sigma)$.

Степень увлажнения сезонов по осадкам выражена в процентах от нормы и оценена баллами от 0 до 5: 0 - очень сухо (0-40\%), 1 сухо (41-80\%), 2 - нормальное увлажнение (81-120\%), 3 - влажно (121-160\%), 4 - очень влажно (161-200\%), 5 - экстремально влажно, осадки больше 200\% нормы. Тогда гидротермическая структура климатического сезона выражается формулой из двух чисел: первое число - балл по температуре, второе - по увлажнению. Например: 1.2 - нормальный сезон по температуре и осадкам; 4.0 - очень теплый и очень сухой (такой была весна 1945 г. на предгорных равнинах Рудного Алтая); 7.4 - экстремально холодный и очень влажный (зима 1968/1969 гг. в пределах исследуемого региона). Годовой климатический цикл гидротермического компонента (ГТК) каждого года выражен в виде четырех формул сезонов за период 52-57 лет.

Анализ табличного материала позволяет судить о динамике циркуляционных процессов, об энергетической напряженности атмосферы, с которой связывается повторяемость экстремальных сезонов. Так, на экстремальные сезоны (с баллами 4,6 и 5,7) приходится от 13 до 18\% по природным комплексам Юго-Западного Алтая; на типы предельной экстремальности (6 и 7) всего лишь 2-7\%. 
Многолетние средние нормы температуры $\left({ }^{0} \mathrm{C}\right)$ воздуха и сумм осадков по сезонам года,

квадратичное отклонение температуры воздуха сезонов за период наблюдений.

Повторяемость нормальных, теплых, холодных и нормальных , влажных сухих сезонов за период наблюдений, \%

\begin{tabular}{|c|c|c|c|c|c|c|c|c|c|c|}
\hline $\begin{array}{ll}\text { Сезоны } & \text { Параметры } \\
\end{array}$ & $\mathrm{t}^{0} \mathrm{C}$ & r, MM & $\sigma^{0} \mathrm{C}$ & $\begin{array}{l}\text { Нормальные } \\
\pm \mathrm{T}<| \pm \sigma|\end{array}$ & $\begin{array}{c}\text { Теплые } \\
\mathrm{T}^{0}>\sigma\end{array}$ & $\begin{array}{c}\text { Холодные } \\
|-\mathrm{T}|>\sigma\end{array}$ & $\begin{array}{c}\text { Нормальные } \\
80-120 \% \\
\end{array}$ & $\begin{array}{l}\text { Влажные } \\
|>120 \%|\end{array}$ & $\begin{array}{c}\text { Сухие } \\
|<80 \%|\end{array}$ & $\begin{array}{c}\text { Число лет } \\
\text { наблюдений }\end{array}$ \\
\hline \multicolumn{11}{|c|}{ Усть-Каменогорск } \\
\hline XI-III & -12.2 & 150 & 2.4 & 63 & 20 & 17 & 48 & 27 & 25 & 57 \\
\hline IV-V & 9.1 & 74 & 1.8 & 66 & 16 & 18 & 23 & 44 & 33 & 54 \\
\hline VI-VIII & 19.3 & 159 & 1.2 & 72 & 10 & 18 & 46 & 17 & 37 & 52 \\
\hline IX-X & 8.7 & 72 & 1.3 & 63 & 8 & 29 & 30 & 41 & 29 & 54 \\
\hline \multicolumn{11}{|c|}{ Риддер } \\
\hline XI-III & -10.0 & 107 & 2.2 & 76 & 12 & 12 & 51 & 28 & 21 & 53 \\
\hline IV-V & 6.6 & 131 & 1.6 & 53 & 20 & 27 & 33 & 35 & 32 & 54 \\
\hline VI-VIII & 15.7 & 263 & 1.0 & 74 & 17 & 9 & 47 & 16 & 37 & 54 \\
\hline IX-X & 6.2 & 129 & 1.2 & 67 & 15 & 18 & 41 & 31 & 28 & 54 \\
\hline \multicolumn{11}{|c|}{ Зыряновск } \\
\hline XI-III & -17.6 & 203 & 2.7 & 70 & 20 & 10 & 64 & 24 & 12 & 51 \\
\hline IV-V & 6.8 & 91 & 1.6 & 60 & 21 & 19 & 25 & 47 & 28 & 53 \\
\hline VI-VIII & 17.5 & 178 & 0.9 & 67 & 19 & 14 & 43 & 19 & 38 & 52 \\
\hline IX-X & 6.4 & 93 & 1.0 & 46 & 26 & 28 & 37 & 34 & 29 & 52 \\
\hline \multicolumn{11}{|c|}{ Катон-Карагай } \\
\hline XI-III & -10.7 & 91 & 2.0 & 78 & 8 & 14 & 53 & 10 & 37 & 54 \\
\hline IV-V & 6.4 & 82 & 1.6 & 62 & 17 & 21 & 37 & 29 & 34 & 55 \\
\hline VI-VIII & 15.4 & 188 & 0.9 & 57 & 17 & 26 & 54 & 10 & 36 & 54 \\
\hline IX-X & 5.9 & 71 & 1.2 & 54 & 23 & 23 & 47 & 30 & 23 & 53 \\
\hline \multicolumn{11}{|c|}{ Зайсан } \\
\hline XI-III & -12.0 & 71 & 2.0 & 75 & 14 & 11 & 42 & 29 & 29 & 57 \\
\hline IV-V & 11.0 & 68 & 1.8 & 60 & 21 & 19 & 32 & 33 & 35 & 56 \\
\hline VI-VIII & 21.5 & 105 & 0.8 & 56 & 29 & 15 & 35 & 25 & 40 & 55 \\
\hline IX-X & 10.8 & 47 & 1.5 & 70 & 11 & 19 & 31 & 40 & 29 & 55 \\
\hline
\end{tabular}


Средняя температура воздуха $\left({ }^{0} \mathrm{C}\right)$ и атмосферные осадки (r в \% от нормы) сезонов

по эпохам циркуляции по метеостанциям Восточно-Казахстанской области

\begin{tabular}{|c|c|c|c|c|c|c|c|c|c|c|}
\hline \multirow{3}{*}{ Метеостанция } & \multicolumn{10}{|c|}{$\begin{array}{rc}\text { Эпохи } & \text { циркуляции } \\
\end{array}$} \\
\hline & \multicolumn{2}{|c|}{ E (1930-1939 гг.) } & \multicolumn{2}{|c|}{ C (1940-1949 гг.) } & \multicolumn{2}{|c|}{$\mathrm{E}+\mathrm{C}(1950-1965$ гг.) } & \multicolumn{2}{|c|}{ E (1966-1979 гг.) } & \multicolumn{2}{|c|}{$\mathrm{E}+\mathrm{C}(1980-1990$ гг.) } \\
\hline & $t^{0} \mathrm{C}$ & $\mathrm{r}, \%$ & $t^{0} \mathrm{C}$ & $\mathrm{r}, \%$ & $\mathrm{t}^{0} \mathrm{C}$ & $\mathrm{r}, \%$ & $t^{0} \mathrm{C}$ & $\mathrm{r}, \%$ & $\mathrm{t}^{0} \mathrm{C}$ & $\mathrm{r}, \%$ \\
\hline \multicolumn{11}{|c|}{ Зима (XI-III) } \\
\hline Усть-Каменогорск & -12.2 & 97 & -11.6 & 87 & -12.6 & 105 & -12.7 & 110 & -11.1 & 108 \\
\hline Риддер & -11.1 & 117 & -10.4 & 90 & -9.9 & 99 & -10.2 & 109 & -8.7 & 114 \\
\hline Зыряновск & -18.7 & 96 & -17.8 & 99 & -17.6 & 108 & -17.0 & 104 & -15.8 & 115 \\
\hline Катон-Карагай & -11.4 & 89 & -11.2 & 99 & -10.6 & 99 & -10.7 & 90 & -9.7 & 90 \\
\hline Зайсан & -12.4 & 106 & -12.0 & 76 & -12.2 & 106 & -12.2 & 118 & -10.6 & 113 \\
\hline \multicolumn{11}{|c|}{ Лето (VI-VIII) } \\
\hline Усть-Каменогорск & 19.7 & 90 & 19.1 & 120 & 19.2 & 104 & 18.7 & 104 & 18.9 & 79 \\
\hline Риддер & 16.5 & 89 & 15.8 & 105 & 15.9 & 105 & 15.9 & 90 & 15.9 & 81 \\
\hline Зыряновск & 16.7 & 91 & 17.6 & 90 & 17.9 & 104 & 17.7 & 95 & 17.7 & 86.9 \\
\hline Катон-Карагай & 15.5 & 91 & 15.3 & 90 & 15.3 & 100 & 15.3 & 85 & 15.2 & 88 \\
\hline Зайсан & 21.8 & 96 & 22.0 & 96 & 22.0 & 96 & 21.7 & 92 & 21.9 & 97 \\
\hline \multicolumn{11}{|c|}{ Весна (IV-V) } \\
\hline Усть-Каменогорск & 8.8 & 126 & 10.3 & 108 & 8.5 & 101 & 9.1 & 129 & 9.2 & 112 \\
\hline Риддер & 5.0 & 129 & 7.1 & 101 & 6.2 & 95 & 6.7 & 103 & 6.9 & 106 \\
\hline Зыряновск & 5.6 & 121 & 6.5 & 126 & 6.6 & 102 & 7.6 & 118 & 7.8 & 115 \\
\hline Катон-Карагай & 5.7 & 114 & 7.0 & 106 & 5.8 & 87 & 6.2 & 95 & 6.6 & 114 \\
\hline Зайсан & 10.8 & 97 & 11.6 & 120 & 10.8 & 92 & 11.2 & 107 & 11.5 & 106 \\
\hline \multicolumn{11}{|c|}{ Осень (IX-X) } \\
\hline Усть-Каменогорск & 8.3 & 106 & 8.6 & 125 & 8.2 & 96 & 8.1 & 123 & 8.5 & 110 \\
\hline Риддер & 6.6 & 106 & 5.7 & 108 & 5.9 & 92 & 6.3 & 115 & 6.4 & 114 \\
\hline Зыряновск & 5.1 & 72 & 5.7 & 116 & 6.2 & 96 & 6.4 & 116 & 6.9 & 124 \\
\hline Катон-Карагай & 5.6 & 97 & 5.6 & 117 & 6.0 & 93 & 5.8 & 113 & 6.0 & 132 \\
\hline Зайсан & 10.3 & 110 & 10.4 & 126 & 10.8 & 86 & 10.6 & 131 & 11.0 & 157 \\
\hline
\end{tabular}


Энергетическая напряженность атмосферы увеличилась во второй половине XX века. Изменения циркуляции особенно сильно сказывается на режиме ГТК зимнего сезона, поэтому приведенные данные относятся к холодному периоду. С 1940 по 1960 гг. наблюдалось два экстремума, оба зимних сезона экстремально холодные: 1944/1945 гг. - 7,2 и 1950/1951 гг. - 5,1 - 7,1 по отдельным станциям. В последующие 20 лет, с 1960 по 1980 гг. - четыре экстремума, три из них со знаком минус (-): зимы 1966/1967, 1968/1969, 1976/1977 гг. с соответствующими формулами их гидротермического режима - 5,2, 7,4, 5,3. Лишь зима 1962/1963 гг. была очень теплой и засушливой. Следующие четыре экстремума уже наблюдались за 10 лет, в эпоху Е + C (1980-1990 гг.), при этом три экстремума со знаком (+). Учащение положительных экстремумов указывает на потепление. Это подтверждается данными табл. 63 и 64.

Т а бли ц а 63

Повторяемость типов ЭЦМ (в числе ЕСП) зимнего периода 1968/1969, 1980/1981, 1982/1983 гг. (в скобках формула ГТК)

\begin{tabular}{|l|c|c|c|}
\hline \multirow{2}{*}{ Типы циркуляции (ЭЦМ) } & \multicolumn{3}{|c|}{ Зимние сезоны } \\
\cline { 2 - 4 } & $\begin{array}{c}1968 / 1969 \text { гг. } \\
(7.4)\end{array}$ & $\begin{array}{c}1980 / 1981 \text { гг. } \\
(4.2)\end{array}$ & $\begin{array}{c}1982 / 1983 \text { гг. } \\
6.2)\end{array}$ \\
\hline 1. Западный антициклонический & 8 & 15 & 13 \\
\hline 2. Западный циклонический & 1 & 2 & 1 \\
\hline $\begin{array}{l}\text { 3. Северо-Западный } \\
\text { антициклонический }\end{array}$ & 6 & 3 & 3 \\
\hline 4. Северо-Западный циклонический & 1 & 0 & 0 \\
\hline 5. Юго-Западный антициклонический & 4 & 9 & 13 \\
\hline 6. Юго-Западный циклонический & 1 & 2 & 4 \\
\hline 7. Ультраполярные вторжения & 10 & 0 & 0 \\
\hline 8. Стационирование циклона & 0 & 0 & 0 \\
\hline Сумма ЕСП & 31 & 31 & 34 \\
\hline
\end{tabular}

Из табл. 63 следует, что тенденция потепления зимних сезонов в регионе наметилась с 50-х годов (Зыряновск, Риддер, Катон-Карагай) и сопровождалась увеличением атмосферных осадков в среднем на $5 \%$ от эпохи к эпохе. Зимний сезон циркуляционной эпохи $\mathrm{E}+\mathrm{C}$ (1980-1990 гг.) оказался чрезвычайно теплым, $\Delta$ Т колеблется от 1,1 
до $1,8^{0} \mathrm{C}$ по отдельным ландшафтам, что значительно превышает изменения температуры воздуха под воздействием естественных планетарно-космических факторов. Одновременно с потеплением зим растет засушливость летнего сезона, достигая в последнее десятилетие экстремальных значений (79-81\% нормы).

Определяющая роль циркуляции атмосферы в формировании гидротермического режима показана на примерах зимнего сезона.

Анализ табл. 63 позволяет заключить, что экстремум со знаком (-) обусловлен преобладанием за сезон ультраполярных и северозападных процессов (зима - 7,4), в то время как в многолетнем разрезе на западные и юго-западные процессы приходится $74 \%$ от общего числа ЕСП (см. модель циркуляции, табл. 14).

Экстремумы со знаком (+) формируются при исключении ультраполярных вторжений и резком уменьшении (в два раза) повторяемости северо-западных процессов, при увеличении югозападных, особенно циклонических.

Уровень летних температур мало изменяется по эпохам циркуляции, скорее слабо выражена тенденция к похолоданию: Риддер, Катон-Карагай (см. табл. 63 и 64), но сохраняется и усиливается тенденция к засушливости сезонов. Весенний сезон более теплый и влажный в сравнении с нормой (см. табл. 61), а в сравнении с ГТК осеннего сезона эпохи - более теплый и менее влажный.

Приведенный выше анализ метеорологических данных методами климатологии средних позволил наметить некоторые региональные особенности изменения местного климата. Потепление климата Юго-Западного Алтая идет за счет зимнего, в Западной Европе - летнего сезонов. Средняя температура зимы эпохи $\mathrm{E}+\mathrm{C}$ (1980-1990) выше нормы на 1,1-1,80. Этот параметр абстрактный. Трудно сразу заключить, каков же действительно был режим температуры. Местные жители, однако, знают, что уже последние 15 лет не было «настоящих» зим, почти 5 месяцев длится «погода марта».

Человек воспринимает изменение климата в виде комплекса, как среднюю погоду сезона, ибо на него действуют не отдельные параметры метеоэлементов, а весь комплекс погодных явлений и процессов. В связи с этим характеристика климата сезона через комплекс сочетаний температуры и влажности позволяет осветить 
Структура годового цикла ГТК и его динамика в эпоху Е +C (1980-1990 гг.)

\begin{tabular}{|c|c|c|c|c|c|c|c|c|c|c|c|c|c|c|c|c|c|c|c|c|}
\hline \multirow[b]{2}{*}{ Сезоны } & \multicolumn{4}{|c|}{ Усть-Каменогорск } & \multicolumn{4}{|c|}{ Риддер } & \multicolumn{4}{|c|}{ Зыряновск } & \multicolumn{4}{|c|}{ Катон-Карагай } & \multicolumn{4}{|c|}{ Зайсан } \\
\hline & 㞼 & 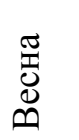 & 惫 & $\begin{array}{l}\text { 氶 } \\
\text { O }\end{array}$ & 芴 & 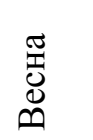 & $\stackrel{\stackrel{\leftrightarrow}{\oplus}}{\stackrel{\oplus}{g}}$ & $\begin{array}{l}\text { 离 } \\
\text { Oू }\end{array}$ & $\sum_{m}^{\frac{\pi}{n}}$ & 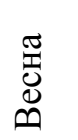 & 夰 & $\begin{array}{l}\text { 茍 } \\
\text { ठ }\end{array}$ & $\sum_{m}^{\frac{\pi}{n}}$ & 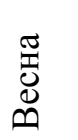 & 足 & $\begin{array}{l}\text { 咅 } \\
\text { ठ }\end{array}$ & 䖩 & 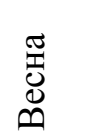 & 苞 & $\begin{array}{l}\text { 竭 } \\
\text { ठ }\end{array}$ \\
\hline $1980-1981$ & 2.2 & 2.3 & 1.1 & 1.2 & 1.3 & 4.2 & 1.1 & 1.1 & 4.3 & 6.2 & 2.1 & 1.3 & 1.2 & 4.1 & 2.1 & 1.2 & 4.2 & 4.2 & 2.2 & 1.5 \\
\hline $1981-1982$ & 1.2 & 2.2 & 1.1 & 2.2 & 1.2 & 4.3 & 2.1 & 2.3 & 1.2 & 4.2 & 2.1 & 6.3 & 1.1 & 4.1 & 1.2 & 2.4 & 2.2 & 4.1 & 4.1 & 2.2 \\
\hline $1982-1983$ & 6.2 & 1.4 & 1.1 & 1.2 & 4.2 & 1.3 & 1.1 & 1.2 & 4.2 & 1.5 & 1.1 & 1.2 & 6.2 & 3.4 & 1.2 & 1.2 & 4.2 & 1.3 & 1.4 & 1.3 \\
\hline $1983-1984$ & 1.2 & 1.2 & 3.2 & 1.2 & 1.3 & 1.2 & 1.2 & 1.2 & 1.2 & 1.2 & 1.2 & 1.3 & 1.2 & 3.3 & 3.2 & 1.3 & 1.3 & 1.1 & 1.2 & 1.4 \\
\hline $1984-1985$ & 5.2 & 1.2 & 1.1 & 1.4 & 3.2 & 1.2 & 1.2 & 1.3 & 1.2 & 1.1 & 1.2 & 1.3 & 3.2 & 1.2 & 3.2 & 1.3 & 5.2 & 1.3 & 1.2 & 1.3 \\
\hline $1985-1986$ & 1.2 & 1.2 & 1.1 & 1.2 & 1.1 & 1.2 & 1.1 & 1.2 & 1.2 & 1.1 & 1.1 & 2.2 & 1.1 & 1.2 & 1.1 & 1.3 & 1.2 & 1.2 & 1.1 & 1.5 \\
\hline $1986-1987$ & 1.2 & 1.1 & 1.2 & 3.2 & 1.2 & 1.3 & 1.2 & 5.3 & 1.2 & 1.3 & 1.2 & 5.4 & 1.2 & 1.4 & 1.2 & 7.4 & 1.2 & 1.2 & 1.1 & 3.3 \\
\hline $1987-1988$ & 1.3 & 1.1 & 1.3 & 1.2 & 1.3 & 1.3 & 1.2 & 1.2 & 1.3 & 1.3 & 1.2 & 6.3 & 1.2 & 1.4 & 1.2 & 1.2 & 1.4 & 1.4 & 1.2 & 1.2 \\
\hline $1988-1989$ & 4.1 & 1.3 & 1.1 & 1.3 & 4.2 & 1.2 & 1.1 & 1.3 & 6.2 & 1.3 & 1.1 & 4.2 & 6.1 & 1.1 & 1.1 & 1.3 & 4.1 & 1.1 & 1.1 & 1.4 \\
\hline $1989-1990$ & 4.3 & 1.1 & - & - & 2.3 & 1.2 & - & - & 6.4 & 1.3 & - & - & 2.2 & 1.2 & - & - & 6.3 & - & - & - \\
\hline
\end{tabular}


Сезонная структура гидротермического компонента (ГТК) годового климатического цикла по метеостанциям Юго-Западного Алтая (для типичных региональных геосистем), повторяемость в \% от числа лет наблюдений*

\begin{tabular}{|c|c|c|c|c|c|c|c|c|c|c|c|c|c|c|c|c|c|c|c|c|}
\hline \multirow[b]{2}{*}{$\begin{array}{l}\text { Структура } \\
\text { ГТК }\end{array}$} & \multicolumn{4}{|c|}{ Усть-Каменогорск } & \multicolumn{4}{|c|}{ Риддер } & \multicolumn{4}{|c|}{ Зыряновск } & \multicolumn{4}{|c|}{ Катон-Карагай } & \multicolumn{4}{|c|}{ Зайсан } \\
\hline & XI-II & $\begin{array}{l}\text { IV- } \\
\text { V }\end{array}$ & $\begin{array}{l}\text { VI- } \\
\text { VIII }\end{array}$ & $\begin{array}{l}\text { IX - } \\
X\end{array}$ & $\begin{array}{l}\text { XI - } \\
\text { III }\end{array}$ & \begin{tabular}{|l} 
IV- \\
V
\end{tabular} & $\begin{array}{l}\text { VI - } \\
\text { VIII }\end{array}$ & $\begin{array}{l}\text { IX- } \\
X\end{array}$ & $\begin{array}{l}\text { XI - } \\
\text { III }\end{array}$ & $\begin{array}{l}\text { IV- } \\
\text { V }\end{array}$ & $\begin{array}{l}\text { VI - } \\
\text { VIII }\end{array}$ & \begin{tabular}{|l|} 
IX- \\
$X$
\end{tabular} & $\begin{array}{l}\text { XI - } \\
\text { III }\end{array}$ & $\begin{array}{l}\text { IV- } \\
\text { V }\end{array}$ & $\begin{array}{l}\text { VI - } \\
\text { VIII }\end{array}$ & $\begin{array}{l}\text { IX- } \\
X\end{array}$ & $\begin{array}{l}\text { XI - } \\
\text { III }\end{array}$ & $\begin{array}{l}\text { IV- } \\
\text { V }\end{array}$ & $\begin{array}{l}\text { VI - } \\
\text { VIII }\end{array}$ & $\begin{array}{l}\text { IX - } \\
\text { X }\end{array}$ \\
\hline $1(0-1)$ & 16 & 22 & 27 & 22 & 17 & 15 & 24 & 17 & 10 & 13 & 19 & 13 & 29 & 17 & 17 & 11 & 19 & 16 & 18 & 22 \\
\hline $1(2)$ & 29 & 13 & 32 & 17 & 35 & 18 & 41 & 28 & 48 & 13 & 35 & 13 & 43 & 26 & 36 & 28 & 35 & 18 & 24 & 22 \\
\hline $1(3-5)$ & 18 & 31 & 13 & 24 & 24 & 20 & 9 & 22 & 12 & 34 & 13 & 20 & 6 & 19 & 4 & 15 & 21 & 26 & 14 & 26 \\
\hline $2(0-1)$ & 4 & 9 & 8 & 2 & 2 & 9 & 11 & 9 & 0 & 13 & 17 & 8 & 4 & 13 & 17 & 8 & 5 & 12 & 20 & 7 \\
\hline $2(2)$ & 12 & 5 & 2 & 4 & 8 & 9 & 4 & 4 & 12 & 8 & 2 & 12 & 4 & 2 & 0 & 13 & 5 & 7 & 9 & 4 \\
\hline $2(3-5)$ & 4 & 2 & 0 & 2 & 2 & 2 & 2 & 2 & 8 & 0 & 0 & 6 & 0 & 2 & 0 & 2 & 4 & 2 & 0 & 0 \\
\hline $3(0-1)$ & 5 & 2 & 2 & 5 & 2 & 8 & 2 & 2 & 2 & 2 & 2 & 8 & 4 & 4 & 2 & 4 & 5 & 7 & 2 & 0 \\
\hline $3(2)$ & 7 & 5 & 12 & 9 & 8 & 6 & 2 & 9 & 4 & 4 & 6 & 12 & 6 & 9 & 18 & 6 & 2 & 7 & 2 & 5 \\
\hline $3(3-5)$ & 5 & 11 & 4 & 15 & 2 & 13 & 5 & 7 & 4 & 13 & 6 & 8 & 4 & 8 & 6 & 13 & 4 & 5 & 11 & 14 \\
\hline Итого: \% & 100 & 100 & 100 & 100 & 100 & 100 & 100 & 100 & 100 & 100 & 100 & 100 & 100 & 100 & 100 & 100 & 100 & 100 & 100 & 100 \\
\hline $\begin{array}{l}\text { Число } \\
\text { лет наб- } \\
\text { людений }\end{array}$ & 57 & 54 & 52 & 54 & 53 & 54 & 54 & 54 & 51 & 53 & 52 & 52 & 54 & 55 & 54 & 53 & 57 & 55 & 55 & \\
\hline
\end{tabular}

* Примечание. Выделены три типа сезонов по температуре: нормальные - 1 балл, теплые - 2 балла (сюда включены сезоны, оцененные баллами 4 и 6), холодные - 3 балла (вошли сезоны с баллом 5 и 7; в скобках около балла по температуре (первое число) - характеристика увлажнения в баллах: (0-1) - сезоны очень сухие и сухие, (2) - нормальное по увлажнению, (3-5) влажные, очень влажные и экстремально влажные. 
большой спектр свойств климата, более полно оценить его экологические и агроклиматические ресурсы.

Малая повторяемость экстремальных сезонов позволила при разработке климатической модели взять за основу по температуре нормальные сезоны (балл 1), теплые (балл 2), влажные (балл 3-5). Сравнивая величины гидродинамического компонента сезонов и их динамику в последнюю эпоху (см. табл. 64) с параметрами ГТК климатической модели, можно с уверенностью говорить о направленности изменений климатических элементов, подчеркивая региональные изменения климата. Последнюю в XX столетии циркуляционную эпоху, самую теплую на всем Земном шаре, на предгорных равнинах Рудного Алтая (по наблюдениям в УстьКаменогорске) нормальные типы зим составляли 50\% (при норме $63 \%$, см. табл. 61), теплые - 40\%, в два раза больше нормы, а холодных сезонов было в два раза меньше. За 10 лет один лишь сезон, 1988/1989 гг. был сухим, два влажных, остальные с нормальным увлажнением. Зима этой циркуляционной эпохи оказалась экстремально теплой с нормальным увлажнением. В Зыряновске, в многолетнем разрезе (52 года) на нормальные по температуре летние сезоны приходится 67\%, из них сухие составляют $19 \%$ (табл. 65), на теплые - 19\%, из них 17\% сезонов сухие, холодные сезоны (14\%) обычно влажные. В десятилетие (1980-1990 гг.) нормальные типы составили 78\%, на 11\% больше нормы, при этом повторяемость сухих сезонов в 2 раза превысила норму, а теплые сезоны (20\%) все оказались сухими. Увеличилась повторяемость нормальных по температуре сезонов и особенно сухих (табл. 61, 65).

Представляет интерес структура ГТК по сезонам годового цикла и ее динамика в типичных ландшафтах Юго-Западного Алтая (см. табл. 65). Сравнивая с нормативной моделью структуру ГТК за эпоху, можно судить об особенности направленных изменений климата в различных региональных системах Казахстанского Алтая и связанных с ними геоэкологических процессов в окружающей среде, которые можно свести к следующему:

1. В средне- и высокогорной частях Юго-Западного и Центрального Алтая отмечается омоложение верхней границы леса и сближение ее со снеговой границей, что указывает на потепление климата и обильное увлажнение в горах $[6,8,9,49]$.

2. Усиление энергетической напряженности атмосферы над регионом приводит к усилению скоростей переноса воздушных масс, 
увеличению турбулентного перемешивания нижних слоев атмосферы. При общем потеплении эти процессы приводят к увеличению зимних осадков, учащению схода снежных лавин и к увеличению продуваемости ландшафтов.

3. Насыщение осадочного чехла склонов гор талыми водами часто приводит к возникновению оползней типа среднеазиатских (май 2001, трасса Усть-Каменогорск - Зыряновск).

4. Зимние оттепели осложняют сохранность озимых культур.

5. Увеличиваются контрасты увлажнения на предгорных равнинах и склонах гор (за последние 9 лет в Усть-Каменогорске насчитывалось 6, в Риддере 5, в Катон-Карагае 3 сухих летних сезона). Нижняя граница леса в Рудном Алтае за счет антропогенных воздействий смещена вверх на 100-200 м.

6. Атмосфера осенью испытывает большее энергетическое напряжение, чем весной, что выражается в более частой смене типов сезонов (в Зыряновске за 9 лет отмечено 5 типов сезонов), поэтому частота появления ранних заморозков осенью больше, чем поздних весной.

7. Усиление засушливости летом и испарения массы снега в марте - апреле приведет к уменьшению речного стока, что скажется на водном балансе водохранилищ и отразится на энергетике.

8. Теплые зимы в умеренном климате сопровождаются засушливостью в теплом периоде и учащением повторяемости засух.

9. По М.И. Будыко, глобальное потепление на $1{ }^{0} \mathrm{C}$ приведет к сдвигу природных зон на 200-300 км к северу, а в Срединном регионе, возможно, и больше.

10. Тенденция глобального потепления климата объясняется не только антропогенным влияниям на атмосферу, оно связано и с развитием геоклиматического цикла. 


\section{ГЛАВА VI Туманы}

\section{Вместо введения.}

В условиях крупных промышленных городов уровень загрязнения приземного слоя воздуха зависит не только от количества промышленных и транспортных выбросов, но и от их вертикального и горизонтального рассеивания, которое определяется в основном метеорологическими факторами. Прогноз метеоусловий, способствующих рассеиванию или накоплению вредных примесей в приземном слое воздуха, может стать основой нормирования выброса и обеспечения чистоты воздушного бассейна.

Исследование влияния метеорологических условий на распределение примесей в атмосфере в настоящее время привлекает особое внимание в связи с разработкой региональной программы устойчивого социально-экономического развития.

В связи с возрастанием интенсивного освоения территорий всё более острыми становятся проблемы, связанные с природными и антропогенными процессами. Районы, подверженные некоторым особенностям протекания метеорологических процессов и связанных с ними загрязнений атмосферного воздуха, требуют тщательного и систематического комплексного исследования. Образование туманов и ухудшение видимости негативно сказываются на работе всех видов хозяйственной деятельности.

Юго-Западный Алтай - наиболее освоенный в промышленном отношении регион, один из самых загрязненных на Алтае, где произошли устойчивые изменения окружающей среды с нарушением природного равновесия.

Туман принадлежит к числу явлений погоды, особо неблагоприятных, прежде всего, для всех видов транспорта. Влияние туманов на содержание примесей в атмосферном воздухе носит сложный характер. Примеси частично поглощаются водяными каплями, при их растворении иногда образуются новые, более токсичные вещества. Ввиду сложности протекающих процессов особую важность приобретает развитие теории загрязнения при туманах.

В связи с большой пространственной изменчивостью туманов, в пределах ограниченных территорий, количественная оценка туманов приобретает особую ценность. Учет микроклимата туманов важен 
для принятия оптимальных решений при проектировании развития промышленных городов с высокой их повторяемостью.

Недостаток сведений о пространственной и временной изменчивости параметров тумана значительно затрудняет решение вопроса об эффективном прогнозировании этого опасного явления, а также неблагоприятных метеорологических условий (НМУ) загрязнения атмосферы, связанных с процессами туманообразования.

Исследование туманообразования

B

условиях ороклиматического барьера Юго-Западного Алтая может рассматриваться как один из этапов научного подхода к решению проблемы более точного прогнозирования самого тумана и неблагоприятных метеорологических условий загрязнения атмосферного воздуха при туманах в данном регионе. Выбор ЮгоЗападного Алтая объектом исследования представляется целесообразным в силу недостаточной изученности роли ороклиматического барьера в процессах туманообразования и влияния его на метеорологический потенциал загрязнения атмосферы.

\section{1 Теоретические основы и современное состояние проблемы туманообразования в условиях ороклиматического барьера}

Туманы над сушей и водоемами - явление достаточно частое. Туманы представляют собой серьёзную опасность для народного хозяйства, особенно при эксплуатации всех видов транспорта, которые нуждаются в сведениях о режиме этого явления и в их прогнозе. По мере развития физики атмосферы становится возможным решение проблемы искусственного рассеяния туманов.

Туман - результат скопления продуктов конденсации или сублимации водяного пара в приземном слое воздуха, ухудшающий горизонтальную видимость до 1000 м и менее. В зависимости от дальности видимости, выделяют следующие по интенсивности виды тумана: очень сильный, видимость менее 50 м; сильный - от 50 до 200 м; умеренный - от 200 до 500 м; слабый - от 500 до 1000 м.

Для образования тумана необходимо охлаждение воздуха, то есть приближение его к состоянию насыщения. При некоторых условиях существенную роль играет увеличение влажности воздуха вследствие испарения с открытой водной поверхности или с относительно теплой поверхности в более холодный воздух. 
В зависимости от происхождения туманы делят на две группы туманы испарения и туманы охлаждения; в зависимости от вида процесса, приводящего к охлаждению: на радиационные и адвективные. Туманы могут образоваться также под влиянием орографии, больших водоёмов, городов и других факторов.

Рассматривая некоторые фундаментальные работы А.С.Зверева, М.Е.Берлянда, Н.В.Петренко, Никандрова В.Я. и другие $[1,2,3,4]$ можно выделить три основных вопроса, подвергшиеся широкой дискуссии: 1) роль отдельных метеорологических процессов в образовании и рассеянии туманов; 2) роль ядер конденсации в образовании туманов; 3) генетическая классификация туманов.

К сожалению, физическую сущность образования и рассеяния туманов нельзя считать полностью выясненной: в этом вопросе существует ряд до сих пор нерешенных задач [4]. Сравнительные оценки роли различных процессов образования и рассеяния туманов, которые анализируются разными авторами, противоречивы, а нередко даже диаметрально противоположны. Такое положение обусловлено, прежде всего, недостаточным исследованием физики туманов, отсюда и ограниченностью фактических данных об условиях образования, существования и рассеяния туманов.

\section{2 Исходные понятия и методы исследования туманообразования}

Образование, эволюция и рассеяние облаков и туманов определяется совместным действием нескольких факторов: адвективным и турбулентным притоком тепла и влаги, радиационным теплообменом, микрофизическими процессами в облаках и туманах, взаимодействием с подстилающей поверхностью. Для реалистичного описания облаков и туманов, взаимосвязи с другими характеристиками планетарного пограничного слоя в модели необходимо учитывать все эти процессы.

Однако при этом возникают трудности, связанные с пониманием физики процессов, отсутствия полного комплекса данных измерений метеовеличин на разных этапах.

Численные модели туманов в основном развивались в двух направлениях. Первое связано с описанием адвективной трансформации воздушной массы, приводящей к возникновению туманов адвективного происхождения. Такие модели двумерны, в 
них учитывается горизонтальная неоднородность, но не рассматриваются радиационные процессы.

В моделях второго направления, туманы, возникающие вследствие радиационного охлаждения подстилающей поверхности, рассматриваются в приближении горизонтальной однородности, т. е. при отсутствии адвективных процессов. Такие модели одномерны, но в них обычно более детально рассчитывается радиационный теплообмен и более точно вертикальный турбулентный перенос.

В настоящее время одной из актуальных задач является изучение различных видов туманов в целях усовершенствования методов их прогнозирования, при этом наиболее полные результаты получаются при сочетании теоретических и статистических исследований.

Поскольку опытных данных по туманам недостаточно, необходима разработка моделей образования туманов с использованием возможностей исследования с помощью ЭВМ.

Из общих положений термодинамики следует, что конденсация влаги в определенном слое атмосферы возможна, если водяной пар в данном слое находится в состоянии пересыщения. При конденсации водяного пара его давление под поверхностью капель тумана должно быть равно упругости пара в окружающем воздухе. При соблюдении этих условий, система, содержащая парообразную и жидкую фазы (в нашем случае туман), будет находиться в устойчивом термодинамическом равновесии [4].

Поскольку условия конденсации связаны с изменениями температуры и влажности воздуха, возникновение туманов обусловлено определенным соотношением между изменениями этих метеорологических элементов. Туманы можно классифицировать по причинам изменения температуры и влажности воздуха.

Большое число различных видов туманов можно свести к трем основным видам: радиационные, возникающие в результате местного выхолаживания воздуха в ночные часы; адвективные, представляющие собой результат переноса воздуха с определенными значениями температуры и влажности из одних областей в другие; смешанные или адвективно-радиационные.

Радиационные туманы образуются в результате выхолаживания земной поверхности путем излучения (радиационное охлаждение), как правило, при малооблачной погоде и слабом ветре, скорость которого не превышает 3 м/сек или при штиле. Охлаждение от 
подстилающей поверхности распространяется на небольшой слой воздуха, обычно ограниченный инверсией температуры, вследствие слабой турбулентности и молекулярной теплопроводности. Вертикальная мощность радиационных туманов невелика (до 200 м). Утром или днем они рассеиваются или приподнимаются, образуя, тонкие разорвано слоистые облака.

Адвективные туманы образуются в результате перемещения влажных относительно теплых воздушных масс на более холодную подстилающую поверхность, при скорости ветра 2-5 м/сек и более. Вследствие динамической турбулентности, охлаждение воздуха наиболее интенсивно происходит на некоторой высоте - под слоем адвективной инверсии. Адвективные туманы занимают обширные площади; их вертикальная мощность обычно больше вертикальной мощности радиационных туманов.

Остальные виды туманов, по существу, являются частными случаями основных.

Туманы восхождения (склонов) образуются в результате подъема воздуха вдоль склонов возвышенностей и его адиабатического охлаждения.

Частными случаями адвективных туманов являются туманы испарения (речные туманы), как следствие переноса влажного воздуха с водной поверхности и охлаждение его на побережье.

Известным стимулом образования туманов является наличие большого числа ядер конденсации в городах, поэтому выделяют городские туманы.

При низких температурах (< минус $40^{\circ}$ C) образуются ледяные туманы.

Кроме того, выделяют орографические, фронтальные и другие виды туманов, которые всегда относятся к одному из основных видов.

Четкой границы между отдельными видами туманов нет. Так, при образовании адвективных туманов, почти всегда существенное значение имеет понижение температуры вследствие радиационных потерь тепла подстилающей поверхностью. Большое значение имеет степень выхолаживания воздуха над почвой или снежным покровом при возникновении речных туманов и туманов испарения. Иногда бывает трудно выделить и случаи воздушных масс, достаточно однородных по горизонтали, в которых было бы несущественно влияние адвективных изменений температуры и влажности. Можно 
говорить лишь о некотором преобладающем влиянии радиационных или адвективных факторов.

Условия туманообразования на Юго-Западном Алтае отличаются большим разнообразием. Наличие незамерзающих водоемов (рек Иртыш и Ульба), интенсивное загрязнение атмосферного воздуха в городах промышленными предприятиями, низкие температуры и другие факторы очень осложняют отнесение туманов к тому или иному типу.

С физической точки зрения, туман представляет собой полидисперсную систему, состоящую из взвешенных (медленно падающих) капель воды или льдинок. Полидисперсность туманов обуславливается наличием в воздухе ядер конденсации, которые имеют различные размеры и состоят из веществ, отличающихся друг от друга по своим физико-химическим свойствам (смачиваемость частицы, её растворимость в воде, гигроскопичность, наличие электрических зарядов и т. д.).

Наблюдения показали, что при температуре до минус $20{ }^{0} \mathrm{C}$ туманы преимущественно состоят из капель воды, при температуре минус $30{ }^{0} \mathrm{C}$ и ниже - из кристаллов льда. Водность туманов зависит от температуры. Для туманов средней интенсивности водность составляет $0,1-0,2$ г/м ${ }^{3}$ при температуре минус $15 \div 20{ }^{0} \mathrm{C}$, при температуре минус $5 \div 10{ }^{0} \mathrm{C}$ водность повышается до $0,5-1,0 \Gamma / \mathrm{M}^{3}$.

Значения водности туманов по различным источникам колеблется от 0,04г/м3 до 1,72 г/м3 [21, 2,6].

Зависимость видимости в тумане от его водности хорошо выражена в табл. 66.

Таблица 66

Соотношение между видимостью и водностью в тумане

\begin{tabular}{|c|c|}
\hline Градации видимости в метрах & Водность в $\Gamma / \mathrm{M}^{3}$ \\
\hline $50-200$ & $>0,1$ \\
\hline $200-500$ & $0,1-0,02$ \\
\hline $500-1000$ & $<0,02$ \\
\hline
\end{tabular}

Абсолютная влажность сильно зависит от температуры. При температуре минус $40{ }^{\circ} \mathrm{C}$ и состоянии насыщения абсолютная влажность составляет $0,18 \Gamma / \mathrm{M}^{3}$, при температуре $+40{ }^{\circ} \mathrm{C}-51,13 \Gamma / \mathrm{M}^{3}$.

Конденсация водяного пара при положительной температуре на нерастворимых ядрах конденсации происходит при некотором пресыщении, на растворимых ядрах - при недосыщении. 
При отрицательных температурах конденсация обычно начинается тогда, когда достигается упругость насыщенного пара надо льдом при температуре точки инея.

Дефицит точки росы или разность между температурой воздуха (T) и точкой росы (Td) дает представление о степени насыщения воздуха и, в частности, об условиях возникновения тумана. При положительной температуре туман возникает тогда, когда $\mathrm{T}-\mathrm{Td}$ находится от 0 до $1,6{ }^{\circ} \mathrm{C}$; при отрицательной температуре от 0 до $4{ }^{\circ} \mathrm{C}$; при температуре ниже минус $25^{\circ} \mathrm{C}$ дефицит находится в пределах от 2 до $4{ }^{\circ} \mathrm{C}$.

На образование и рассеяние туманов существенное влияние оказывает вертикальное распределение температуры и влажности в атмосфере, а также турбулентный обмен между слоями воздуха.

\section{3 Современное состояние проблемы туманообразования Юго-Западного Алтая}

Знание о возможном появлении туманов, их интенсивности, непрерывной продолжительности, площади одновременного охвата является существенным элементом планирования. В связи с быстрым развитием авиации, автомобильного и морского транспорта интерес к туманам все время возрастает. Проблема по искусственному рассеянию туманов за последнее время получила значительное развитие. В 70-е годы прошлого века была начата работа по изучению условий туманообразования в Усть-Каменогорске и его окрестностях. Собран большой материал почти за 35 летний период метеорологических и синоптических условий образования и рассеяния туманов в регионе. Проведена его первоначальная статистическая и климатологическая обработка. Но работа не была завершена. В настоящем исследовании используется большинство вышеуказанных материалов, в обработке которых активное участие принимал автор данной работы.

Изучение туманов на территории Юго-Западного Алтая имеет большое практическое значение. Для Восточного Казахстана подобное исследование выполнено впервые. Особую важность представляет исследование процессов туманообразования в условиях ороклиматического барьера, и влияние геоэкологических условий на их образование. 
Так, определённые значения температуры воздуха при туманах приводят к образованию различных видов туманов: радиационных, адвективных, фронтальных, испарения, ледяных, орографических, городских.

Поскольку условия конденсации связаны с изменениями температуры и влажности воздуха, возникновение туманов обусловлено определённым соотношением между изменениями этих метеорологических элементов. Туманы можно классифицировать по причинам изменения температуры и влажности воздуха. Чёткой границы между отдельными видами туманов нет. Так, при образовании адвективных туманов почти всегда существенное значение имеет понижение температуры, вследствие радиационных потерь тепла подстилающей поверхностью. Большое значение имеет степень выхолаживания воздуха над почвой или снегом при возникновении туманов испарения. Можно говорить лишь о некотором преобладающем влиянии радиационных или адвективных факторов.

Исследования по классификации туманов предложены А.П. Гальцовым, А.Д. Заморским, А.С. Зверевым и др. $[39,2,4]$. В образовании туманов обычно участвует несколько процессов, разделить которые не всегда представляется возможным. Это вносит известную условность в классификацию туманов.

Выделение определенных видов туманов имеет лишь вспомогательное значение для анализа явлений и некоторых качественных выводов о возможности дальнейшего развития процесса.

Речные и смешанные туманы. При теоретическом исследовании трансформации воздушных масс под влиянием подстилающей поверхности обычно ограничиваются изучением изменения их характеристик при смещении над однородной подстилающей поверхностью, свойства которой резко отличаются от свойств подстилающей поверхности, над которой воздушные массы смещались ранее [8].

Вместе с тем, нередко, следует принимать во внимание более сложный характер неоднородностей подстилающей поверхности и условий турбулентного обмена в нижних слоях атмосферы. Пример такой задачи нами рассмотрен при исследовании условий образования речных туманов рек Иртыш и Ульба в холодный период года, когда земная поверхность охлаждена и обычно покрыта снегом, 
а реки из-за близости гидроэлектростанции и сброса теплых сточных вод промышленными предприятиями не замерзают. Температура водной поверхности может значительно превышать температуру подстилающей поверхности на берегах. При этом отмечается резкое отличие условий тепло и влагообмена над водной поверхностью и сушей, а именно, значительное изменение по горизонтали составляющих теплового баланса подстилающей поверхности, а также интенсивности турбулентного обмена.

Проведенные исследования показали, что при наличии штилевого слоя вблизи подстилающей поверхности возможно образование речных туманов. При этом водность тумана и пересыщение водяного пара больше наверху, чем у подстилающей поверхности, что указывает на вероятность перехода при определенных условиях речных туманов в слоистую облачность. Это подтверждается и фактическими наблюдениями в районе аэродрома Усть-Каменогорск.

Строительство ГЭС на многих крупных реках бывшего СССР привело к нарушению естественного режима водоемов: изменилась температура воды; зарегулированный сток и его объемы стали зависеть от субъектов хозяйственной деятельности.

Сведения о влиянии открытых водоемов на образование тумана в холодное время года приведены в ряде работ $[9,2,10,11,4]$. Образование тумана рассматривается над открытой частью незамерзающего водоема или в береговой зоне, при этом основным процессом насыщения воздуха водяным паром является испарение. Образование его на некотором удалении от водоема рассматривается как результат выноса готового тумана испарения.

Появление тумана, как в городе, так и на аэродроме УстьКаменогорского аэропорта, также объясняется выносом тумана испарения с реки Иртыш. Задачей исследования является изучение влияния незамерзающего участка Иртыша ниже Усть-Каменогорской ГЭС на механизм образования тумана на аэродроме УстьКаменогорского аэропорта. Для ее решения использованы синоптические и метеорологические данные за период с 1955 по 2002 гг. Анализ и обработка всех материалов проведена синоптикостатистическим методом и методом математической статистики.

Аэропорт г. Усть-Каменогорска расположен на правом берегу реки Иртыш в 20 км от Усть-Каменогорской ГЭС и в 10 км от впадения реки Ульбы, в северо-восточной части города. 
Зарегулированный сток Иртыша, полностью нарушает температурный режим реки, на протяжении 25-30 км ниже плотины ГЭС. Таким образом, участок реки в холодное время года превратился в открытый водоем. Река Ульба также незамерзающий водоем в холодное время года из-за сброса теплых сточных вод предприятиями города Усть-Каменогорска.

Южнее города после сооружения плотины Усть-Каменогорской ГЭС на Иртыше в 1953 году образовалось водохранилище. Ширина Усть-Каменогорского водохранилища вместе с заливами от 1000 до 1500 метров. Ниже плотины ГЭС в районе города Усть-Каменогорска на удалении до 25 км Иртыш не замерзает даже в самые суровые зимы. Ширина незамерзающего участка Иртыша в районе аэропорта составляет 500-800 м.

Город Усть-Каменогорск расположен при слиянии рек Иртыша и Ульбы, распластываясь по ровным поверхностям речных террас. Над долинами рек возвышаются отроги Калбинского и Ульбинского хребтов, поднимаясь над дном долины на 150-300 метров.

Ледяные туманыл. На территории Юго-Западного Алтая имеют место случаи образования так называемых «ледяных» туманов. Например, в Якутии такие туманы получили название «морозных». Их образование характерно для районов, которые отличаются ороклиматическими особенностями, как межгорные котловины и расширенные долины. К таким районам можно отнести УстьКаменогорск, Зыряновск, Орловку, Секисовку. Туманы образуются при сильных морозах минус $40{ }^{0} \mathrm{C}$ и ниже и имеют радиационное происхождение. Повторяемость ледяных туманов около 1\%.

Средняя повторяемость и продолжительность тумана в районе Усть-Каменогорского аэропорта за зимние месяцы 1955-1977 гг. дает достаточно хорошее представление о влиянии открытой водной поверхности на образование этого явления. В Усть-Каменогорске от октября к ноябрю происходит значительное увеличение как средней месячной повторяемости (от 4 случаев в октябре до 8 случаев в ноябре), так и средней месячной продолжительности тумана (от 16 часов в октябре до 44 часов в ноябре).

Влияние реки на образование тумана проявляется более четко при сравнении с повторяемостью его до сооружения плотины ГЭС (30-35 случаев в год) и после строительства плотины (60 - 65 случаев в год). Это означает, что разность между температурой воды в Иртыше и минимальной температурой воздуха часто составляет 
более $12{ }^{0} \mathrm{C}$. При этих условиях испарения с поверхности Иртыша может существенно влиять на образование тумана в районе аэропорта, что подтверждает предположение о влиянии испарения с поверхности реки на образование тумана в районе аэропорта после сооружения плотины ГЭС.

Свой вклад в процесс туманообразования вносит также антропогенное загрязнение атмосферного воздуха в г. УстьКаменогорске.

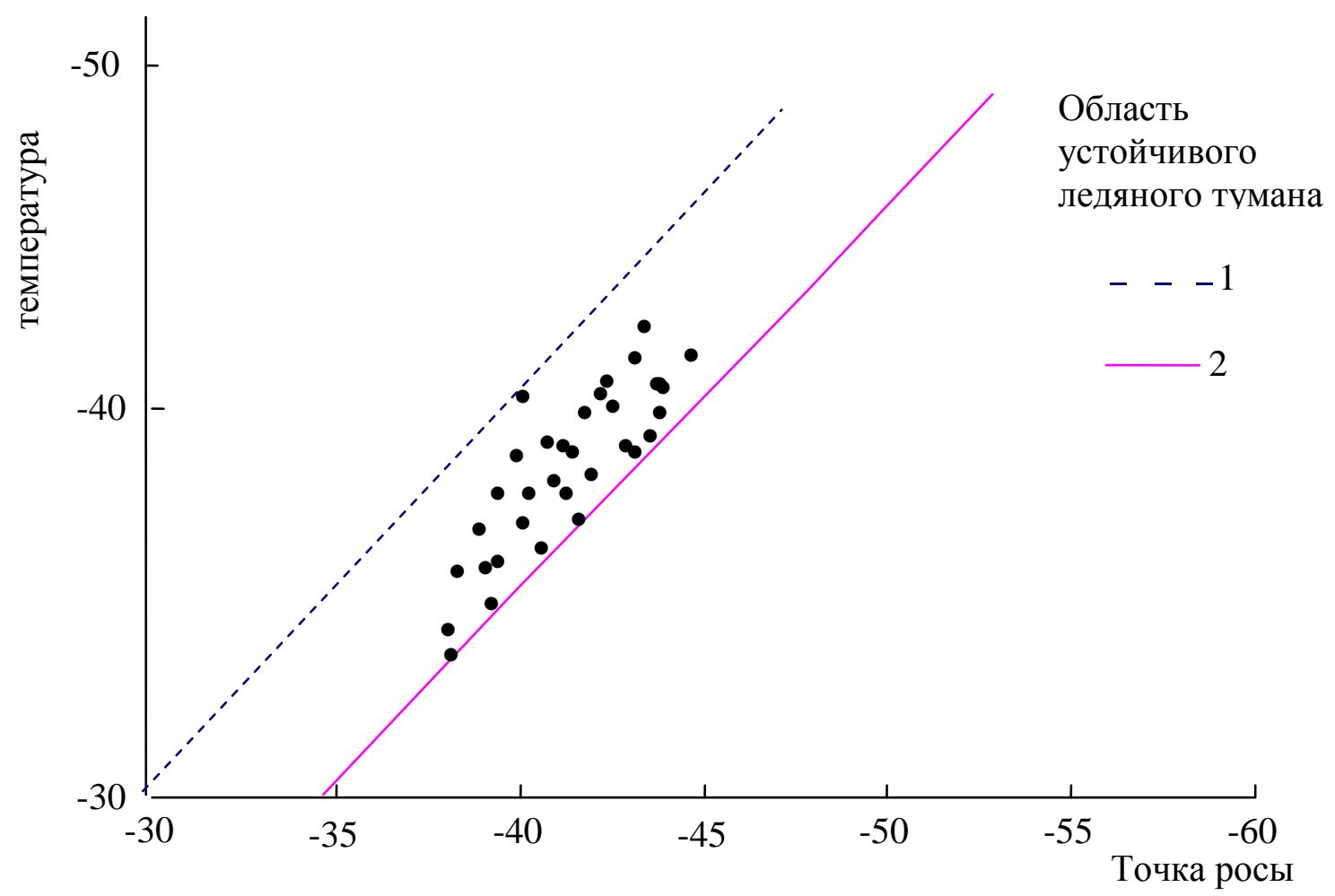

1 - линия равных значений Т и Td; 2 - линия насыщения воздуха по отношению ко льду

Рис. 61 Соотношение между температурой воздуха и точкой росы, необходимые для образования ледяного тумана Усть-Каменогорск - аэропорт

Таким образом, из всего вышеизложенного следует, что в большинстве случаев влияние испарения с открытой водной поверхности реки Иртыш прослеживается в обогащении влагой приземного слоя воздуха и выражается через сложный процесс взаимодействия местных факторов и туманообразующих процессов в механизме образования тумана.

Схематически процесс образования такого тумана можно представить следующим образом. Водяной пар, поступающий вместе 
с ядрами конденсации из теплового источника в морозный воздух, быстро конденсируются, а образовавшиеся капельки тумана обычно быстро замерзают. Образование тумана при сильном морозе может быть связанно с дополнительным воздействием, как правило, это поступление в атмосферный воздух продуктов сгорания топлива или выбросов промышленных предприятий.

Соотношение между температурой и точкой росы, необходимое условие для образования ледяного тумана в Усть-Каменогорске представлено на графике (рис.61). Прерывистая линия является линией равных значений температуры и точки росы. Справа от нее расположена область устойчивого ледяного тумана, где воздух перенасыщен по отношению ко льду. Справа от сплошной линии лежит область неустойчивого ледяного тумана или туман вообще не образуется. Представленный график, можно использовать в оперативной работе при прогнозе устойчивого ледяного тумана.

\section{4 Туманообразование в условиях антропогенных воздействий}

Исследование влияния метеорологических условий на распределение примесей в атмосфере в настоящее время привлекает особое внимание в связи с разработкой региональных программ устойчивого социально-экономического развития.

Изучение влияния туманов и дымки на загрязнение воздуха в Усть-Каменогорске представляет повышенный интерес, поскольку известно, что увеличение влагосодержания воздуха способствует перераспределению примесей к поверхности земли из более высоких слоев, а также приводит к сложным преобразованиям структуры примесей, вследствие чего образуются новые, более токсичные вещества [12].

Известно, что туманы наносят значительный экономический ущерб народному хозяйству. Развитие промышленности и связанное с ним загрязнение воздушного бассейна оказывает существенное влияние на метеорологический режим городов и в частности на режим туманов. Важное значение при разработке методов защиты воздушного бассейна от загрязнения промышленными выбросами имеет изучение метеорологических условий, благоприятствующих созданию высоких концентраций примесей в пограничном слое атмосферы. К ним в первую очередь можно отнести инверсии, штили и туманы. В этой связи возникает необходимость совместного 
изучения условий образования городских туманов и загрязнения воздушного бассейна.

Влияние туманов на содержание и распределение примесей в воздухе весьма сложно и своеобразно. Теоретические оценки влияния тумана на диффузию примесей сделаны в ряде работ $[8,13,14]$.

Исследования, проведенные в работе С.И. Тюребаевой [15] позволили сделать выводы, что при туманах количество примеси в воздухе увеличивается, причем сочетание тумана с инверсией приводит к более интенсивному росту концентрации примеси в воздухе.

При туманах продолжительностью до шести часов наблюдается увеличение содержания примеси в среднем в два раза, а в отдельных случаях и в 8 раз [16].

Эти результаты вполне подтверждаются данными наблюдений за состоянием загрязнения атмосферного воздуха в УстьКаменогорске и Зыряновске, а в Риддере такая зависимость очень слабая.

При изучении связи туманов с загрязнением воздушного бассейна чаще рассматривается горизонтальная видимость в туманах. Известно, что уже само наличие тумана приводит к тому, что в его каплях концентрируется не только вредная примесь, которая находится вблизи подстилающей поверхности, но и также значительная часть примеси из вышележащих и наиболее загрязненных слоев воздуха [12].

Таким образом, чем выше верхняя граница тумана, тем из большего слоя воздуха происходит аккумуляция вредных примесей.

\section{5 Оценка состояния туманообразования и его воздействия на хозяйственную деятельность}

В целях эффективной защиты воздушного бассейна от загрязнения вредными промышленными выбросами, по мнению М.Е. Берлянд [23], требуется развитие исследований закономерностей атмосферной диффузии при различных погодных ситуациях. Особенно существенны исследования для опасных условий погоды, когда могут наблюдаться большие концентрации примеси в приземном слое воздуха. Такие условия погоды характерны для городов Юго-Западного Алтая: Усть-Каменогорск и Зыряновск. Учет этих закономерностей при проектировании и эксплуатации предприятий позволяет более объективно нормировать 
промышленные выбросы в целях избежания недопустимых концентраций вредных веществ в атмосфере даже при неблагоприятном сочетании метеорологических факторов, определяющих распространение примесей.

Рассмотрение случаев интенсивного загрязнения воздуха показывает, что часть их относится к периодам продолжительных туманов. Это хорошо видно на графиках зависимости количества дней с туманами в году и интенсивностью загрязнения атмосферы диоксидом серы в городах Усть-Каменогорск и Зыряновск. Вредное действие дымовых и газовых примесей при туманах обнаруживается более остро, чем при других погодных условиях, усиливается неприятное ощущение их, наличие примеси в туманах дополнительно ухудшает видимость и т.п. Таким образом, имеет место, взаимно усиливающее действие дымов и туманов.

Вместе с тем условия загрязнения воздуха при туманах и характер непосредственного воздействия туманов на диффузию примесей изучены мало. Имеющийся опытный материал весьма небольшой, недостаточно систематизирован и проанализирован. Отчасти это вызвано трудностями отбора для сопоставления случаев с туманами и без туманов при прочих аналогичных погодных условиях. Влияние туманов на содержание примесей в воздухе носит весьма сложный характер. С одной стороны, при туманах нередко наблюдаются специфические условия распределения метеорологических элементов, способствующие увеличению концентрации примесей у земли. Некоторые теоретические оценки в этом плане, выполненные в работах Ф.А. Гисиной [24], в основном относятся к оценке загрязнения приземного слоя воздуха при определенных условиях распределения интенсивности турбулентного обмена по вертикали. С другой стороны, при наличии туманов изменяется качественный состав атмосферных примесей и токсичный характер их воздействия.

Учитывая сложность протекающих процессов, приобретает особую важность развитие теоретических вопросов загрязнения атмосферы при туманах. При этом следует по возможности полнее и строже учесть такие характеристики, как размеры занимаемой туманом площади, водность, температурную стратификацию, осадки.

Поскольку экспериментальных данных об этих характеристиках в настоящее время мало (отсутствие вертикального температурноветрового зондирования), то для некоторых типов туманов 
целесообразно пользоваться теоретическими исследованиями. Фундаментальные разработки по исследованию были выполнены М. Е. Берлянд, Р. И. Оникул, Л.Р. Сонькиным и др.[8, 13, 17] в 70-80 годах.

Как уже отмечалось в предыдущих разделах данного исследования, для Усть-Каменогорска характерна большая повторяемость радиационных и речных туманов (96,5\%). Поэтому изучение диффузии примесей при испарениях и радиационных туманах представляет специальный интерес и требует отдельного исследования.

Для исследования взаимосвязей между метеорологическими явлениями, ухудшающими видимость (туман, дымка) и загрязнением воздуха в целом по городу Усть-Каменогорску привлечены данные наблюдений в аэропорту.

Проведенные исследования приводят к выводу, что повышенное и высокое загрязнение воздуха в Усть-Каменогорске наблюдается в 80-90 \% случаев туманов. Наиболее опасное загрязнение при туманах отмечается в январе, декабре (10-15\%). В большинстве случаев такое положение обусловлено наличием над Юго-Западным Алтаем отрога Сибирского антициклона с преобладанием ясной со слабыми ветрами погодой.

Существенный интерес представляет исследование влияния тумана на диффузию сернистого газа, относящегося к наиболее распространенным в атмосфере вредным примесям для территории Юго-Западного Алтая, особенно для Усть-Каменогорска.

Временная изменчивость концентраций вредных веществ в атмосфере города имеет сложную структуру. Это связано с тем, что поле концентраций и его временная изменчивость определяется, как неравномерностью во времени выбросов различных веществ в атмосферу промышленными предприятиями, так и существенным влиянием метеорологических условий, которые в свою очередь обладают значительной временной изменчивостью.

Сернистый газ (диоксид серы) - невидимый, не воспламеняющийся газ-восстановитель. Сернистый газ хорошо поглощается снегом, влажной почвой, туманом и растениями. Основным источником выбросов сернистого газа в атмосферу в исследуемом районе являются предприятия цветной металлургии и топливно-энергетического комплекса, на их долю приходится 65\% всех выбросов вредных примесей в атмосферу. Это 165 тыс. тонн в 
год. Только в Усть-Каменогорске в атмосферу города в год поступает около 80 тыс. тонн сернистого газа. Сернистый газ является основным загрязнителем воздушного бассейна города. Его среднегодовое содержание в воздухе превышает предельно допустимые концентрации в 2-3 раза.

Система контроля концентраций примесей в воздухе, основанная на методах неавтоматических химических анализов, ограничена относительно малым количеством анализируемых проб воздуха, отбираемых преимущественно в дневное время суток. Поэтому понятны большие трудности исследования временной изменчивости концентраций сернистого газа при использовании неавтоматических методов анализа.

Исследования, проведенные А.С. Зайцевым [18] позволили сделать выводы, что для решения задачи организации контроля за уровнем концентраций сернистого газа в городе необходимо фиксировать процессы примерно через 1 час, а для целей разработки методов метеорологического прогноза уровня концентраций следует фиксировать процессы с характерным временем примерно 6-8 часов.

Нами прослежена зависимость повторяемости числа дней с туманом и среднегодовой концентрации сернистого ангидрида в Усть-Каменогорске за период с 1974 по 2002 год Между ними прослеживается очень тесная связь. Коэффициент корреляции $>0,90$.

При рассмотрении соотношений между выбросами и концентрацией вредных веществ принималось, что все выбросы серы находятся в атмосфере в виде сернистого газа. В действительности в туманах и осадках очень быстро происходит его окисление до $\mathrm{SO}_{4} \mathrm{c}$ дальнейшим образованием серной кислоты. При этом происходит возрастание массовой концентрации примеси: из 1 г сернистого газа образуется 1,5 г серной кислоты.

Растворение сернистого газа в каплях тумана приводит к образованию аэрозоля сернистой кислоты. Последняя по сравнению с сернистым газом обладает большей токсичностью, при её наличии в атмосфере существенно усиливается коррозия металлических предметов и др. Кроме того, сернистый газ, растворенный в каплях тумана, значительно быстрее, чем сернистый газ в газообразном состоянии, окисляется до серного ангидрида. Это обусловлено тем, что обычно в каплях тумана содержатся некоторые микроэлементы (цинк, кадмий, медь и др.), обладающие католитическими свойствами, в их присутствии окисление происходит более 
интенсивно. Этот механизм появления серной кислоты в каплях тумана характерен для так называемых «сернокислотносульфатных» туманов в Усть-Каменогорске.

В туманах также как и в облаках, происходит поглощение примесей каплями. Однако эти примеси вместе с каплями остаются в приземном слое воздуха и оказывают не меньшее вредное воздействие на здоровье людей, растения и др. В тоже время за счет значительных градиентов концентрации в воздухе (вне капель) происходит перенос примесей в область тумана из окружающего пространства, в том числе из выше лежащих слоев [26, 29]. В связи с этим суммарная концентрация примесей возрастает. Значительную опасность представляют расположенные над туманом факелы дыма, которые опускаются в приземный слой воздуха. Важно также, что над туманом обычно образуется приподнятая инверсия температуры. Следовательно, в туманах в нижнем слое воздуха создается значительное скопление вредных веществ. Туманами сопровождались многие из известных эпизодов опасного загрязнения воздуха в городах, при которых имели место человеческие жертвы $[19,20]$. Очевидно, туманы в этих случаях явились одной из причин создания крайне неблагоприятных условий.

Bce представленные данные достаточно определенно свидетельствуют о том, что туманы способствуют повышению загрязнения приземного слоя воздуха в городах. В связи с этим зимой дополнительную опасность представляют расположенные в черте города Усть-Каменогорска незамерзающие водоемы (р.Иртыш, Ульба), вблизи которых и над ними часто возникают туманы.

Поскольку значительная часть примесей в туманах поглощается и находится не в воздухе, а в каплях или кристаллах, то часто не удается измерить их концентрации.

Проводимый на сегодняшний день экологический мониторинг за серосодержащими соединениями в атмосферном воздухе городов, исследуемой территории, ограничивается контролем только сернистого газа. Концентрации серной кислоты и сульфатов не измеряются и поэтому провести более детальный анализ влияния тумана на диффузию сернистого газа не предоставляется возможным. Вместе с тем оседание крупных капель тумана, при которых растворенная примесь из вышележащих и часто очень загрязненных слоев переносится к подстилающей поверхности указывает, что при сильных туманах на подстилающую поверхность выпадает морось, 
капли которой содержат заметные концентрации серной кислоты. Иными словами выпадает «кислотный дождь».

Как известно индикатором большого присутствия в атмосферном воздухе соединений серы являются хвойные деревья. Примером тому может служить гибель соснового бора в Лениногорске и периодическая гибель хвойных насаждений в УстьКаменогорске.

Установлено, что вредные вещества поглощаются растениями. Поэтому необходимо знать не только ПДК или стандарты вредных веществ, неблагоприятные для здоровья населения, но и уровни загрязнения, определяющие пагубное воздействие на окружающую среду (растительность, животный мир), т.е. биологические нормативы, должны быть установлены уровни предельно допустимой экологической нагрузки (ПДЭН). Следуя определению Ю.А. Израэля [61], за ПДЭН для атмосферы можно принять уровни, которые не влияют на экосистему или изменяют её в допустимых пределах.

Полученные результаты показали, что использованные методы исследования позволяют выяснить ряд важных особенностей распространения примеси в тумане. Однако этот вопрос весьма сложен и требуется дальнейшая его разработка.

Попадая в атмосферу сернистый газ переносится на значительные расстояния, окисляясь и трансформируясь в другие соединения серы.

Изучая химический состав атмосферы в промышленных районах [99], обнаружено кроме сернистого газа, также сульфаты. Единственным путем образования, которых может явиться окисление $\mathrm{SO}_{2}$ до $\mathrm{SO}_{3}$, которые с влагой воздуха дает серную кислоту $\mathrm{H}_{2} \mathrm{SO}_{4}$. Особенно интенсивно окисление сернистого газа до $\mathrm{SO}_{3}$ происходит фотохимическим путем. При этом скорость реакции в значительной степени зависит от интенсивности солнечной радиации, повышенной влажности атмосферы в присутствии незначительного количества католических соединений (окислов азота, озон и др.). Большая скорость процесса окисления наблюдается в каплях тумана, однако, при снижении рН до 2,5 окисление приостанавливается [27]. Если водяные капли в туманах содержат следы каталитических ионов металлов, таких, как железо, медь, свинец, цинк, то быстрое окисление может происходить и без света. Скорость реакции окисления $\mathrm{SO}_{2}$ возрастает при добавлении аммиака, который нейтрализует кислоты в каплях тумана. 
Исходя, из наличия в загрязненной атмосфере подобных катализаторов в городах Усть-Каменогорске и Зыряновске время жизни SO2 может составлять 4-6 дней [32]. Данные исследования хорошо коррелируются со сведениями о повышенном содержании сернистого газа в Усть-Каменогорске продолжительностью более 5 дней. Как следует из приведенных исследований, скорость пребывания сернистого газа в атмосфере зависит от многих факторов (интенсивности солнечной радиации, влажности, наличия каталитических примесей т. д.). И в различных районах может сильно варьировать. Поэтому исследования количественного содержания примесей в ряде городов Рудного Алтая по выяснению соотношения между содержанием сернистого газа и сульфатов в воздухе требует дополнительного и более детального изучения.

Таким образом, измерение только содержания двуокиси серы не могут служить достаточной характеристикой загрязненности атмосферы. Наряду с $\mathrm{SO}^{2}$ необходимо определять содержание сульфатов в атмосферном воздухе. Накопление подобных данных позволит оценить среднее время жизни сернистого газа для промышленных городов исследуемой территории и повысить точность прогнозирования атмосферы, особенно в периоды неблагоприятных метеорологических условий.

Загрязнение атмосферного воздуха в городах и промышленных центрах области обусловлено деятельностью предприятий металлургической промышленности, теплоэнергетики и автотранспорта. Концентрация вредных веществ в этих районах на два три порядка выше, чем в чистых районах неподверженных городскому влиянию. $\mathrm{K}$ наиболее неблагоприятным регионам относится и город Усть-Каменогорск.

Индекс загрязнения атмосферы (ИЗА) в городе рассчитан по формуле:

$$
\text { ИЗ } \mathrm{A}_{\mathrm{i}}=\frac{\mathrm{q}_{\mathrm{cP}}}{\Pi \underline{\mathrm{K}}_{\mathrm{c.c}}}
$$

ИЗА $\mathrm{A}_{\mathrm{i}}$ - индекс загрязнения единичной примеси;

$\mathrm{q}_{\mathrm{cp} \mathrm{-}}$ средняя концентрация примеси за год;

ПДК

$\mathrm{C}_{\mathrm{i}}$ - коэффициент, зависящий от класса опасности вещества

для примесей 1 класса опасности $\mathrm{C}_{\mathrm{i}}=1,7$

для примесей 2 класса опасности $\mathrm{C}_{\mathrm{i}}=1,3$ 
для примесей 3 класса опасности $\mathrm{C}_{\mathrm{i}}=1,0$

для примесей 4 класса опасности $\mathrm{C}_{\mathrm{i}}=0,9$

Для расчета комплексного индекса загрязнения ИЗА выбирается пять индексов по отдельно взятым примесям с наибольшим числовым значением, и суммируются. Значения ИЗА для г. Усть-Каменогорска за период с 1974 по 2002 года представлены в таблице 67.

Максимальное свое значение индекс загрязнения достигал в 1991 году - 21,7 и далее постепенно снижался до 8,6 в 1995 г. Это объясняется двумя причинами: сокращением объёмов производства продукции многими предприятиями города и тем, что еще по инерции ощущалось действие на окружающую среду ранее реализованных природоохранных мероприятий

В 1996 году снижение производства было остановлено, наметилась тенденция к стабилизации, особенно в отраслях цветной металлургии, энергетики. В 2000 году отмечается тенденция роста выбросов по отношению к 1990 г. на 71\% при росте физического объема производства в этом же году на 56\%.

Таблица 67

Сравнительная характеристика ИЗА 5 в некоторых регионах Восточного Казахстана

\begin{tabular}{|l|c|c|c|}
\hline & 1980 & 1990 & 2000 \\
\hline Усть-Каменогорск & 43,7 & 21,7 & 17,8 \\
\hline Риддер & 13,0 & 17,1 & 10,0 \\
\hline Семей & - & 4,4 & 4,0 \\
\hline
\end{tabular}

Средний индекс загрязнения по республике Казахстан - 6.

Таким образом, атмосфера г. Усть-Каменогорска является одной из самых загрязненных, и это является одной из причин туманообразования даже при недостаточном влагонасыщении атмосферного воздуха.

В настоящее время загрязнение природной среды достигло таких значительных размеров, что стало серьёзно сказываться на колебаниях климата, народном хозяйстве и здоровье населения. Многие из таких проявлений выходят далеко за пределы городских границ и вполне могут считаться крупномасштабными, отрицательно влияя на урожайность сельскохозяйственных культур, росте и 
развитии растительного покрова, на качестве воды в реках и водоёмах.

За последние годы получен значительный материал теоретических и практических исследований [21,22,23], позволяющий оценить состояние загрязнения атмосферного воздуха в результате антропогенного воздействия и рассмотреть его метеорологические аспекты. Большой интерес при этом представляет Усть-Каменогорск, где наиболее чётко проявляются негативные последствия антропогенного воздействия на природную среду.

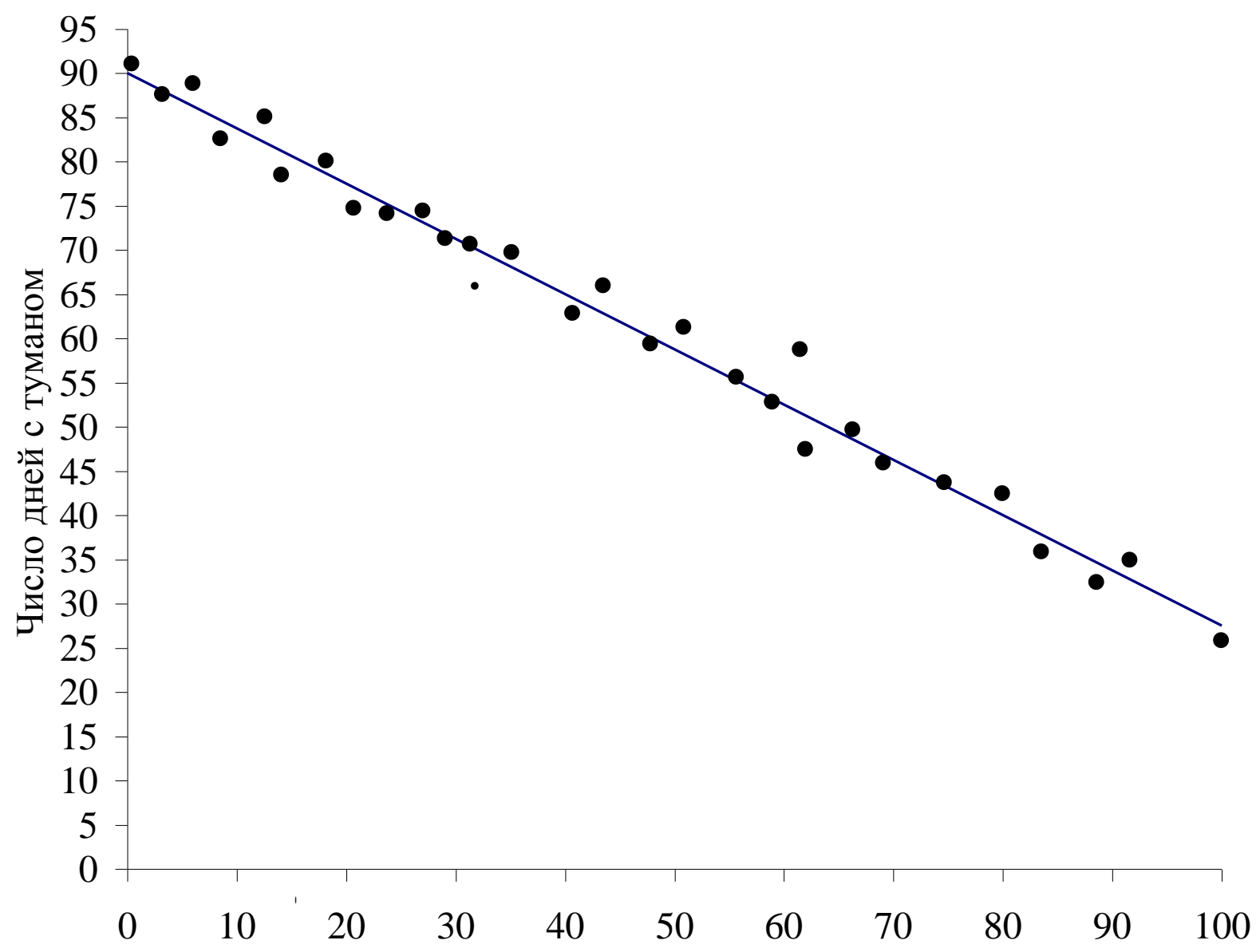

Рис. 62 Число дней с туманом различной обеспеченности (Усть-Каменогорск - аэропорт)

$\mathrm{P} \%$

Условия конденсации водяного пара и туманообразования существенно изменяются при наличии в воздухе достаточно крупных ядер конденсации [24].

Исследования проведенные в работе [25] по изучению загрязнения атмосферы соединениями серы и азота и последующее их окисление до кислотных аэрозолей вполне согласуются с 
материалами наших наблюдений в Усть-Каменогорске. Такие ситуации наблюдаются преимущественно при температурах ниже минус $20^{\circ} \mathrm{C}$, когда погода определяется антициклональным барическим полем у земли со штилями. Интенсивно кислотообразование начинается при влажности более $70 \%$.

Нами проанализированы данные повторяемости туманов за более чем 60 лет. За 10 лет до введения в строй промпредприятий в городе и за 20 лет до строительства Усть-Каменогорской ГЭС и после пуска указанных объектов.

В результате получены следующие характеристики:

1. Средняя годовая повторяемость туманов после введения в строй промпредприятий возросла более чем в 2 раза.

2. На ограниченной территории промкомплекса (УК СЦК, ТЭЦ, завод УМЗ) и примыкающей к ней части города повторяемость туманов в течение года значительно больше, чем в других частях города.

Анализ динамики повторяемости туманов в районе промпредприятий в течение года с учетом полученных результатов позволяет сделать вывод, что в холодный период года увеличение повторяемости туманов происходит преимущественно за счет образования в воздухе кислотных аэрозолей. Увеличение повторяемости туманов связано с уменьшением видимости, с понижением температуры воздуха, повышением влажности, сокращению числа ясных дней в течение года.

Детальное изучение причин и условий возникновения промышленных туманов как метеорологического так и технологического характера позволили бы, во-первых, определить комплекс неблагоприятных метеорологических условий с целью их прогноза, во-вторых, разработать и внедрить ряд мероприятий по сокращению и даже устранению отдельных выбросов.

\section{6 Влияние туманов на метеорологический потенциалзагрязнения атмосферы}

Все хозяйственные объекты, взаимодействуя с окружающей средой, наносят тот или иной ущерб природным компонентам. В связи с этим необходима систематизация воздействий различных видов хозяйственной деятельности, на компоненты и параметры окружающей среды, последствий и мер по их смягчению. 
При осуществлении градостроительных мероприятий по охране окружающей среды, планировании взаимного расположения территорий различного назначения, нормировании количества выбросов для промышленных предприятий необходимо учитывать условия переноса и распределения примесей в городском воздухе.

В течение 1993-1998 гг. проводились исследования распределения примесей в городе Усть-Каменогорске. Результаты анализа материалов показали, что особенности поля концентраций примесей в городе зависят от вида примеси и её химической активности. Так, например, особенности распределения концентрации сернистого газа и двуокиси азота связано с тремя основными факторами: характером и размещением источников выбросов, розой ветров и близостью крупных водных объектов.

Усиливающим фактором вредного воздействия сернистого газа и двуокиси азота на окружающую среду и здоровье населения является большая повторяемость туманов в течение года.

Фактором, оказывающим очищающее действие на атмосферу города, являются водные объекты (реки Иртыш и Ульба). Например, в левобережном районе города концентрации $\mathrm{SO} 2$ и $\mathrm{NO} 2$ значительно ниже.

В работе [26] отмечено большое влияние загрязняющего направления ветра. Для Усть-Каменогорска более часты случаи отсутствия загрязняющего направления для разных пунктов города. Это может быть объяснено тем, что большие по абсолютной величине концентрации (3-5 ПДК) возникают, как правило, при штилевой погоде или слабом ветре $1-3 \mathrm{~m} /$ сек, а при сильном ветре более $6 \mathrm{~m} /$ сек значения концентраций примесей небольшие по величине $(<1$ ПДК), при этом, основная масса выбросов выносится за пределы города и не фиксируется пунктами контроля загрязнения (ПНЗ).

Одним из основных факторов, определяющих потенциал загрязнения воздуха, является ветровой режим и, в частности, режим слабых скоростей ветра.

Как показал ряд исследований $[27,13]$, максимальная концентрация примесей формируется при различных скоростях ветра в зависимости от характера источников выбросов. Так, «опасными» скоростями, обуславливающими значительные концентрации выбросов у земли для тепловых электростанций при высоких трубах, являются ветры 5-7 м/сек. В то же время такие скорости 
способствуют быстрому рассеиванию примесей от источников с холодными выбросами из труб, вблизи которых наибольшая концентрация бывает при скорости ветра 1-2 м/сек. Многочисленные случаи опасных загрязнений воздуха связывают с малыми скоростями ветра. Все это свидетельствует о необходимости изучения повторяемости различных скоростей ветра и учете её при оценке потенциала загрязнения.

Анализ метеорологической информации и данных о концентрации примесей в городах Юго-Западного Алтая: УстьКаменогорск, Зыряновск и Риддер позволил обнаружить связь между сезонными изменениями примесей и повторяемостью скорости ветра 0-1 м/сек. Коэффициенты корреляции между повторяемостью скорости ветра 0-1 м/сек и средней месячной концентрацией сернистого газа были от 0,71 до 0,9. Это указывает на необходимость изучения для городских условий, прежде всего повторяемости штилей, являющихся опасными при решении многих задач.

В работе, по климатическим данным на метеостанциях Восточного Казахстана и сопредельным метеостанциям Алтайского края и Горно-Алтайской области выявлены районы различной повторяемости штилей.

Анализ распределения повторяемостей штилей позволяет выявить некоторые важные закономерности в режиме малых скоростей ветра. На территории Юго-Западного Алтая выделяется ряд крупных районов, значительно различающихся по повторяемости таких скоростей (рис.63).

Наименьшая повторяемость (до $10-20$ \% времени года) наблюдается на ровных открытых пространствах запада ВосточноКазахстанской области и юге Алтайского края (I - II районы). По мере продвижения к ороклиматическому барьеру в отдельных пунктах, расположенных в более защищенных условиях, при возрастающей общей защищенности территории повторяемость штилей возрастает до 30 \% ( III - район). Внутри этого района на отдельных близко расположенных станциях повторяемость штилей различается довольно значительно, что объясняется особенностями месторасположения, учет которого при схематическом рассмотрении на карте не всегда возможен. Следует отметить, что вблизи крупных рек, водохранилищ, озер повторяемость штилей уменьшается до 5-10 \% (Тугыл на Зайсане, Семиярка на Иртыше). 


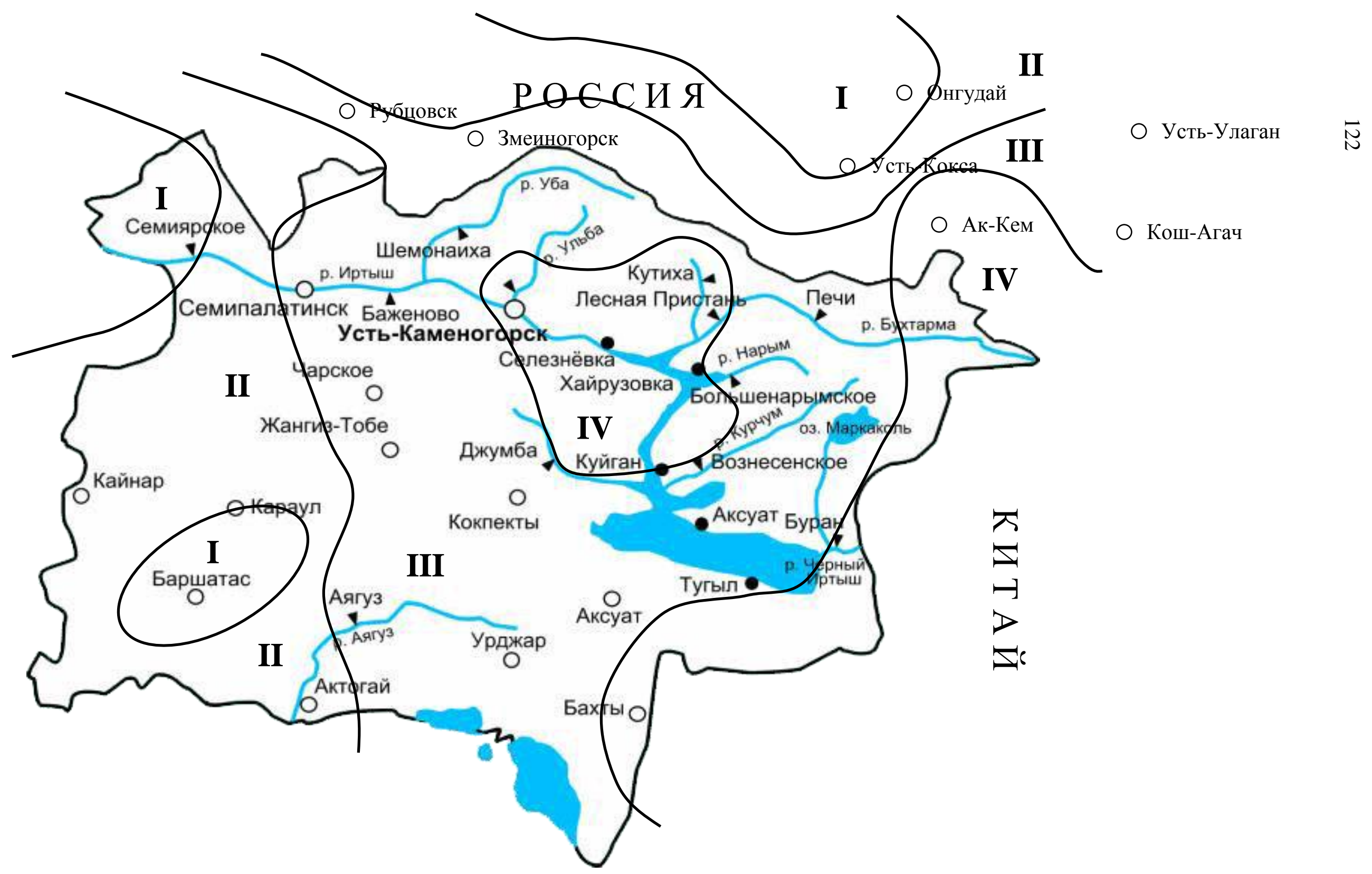

Рис. 63 Районы различной повторяемости штилей

I - менее 10 \%; II - 10-20 \%; III - 20-30 \%; IV - более 30 \% 
В закрытых долинах и горных котловинах повторяемость значительно колеблется в зависимости от рельефа. Она составляет 30 $40 \%$, а в некоторых, наиболее защищенных условиях местоположения до 50-80 \% (IV - район).

Однако общая оценка возможных штилевых условий недостаточна для планирования и нормирования работы промышленных предприятий, создающих значительные концентрации вредных примесей в воздухе. Большое значение имеет учет годового и суточного хода малых скоростей ветра.

Анализ малых скоростей ветра на территории Юго-Западного Алтая не проводился. Нами рассмотрена годовая повторяемость слабых ветров в исследуемом регионе по некоторым пунктам (рис.62).

В районах с небольшой повторяемостью ветра 0-1 м/с годовой ход сглажен, колебания от месяца к месяцу в течение года составляют 10-15 \%. В большинстве пунктов региона в годовом ходе отмечается два максимума повторяемости слабых ветров. Один отмечается в феврале, другой в августе, что достаточно хорошо согласуется с высокими уровнями загрязнения атмосферного воздуха в эти месяцы (Усть-Каменогорск, Риддер).

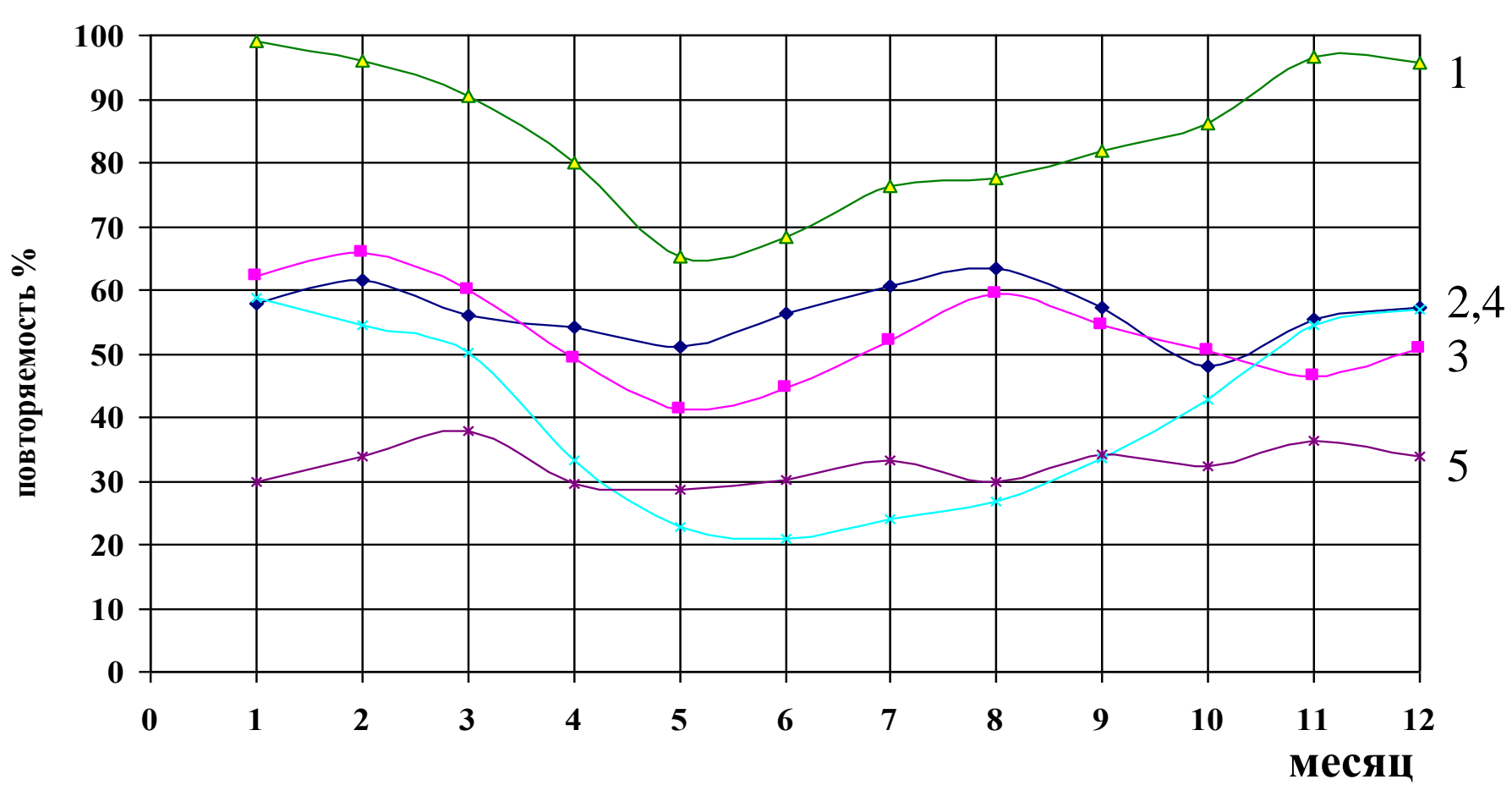

Рис. 64 Годовой ход скорости ветра $0-1$ м/с в Зыряновске (1), Риддере (2), Усть-Каменогорске (3), Зайсане (4), Катон-Карагае (5). 
Наибольший интерес представляет годовой ход затиший в межгорных котловинах (Зыряновской, Секисовской, Орловской и др.), где повторяемость их достигает 70-90 \% времени года. В зимние месяцы в этих районах практически господствует штиль при небольшом увеличении скорости ветра в весенние и летние месяцы. Однако различие повторяемости между максимумом и минимумом составляет более 30 \%. Хорошо выражены: один максимум - январефеврале и один минимум - мае-июне.

Резюмируя результаты анализа годового хода малых скоростей ветра, отметим, что наиболее важен учет его в районах, где колебания от сезона к сезону достигают значительного диапазона.

Кроме годового хода, скорости ветра имеют суточный ход, амплитуда которого весьма различна и зависит как от времени года, так и от ороклиматических условий района.

Анализ данных о суточном ходе различных скоростей ветра, опубликованных в Справочнике по климату [28], позволяет говорить о очень малом суточном ходе в зимние месяцы и может не учитываться при использовании этих данных. Летом же суточный ход настолько велик, что от ночи ко дню повторяемость затиший уменьшается в 2-3 раза. Следовательно, если рассматривать повторяемость скоростей ветра $0-1$ м/сек и штилей как некоторую меру возможного увеличения выбросов примесей в атмосферный воздух городов, то следует иметь в виду, что суточный ход этих величин очень велик в переходные сезоны и летом.

Все это позволяет сделать некоторые выводы:

1. На территории Юго-Западного Алтая имеются обширные районы, где скорости ветра 0-1м/сек наблюдаются в 35-45 \% времени года и более (Зыряновск $80 \%$ ).

2. Годовой ход повторяемости скоростей ветра $0-1 \mathrm{~m} / \mathrm{c}$ и штилей наиболее существенен в межгорных котловинах, где летом они наблюдаются на 30-35 \% реже, чем зимой.

3. Суточный ход затиший во всех районах очень велик в переходные сезоны и летом.

4. При определении условий возможного застоя воздуха и оценке потенциала загрязнения следует использовать данные о повторяемости скоростей ветра 0-1 м/сек, как по месяцам, так и в различные часы суток.

Антропогенное воздействие характеризуется понятием «антропогенная нагрузка». Это величина прямого или 
опосредованного антропогенного воздействия на природную среду в целом или на её отдельные компоненты. По расчетам специалистов, антропогенная нагрузка на природную среду удваивается каждые 1015 лет [29].

Существует несколько подходов к классификации загрязнения: по происхождению, по объектам загрязнения, по продолжительности и масштабам распространения, по источникам и видам загрязнителей.

Существует большое количество монографий $[30,31,12,6]$, посвященных влиянию на окружающую среду отдельных видов человеческой деятельности. Они очень полезны с точки зрения понимания механизма их воздействия на природу, но мало пригодны для целей сравнения. Как правило, авторы таких монографий склонны существенно завышать «вклад» описываемой ими деятельности в деградацию окружающей среды. Что касается сравнительных оценок, то их в современной литературе содержится достаточно много. Впрочем, надо отметить, что при этом нередко путаются понятия объемов выбросов загрязняющих веществ и опасности для природной среды, обусловленной ими.

Например, по количеству выбрасываемых загрязняющих веществ в атмосферу (валовый выброс) нельзя однозначно оценить степень загрязнения атмосферного воздуха в том или ином регионе. Другое дело, когда учитывается метеорологический или климатический потенциал загрязнения атмосферы (ПЗА).

Как известно, распределение примесей по территории города и их перенос на большие расстояния находится в тесной взаимосвязи с рядом метеорологических величин характеризующих состояние приземного и пограничного слоя атмосферы. Для того, чтобы обеспечить научно обоснованное управление качеством воздуха, необходима информация о выбросах вредных веществ, об уровнях загрязнения их изменениях в течение длительного периода, а также о метеорологических условиях распределения примесей в атмосфере. Совместное рассмотрение этих сведений позволяет установить правильный диагноз состояния загрязнения воздушного бассейна и прогнозировать его на длительный период. При постоянном режиме выбросов вредных веществ, колебания уровня загрязнения происходит под влиянием условий переноса и рассеивания примесей в атмосфере.

Повышение концентраций примесей в конкретном районе зависит от определённых сочетаний метеорологических параметров. 
Чем точнее установлено это сочетание, тем с большей надёжностью будут осуществляться предупреждения о возможном накоплении примесей в атмосферном воздухе.

Сочетание метеорологических параметров, определяющих возможный при заданных выбросах уровень загрязнения атмосферы, называют потенциалом загрязнения атмосферы (ПЗА) [21, 31].

Различают метеорологический и климатический ПЗА. Метеорологический ПЗА включает сочетание наблюдаемых (или ожидаемых) метеорологических параметров в определенный период (час, сутки) и используется при прогнозировании возможных изменений уровня загрязнения на короткие временные интервалы. Климатический ПЗА включает многолетние климатические характеристики. Поэтому он позволяет оценить ожидаемый в данном физико-географическом районе (при заданных выбросах) средний уровень загрязнения. Поскольку формирование уровня загрязнения атмосферы связанно с условиями вертикального и горизонтального переноса и рассеивания примесей, то ПЗА может представляться в различных сочетаниях метеорологических параметров, определяющих эти условия.

Для выбора наиболее оптимального варианта размещения производительных сил, необходимо знать метеорологический потенциал самоочищения атмосферы. Под метеорологическим потенциалом самоочищения атмосферы в данном случае подразумевается комплекс метеорологических условий, характерных для той или иной местности и способствующих как загрязнению, так и самоочищению атмосферного воздуха.

В настоящее время для такой оценки используется метеорологический потенциал загрязнения атмосферы (ПЗА), разработанный ГГО им. А. И. Воейкова Э.Ю. Безуглой [20], который учитывает повторяемости скорости ветра (0-1м/сек), туманов, приземных инверсий и периоды застоя воздуха, то есть сочетание инверсий со штилями.

Как известно, сочетание тумана с инверсией приводит к более интенсивному росту концентраций примеси в воздухе $[23,16]$. При изучении ПЗА немаловажное значение имеет рассмотрение комплексных характеристик и, в частности, таких, как наличие инверсионных слоев при тумане и скорости ветра меньше 2 м/сек.

В работе [36] изучена связь температурных инверсий с туманом по 36 аэрологическим станциям Госкомгидромета. На основании этих 
материалов были вычислены повторяемости инверсий с туманом в теплый и холодный периоды года.

Полученные результаты и проведенная типизация приземных и приподнятых инверсий по регионам бывшего СССР могут быть использованы с очень большой отдачей в исследованиях для рассматриваемого района, где отсутствует температурно-ветровое зондирование атмосферы. Для Юго-Западного Алтая характерен третий тип, когда максимальное число дней с инверсиями и туманом приходится на зимние месяцы, минимальное - на летние.

По значениям ПЗА, рассчитанным на станциях аэрологического зондирования, Безуглой было произведено районирование территории СССР и выделено пять зон по степени предрасположенности атмосферы к загрязнению.

Территория Юго-Западного Алтая (Казахстанский Алтай), исходя из предлагаемых Безуглой условий, попала в зоны высокого и очень высокого потенциала загрязнения атмосферы.

Недостатком предложенного метода оценки метеорологического потенциала загрязнения атмосферы, на наш взгляд, является его низкая разрешающая способность по территории. Показатель требует данных аэрологического зондирования, которое отсутствует на территории исследуемого района. Поэтому проведенное районирование следует рассматривать как общий фон метеорологической обстановки без её конкретной детализации, При прогнозировании неблагоприятных метеорологических условий (НМУ), требуется знание детальной картины метеорологического потенциала атмосферы. Кроме того, при расчете ПЗА учитываются лишь условия, способствующие загрязнению атмосферы, но не рассматриваются условия её рассеивания, а также отсутствует количественная оценка преобладания тех или иных процессов в конкретной местности.

Потенциал загрязнения атмосферы практически является функцией лишь двух величин: повторяемости штилей и повторяемости туманов [32]. Повторяемость штилей - один из основных метеорологических факторов, при которых происходят явления застоя накопления вредных примесей в приземном слое воздуха, а наличие туманов, кроме всего прочего, приводит ещё и к увеличению токсичных примесей.

Очищение атмосферы происходит в основном за счет сильных ветров, способствующих быстрому выдуванию и рассеиванию 
примесей, а также за счет вымывания примесей атмосферными осадками.

По мнению Т.С. Селегей [24] можно получить некоторый коэффициент, характеризующий преобладание тех или иных процессов в течение определенного времени на данной местности.

Для Юго-Западного Алтая введем некоторые изменения в предлагаемые параметры. За повторяемость скоростей ветра 0-1м/сек, взята повторяемость штилей, за повторяемость дней с осадками взята величина не 0,5 мм и более, а 1 мм и более.

Обозначим этот коэффициент $K м$ и назовем его метеорологическим потенциалом самоочищения атмосферы (МПСА). Исходя, из вышеизложенного следует, что:

$$
K м=\frac{P u+P m}{P o+P b}, \text { где }
$$

$P m$ - повторяемость штилей, \%;

$P m$ - повторяемость дней с туманами (находится по числу дней с туманами за год и делится на 365$), \%$;

Ро - повторяемость дней с осадками $\geq 1$ мм (находится по числу дней с осадками $\geq 1$ мм и делится на 365$), \%$;

$P в$ - повторяемость скоростей ветра $\geq 6$ м/сек, \%.

Граничным условием для количества осадков способных очистить атмосферу, принята их величина 1 мм и более.

Граничные условия для скорости ветра, способной перенести из очага загрязнения вредную примесь, была принята величина $\geq 6$ м/сек.

Граничные условия, принятые в качестве параметров, способствующих самоочищению атмосферы, проанализированы и прослежены почти по 30-летнему периоду наблюдений за загрязнением атмосферного воздуха на ПНЗ городов: УстьКаменогорска, Риддера и Зыряновска.

По данным климатического справочника нами были вычислены многолетние средние значения $K м$ по 23 опорным станциям ЮгоЗападного Алтая.

Расчеты показали: по средним многолетним данным метеорологический потенциал самоочищения атмосферы на исследуемой территории изменяется в пределах от 0,3 до 3,3.

Если Км больше единицы, то процессы, способствующие накапливанию вредных примесей, в течение года преобладают над процессами самоочищения атмосферы. Если Км меньше единицы, то 
наоборот, процессы самоочищения атмосферы преобладают над процессами, способствующими накапливанию вредных примесей. Чем больше по абсолютной величине $K м$ в рассматриваемом районе, тем не благоприятнее условия для рассеивания примесей.

На основе проведенной типизации, на изучаемой территории выделено четыре зоны с различными условиями самоочищения атмосферы (рис.63).

По значению $K м$ проведено районирование территории ЮгоЗападного Алтая с выделением следующих зон:

1 - зона благоприятных условий рассеивания в атмосфере при $K_{M}<0,8$;

2 - зона ограниченно благоприятных условий рассеивания примесей в атмосфере при $0,8 \leq K_{M} \leq 1,2$;

3 - зона неблагоприятных условий рассеивания примесей в атмосфере при $K_{м}>1,2$;

4 - зона крайне неблагоприятных условий рассеивания примесей в атмосфере при $К м>3,0$.

Первая зона - зона благоприятных условий рассеивания примесей занимает западную часть территории, район Зайсанской котловины, горные районы с преобладанием горно-долинной циркуляции (Катон-Карагай) и районы склоновых ветров (Риддер).

Вторая - переходная зона, где процессы самоочищения атмосферы и процессы загрязнения повторяются примерно одинаково, названа, зоной ограничено благоприятных условий рассеивания. Она занимает практически всю территорию Кокпектинско-Чарского мелкосопочника, за исключением горных районов.

Вся остальная территория находится в условиях неблагоприятных для рассеивания примесей, т. е. там процессы, способствующие загрязнению атмосферы, в течение года в два раза встречаются чаще, чем процессы, способствующие самоочищению атмосферы. В этой же зоне выделяются районы и с крайне неблагоприятными условиями рассеивания $(K M>3)$. Это межгорные котловины (Зыряновская, Секисовская).

Если сравнить предложенное районирование с районированием по ПЗА Безуглой, то оба районирования имеют одинаковую тенденцию и совпадение зон благоприятных и крайне неблагоприятных условий рассеивания атмосферы. 
Однако, районирование территории Юго-Западного Алтая по методике, предложенной Селегей, выигрывает перед районированием, предложенным Безуглой в том плане, что значение Км можно рассчитывать для любого района, где имеются элементарные наблюдения за метеоэлементами, что в свою очередь позволяет выбрать наиболее оптимальный вариант размещения промышленных предприятий, прогноза неблагоприятных метеорологических условий.

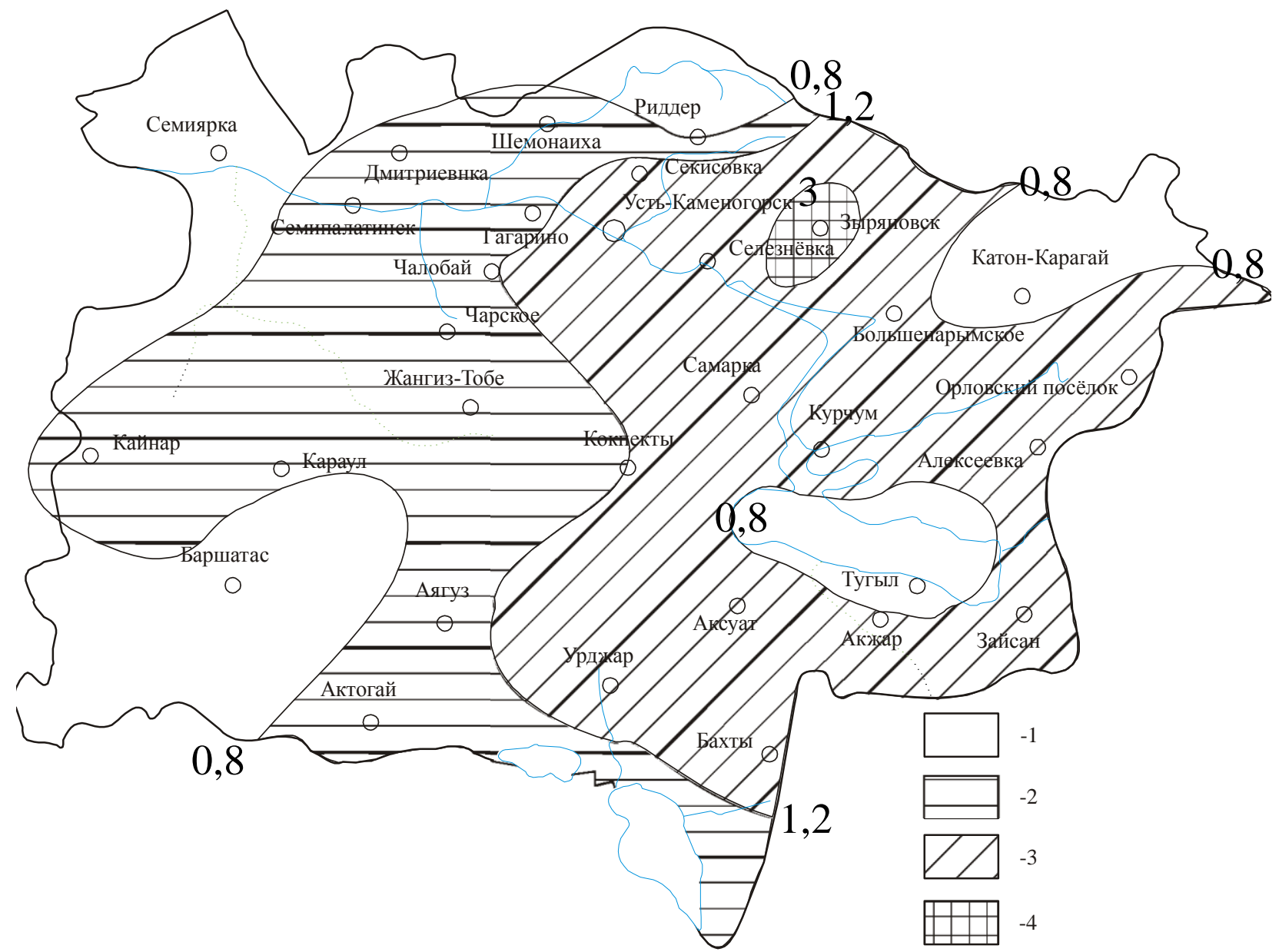

Рис. 65 Коэффициент самоочищения атмосферы на Юго-Западном Алтае

1. Зона благоприятных условий рассеивания; 2. Зона ограниченно благоприятных условий рассеивания; 3. Зона неблагоприятных условий рассеивания; 4. Зона крайне неблагоприятных условий рассеивания.

\section{7 Способы устранения или ослабления воздействия туманов на ландшафты и хозяйственную деятельность}

Наука о воздействии на атмосферные процессы в недалеком будущем, несомненно, станет одной из ведущих, это обусловлено следующими обстоятельствами. 
Ураганы, грозы, град, сильные ливни, туманы и другие опасные атмосферные явления и хозяйственная деятельность нередко наносят ощутимый ущерб национальному доходу даже наиболее развитых в экономическом отношении стран. Многие ученые в мире сходятся во мнении, что в ближайшее время производимого на Земле Валового Национального Продукта (ВНП) будет недостаточно, чтобы устранять последствия как природных так и антропогенных воздействий на окружающую среду.

Поэтому естественно, что наука ищет возможности не только прогнозировать эти явления, но и предотвращать их.

Важным обстоятельством, стимулирующим необходимость поисков путей управления погодой, является возросшее стихийное вмешательство человека в ход атмосферных процессов, которое в настоящее время уже вполне ощутимое.

Темп подобной искусственной трансформации свойств атмосферы непрерывно нарастает, и это заставляет уже сейчас думать как о неизбежных последствиях, так и о контрмерах, ибо возможности человека (и окружающего его животного и растительного мира) адаптироваться к ухудшающимися условиям существования ограничены [38]. Уже сейчас мы вынуждены начать планомерное регулирование и нормирование антропогенного воздействия на атмосферу, чтобы предотвратить стихийное ухудшение свойств атмосферы, которое может привести к необратимым изменениям баланса тепла и примесей в системе Земляатмосфера.

Когда мы говорим об устранении или ослаблении влияния того или иного явления на хозяйственную деятельность, в частности туманов, то подразумеваем движение по двум направлениям:

1. Эффективный прогноз образования или рассеяния тумана. Его временные и пространственные параметры.

2. Искусственное рассеяние или создание туманов.

Прогноз образования и рассеяния тумана нами более подробно будет рассмотрен в четвертой главе данного исследования. Остановимся несколько детальнее на процессах активного воздействия на туманы.

История взлетов и падений наших надежд на управление погодой, свидетельствует о бесполезности штурмовых атак на природу, не обеспеченных солидными научно-техническими плацдармами [34, 35, 36, 37]. 
Управление погодой требует точнейшего анализа состояния атмосферы и возможной его эволюции, а также тщательного выбора средств и способов воздействия. В ряде случаев незначительный просчет может не только обречь на неуспех само воздействие, но и вызвать нежелательный эффект либо сразу же непосредственно в районе опыта, либо в отдаленном будущем и даже в другом районе планеты.

Воздействие на туманы осуществляется главным образом в районах аэродромов, морских и речных портов в связи с необходимостью увеличения дальности видимости.

Наряду с этим искусственно созданные туманы используются в качестве «одеяла», которое прикрывает ценные морозонеустойчивые сельскохозяйственные культуры и препятствует тем самым их радиационному выхолаживанию.

В соответствии с поставленной задачей, а также при учете физических условий образования туманов, методы воздействия на них делят на следующие группы:

1) методы рассеяния капельножидких и смешанных туманов (независимо от температуры) - основанные на механическом удалении капель, тепловые, сорбционные; 2) методы рассеяния водных переохлажденных туманов - с помощью хладореагентов, посредством введения в туман искусственных ядер конденсации; 3) стабилизация туманов.

Как уже отмечалось в предыдущих разделах данной работы для Юго-Западного Алтая характерно образование туманов в основном в холодный период года (октябрь-март), то есть при отрицательных температурах воздуха.

Теоретические исследования и практические опыты проводимые по рассеянию туманов показывают, что именно переохлажденные туманы при температурах от минус $5{ }^{\circ} \mathrm{C}$ до минус $25{ }^{\circ} \mathrm{C}$ наиболее эффективно поддаются рассеянию.

На сегодняшний день наиболее эффективные методы:

- рассеяние (просветление) туманов с помощью искусственных тепловых источников;

- динамический метод рассеяния тумана;

- изменение поглощающих свойств тумана с целью их рассеяния;

- рассеяние туманов с помощью реагентов, интенсифицирующих конденсационные процессы;

- акустические методы просветления туманов; 
- использование лазеров для просветления туманов;

- электрические методы просветления туманов;

- предупреждение туманов путем пассивации ядер конденсации.

Влияние хозяйственной деятельности человека на климат стало проявляться несколько тысяч лет назад связи с развитием земледелия. Во многих районах для обработки земли уничтожалась лесная растительность, что приводило к увеличению скорости ветра у земной поверхности, некоторым изменениям режима температуры и влажности нижнего слоя воздуха, а также к изменению режима влажности почвы, испарения и речного стока.

Другой путь влияния деятельности человека на климат был связан с применением искусственного орошения. Применение орошения резко изменяет микроклимат орошаемых полей. Из-за значительного увеличения затрат на испарение снижается температура земной поверхности, что приводит к понижению температуры и повышению относительной влажности нижнего слоя воздуха.

Другие виды человеческой деятельности в прошлом не оказывали заметного влияния на метеорологический режим скольконибудь обширных пространств, в связи, с чем до недавнего времени климатические условия на нашей планете в основном определялись естественными факторами.

Современные воздействия человека на климат можно разделить на две группы, из которых первая охватывает направленные воздействия на гидрометеорологический режим, а вторая воздействия, являющиеся побочными следствиями хозяйственной деятельности человека.

В первую группу входят, в частности, мероприятия по регулированию водного режима земной поверхности и растительного покрова.

Во вторую группу входит хозяйственная деятельность, которая приводит к ненаправленным изменениям климата на Земле. Одним из следствий такой хозяйственной деятельности является прогрессирующее загрязнение атмосферы. Влияние загрязнения атмосферы на климатические условия многообразно.

Для последних 20 лет характерны климатические аномалии. Так, среднегодовые глобально усредненные температуры воздуха у поверхности Земли были наивысшими за последние 130 лет. Во многих местах отмечены сильные региональные аномалии в виде 
засух или, наоборот, необычайно обильных осадков, наводнений и т.д. Среднегодовая температура за последние столетие выросла примерно на полградуса.

Большинство ученых считает, что указанные аномалии вызваны изменением химического состава атмосферного воздуха с ростом концентрации углекислого газа (парникового газа).

Суть парникового эффекта заключается в том, что парниковые газы хорошо пропускают солнечное излучение, доходящее до поверхности Земли и нагревающее её, и заметно поглощают отраженное тепловое (длинноволновое) излучение нагретой поверхности и нижних слоев атмосферы. Часть этого поглощенного теплового излучения возвращается атмосферой к поверхности Земли. Не будь этого эффекта, средняя температура земной поверхности была бы на $3,2 \ldots 5,0{ }^{\circ} \mathrm{C}$ ниже нынешних $14,5{ }^{\circ} \mathrm{C}$.

В течение последнего десятилетия ученые и мировая общественность обеспокоены судьбой озонового слоя. Именно озоновый слой, поглощая коротковолновое ультрафиолетовое излучение Солнца, сохраняет все живое на Земле и предопределяет тепловой режим, а также динамику атмосферы.

Необходимо снижение выбросов хлор и фторсодержащих углеводородов, которые способствуют разрушению озонового слоя.

Вопрос о влиянии создаваемого человеком загрязнения атмосферы на термический режим довольно сложен.

При обсуждении вопроса о возможности преобразования климата и в частности воздействия на туманы, следует учитывать естественные тенденции колебания климата современной эпохи [38].

\section{С писокиспользованных источников к Глав}

\section{т у м а н ы}

1. Анапольская Л.Е. О вероятности слабых скоростей ветра на территории СССР / Л.Е. Анапольская, Э.Ю. Безуглая // Труды ГГО. - 1975. - Вып. 325. - С. 61 - 67.

2. Антропогенные изменения климата / Под редакцией М.И. Будыко., Ю.А Израэля. - Л.: Гидрометеоиздат, 1987. - 406 с.

3. Безуглая Э.Ю. Метеорологический потенциал и климатические особенности загрязнения воздуха городов / Э.Ю. Безуглая. - Л.: Гидрометеоиздат, 1980. - 184 с.

4. Безуглая Э.Ю. Мониторинг состояния загрязнения атмосферы в городах / Э.Ю. Безуглая. - Л.: Гидрометеоиздат, 1986. - 245 с. 
5. Безуглая Э.Ю. Распределение концентрации примесей в городском воздухе / Э.Ю. Безуглая, Е.К. Завадская Е.К. // Тр. ГГО. - 1975. - Вып. 325. - С. 87 - 96.

6. Берлянд М.Е. К теории трансформации воздушных масс и образования речных туманов / М.Е. Берлянд, Р.И. Оникул// Труды ГГО. - 1968. - Вып. 207. - С. 14 - 27.

7. Берлянд М.Е., Оникул Р.И., Рябова Г.В. К теории атмосферной диффузии в условиях тумана / М.Е. Берлянд, Р.И. Оникул, Г.В. Рябова // Труды ГГО. - 1968. - Вып. 207. - С. 3 - 13.

8. Берлянд М.Е. Прогноз и регулирование загрязнения атмосферы / М.Е. Берлянд. - Л.: Гидрометеоиздат, 1985. - 272 с.

9. Берлянд М.Е. Метод предсказания радиационных туманов / M.Е. Берлянд // Тр. ГГО. - 1954. - Вып. 48. - С. 84 - 92.

10. Берлянд М.Е. Современные проблемы атмосферной диффузии и загрязнения атмосферы / М.Е. Берлянд. - Л.: Гидрометеоиздат, 1975. - $448 \mathrm{c}$.

11. Берлянд М.Е. К теории образования радиационных туманов и их влияния на распространение примесей / М.Е. Берлянд, Я.С. Канчан // Тр. ГГО. - 1973. - Вып. 293. - С. 3- 20.

12. Блютген И. География климатов / И. Блютген. - М.: Прогресс, 1972. -1 т. -400 c.

13. Воробьев В.И. Некоторые алгоритмы разработки физикостатистических методов авиационных прогнозов погоды / В.И. Воробьев, Ю.Н. Волконский // Труды ЛГМИ. - 1974. - Вып.51. - С. $40-49$.

14. Голубов Р.С. Синоптико-климатическое описание Казахстана / Р.С. Голубов // Труды Каз НИГМИ. - 1956. - Вып. 6. - С. 26-34.

15. Грачева И.Г. К разработке методики расчета рассеивания примесей в условиях сложного рельефа / И.Г. Грачева // Тр. ГГО. 1979. - Вып. 417. - С. 36-44.

16. Егорина А.В. Пространственно-временная изменчивость гидротермических показателей в предгорных комплексах Восточного Казахстана: Автореферат канд. дис. / А.В. Егорина. Л., 1990. - 30 с.

17. Егорина А.В., Зинченко Ю.К., Зинченко Е.С.. Физическая география Восточно-Казахстанской области / А.В. Егорина, Ю.К. Зинченко, Е.С. Зинченко. - Усть-Каменогорск, 2000. - Ч.І. - 124 с.

18. Зверев А.С. Синоптическая метеорология / А.С. Зверев. - Л.: Гидрометеоиздат, 1977. - 711 с. 
19. Guide for control of air pollution episodes in mediam-sized urban areas // U. S. Environ. Protec. Agency. -1971. - 55 p.

20. Munn R.E. the application of an air pollution climatology to town planning / R.E. Munn //Int. J. Air Pollut. - 1959. - V. 1, N 4.

21. Климат Юго-Западного Алтая / Под ред. А.В. Егориной. - УстьКаменогорск, 2002. - 240 с.

22. Климатические характеристики условий распространения примесей в атмосфере: Справ. пособие. / Под ред.Э.Ю. Безуглой, М.Е. Берлянд. - Л.: Гидрометеоиздат, 1983. - 328 с.

23. Красиков П.Н. Метеорологические условия при зимних ангарских туманах в районе г. Иркутска / П.Н. Красиков, Г.М. Башкиров // Тр. ГГО, 1958. - Вып. 73. - С. 12 - 24.

24. Макар С.В. Основы экономики природопользования / С.В. Макар. - М., 1998. - 192 с.

25. Попова К.И., Егорина А.В. и др. Барико-циркуляционный режим атмосферы над Алтаем и сопредельными территориями в теплый период / К.И. Попова, А.В. Егорина. - Томск: Изд-во ТГУ, 1986. С. $12-59$.

26. Попова К.И. Режим атмосферного увлажнения г. УстьКаменогорска и его окрестностей / К.И. Попова, А.С., Чурсин, А.В. Егорина // Вопросы Казахстанской целины: Сб. - А-Ата, 1983. - С. 18-27.

27. Селегей Т.С. Метеорологический потенциал самоочищения атмосферы Сибирского экономического района /Т.С. Селегей // Тр. Зап.Сиб НИГМИ. -1989. - Вып. 86. - С. 84 - 89.

28. Сонькин Л.Р. Синоптико-статистический анализ и краткосрочный прогноз загрязнения атмосферы / Л.Р. Сонькин. Л.: Гидрометеоиздат, 1991. - 223 с.

29. Сонькин Л.Р., Ивлева Т.П. Вопросы прогнозирования загрязнения воздуха в городе отдельными примесями. Труды ГГО, 1982, вып. 450, с. $89-96$.

30. Справочник по климату СССР. - Л.: Гидрометеоиздат, 1968. Вып.18.:Ч 1-6.

31. Терзиев Ф.С. Образование морских туманов типа испарения и некоторые рекомендации к их прогнозу / Ф.С. Терзиев // Тр. ГМЦ СССР. - 1969. - Вып. 45. - С. 25 - 38.

32. Туманы /М.Е. Берлянд, П.А. Воронцов, П.Н. Красиков и др. - Л.: Гидрометеоиздат, 1969. - 387 с. 
33. Тюребаева С.И. О пространственном распределении вредных примесей в Алма-Ате / С.И. Тюребаева //Труды КазНИИ. - 1984. №82. - С. $51-55$.

34. Федоров Е.К. Взаимодействие общества и природы / Е.К. Федоров. - Л.: Гидрометеоиздат, 1972. - 268 с.

35. Царев А.М. К вопросу о загрязнении воздуха при туманах. // Труды ГГО. - 1975. - Вып. 352. - С. 113 - 118.

36. Цефрас К.Э. Характеристики некоторых элементов, определяющих потенциально возможное загрязнение атмосферы в Узбекистане / К.Э. Цефрас // Тр. САР НИГМИ. - Ташкент, 1976. Вып. 29 (110). - С. 2 - 12.

37. Чебаненко Б.Б. Роль промышленных туманов в загрязнении атмосферы и их влиянии на микроклимат района / Б.Б. Чебаненко // Труды Зап Сиб НИГМИ. - 1977. - Вып. 33. - С.109 - 115.

38. Шевчук И.А Прогноз потенциала загрязнения атмосферы / А.И. Шевчук, Э.И. Мартыненко, З.И. Ольховик // Труды ЗСР НИГМИ. 1985. - Вып. 73. - С. 7 - 18.

39. Климат Юго-Западного Алтая / Под ред. А.В. Егориной. - УстьКаменогорск, 2002. - 240 с

40. Климатические характеристики условий распространения примесей в атмосфере: Справ. пособие. / Под ред.Э.Ю. Безуглой, М.Е. Берлянд. - Л.: Гидрометеоиздат, 1983. - 328 с 


\section{ЗАК Л Ю ЕН ИЕ}

В естественных науках, технике, экономике, социологии прогрессивно только то, что идет на благо, а не во вред человечеству.

Акад. В.Б.

Сочава.

Из материалов, изложенных в представленном исследовании, можно сделать ряд заключений, важных для решения вопросов рационального природопользования.

1. Юго-Западный Алтай в широтной зоне выступает как теплый и влажный район за счет проявления «барьерного эффекта» в формировании климата. Структура и динамика гидротермического режима природных комплексов определяется особенностями развития циркуляции атмосферы на границе великих равнин Евразии и Высокой Азии.

2. Каждый компонент геосистемы выполняет свою функцию, одинаково важную для обеспечения стабильности существования жизни и сбалансированности в ней биохимических круговоротов. Роль атмосферы в обеспечении сбалансированности круговоротов в геосистемах исключительно велика. Связи между компонентами геосистем существенны, взаимодействия между ними представляют строго детерминированные процессы. Характеристика структуры и динамики гидротермического режима в ландшафтах Юго-Западного Алтая позволяет более глубоко понять вещественный обмен энергетических процессов и оценить биоресурсный потенциал региональных систем.

3. Рассматривая горную систему Юго-Западного Алтая как подсистему Срединного ПТК умеренных широт и учитывая общие закономерности его развития, определены ведущие факторы формирования климата региона, дана их качественная и количественная определенность, связанная с уникальностью географического положения региона в надсистеме. Составлена развернутая характеристика климата. При этом рассматриваются генезис, география, изменчивость элементов климата. 
4. Элементами обобщения материала являются сконструированные авторами геоэкологические модели типичных ландшафтов Юго-Западного Алтая. Энергетика ландшафта представлена метеорологическими элементами. Экологические характеристики и ресурсы - длительностью вегетационного безморозного периода, периода активной вегетации и суммой температур выше $0,5,10^{0} \mathrm{C}$. Биопродуктивность растительного покрова отражает эффективность использования экосистемной энергии Солнца и выражением энергетики ландшафта через биомассу, а следовательно, устойчивость геосистемы. Разнообразие природных ландшафтов выражается через экологический состав флоры, и ее географический спектр характеризует богатство генофонда. Из теории систем следует: чем больше разнообразие системы, тем она богаче и устойчивее.

5. Глава 5 посвящена региональным особенностям современного изменения климата и ожидаемым изменениям в геоэкологических процессах геосистем. Данные будут полезны для мероприятий по преобразованию природы и для выработки программы приспособления к изменяющимся природным условиям.

6. В главе 6 рассмотрены теоретические основы туманообразования в условиях ороклиматического барьера ЮгоЗападного Алтая, воздействие этого опасного явления при неблагоприятных метеорологических условий (НМУ) на загрязнение атмосферы н в целом на хозяйственную деятельность. 


\section{СПИСОК ЛИТЕРАТУРЫ}

1. Исаченко А.Г. Ландшафтоведение и физико-географическое районирование. - М.: Высшая школа, 1991.

2. Исаченко А.Г. Оптимизация природной среды. - М.: Мысль, 1980. - C. 40-50.

3. Солнцев В.Н. Системная организация ландшафтов. - М.: Мысль, 1981. $-240 \mathrm{c}$.

4. Сочава В.Б. Проблемы физической географии и геоботаники. Новосибирск, 1986. - 344 с.

5. Тронов М.В. Очерки оледенения Алтая. - М.: Географгиз, 1949.

6. Ивановский Л.Н. Формы ледникового рельефа и их палеографическое значение на Алтае. - Л.: Наука, 1967.

7. Попов В.Е. К вопросу о режимах отступания древних ледников Алтая // Доклады Академии наук СССР, 1962. - Т. 1. - 142 с. - № 2. - С. 431-434.

8. Ревякин В.С. Природные льды Алтае-Саянской горной области. Л.: Гидрометеоиздат, 1981. - 288 с.

9. Тронов М.В. Ледники и климат. - Л.: ГИМИЗ, 1966. -404c. 10. Геология СCCP. Т. XLI, ч. I. М.,1967.

10. Климат Казахстана / Под ред. канд. геогр. наук А.С. Утешева. Л.: Гидрометеоиздат, 1959. - 367 с.

11. Природные условия и естественные ресурсы Восточного Казахстана. - Алма-Ата: Наука, 1978. - 190 с.

12. Справочник по климату СССР. - Вып. 18. - Ч. I-VI. - 1966-1968 гг.

13. Атлас теплового баланса земного шара / Под ред. М.И. Будыко. M., 1963.

14. Ревякин В.С., Галахов В.П., Голещихин В.П. Горноледниковые бассейны Алтая. - Томск: ТГУ, 1979. - 310 с.

15. Борзенкова И.И. Об особенностях радиационного режима горных областей // Труды ГГО. - Л., 1970. - Вып. 263.

16. Ефимова Н.А. Радиационные факторы продуктивности растительного покрова. - Л.: Гидрометеоиздат, 1977. - С. 73-199.

17. Егорина А.В. Пространственно-временная изменчивость гидротермических показателей в природных комплексах Восточного Казахстана / Автореферат канд. дис. - Л., 1990. - 17 с. 18. Константинов А.Р. Испарение в природе. - Л., 1963. 
19. Иванов Н.Н. Ландшафтно-климатические зоны земного шара / Записки ВГО, новая серия. - Т. 1, 1948.

20. Вангенгейм Г.Я. О степени однородности атмосферной циркуляции различных частей северного полушария при основных формах Е, W, С. Тр. ААНИИ. Т. 240, 1961.

21. Гирс А.А. Особенности планетарной высотной фронтальной зоны, свойственные основным формам циркуляции. - М, 1963.

22. Байдал М.X. Долгосрочные прогнозы и колебания климата Казахстана. - Ч. І и II. - Л.: Гидрометеоиздат, 1964.

23. Бугаев В.А. Климат Средней Азии и Казахстана. Ташкент, 1946.

24. Орлова В.В. Климат СССР. - Вып. 4. Западная Сибирь. - Л.: Гидрометеоиздат, 1962.

25. Сляднев А.П. Природно-климатическое районирование Западной Сибири // Труды ГГО. - Вып. 162, 1964.

26. Попова К.И., Лупина Н.Х., Панженская Е.И., Егорина А.В. Бариоко-циркуляционный режим атмосферы над Алтаем и сопредельными территориями в теплый период. - Томск: Изд-во ТГУ, 1986 // Гляциология Сибири. - № 3 (18). - С. 12-59.

27. Циркуляционные механизмы современных колебаний климата / Отв. ред. канд. физико-математ. наук К.В. Кувшинова. АН СССР, институт географии. - М.: Наука, 1987.

28. Безуглая Э.Ю. Метеорологический потенциал и климатические особенности загрязнения воздуха городов. - Л.: Гидрометеоиздат, 1980. - $184 \mathrm{c}$.

29. Попова К.И. Некоторые особенности метеорологического режима абляционных периодов 1957-1959 гг. на ледниках Актру Центрального Алтая // Гляциология Алтая. - Томск, 1964. - Вып. 3. - C. 65-77.

30. Попова К.И. Метеорологический режим интенсивного таяния ледников долины Актру в 1957 г. // Гляциология Алтая. - Томск, 1962. - Вып. 1.

31. Попова К.И., Курсанова О.Н. Волновая деятельность на холодных фронтах над Алтаем в теплый период // Сб. Гляциология Алтая. Вып. 2. Изд-во ТГУ. - Томск, 1962.

32. Попова К.И. О типах годового хода атмосферных осадков в Горном Алтае // Сб. Гляциология Алтая. - Томск, 1972.

33. Барахтин В.Н. К характеристике значительных снегопадов и распределения снежного покрова на пастбищах Горного Алтая // Труды ЗСРНИГМИ, 1972. - Вып. 7. 
34. Панженская Е.И. Спектр зимних погод в Горном Алтае. Проблемы гляциологии Алтая. - Томск: ТГУ, 1972. - С. 48-52.

35. Панженская Е.И., Попова К.И., Шевченко В.И. Синоптические процессы и их погодно-климатические проявления в зимний период над Горным Алтаем // Труды ЗСРНИГМИ. - Л.: Гидрометеоиздат, С. 120-134.

36. Попова К.И. Распределение и годовой ход осадков в юговосточной части Западно-Сибирской низменности // Труды Томского Госуниверситета. - Т. 147. - Томск, 1967.

37. Попова К.И., Рутковская Н.В. О связи осадков с циркуляционным режимом в холодный период над юго-востоком ЗападноСибирской низменности // Труды ГГО. - Вып. 113. - Л., 1960.

38. Попова К.И. К вопросу о циркуляции атмосферы над Западной Сибирью в летний сезон // Труды ГГО. - Вып. 164. - Л., 1964.

39. Попова К.И. Краткая характеристика связей осадков с циркуляционным режимом за теплый период над юго-восточной частью Западно-Сибирской низменности // Вопросы географии Сибири. - Сб. четвертый. - Томск: Университетское, 1962. - С. 136-148.

40. Орлова В.В. Климатологический очерк Барабинской низменности. - Л.: Гидрометеоиздат, 1954.

41. Байдал М.X. Колебания климата Кустанайской области в XX столетии. - Л.: Гидрометеоиздат, 1971.

42. Байдал М.X., Ханжина Д.Г. Многолетняя изменчивость макроциркуляционных факторов климата. - М.: Гидрометеоиздат, 1986. - $98 \mathrm{c}$.

43. Егорина А.В., Попова К.И. Структура годового цикла осадков по эпохам циркуляции в пределах Юго-Западного Алтая // Проблемы горного природопользования. - Ч. 1. - Барнаул, 1989. - С. 108-110.

44. 45.Панова Е.Н. Некоторые особенности структуры циркуляционных эпох. Вопросы долгосрочных прогнозов погоды // Труды КазНИГМИ. - М.: Гидрометеоиздат, 1980. - Вып. 67. - С. 46-50.

45. Аэроклиматический атлас СССР. М., 1958.

46. Ибраева Ж.А. Краткая характеристика ветров в регионах отгонного животноводства // Географические науки. - Алма-Ата, 1972. - Вып. 3.

47. Анапольская Л.Е. Режим скоростей ветра на территории СССР. Л.: Гидрометеоиздат, 1961. 
48. Ревякин В.С., Кравцова В.И. Снежный покров и лавины Алтая. Томск: ТГУ, 1977. - 61 с.

49. Гашинская Э.Н. Предварительные данные о тепловой трансформации воздуха в летнее время года над равнинной частью Казахстана // Труды КазНИГМИ, 1966. - Вып. 25.

50. Дроздов О.А. Баланс влаги в атмосфере / Сб. А.И. Воейков и современные проблемы климатологии. - Л.: Гидрометеоиздат, 1956.

51. Научно-прикладной справочник по агроклиматическим ресурсам СССР. Сер. 2. Ч. Вып. 18. Алма-Ата, 1992.

52. Дроздов О.А., Григорьева А.С. Влагооборот в атмосфере. - Л.: Гидрометеоиздат, 1963.

53. Будыко М.И. Климат и жизнь. - Л. ГИМИЗ, 1971. - 347 с.

54. Дроздов О.А. и др. Климатология. - Л.: Гидрометеоиздат, 1989. $568 \mathrm{c.}$

55. Жаков С.И. Происхождение осадков в теплое время года. Л., ГИМИЗ, 1966.

56. Кузнецова Л.П. Колебания годовых величин атмосферных осадков и температуры воздуха материков (Европа и Северная Америка) // Сб. Формирование ресурсов вод и суши. М.: Наука, 1972.

57. Попова К.И., Чурсин А.С., Егорина А.В. Режим атмосферного увлажнения г. Усть-Каменогорска и его окрестностей // Сб. Вопросы географии Казахстанской целины. - Алма-Ата, 1983.

58. Дроздов О.А. Засухи и динамика увлажнения. - Л.: Гидрометеоиздат, 1980. - 96 с.

59. Калесник С.В. Общие географические закономерности Земли. М.: Мысль, 1970.

60. Кренке А.Н. Климатические условия существования ледников и формирование ледниковых климатов // Метеорология и климатология. Сер. геогр., 1971. - Вып. 1. - С. 168-207.

61. Ресурсы поверхностных вод СССР. - Т. 15. - Вып. 1. - Л.: Гидрометеоиздат, 1969.

62. Соседов И.С., Гальперин Р.И. Годовое количество осадков на территории Восточного Казахстана. - Сб. Вопросы гидрологии Казахстана. - Алма-Ата, 1963.

63. Попова К.И., Егорина А.В. Атмосферные осадки Юго-Западного Алтая (генезис, география, изменчивость) // Гляциология Сибири. - Томск: Изд-во университетское, 1993. - Вып. 4 (19). - 22 с. 
64. Кривоносов Б.М. Климаты Горного Алтая / Автореферат канд. дис. - Томск, 1975. $-27 \mathrm{c}$.

65. Шпень П.С. Современное оледенение Кузнецкого Алатау / Автореферат канд. дис. - Иркутск, 1974.

66. Антропогенные изменения климата / Под ред. М.И. Будыко, Ю.А. Израэля. - Гидрометеоиздат, 1987. - 406 с.

67. Лободин Т.В. Продолжительность гроз на территории СССР // Метеорология и гидрология. - № 2. - 1973. - С. 106-110.

68. Парфенова Г.И. Аэросиноптические условия вознокновения фронтальных гроз в Юго-Восточном и Восточном Казахстане // Tp. КазНИГМИ. Вып. 6, 1956.

69. Чурсин А.С. Синоптико-климатическая характеристика гроз в Усть-Каменогорске // Труды КазНИГМИ, 1987. - Вып. 96. - С. 107-112.

70. Иванова Н.Г., Алехина Н.М., Домашенко В.Г. Климатостатистические характеристики грозовой деятельности Рудного Алтая и его предгорий. Гляциология Алтая. - Томск, 1981.

71. Монин А.С. О преобразовании энергии зональной циркуляции атмосферы. // Тр. Ин-та физики атмосферы. АН СССР, №2, 1958.

72. Агроклиматический справочник по Восточно-Казахстанской области. - Л.: Гидрометеоиздат, 1960.

73. Алисов Б.П. Климат СССР. - М.: Высшая школа, 1969.

74. Алисов Б.П., Дроздов О.А., Рубинштейн Е.С. Курс климатологии, часть I и ІІ. - Л.: ГИМИЗ, 1952.

75. Рудковская Н.В. Климатическая характеристика сезонов года Томской области. - Томск: ТГУ, 1979. - 116 с.

76. Веселова Л.К., Гельдыева Г.В. Ландшафтная карта Казахской ССР // Вестник АН КазССР. - 1971. - № 4.

77. Ландшафтная карта Казахской ССР / Отв. ред. Н.А. Гвоздецкий. М.: ГУГК, 1979.

78. Докучаев В.В. Избранные произведения. - Т. III. - 1949.- С. $317-$ 341.

79. Чибилев А.А. Лик степей. - Л.: Гидрометеоиздат, 1990.

80. Алехин В.В. Теоретические проблемы фитоценологии и степеведения. - М., 1986.

81. Соколов А.А. Восточно-Казахстанская область // Труды института почвоведения АН КазССР. - Т. 10. - 1968. - С. 49-74.

82. Соколов А.А. Общие особенности почвообразования и почв Восточного Казахстана. - Алма-Ата: Наука КазССР, 1977. 
83. Егорина А.В. Агроклиматические ресурсы Восточного Казахстана // Актуальные вопросы географии Казахстана. - АлмаАта, 1986. - С. 52-62.

84. Дюкарев А.Д., Егорина А.В. Основные закономерности формирования снежного покрова Восточно-Казахстанской области // Гляциологические исследования в Сибири. - Иркутск, 1987. Вып. 2. - С. 39-50.

85. Осокин И.М., Осокин Н.И. Типы снежности на территории СССР // Вопросы географии и биологии. Материалы XXI и XXII научных конференций Читинского педагогического института им. Н.Г. Чернышевского. - Чита, 1970. - 119 с.

86. Щербаков Б., Прокопенко Л. Земля горит под нашими ногами // Городская газета. - № 17, апрель, 1993.

87. Шашко Д.И. Агроклиматические ресурсы СССР. - Л.: Гидрометеоиздат, 1985. - 244 с.

88. Будыко М.И. Глобальная экология. - М.: Мысль, 1977. - 328 с.

89. Русанов В.И. Методы исследования климата для медицинских целей. - Томск: Университетское, 1973.

90. Яковенко В.А. Радиационно-эффективная температура // Гигиена и санитария. - № 1. - 1945.

91. Научно-прикладной справочник по климату СССР. - Сер. 3. Многолетние данные. - Вып. 18. Казахская ССР. - Кн. 1-2. - Л.: Гидрометеоиздат, 1989.

92. Система ведения лесного хозяйства в лесах Восточного Казахстана. - Алма-Ата: Кайнар, 1984. - 224 с.

93. Сельское хозяйство Рудного Алтая. - М.: АН СССР, 1940. - С. 8132.

94. Высокогорная геоэкология. - М., 1976. - С. 3-98.

95. Стадницкий Г.В., Родионов А.И. Экология. - М.: Высшая школа, 1988. - 272 c.

96. Национальный доклад о состоянии природной среды в Республике Казахстан. - Алма-Ата: Изд-во Министерства экологии и биоресурсов АН Республики Казахстан, 1992. - 90 с.

97. Международная геосферно-биосферная программа «Глобальные изменения» // Официальные материалы. - М., 1987. - 95 с.

98. Вернадский В.И. Размышление натуралиста. Научная мысль как планетарное явление. - М.: Наука, 1977. - 291 с.

99. Сапожников В.В. По Алтаю. - М., 1949. 
100. Попов В.И., Токарев А.А. О лавинной опасности гор Казахстанского Алтая // Труды САРНИГМИ, 1977. - Вып. 32 (1.3). - С. 192-201.

101. Дюкарев А.Д., Токарев А.А.. Некоторые особенности образования и схода снежных лавин в бассейне рек Громотухи и Малой Ульбы (Западный Алтай) // Гляциологические исследования в Сибири. - № 2. - Иркутск: АН СССР, 1987. - С. 51-59.

102. Алюшинская Н.А. Вертикальная зональность и распределение стока на территории Алтая // Уч. зап. ЛГУ, сер. геогр., 1955. - Вып. 46, № 199.

103. Гета Р.И., Долгих Г.М., Кондратьев В.П. Пространственновременные закономерности годового стока рек Западного и Южного Алтая // Материалы Всероссийской научно-практической конференции. Ч. 1. Горно-Алтайск, 1992. С. 91-92.

104. Государственный водный кадастр. Т. V. Казахская СССР. - Вып. 1. - Л., 1987.

105. Мамбетказиев Е.А., Кан Н.С., Адамов Р.Ж., Савельев В.М. Эколого-экономические проблемы Восточно-Казахстанской области // Охрана окружающей среды и природопользования Прииртышья. - Усть-Каменогорск, 1990. - С. 2 -13.

106. Шнитников А.В. Внутривековая изменчивость компонентов общей увлажненности. Очерки. - Л., 1987.

107. Чистяков В.Ф. О двойных максимумах вековых циклов и долгосрочном прогнозе солнечной активности. Солнечные данные. - № 9. - 1981. - С. 107-110.

108. Рубинштейн Е.С., Полозова Л.Г. Современное изменение климата. - Л.: Гидрометеоиздат, 1966.

109. Будыко М.И. Эволюция биосферы. - Л.: Гидрометеоиздат, 1981. $-488 \mathrm{c}$.

110. Большаков В.Н., Дгебуадзе Ю.Ю., Криволуцкий Д.А., Стриганова Б.Р. Развитие экологических перспектив на XXI век // Ж. Экология. - 1991. - № 2. - С. 91-95.

111. Программа действий. Повестка дня на XXI век и другие документы конференции в Рио-де-Жанейро. - Женева. Центр «Наше общее будущее», 1993.

112. Дзердзеевский Б.Л. Многолетние флуктуации общей циркуляции атмосферы и климата, и главнейшие закономерности планетарной циркуляции / Сб. Метеорологические исследования. - М.: Наука, 1968. - № 16. 
113. Моисеев Н.Н. Алгоритмы развития. - М.: Наука, 1987.

114. Голицын Г.С. К итогам Второй Всемирной конференции: некоторые общие замечания // Метеорология и гидрология. - 1991. - № 4. - C. 36-38. 


\section{СОДЕРЖАНИЕ}

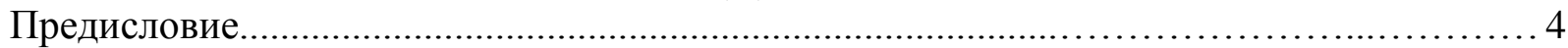

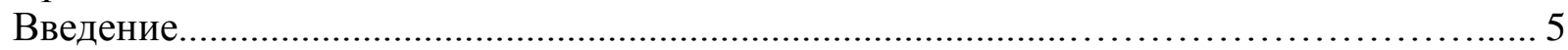

ГЛАВА І. Условия формирования климата Юго-Западного Алтая, его основные

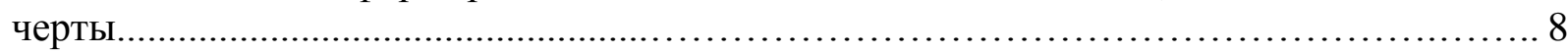

1.1 Физико-географическая характеристика территории....................................... 8

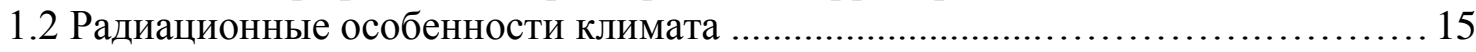

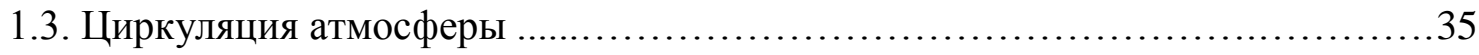

ГЛАВА ІІ. Основные элементы климата. Атмосферные явления ......................... 54

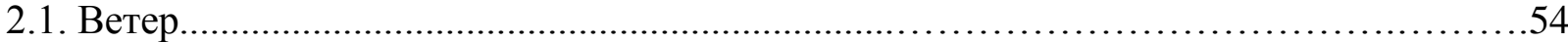

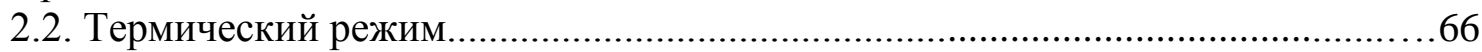

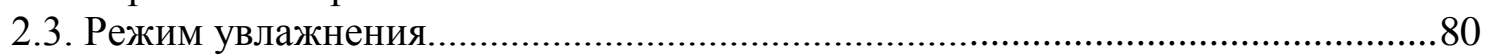

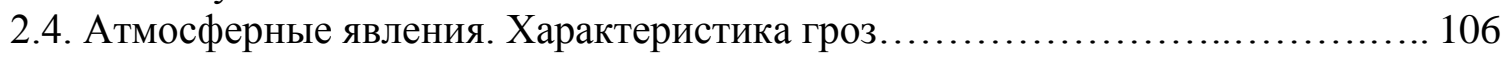

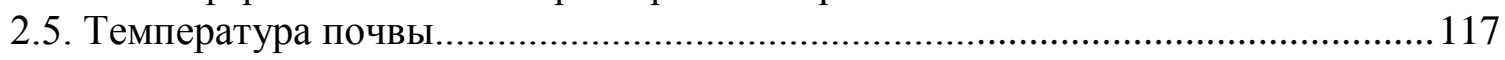

ГЛАВА III. Описание климата Юго-Западного Алтая по сезонам года............................. 127

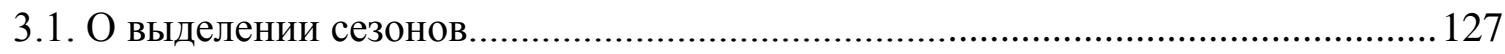

3.2. Климат степей. Сезонная динамика явлений природы........................... 133

3.3. Климат лесов. Сезонная динамика явлений природы........................................ 164

ГЛАВА IV. Снежный покров. Лавины. Режим рек и озер.............................. 181

4.1. Снежный покров........................................................................................... 181

4.2. Особенности образования и схода лавин в бассейнах рек Громотуха

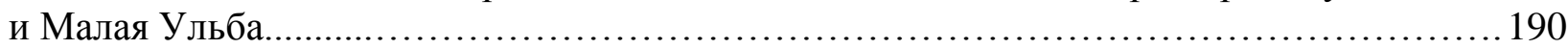

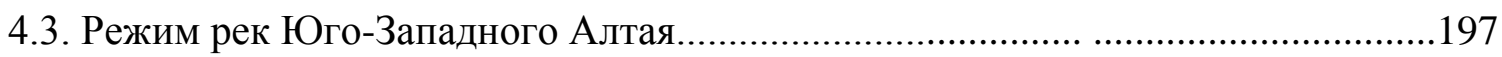

4.4. Краткая характеристика режима водохранилищ и озер....................................2218

ГЛАВА V. Изменения климата Юго-Западного Алтая................................... 221

5.1. Планетарно-космические факторы, колебания и изменения

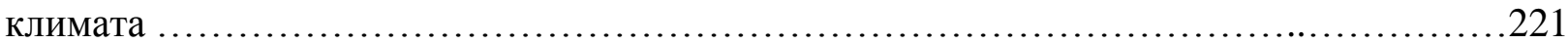

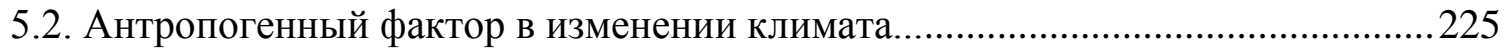

5.3. Региональные особенности изменения климата ............................ 227

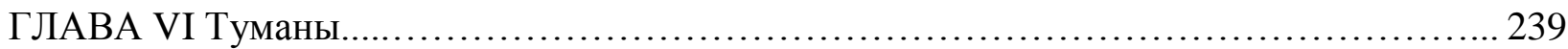

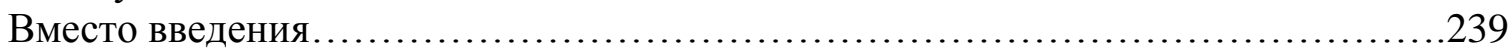

6.1. Теоретические основы и современное состояние проблемы

туманообразования в условиях ороклиматического арьера..........................240

6.2. Исходные понятия и методы исследования туманообразования......................2241

6.3. Современное состояние проблемы туманообразования

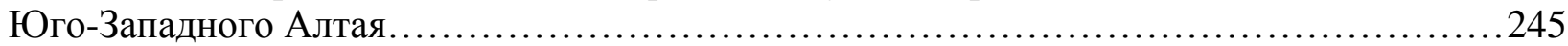

6.4. Туманообразование в условиях антропогенных воздействий .............. 250

6.5. Оценка состояния туманообразования и его воздействия

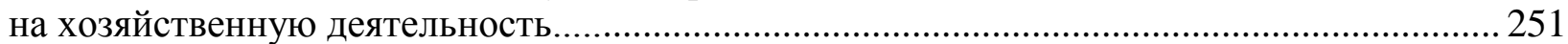

6.6. Влияние туманов на метеорологический потенциалзагрязнения атмосферы 260

6.7. Способы устранения или ослабления воздействия тумановна ландшафты и

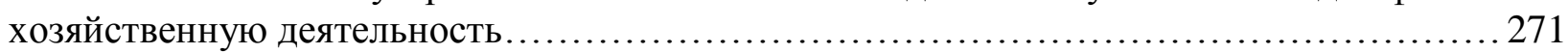

Список использованных источников к главе туманы...................................................2 275

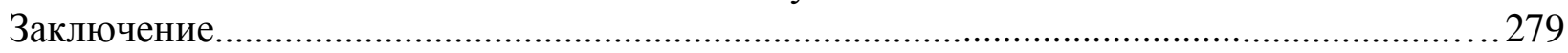

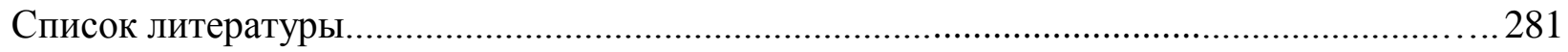

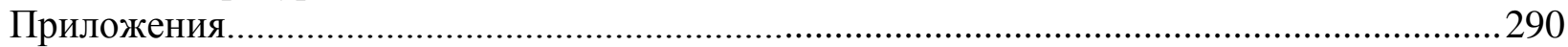


Приложени е I

Склонение солнца $\sigma_{0}$

\begin{tabular}{|c|c|c|c|c|c|c|c|c|c|c|c|c|c|}
\hline \multicolumn{2}{|l|}{ Число } & \multirow[b]{2}{*}{$\mathrm{I}$} & \multirow[b]{2}{*}{ II } & \multirow[b]{2}{*}{ III } & \multirow[b]{2}{*}{ IV } & \multirow[b]{2}{*}{$\mathrm{V}$} & \multirow[b]{2}{*}{ VI } & \multirow[b]{2}{*}{ VII } & \multirow[b]{2}{*}{ VIII } & \multirow[b]{2}{*}{ IX } & \multirow[b]{2}{*}{$\mathrm{X}$} & \multirow[b]{2}{*}{$\mathrm{XI}$} & \multirow[b]{2}{*}{ XII } \\
\hline $\begin{array}{c}\text { Не високосный } \\
\text { год }\end{array}$ & $\begin{array}{c}\text { Високосный } \\
\text { год }^{2}\end{array}$ & & & & & & & & & & & & \\
\hline & 1 & -23.0 & -17.4 & - & - & - & - & - & - & - & - & - & - \\
\hline 1 & 2 & -23.0 & -17.2 & -7.7 & +4.4 & +15.0 & +22.0 & +23.1 & +18.2 & +8.4 & -3.1 & -14.3 & -21.8 \\
\hline 2 & 3 & -22.9 & -16.9 & -7.3 & +4.8 & +15.3 & +22.2 & +23.1 & +17.9 & +8.4 & -3.5 & -14.7 & -21.9 \\
\hline 3 & 4 & -22.9 & $-16,6$ & -6.9 & +5.2 & +15.6 & +22.3 & +23.0 & +17.6 & +7.7 & -3.8 & -15.0 & -22.1 \\
\hline 4 & 5 & -22.8 & -16.4 & -6.6 & +5.6 & $+15,9$ & +22.4 & $+22,9$ & $+17,3$ & $+7,3$ & -4.2 & $-15,3$ & -22.2 \\
\hline 5 & 6 & -22.6 & -16.0 & -6.2 & +6.0 & +16.2 & +22.5 & +22.8 & +17.1 & +6.9 & -4.6 & -15.6 & -22.3 \\
\hline 6 & 7 & -22.5 & -15.7 & -5.8 & +6.3 & +16.5 & +22.6 & +22.7 & +16.8 & +6.6 & -5.0 & -15.9 & -22.5 \\
\hline 7 & 8 & -22.4 & -15.4 & -5.4 & $\begin{array}{l}+6.7 \\
\end{array}$ & +16.7 & +22.7 & +22.6 & +16.5 & +6.2 & -5.4 & -16.2 & -22.6 \\
\hline 8 & 9 & -22.3 & -15.1 & -5.0 & +7.1 & +17.0 & +22.8 & +22.5 & +16.2 & +5.8 & -5.8 & -16.5 & -22.7 \\
\hline 9 & 10 & -22.1 & -14.8 & -4.6 & +7.5 & +17.3 & +22.9 & +22.4 & +16.0 & +5.4 & -6.2 & -16.8 & -22.8 \\
\hline 10 & 11 & -22.0 & -14.4 & -4.2 & +7.8 & +17.5 & +23.0 & +22.3 & +15.7 & +5.0 & -6.5 & -17.1 & -22.9 \\
\hline 11 & 12 & -21.9 & -14.1 & -3.8 & $\begin{array}{r}+8.2 \\
\end{array}$ & +17.8 & +23.1 & +22.2 & +15.4 & +4.7 & -6.9 & -17.3 & -23.0 \\
\hline 12 & 13 & -21.7 & -13.8 & -3.4 & +8.6 & +18.1 & +23.1 & +22.0 & +15.1 & +4.3 & -7.3 & -17.6 & -23.1 \\
\hline 13 & 14 & -21.5 & -13.5 & -3.0 & $\begin{array}{l}+8.9 \\
\end{array}$ & +18.3 & +23.2 & +21.9 & +14.8 & $\begin{array}{l}+3.9 \\
\end{array}$ & -7.7 & -17.9 & -23.1 \\
\hline 14 & 15 & -21.4 & -13.1 & -2.6 & +9.3 & +18.6 & +23.3 & +21.7 & +14.5 & +3.5 & -8.0 & -18.2 & -23.2 \\
\hline 15 & 16 & -21.2 & -12.8 & -2.2 & +9.7 & +18.8 & +23.3 & +21.6 & +14.2 & +3.1 & -8.4 & -18.4 & -23.3 \\
\hline 16 & 17 & -21.0 & -12.4 & -1.9 & +10.0 & +19.0 & +23.3 & +21.4 & +13.8 & +2.8 & -8.8 & -18.7 & -23.3 \\
\hline 17 & 18 & -20.8 & -12.1 & -1.5 & +10.4 & +19.3 & +23.4 & +21.3 & +13.5 & +2.4 & -9.1 & -18.9 & -23.4 \\
\hline 18 & 19 & -20.6 & -11.7 & -1.1 & +10.7 & +19.5 & +23.4 & +21.1 & +13.2 & +2.0 & -9.5 & -19.2 & -23.4 \\
\hline 19 & 20 & -20.4 & -11.4 & -0.7 & +11.1 & +19.7 & +23.4 & +20.9 & +12.9 & +1.6 & -9.9 & -19.4 & -23.4 \\
\hline 20 & 21 & -20.2 & -11.0 & -0.3 & +11.4 & +19.9 & +23.4 & +20.7 & +12.6 & +1.2 & -10.2 & -19.6 & -23.4 \\
\hline 21 & 22 & -20.0 & -10.7 & +0.1 & +11.8 & +20.1 & +23.4 & +20.5 & +12.2 & +0.8 & -10.6 & -19.9 & -23.4 \\
\hline 22 & 23 & -19.7 & -10.3 & +0.5 & +12.1 & +20.3 & +23.4 & +20.3 & +11.9 & +0.4 & -11.0 & -20.1 & -23.4 \\
\hline 23 & 24 & -19.5 & -9.9 & +0.9 & +12.4 & +20.5 & +23.4 & +20.1 & +11.6 & +0.1 & -11.3 & -20.3 & -23.4 \\
\hline 24 & 25 & -19.3 & -9.6 & $\begin{array}{r}+1.3 \\
\end{array}$ & +12.8 & +20.7 & +23.4 & +19.9 & +11.2 & -0.3 & -11.7 & -20.5 & -23.4 \\
\hline 25 & 26 & -19.0 & -9.2 & +1.7 & +13.1 & +20.9 & +23.4 & +19.7 & +10.9 & -0.7 & -12.0 & -20.7 & -23.4 \\
\hline 26 & 27 & -18.8 & -8.8 & +2.1 & +13.4 & +21.1 & +23.4 & +19.5 & +10.5 & -1.1 & -12.3 & -20.9 & -23.3 \\
\hline 27 & 28 & -18.5 & -8.4 & +2.5 & +13.7 & +21.3 & +23.3 & +19.3 & +10.2 & -1.5 & -12.7 & -21.1 & -23.3 \\
\hline 28 & 29 & -18.3 & -8.1 & $\begin{array}{l}+2.9 \\
\end{array}$ & +14.1 & +21.4 & +23.3 & +19.1 & +9.8 & -1.9 & -13.0 & -21.3 & -23.2 \\
\hline 29 & 30 & -18.0 & - & +3.3 & +14.4 & +21.6 & +23.3 & +18.8 & +9.5 & -2.3 & -13.4 & -21.4 & -23.2 \\
\hline 30 & 31 & -17.7 & - & $\begin{array}{r}+3.7 \\
\end{array}$ & +14.7 & +21.7 & +23.2 & +18.6 & +9.6 & -2.7 & -13.7 & -21.6 & -23.1 \\
\hline 31 & & -17.5 & - & +4.0 & - & 2.9 & - & 18.4 & +8.8 & - & 14.0 & - & - \\
\hline
\end{tabular}

1 Таблица составлена по данным Астрономического ежегодника на 1950 г., причем склонение Солнца дается для истинного гринвического полдня.

2 Этой графой следует пользоваться только для января и февраля високосных лет. В остальные месяцы любого года пользоваться первой графой. 
Продолжительность дня (ч. мин.) и высота Солнца над горизонтом в полдень на 15 число месяца

\begin{tabular}{|c|c|c|c|c|c|c|c|c|c|c|c|c|c|c|}
\hline Район, станция & \multicolumn{14}{|c|}{ Месяцы, склонение Солнца (угловые градусы) } \\
\hline & $\begin{array}{l}\text { январь } \\
-21.2^{0}\end{array}$ & $\begin{array}{l}\text { февраль } \\
-13.1^{0}\end{array}$ & $\begin{array}{l}\text { март } \\
-2.2^{0}\end{array}$ & $\begin{array}{c}\text { апрель } \\
9.7^{0}\end{array}$ & $\begin{array}{c}\text { май } \\
18.8^{0}\end{array}$ & $\begin{array}{l}\text { июнь } \\
23.3^{0}\end{array}$ & $\begin{array}{c}22 \text { июня } \\
23.4^{0}\end{array}$ & $\begin{array}{l}\text { июль } \\
21.6^{0}\end{array}$ & $\begin{array}{c}\text { август } \\
14.2^{0}\end{array}$ & $\begin{array}{c}\text { сентябрь } \\
3.1^{0}\end{array}$ & $\begin{array}{l}\text { октябрь } \\
-8.4^{0}\end{array}$ & $\begin{array}{l}\text { ноябрь } \\
-18.4^{0}\end{array}$ & $\begin{array}{c}\text { декабр } \\
\text { ь } \\
-23.3^{0}\end{array}$ & $\begin{array}{l}22 \text { декабря } \\
-23.4^{0}\end{array}$ \\
\hline 1 & 2 & 3 & 4 & 5 & 6 & 7 & 8 & 9 & 10 & 11 & 12 & 13 & 14 & 15 \\
\hline \multicolumn{15}{|c|}{ Рудный Алтай } \\
\hline $\begin{array}{l}\text { Шемонаиха } \\
\varphi=50^{0} 38^{\prime} \text { с. ш. }\end{array}$ & $\begin{array}{c}84.14 \mathrm{M} \\
18^{0} 10\end{array}$ & $\begin{array}{l}94.48 \mathrm{M} \\
26^{0} 16\end{array}$ & $\begin{array}{c}11 ч .39 \mathrm{M} \\
37^{0} 10\end{array}$ & $\begin{array}{c}13 ч .36 \mathrm{M} \\
49^{0} 04\end{array}$ & $\begin{array}{c}15 ч .16 \mathrm{M} \\
58^{0} 10\end{array}$ & $\begin{array}{c}164.13 \mathrm{M} \\
62^{0} 40\end{array}$ & $\begin{array}{c}164.15 \mathrm{M} \\
62^{0} 46\end{array}$ & $\begin{array}{c}15 ч .51 \mathrm{M} \\
60^{0} 58\end{array}$ & $\begin{array}{c}14 \text { ч. } 24 \mathrm{M} \\
52^{0} 34\end{array}$ & $\begin{array}{c}12 ч .30 \mathrm{M} \\
42^{0} 28\end{array}$ & $\begin{array}{c}10 ч .37 \mathrm{M} \\
30^{0} 58\end{array}$ & $\begin{array}{c}8 ч .49 \mathrm{M} \\
20^{\circ} 58\end{array}$ & $\begin{array}{c}7 ч .47 \mathrm{M} \\
16^{0} 04\end{array}$ & $\begin{array}{l}7 ч .45 \mathrm{M} \\
15^{0} 58\end{array}$ \\
\hline $\begin{array}{l}\text { Усть-Каменогорск } \\
\varphi=49^{0} 57^{\prime} \text { с. ш. }\end{array}$ & $\begin{array}{c}84.20 \mathrm{M} \\
18^{0} 51 \\
\end{array}$ & $\begin{array}{l}\text { 9ч.51 M } \\
26^{0} 57 \\
\end{array}$ & $\begin{array}{c}11 ч .59 \mathrm{M} \\
37^{0} 51 \\
\end{array}$ & $\begin{array}{c}13 ч .34 \mathrm{M} \\
49^{0} 45 \\
\end{array}$ & $\begin{array}{c}15 ч .11 \mathrm{M} \\
58^{0} 51 \\
\end{array}$ & $\begin{array}{c}164.07 \mathrm{M} \\
53^{0} 21 \\
\end{array}$ & $\begin{array}{c}16 \text { ч.08 M } \\
63^{0} 27 \\
\end{array}$ & $\begin{array}{c}15 ч .45 \mathrm{M} \\
61^{0} 39 \\
\end{array}$ & $\begin{array}{c}14 \mathrm{y}^{2} 20 \mathrm{M} \\
54^{0} 15 \\
\end{array}$ & $\begin{array}{c}12 ч .30 \mathrm{M} \\
43^{0} 09 \\
\end{array}$ & $\begin{array}{c}10 ч .39 \mathrm{M} \\
31^{0} 39 \\
\end{array}$ & $\begin{array}{c}84.53 \mathrm{M} \\
21^{0} 39 \\
\end{array}$ & $\begin{array}{c}\text { 7ч.58 м } \\
16^{0} 45 \\
\end{array}$ & $\begin{array}{c}\text { 7ч.52 м } \\
16^{0} 39 \\
\end{array}$ \\
\hline $\begin{array}{l}\text { Зыряновск } \\
\varphi=49^{0} 44^{\prime} \text { с. ш. }\end{array}$ & $\begin{array}{c}84.22 \mathrm{M} \\
19^{0} 04 \\
\end{array}$ & $\begin{array}{l}9 \text { ч. } 52 \mathrm{M} \\
27^{0} 10 \\
\end{array}$ & $\begin{array}{c}114.39 \mathrm{M} \\
38^{0} 04 \\
\end{array}$ & $\begin{array}{c}13 ч .33 \mathrm{M} \\
49^{0} 58 \\
\end{array}$ & $\begin{array}{c}15 ч .10 \mathrm{M} \\
59^{0} 04 \\
\end{array}$ & $\begin{array}{c}164.02 \mathrm{M} \\
63^{0} 34 \\
\end{array}$ & $\begin{array}{c}164.06 \mathrm{M} \\
63^{0} 40 \\
\end{array}$ & $\begin{array}{c}15 ч .43 \mathrm{M} \\
61^{0} 52 \\
\end{array}$ & $\begin{array}{c}14 \mathrm{r}^{1} 19 \mathrm{M} \\
54^{0} 28 \\
\end{array}$ & $\begin{array}{c}12 ч .49 \mathrm{M} \\
43^{0} 22 \\
\end{array}$ & $\begin{array}{c}10 ч .40 \mathrm{M} \\
31^{0} 52 \\
\end{array}$ & $\begin{array}{c}84.54 \mathrm{M} \\
21^{0} 52 \\
\end{array}$ & $\begin{array}{c}7.55 \mathrm{M} \\
16^{0} 58 \\
\end{array}$ & $\begin{array}{c}7 ч .54 \mathrm{M} \\
16^{0} 52 \\
\end{array}$ \\
\hline \multicolumn{15}{|c|}{ Южный Алтай } \\
\hline $\begin{array}{l}\text { Катон-Карагай } \\
\varphi=49^{0} 02^{\prime} \text { с. ш. }\end{array}$ & $\begin{array}{c}\text { 8ч. } 27 \mathrm{M} \\
19^{0} 38 \\
\end{array}$ & $\begin{array}{c}94.55 \mathrm{M} \\
27^{0} 44 \\
\end{array}$ & $\begin{array}{c}11 ч .40 \mathrm{M} \\
38^{0} 38 \\
\end{array}$ & $\begin{array}{c}13 ч .31 \mathrm{M} \\
50^{0} 32 \\
\end{array}$ & $\begin{array}{c}15 ч .05 \mathrm{M} \\
59^{0} 38 \\
\end{array}$ & $\begin{array}{c}154.59 \mathrm{M} \\
64^{0} 08 \\
\end{array}$ & $\begin{array}{c}164.00 \mathrm{M} \\
64^{0} 14 \\
\end{array}$ & $\begin{array}{c}15 ч .38 \mathrm{M} \\
62^{0} 26 \\
\end{array}$ & $\begin{array}{c}14 ч .16 \mathrm{M} \\
55^{0} 02 \\
\end{array}$ & $\begin{array}{c}12 ч .29 \mathrm{M} \\
43^{0} 56 \\
\end{array}$ & $\begin{array}{c}10 ч .41 \mathrm{M} \\
32^{0} 26 \\
\end{array}$ & $\begin{array}{l}84.59 \mathrm{M} \\
22^{0} 26 \\
\end{array}$ & $\begin{array}{c}\text { 8ч.01 м } \\
17^{0} 32 \\
\end{array}$ & $\begin{array}{c}8 ч .00 \mathrm{M} \\
17^{0} 26 \\
\end{array}$ \\
\hline $\begin{array}{l}\text { Курчум } \\
\varphi=48^{0} 35^{\prime} \text { с. ш. }\end{array}$ & $\begin{array}{l}84.31 \mathrm{M} \\
20^{0} 13\end{array}$ & $\begin{array}{l}\text { 9ч. } 58 \mathrm{M} \\
28^{0} 19\end{array}$ & $\begin{array}{c}114.40 \mathrm{M} \\
39^{0} 13\end{array}$ & $\begin{array}{c}13 ч .29 \mathrm{M} \\
51^{0} 07\end{array}$ & $\begin{array}{c}15 \text { ч. } 01 \mathrm{M} \\
60^{0} 13\end{array}$ & $\begin{array}{c}15 ч .53 \mathrm{M} \\
64^{0} 43\end{array}$ & $\begin{array}{c}15 \mathrm{y}^{\circ} 55 \mathrm{M} \\
64^{0} 49\end{array}$ & $\begin{array}{c}15 ч .34 \mathrm{M} \\
63^{0} 01\end{array}$ & $\begin{array}{c}14 \mathrm{y} .13 \mathrm{M} \\
55^{0} 37\end{array}$ & $\begin{array}{c}12 ч .28 \mathrm{M} \\
44^{0} 31\end{array}$ & $\begin{array}{c}10 ч .43 \mathrm{M} \\
33^{0} 01\end{array}$ & $\begin{array}{l}\text { 9ч.03 м } \\
23^{0} 01\end{array}$ & $\begin{array}{c}84.07 \mathrm{M} \\
18^{0} 07\end{array}$ & $\begin{array}{l}8 \text { ч. } 05 \mathrm{M} \\
18^{0} 01\end{array}$ \\
\hline \multicolumn{15}{|c|}{ Калба } \\
\hline $\begin{array}{l}\text { Самарка } \\
\varphi=49^{0} 02^{\prime} \text { с. ш. }\end{array}$ & $\begin{array}{c}84.28 \mathrm{M} \\
19^{0} 46\end{array}$ & $\begin{array}{c}94.56 \mathrm{M} \\
27^{0} 52 \\
\end{array}$ & $\begin{array}{c}11 ч .40 \mathrm{M} \\
38^{0} 46\end{array}$ & $\begin{array}{c}13 ч .31 \mathrm{M} \\
50^{0} 40\end{array}$ & $\begin{array}{c}15 ч .05 \mathrm{M} \\
59^{0} 46\end{array}$ & $\begin{array}{c}154.58 \mathrm{M} \\
64^{0} 16 \\
\end{array}$ & $\begin{array}{c}154.59 \mathrm{M} \\
64^{0} 22 \\
\end{array}$ & $\begin{array}{c}15 ч .37 \mathrm{M} \\
62^{0} 34\end{array}$ & $\begin{array}{c}14 ч .16 \mathrm{M} \\
55^{0} 10\end{array}$ & $\begin{array}{c}12 ч .29 \mathrm{M} \\
44^{0} 04\end{array}$ & $\begin{array}{c}10 ч .41 \mathrm{M} \\
32^{0} 34\end{array}$ & $\begin{array}{c}84.59 \mathrm{M} \\
22^{0} 34 \\
\end{array}$ & $\begin{array}{c}84.02 \mathrm{M} \\
17^{0} 40\end{array}$ & $\begin{array}{c}84.01 \mathrm{M} \\
17^{0} 34 \\
\end{array}$ \\
\hline \multicolumn{15}{|c|}{ Зайсанская впадина } \\
\hline $\begin{array}{l}\text { Буран } \\
\varphi=48^{0} 00^{\prime} \text { с. ш. }\end{array}$ & $\begin{array}{c}84.36 \mathrm{M} \\
20^{\circ} 48 \\
\end{array}$ & $\begin{array}{c}10 ч .00 \mathrm{M} \\
28^{0} 54 \\
\end{array}$ & $\begin{array}{c}11 ч .41 \mathrm{M} \\
39^{0} 48\end{array}$ & $\begin{array}{c}13 ч .27 \mathrm{M} \\
51^{0} 42 \\
\end{array}$ & $\begin{array}{c}14 ч .58 \mathrm{M} \\
60^{\circ} 48 \\
\end{array}$ & $\begin{array}{c}15 ч .49 \mathrm{M} \\
65^{0} 18 \\
\end{array}$ & $\begin{array}{c}16 ч .50 \mathrm{M} \\
65^{0} 24 \\
\end{array}$ & $\begin{array}{c}15 ч .29 \mathrm{M} \\
63^{0} 36 \\
\end{array}$ & $\begin{array}{c}14 ч .10 \mathrm{M} \\
56^{0} 12 \\
\end{array}$ & $\begin{array}{c}12 ч .28 \mathrm{M} \\
45^{0} 06 \\
\end{array}$ & $\begin{array}{c}10 ч .44 \mathrm{M} \\
33^{0} 36 \\
\end{array}$ & $\begin{array}{c}94.07 \mathrm{M} \\
23^{0} 36 \\
\end{array}$ & $\begin{array}{c}\text { 8ч.11 м } \\
18^{0} 42 \\
\end{array}$ & $\begin{array}{c}8 ч .10 \mathrm{M} \\
18^{0} 36 \\
\end{array}$ \\
\hline $\begin{array}{l}\text { Зайсан } \\
\varphi=47^{0} 28^{\prime} \text { с. ш. }\end{array}$ & $\begin{array}{l}8 ч .40 \mathrm{M} \\
21^{0} 20 \\
\end{array}$ & $\begin{array}{c}10 ч .02 \mathrm{M} \\
28^{0} 54 \\
\end{array}$ & $\begin{array}{c}11 ч .41 \mathrm{M} \\
40^{\circ} 20 \\
\end{array}$ & $\begin{array}{c}13 ч .26 \mathrm{M} \\
52^{0} 14 \\
\end{array}$ & $\begin{array}{c}14 ч .54 \mathrm{M} \\
61^{0} 20 \\
\end{array}$ & $\begin{array}{c}15 ч .43 \mathrm{M} \\
65^{0} 50 \\
\end{array}$ & $\begin{array}{c}15 ч .45 \mathrm{M} \\
65^{0} 56 \\
\end{array}$ & $\begin{array}{c}15 ч .25 \mathrm{M} \\
64^{0} 08 \\
\end{array}$ & $\begin{array}{c}14 ч .09 \mathrm{M} \\
56^{0} 44 \\
\end{array}$ & $\begin{array}{c}12 ч .27 \mathrm{M} \\
45^{0} 38 \\
\end{array}$ & $\begin{array}{c}10 ч .46 \mathrm{M} \\
34^{0} 08 \\
\end{array}$ & $\begin{array}{l}94.10 \mathrm{M} \\
24^{0} 08 \\
\end{array}$ & $\begin{array}{c}\text { 8ч. } 16 \mathrm{M} \\
19^{0} 14 \\
\end{array}$ & $\begin{array}{c}8 ч .15 \mathrm{M} \\
19^{0} 08 \\
\end{array}$ \\
\hline
\end{tabular}

$\mathrm{h}_{0}=90^{\circ}-\varphi+\delta ; \quad \mathrm{N}=2^{-} ; \cos { }^{-}=-\operatorname{tg} \varphi \cdot \operatorname{tg} \delta ;$ где ${ }^{-}-$часовой угол, $\varphi-$ широта места, $\delta-$ склонение Солнца. Продолжительность дня ( $\mathrm{N})$ дается без учета рефракции. Продолжительность дня и полуденная высота Солнца $\left(\mathrm{h}_{0}\right)$ дается на 15 число месяца, на 22 июня (самый длинный день), на 22 декабря (самый короткий день), для этих чисел приводится склонение Солнца ( $\delta$ ), 14 февраля $\delta=-13.1^{0}$. 
Таблица Бемпорада для вычисления масс атмосферы (Т)

\begin{tabular}{|c|c|c|c|c|c|c|c|c|c|c|}
\hline $\mathrm{N}_{0}$ & 0.0 & 0.1 & 0.2 & 0.3 & 0.4 & 0.5 & 0.6 & 0.7 & 0.8 & 0.9 \\
\hline $1^{0}$ & 26.29 & 26.06 & 25.20 & 24.40 & 23.63 & 22.91 & 22.22 & 21.57 & 20.34 & 20.35 \\
\hline $5^{0}$ & 10.40 & 10.22 & 10.06 & 9.90 & 9.74 & 9.59 & 9.45 & 9.30 & 9.17 & 9.03 \\
\hline $10^{0}$ & 5.60 & 5.55 & 5.50 & 5.45 & 5.40 & 5.35 & 5.30 & 5.26 & 5.21 & 5.16 \\
\hline $15^{0}$ & 3.82 & 3.79 & 3.77 & 3.74 & 3.72 & 3.70 & 3.68 & 3.65 & 3.63 & 3.61 \\
\hline $20^{0}$ & 2.90 & 2.89 & 2.88 & 2.86 & 2.85 & 2.84 & 2.82 & 2.81 & 2.80 & 2.78 \\
\hline $25^{0}$ & 2.36 & 2.35 & 2.34 & 2.33 & 2.32 & 2.31 & 2.31 & 2.30 & 2.29 & 2.28 \\
\hline $30^{0}$ & 2.00 & 1.99 & 1.98 & 1.98 & 1.97 & 1.97 & 1.96 & 1.95 & 1.95 & 1.94 \\
\hline
\end{tabular}

\begin{tabular}{|c|c|c|c|c|c|c|c|c|c|c|}
\hline $\mathrm{N}_{0}$ & 0 & 1 & 2 & 3 & 4 & 5 & 6 & 7 & 8 & 9 \\
\hline $30^{0}$ & 2.00 & 1.94 & 1.88 & 1.83 & 1.78 & 1.74 & 1.70 & 1.66 & 1.62 & 1.59 \\
\hline $40^{0}$ & 1.55 & 1.52 & 1.49 & 1.46 & 1.44 & 1.41 & 1.39 & 1.37 & 1.34 & 1.32 \\
\hline $50^{0}$ & 1.30 & 1.28 & 1.27 & 1.25 & 1.24 & 1.22 & 1.20 & 1.19 & 1.18 & 1.17 \\
\hline $60^{0}$ & 1.15 & 1.14 & 1.13 & 1.12 & 1.11 & 1.10 & 1.09 & 1.09 & 1.08 & 1.07 \\
\hline $70^{0}$ & 1.06 & 1.06 & 1.05 & 1.05 & 1.04 & 1.04 & 1.04 & 1.02 & 1.02 & 1.02 \\
\hline
\end{tabular}


Прилло жен и е I V

Повторяемость по трапециям циклонов и антициклонов

в апреле-октябре за 20-летний период (1942-1961 гг.)

(К.И. Попова)

\begin{tabular}{|c|c|c|c|c|c|c|c|c|c|c|c|}
\hline \multirow[b]{3}{*}{$\begin{array}{l}\text { Широта в } \\
\text { градусах }\end{array}$} & \multirow[b]{3}{*}{$\begin{array}{l}\vec{E} \\
\stackrel{\Xi}{\Sigma} \\
\sum\end{array}$} & \multicolumn{10}{|c|}{ Долгота. градусы в.д. } \\
\hline & & \multicolumn{2}{|c|}{$66-72$} & \multicolumn{2}{|c|}{$72-78$} & \multicolumn{2}{|c|}{$78-84$} & \multicolumn{2}{|c|}{$84-90$} & \multicolumn{2}{|c|}{$90-96$} \\
\hline & & 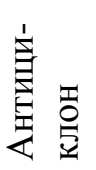 & $\begin{array}{l}\text { 罢 } \\
\text { 总 } \\
\text { 总 }\end{array}$ & 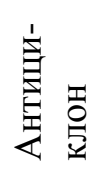 & 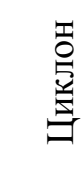 & 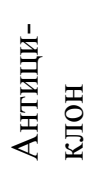 & $\begin{array}{l}\text { 壱 } \\
\text { 鄫 } \\
\end{array}$ & 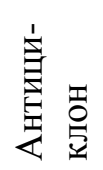 & 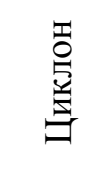 & 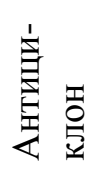 & 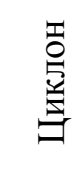 \\
\hline \multirow{7}{*}{ 64-68 с. ш. } & IV & 20 & 35 & 12 & 44 & 6 & 42 & 5 & 35 & 4 & 33 \\
\hline & $\mathrm{V}$ & 37 & 32 & 26 & 48 & 12 & 39 & 9 & 42 & 7 & 39 \\
\hline & VI & 21 & 45 & 17 & 45 & 11 & 52 & 9 & 55 & 8 & 49 \\
\hline & VII & 17 & 22 & 11 & 21 & 9 & 31 & 8 & 34 & 6 & 32 \\
\hline & VIII & 15 & 18 & 14 & 21 & 11 & 26 & 5 & 33 & 5 & 36 \\
\hline & IX & 6 & 42 & 6 & 39 & 7 & 32 & 4 & 33 & 4 & 28 \\
\hline & $X$ & 10 & 44 & 7 & 44 & 3 & 48 & 5 & 46 & 3 & 37 \\
\hline \multirow{7}{*}{ 60-64 с. ш. } & IV & 15 & 30 & 25 & 44 & 15 & 47 & 11 & 58 & 6 & 49 \\
\hline & $\mathrm{V}$ & 26 & 50 & 26 & 57 & 15 & 67 & 9 & 58 & 9 & 53 \\
\hline & VI & 13 & 57 & 19 & 59 & 14 & 66 & 14 & 57 & 13 & 57 \\
\hline & VII & 14 & 42 & 9 & 44 & 4 & 48 & 5 & 48 & 6 & 43 \\
\hline & VIII & 17 & 40 & 20 & 38 & 18 & 41 & 14 & 47 & 11 & 36 \\
\hline & IX & 7 & 41 & 6 & 40 & 8 & 44 & 5 & 33 & 7 & 31 \\
\hline & $X$ & 10 & 49 & 10 & 60 & 5 & 56 & 9 & 49 & 2 & 49 \\
\hline \multirow{7}{*}{ 56-60 с. ш. } & IV & 14 & 53 & 19 & 50 & 20 & 52 & 17 & 43 & 15 & 27 \\
\hline & $\mathrm{V}$ & 34 & 35 & 29 & 41 & 32 & 45 & 17 & 52 & 11 & 33 \\
\hline & VI & 24 & 33 & 26 & 47 & 19 & 58 & 16 & 56 & 15 & 45 \\
\hline & VII & 16 & 41 & 17 & 54 & 14 & 58 & 7 & 54 & 3 & 32 \\
\hline & VIII & 13 & 39 & 21 & 46 & 25 & 52 & 17 & 53 & 12 & 33 \\
\hline & IX & 7 & 34 & 9 & 40 & 11 & 38 & 11 & 30 & 14 & 23 \\
\hline & $X$ & 9 & 34 & 22 & 43 & 10 & 39 & 9 & 39 & 9 & 25 \\
\hline \multirow{7}{*}{ 52-56 с. ш. } & IV & 30 & 30 & 38 & 34 & 47 & 32 & 47 & 17 & 34 & 11 \\
\hline & V & 34 & 31 & 46 & 40 & 46 & 26 & 44 & 20 & 42 & 16 \\
\hline & VI & 26 & 47 & 36 & 56 & 29 & 53 & 34 & 39 & 36 & 26 \\
\hline & VII & 18 & 47 & 19 & 54 & 15 & 64 & 19 & 38 & 16 & 19 \\
\hline & VIII & 30 & 46 & 28 & 52 & 33 & 52 & 36 & 35 & 22 & 17 \\
\hline & IX & 34 & 32 & 34 & 39 & 37 & 32 & 35 & 25 & 36 & 11 \\
\hline & $X$ & 21 & 39 & 28 & 36 & 38 & 27 & 44 & 19 & 48 & 9 \\
\hline \multirow{7}{*}{ 48-52 с. ш. } & IV & 45 & 20 & 63 & 35 & 49 & 28 & 50 & 17 & 47 & 8 \\
\hline & $\mathrm{V}$ & 52 & 18 & 72 & 12 & 70 & 16 & 55 & 12 & 54 & 5 \\
\hline & VI & 32 & 33 & 38 & 30 & 27 & 34 & 33 & 23 & 26 & 9 \\
\hline & VII & 38 & 38 & 34 & 29 & 27 & 26 & 21 & 10 & 16 & 2 \\
\hline & VIII & 36 & 23 & 38 & 29 & 37 & 32 & 31 & 14 & 19 & 4 \\
\hline & IX & 37 & 12 & 47 & 15 & 48 & 9 & 39 & 7 & 22 & 3 \\
\hline & $X$ & 50 & 25 & 49 & 25 & 59 & 17 & 64 & 8 & 61 & 1 \\
\hline \multirow{7}{*}{ 44-48 с. ш. } & IV & 26 & 25 & 34 & 25 & 33 & 15 & 17 & 0 & 5 & 0 \\
\hline & V & 29 & 13 & 38 & 9 & 29 & 6 & 18 & 3 & 10 & 0 \\
\hline & VI & 26 & 24 & 29 & 26 & 22 & 12 & 15 & 4 & 4 & 0 \\
\hline & VII & 14 & 14 & 8 & 16 & 7 & 9 & 5 & 0 & 3 & 0 \\
\hline & VIII & 17 & 13 & 14 & 19 & 12 & 10 & 2 & 0 & 0 & 0 \\
\hline & IX & 37 & 10 & 35 & 7 & 24 & 3 & 12 & 2 & 8 & 0 \\
\hline & $\mathrm{X}$ & 45 & 14 & 52 & 9 & 49 & 4 & 36 & 1 & 9 & 0 \\
\hline
\end{tabular}


Приложени е $\mathrm{V}$

ПДК веществ, загрязняющих поверхностные воды

\begin{tabular}{|l|c|}
\hline \multicolumn{1}{|c|}{ Наименование } & $\begin{array}{c}\text { ПДК для водоемов } \\
\text { рыбохозяйственного водопользования. } \\
\text { мг/л }\end{array}$ \\
\hline Хром $(6+)$ & 0.02 \\
\hline Железо & 0.1 \\
\hline Цинк & 0.01 \\
\hline Ртуть & 0.0001 \\
\hline Кадмий & 0.005 \\
\hline Мышьяк (3+) & 0.05 \\
\hline Медь & 0.001 \\
\hline Фенолы & 0.001 \\
\hline Нефтепродукты & 0.05 \\
\hline Фториды & 0.05 \\
\hline Азот нитритный & 0.08 \\
\hline
\end{tabular}

(ПДК $=0.02$ по $\left.\mathrm{N}_{2}\right)$ 
Связь осадков в процентах от их десятилетней суммы (1961-1970 гг.) с основными осадкообразующими типами циркуляции по месяцам холодного периода (А.В. Егорина. К.И. Попова)

\begin{tabular}{|c|c|c|c|c|c|c|c|c|c|c|c|c|c|}
\hline \multirow{3}{*}{ 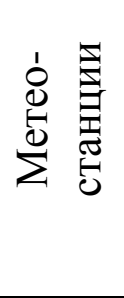 } & \multirow{3}{*}{ 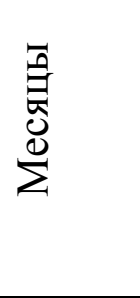 } & \multicolumn{2}{|c|}{ Осадки } & \multicolumn{9}{|c|}{ Потоки влаги } & \multirow{3}{*}{$\begin{array}{c}\text { Ультра- } \\
\text { полярные } \\
\text { вторжения }\end{array}$} \\
\hline & & \multirow[b]{2}{*}{$\begin{array}{c}\text { Норма, } \\
\text { мм }\end{array}$} & \multirow{2}{*}{$\begin{array}{c}\text { Из } 10 \\
\text { лет, } \\
\text { мм }\end{array}$} & \multicolumn{3}{|c|}{ Западные } & \multicolumn{3}{|c|}{ Северо-западные } & \multicolumn{3}{|c|}{ Юго-западные } & \\
\hline & & & & $\%$ & $1 \mathrm{~A}$ & $2 / A, 5$ & $\%$ & $3 / \mathrm{A}, \mathrm{B}$ & 4 & $\%$ & $5 \mathrm{~A}$ & 6 & \\
\hline 1 & 2 & 3 & 4 & 5 & 6 & 7 & 8 & 9 & 10 & 11 & 12 & 13 & 14 \\
\hline \multirow{6}{*}{ 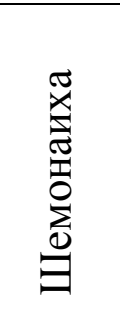 } & XI & 34 & 45 & 46.6 & 64.5 & 14.6 & 21.4 & 100 & - & 31.3 & 70.0 & 30.0 & 0.7 \\
\hline & XII & 29 & 31 & 38.4 & 73.5 & 14.3 & 26.4 & 74.3 & 25.7 & 31.0 & 93.0 & 7.0 & 4.2 \\
\hline & I & 17 & 25 & 46.2 & 72.5 & - & 12.5 & 60.1 & 39.9 & 35.2 & 95.2 & - & 6.0 \\
\hline & II & 16 & 24 & 55.5 & 25.5 & 71.4 & 12.3 & 100 & - & 25.7 & 91.8 & - & 6.4 \\
\hline & III & 18 & 29 & 56.6 & 56.6 & 31.0 & 9.0 & 100 & - & 34.1 & 69.8 & 28.1 & 0.3 \\
\hline & XI-III & 114 & 154 & 47 & 60 & 27 & 18 & 87 & 13 & 32 & 82 & 18 & 3 \\
\hline \multirow{6}{*}{ 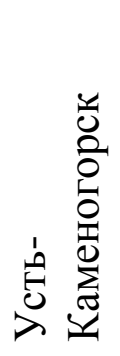 } & $\mathrm{XI}$ & 44 & 44 & 47.1 & 68.3 & 7.5 & 31.4 & 83.8 & 16.2 & 20.6 & 78 & 22 & 0.9 \\
\hline & XII & 35 & 42 & 37.7 & 80.0 & 6.5 & 20.8 & 75.7 & 24.3 & 38.1 & 90.0 & 10.0 & 3.4 \\
\hline & I & 20 & 26 & 51.2 & 67.5 & - & 14.0 & 57.1 & 42.9 & 30.5 & 98.4 & - & 4.3 \\
\hline & II & 22 & 21 & 59.6 & 34.8 & 63.1 & 6.3 & 100.0 & - & 29.5 & 93.5 & 2.5 & 4.6 \\
\hline & III & 29 & 33 & 50.7 & 46.0 & 30.0 & 11.3 & 100.0 & - & 37.7 & 58.0 & 40.0 & 0.3 \\
\hline & XI-III & 150 & 166 & 48 & 60 & 20 & 19 & 81 & 19 & 31 & 82 & 17 & 2 \\
\hline \multirow{6}{*}{$\begin{array}{l}\frac{1}{0} \\
0 \\
0 \\
0 \\
0 \\
0 \\
0 \\
0 \\
0\end{array}$} & XI & 41 & 40 & 45.6 & 68.7 & 16.6 & 16.7 & 100.0 & - & 36.2 & 76.0 & 24.0 & 1.5 \\
\hline & XII & 25 & 21 & 29.3 & 71.0 & 21.5 & 12.4 & 86.8 & 13.2 & 54.5 & 79.0 & 21.0 & 3.8 \\
\hline & I & 13 & 13 & 44.5 & 83.1 & - & 15.6 & 64.3 & 35.7 & 31.1 & 100.0 & - & 8.9 \\
\hline & II & 10 & 16 & 58.4 & 37.9 & 58.9 & 5.8 & 100.0 & - & 31.3 & 92.0 & 8.0 & 4.4 \\
\hline & III & 18 & 31 & 49.3 & 57.7 & 31.3 & 7.7 & 100.0 & - & 42.6 & 64.0 & 36.0 & 0.4 \\
\hline & XI-III & 107 & 121 & 45 & 62 & 27 & 12 & 93 & 7 & 40 & 77 & 23 & 3 \\
\hline
\end{tabular}


Продолжение приложения VI

\begin{tabular}{|c|c|c|c|c|c|c|c|c|c|c|c|c|c|}
\hline 1 & 2 & 3 & 4 & 5 & 6 & 7 & 8 & 9 & 10 & 11 & 12 & 13 & 14 \\
\hline \multirow{6}{*}{ 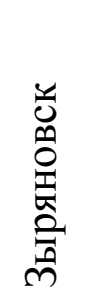 } & $\mathrm{XI}$ & 55 & 55 & 36.5 & 56.0 & 8.0 & 23.0 & 100.0 & - & 37.3 & 59.0 & 41.0 & 3.2 \\
\hline & XII & 54 & 47 & 34.8 & 76.6 & 8.7 & 15.4 & 68.9 & 31.1 & 43.9 & 85.0 & 15.0 & 5.9 \\
\hline & I & 39 & 32 & 40.3 & 79.3 & - & 16.3 & 74.2 & 25.8 & 38.9 & 95.9 & - & 4.4 \\
\hline & II & 27 & 33 & 43.5 & 36.5 & 60.3 & 0.7 & 100.0 & - & 39.6 & 85.2 & 1.2 & 7.1 \\
\hline & III & 28 & 37 & 62.5 & 65.0 & 18.0 & 11.1 & 100.0 & - & 26.0 & 89.0 & 11.0 & 0.4 \\
\hline & XI-III & 203 & 204 & 43 & 62 & 18 & 16 & 89 & 11 & 37 & 80 & 17 & 4 \\
\hline \multirow{6}{*}{ 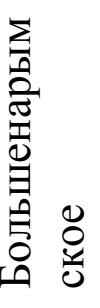 } & XI & 28 & 26 & 44.2 & 63.3 & 3.3 & 24.1 & 100.0 & - & 30.2 & 67.0 & 33.0 & 1.5 \\
\hline & XII & 24 & 22 & 38.2 & 63.6 & 28.1 & 23.9 & 66.0 & 34.0 & 30.8 & 82.3 & 17.7 & 7.1 \\
\hline & I & 16 & 17 & 47.6 & 81.6 & - & 18.0 & 66.8 & 33.2 & 30.6 & 99.6 & - & 3.8 \\
\hline & II & 13 & 14 & 60.0 & 48.7 & 48.8 & 5.9 & 100.0 & - & 29.6 & 76.8 & 2.7 & 4.4 \\
\hline & III & 16 & 15 & 49.2 & 38.8 & 33.4 & 14.8 & 100.0 & - & 36.0 & 91.0 & 9 & - \\
\hline & XI-III & 97 & 94 & 47 & 60 & 21 & 19 & 84 & 16 & 31 & 82 & 14 & 3 \\
\hline \multirow{6}{*}{ 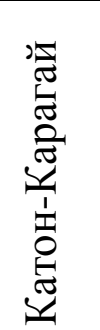 } & XI & 27 & 32 & 41.9 & 58.3 & 11.9 & 30.3 & 100.0 & - & 25.3 & 78.5 & 21.5 & 2.5 \\
\hline & XII & 22 & 18 & 38.3 & 60.4 & 30.8 & 27.9 & 71.5 & 28.5 & 25.2 & 85.3 & 14.7 & 8.6 \\
\hline & I & 16 & 12 & 54.4 & 76.6 & - & 19.1 & 80.1 & 19.9 & 23.9 & 99.3 & - & 2.5 \\
\hline & II & 12 & 10 & 69.5 & 41.5 & 57.9 & 5.5 & 100.0 & - & 17.8 & 75.1 & - & 7.2 \\
\hline & III & 14 & 15 & 59.5 & 24.9 & 42.0 & 16.0 & 100.0 & - & 23.5 & 100.0 & - & 1.0 \\
\hline & XI-III & 91 & 87 & 49 & 52 & 27 & 23 & 90 & 10 & 24 & 86 & 12 & 4 \\
\hline
\end{tabular}


Прило жен и е V I I

Связь осадков в \% от их десятилетней суммы (1961-1970 гг.) с осадкообразующими типами циркуляции в переходные сезоны (А.В. Егорина, К.И. Попова)

\begin{tabular}{|c|c|c|c|c|c|c|c|c|c|c|c|c|c|}
\hline \multirow{3}{*}{$\begin{array}{l}\text { Метео- } \\
\text { станция }\end{array}$} & \multirow{3}{*}{$\begin{array}{c}\text { Меся } \\
\text { цы }\end{array}$} & \multicolumn{2}{|c|}{ Осадки } & \multicolumn{9}{|c|}{ Потоки влаги } & \multirow{3}{*}{$\begin{array}{c}\text { Ульт- } \\
\text { ра- } \\
\text { поляр- } \\
\text { ные }\end{array}$} \\
\hline & & \multirow{2}{*}{$\begin{array}{l}\text { нор- } \\
\text { ма, } \\
\text { мм }\end{array}$} & \multirow{2}{*}{$\begin{array}{c}\text { из } \\
10 \\
\text { лет }\end{array}$} & \multicolumn{3}{|c|}{ западные } & \multicolumn{3}{|c|}{ северо-западные } & \multicolumn{3}{|c|}{ юго-западные } & \\
\hline & & & & $\%$ & IA & $\begin{array}{c}\text { IIA, } \\
\text { Б }\end{array}$ & $\%$ & $\begin{array}{c}\text { IIIA, } \\
\text { Б }\end{array}$ & IV & $\%$ & VA & VI & \\
\hline 1 & 2 & 3 & 4 & 5 & 6 & 7 & 8 & 9 & 10 & 11 & 12 & 13 & 14 \\
\hline \multirow[t]{6}{*}{$\begin{array}{c}\text { Шемо- } \\
\text { наиха }\end{array}$} & IV & 29 & 24 & 35.2 & 77.8 & 0.0 & 7.7 & 90.3 & 9.7 & 50.7 & 57.5 & 42.5 & \\
\hline & $\mathrm{V}$ & 45 & 39 & 42.5 & 39.8 & 29.6 & 19.8 & 55.5 & 44.3 & 37.7 & 49.0 & 50.9 & - \\
\hline & IV-V & & & & & & & & & & & & \\
\hline & IX & 29 & 32 & 15.7 & 55.0 & 45.0 & 40.5 & 73.6 & 26.4 & 43.7 & 78.7 & 21.3 & 0.1 \\
\hline & $\mathrm{X}$ & 40 & 59 & 33.4 & 68.1 & 3.4 & 16.4 & 71.2 & 28.8 & 50.1 & 46.8 & 52.1 & 0.1 \\
\hline & IX-X & & & & & & & & & & & & \\
\hline \multirow{6}{*}{$\begin{array}{c}\text { Усть- } \\
\text { Камено- } \\
\text { горск } \\
\end{array}$} & IV & 31 & 26 & 44.6 & 87.2 & - & 17.1 & 95.1 & 3.5 & 34.0 & 65.3 & 34.7 & 4.3 \\
\hline & $\mathrm{V}$ & 43 & 43 & 52.0 & 49.7 & 23.9 & 16.0 & 52.9 & 47.1 & 32.0 & 59.9 & 35.0 & - \\
\hline & IV-V & & & & & & & & & & & & \\
\hline & IX & 29 & 31 & 18.0 & 59.6 & 25.0 & 38.5 & 56.2 & 43.8 & 42.7 & 73.2 & 26.8 & 0.8 \\
\hline & $X$ & 43 & 58 & 34.0 & 64.5 & - & 19.0 & 66.1 & 19.6 & 47.0 & 45.0 & 54.7 & - \\
\hline & IX-X & & & & & & & & & & & & \\
\hline \multirow[t]{6}{*}{$\begin{array}{c}\text { Ленино- } \\
\text { горск } \\
\end{array}$} & IV & 42 & 38 & 47.1 & 85.9 & 0.0 & 17.8 & 78.1 & 21.9 & 33.9 & 61.2 & 38.8 & 1.2 \\
\hline & $\mathrm{V}$ & 89 & 68 & 42.3 & 42.6 & 18.1 & 21.4 & 51.7 & 48.3 & 36.2 & 61.8 & 32.5 & - \\
\hline & IV-V & & & & & & & & & & & & \\
\hline & IX & 67 & 64 & 27.0 & 64.0 & 0.0 & 39.7 & 82.2 & 17.8 & 32.6 & 72.9 & 27.1 & 0.7 \\
\hline & $\mathrm{X}$ & 62 & 69 & 28.9 & 63.4 & 7.5 & 83 & 74.8 & 15.5 & 60.4 & 42.0 & 58.0 & 0.3 \\
\hline & IX-X & & & & & & & & & & & & \\
\hline \multirow[t]{6}{*}{$\begin{array}{l}\text { Зыря- } \\
\text { новск }\end{array}$} & IV & 35 & 23 & 39.0 & 83.7 & - & 18.9 & 92.0 & 7.6 & 39.7 & 58.8 & 37.7 & 2.3 \\
\hline & $\mathrm{V}$ & 56 & 50 & 43.6 & 46.8 & 25.3 & 24.3 & 44.8 & 55.2 & 32.1 & 73 & 21.9 & - \\
\hline & IV-V & & & & & & & & & & & & \\
\hline & IX & 39 & 48 & 22.0 & 66.3 & 22.7 & 39.3 & 70.8 & 29.2 & 37.7 & 47.6 & 52.4 & 0.9 \\
\hline & $\mathrm{X}$ & 54 & 71 & 35.3 & 90.3 & 2.3 & 24.0 & 71.5 & 26.2 & 41.3 & 48.2 & 51.6 & - \\
\hline & IX-X & & & & & & & & & & & & \\
\hline \multirow[t]{6}{*}{$\begin{array}{c}\text { Большен } \\
\text { арым }\end{array}$} & IV & 28 & 22 & 42.7 & 82.2 & - & 29.5 & 61.0 & 30.3 & 27.6 & 40.8 & 59.2 & 0.2 \\
\hline & $\mathrm{V}$ & 50 & 33 & 42.1 & 84.9 & 11.5 & 29.1 & 45.7 & 54.7 & 28.8 & 71.0 & 22.5 & - \\
\hline & IV-V & & & & & & & & & & & & \\
\hline & IX & 30 & 29 & 29.1 & 47.2 & 46.9 & 41.7 & 62.2 & 37.8 & 28.2 & 46.7 & 53.3 & 1.0 \\
\hline & $\mathrm{X}$ & 35 & 43 & 38.5 & 77.0 & 2.0 & 18.7 & 91.0 & 9.1 & 42.7 & 36.2 & 63.5 & 0.1 \\
\hline & IX-X & & & & & & & & & & & & \\
\hline \multirow[t]{5}{*}{$\begin{array}{c}\text { Катон- } \\
\text { Карагай }\end{array}$} & IV & 26 & 22 & 47.9 & 77.4 & - & 23.2 & 75.5 & 24.5 & 26.0 & 51.0 & 49.0 & 2.8 \\
\hline & $\mathrm{V}$ & 56 & 48 & 41.8 & 57.4 & 18.4 & 29.2 & 55.0 & 44.9 & 23.9 & 87.8 & 9.4 & 5.2 \\
\hline & IV-V & & & & & & & & & & & & \\
\hline & IX & 36 & 35 & 30.2 & 59.8 & 31.9 & 39.4 & 74.9 & 25.1 & 29.3 & 57.7 & 42.3 & 1.1 \\
\hline & $\mathrm{X}$ & 36 & 34 & 36.3 & 60.5 & 2.9 & 17.7 & 85.0 & 14.6 & 45.8 & 53.2 & 46.8 & 0.2 \\
\hline
\end{tabular}


Приложени е VIII

Связь осадков ( в \% от суммы за период 1961-1970 гг. ) с осадкообразующими типами циркуляции в летнем сезоне (А.В. Егорина, К.И. Попова)

\begin{tabular}{|c|c|c|c|c|c|c|c|c|c|c|c|c|c|}
\hline \multirow{3}{*}{$\begin{array}{l}\text { Метео- } \\
\text { станция }\end{array}$} & \multirow{3}{*}{$\begin{array}{l}\text { Меся- } \\
\text { цы }\end{array}$} & \multicolumn{2}{|c|}{ Осадки } & \multicolumn{9}{|c|}{ Потоки влаги } & \multirow{3}{*}{$\begin{array}{c}\text { Стаци } \\
\text { онир- } \\
\text { ние } \\
\text { цикло } \\
\text { на }\end{array}$} \\
\hline & & \multirow{2}{*}{$\begin{array}{l}\text { нор } \\
\text { ма, } \\
\text { мм }\end{array}$} & \multirow{2}{*}{$\begin{array}{c}\text { из } \\
10 \\
\text { лет }\end{array}$} & \multicolumn{3}{|c|}{ западные } & \multicolumn{3}{|c|}{ северо-западные } & \multicolumn{3}{|c|}{ юго-западные } & \\
\hline & & & & $\%$ & IA & $\begin{array}{l}\text { IIA, } \\
\text { Б }\end{array}$ & $\%$ & $\begin{array}{c}\text { IIIA, } \\
\text { Б }\end{array}$ & IV & $\%$ & VA & VI & \\
\hline 1 & 2 & 3 & 4 & 5 & 6 & 7 & 8 & 9 & 10 & 11 & 12 & 13 & 14 \\
\hline \multicolumn{14}{|c|}{ Рудный Алтай } \\
\hline \multirow{4}{*}{$\begin{array}{l}\text { Шемо- } \\
\text { наиха }\end{array}$} & VI & 48 & $\frac{44}{91 \%}$ & 22.7 & 67.8 & 32.2 & 12.2 & 69.7 & 30.3 & 57.6 & 36.6 & 54.7 & 7.5 \\
\hline & VII & 57 & $\frac{49}{85 \%}$ & 34.4 & 43.0 & 47.0 & 20.8 & - & 85.1 & 39.0 & 54.7 & 45.3 & 5.8 \\
\hline & VIII & 36 & $\frac{48}{133 \%}$ & 21.0 & 56.0 & 24.3 & 33.4 & 45.2 & 44.8 & 44.6 & 24.5 & 75.5 & 1.0 \\
\hline & VI-VIII & 141 & $\frac{141}{100 \%}$ & 26.2 & 53.2 & 36.8 & 22.5 & 44.6 & 55.4 & 46.6 & 37.9 & 58.7 & 4.7 \\
\hline \multirow{4}{*}{$\begin{array}{c}\text { Усть- } \\
\text { Каме- } \\
\text { ногорск }\end{array}$} & VI & 56 & $\frac{36}{64 \%}$ & 26.0 & 78.2 & 21.8 & 11.0 & 61.9 & 38.1 & 59.0 & 49.8 & 42.2 & 4.0 \\
\hline & VII & 60 & $\frac{40}{67 \%}$ & 30.8 & 23.9 & 76.1 & 34.0 & 20.7 & 79.3 & 30.8 & 40.4 & 59.6 & 4.4 \\
\hline & VIII & 43 & $\frac{54}{125 \%}$ & 23.0 & 34.0 & 45.9 & 33.0 & 55.0 & 36.6 & 42.0 & 25.6 & 74.4 & 2.0 \\
\hline & VI-VIII & 159 & $\frac{130}{82 \%}$ & 26.2 & 42.4 & 52.1 & 27.3 & 46.9 & 53.2 & 42.9 & 38.0 & 59.0 & 3.6 \\
\hline \multirow{4}{*}{$\begin{array}{l}\text { Лени- } \\
\text { ногорск }\end{array}$} & VI & 89 & $\frac{73}{82 \%}$ & 27.2 & 83.5 & 26.5 & 19.2 & 57.3 & 42.7 & 49.2 & 54.8 & 45.2 & 4.3 \\
\hline & VII & 102 & $\frac{95}{93 \%}$ & 40.5 & 49.4 & 40.0 & 19.3 & 23.4 & 76.6 & 36.4 & 35.6 & 64.4 & 3.8 \\
\hline & VIII & 72 & $\frac{74}{102 \%}$ & 33.1 & 72.8 & 27.2 & 30.4 & 50.0 & 50.0 & 34.6 & 37.3 & 62.7 & 1.8 \\
\hline & VI-VIII & 263 & $\frac{242}{92 \%}$ & 34.2 & 66.3 & 30.6 & 22.7 & 42.9 & 57.1 & 39.8 & 43.2 & 56.8 & 3.3 \\
\hline
\end{tabular}




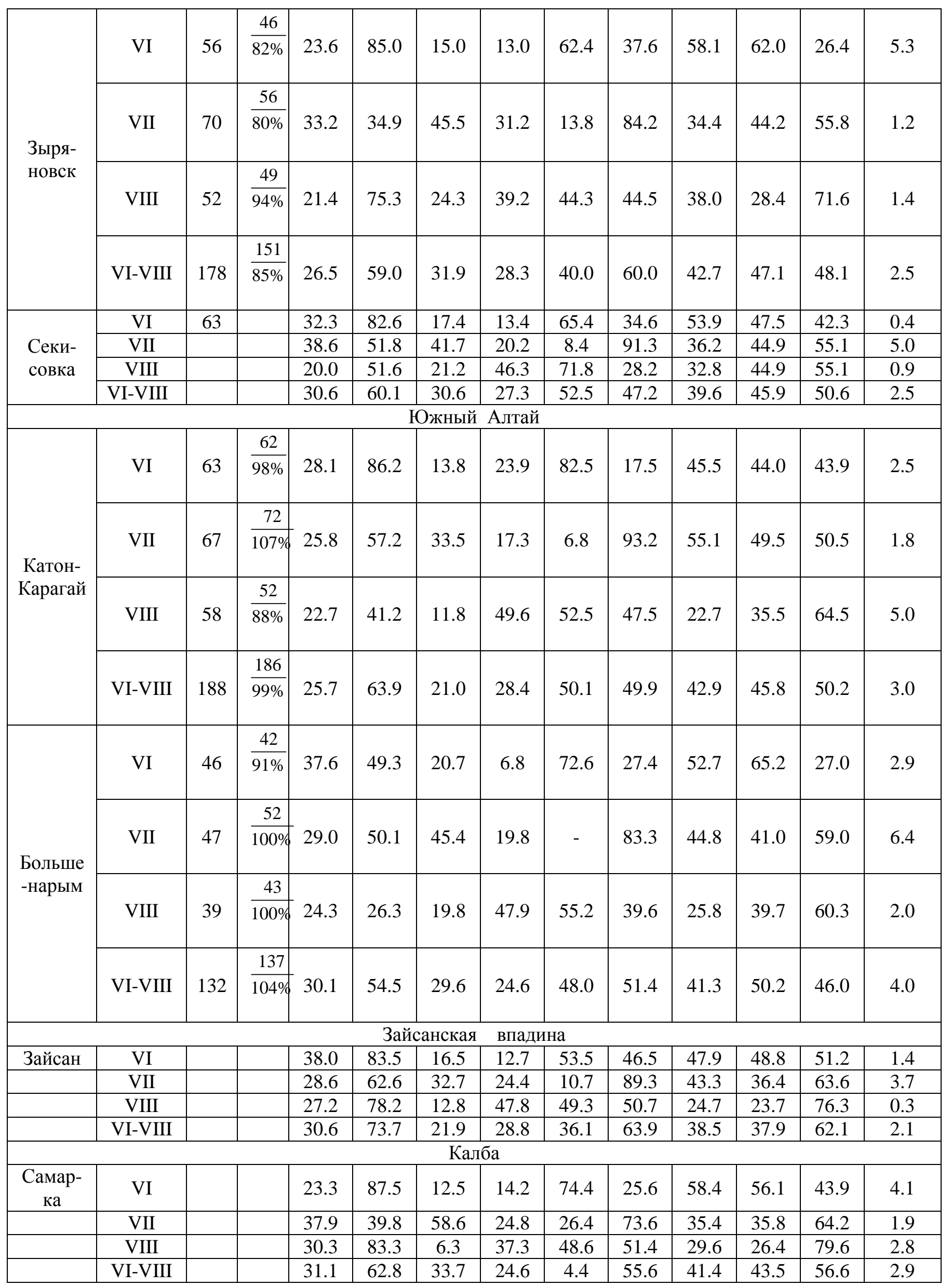


Сезонная структура годового цикла ГТК и его динамика (К.И. Попова, А.Т. Жазнаева)

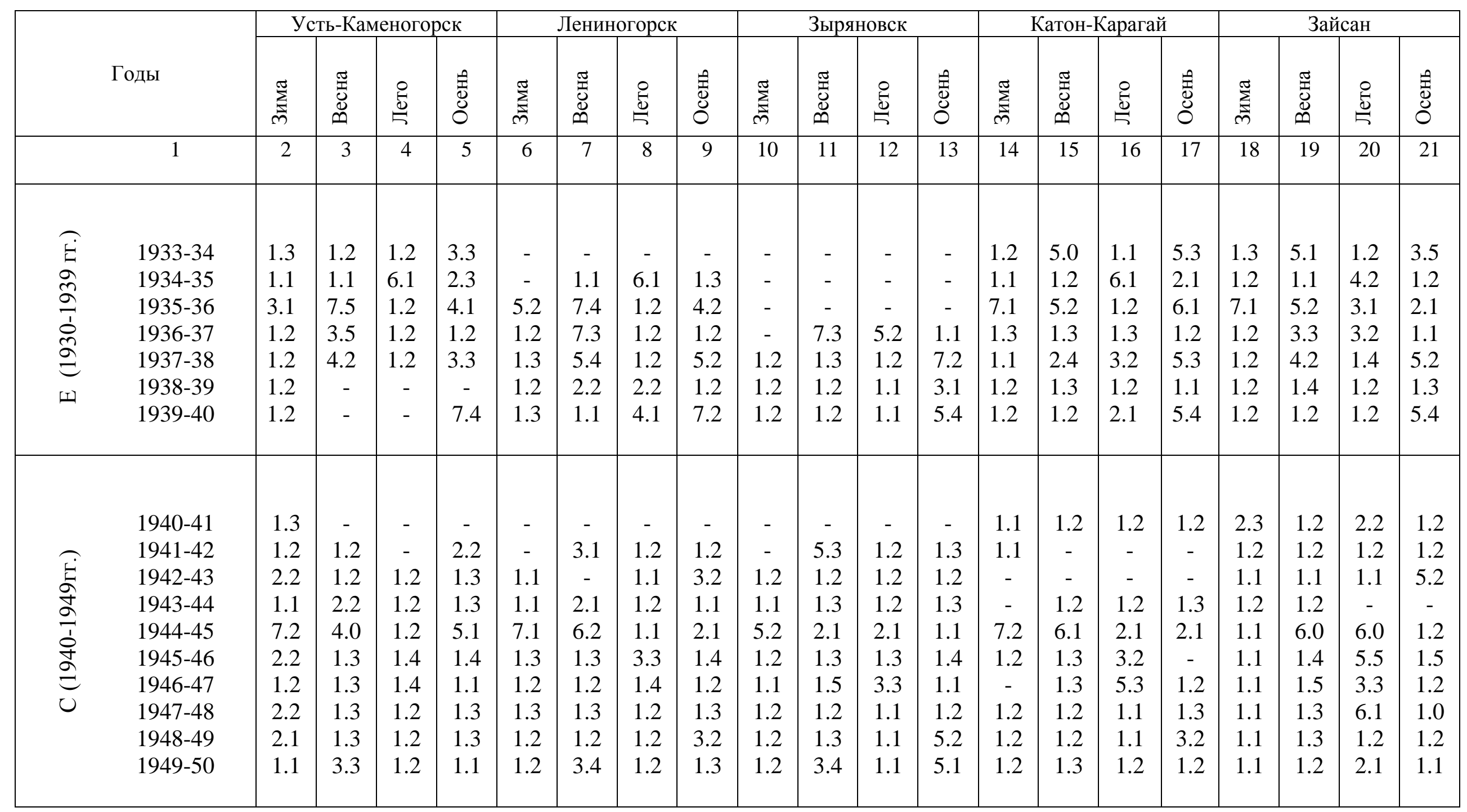




\begin{tabular}{|c|c|c|c|c|c|c|c|c|c|c|c|c|c|c|c|c|c|c|c|c|c|}
\hline & 1 & 2 & 3 & 4 & 5 & 6 & 7 & 8 & 9 & 10 & 11 & 12 & 13 & 14 & 15 & 16 & 17 & 18 & 19 & 20 & 21 \\
\hline \multirow{16}{*}{ 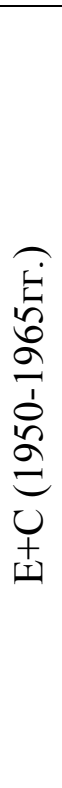 } & $1950-51$ & 5.1 & 4.1 & 1.1 & 1.3 & 5.2 & 4.2 & 1.1 & 1.3 & 5.1 & 2.1 & 2.1 & 2.2 & 7.2 & 1.1 & 1.2 & 1.3 & 7.1 & 2.1 & 2.1 & 1.4 \\
\hline & $1951-52$ & 1.1 & 1.3 & 1.1 & 1.1 & 1.2 & 1.4 & 1.2 & 1.1 & 1.2 & 1.5 & 1.2 & 5.1 & 1.1 & 1.1 & 1.2 & 1.1 & 1.2 & 1.1 & 2.2 & 1.1 \\
\hline & $1952-53$ & 1.1 & 1.0 & 1.2 & 1.1 & 1.1 & 1.1 & 1.1 & 2.1 & 1.2 & 1.0 & 2.1 & 4.2 & 1.2 & 1.1 & 2.1 & 2.2 & 1.2 & 1.1 & 2.1 & 2.1 \\
\hline & $1953-54$ & 3.2 & 7.2 & 3.2 & 1.1 & 1.2 & 7.2 & 1.2 & 1.1 & 1.2 & 3.3 & 1.1 & 1.2 & 1.1 & 5.3 & 3.2 & 1.1 & 1.3 & 3.3 & 3.3 & 1.1 \\
\hline & $1954-55$ & 3.1 & 1.1 & 4.1 & 5.1 & 1.2 & 1.1 & 4.1 & 1.2 & 1.3 & 1.1 & 6.0 & 1.2 & 1.2 & 1.1 & 6.1 & 1.2 & 1.3 & 1.0 & 6.1 & 1.1 \\
\hline & $1955-56$ & 1.1 & 1.3 & 1.2 & 1.0 & 1.1 & 1.2 & 1.3 & 1.1 & 1.2 & 1.4 & 1.5 & 2.1 & 1.1 & 1.2 & 1.3 & 1.3 & 1.2 & 1.2 & 1.1 & 1.2 \\
\hline & $1956-57$ & 1.2 & 3.3 & 1.3 & 1.2 & 1.2 & 5.1 & 1.3 & 1.1 & 1.2 & 3.2 & 1.2 & 1.1 & 1.1 & 5.2 & 3.2 & 1.2 & 1.2 & 3.2 & 1.3 & 1.1 \\
\hline & $1957-58$ & 1.4 & 1.3 & 5.2 & 3.2 & 1.3 & 3.4 & 3.2 & 1.3 & 1.3 & 3.4 & 3.3 & 1.2 & 1.2 & 3.2 & 7.3 & 1.2 & 1.4 & 3.4 & 1.2 & 1.1 \\
\hline & $1958-59$ & 1.1 & 1.3 & 1.4 & 1.1 & 1.1 & 1.3 & 1.2 & 1.1 & 1.2 & 1.3 & 1.5 & 1.1 & 1.1 & 1.2 & 1.2 & 2.1 & 1.2 & 1.2 & 1.3 & 6.1 \\
\hline & $1959-60$ & 3.3 & 7.2 & 3.5 & 3.2 & 1.3 & 5.2 & 3.4 & 3.2 & 1.3 & 7.2 & 3.3 & 3.1 & 3.4 & 7.1 & 5.2 & 3.1 & 1.2 & 5.1 & 3.4 & 1.1 \\
\hline & $1960-61$ & 1.3 & 1.3 & 3.2 & 5.3 & 1.1 & 2.2 & 1.3 & 7.3 & 1.2 & 2.2 & 3.2 & 3.2 & 1.2 & 2.2 & 7.4 & 7.1 & 1.1 & 4.3 & 5.4 & 5.3 \\
\hline & $1961-62$ & 1.3 & 2.1 & 2.1 & 1.3 & 2.1 & 4.1 & 4.1 & 1.2 & 1.2 & 4.1 & 2.1 & 6.2 & 1.2 & 2.1 & 4.1 & 1.1 & 2.1 & 4.1 & 6.0 & 1.1 \\
\hline & $1962-63$ & 4.2 & 3.1 & 1.1 & 1.4 & 4.2 & 5.1 & 1.1 & 1.1 & 2.2 & 1.1 & 1.2 & 1.3 & 4.1 & 5.1 & 1.2 & 1.2 & 2.1 & 1.1 & 1.3 & 1.1 \\
\hline & $1963-64$ & 1.2 & 1.1 & 1.1 & 3.2 & 1.1 & 3.1 & 1.1 & 5.1 & 1.2 & 1.2 & 2.1 & 5.1 & 1.2 & 1.2 & 1.2 & 6.2 & 1.2 & 1.2 & 2.1 & 3.2 \\
\hline & $1964-65$ & 1.3 & 1.1 & 2.2 & 1.3 & 2.2 & 1.0 & 2.3 & 1.2 & 2.2 & 4.1 & 6.2 & 1.4 & 1.2 & 2.1 & 2.1 & 1.2 & 1.2 & 4.2 & 6.1 & 1.4 \\
\hline & $1965-66$ & 1.5 & 5.4 & 1.4 & 5.1 & 1.4 & 3.2 & 1.5 & 2.1 & 1.4 & 5.3 & 1.3 & 2.1 & 1.5 & 7.3 & 1.2 & 2.2 & 1.4 & 5.2 & 1.2 & 1.2 \\
\hline \multirow{14}{*}{ 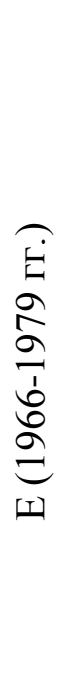 } & $1966-67$ & 5.2 & 2.1 & 3.1 & 1.1 & 1.1 & 4.1 & 3.3 & 1.2 & 3.2 & 4.1 & 1.3 & 1.2 & 1.3 & 2.1 & 3.2 & 1.2 & 3.4 & 5.0 & 1.4 & 1.5 \\
\hline & $1967-68$ & 1.1 & 1.0 & 1.1 & 7.3 & 1.2 & 1.1 & 1.2 & 7.3 & 1.1 & 3.1 & 3.1 & 7.2 & 1.1 & 1.1 & 1.1 & 5.2 & 1.3 & 1.1 & 1.1 & 5.3 \\
\hline & $1968-69$ & 7.4 & 3.2 & 1.3 & 1.4 & 7.4 & 1.3 & 1.1 & 1.4 & 5.3 & 1.3 & 1.2 & 1.3 & 7.3 & 1.1 & 1.2 & 3.5 & 7.3 & 1.4 & 1.3 & 1.5 \\
\hline & $1969-70$ & 1.2 & 1.4 & 1.1 & 1.2 & 1.2 & 1.4 & 1.2 & 1.3 & 1.1 & 1.2 & 1.2 & 1.3 & 1.1 & 1.3 & 3.1 & 1.1 & 1.2 & 1.3 & 1.2 & 1.3 \\
\hline & $1970-71$ & 1.2 & 1.4 & 3.2 & 1.0 & 1.3 & 1.4 & 1.2 & 4.1 & 1.3 & 1.4 & 1.2 & 2.1 & 1.2 & 1.4 & 3.2 & 2.2 & 1.4 & 1.4 & 1.1 & 2.0 \\
\hline & $1971-72$ & 2.4 & 1.4 & 3.2 & 3.2 & 1.2 & 1.2 & 3.1 & 1.2 & 2.3 & 1.3 & 3.2 & 3.2 & 1.1 & 1.3 & 5.2 & 3.2 & 1.3 & 1.3 & 5.3 & 3.3 \\
\hline & $1972-73$ & 1.3 & 1.4 & 1.1 & 1.2 & 1.3 & 1.3 & 1.2 & 1.2 & 2.3 & 1.5 & 1.2 & 1.1 & 1.2 & 1.2 & 1.2 & 1.2 & 1.2 & 1.5 & 1.3 & 1.2 \\
\hline & $1973-74$ & 1.2 & 4.1 & 4.0 & 3.3 & 1.2 & 4.1 & 6.0 & 1.2 & 1.1 & 6.1 & 6.0 & 3.2 & 1.2 & 4.1 & 6.1 & 3.3 & 1.1 & 4.1 & 6.0 & 3.4 \\
\hline & $1974-75$ & 1.2 & 1.5 & 1.1 & 1.4 & 1.2 & 3.3 & 1.1 & 1.3 & 1.2 & 1.3 & 1.1 & 1.4 & 1.1 & 5.2 & 1.1 & 1.2 & 1.1 & 3.2 & 1.1 & 1.1 \\
\hline & $1975-76$ & 1.1 & 1.2 & 1.2 & 3.5 & 1.2 & 1.2 & 1.1 & 3.5 & 1.2 & 1.1 & 1.2 & 3.5 & 1.1 & 1.1 & 1.1 & 3.4 & 1.1 & 2.1 & 1.1 & 3.4 \\
\hline & $1976-77$ & 5.3 & 1.1 & 1.2 & 3.3 & 3.2 & 2.1 & 2.2 & 2.2 & 3.3 & 2.1 & 1.3 & 2.2 & 3.1 & 1.2 & 1.2 & 2.2 & 5.1 & 2.0 & 4.2 & 2.2 \\
\hline & $1977-78$ & 1.3 & 1.1 & 3.3 & 1.1 & 1.2 & 1.1 & 1.2 & 2.1 & 2.2 & 2.2 & 1.2 & 2.1 & 1.2 & 1.2 & 1.2 & 2.2 & 1.2 & 4.2 & 1.1 & 1.2 \\
\hline & $1978-79$ & 2.2 & 5.4 & 1.2 & 1.1 & 1.3 & 3.3 & 1.2 & 1.3 & 2.2 & 5.3 & 1.2 & 2.3 & 1.2 & 3.2 & 1.2 & 2.2 & 1.3 & 3.1 & 1.2 & 1.4 \\
\hline & $1979-80$ & 1.2 & 1.1 & 1.2 & 1.1 & 1.2 & 1.1 & 1.2 & 1.1 & 1.2 & 1.1 & 1.3 & 1.0 & 1.2 & 1.2 & 1.2 & 1.1 & 1.3 & 1.3 & 1.2 & 1.2 \\
\hline
\end{tabular}




\begin{tabular}{|c|c|c|c|c|c|c|c|c|c|c|c|c|c|c|c|c|c|c|c|c|c|}
\hline & 1 & 2 & 3 & 4 & 5 & 6 & 7 & 8 & 9 & 10 & 11 & 12 & 13 & 14 & 15 & 16 & 17 & 18 & 19 & 20 & 21 \\
\hline \multirow{10}{*}{ 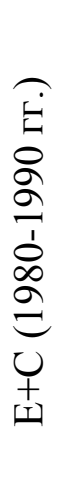 } & $1980-81$ & 2.2 & 2.3 & 1.1 & 1.2 & 1.3 & 4.2 & 1.1 & 1.1 & 4.3 & 6.2 & 2.1 & 1.3 & 1.2 & 4.1 & 2.1 & 1.2 & 4.2 & 4.2 & 2.2 & 1.5 \\
\hline & $1981-82$ & 1.2 & 2.2 & 1.1 & 2.2 & 1.2 & 4.3 & 2.1 & 2.3 & 1.2 & 4.2 & 2.1 & 6.3 & 1.1 & 4.1 & 1.2 & 2.4 & 2.2 & 4.1 & 4.1 & 2.2 \\
\hline & $1982-83$ & 6.2 & 1.4 & 1.1 & 1.2 & 4.2 & 1.3 & 1.1 & 1.2 & 4.2 & 1.5 & 1.1 & 1.2 & 6.2 & 3.4 & 1.2 & 1.2 & 4.2 & 1.3 & 1.4 & 1.3 \\
\hline & $1983-84$ & 1.2 & 1.2 & 3.2 & 1.2 & 1.3 & 1.2 & 1.2 & 1.2 & 1.2 & 1.2 & 1.2 & 1.3 & 1.2 & 3.3 & 3.2 & 1.3 & 1.3 & 1.1 & 1.2 & 1.4 \\
\hline & $1984-85$ & 5.2 & 1.2 & 1.1 & 1.4 & 3.2 & 1.2 & 1.2 & 1.3 & 1.2 & 1.1 & 1.2 & 1.3 & 3.2 & 1.2 & 3.2 & 1.3 & 5.2 & 1.3 & 1.2 & 1.3 \\
\hline & $1985-86$ & 1.2 & 1.2 & 1.1 & 1.2 & 1.1 & 1.2 & 1.1 & 1.2 & 1.2 & 1.1 & 1.1 & 2.2 & 1.1 & 1.2 & 1.1 & 1.3 & 1.2 & 1.2 & 1.1 & 1.5 \\
\hline & $1986-87$ & 1.2 & 1.1 & 1.2 & 3.2 & 1.2 & 1.3 & 1.2 & 5.3 & 1.2 & 1.3 & 1.2 & 5.4 & 1.2 & 1.4 & 1.2 & 7.4 & 1.2 & 1.2 & 1.1 & 3.3 \\
\hline & $1987-88$ & 1.3 & 1.1 & 1.3 & 1.2 & 1.3 & 1.3 & 1.2 & 1.2 & 1.3 & 1.3 & 1.2 & 6.3 & 1.2 & 1.4 & 1.2 & 1.2 & 1.4 & 1.4 & 1.2 & 1.2 \\
\hline & $1988-89$ & 4.1 & 1.3 & 1.1 & 1.3 & 4.2 & 1.2 & 1.1 & 1.3 & 4.2 & 1.3 & 1.1 & 4.2 & 6.1 & 1.1 & 1.1 & 1.3 & 4.1 & 1.1 & 1.1 & 1.4 \\
\hline & $1989-90$ & 4.3 & 1.1 & & & 2.3 & 1.2 & & & 6.4 & 1.3 & & - & 2.2 & 1.2 & - & - & 6.3 & & & \\
\hline
\end{tabular}


Средняя месячная и годовая общая и нижняя облачность (баллы)

\begin{tabular}{|c|c|c|c|c|c|c|c|c|c|c|c|c|c|c|}
\hline Станции & Облачность & I & II & III & IV & $\mathrm{V}$ & VI & VII & VIII & IX & $\mathrm{X}$ & $\mathrm{XI}$ & XII & Год \\
\hline \multicolumn{15}{|c|}{ Рудный $\quad$ Алтай } \\
\hline \multirow[t]{2}{*}{ Шемонаиха } & $\mathrm{O}^{*}$. & 5.6 & 5.6 & 6.0 & 5.9 & 5.5 & 5.2 & 5.0 & 4.7 & 5.0 & 6.4 & 6.9 & 6.8 & 5.7 \\
\hline & H. & 1.7 & 1.7 & 2.1 & 2.9 & 3.1 & 2.8 & 2.9 & 2.6 & 2.6 & 3.5 & 3.1 & 2.6 & 2.6 \\
\hline \multirow[t]{2}{*}{ Лениногорск } & O. & 5.4 & 5.4 & 6.0 & 6.1 & 6.0 & 5.7 & 5.6 & 5.3 & 5.5 & 6.6 & 6.8 & 6.6 & 5.9 \\
\hline & $\mathrm{H}$. & 2.6 & 2.5 & 2.6 & 3.2 & 3.6 & 3.5 & 3.5 & 3.3 & 3.4 & 4.3 & 4.1 & 3.6 & 3.4 \\
\hline \multirow[t]{2}{*}{ Усть-Каменогорск } & $\mathrm{O}$. & 5.7 & 5.5 & 6.0 & 5.9 & 5.6 & 5.2 & 5.2 & 4.8 & 5.0 & 6.4 & 6.9 & 6.7 & 5.7 \\
\hline & H. & 3.0 & 2.9 & 3.0 & 3.4 & 3.1 & 2.8 & 3.0 & 2.9 & 3.1 & 4.2 & 4.2 & 3.9 & 3.3 \\
\hline \multirow[t]{2}{*}{ Пос. Северный } & $\mathrm{O}$. & 5.4 & 5.3 & 6.0 & 5.9 & 5.2 & 5.1 & 4.9 & 4.5 & 4.9 & 6.2 & 6.5 & 6.4 & 5.5 \\
\hline & $\mathrm{H}$. & 2.4 & 2.3 & 3.0 & 3.1 & 2.4 & 2.4 & 2.3 & 2.3 & 2.5 & 3.6 & 3.7 & 3.3 & 2.6 \\
\hline \multicolumn{15}{|c|}{ Ка л ба } \\
\hline \multirow[t]{2}{*}{ Самарка } & $\mathrm{O}$. & 4.9 & 4.8 & 5.1 & 5.0 & 5.1 & 4.8 & 4.7 & 4.3 & 4.0 & 5.1 & 5.9 & 6.0 & 5.0 \\
\hline & H. & 1.7 & 1.4 & 1.3 & 2.0 & 2.6 & 3.0 & 2.9 & 2.6 & 2.3 & 2.6 & 5.9 & 2.5 & 2.3 \\
\hline \multicolumn{15}{|c|}{ Южный Алтай } \\
\hline \multirow[t]{2}{*}{ Большенарымское } & O. & 4.9 & 4.9 & 5.4 & 5.3 & 5.2 & 4.9 & 4.8 & 4.4 & 4.5 & 5.5 & 6.0 & 6.0 & 5.2 \\
\hline & H. & 1.1 & 1.4 & 1.7 & 2.3 & 2.8 & 2.7 & 2.7 & 2.5 & 2.4 & 2.9 & 2.8 & 2.2 & 2.3 \\
\hline \multirow[t]{2}{*}{ Катон-Карагай } & O. & 4.8 & 4.7 & 5.4 & 5.8 & 6.0 & 5.8 & 5.6 & 5.3 & 5.0 & 5.8 & 6.0 & 5.8 & 5.5 \\
\hline & $\mathrm{H}$. & 0.5 & 0.5 & 1.1 & 2.3 & 2.6 & 3.1 & 3.0 & 2.9 & 2.2 & 2.6 & 1.7 & 1.0 & 2.0 \\
\hline \multirow[t]{2}{*}{ Пос. Орловский } & $\mathrm{O}$. & 4.9 & 5.1 & 5.3 & 5.5 & 5.5 & 5.6 & 5.6 & 5.3 & 4.7 & 5.3 & 5.8 & 5.8 & 5.4 \\
\hline & H. & 1.5 & 1.4 & 1.6 & 2.1 & 2.6 & 3.0 & 3.2 & 3.3 & 2.6 & 2.6 & 2.6 & 1.9 & 2.4 \\
\hline \multirow[t]{2}{*}{ Курчум (Кумашкино) } & $\mathrm{O}$. & 4.9 & 5.0 & 5.4 & 5.1 & 5.1 & 4.8 & 4.5 & 4.0 & 4.0 & 5.1 & 5.8 & 5.8 & 5.0 \\
\hline & $\mathrm{H}$. & 1.6 & 1.5 & 1.7 & 2.1 & 2.4 & 2.5 & 2.5 & 2.1 & 2.0 & 2.6 & 3.1 & 2.5 & 2.2 \\
\hline \multicolumn{15}{|c|}{ Зайсанская } \\
\hline \multirow[t]{2}{*}{ Зайсан } & O. & 4.6 & 5.0 & 5.6 & 5.5 & 5.6 & 5.3 & 4.9 & 4.5 & 4.1 & 5.0 & 5.7 & 5.6 & 5.1 \\
\hline & H. & 1.9 & 1.9 & 2.5 & 2.6 & 2.8 & 2.7 & 2.6 & 2.4 & 2.2 & 2.4 & 3.1 & 2.6 & 2.5 \\
\hline \multirow[t]{2}{*}{ Буран } & O. & 5.0 & 5.5 & 5.4 & 5.4 & 5.2 & 5.1 & 4.9 & 4.5 & 4.1 & 5.0 & 5.6 & 5.8 & 5.1 \\
\hline & H. & 1.1 & 1.2 & 1.5 & 1.9 & 1.9 & 2.0 & 2.1 & 1.8 & 1.6 & 2.1 & 2.5 & 1.8 & 1.8 \\
\hline
\end{tabular}

* Примечание: О. - общая облачность; Н. - нижняя облачность (облака нижнего яруса и вертикального развития). 
Показатели увлажнения (влагообеспечения) территории и коэффициент снежности

\begin{tabular}{|c|c|c|c|}
\hline $\begin{array}{l}\text { Автор: Будыко М.И. - Григорьев А.А. } \\
\text { Формула: К }=\frac{B}{L r}\end{array}$ & $\begin{array}{l}\text { Иванов Н.Н. } \\
\qquad \mathrm{K}=\frac{r}{E_{o}}\end{array}$ & $\begin{array}{l}\text { Селянинов Г.Т. К } \\
\text { ГТК }=\frac{\sum r}{\sum t^{o}: 10}\end{array}$ & $\begin{array}{l}\text { Осокин И.М. } \\
\mathrm{K}=\frac{T_{y c m} H_{c p} .}{100}\end{array}$ \\
\hline От 0,3 до 0,5 - избыточное увлажнение (тундра) & $\begin{array}{l}\text { От } 1,5 \text { и > } 1,5-\text { зона } \\
\text { избыточного увлажнения }\end{array}$ & $0,5-$ сухо & 3 - почти бесснежные зимы \\
\hline От 0,5 до 1,1 - оптимальное увлажнение (лес) & \begin{tabular}{lrrr} 
От 1,0 до & 1,5 & - & зона \\
достаточного & увлажнения. В \\
умеренных & \multicolumn{3}{c}{ широтах } \\
формируются & хвойные \\
лиственные леса
\end{tabular} & $\begin{array}{l}0,5-1,0-\text { засушливо } \\
1,0-1,5-\text { достаточное } \\
\text { увлажнение }\end{array}$ & 8-20 малоснежные \\
\hline $\begin{array}{l}\text { От } 1,1 \text { до } 2,3-\text { умеренно-недостаточное } \\
\text { увлажнение (лесостепь, степь) }\end{array}$ & 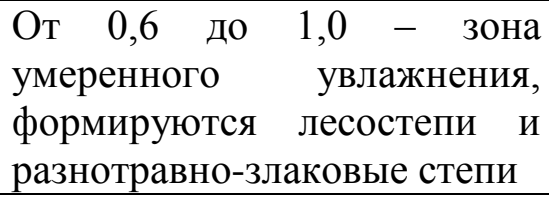 & $\begin{array}{l}>1,5-\text { избыточное } \\
\text { увлажнение }\end{array}$ & $\begin{array}{l}\text { 20-40 умеренно снежные } \\
\text { 40-70 значительно снежные }\end{array}$ \\
\hline $\begin{array}{l}\text { От } 2,4 \text { до } 3,4 \text { - недостаточное увлажнение } \\
\text { (полупустыня умеренного пояса) }\end{array}$ & $\begin{array}{lr}\text { От } 0,30 \text { до } & 0,60-\text { зона } \\
\text { слабого } & \text { увлажнения, } \\
\text { формируются } & \text { ландшафты } \\
\text { степей } & \\
\end{array}$ & & 70-120 многоснежные \\
\hline $\begin{array}{l}>3,4-\text { крайне недостаточное увлажнение } \\
\text { (пустыня умеренного пояса) }\end{array}$ & 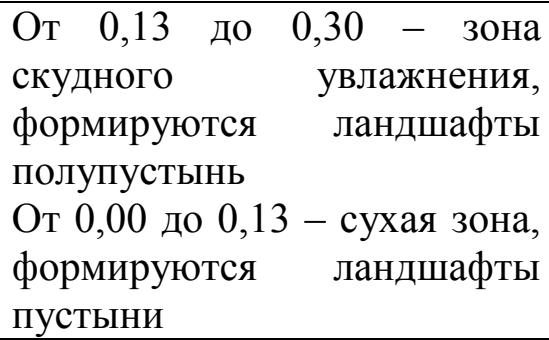 & & 120-200 очень многоснежные \\
\hline
\end{tabular}

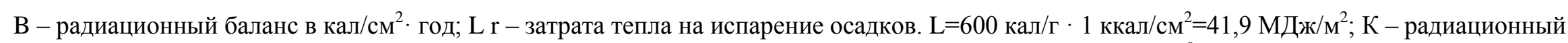
индекс сухости; $\mathrm{r}$ - сумма осадков в мм/ за год; $\mathrm{E}_{0}$ - испаряемость в мм/ за год; К - коэффициент увлажнения; $\sum \mathrm{t}^{0}-$ сумма эффективных температур (выше $\left.10^{0}\right) ; \sum \mathrm{r}$ - сумма осадков за период активной вегетации $\left(\mathrm{t}^{0} \mathrm{C}>10^{0}\right)$; ГТК - гидротермический коэффициент; Т уст. - продолжительность устойчивости покрова в днях; $\mathrm{H}_{\text {cp. }}$ - средняя высота снежного покрова в см; К - коэффициент снежности для удобства берется в сотнях единиц. 


\title{
Характеристика основных типов ландшафтов
}

\author{
ГОРНЫЕ ЛАНДШАФТЫ
}

Нивальнье ландмафтьл:

375 Высокогорные с альпийскими формами рельефа, современным оледенением, сложенное гранитами, гранодиоритами, габбро, с единичными цветковыми растениями, лишайниками, мхами.

\section{Луговые ландиафтыл:}

376 Среднегорье поверхностей выравнивания, сложенное песчаниками, кварцитами, известняками, гранитами, с субальпийскими и альпийскими лугами на горно-луговых почвах и лугами-сазами на сазовых луговых почвах.

377 Высокогорье с останцами поверхностей выравнивания сдревнеледниковыми формами рельефа, с субальпийскими и альпийскими лугами на горно-луговых и высокогорных степных почвах.

ЛЕСНЫЕ ЛАНДШАФТЫ

Низкогорные ландмафты:

378 Низкогорье холмисто-увалистое, сложенное гранитами, с сосновыми лесами на горных каштановых почвах.

381 Низкогорье увалистое, сложенное эффузивно-осадочной толщей, с пихтовыми лесами и участками лесов на горно-лесных (кислых) неоподзоленных и горно-луговых почвах.

385 Низкогорье увалистое, сложенное порфиритами, туфами, туфопесчаниками, с березово-осиновыми лесами и луговыми степями на горных черноземах, лесных и лугово-степных почвах.

Среднегорные ландмафты:

387 Среднегорье грядовое, сложенное осадочно-эффузивной толщей, с горными лиственничными лесами и кустарниками на горных черноземах и горно-лесных почвах.

389 Тоже, грядово-гривистое, с пихтовыми лесами, участками лугов на горно-лесных (кислых неоподзоленных) и горно-луговых почвах. 
390 Тоже, с лиственничными лесами на горно-лесных оподзоленных почвах.

391 Среднегорье увалисто-грядовое, сложенное осадочно-эффузивными породами с пихтовыми лесами на горно-лесных серых оподзоленных почвах.

СТЕПНЫЕ ЛАНДШАФТЫ

\section{Предгорные ландшафты:}

393 Предгорная аллювиально-пролювиальная равнина, сложенная суглинками, гравийно-щебнистым материалом, с тырсовой растительностью на каштановых почвах.

394 Предгорья холмисто-увалистые, сложенные эффузивно-осадочными породами, с кустарниково-типчаково-красноковыльной растительностью с березовыми колками на черноземах обыкновенных выщелоченных.

395 Предгорья увалисто-грядовые, сложенные гранитами, гранодиоритами, с кустарниково-овсецово-красноковыльной растительностью на черноземах обыкновенных, выщелоченных и оподзоленных.

396 Предгорное увалистое плато, сложенное эффузивно-осадочными породами, с кустарниково-типчаково-красноковыльной растительностью на черноземах южных нормальных.

397 Предгорное холмисто-увалистое плато, сложенное эффузивно-осадочными породами, с кустарниково-овсецово-красноковыльной растительностью на черноземах южных нормальных.

400 Предгорья мелкосопочные, сложенные эффузивно-осадочными породами с кустарниково-овсецово-красноковыльной растительностью на горнокаштановых почвах.

402 Тоже, с кустарниково-типчаково-красноковыльной растительностью на обыкновенных черноземах.

403 Предгорье мелкосопочное, сложенное осадочно-эффузивными отложениями, с кустарниково-лесинговиднополынно-ковыльной растительностью на каштановых малоразвитых почвах в сочетании с солонцами.

404 Предгорье увалистое, сложенное лессовидными суглинками валунногалечниками, с кустарниково-полынно-тырсовой растительностью на темнокаштановых почвах. 


\section{Низкогорные ландмафты:}

408 Низкогорье грядово-увалистое, сложенное осадочно-вулюаногенными породами, гранитами, с типчаковой и ковыльно-типчаковой горной растительностью, с участием кустарников разнотравных лугов на горных каштановых почвах.

410 Тоже, с кустарниково-злаковой растительностью, на горных каштановых почвах.

411 Низкогорье увалисто-холмистое, сложенное песчаниками, туфопесчаниками, туфопорфиритами с кустарниково-овсецово-красноковыльной и кустарниково-типчаково-красноковыльной растительностью на горных черноземах и горно-каштановых почвах.

413 Тоже, с крупнозлаковой растительностью (разнотравной) и кустарниками на горных каштановых почвах.

\section{Среднегорные ландиафтыл:}

433 Среднегорье складчато-горстовое, сложенное порфиритами, туфами, песчаниками, с типчаковой и типчаково-ковыльной горной растительностью с участием кустарников, разнотравных лугов на горных черноземах и горных каштановых почвах.

\section{ЛАНДШАФТЫ ВНУТРИГОРНЫХ И МЕЖГОРНЫХ ВПАДИН}

437 Внутригорная аллювиально-пролювиальная равнина, сложенная суглинками, валунно-калечниками, с полынно-ковыльно-тырсовой растительностью и разнотравно-злаковыми лугами на горных каштановых почвах.

440 Межгорная аллювиальная равнина, сложенная суглинками, песками, глинами, с разнотравно-злаковой растительностью на луговых почвах с солонцами.

ПОЛУПУСТЫННЫЕ ЛАНДШАФТЫ

\section{Предгорные ландмафты:}

442 Предгорная аллювиально-пролювиальная равнина, сложенная суглинками, валунно-галечниками, с кустарниково-полынно-тырсовой растительностью на каштановых и горных каштановых почвах. 
443 Тоже, с полынно-тырсовой растительностью на светло-каштановых почвах.

444 Предгорная увалистая равнина, сложенная глинами, песками, с полынной растительностью и участием кустарников на светло-каштановых почвах.

\section{Низкогорные ландшафты:}

457 Низкогорье, сложенное песчаниками, конгломератами, эффузивами, туфами, с кустарниково-полынно-типчаковой растительностью на горных каштановых неполноразвитых почвах.

\section{Ландмафты внутригорных и межгорных впадин:}

461 Межгорная золовая равнина, сложенная песками, с разнотравно-полынноеркеновой растительностью с участием сосны на серо-бурых почвах и песках.

\section{ПУСТЫННЫЕ ЛАНДШАФТЫ}

\section{Ландшафты внутригорных и межгорных впадин:}

472 Межгорная озерно-аллювиальная равнина, сложенная суглинками, супесями, глинами и сарсазановой, карбараковой, обионовой растительностью на серо-бурых нормальных, лугово-бурых и лугово-сероземных почвах с луговыми солонцами.

473 Межгорная золовая равнина, с эфемеровыми, терескеновыми, серополынными и жузгуновыми группировками на песках в сочетании с солонцами и такыровидными почвами.

Долинные ландмафты:

477 Поймы, сложенные глинами, суглинками, песками, с разнотравнозлаковыми лугами и мелколиственными лесами на пойменно-луговых почвах.

478 Поймы, сложенные глинами, суглинками, песками, с разнотравнозлаковыми лугами, зарослями ивы на аллювиальных почвах.

481 Поймы, сложенные суглинками, супесями, с гиевыми, волоснецовыми, ажрековыми лугами на аллювиальных почвах.

485 Поймы, сложенные суглинками, песками с тугаями на аллювиальнолуго- вых почвах. 
Сеть метеорологических станций Восточно-Казахстанской области

\begin{tabular}{|c|c|c|c|c|c|c|c|}
\hline \multirow{2}{*}{ № } & \multirow{2}{*}{ Наименование станций } & \multirow{2}{*}{ Район } & \multicolumn{2}{|c|}{ Координаты } & \multirow[t]{2}{*}{ Высота, м } & \multirow{2}{*}{$\begin{array}{c}\text { Год } \\
\text { открытия } \\
\end{array}$} & \multirow{2}{*}{ Примечание } \\
\hline & & & Широта & Долгота & & & \\
\hline 1 & Большенарымское & Большенарымский & $49^{\circ} 12^{\prime}$ & $84^{\circ} 31^{\prime}$ & 400 & 1931 & \\
\hline 2 & Зайсан & Зайсанский & $47^{\circ} 28^{\prime}$ & $84^{\circ} 52^{\prime}$ & 603 & 1876 & \\
\hline 3 & Зыряновск & Зяряновский & $49^{\circ} 48^{\prime}$ & $84^{\circ} 13^{\prime}$ & 458 & 1887 & \\
\hline 4 & Катон-Карагай & Катон-Карагайский & $49^{\circ} 08^{\prime}$ & $85^{\circ} 40^{\prime}$ & 1081 & 1898 & \\
\hline 5 & Курчум & Курчумский & $48^{\circ} 35^{\prime}$ & $83^{\circ} 39^{\prime}$ & 425 & 1936 & \\
\hline 6 & Лениногорск & Глубоковский & $50^{\circ} 20^{\prime}$ & $83^{\circ} 33^{\prime}$ & 809 & 1930 & \\
\hline 7 & Пос. Орловский & Маркакольский & $48^{\circ} 42^{\prime}$ & $86^{\circ} 29^{\prime}$ & 1081 & 1908 & \\
\hline 8 & Приозерный & Тарбагатайский & $47^{\circ} 45^{\prime}$ & $84^{\circ} 13^{\prime}$ & - & 1931 & $\begin{array}{c}\text { В } 1993 \text { г. } \\
\text { переим. В } \\
\text { Тугыл }\end{array}$ \\
\hline 9 & Самарка & Самарский & $49^{\circ} 02^{\prime}$ & $83^{\circ} 24^{\prime}$ & 497 & 1923 & \\
\hline 10 & Селезневка & Серебрянский & $49^{\circ} 36^{\prime}$ & $83^{\circ} 29^{\prime}$ & - & 1962 & \\
\hline 11 & Усть-Каменогорск & Глубоковский & $49^{\circ} 57^{\prime}$ & $82^{\circ} 34^{\prime}$ & 284 & 1899 & \\
\hline 12 & Шемонаиха & Шемонаихинский & $50^{\circ} 38^{\prime}$ & $81^{\circ} 55^{\prime}$ & 329 & 1934 & \\
\hline 13 & Акжар & Тарбагатайский & $47^{\circ} 34^{\prime}$ & $83^{\circ} 42^{\prime}$ & & 1961 & \\
\hline 14 & Маркакольский заповедник & Маркакольский & $48^{\circ} 47^{\prime}$ & $86^{\circ} 02^{\prime}$ & 1410 & 1982 & \\
\hline 15 & Буран & Маркакольский & $48^{\circ} 00^{\prime}$ & $85^{\circ} 12^{\prime}$ & 414 & 1937 & $\begin{array}{c}\text { Закрыта в } 1992 \\
\text { г. }\end{array}$ \\
\hline 16 & Алексеевка & Маркакольский & $48^{\circ} 25^{\prime}$ & $85^{\circ} 43^{\prime}$ & - & 1970 & \\
\hline 17 & Гагарино & Таврический & $50^{\circ} 11^{\prime}$ & $81^{\circ} 53^{\prime}$ & - & 1956 & \\
\hline
\end{tabular}


Средне количество осадков, приведенное к показаниям осадкомера, мм (Восточно-Казахстанская область)

\begin{tabular}{|c|c|c|c|c|c|c|c|c|c|c|c|c|c|c|c|c|}
\hline № & Станция & I & II & III & IV & $\mathrm{V}$ & VI & VII & VIII & IX & $\mathrm{X}$ & XI & XII & XI-III & IV-X & Год \\
\hline 1 & Большие Пороги & 53 & 48 & 58 & 81 & 82 & 89 & 81 & 59 & 51 & 118 & 99 & 95 & 353 & 561 & 914 \\
\hline 2 & Уба - Большие Пороги & 46 & 39 & 71 & 45 & 92 & 67 & 84 & 71 & 90 & 102 & 90 & 50 & 296 & 551 & 847 \\
\hline 3 & Шемонаиха & 17 & 16 & 18 & 29 & 45 & 48 & 57 & 36 & 29 & 40 & 34 & 29 & 114 & 284 & 398 \\
\hline 4 & Камешки & 24 & 25 & 37 & 28 & 47 & 60 & 74 & 45 & 34 & 50 & 47 & 31 & 164 & 338 & 502 \\
\hline 5 & Александровка & 44 & 44 & 44 & 59 & 83 & 72 & 97 & 65 & 39 & 96 & 85 & 74 & 291 & 511 & 802 \\
\hline 6 & Лениногорск & 13 & 10 & 18 & 42 & 89 & 89 & 102 & 72 & 67 & 62 & 41 & 25 & 107 & 523 & 630 \\
\hline 7 & Быструха & 27 & 25 & 28 & 46 & 71 & 77 & 90 & 57 & 46 & 63 & 54 & 46 & 180 & 450 & 630 \\
\hline 8 & Орловка & 53 & 46 & 38 & 72 & 73 & 82 & 77 & 62 & 53 & 84 & 84 & 76 & 297 & 503 & 800 \\
\hline 9 & Секисовка & 25 & 26 & 41 & 50 & 57 & 53 & 82 & 48 & 32 & 93 & 54 & 48 & 194 & 415 & 609 \\
\hline 10 & Громотуха & 12 & 12 & 18 & 33 & 55 & 69 & 87 & 53 & 42 & 59 & 22 & 15 & 79 & 398 & 477 \\
\hline 11 & Красный Яр & 21 & 22 & 32 & 32 & 34 & 25 & 34 & 41 & 35 & 53 & 42 & 27 & 144 & 254 & 398 \\
\hline 12 & Проходной Белок & 29 & 27 & 66 & 53 & 102 & 125 & 172 & 104 & 119 & 137 & 96 & 60 & 278 & 812 & 1090 \\
\hline 13 & Малая Ульба & 61 & 95 & 137 & 90 & 162 & 108 & 183 & 101 & 162 & 154 & 151 & 112 & 556 & 960 & 1516 \\
\hline 14 & Зерносовхоз им. Калинина & 11 & 10 & 16 & 20 & 28 & 27 & 38 & 27 & 18 & 20 & 25 & 18 & 80 & 178 & 258 \\
\hline 15 & Семипалатинское опытное поле & 15 & 12 & 15 & 13 & 24 & 32 & 35 & 23 & 18 & 24 & 24 & 18 & 84 & 169 & 253 \\
\hline 16 & Ульба - Перевалочная & 39 & 27 & 28 & 24 & 55 & 55 & 69 & 51 & 38 & 53 & 54 & 53 & 201 & 355 & 556 \\
\hline 17 & Сержиха & 29 & 35 & 46 & 69 & 81 & 74 & 75 & 64 & 44 & 99 & 74 & 63 & 247 & 506 & 753 \\
\hline 18 & Усть-Каменогорск & 20 & 22 & 29 & 31 & 43 & 56 & 60 & 43 & 29 & 43 & 44 & 35 & 150 & 305 & 455 \\
\hline 19 & $\begin{array}{l}\text { Учебное } \\
\text { педагогического техникума }\end{array}$ & 31 & 30 & 41 & 29 & 49 & 50 & 75 & 46 & 46 & 61 & 63 & 35 & 200 & 356 & 556 \\
\hline 20 & Кутиха & 54 & 38 & 39 & 49 & 78 & 78 & 97 & 72 & 54 & 75 & 76 & 75 & 282 & 503 & 785 \\
\hline 21 & Пос. Северный & 24 & 20 & 29 & 47 & 60 & 75 & 71 & 56 & 51 & 51 & 48 & 44 & 165 & 411 & 576 \\
\hline 22 & Усть-Каменогорская ферма & 22 & 23 & 31 & 33 & 46 & 60 & 64 & 46 & 31 & 46 & 48 & 38 & 162 & 326 & 488 \\
\hline 23 & Пос. Васильевский & 8 & 9 & 19 & 23 & 38 & 39 & 69 & 36 & 36 & 46 & 21 & 14 & 71 & 287 & 358 \\
\hline 24 & Зыряновское & 39 & 27 & 28 & 35 & 56 & 56 & 70 & 52 & 39 & 54 & 55 & 54 & 203 & 362 & 565 \\
\hline 25 & Огневка & 18 & 20 & 27 & 29 & 40 & 52 & 55 & 39 & 27 & 40 & 41 & 32 & 138 & 282 & 420 \\
\hline 26 & Бухтарма & 19 & 20 & 28 & 30 & 41 & 54 & 57 & 41 & 28 & 41 & 42 & 33 & 142 & 292 & 434 \\
\hline 27 & Бухтарминская & & & & & & & & & & & & & & & \\
\hline 28 & Никитинка & 21 & 18 & 21 & 25 & 32 & 38 & 42 & 33 & 29 & 33 & 44 & 30 & 134 & 232 & 366 \\
\hline
\end{tabular}




\begin{tabular}{|c|c|c|c|c|c|c|c|c|c|c|c|c|c|c|c|c|}
\hline \multicolumn{17}{|c|}{ Продолжение приложения XIV } \\
\hline 29 & Средигорное & 25 & 25 & 33 & 36 & 49 & 64 & 69 & 49 & 33 & 49 & 51 & 40 & 174 & 349 & 523 \\
\hline 30 & Сенное & 46 & 32 & 33 & 41 & 66 & 66 & 82 & 60 & 45 & 63 & 64 & 63 & 238 & 423 & 661 \\
\hline 31 & Усть-Язовая & 27 & 21 & 24 & 42 & 67 & 67 & 84 & 63 & 46 & 65 & 47 & 38 & 157 & 434 & 591 \\
\hline 32 & Таинты & 11 & 10 & 12 & 27 & 38 & 57 & 69 & 46 & 23 & 24 & 23 & 16 & 72 & 284 & 356 \\
\hline 33 & Белая & 21 & 16 & 18 & 34 & 74 & 83 & 88 & 76 & 47 & 46 & 36 & 29 & 120 & 448 & 568 \\
\hline 34 & Берель & 20 & 15 & 17 & 33 & 71 & 80 & 85 & 73 & 45 & 44 & 34 & 28 & 114 & 431 & 545 \\
\hline 35 & Печи & 20 & 15 & 17 & 32 & 70 & 79 & 83 & 72 & 45 & 44 & 34 & 28 & 114 & 425 & 539 \\
\hline 36 & Черновая & 13 & 10 & 11 & 21 & 45 & 51 & 54 & 47 & 29 & 28 & 22 & 18 & 74 & 275 & 349 \\
\hline 37 & Урыль & 17 & 12 & 14 & 27 & 58 & 65 & 69 & 59 & 37 & 36 & 28 & 23 & 94 & 351 & 445 \\
\hline 38 & Большенарымское & 16 & 13 & 16 & 28 & 50 & 46 & 47 & 39 & 30 & 35 & 28 & 24 & 97 & 275 & 372 \\
\hline 39 & Катон-Карагай & 16 & 12 & 14 & 26 & 56 & 63 & 67 & 58 & 36 & 35 & 27 & 22 & 91 & 341 & 432 \\
\hline 40 & Самарка & 21 & 17 & 21 & 25 & 32 & 38 & 42 & 33 & 29 & 33 & 44 & 30 & 133 & 232 & 265 \\
\hline 41 & Джумба & 22 & 17 & 23 & 26 & 38 & 45 & 48 & 39 & 26 & 32 & 49 & 40 & 151 & 254 & 405 \\
\hline 42 & Баты & 19 & 15 & 15 & 18 & 38 & 43 & 46 & 40 & 25 & 24 & 28 & 28 & 105 & 234 & 339 \\
\hline 43 & Пос. Александровский & 34 & 26 & 22 & 20 & 35 & 48 & 50 & 35 & 30 & 32 & 48 & 42 & 172 & 250 & 422 \\
\hline 44 & Урунхай & 27 & 25 & 23 & 28 & 42 & 60 & 89 & 67 & 38 & 39 & 37 & 37 & 149 & 363 & 512 \\
\hline 45 & Еловка & 31 & 29 & 27 & 14 & 29 & 40 & 74 & 45 & 29 & 29 & 40 & 35 & 162 & 260 & 422 \\
\hline 46 & Пос. Орловский & 17 & 16 & 15 & 18 & 27 & 38 & 57 & 43 & 24 & 25 & 24 & 24 & 96 & 232 & 328 \\
\hline 47 & Маркаколь & 37 & 34 & 32 & 15 & 32 & 45 & 84 & 51 & 32 & 32 & 48 & 42 & 193 & 291 & 484 \\
\hline 48 & Вознесенское & 12 & 12 & 15 & 26 & 33 & 31 & 29 & 23 & 21 & 27 & 33 & 19 & 91 & 190 & 281 \\
\hline 49 & Курчум (Кумашкино) & 12 & 12 & 14 & 24 & 30 & 29 & 27 & 21 & 19 & 25 & 30 & 18 & 86 & 175 & 261 \\
\hline 50 & Алексеевка & 16 & 14 & 14 & 17 & 25 & 35 & 52 & 39 & 22 & 23 & 22 & 22 & 88 & 213 & 301 \\
\hline 51 & Энбек (Каратогай) & 12 & 9 & 12 & 18 & 23 & 20 & 22 & 17 & 15 & 23 & 22 & 17 & 72 & 138 & 210 \\
\hline 52 & Черняевка & 10 & 8 & 11 & 16 & 19 & 17 & 19 & 15 & 13 & 19 & 19 & 14 & 62 & 118 & 180 \\
\hline 53 & Рождественское & 5 & 4 & 8 & 9 & 15 & 17 & 14 & 11 & 8 & 8 & 11 & 9 & 37 & 82 & 119 \\
\hline 54 & Буран & 10 & 9 & 12 & 16 & 20 & 18 & 19 & 15 & 13 & 20 & 21 & 16 & 68 & 121 & 189 \\
\hline 55 & Тополев Мыс & 9 & 7 & 12 & 14 & 17 & 22 & 21 & 12 & 10 & 14 & 15 & 10 & 53 & 110 & 163 \\
\hline 56 & Акжар & 8 & 6 & 16 & 24 & 22 & 29 & 31 & 23 & 13 & 21 & 17 & 21 & 68 & 163 & 231 \\
\hline 57 & Зайсанская ферма & 6 & 5 & 11 & 19 & 32 & 36 & 30 & 22 & 18 & 18 & 13 & 10 & 45 & 175 & 220 \\
\hline 58 & Благодарненское & 10 & 8 & 16 & 16 & 28 & 31 & 26 & 20 & 15 & 15 & 20 & 16 & 70 & 151 & 221 \\
\hline 59 & Зайсан & 9 & 9 & 16 & 28 & 40 & 41 & 37 & 27 & 23 & 24 & 21 & 16 & 71 & 220 & 291 \\
\hline 60 & Пос. Рюриковский & 9 & 8 & 13 & 24 & 36 & 45 & 48 & 27 & 25 & 18 & 7 & 5 & 42 & 223 & 265 \\
\hline
\end{tabular}


Прило жени е $\mathrm{X} \mathrm{V}$

Распределение озер Восточно-Казахстанской области по площадям

\begin{tabular}{|c|c|c|c|}
\hline \multirow{2}{*}{ Площадь, км } & \multirow{2}{*}{ Количество озер } & \multicolumn{2}{|c|}{ Общая площадь } \\
\cline { 3 - 4 } & & км $^{2}$ & $\%$ \\
\hline 0.01 до 0.1 & 893 & 25.73 & 4.87 \\
\hline 0.11 до 0.2 & 51 & 7.58 & 1.43 \\
\hline 0.21 до 0.3 & 22 & 5.59 & 0.06 \\
\hline 0.31 до 0.4 & 4 & 1.44 & 0.54 \\
\hline 0.41 до 0.5 & 6 & 2.83 & 0.32 \\
\hline 0.51 до 0.6 & 3 & 1.72 & 0.12 \\
\hline 0.61 до 0.7 & 1 & 0.65 & 0.45 \\
\hline 0.71 до 0.8 & 3 & 2.40 & 0.17 \\
\hline 0.81 до 0.9 & 1 & 0.90 & 5.18 \\
\hline 0.91 до 1.0 & 1 & 0.95 & - \\
\hline 1.01 до 5 & 17 & 28.55 & - \\
\hline 5.01 до 10 & - & - & - \\
\hline 10.01 до 50 & - & - & 85.17 \\
\hline 50.01 до 100 & - & - & 100 \\
\hline Свыше 100 & 1 & 449.83 & 528 \\
\hline Итого: & 1003 & & \\
\hline
\end{tabular}


Средняя месячная и годовая температура воздуха (по 108)

\begin{tabular}{|c|c|c|c|c|c|c|c|c|c|c|c|c|c|c|}
\hline № & Станция & $\mathrm{I}$ & II & III & IV & $\mathrm{V}$ & VI & VII & VIII & IX & $\mathrm{X}$ & XI & XII & Год \\
\hline 1 & Шемонаиха & -18.2 & -17.6 & -10.2 & 2.2 & 11.7 & 17.6 & 19.6 & 17.6 & 11.5 & 3.2 & -7.8 & -15.2 & 1.2 \\
\hline 2 & Лениногорск & -12.9 & -12.7 & -7.3 & 2.1 & 9.7 & 15.1 & 16.7 & 15.1 & 9.6 & 2.0 & -7.8 & -12.2 & 1.5 \\
\hline 3 & Секисовка & -18.7 & -17.7 & -10.4 & 0.9 & 10.6 & 16.1 & 18.2 & 16.2 & 9.9 & 2.7 & -7.9 & -15.8 & 0.3 \\
\hline 4 & Зерносовхоз им. Калинина & -17.6 & -17.0 & -9.1 & 3.2 & 12.6 & 18.4 & 20.6 & 18.7 & 11.8 & 3.9 & -7.2 & -14.4 & 2.0 \\
\hline 5 & $\begin{array}{l}\text { Семипалатинское опытное } \\
\text { поле }\end{array}$ & -18.0 & -17.0 & -9.9 & 3.4 & 12.5 & 18.7 & 21.3 & 18.7 & 12.1 & 3.4 & -7.7 & -15.1 & 1.9 \\
\hline 6 & $\begin{array}{l}\text { Прапорщиково } \\
\text { Каменогорск) }\end{array}$ & -18.8 & -17.8 & -9.8 & 3.1 & 12.1 & 17.8 & 19.6 & 17.8 & 11.5 & 3.7 & -7.7 & -14.8 & 1.4 \\
\hline 7 & г. Усть-Каменогорск & -16.2 & -15.7 & -7.9 & 4.3 & 13.7 & 18.9 & 21.2 & 19.1 & 12.9 & 5.0 & -6.5 & -13.3 & 3.0 \\
\hline 8 & Усть-Каменогорск & -16.8 & -16.1 & -8.6 & 3.5 & 12.9 & 18.2 & 20.3 & 18.2 & 12.7 & 4.7 & -6.5 & -13.7 & 2.4 \\
\hline 9 & Пос. Северный & -13.5 & -13.4 & -8.3 & 1.8 & 10.3 & 15.6 & 17.6 & 16.3 & 10.9 & 2.6 & -7.5 & -13.1 & 1.6 \\
\hline 10 & Усть-Каменогорская ферма & -15.4 & -14.8 & -7.6 & 4.1 & 12.5 & 17.9 & 20.2 & 17.9 & 11.9 & 4.4 & -6.3 & -13.4 & 2.6 \\
\hline 11 & Зыряновский рудник & -22.4 & -21.7 & -12.6 & 1.6 & 12.2 & 17.7 & 19.6 & 17.0 & 10.8 & 3.0 & -10.9 & -20.8 & -0.5 \\
\hline 12 & Зыряновское & -23.8 & -22.0 & -13.9 & -0.7 & 11.2 & 16.5 & 18.5 & 16.5 & 10.2 & 1.5 & -11.6 & -20.3 & -1.5 \\
\hline 13 & Бухтарма & -18.3 & -16.0 & -9.6 & 3.3 & 12.0 & 17.7 & 20.4 & 18.4 & 12.2 & 4.4 & -7.6 & -16.0 & 1.7 \\
\hline 14 & Большенарымское & -22.5 & -20.7 & -12.4 & 2.8 & 12.7 & 18.1 & 20.6 & 18.9 & 12.5 & 3.3 & -9.9 & -19.1 & 0.4 \\
\hline 15 & Катон-Карагай, северная & -13.6 & -12.7 & -7.7 & 1.5 & 8.8 & 14.0 & 16.0 & 14.8 & 9.4 & 1.6 & -7.8 & -12.8 & 1.0 \\
\hline 16 & Катон-Карагай & -14.8 & -12.5 & -6.1 & 3.2 & 10.2 & 15.1 & 17.2 & 15.2 & 10.6 & 2.8 & -8.5 & -13.6 & 1.6 \\
\hline 17 & Самарка & -17.9 & 15.4 & -8.1 & 4.9 & 13.4 & 19.0 & 21.4 & 19.8 & 13.7 & 4.9 & -7.2 & -15.6 & 2.7 \\
\hline 18 & Пос. Александровский & -14.6 & -13.0 & -5.9 & 3.8 & 11.4 & 16.3 & 19.1 & 17.5 & 12.6 & 3.5 & -7.3 & -12.7 & 2.6 \\
\hline 19 & Пос. Орловский & -27.1 & -23.4 & -14.7 & -1.3 & 8.9 & 14.0 & 15.6 & 13.5 & 7.6 & -0.8 & -14.2 & -24.2 & -3.8 \\
\hline 20 & Маркаколь & -25.9 & -22.8 & -15.4 & -5.1 & 4.0 & 11.9 & 14.1 & 13.1 & 8.1 & 0.0 & -9.6 & -21.5 & -4.1 \\
\hline 21 & Кумашкино & -20.4 & -18.0 & -9.9 & 4.9 & 13.7 & 19.0 & 21.0 & 19.2 & 13.3 & 4.8 & -7.3 & -17.4 & 1.8 \\
\hline 22 & Рождественское & -18.3 & -16.5 & -7.0 & 7.6 & 14.7 & 20.5 & 23.5 & 21.1 & 15.1 & 6.3 & -6.2 & -14.8 & 3.8 \\
\hline 23 & Буран & -18.8 & -16.5 & -7.3 & 6.2 & 14.4 & 20.1 & 22.2 & 20.0 & 13.6 & 4.7 & -6.2 & -15.0 & 3.1 \\
\hline 24 & Тополев Мыс, западная & -22.1 & -19.9 & -10.3 & 3.6 & 14.0 & 20.0 & 22.6 & 20.0 & 13.5 & 3.7 & -7.8 & -17.1 & 1.7 \\
\hline 25 & Тополев Мыс & -20.2 & -18.3 & -9.6 & 2.6 & 13.4 & 19.8 & 22.2 & 20.5 & 14.2 & 5.5 & -6.0 & -16.9 & 2.3 \\
\hline 26 & Зайсанская ферма & -18.8 & -17.3 & -9.9 & 6.3 & 14.6 & 19.8 & 21.3 & 19.4 & 13.2 & 4.7 & -7.3 & -16.5 & 2.5 \\
\hline 27 & Зайсан & -17.8 & -15.8 & -7.7 & 5.8 & 14.2 & 20.4 & 22.7 & 21.4 & 15.2 & 5.7 & -6.1 & -15.0 & 3.6 \\
\hline 28 & г. Зайсан & -16.6 & -15.0 & -6.6 & 7.0 & 15.3 & 20.4 & 23.1 & 20.9 & 15.2 & 6.5 & -6.0 & -14.6 & 4.1 \\
\hline
\end{tabular}


Среднегодовые значения метеорологических параметров, определяющих потенциал загрязнения атмосферы (ПЗА) по зонам (по Э.Ю. Безуглой)

\begin{tabular}{|c|c|c|c|c|c|c|c|}
\hline \multirow{2}{*}{$\begin{array}{l}\text { Зоны ПЗА и его } \\
\text { характеристики }\end{array}$} & \multicolumn{3}{|c|}{ Приземные инверсии } & \multicolumn{2}{|c|}{ Повторяемость, \% } & \multirow[b]{2}{*}{$\begin{array}{l}\text { Высота } \\
\text { слоя } \\
\text { перемеш } \\
\text { ивания } \\
\text { (ВСП) }\end{array}$} & \multirow[b]{2}{*}{$\begin{array}{c}\text { Продол- } \\
\text { житель- } \\
\text { ность } \\
\text { туманов, } \\
\text { часы }\end{array}$} \\
\hline & $\begin{array}{c}\text { Повтор } \\
\text { яемость } \\
\%\end{array}$ & $\begin{array}{c}\text { Мощ- } \\
\text { ность, } \\
\text { км }\end{array}$ & $\begin{array}{c}\text { Интен- } \\
\text { сивность, } \\
{ }^{0} \mathrm{C}\end{array}$ & $\begin{array}{c}\text { Скорость } \\
\text { ветра } \\
0-1,0 \mathrm{~m} / \mathrm{c}\end{array}$ & $\begin{array}{l}\text { Застоев } \\
\text { воздуха }\end{array}$ & & \\
\hline I - низкий & $20-30$ & $0.3-0.4$ & $2-3$ & $10-20$ & $5-10$ & $0.7-0.8$ & $80-350$ \\
\hline II - умеренный & $30-40$ & $0.4-0.5$ & $3-5$ & $20-30$ & $7-12$ & $0.8-1.0$ & $100-550$ \\
\hline $\begin{array}{l}\text { III - } \\
\text { повышенный } \\
\text { континентальн } \\
\text { ый } \\
\text { Приморский }\end{array}$ & $30-45$ & $0.3-0.7$ & $2-6$ & $10-30$ & $10-25$ & $0.4-1.0$ & $100-800$ \\
\hline IV - высокий & $40-50$ & $0.3-0.7$ & $3-6$ & $30-60$ & $10-30$ & $0.7-1.6$ & $50-200$ \\
\hline $\begin{array}{l}\mathrm{V}-\text { очень } \\
\text { высокий }\end{array}$ & $40-60$ & $0.3-0.9$ & $3-10$ & $50-70$ & $20-35$ & $0.8-1.6$ & $10-600$ \\
\hline
\end{tabular}


Научное издание

Климат Юго-западного Алтая

Авторы: Попова Ксения Ивановна,

Егорина Анна Васильевна, Дюкарев Александр Дмитриевич, Кондратьев Владимир Павлович, Чурсин Анатолий Сергеевич

ISBN 9965-578-02-8

Технический редактор: Прокопенко Л. Г.

Корректура: Прокопенко Л.Г.

Компьютерная верстка и оригинал-макет: Кривец А. В.

Подписано в печать

Бумага

Отпечатано в
Формат

Печать
Усл. печ. л.

Тираж__ 100 экз. _ Заказ

